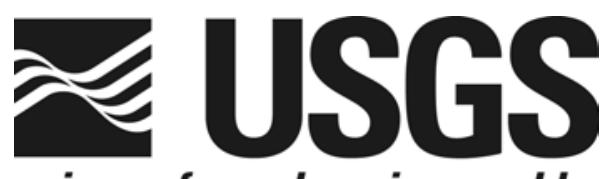

science for a changing world

WASHINGTON STATE

D E P A R T MENT OF

E C $\begin{array}{llllllllllll} & 0 & \text { L } & \text { G } & \text { Y }\end{array}$

\title{
Southwest Washington Coastal Erosion Workshop Report 2000
}

\section{Editors}

Guy Gelfenbaum ${ }^{1}$ and George M. Kaminsky ${ }^{2}$

Open-File Report 02-229

June 2002

\section{Prepared in Cooperation with Washington State Department of Ecology}

This report is preliminary and has not been reviewed for conformity with the U.S. Geological Survey editorial standards or with the North American Stratigraphic code. Any use of trade, firm, or product names is for descriptive purposes only and does not imply endorsement by the U.S. Government.

\author{
U.S. Department of the Interior \\ U.S. Geological Survey \\ ${ }^{1}$ U.S. Geological Survey, Menlo Park, CA \\ 2 Washington State Department of Ecology, Olympia, WA
}


Cover Photograph: Photograph of the beach and dunes near Ocean Shores, Washington in July, 1996. Overlain is a schematic time series of several past and future coastal change scenarios.

For a full description of the schematic see "Columbia-River cell coastal erosion project: Limits to Knowledge" by Peter Cowell, this volume. 


\section{TABLE OF CONTENTS}

\section{SOUTHWEST WASHINGTON COASTAL EROSION WORKSHOP REPORT 2000}

Workshop Agenda $\ldots \ldots \ldots \ldots \ldots \ldots \ldots \ldots \ldots \ldots \ldots \ldots \ldots \ldots \ldots \ldots$

Introduction. . . . . . . . . . . . .

Motivation, Goals, and Status of the Southwest Washington Coastal Erosion Study . . . 17

Guy Gelfenbaum, U.S. Geological Survey

George M. Kaminsky, Washington Department of Ecology

\section{COLUMBIA RIVER \& ESTUARY}

Geophysical Survey of the John Day Reservoir: Columbia River . . . . . . . . . 25

David Twichell, U.S. Geological Survey

Michael Parsley, U.S. Geological Survey

Guy Gelfenbaum, U.S. Geological Survey

VeeAnn Cross, U.S. Geological Survey

Mindi Sheer, U.S. Geological Survey

Ken Parolski, U.S. Geological Survey

Laura Kerr, U.S. Geological Survey

Warrenton Borehole - Sedimentation Rates . . . . . . . . . . . . . . . . . 29

Diana L. Baker, Portland State University

Preliminary Results of the Columbia River Estuary Vibracoring Study $\ldots \ldots \ldots \ldots \ldots 32$

Sandy Vanderburgh, University College of the Fraser Valley

Curt Peterson, Portland State University

Diana Baker, Portland State University

Dave Qualman, Portland State University

Jeff Heeren, Portland State University

Dave Percy, Portland State University

Rebecca Treat, Portland State University

Separating Human and Climate Impacts on Columbia River Hydrology and

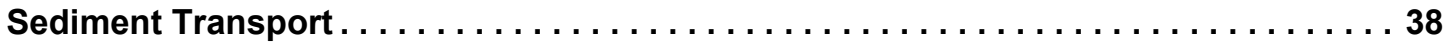

David A. Jay, Department of Environmental Science and Engineering, Oregon Graduate Institute

Pradeep Naik, Department of Environmental Science and Engineering, Oregon Graduate Institute

Mouth of the Columbia River - Trends in Sediment Management . . . . . . . . . . 49

Rod Moritz, U.S. Army Corps of Engineers - Portland District

A Review of Columbia River Dredging: Past Practices and Recent Proposals . . . . . . 53

George M. Kaminsky, Washington Department of Ecology 
High Resolution Sediment Dynamics in Salt-wedge Estuaries $\ldots \ldots \ldots \ldots \ldots \ldots \ldots \ldots 1$

Philip Orton, Department of Environmental Science and Engineering, Oregon Graduate Institute

Douglas Wilson, Department of Environmental Science and Engineering, Oregon Graduate Institute

David Jay, Department of Environmental Science and Engineering, Oregon Graduate Institute

Annika Fain, School of Oceanography, University of Washington

Estimation of the Columbia River Virgin Flow $\ldots \ldots \ldots \ldots \ldots \ldots \ldots \ldots \ldots \ldots \ldots \ldots$

Pradeep K. Naik, Oregon Graduate Institute of Science and Technology

David A. Jay, Oregon Graduate Institute of Science and Technology

\section{CoAstal BARRIERs \& BEAcHes}

Correlation of Shoreface Retreat Scarps, Foredune Ridges, and Late-Holocene

Shoreline Ages in the Columbia River Littoral Cell, Washington-Oregon, USA . . . . . 75

Curt Peterson, Portland State University

Harry Jol, University of Wisconsin-Eau Claire

David Percy, Portland State University

James Phipps, Grays Harbor College

Frank Reckendorf, Reckendorf \& Associates

Sandy Vanderburgh, University College of the Fraser Valley

Lorraine Woxell, Portland State University

Data Integration and Modeling . .

David C. Percy, Portland State University

Peter J. Cowell, University of Sydney

Curt D. Peterson, Portland State University

Shoreface Sand Supply for Barrier Progradation $\ldots \ldots \ldots \ldots \ldots \ldots \ldots \ldots \ldots \ldots \ldots$

Peter J. Cowell, Coastal Studies Unit, University of Sydney

Marcel J.F. Stive, Department of Hydraulic Engineering, Delft Technical University

George M. Kaminsky, Washington Department of Ecology

Maarten C. Buijsman, Washington Department of Ecology

High Resolution 2D and 3D Ground Penetrating Radar Datasets $\ldots \ldots \ldots \ldots \ldots \ldots \ldots 9$

Harry Jol, University of Wisconsin-Eau Claire

George M. Kaminsky, Washington Department of Ecology

Exploring Correlations Between Shoreline Progradation and Climate Indices,

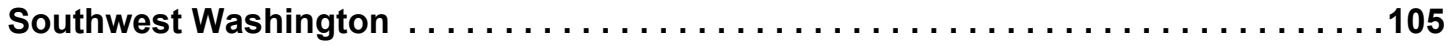

Laura Moore, U.S. Geological Survey and University of South Florida

Harry Jol, University of Wisconsin-Eau Claire

George M. Kaminsky, Washington Department of Ecology

Historical Bathymetric and Topographic Change Analysis - An Overview . . . . . . 112

Maarten Buijsman, Washington Department of Ecology 
Aggregating Beach Monitoring Data to Inform Management Scale Predictive

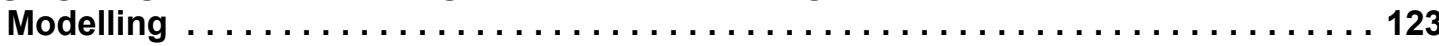

Peter Ruggiero, Washington Department of Ecology

George M. Kaminsky, Washington Department of Ecology

Guy Gelfenbaum, U.S. Geological Survey

David Thompson, University of Delaware

Etienne Kingsley, Washington Department of Ecology

Assessing Coastal Susceptibility in the Columbia River Littoral Cell $\ldots \ldots \ldots \ldots \ldots 137$

Brian Voigt, Washington Department of Ecology

Peter Ruggiero, Washington Department of Ecology

Predicting Shoreline Change at Management Scale. . . . . . . . . . . . . 142

George M. Kaminsky, Washington Department of Ecology

Maarten C. Buijsman, Washington Department of Ecology

Peter Ruggiero, Washington Department of Ecology

Historical Shoreline Change Rates for the Columbia River Littoral Cell $\ldots \ldots \ldots \ldots \ldots 154$

Richard C. Daniels, Washington Department of Ecology

Diana McCandless, Washington Department of Ecology

Robert H. Huxford, Washington Department of Natural Resources

Digitizing Shorelines from Aerial Photography. . . . . . . . . . . . .

Diana C. McCandless, Washington Department of Ecology

Richard C. Daniels, Washington Department of Ecology

WILLAPA BAY \& GRAYS HARBOR

Bay Center Channel and Willapa Navigation Studies $\ldots \ldots \ldots \ldots \ldots \ldots \ldots \ldots \ldots$

David Simpson, Pacific International Engineering

Linking Equatorial SST and Hydrodynamics off SW Washington, USA $\ldots \ldots \ldots \ldots \ldots 18$

Edward B. Hands, U.S. Army Engineer Waterways Experiment Station, Coastal and

Hydraulics Laboratory

Evidence of Large-scale, Long-term Cycles of Beach Deposition and Erosion,

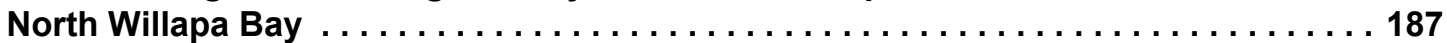

Robert A. Morton, U.S. Geological Survey

Noreen Purcell, U.S. Geological Survey

David Qualman, Portland State University

Jeff Heeren, Portland State University

Recent Sea-level History in the CRLC as Detected from Tide Gauge Records . .

Ann E. Gibbs, U.S. Geological, Survey

Holly F. Ryan, U.S. Geological Survey 


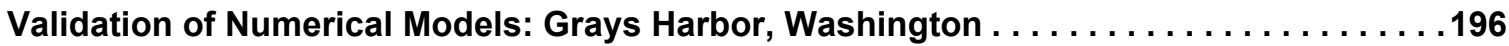

Mary A. Cialone, U.S. Army Engineer Research and Development Center, Coastal and Hydraulics Laboratory

Nicholas C. Kraus, U.S. Army Engineer Research and Development Center, Coastal and Hydraulics Laboratory

Hiram T. Arden, U.S. Army Engineer District

Robert M. Parry, U.S. Army Engineer District

David B. Hericks, Pacific International Engineering

The Relation Between Jetty Construction/Rehabilitation and Shoreline Change at

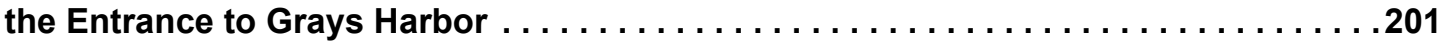
Maarten Buijsman, Washington Department of Ecology

\section{EBb-TidAL DELTAS \& INNER SHELF}

Latest Holocene Evolution of the SW Washington Shelf and Coastal System . . . . . . 210

David Twichell, U.S. Geological Survey

VeeAnn Cross, U.S. Geological Survey

Curt Peterson, Portland State University

Dave Percy, Portland State University

Sandy Vanderburgh, University College of the Fraser Valley

Jim Phipps, Grays Harbor Community College

April Herb, Portland State University (graduated)

Results from a Multibeam Sonar Survey on the Inner Shelf off Grays Harbor:

Relevance to the Southwest Washington Coastal Erosion Study . . . . . . . . . 217

Vicki Lynn Ferrini, Marine Sciences Research Center, SUNY Stony Brook

Roger D. Flood, Marine Sciences Research Center, SUNY Stony Brook

The Wave Climate of the Eastern North Pacific: Long-term Trends and an

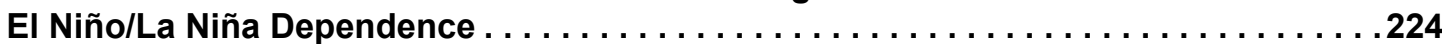

Jonathan C. Allan, Oregon Department of Geology \& Mineral Industries

Paul D. Komar, College of Oceanic \& Atmospheric Sciences, Oregon State University

SWAN Model Calibration and Validation on the Southwest Washington Inner

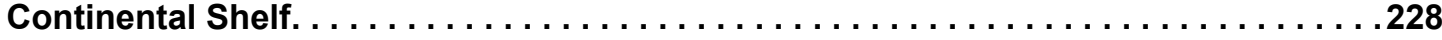

Meg Palmsten, University of South Florida

Sediment Transport During the 1999 Grays Harbor Wave Refraction Experiment. . . . . . 236 Christopher R. Sherwood, U.S. Geological Survey

Models, Data, Assumptions, and What We Know for Sure . . . . . . . . . . . . 237 Peter Howd, College of Marine Science, University of South Florida

Feasibility of a Submerged Spur to Control Navigation Channel Shoaling at North Jetty, Grays Harbor: Evaluation of North Jetty Sediment Transport Conditions . . . . 238

Philip D. Osborne, Pacific International Engineering, PLLC

Vladimir Shepsis, Pacific International Engineering, PLLC 


\section{DISCUSSION TOPICS \& REVIEWS OF STUDY PROGRESS}

An Integrated Contemporary Sediment Budget for the Columbia River Littoral Cell . . . 244

George M. Kaminsky, Washington Department of Ecology

Maarten C. Buijsman, Washington Department of Ecology

Peter Ruggiero, Washington Department of Ecology

Guy Gelfenbaum, U.S. Geological Survey

Regional Sediment Management in Columbia River Littoral Cell: Problems and

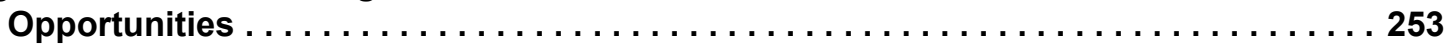

George M. Kaminsky, Washington Department of Ecology

But What Does It All Mean? Distilling the Science for Use on a Local Management Scale: Observations, Recommendations, and Examples of Information Sharing

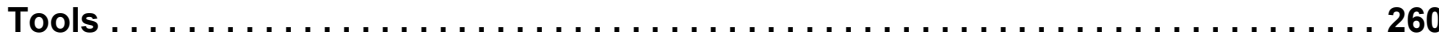

Christian J. Stewart, Christian J. Stewart Consulting

Coming to Grips with Large-Scale Coastal Systems - Thoughts about the Columbia

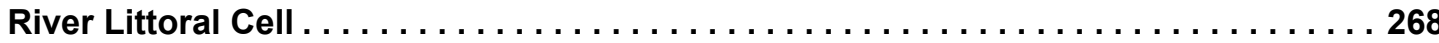

Paul D. Komar, College of Oceanic \& Atmospheric Sciences, Oregon State University

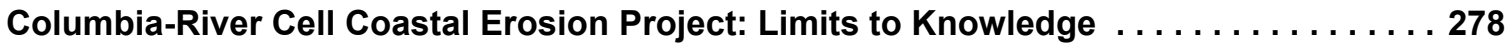
Peter J. Cowell, Coastal Studies Unit, University of Sydney

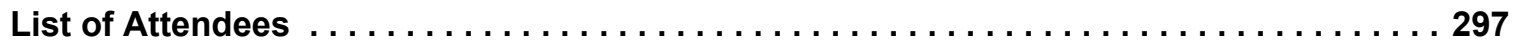

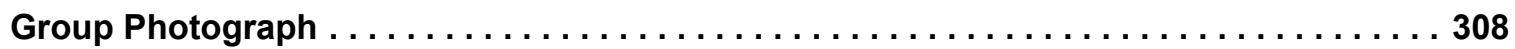




\title{
Fifth Southwest Washington Coastal Erosion Study Workshop
}

\author{
Olympia, Washington \\ November 15-17, 2000 \\ WORKSHOP AGENDA
}

\section{Wednesday, November 15}

0800 PICK-UP AT HOTEL FOR SHUTTLE TO WORKSHOP
0815 Welcome
G. Gelfenbaum, USGS
G. Kaminsky, DOE
0830
Motivation, goals, and status of USGS/DOE study
G. Gelfenbaum, USGS

\section{COLUMBIA RIVER \& ESTUARY}

0930 Preliminary findings from a geophysical survey of the John Day Reservoir, Columbia River

D. Twichell, USGS

0945 Holocene sedimentation rates in Columbia River estuary

D. Baker, PSU

1000 BREAK

1030 Preliminary results and interpretation of Columbia River estuary vibracoring

1045 Separating human and climate effects on Columbia River flow and sediment transport D. Jay, Oregon Graduate Inst.

1100 Columbia River mouth dredged material disposal plans

1115 MCR - trends in sediment management H. Moritz, COE

1130 LUNCH \& Posters

1300 Group Discussion: Columbia River Sediment Source

1500 BREAK 
COASTAL BARRIERS \& BEACHES

1530 Prehistoric shorelines in the Columbia River littoral cell

C. Peterson, PSU

1545 Data integration and modeling

D. Percy, PSU

1600 Modeling shoreface and barrier response to subsidence events

P. Cowell, U of Sydney

1615 Group Discussion and Posters

1700 Session ends

1830 SOCIAL MIXER \& DINNER (sponsored by SWCES at the Schmidt House)

Thursday, November 16

0800 PICK-UP AT HOTEL FOR SHUTTLE TO WORKSHOP

0830 High resolution 2D and 3D GPR datasets H. Jol, UWEC

0845 Shoreline response to climate variability L. Moore, USF/USGS

0900 An overview of historic bathymetric and topographic change analysis

M. Buijsman, DOE

0915 Aggregating beach monitoring data to inform management-scale predictive modeling

P. Ruggiero, DOE

0930 Assessing coastal susceptibility in the CRLC

B. Voigt, DOE

1000 BREAK

1030 Group Discussion: Shoreline Change Predictions

1200 LUNCH \& Posters

\section{WILLAPA BAY \& GRAYS HARBOR}

1330 Status of Seattle District COE coastal projects E. Nelson, COE

1345 Bay Center channel and Willapa navigation studies D. Simpson, PIE

1400 Linking equatorial SST and hydrodynamics off SW WA

E. Hands, WES 
1415 Willapa Bay North Cove - monitoring program observations and analysis

N. Sultan, PIE

1430 Evidence of large-scale, long-term beach deposition and erosion, north Willapa Bay

R. Morton, USGS

1445 Recent sea-level history from tide gauge records

A. Gibbs, USGS

1500 BREAK

1530 Validation of numerical models: Grays Harbor WA

M. Cialone, WES

1545 Relation between jetty construction/rehabilitation and shoreline change at the entrance to Grays Harbor

M. Buijsman, DOE

1600 Discussion \& Posters

1700 Session ends

1830 DINNER (sponsored by SWCES at Jazmines Restaurant)

Friday, November 17

0800 PICK-UP AT HOTEL FOR SHUTTLE TO WORKSHOP

\section{EBB-TIDAL DELTAS \& INNER SHELF}

0830 Late Holocene framework and evolution of the Southwest Washington coast

D. Twichell, USGS

0845 Insights from high-resolution bathymetry and backscatter studies on the inner shelf

V. Ferrini, SUNY-SB

0900 Wave climatology in the Pacific Northwest

P. Komar, OSU

0915 SWAN model calibration and validation on the SW WA inner continental shelf

M. Palmsten, USF

0930 Sediment transport during the 1999 Grays Harbor wave refraction experiment

C. Sherwood, USGS

0945 BREAK

1015 Models, assumptions, and what we know for sure

P. Howd, USF 
1030 Feasibility of a submerged spur at North Jetty, Grays Harbor: Evaluation of sediment transport conditions

P. Osborne, PIE

1045 Group Discussion: Shelf Sediment Transport and Connection to Littoral Transport

1200 LUNCH \& Posters

1330 Group Discussion: Sediment Budgets and Regional Sediment Management

1500 BREAK

1530 Group Discussion: Study Completion, Final Products, and Future Work

1615 Objective evaluation of the Study

P. Komar, OSU

P. Cowell, U of Sydney

1700 End of Workshop 


\section{INTRODUCTION}

This report is a compilation of abstracts that correspond to oral presentations and posters presented at the fifth principal investigators workshop of the Southwest Washington Coastal Erosion Study. The workshop was held November $15-17,2000$ at the Department of Ecology headquarters building in Olympia, WA. For the fourth consecutive year in November, the workshop convened the entire multi-disciplinary group of scientists and engineers working on the Study or on related projects within the Columbia River littoral cell (CRLC) (Figures 1 and 2). The workshop participants are listed in the List of Attendees section towards the end of this report.

The purpose of this workshop was to bring all Study investigators and associated engineers and scientists together to discuss recent work, ongoing tasks, and future research plans in the CRLC. Investigators were asked to present recent data, preliminary interpretations, and research results to invoke discussion and correlation with parallel scientific efforts. The abstracts compiled in this report represent a wealth of information on the CRLC, but because much of the work is in progress, the reader is advised that the information provided herein is preliminary and subject to change.

The workshop abstracts are grouped together into the different sedimentary environments that make up the Columbia River littoral cell. After an introductory abstract summarizing the motivation, goals, and status of the Study, the workshop report continues with a set of abstracts on the Columbia River and estuary. These abstracts discuss the Columbia River as a source of sediment to the littoral cell, as well as the roles that the estuary and river play as sinks of sediment. Several of these studies explore the impacts of human interventions, such as channel dredging and flow regulation, on altering the flow, sediment transport, and sediment accumulations in the river and estuary. The next set of abstracts discusses results from studies of the coastal barriers and beaches of the CRLC. These abstracts describe studies that have quantified changes in the barriers and beaches over pre-historical and historical time scales. Also included are summaries of processes associated with coastal evolution such as shoreface sand supply and the influence of climate changes, and a paper describing a method of predicting coastal change. Next in the report are a group of abstracts on studies from Willapa Bay and Grays Harbor, the two major bays of the littoral cell. These abstracts include reviews of ongoing, recent, and early $20^{\text {th }}$ century coastal engineering projects at the entrances to Grays Harbor and Willapa Bay. Also included are summaries of natural cycles of sea level and morphological changes in Willapa Bay. The final group of abstracts associated with a CRLC sedimentary environment describes studies of the ebb-tidal deltas and inner shelf. This group includes abstracts of studies covering the complete range of time scales over which sediment from the Columbia River is transported and accumulates, from long-term evolution of the shelf to short-term wave, current, and sediment transport processes associated with storms.

The last group of abstracts in this report addresses topics that are integrated across the different sedimentary environments, including the sediment budget, a straw plan for 
regional sediment management, information sharing tools, and two reviews of the Study. In part, these abstracts describe examples of the important function that science can play in improving management decisions. Abstracts by internationally renowned coastal scientists Drs. Paul Komar of Oregon State University and Peter Cowell of the University of Sydney offer independent evaluations of the progress of the Study.

\section{ACKNOWLEDGEMENTS}

We would like to thank Brian Voigt for his help in organizing the workshop and Etienne Kingsley, Laura Kerr, and David Thompson for their help in preparing the workshop. Much thanks goes to Laura Kerr and Brian Voigt for preparing this workshop report. Finally, we would like to thank John Chin of the U.S. Geological Survey for his thoughtful review of this report. 


\section{Columbia River Littoral Cell}

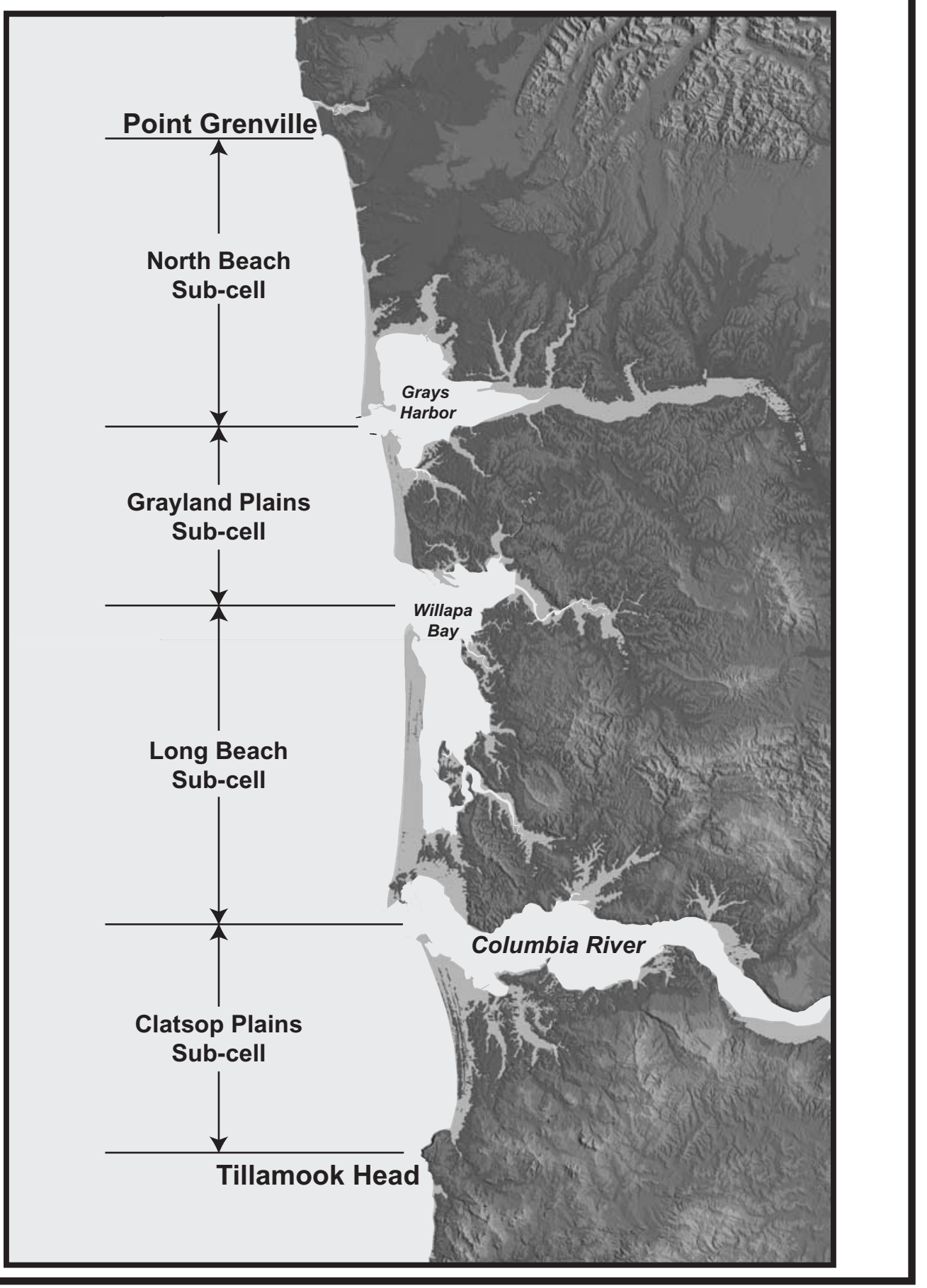

Figure 1. The Columbia River littoral cell is bound by Tillamook Head in the south and Point Grenville in the north. 


\section{Columbia River Littoral Cell}

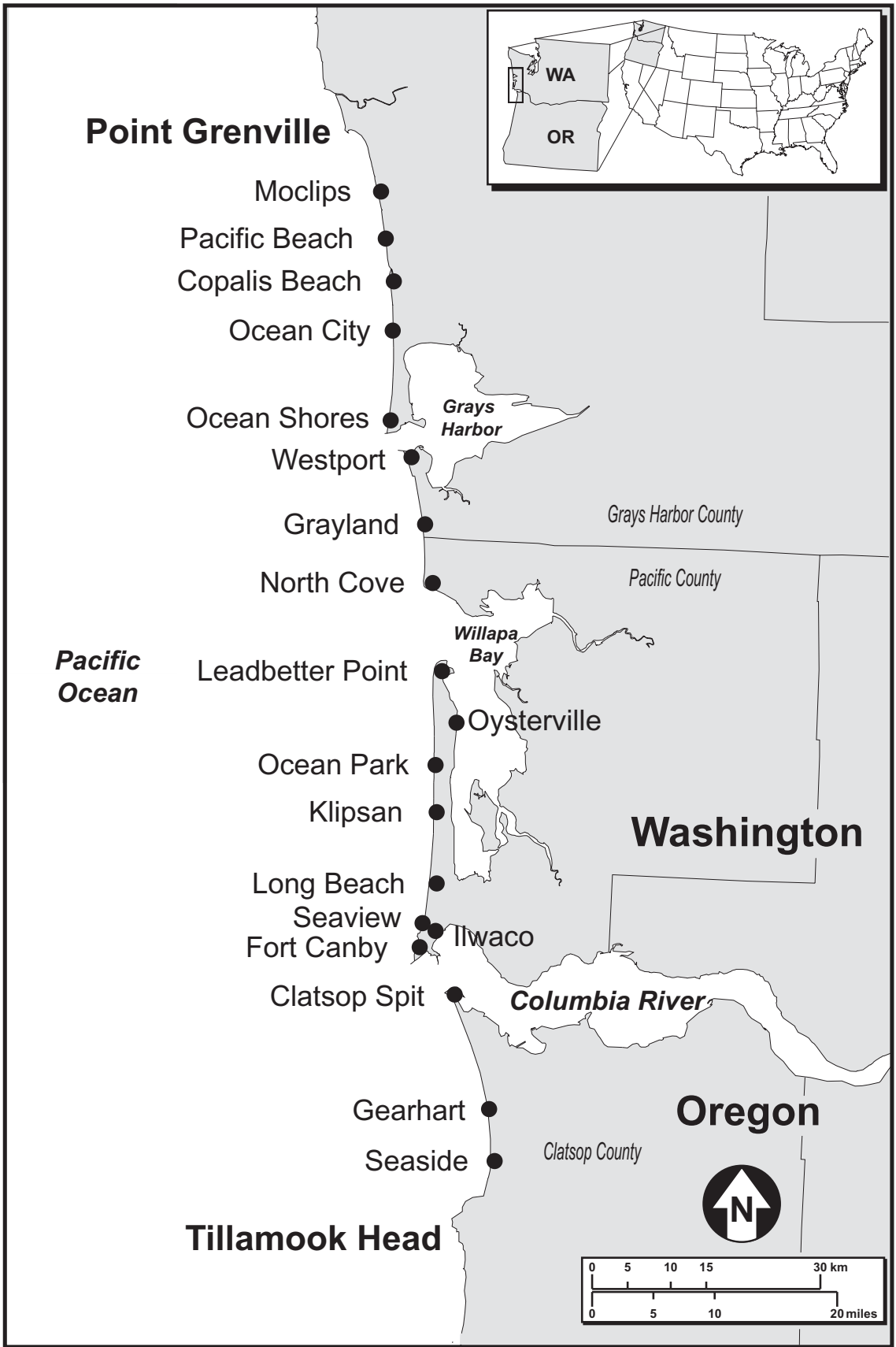

Figure 2. Coastal communities and geographic features of the Columbia River littoral cell. 


\section{MOTIVATION, GOALS, AND STATUS OF THE SOUTHWEST WASHINGTON COASTAL EROSION STUDY}

Guy Gelfenbaum, U.S. Geological Survey

George M. Kaminsky, Washington Department of Ecology

\section{CONCLUSIONS}

Below is a short synopsis of important preliminary findings and progress of the Study:

- The Study is actively integrating geologic data sets from the shelf, bays, and barriers to reconstruct the Holocene evolution of the coastal system. Dated material from cores and the occurrence of tephra (volcanic glass) layers are enabling the calculation of sedimentation rates and the development of a time history of sediment accumulation along the mid-shelf and within the Columbia River littoral cell (CRLC).

- Dune ridges are common features along the coastal plains of all four CRLC subcells. The Study has correlated the dune ridges along each sub-cell and across the sub-cell boundaries. The locations of dune ridges are being interpreted to be correlated to prehistoric shoreline positions. Tentatively, shoreline positions from $4.0,2.5,1.7,1.2$, and 0.3 thousand years ago have been identified. These times correspond to co-seismic subsidence events associated with Cascadia Subduction Zone earthquakes and they allow for the calculation of shoreline change rates prior to human intervention.

- Simulations of the shoreface and shoreline response to co-seismic subsidence events are being conducted using a geometrical-based coastal evolution model. Preliminary simulations for Long Beach Peninsula suggest significant shoreline retreat (erosion) associated with a subsidence event similar to those documented to have occurred over the last few thousand years on the Washington coast. Initial model results suggest shoreline recession varying from 100-900 $\mathrm{m}$ depending on whether or not the inner shelf is considered as a source of sand to the beaches.

- Grays Harbor and Willapa Bay are predominately filled with sediment that originated from the Columbia River. Are the bays still filling with sediment from the open coast or has the filling ceased? Whether the bays are sinks or sources of sediment to the coast is important to the CRLC sediment budgets and thus to shoreline change predictions. Bay sediments are being examined to assess their late Holocene to historical sedimentation history.

- The historical evolution of the CRLC barriers is now well documented. Through systematic, detailed analysis of historical topographic surveys (NOS T-Sheets back to 1868) and aerial photographs (through 1999) the Study has determined the spatial patterns and temporal trends of shoreline change between Tillamook Head, 
OR and Point Grenville, WA. In addition, sediment accumulation rates over three periods since the late 1800 s have been derived for each of the sub-cells.

- A multibeam survey of the region off Grays Harbor and Grayland Plains was conducted to provide accurate and detailed bathymetry and backscatter data. The survey reveals several distinct depressions in the seafloor surface along both the north and south sides of the Grays Harbor entrance. A series of obliquely-angled depressions south of the South Jetty in water depths from 10-16 m, are up to $2 \mathrm{~m}$ deep, $200 \mathrm{~m}$ wide, and $1 \mathrm{~km}$ long. A wider and longer shore-perpendicular depression exists north of the Grays Harbor entrance. The bottoms of the depressions contain well-rounded gravel-size sediment probably of glacial origin. The depressions are surrounded by fine to medium-sized sand that originated from the Columbia River.

- Climate changes associated with El Niño cycles and the Pacific Decadal Oscillation affect precipitation and thus river flow and sediment discharge. There is also a correlation with shifting storm tracts, frequency, and severity and thus wave height and direction, and sea level. These factors may have a measurable effect on both the sediment discharge from the Columbia River and on the magnitude and direction of longshore sediment transport along the coast. The degree to which these climate change factors effect coastal morphology is of great interest and they are currently being studied.

- The construction of jetties at the entrances to the Columbia River and Grays Harbor have had a profound effect on the local sea floor morphology and the positions of the adjacent shorelines. Detailed sediment budgets at both estuary entrances accounting for these changes are providing critical data necessary to calibrate and predict future shoreline change.

- The magnitude and direction of longshore sediment transport along the beaches of the CRLC, and ultimately the shoreline change that results from gradients in transport, are sensitive to the magnitude and direction of incoming waves. Sensitivity analyses are improving the ability to accurately numerically simulate the shoaling and refraction of incoming waves. Extensive field experiments in which waves, currents, sea level, and suspended-sediment concentration were measured are being used to test and calibrate wave and sediment transport models.

- The beaches of the CRLC undergo morphological change, including net accretion and erosion, at several spatial and temporal scales. A variety of highly accurate GPS techniques are used to conduct extensive and detailed mapping of the beach from the dune fields to $-10 \mathrm{~m}$ elevation (MSL) along each of the four sub-cells. Results are used to document short-term changes in beach elevation and shoreline position, as input to shoreline change models, and in assessments of susceptibility to coastal flooding and beach erosion. 
- Findings from the Study are being used in a variety of cases to aid in management decisions. For example, Washington State Park officials are developing long-term plans for Fort Canby State Park using historical analysis and shoreline change predictions based on Study findings (Kaminsky et al., 1999a). Other examples of the application of Study results to management decisions include the erosion at Damon Point (Kaminsky et al., 1999b) and at Ocean Shores (Voigt and Ruggiero, 1998).

\section{ACCOMPLISHMENTS}

The paucity of data and lack of understanding of the sedimentary processes along the southwest Washington coast necessitated the development of a comprehensive Study plan. All relevant aspects of the coastal geologic and oceanographic processes that operate on scales ranging from meters to kilometers and from seconds to thousands of years needed to be addressed. The timeline below shows the tasks that have been addressed in the Study as well as the phasing of Study elements. The timeline has been modified over the life of the Study to reflect changes in emphasis, and the need to pursue important findings.

\begin{tabular}{|c|c|c|c|c|c|c|}
\hline Task & FY96 & FY97 & FY98 & FY99 & FY00 & FY01 \\
\hline "Assess Previous Studies & & & & & & \\
\hline Establish Geodetic Cont & & & & & & \\
\hline $\begin{array}{l}\text { Barrier Accretion/Erosio } \\
\text { Studv }\end{array}$ & & & & & & \\
\hline Shoreline Change Analy & & & & & & \\
\hline $\begin{array}{l}\text { Bathymetric Change } \\
\text { Analysis }\end{array}$ & & & & & & \\
\hline Sediment Source Analys & & & & & & \\
\hline $\begin{array}{l}\text { Inner Shelf Framework } \\
\text { Studies }\end{array}$ & & & & & & \\
\hline $\begin{array}{l}\text { Beach Morphology } \\
\text { Monitoring }\end{array}$ & & & & & & \\
\hline Shoreface Processes & & & & & & \\
\hline Coastal Change Modelin & & & & & & \\
\hline Develop Database/GIS & & & & & & \\
\hline Education and Outreach & & & & & & \\
\hline
\end{tabular}

The data collection phase of many of the tasks is complete. For example, the data collection for the geodetic control network, the historical shoreline change, and the inner 
shelf framework studies are complete. Likewise, the data and error analyses are complete or are near completion for the historical shoreline change task and the bathymetric change task. Several tasks, such as the sediment source analysis have extended beyond the original end date, and other tasks, such as the beach morphology monitoring, are still in progress. The array of multi-scale and multi-disciplinary tasks of the Study can be grouped into the following five categories:

1) Coastal Change: these tasks involve the analyses of past and present changes in geomorphic features that include barrier evolution, shoreline behavior, beach morphology monitoring, and bathymetric change. These efforts involve mapping the evolution of the littoral cell over a continuum of scales in order to understand the system functioning. The observed coastal changes are being related to environmental forcing, climatological events, sediment budgets, and other influences, including human intervention and tectonic activity.

2) Sediment Budget: this research characterizes and quantifies the sources, pathways and sinks of sediment within the littoral cell. Research is conducted to determine the volumes, accumulation rates, and transport rates of sediment for each of the major environments of the CRLC, including the Columbia River, Willapa Bay, Grays Harbor, the beaches and dunes, and nearshore and shelf sand bodies. This information is critical for determining the sand supply available for shoreline change.

3) Coastal Processes: these tasks include measuring, monitoring, and/or modeling currents, waves, sea level, sediment transport and other climatic conditions that drive coastal responses over a wide range of spatial and temporal scales. The Study also uses historical data, hindcast data, and interpretations of morphologic expression to infer process-response relationships.

4) Predictive Modeling: modeling efforts are based on integrated input data sets derived from the analysis of coastal change, sediment budgets, coastal processes, and other environmental forcing conditions and geological constraints. The initial tasks help clarify important geologic and oceanographic processes that govern the coastal changes and refine the conceptual and mathematical models used to make quantitative predictions. Modeling efforts include shoaling and refraction of waves as they propagate from deep to shallow water, inner shelf and surf zone sediment transport due to storms, changing shoreline position, and shoreface change due to episodic coastal subsidence events.

5) Management Support: these tasks involve the development of information and products of direct value to coastal management and the land-use planning efforts of local communities. In addition to basic products such as maps and reports, this work includes susceptibility analyses, development of geographic information system (GIS)based decision support systems, databases and the application of research results to case studies. 
The Study approach and research topics described above were developed in recognition of the need to predict shoreline change at a temporal scale relevant to developing viable long-term management alternatives. Because quantitatively accurate prediction of coastal change is inherently difficult at any scale, the Study tasks are directed toward obtaining the most fundamental information needed to develop a sufficient understanding of the natural and human-induced complexity of the littoral system so that a predictive capability may be developed. This includes developing an understanding of errors, model sensitivities, and limits to predictability.

\section{QUESTIONS}

In the course of the Study questions have been raised based on preliminary findings and our developing conceptual understanding of the CRLC. In addition, some questions that were raised at the onset of the Study have remained unanswered. Below is a list of a few of these questions:

1) What is the net flux of sediment out of the Columbia River estuary into the coastal system? Has the sediment flux changed over time? What is the influence of natural climatic-induced changes in runoff versus modifications in discharge due to flow regulation on the sediment flux out of the estuary? Is the Columbia River estuary a net sink of littoral sediment?

2) Is there a relationship between nearshore morphology (number of bars, size of bars, etc.) and short-term shoreline change trends? If so, does a certain bar morphology cause shoreline change, or is it a result of the shoreline change?

3) Is there significant sediment transport between the inner shelf and the littoral zone? What are the underlying conditions that favor exchange between the inner shelf and the littoral zone? Is the exchange controlled by certain processes (e.g., large waves), by the sediment supply, or by both in some combination?

4) Is there a record of climate variability or climate change in the progradational strata of the coastal barrier plains?

5) Can the sediment budget be constrained enough to provide useful boundary conditions and input to shoreline change predictions? Does the sediment budget balance? Are the errors and uncertainties in the sediment budget too large to make it useful?

\section{ANALYSIS}

The Southwest Washington Coastal Erosion Study was initially conceived in 1994 as a result of the recognition by public officials of a lack of basic understanding of coastal processes and shoreline changes along the southwest Washington coast. The Study began in the spring of 1996 and is now in the fifth year of a five-year plan. The Study is a multidisciplinary investigation of the 165-km long coastal region between Tillamook Head, Oregon and Point Grenville, Washington, that is referred to as the Columbia River littoral 
cell. The Study is jointly sponsored and directed by the U.S. Geological Survey, Coastal and Marine Geology Program, and the Washington Department of Ecology, Coastal Monitoring \& Analysis Program, with active participation by local communities. Kaminsky and Gelfenbaum (1999) provide details about the development of this federalstate-local partnership. Gelfenbaum et al. (1997) is a report of the first workshop and provides an inventory of the state of the knowledge at the beginning of the Study. An overview of the Study elements and initial results is provided in Kaminsky et al. (1997). The abstracts of the 1998 principal investigators workshop are compiled in Gelfenbaum and Kaminsky (1999) and the abstracts of the 1999 principal investigators workshop are compiled in Gelfenbaum and Kaminsky (2000).

The Study has three principal goals:

1) understand regional sediment system dynamics;

2) determine natural and anthropogenic influences on the littoral system; and

3) predict coastal behavior at management scales (i.e., decades and tens of kilometers).

These goals are pursued through a wide range of investigations into the geology and coastal processes that span over four orders of magnitude in time and space (days to millennia and meters to hundreds of kilometers). The Study approach is to apply a hierarchical systems perspective that considers coastal morphodynamics at the scale of interest in context with the morphodynamics at both smaller and larger scales. At the smaller scale are the important process-drivers of aggregated-scale coastal change, and at the larger scale are the boundary conditions that impose constraints on the morphodynamics at smaller scale.

\section{REFERENCES}

Gelfenbaum, G., and Kaminsky, G. M. (editors) 1999. Southwest Washington coastal erosion workshop report, 1998. U.S. Geological Survey Open-File Report 99-524, $182 \mathrm{p}$.

Gelfenbaum, G. and Kaminsky, G.M. (editors) 2000. Southwest Washington Coastal Erosion Study workshop report 1999, U.S. Geological Survey Open-File Report 00-439, $187 \mathrm{p}$.

Gelfenbaum, G., Kaminsky, G.M., Sherwood, C.R., and Peterson, C.D. 1997. Southwest Washington coastal erosion workshop report, U.S. Geological Survey Open-File Report 97-471, 102 p.

Kaminsky, G.M. and Gelfenbaum, G. 1999. The Southwest Washington Coastal Erosion Study: Research in support of coastal management, Proceedings of Coastal Zone '99, pp. 737-739. 
Kaminsky, G., Ruggiero, P., McCandless, D., Lindstrum, E., McInnis, J., and Daniels, R., 1999a. Road wash-outs and shoreline change at Damon Point, Washington, Report to the Washington State Parks and Recreation Commission.

Kaminsky, G., Ruggiero, P., McCandless, D., Lindstrum, E., McInnis, J., and Daniels, R., 1999b. Road wash-outs and shoreline change at Damon Point, Washington, Report to the Washington State Parks and Recreation Commission.

Kaminsky, G.M., Ruggiero, P., Gelfenbaum, G., and Peterson, C. 1997. Long-term coastal evolution and regional dynamics of US Pacific Northwest littoral cell, Proceedings of Coastal Dynamics '97, ASCE, pp. 614-623.

Voigt, B. and Ruggiero, P. 1998. Initial evaluation of Ocean Shores shoreline monitoring data, Report to the Ocean Shores City Planner's Office. 3 p. 
Columbia River \& Estuary 


\title{
GEOPHYSICAL SURVEY OF THE JOHN DAY RESERVOIR: COLUMBIA RIVER
}

\author{
David Twichell, U.S. Geological Survey \\ Michael Parsley, U.S. Geological Survey \\ Guy Gelfenbaum, U.S. Geological Survey \\ VeeAnn Cross, U.S. Geological Survey \\ Mindi Sheer, U.S. Geological Survey \\ Ken Parolski, U.S. Geological Survey \\ Laura Kerr, U.S. Geological Survey
}

\section{CONCLUSIONS}

A geophysical and video sampling cruise was conducted in the John Day Reservoir of the Columbia River to assess whether sediment has accumulated since impoundment in 1968 and if so, has the bottom type changed enough to alter the habitat for spawning fishes. Results from the John Day study will also address the effects that dams and flow regulation have on sediment supply from the Columbia River. Preliminary findings from the recently completed field work include:

- A thin layer of mud, from less than $1 \mathrm{~cm}$ to several decimeters thick covers much of the reservoir floor, blanketing well-rounded gravel, cobbles, and boulders.

- Many large-scale features such as gravel or cobble bars, abandoned roads, etc. as discerned in sidescan sonar images appear unaltered as compared to preimpoundment photography of the river.

\section{QUESTIONS}

The findings in the John Day reservoir suggest several important questions:

- Has the thin layer of mud that blankets the reservoir bottom accumulated since impoundment in 1968, since the most recent large river flow in 1997, or since the last spring freshet a few months prior to our survey?

- How representative is the John Day Reservoir as compared to other reservoirs within the Columbia basin with respect to trapping of sediment since impoundment?

\section{ANALYSIS}

Over 400 dams have been constructed on the Columbia River and its tributaries, however, the volumes of sediment trapped behind the dams and a detailed understanding of changes in the surface sediment cover are not well understood. To better understand the effects of a dam on sedimentation within an individual pool, a collaborative field program was 
conducted by geologists and biologists from the USGS. The John Day Reservoir was selected for this pilot study because of a large amount of data that had already been compiled by USGS fisheries biologists, and because the John Day was being considered by the U.S. Army Corps of Engineers for partial drawdown. The John Day Reservoir, also known as Lake Umatilla, is located along the mainstem of the Columbia River, approximately $348 \mathrm{~km}$ (216 miles) upstream from the mouth. The reservoir, extending upriver to McNary Dam, is approximately $125 \mathrm{~km}$ long and $1 \mathrm{~km}$ wide with water depths up to $57 \mathrm{~m}$. Construction of the John Day Dam began in 1958 and was completed in 1968. The dam was built primarily for power generation and flood control, however irrigation and recreation are additional beneficial uses. The reservoir is surrounded by highly resistant basalts that form high cliffs around the western part and lower lying plateaus around the eastern part. Surrounding high plateaus contain very little natural vegetation as most of the area is heavily farmed for agriculture. A small number of tributaries enter the reservoir, the largest are the John Day River and the Umatilla River. Neither river is a major source of water and probably not a significant source of sediment.

New data collected during a two week field program included sidescan sonar coverage of a large part of the reservoir, high-resolution seismic-reflection profiles from a more limited area, and 48 ground-truth stations where underwater video observations were made and sediment samples and bottom photography were attempted. Preliminary results suggest little change to the area since completion of the John Day dam in 1968 (Figure 1). Orthophotographs taken in 1964, prior to filling the reservoir, show numerous gravel and cobble bars in the river, and subsequent bathymetric surveys show that these bars are preserved and appear not to have moved. The seismic-reflection profiles show that these bars are still present and that any sediment that blankets them or other parts of the reservoir floor is below the resolution of the seismic system (approximately $50 \mathrm{~cm}$ ). Although the seismic data do not show a thick accumulation of sediment covering the preimpoundment surface, the sidescan imagery does suggest that some parts of the reservoir are covered by a thin veneer of post-impoundment sediment while other parts appear to have no sediment cover. Several roads and railroad tracks remain well preserved on the lake floor and large areas of the western part of the reservoir appear to have outcrops of Tertiary volcanics still exposed on the reservoir floor. The eastern end of the reservoir appears to be mostly floored by gravel deposits with a surface sculpted by furrows. These furrows probably are the result of scouring by the stronger currents in the eastern part of the reservoir. Bars that were mined for aggregate still show the causeways leading to them as well as evidence of mining on the bars themselves. In contrast to these areas where pre-impoundment features are well preserved, other parts of the reservoir floor have a low-backscatter signature on the sidescan image that is interpreted to represent accumulations of finer-grained sediment. These areas are most common in the deeper parts of the reservoir along the original riverbed and in the lee of promontories and bars.

Video imagery and bottom photographs provide a higher-resolution view and document the actual sediment types on the floor of the reservoir. Well-rounded gravel, cobbles, and boulders observed in many photographs are interpreted to be pre-impoundment deposits while an unconsolidated mud and sandy-mud drape that was sampled at many stations is interpreted to be the result of post-impoundment deposition (Figure 1). Gravel, well- 
rounded cobbles, and boulders still remain uncovered by mud on the crests of some bars. Along the flanks of the bars and in the deeper parts of the reservoir cobbles and boulders had a thin veneer of sediment that partially covered them. At a few stations the sediment cover was thick enough that the cobbles were completely buried. Samples show that the sediment covering the cobbles is mud in the western part of the reservoir and that the sand content increases slightly in the eastern half of the reservoir.

The results of this survey show a discontinuous thin cover of fine-grained sediment has been deposited on the floor of this reservoir since impoundment. The sidescan imagery suggests this fine sediment covers approximately 50 percent of the reservoir floor. Assuming this sediment is on average $5 \mathrm{~cm}$ thick (based on video and sampling), the volume of post-impoundment sediment is approximately $3 \mathrm{Mm}^{3}$. This volume is small relative to the storage capacity of the reservoir, the influence of up-river dams on the sediment load provided to this reservoir and the importance of local sediment sources to this reservoir are needed to better understand the effectiveness of this reservoir as a sediment trap. 


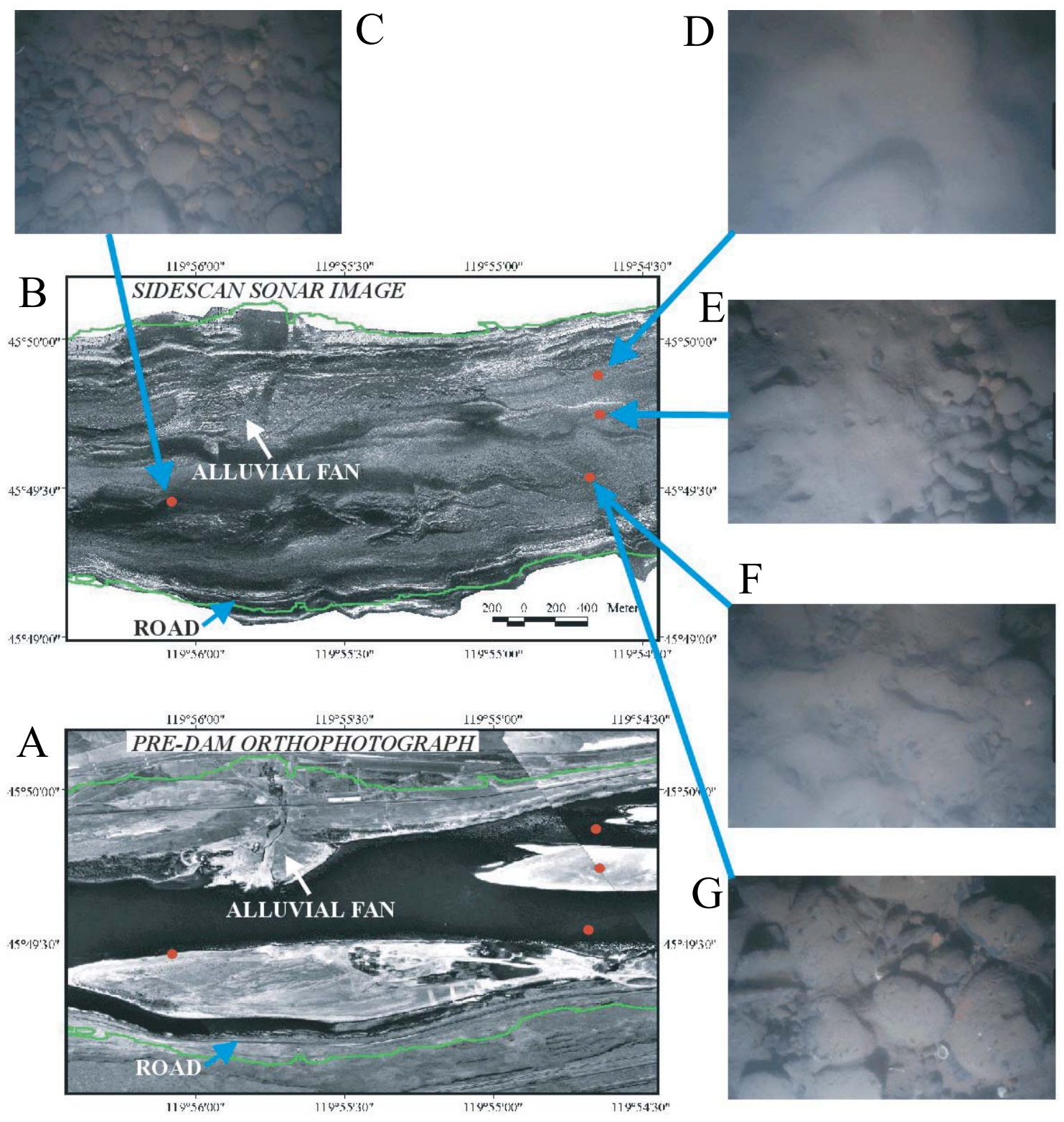

Figure 1. Orthophotograph taken prior to construction of the John Day Dam (A) and sidescan sonar image from the same area $(B)$. The presence of roads and the alluvial fan in the sidescan image indicates that the floor of the reservoir has not been significantly modified since construction of the dam. The photographs show well rounded cobbles (C), often with a thin veneer of finer sediment ( $D$ through $G$ ) exposed on the reservoir floor. 


\title{
WARRENTON BOREHOLE - SEDIMENTATION RATES
}

\author{
Diana L. Baker, Portland State University
}

\section{CONCLUSIONS}

The Lower Columbia River valley underwent a period of high sedimentation between 13,300 and 8,000 years before present. During that time period approximately $85 \mathrm{~m}$ of sediment accumulated at the site of the Warrenton borehole. The average sedimentation rate was $17 \mathrm{~m} / \mathrm{ka}$. The sedimentation rates then substantially decreased during the last 8,000 years to an average of $2.1 \mathrm{~m} / \mathrm{ka}$. This may suggest a lack of basin accommodation space for this later period.

\section{ACCOMPLISHMENTS}

In 1999 a 123 m deep borehole was obtained at the mouth of the Columbia River in Warrenton, Oregon. In 1999, ten $\mathrm{C}^{14}$ AMS dates were obtained to constrain sedimentation rates. These dates have been augmented by 5 new $\mathrm{C}^{14}$ AMS dates obtained in October 2000 (Figure 1). This core represents a time interval of 13,300 years.

Preliminary sedimentation rates were then calculated for five distinct intervals of time picked on the basis of a change in slope of the sedimentation curve.

\section{QUESTIONS}

What are the sediment fill rates for the Lower Columbia River valley?

- Age dating the summer 2000 vibracores (Vanderburgh et al., this volume) and integrating the data with the Warrenton Borehole data will be required to recalculate the sediment fill rates for the Lower Columbia River valley. The recalculations of Columbia River basin fill rates will require:

- New isopach mapping of the Missoula flood(s) deposits.

- Integration of the Grays Harbor sea level curve and the Columbia River basin sediment level curves.

- Application of the newly constrained sedimentation rates to basin depth/ volume curves for the Lower Columbia River Valley.

\section{ANALYSIS}

Preliminary sedimentation rates have been calculated for five distinct intervals of sedimentation picked on the basis of a change in slope of the sedimentation curve. The intervals and sedimentation rates are included in Table 1. The sedimentation rates 
calculated here can be compared to the sedimentation rates determined by Peterson and Phipps (1992) for Grays Harbor. The sedimentation rate for the first 3,000 years from the Warrenton core, $5.7 \mathrm{~m} / \mathrm{ka}$, appears to lag behind sedimentation observed at Grays Harbor. For the time period between 10,100 and 7,980 years before present a sedimentation rate of $31.6 \mathrm{~m} / \mathrm{ka}$ exceeds that of Grays Harbor. During the next 5,000 years, the sedimentation rate for the Warrenton core slows to a mere $1.3 \mathrm{~m} / \mathrm{ka}$. This sedimentation rate is slightly lower than that of Grays Harbor. Sedimentation increases again to $7.1 \mathrm{~m} / \mathrm{ka}$ during the next interval from 3,120 to 2,350 years before present. During the last 2,350 years the sedimentation rate has again slowed to $1.9 \mathrm{~m} / \mathrm{ka}$. Both the Warrenton and Grays Harbor data sets suggest a substantially lower sedimentation rate for the last 8,000 years

\section{REFERENCES}

Vanderburgh, S., Peterson, C., Baker, D., Qualman, D., Heeren, J., Percy, D., and Treat, R. this volume. Preliminary results of the Columbia River estuary vibracoring study, Southwest Washington Coastal Erosion Workshop Report 2000, U.S. Geological Survey Open-File Report.

Peterson, C.D., and Phipps, J.B. 1992. Holocene sedimentary framework of Grays Harbor Basin, Washington, USA, in Fletcher, C.H., and Wehmiller, J.F., eds., Quaternary Coasts of the United States: Marine and Lacustrine Systems, SEPM Special Publication No. 48, pp. 273-285.

Table 1. Warrenton Sedimentation Rates.

\begin{tabular}{ll}
$\begin{array}{l}\text { Years Before } \\
\text { Present }\end{array}$ & $\begin{array}{l}\text { Sed } \\
\text { Rate } \\
\text { (m/ka) }\end{array}$ \\
\hline 13,300 to 10,100 & 5.7 \\
10,100 to 7,980 & 31.6 \\
7,980 to 3,210 & 1.3 \\
3,210 to 2,350 & 7.1 \\
2,350 to 0 & 1.9
\end{tabular}




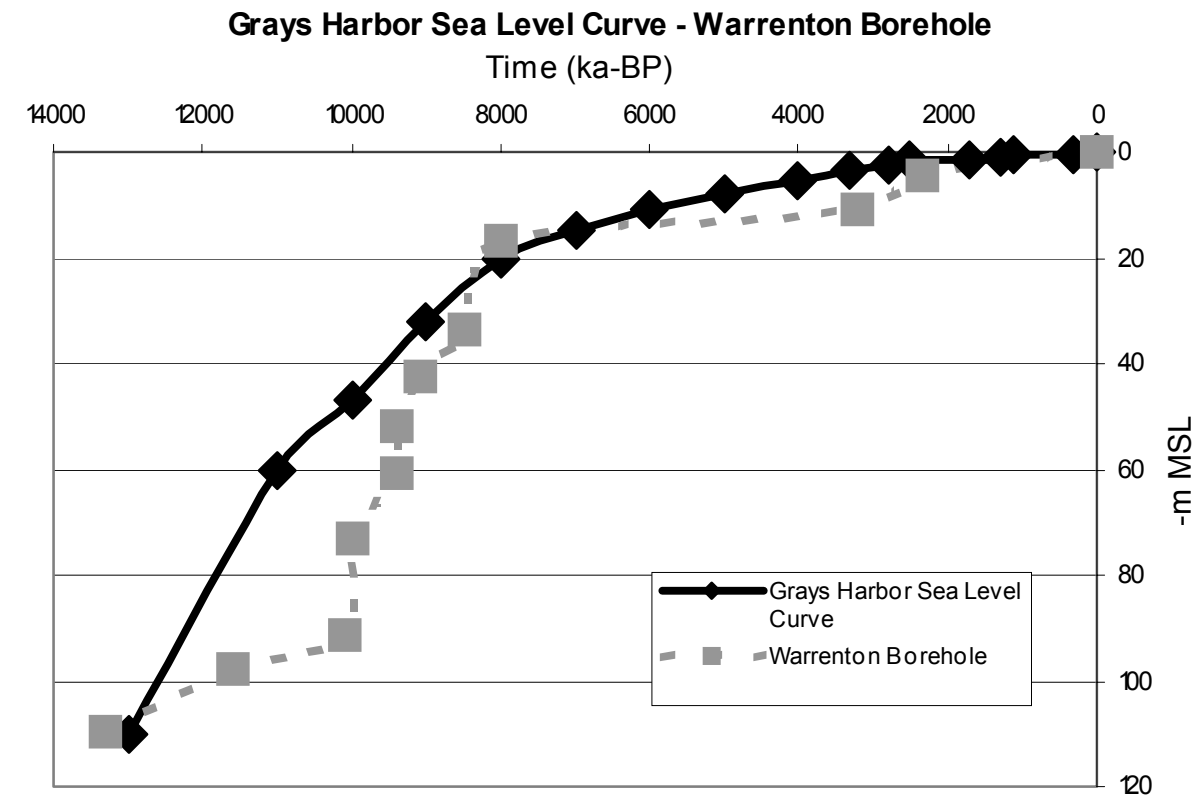

Figure 1. Grays Harbor sea level curve (Peterson and Phipps, 1992) and the sea-level curve derived from the Warrenton borehole. 


\title{
PRELIMINARY RESULTS OF THE COLUMBIA RIVER ESTUARY VIBRACORING STUDY
}

\author{
Sandy Vanderburgh, University College of the Fraser Valley \\ Curt Peterson, Portland State University \\ Diana Baker, Portland State University \\ Dave Qualman, Portland State University \\ Jeff Heeren, Portland State University \\ Dave Percy, Portland State University \\ Rebecca Treat, Portland State University
}

\section{PRELIMINARY CONCLUSIONS}

The study results indicate that a bay-head delta has prograded down river from the Clatskanie Floodplain Reach to the Woody Island Reach of the lower Columbia River estuary in late Holocene time. A lack of basin accommodation space in the bay-head delta islands of the Woody Channel Reach is demonstrated by the dominance of lateral channel migration during the latest-prehistoric time period. The delta front, or central bay depocenter, has been located in the lower Cathlamet Bay, Grays Bay, and Taylor Sands shoal region for the last part of the Holocene. Inter-tidal sand shoals and deeply incised tidal channels demonstrate active sand flux and minimal accommodation space in the central bay area at present. Fine-grained sediments in this portion of the estuary are winnowedout of the central bay shoals by wind wave re-suspension superimposed on ebb surface flow. Downstream of the delta front (west of the Astoria Bridge) basin accommodation space is transitional to the tidal inlet. Thin sand veneers over the Skipanon Channel entrance, Youngs Bay and Chinook Point flats, and over the entrance to Baker Bay, argue for limited accommodation space in the marginal bays prior to any early-historic sand influx. The potential thickness of the lower central-bay sand shoals (Desdemona and Taylor Sands) was not addressed in this shallow vibracore study.

\section{ACCOMPLISHMENTS}

Four major objectives were proposed and completed for this study:

1) Ground-truthing of historic bathymetric change maps of the lower estuary (Baker Bay, Youngs Bay, Grays Bay, Taylor Sands, Cathlamet Bay, and Woody Islands) was conducted. The Desdemona Sands were not cored to sufficient depth due to wavecompacted sands.

2) In order to establish sediment composition in late prehistoric, early-historic, and latehistoric deposits, approximately 30 cores were drilled to prehistoric deposits, while all of the cores recovered modern deposits.

3) At least 30 cores collected during the study contain abundant woody material and peat and/or shell fragments for radiocarbon dating to establish prehistoric sedimentation 
rates. Subsidence events dating prehistoric earthquakes were observed in 10-15 of the core sites.

4) Analysis of historic time intervals was facilitated by the collection of about 20 cores that exhibited muddy upper sections that can be used to search for anthropogenic tracers, e.g., Cs137, and other radioisotopes, organic byproducts, and trace metals, that may serve as historic timelines.

\section{Data Collection}

A total of 44 vibracore sites and 3 cut-bank sections were analyzed in order to obtain representative stratigraphic sections from the upper, middle, and lower reaches of the Columbia River estuary (Figure 1). Vibracoring was performed with $7.5 \mathrm{~cm}$ diameter aluminum pipe and a boat-mounted drill platform (Figure 2). Average vibracore penetration depths of $5 \mathrm{~m}$ (lower reaches) and maximum penetration of $7 \mathrm{~m}$ in floodplain settings (upper reaches) were obtained. All vibracore and cut-bank sites were mapped using global positioning systems with $2-5 \mathrm{~m}$ horizontal resolution (real-time). Water depth and time were also recorded for calibration of deposit surface to MTL (mean tide level) with NOAA predicted tide tables.

Approximately $200 \mathrm{~m}$ of core was logged to within $1-\mathrm{cm}$ resolution during the field study. Cores were logged for lithology, sedimentary structures, sand grain-size, woody fragments, shell fragments, and paleo-liquefaction structures. All core sections were labeled, digitally photographed, and recorded in a database. An average compaction of $1.3 \mathrm{~m}$, or 20 percent, was identified for the core samples and core recovery was generally greater than 90 percent. In addition, 60 radiocarbon samples were collected. The $\mathrm{C} 14$ and core samples are currently archived in the Geology Department at Portland State University.

A preliminary field report of the vibracoring study was submitted to the U.S. Geological Survey, Coastal and Marine Geology Program, at the end of the field season. The study is currently being prepared for publication as a USGS open-file report.

\section{QUESTIONS}

Radiometric age dating is required to delineate timelines of prehistoric and historic sedimentation rates. The core samples contain several different prehistoric time-marker horizons including Cascadia earthquake subsidence horizons, tephra layers, flood deposits, and/or gross-lithologic changes that can be $\mathrm{C} 14$ dated. Early historic timelines that might be apparent in the cores include Corbicula fluminea bivalves (early 1900s), sawn lumber or artifacts, and oxidized core tops (recent bioturbation). Can early historic timelines also be established from introduced pollens, diatoms, and anthropogenic geochemical tracers in the muddy sections?

Can additional vibracoring identify the lower Columbia River estuary as a sediment sink or source? 
In addition to establishing recent basin sedimentation rates, the prehistoric-historic transitions should also be of interest to environmental studies. For example, can the cores be used to establish background contaminant levels, pre-impoundment bio-productivity (macro- and micro-fossils), and local substrate conditions of oxidation/reduction, permeability, etc.?

Radiocarbon dating is also needed to constrain the ages of late-prehistoric channel migrations, the tephra layers, and the catastrophic flood-sand layers in the Clatskanie and Puget Island sites. Future vibracoring in upriver floodplains is warranted to establish event correlation with source tributaries, volcanic centers, etc. Diatom analysis and/or radiocarbon dating will be required to establish historic sedimentation rates in the more uniform deposits of the Desdemona and Taylor Sands, and Cathlamet Bay deposits. Is it possible to resolve the relative age and origin of the coarser sand fractions in the lower estuary channel axes using deeper vibracores (USACE shipping channel)?

\section{ANALYSIS}

The study findings suggest that basin accommodation space in the lower Columbia River estuary is limited, i.e., shallow tide flats, shoals, central islands, and lateral accretion floodplains dominate the surficial geomorphology. Wind wave re-suspension in the lower tidal basin erodes exposed shoal tops to just below MLLW (mean lower low water), giving the appearance of more accommodation space than does actually exist. Deep channels $(10-15 \mathrm{~m})$ are incised into shoals of the central bay area, or are pinned against valley-wall hard-points. Some secondary channels located adjacent to dredge disposal sites (Cathlamet Bay and the Woody Island Reach) have shallowed dramatically $(2-7 \mathrm{~m})$ since the most recent bathymetric charts. However, the distal channels (shoreward of the islands) show relative stability or slight erosion, and little or no shallowing relative to the latest bathymetric updates. In contradiction to the geologic 'late-stage' filling of the lower tidal basin (Baker, this volume), the modern shorelines show little or no progradation. Wind-wave erosion has produced modern scarps $(>0.5 \mathrm{~m})$ around most of the exposed shorelines. The dominant process appears to be channelized sediment throughput, rather than shoreline ravinement or tidal flat progradation.

\section{Stratigraphy}

The lithologies of the shoals, open bays, and island platform deposits in the lower Columbia River tidal basin are sand-dominated. Modern surface deposits are relatively similar to early historic and late-prehistoric deposits in most of the central bay settings. Modern tidal flats from the exposed areas of Grays Bay, Taylor Sands, and Cathlamet Bay are dominated by active wind wave re-suspension superimposed on tidal currents. No seasonal mud drapes were preserved on any of the exposed shoals and burrow openings are uncommon in most of the central bay tidal flats. Wave compacted sand was experienced during vibracoring of the shoal tops $(+0.5 \mathrm{~m} \mathrm{MLLW}=<1 \mathrm{~m}$ penetration) but not in deeper shoal margins (-0.5 m MLLW $=2-3 \mathrm{~m}$ penetration) in the Taylor Sands and Desdemona Sands. Clay-rich accretionary bank deposits were not observed in channel margin vibracores from central bay areas and few mud laminae were identified in FU (fine upper)-MU (medium upper) sand. Occasional, thin, mud laminae were observed in 
fining-upward sand units of the Woody Island Reach, Cathlamet Bay, and Grays Bay. Mud laminae (drapes) are present but uncommon in deeper (3-4 m subsurface) sand sections of Taylor Sands and Desdemona Sands (Figure 3).

Muddy surfaces of prehistoric islands, and floodplains down river of the Clatskanie Reach are shallow (1-4 m), and underlain by tidal flat or channel sand. The thickest mud units $(>1 \mathrm{~m})$ in the lower Columbia River tidal-flat settings are restricted to (1) back-bay delta heads (Youngs Bay, Grays Bay), (2) wind-protected shorelines (Baker Bay), and (3) abandoned channels protected by windward shoals (Cathlamet Bay). Mud caps on floodplain surfaces of the Clatskanie and Woody Island Reaches rapidly thin to the north, indicating northward migration of the main channel in latest prehistoric time. Latestprehistoric channel migration is indicated by distinctive landforms such as translational bar forms, oxbows, and drainage channels.

Organic-rich tidal-flats deposits change color from black (down river of Tongue Point) to gray (upriver of Cathlamet Bay). Mica is an abundant trace mineral (3-5 percent) down river to Cathlamet Bay, but limited $(<1$ percent) in the Taylor and Desdemona Sands area. Shell fragments are uncommon throughout the study area. Bivalve fragments (razors, cockles, sand dollars, etc.) are absent in cores from the Desdemona Sands where beach and inlet facies are delineated. By contrast, razor clam shell fragments were observed in dredge spoils from Baker Bay Sand Island. The overall distribution of sand, mud, and organic-rich deposits define three facies in the open-bay shoals of the lower tidal basin, i.e., (1) fluvial-tidal facies upriver of Tongue Point, (2) tidal-fluvial facies between Tongue Point and Chinook Point, and (3) tidal inlet facies west of Chinook Point.

Oxidation zones that may represent historic sedimentation intervals were observed in the upper sections of vibracores at several sites in Baker Bay, Youngs Bay, and Grays Bay. At least one such transition occurred just below an in-situ Corbicula fluminea bivalve. Coseismic subsidence features are apparent but uncommon in the cores. Coseismic subsidence sequences are restricted to the back-bay settings of Grays Bay, Cathlamet Bay, the Woody Island Reach, and the Clatskanie floodplain. At least 3-4 coseismic subsidence events are recorded in the Clatskanie floodplain (Figure 4). Cut bank exposures of buried peat horizons were measured in Grays Bay, and the Woody Island Reach. The westernmost record of buried peat horizons is from the Clatsop vibracore site and cut-bank site east of the Skipanon channel; buried peats overlain by thin sand layers are an indication of co-seismic subsidence events followed by a tsunami. A cut-bank section at the Skipanon entrance contains a 3-cm thick tsunami sand layer above the latest buried peat (1700 AD event?) and a discontinuous tsunami sand laminae above the second buried peat $(1,100$ yrbp event?).

\section{REFERENCES}

Baker, D.L. this volume. Warrenton borehole-Sedimentation rates, Southwest Washington Coastal Erosion Workshop Report 2000, U.S. Geological Survey Open-File Report. 


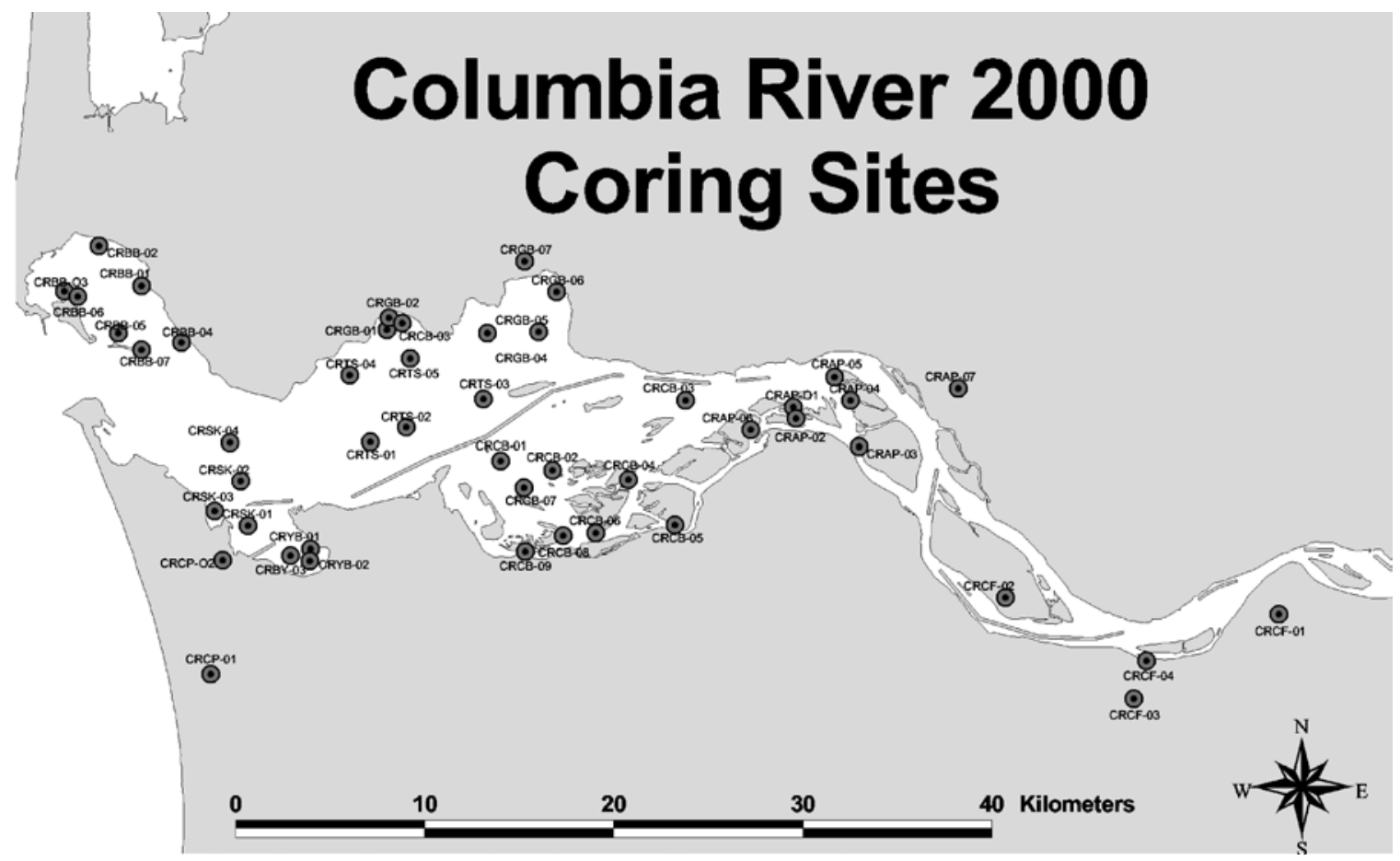

Figure 1. Location of core sites and cut-bank sections in the lower Columbia River estuary.

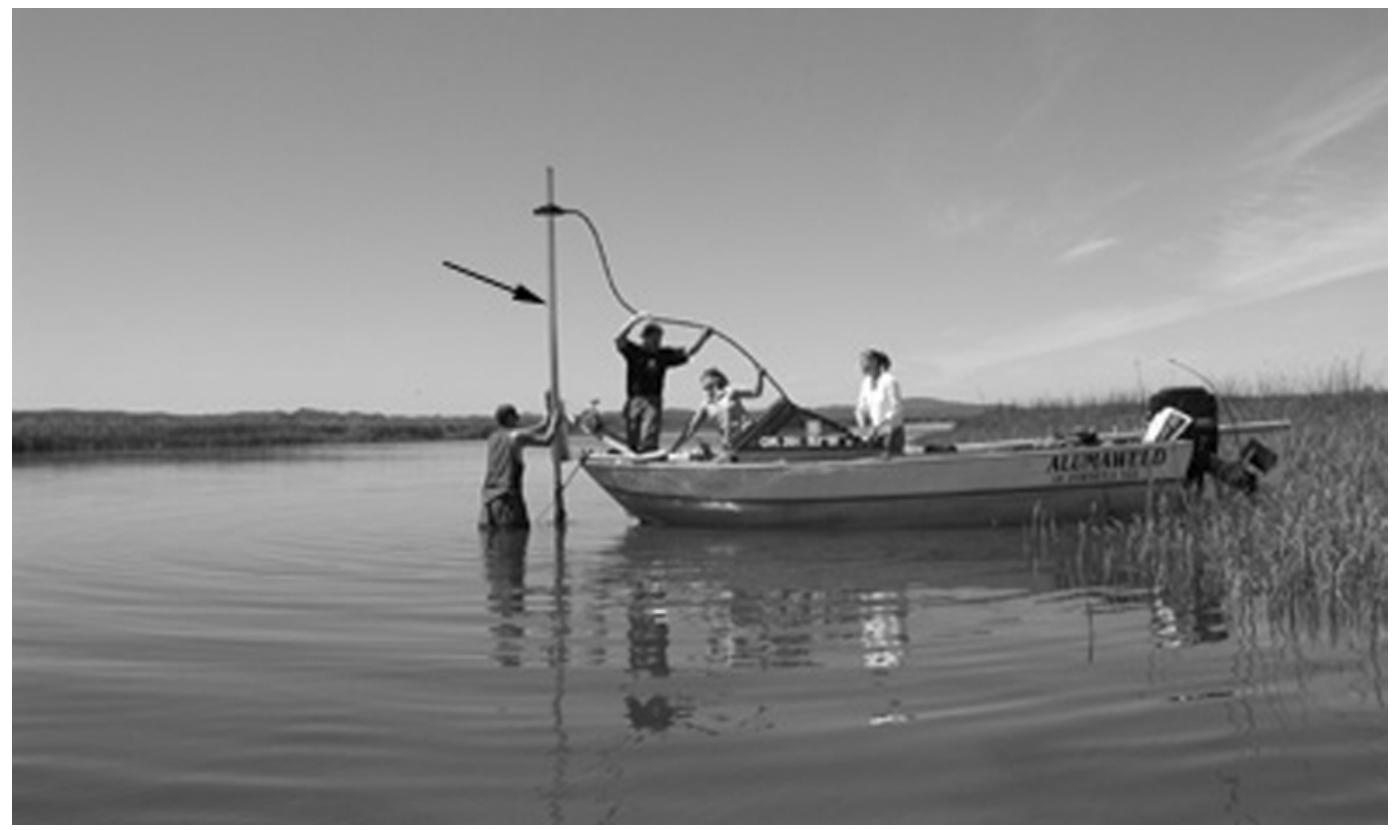

Figure 2. Vibracoring apparatus used in the study. 


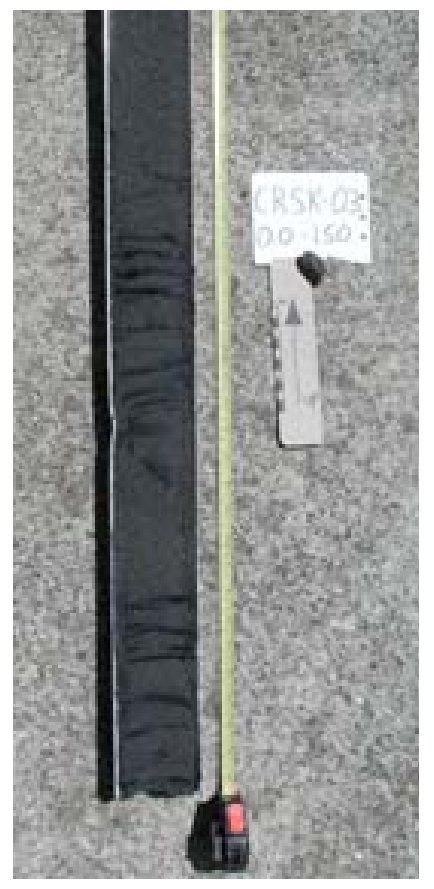

Figure 3. Core sample of the Desdemona Sands taken near the mouth of the Skipanon Channel (CRSK-03, 0.0-1.50 m depth). Note abundance of sand and few mud laminae.

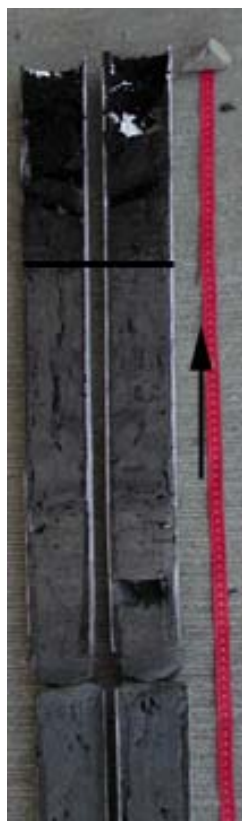

Figure 4. Core sample of the Clatskanie Floodplain (CRCF-04, 1.5-2.2 $\mathrm{m}$ depth). Dark line shows the transition from floodplain mud to paleo- floodplain surface. Top of core represents a coseismic subsidence event. 


\title{
SEPARATING HUMAN AND CLIMATE IMPACTS ON COLUMBIA RIVER HYDROLOGY AND SEDIMENT TRANSPORT
}

\author{
David A. Jay, Department of Environmental Science and Engineering, Oregon \\ Graduate Institute \\ Pradeep Naik, Department of Environmental Science and Engineering, Oregon \\ Graduate Institute
}

\section{CONCLUSIONS}

Analyses of river flow and sediment transport records for the Columbia River and other climate data suggest the following:

1) The mean flow of the Columbia River is now about 16 percent smaller than it was in the latter part of the $19^{\text {th }}$ century. The change is due to climate change ( $\sim 9$ percent) and water withdrawal ( $\sim 7$ percent).

2) Spring freshet peak flows are now $\sim 44$ percent less than they were before 1900, and peak flow occurs 14-30 days earlier. Flow regulation is the primary reason for the decrease in maximum freshet flow. Climate, flow regulation, and irrigation depletion have all contributed to the change in freshet timing.

3) Major decreases relative to late $19^{\text {th }}$ century levels have occurred in Columbia River annual average total sediment ( $\sim 60$ percent) and sand discharge (70 percent). These decreases appear to be due primarily to the decrease in freshet flow. These estimates, prepared using a model based on limited observations, are sensitive to historical changes in the supply of fine sediment.

4) Because of the non-linear dependence of sediment transport on flow, changes in sediment transport cannot be apportioned precisely between human and climate influences. Climate impacts on sediment load are, however, modest in comparison to those of flow regulation and water withdrawal.

5) The occurrence of overbank flow has decreased drastically, because revetments have increased the flow level necessary to cause overbank flow at the same time that climate change and human impacts have reduced the incidence of high flows.

6) Flow regulation for flood control and power generation has greatly changed the spectrum of Columbia River flow, decreasing energy at periods longer than a few months and increasing it at shorter periods.

7) There are three "styles" apiece for Columbia River spring and winter freshets. Climate change projections suggest that several of these freshet styles will become less common if the climate warms. One style of winter freshet may, however, become more prominent. 


\section{ACCOMPLISHMENTS}

Our studies provide the most detailed study to date of Columbia River hydrology. They include implications of climate processes for flow and sediment transport, changes in disturbance frequency and the flow power spectrum, and separation of human and climate influences.

\section{QUESTIONS}

A study of this sort inevitably raises as many questions as it resolves. Amongst the issues still to be considered are the following:

1) Historical changes in the estuarine current, salinity and sediment transport regimes remain poorly understood. Understanding them will require a combination of historical data analyses, numerical modeling, and new observations.

2) The fate of the sediment no longer supplied to the estuary is unknown.

3) Historical changes in the system's tidal-fluvial interactions have not been analyzed. Considering the role of tides in sediment transport and the fact that power peaking cycles at Bonneville Dam create a "pseudo-tide" propagating down river, this issue deserves attention.

4) Changes in export of sediment from the estuary to the ocean are not understood. These stem directly from changes in sediment supply to the estuary, and indirectly from alteration of estuarine topography and circulation processes. The latter are in part driven by changes in river flow.

5) Historical changes in the quality of sediment supplied to the estuary have not been defined, but may have substantially impacted the estuarine ecosystem, whose food web is based on detritus captured in estuarine turbidity maxima.

\section{ANALYSIS \\ Strategic Considerations}

Distinguishing human and climate impacts on flow and sediment transport is a key aspect of a range of issues in the Columbia River and its estuary, from restoring salmon runs to managing dredged material and coastal erosion. The work described here has sought to understand the impacts of hydrological changes on juvenile salmonids and on sediment supply to the estuary. Achieving the desired understanding of human and climate effects requires confronting three conflicting methodological issues. The first is the disparity between the relatively modest changes in river flow that have occurred and the very large historical ecosystem response. This suggests that it is necessary to seek points where climate or human-induced changes are amplified by the ecosystem. One example of this leverage is the effect of sediment transport on salmonids and the ecosystem that supports them. Because of threshold effects and the non-linear relationship between flow and sediment transport, small fluctuations in climate or changes in flow regulation cause large 
changes in the timing and magnitude of sediment transport, overbank flow, and perhaps in visually-based predation. The quality of the sediment input, important to its utilization by the estuary, has also been affected. Bottom et al. (2001) have attempted to understand how changes in hydrology and salmonid life-history diversity have interacted to cause the observed major decreases in Columbia River salmonid populations.

Another issue, an especially vital one for management purposes, is the separation of the anthropogenic and climate impacts in a non-linear system. The incidence of overbank flow and its impacts on salmonid floodplain access and the supply of organic matter and large woody debris to the estuary is a good example. Either flow regulation or climate change alone would individually have caused much smaller changes in overbank flow than the two have together. How then do management agencies assign "cause and effect" and apportion mitigation expenses? Finally, there is the problem of multiple time scales. Columbia River flow and sediment transport are subject to climate fluctuations on scales both long and short relative to the 140-year flow record available. Human management has substantially altered key parts of the flow spectrum, changing the energy at frequencies between about two years and a few hours. In this circumstance, there is not a unique definition of the historical base or of human and climate changes therein.

Separation of anthropogenic and climate effects on Columbia River hydrologic processes has been facilitated by definition of three measures of river flow (Figure 1):

- Observed flow - the flow actually observed at a gauge, available on a daily basis for 1878 to present.

- Estimated adjusted flow - the observed flow corrected for reservoir manipulations calculated by the U.S. Geological Survey on a monthly basis for 1878-1999 as per Orem (1968).

- Estimated virgin flow - an estimate of the river flow as it would be without human alteration; i.e., the observed flow corrected for irrigation depletion and return flows, as well as for reservoir manipulation (Bonneville Power Administration, 1993; Naik and Jay, in review).

The effects of climate fluctuations and change can be seen in the virgin flow time series, independent of human perturbations. Comparison of the virgin and adjusted flows allows evaluation of the effects of irrigation depletion. The difference between the adjusted and observed flows quantifies the impacts of reservoir manipulations. The total change due to the combination of human and anthropogenic effects can be seen by comparison of the pre-1900 virgin flows with the contemporary observed flows. Because of the non-linear dependence of sediment transport on flow, there is no unique decomposition of the changes in sediment transport into human and climate effects. It is evident, however, that climate effects have made only a modest contribution to the total changes to sediment transport over time. 
The differences in the time scales of human alteration and climate fluctuations/change can be dealt with by averaging over different time scales. Thus for example, the climatic "present" has been defined as the period since 1945, which encompasses one full Pacific Decadal Oscillation (PDO) cycle plus (perhaps) the beginning of a new cold PDO phase. The pre-development climate regime is conveniently described in terms of averaging of the data before 1900. In terms of management, there are three periods: a) the nearly unaltered hydrologic regime that prevailed before 1900 , b) the intermediate phase of irrigation development and dam building from 1900 to 1970, and c) the contemporary period (after 1970) of highly centralized hydrologic management.

The hydrologic issues discussed in the following paragraphs are considered in greater detail by Naik and Jay (in review, in prep.) and Jay and Naik (in prep.).

\section{Setting and Climate Influences}

The Columbia River has the largest annual flow (ca. $7,300 \mathrm{~m}^{3} \mathrm{~s}^{-1}$ at the mouth) of any river on the Pacific coast of North America. Its annual average sediment discharge (ca. 10 million m tons $\mathrm{yr}^{-1}$ ) is not unusually large, however, and is exceeded by several other western rivers. For hydrologic purposes, the Columbia River basin can be divided by the Cascade Mountains into western and interior sub-basins. The interior sub-basin (with 92 percent of the surface area and three-quarters of the flow) is, aside from its Canadian part, relatively arid. The Canadian component of the interior sub-basin supplies almost half the total flow of the interior sub-basin from only one-quarter of the total surface area. Almost the entire interior sub-basin flow passes the gauge at The Dalles, which has the longest daily flow record on the U.S. west coast (1878-present). The western sub-basin contains only 8 percent of the basin's area, but contributes about one-quarter of the flow. The Willamette River, a major tributary to the Columbia River, is typical of the western subbasin; the flow record at Albany extends from 1892 to present.

Cyclical climate phenomena exert a strong influence on Columbia River hydrology. Although the history of climate fluctuations in the region during the $19^{\text {th }}$ century is unclear, the effects of two cyclical processes were quite prominent throughout the $20^{\text {th }}$ century:

a) The Pacific Decadal Oscillation has a cycle that lasts $40-60$ years and has likely been active for at least 300 years (Finney et al., 2000). The cold phase of the PDO (e.g., 1945-1976) has generally high river flow (Mantua et al., 1997), whereas low river flows prevail during the warm phase (e.g., 1977 to 1995). A new cold phase may have begun about 1996.

b) Indices of the El Niño-Southern Oscillation (ENSO; typically 3-7 yrs in duration) are also correlated with Columbia River flow (Redmond and Koch, 1991; Kathya and Dracup, 1993; Dracup and Kathya, 1994). The PDO and ENSO cycles interact such that El Niño years are most intense during the warm PDO phase and La Niña years during the cold PDO phase (Gerushonov et al., 1999). The average annual Columbia River flow at The Dalles is 111 percent of normal during cold PDO-La Niña years, whereas it is only 85 percent of normal during 
warm PDO-El Niño years. The corresponding figures for the Willamette River are 119 percent and 81 percent (Figure 2).

Flow fluctuations are amplified by fluvial sediment transport, because sediment transport varies more than linearly with flow (Figure 3). Total sediment load during cold PDO-La Niña years is $>200$ percent of that during warm PDO-El Niño years in both the Columbia (at Vancouver) and the Willamette Rivers. Furthermore, climate effects on sand transport are even stronger than those on total sediment load.

The Columbia basin's climate response is conditioned by its position within a latitudinal band of strong response to both the ENSO and PDO cycles. The flow per unit area is much larger in the western than in the interior sub-basin, and latitudinal differences in the timing of smowmelt influence spring freshet properties. Still, there are only modest variations across the basin in response to ENSO or PDO forcing.

\section{Annual Average and Freshet Flows}

Changes in annual average flow are an integral measure of system alteration. The mean annual average Columbia River flow at The Dalles has decreased ca. 17 percent from $6,320 \mathrm{~m}^{3} \mathrm{~s}^{-1}$ (1879-1899 estimated natural or virgin flow) to $5,250 \mathrm{~m}^{3} \mathrm{~s}^{-1}(1970-1999$ observed flow). A $\sim 9$ percent decrease is due to climate change, and $\sim 8$ percent is due to irrigation depletion and reservoir manipulation.

Spring freshet timing, strength and duration are quite important to downstream migrant juvenile salmon as well as to sediment supply to the estuary and coasts. Spring-freshet properties have been much more highly altered than the mean flow. The average natural or virgin flow for the spring-freshet season (May- July) was $\sim 13,600 \mathrm{~m}^{3} \mathrm{~s}^{-1}$ before 1900 . This has decreased by $\sim 5,870 \mathrm{~m}^{3} \mathrm{~s}^{-1}$ (43 percent) to $7,740 \mathrm{~m}^{3} \mathrm{~s}^{-1}$, with most of this reduction ( 26.5 percent) due to flow regulation, 11 percent due to irrigation depletion, and 5.6 percent due to climate change. Thus, freshet-season flow at The Dalles is now only 148 percent of the current (reduced) mean flow, while it was 215 percent of the higher $19^{\text {th }}$ century flow. Flow regulation and the annual irrigation cycle have also increased fall and winter flows, the latter because of pre-release of water before the freshet.

The observed maximum daily spring freshet flow has been reduced slightly more than freshet season flow, from $19,300 \mathrm{~m}^{3} \mathrm{~s}^{-1}(1858-1899)$ to $10,870 \mathrm{~m}^{3} \mathrm{~s}^{-1}$ (1970-1999), a decrease of 44 percent. This is a change from 305 percent to 207 percent of the mean flow. The timing of the maximum spring freshet flow has also changed. Maximum daily spring freshet flow now typically occurs about two weeks earlier than during the $19^{\text {th }}$ century, at water year-day 241 (May 28) instead of at water year-day 256 (June 12). Continuous wavelet transform analysis suggests a larger change in timing of about a month. The difference between the two estimates of freshet timing is related to the change in shape of the freshet hydrograph, which has been made more prolonged by flow regulation. Specifically, there is now pre-release of flow prior to the freshet peak and desynchronization of freshet peaks in the various sub-basins. 
Changes in the western sub-basin have been similar to those in the interior sub-basin, and are exemplified by the Willamette River. The observed annual average Willamette River flow at Albany has decreased from $\sim 460 \mathrm{~m}^{3} \mathrm{~s}^{-1}$ for $1893-1900$ to $\sim 390 \mathrm{~m}^{3} \mathrm{~s}^{-1}$ for 19701999 , or $\sim 15$ percent. Late summer and fall (August to December) flows have been augmented, whereas average monthly flows during the January to July periods have decreased.

There has been a change in average annual flow at the mouth that mirrors changes in the two sub-basins. The long-term average flow at the mouth of the Columbia River is $7,300 \mathrm{~m}^{3} \mathrm{~s}^{-1}$ (1892-1999). The value of the Columbia River flow at the mouth prior to 1900 was $\sim 8,530 \mathrm{~m}^{3} \mathrm{~s}^{-1}$, and has decreased to $\sim 7,080 \mathrm{~m}^{3} \mathrm{~s}^{-1}(1970-1999)$.

\section{Changes in Sediment Transport}

Hindcasts of total sediment load and sand transport have been made using a rating curve, based on 8 years of sediment transport data collected during the 1960s (Haushild et al., 1966; Hubbell et al., 1971). These hindcasts suggest that average sediment transport from the interior sub-basin has decreased from ca. 21 million metric tons (1858-1878) to $\sim 8$ million metric tons (1970-1999), a reduction of $\sim 60$ percent. Hindcast sand transport was $>10$ million metric tons for 1858-1899, which has decreased to 3.2 million metric tons, a reduction of $\sim 70$ percent. Most of the reduction in interior sub-basin sediment transport is related to the dam system, especially reduced spring freshet flow. Hindcast Willamette River total sediment transport for 1893-1903 was 2.4 million metric tons, whereas it was only 1.5 million metric tons for 1970-99, a reduction of $\sim 35$ percent. It is unclear whether sediment transport in the Willamette has been less affected by flow regulation, or whether the absence of flow data for the 1878-1892 period of very high flows has skewed the result.

\section{Disturbance Frequency and Freshet Styles}

The frequency and magnitude of disturbance to the river system by major floods is important both to salmonids and society. The historic bankfull flow level of the Columbia was $\sim 18,000 \mathrm{~m}^{3} \mathrm{~s}^{-1}$ for the mainstem below Vancouver. Modern bankfull level is set by the standard project flood level of $\sim 24,000 \mathrm{~m}^{3} \mathrm{~s}^{-1}$ for the lower river. Some overbank flow occurred in multiple years before 1900. Flow regulation and water withdrawal have made overbank flow (above $24,000 \mathrm{~m}^{3} \mathrm{~s}^{-1}$ ) rare, with significant events occurring only five times since 1948 (Figure 4). Climate is a secondary factor with regard to the incidence of overbank flow. Overbank flow is now rare even during cold PDO phases, and it was totally absent during the last PDO warm phase (1977-1995).

Flow regulation for flood control and power generation has greatly changed the spectrum of Columbia River flow. Low-frequency flow variations with periods between $\sim 2$ yrs and 6 months have been suppressed by the dam system, whereas high frequency variations associated with power peaking have been greatly augmented. The daily power peaking cycle also perturbs the diurnal (daily) tidal signal in the river, essentially creating an artificial tide that propagates seaward from Bonneville Dam. This pseudo-tide interacts with river flow and may affect mainstem spawning of salmonids below Bonneville Dam. 
The flow cycle is different each year, but there are three recurring styles of spring freshets: a) a large winter snow pack without exceptional spring rain (e.g., 1974 and 1997), b) a normal winter snow pack with very high spring rainfall (e.g., 1948), and c) a large winter snow pack combined with very high spring rainfall (e.g., 1894). The largest known freshet (1894) was of type c), and the second largest (1948) was of type b). There are also three types of winter freshets, based on the source of the flow: a) western sub-basin only, b) interior plus western sub-basin, and c) interior sub-basin only. All winter freshets are generated by rain-on-snow events, and the largest known freshets (e.g., 1861, 1881 and 1892) involved both sub-basins. To date, there has only been one example of a winter freshet that affected only the interior sub-basin (1934), and this example is not perfect, because part of the western sub-basin in Washington was affected. The Canadian portion of the interior sub-basin is not usually affected by winter floods.

\section{Effects of future climate change}

Although climate effects on hydrology have been and will likely remain over the coming decades smaller than those of human manipulation, it is still vital to consider how climate will constrain future management. Climate projections covering the study area (e.g,. Hamlet and Lettenmaier, 1999; Miles et al., 2000) suggest gradual regional warming, possibly accompanied by higher precipitation, especially in winter. This would likely lead to increased incidence of winter freshets (especially those involving snowmelt in the interior sub-basin) and lower natural spring freshet flows. These changes would exacerbate conflicts over water supply during the critical spring freshet period, by increasing demand and decreasing natural flows. If the climate regime shifted back to a cold PDO regime (ca. 1996), however, the impact of longer term climate change may be delayed 20-30 years. Also, because rain-on-snow events are particularly good at causing erosion of poorly vegetated soils (Waananen et al., 1971), an increased incidence of winter freshets may cause an increase in fine sediment transport in the system.

\section{ACKNOWLEDGEMENTS}

This study has been supported by the National Science Foundation, Bonneville Power Administration, and the National Marine Fisheries Service.

\section{REFERENCES}

Bonneville Power Administration 1993. 1990 level modified streamflow (1928-89), $279 \mathrm{p}$.

Bottom, D.L., Simenstad, C.A., Baptista, A.M., Jay, D.A., Burke, J., Jones, K.K., Casillas, E., and Schiewe, M.H. 2001. Salmon at river's end, the role of the estuary in the decline and recovery of Columbia River salmon, National Marine Fisheries Service, Seattle, WA., various paginations.

Dracup J.A., and Kathya, E. 1994. The relationships between U.S. streamflow and La Niña events, Water Resources Research, 30, pp. 2133-2141. 
Finney, B.P., Gregory-Eaves, I., Sweetman, J., Douglas, M.S.V., and Smol, J.P. 2000. Impacts of climatic change on Pacific Salmon abundance over the past 300 years, Science, 290, pp. 795-799.

Gershunov A., Barret, T.P., and Caya, D.R. 1999. North Pacific interdecadal oscillation seen as factor in ENSO-related North American climate anomalies, EOS, Transactions, American Geophysical Union, 80 (3).

Hamlet, A.F., and Lettenmaier, D.P. 1999. Effects of climate change on hydrology and water resources in the Columbia River basin, Journal of the American Water Resources Association, 35, pp. 1597-1623.

Haushild, W.L., Perkins, R.W., Stevens, H.H., Dempster, G.R., and Glenn, J.L. 1966. Radionuclide transport in the Pasco to Vancouver, Washington reach of the Columbia River July 1962 to September 1963, U.S. Geological Survey Open-File Report, various paginations.

Hubbell, D.W., Glenn, J.L., and Stevens, Jr., H.H. 1971. Studies of sediment transport in the Columbia River estuary, Proc. Technical Conf. on Estuaries in the Pacific Northwest, Proceedings Circular 42, pp. 190-226.

Jay, D.A., and Naik, P. 2000. Climate effects on Columbia River sediment transport, Southwest Washington Coastal Erosion Workshop Report 1999, U.S. Geological Survey Open-File Report 00-439, pp. 97-106.

Jay, D.A., and Naik, P.K. in prep. Distinguishing human and climate influences on the Columbia River: Part 2: changes in disturbance frequency and power spectrum, to be submitted to Water Resources Research.

Kathya, E., and Dracup, J.A. 1993. U.S. streamflow patterns in relation to the E1 Niño/ Southern Oscillation, Water Resources Research, 29, pp. 2491-2503.

Mantua, N.J., Hare, S.R., Zhang, Y., Wallace, J.M., and Francis, R.C. 1997. A Pacific interdecadal climate oscillation with impacts on salmon production, Bulletin of the American Meteorological Society, 78(6), pp. 1069-1079.

Miles, E.L., Snover, A.K., Hamlet, A.F., Callahan, B., and Fluherty, D. 2000. Pacific Northwest regional assessment: the impacts of climate variability and climate change on the water resources of the Columbia River basin, Journal of the American Water Resources Association, 36, pp. 399-420.

Naik, P.K., and Jay, D.A. in review. Columbia River virgin flow estimation, 1879-1928, submitted to Water Resources Planning and Management. 
Naik, P.K., and Jay, D.A. in prep. Distinguishing human and climate influences on the Columbia River: Part 1: changes in mean flow and sediment transport, to be submitted to Water Resources Research.

Orem, H.M. 1968. Discharge in the lower Columbia River basin, 1928-65, Circular 550, U.S. Geological Survey, 24 p.

Redmond, K.T. and Koch, R.W. 1991. Surface climate and streamflow variability in the western United States and their relationship to large-scale circulation indices, Water Resources Research, 27, pp. 2381-2399.

Waananen, A.O., Harris, D.D., and Williams, R.C. 1971. Floods of December 1964 and January 1965 in the far Western States Part 1, Description, Geological Survey Water-Supply Paper 1866-A, 265 p. 
Columbia Flow Hydrographs at The Dalles (1970-99)

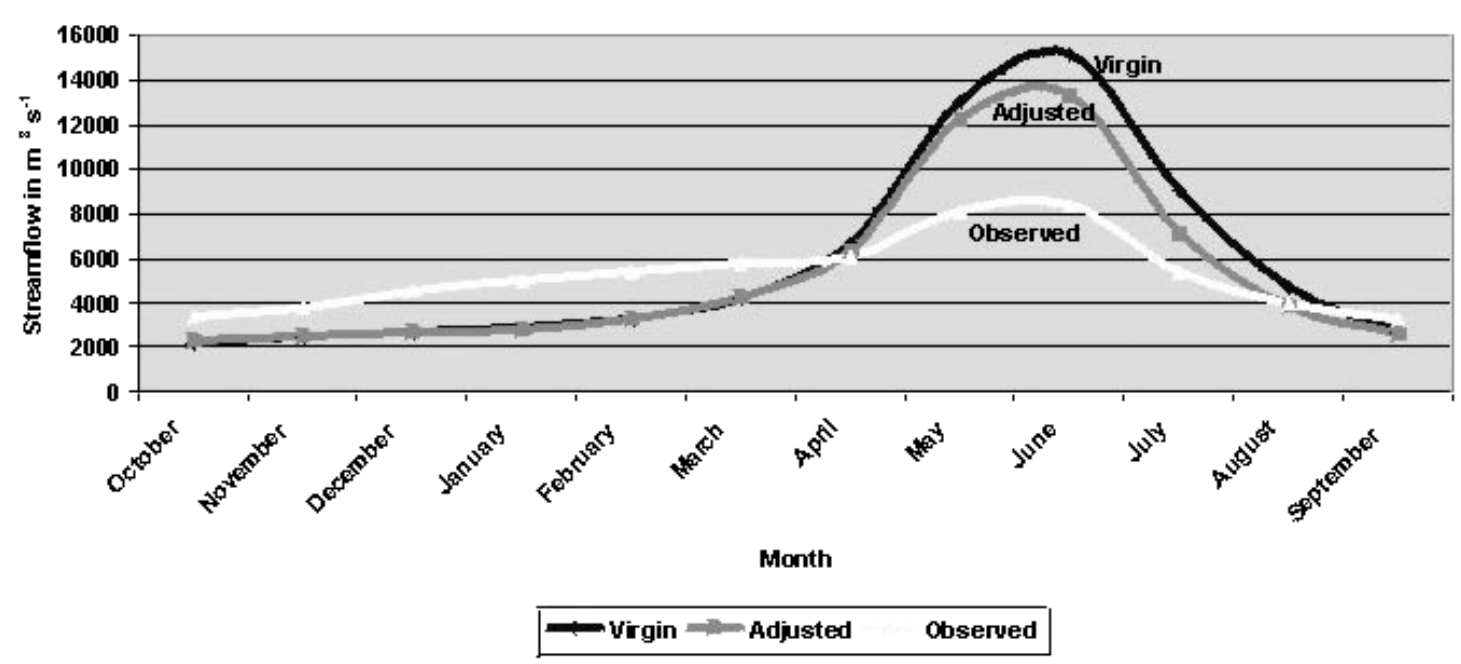

Figure 1. Comparison of the monthly averaged Columbia River interior sub-basin virgin, adjusted and observed river flow estimates from the period 1970-1999. Flow regulation and irrigation depletion have greatly decreased spring and summer flows (May to August), while increasing flows from September to March.

ENSO and PDO Response of the Columbia River at The Dalles (1878-1999)

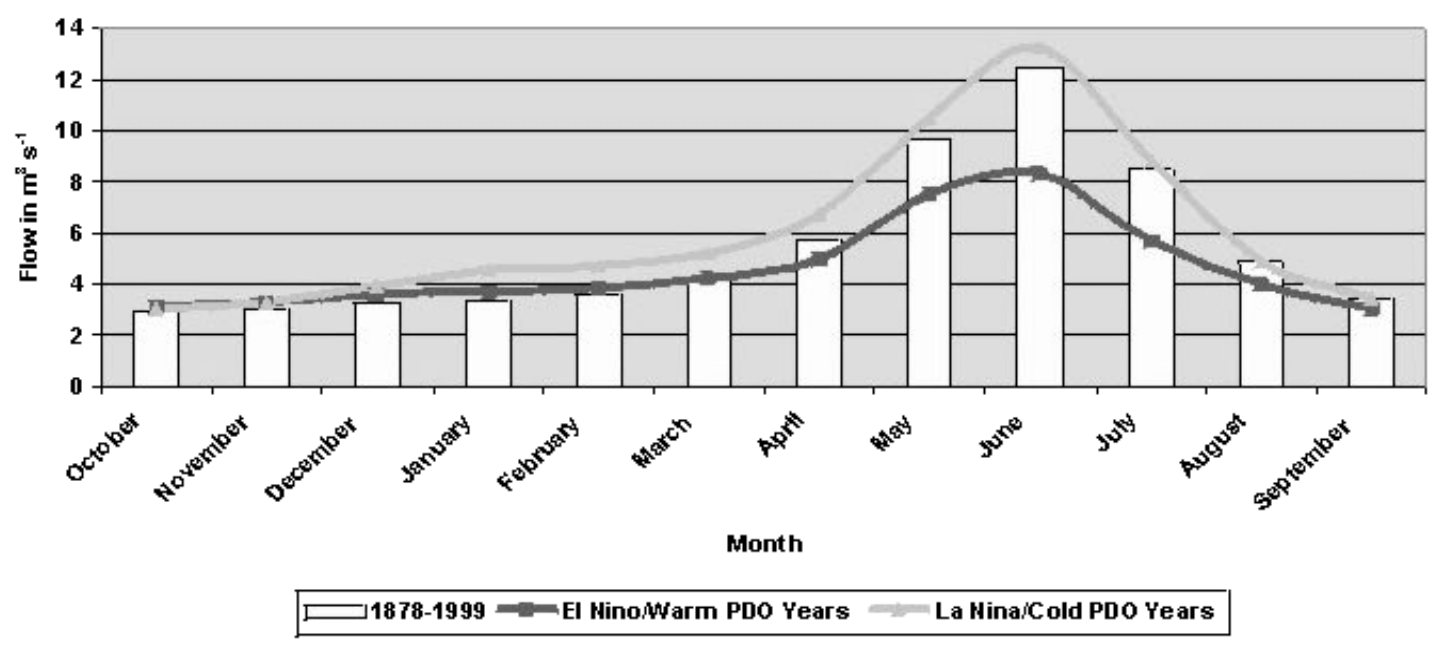

Figure 2. The ENSO/PDO response of interior sub-basin flow at The Dalles. 


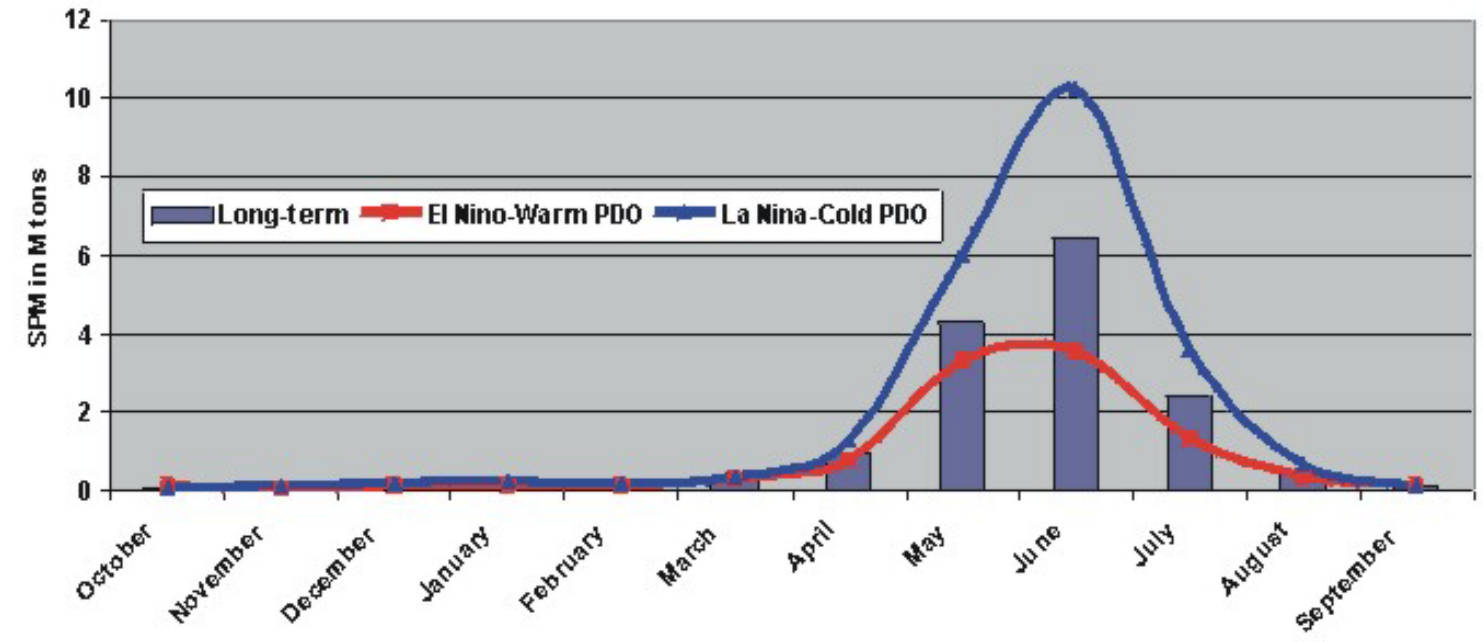

Figure 3. The ENSO/PDO response of interior sub-basin total sediment load; climate effects on flow are amplified in the sediment transport, because of the non-linear dependence of transport on flows.

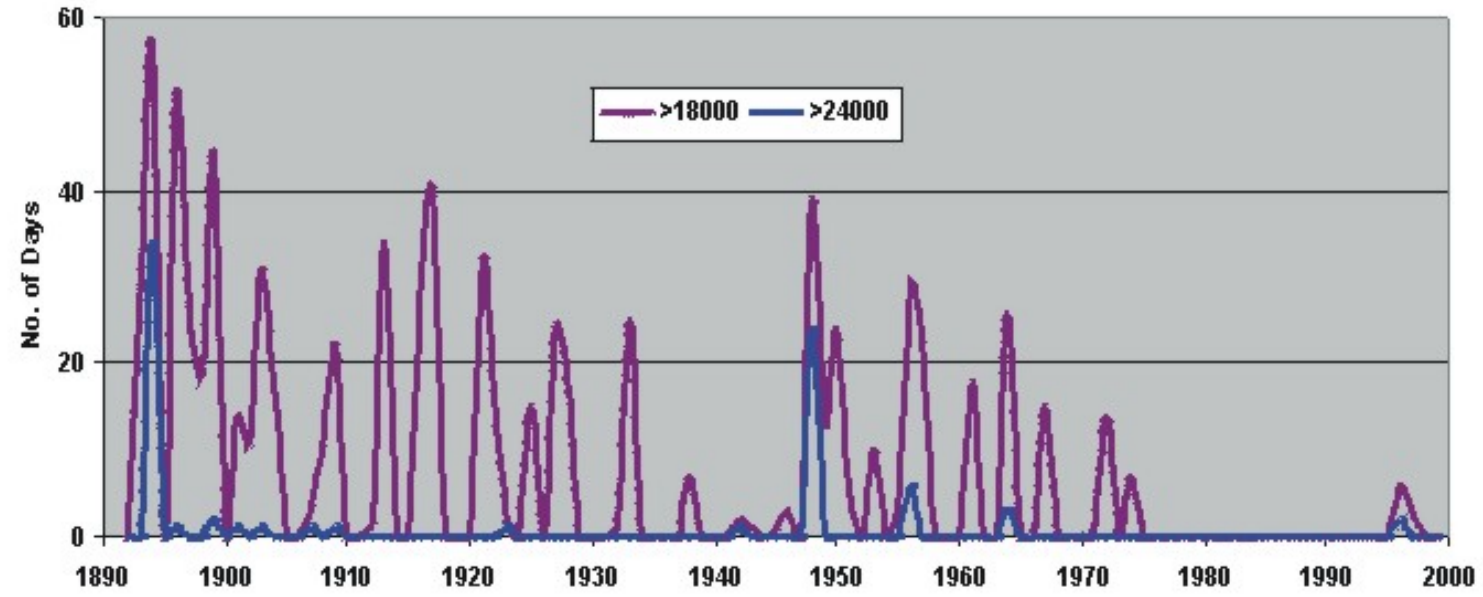

Figure 4. The incidence of flows at Beaver $>18,000 \mathrm{~m}^{3} \mathrm{~s}^{-1}$ (the pre-1900 estimated bankfull flow level) and $>24,000 \mathrm{~m}^{3} \mathrm{~s}^{-1}$ (the present bankfull flow level). The present bankfull flow level has only been exceeded in four years since 1948. 


\title{
MOUTH OF THE COLUMBIA RIVER - TRENDS IN SEDIMENT MANAGEMENT
}

\author{
Rod Moritz, U.S. Army Corps of Engineers - Portland District
}

\section{ANALYSIS Mouth of the Columbia River Navigation Project}

The construction of jetties during 1885-1917 pushed the ebb-tidal shoal offshore, supplying a large volume of sand to adjacent shore areas. The result was long-term accretion of shoreland near the mouth of the Columbia River (MCR). At present longterm accretion is giving way to shoreline recession as waves and currents act to establish equilibrium with the displaced ebb-tidal shoal. What appears to be widespread erosion within the Columbia River littoral cell (CRLC) is very likely a localized re-distribution of accreted sand due to the dynamic estuary entrances of the Columbia River, Willapa Bay and Grays Harbor.

Currently, most of the sand dredged during annual maintenance dredging of the $8 \mathrm{~km}$ [5 mile] long MCR navigation channel originates from the ebb-tidal shoal or from deposits within the river mouth. After several decades of waves and currents transporting sand off the ebb-tidal shoal, the western edge of the shoal has migrated to the north and offshore. The crest of the ebb-tidal shoal, Peacock Spit, has been reduced in elevation. The migration and reduction of the ebb-tidal shoal at MCR has resulted in shoreline migration (re-distribution of accreted sand), as noted above. The potential for shoreline erosion elevates the long-term management of sand dredged from the MCR channel as a relevant issue. What has been the disposition of sand dredged from the MCR channel, and could erosion of the ebb-tidal shoal (erosion of shoreline) be attributed to dredging-disposal practices at MCR? Based on a brief summary of dredging-disposal at MCR, the answer to the above appears to be "no" for the following reasons:

1905 -1950: The MCR channel was maintained at a shallower depth than at present and dredging of the MCR channel was sporadic. Whenever dredging of the MCR channel was conducted, all dredged sand was placed either in a high flow area of the estuary or on the ebb-tidal shoal.

1950 - present: About $5.2 \mathrm{Mm}^{3}$ [4 million cy] of sand is dredged annually from the MCR channel with two-thirds of all sediment dredged at MCR having been placed within the active sediment transport zones of the Columbia River mouth or adjacent nearshore (littoral) areas (i.e., depth less than $18 \mathrm{~m}[60 \mathrm{ft}]$ ). Based on recent bathymetric surveys, it appears likely that most of the dredged material placed in water depths up to $30 \mathrm{~m}$ [100 ft] is being transported by waves/currents along the ebb-tidal shoal. This means that close to 90 percent of all sediment dredged from the MCR project has been placed at a location which directly or indirectly benefits littoral areas of the Columbia River littoral cell (CRLC). 
1997- present: 90 percent of sand dredged from the MCR channel (or 14.4 million

$\mathrm{m}^{3}$ [11 million cy]) has been placed at two highly dispersive nearshore sites located on the ebb-tidal shoal: ODMDS E and the North Jetty site. The objectives of using these sites are to abate erosion of the ebb-tidal shoal, provide an efficient method for re-introducing sand into the littoral system north of MCR, and protect the North Jetty from scour. To date, 80 percent of all material placed at these sites has been dispersed out of the sites. Less than 10 percent of the material placed has been transported into the MCR channel. Results indicate that since 1997, 10 million $\mathrm{m}^{3}$ [7.7 million cy] of sand dredged from the MCR has been (re) introduced onto the ebb-tidal shoal, and ultimately into the littoral system.

Based on the dredging-disposal history at MCR, it appears that the past practice of dredging sand from the MCR channel and placing it at various locations on the ebb-tidal shoal has helped to maintain the ebb-tidal shoal and abate erosion of the adjacent shoreline. Continued utilization of ODMDS E and the North Jetty site should enhance this desirable effect.

\section{SUGGESTIONS FOR THE SOUTHWEST WASHINGTON COASTAL EROSION STUDY: TOPICS FOR DISCUSSION}

While highly desirable for littoral management of MCR sand, continued utilization of available nearshore sites for MCR dredged material placement is uncertain due to capacity limitations. To leverage opportunities for continued littoral management of sand dredged from MCR, the following may be considered:

a) The Southwest Washington Coastal Erosion Study (SWCES) should identify pathways of littoral transport on the ebb-tidal shoal of MCR and on the shore profile for areas north and south of MCR. If possible, assess various locations for nearshore (or onshore) dredged material placement in terms of enhancing littoral availability.

b) The SWCES should form a "monitoring team" which would continue to function after conclusion of the SWCES. The "monitoring team" would monitor key coastal areas within the CRLC to improve the understanding of coastal processes affecting shorelands within the CRLC. The "monitoring team" would also function as an objective observer for assessing the performance of various future coastal projects within the CRLC.

Are there shoreline areas within the CRLC, located away from estuaries, that are experiencing recession? If not, then present conditions within the CRLC indicate that erosion areas are the result of the dynamics due to estuary entrances: Inference relating open coast shoreline erosion due to an interruption of Columbia River sediment supply is probably weak at best. If there are erosion areas located away from the active influence of estuaries, then what is the likelihood that the shoreline erosion at these areas is due to large-scale regional processes having influence far beyond the CRLC? To answer this, the SWCES should examine the CRLC in the larger context of other littoral cells along the 
Northwest coast, particularly in central Oregon, to determine if there is a regional coastal process affecting shoreline erosion.

What is the status of erosion along Benson Beach? Has the erosion trend changed in the last 2 years? What is the SWCES view of the enhanced use of ODMDS E.

The concept of large volumes of sand continually being transported from the Columbia River through the estuary, into the ocean, and onto the adjacent coastal shoreline lacks validity. Most of the 5.2 million $\mathrm{m}^{3}$ [4 million cy] per year of sand which is dredged from the MCR channel originates from the ocean side of the mouth, basically the ebb-tidal shoal. Topical reasons:

a) Shoaling within the MCR channel occurs late in summer, when river flow is lowest. A strong flood tide brings ebb-tidal shoal sediment into the MCR channel. During years of high river flow, MCR channel shoaling is low and vice versa.

b) Examination of bathymetric differences for the MCR channel over time shows that the throat of the entrance channel has become wider. This indicates that the MCR channel shoals from the sides (sediment is supplied by Clatsop Spit and Peacock Spit ebb-tidal shoal).

c) The annual average volume of sand dredged from the $8 \mathrm{~km}$ - [5 mile-] long MCR channel is 5.2 million $\mathrm{m}^{3} / \mathrm{yr}$ [ $4 \mathrm{mcy} / \mathrm{yr}$ ]. The annual average volume of sand dredged from the Columbia River navigation channel, passing through the entire estuary (upriver from MCR for an extent of $32.2 \mathrm{~km}$ [20 miles]) is $7.8 \times 10^{3} \mathrm{~m}^{3} / \mathrm{yr}$ [6 kcy/yr]. The annual average volume of sediment dredged from the entire Columbia River navigation channel (161 km [100 miles] upriver from MCR) is 1.5 million $\mathrm{m}^{3} / \mathrm{yr}[8 \mathrm{mcy} / \mathrm{yr}]$. The reason for the above discrepancy is that the ebbtidal shoal at MCR is exposed to ocean waves, coastal margin currents, and flood tidal currents which are very effective at transporting sediment into the mouth (upstream) from the ocean. Conveyance of sand into the MCR channel from the coastal margins is high. Within the Columbia River, conveyance of sand-sized sediment downstream, from the river through the estuary is low compared to MCR.

Collectively, the above observations indicate that within the last 80 years, the rapid influx of sand to the coastal areas north and south of MCR has come from the displacement of the ebb-tidal shoal, most likely due to jetty construction. If this is the case, then the evolution of MCR sediments (ebb-tidal shoals, etc.) is a key factor for the SWCES to consider with regard to long-term coastal behavior within the southern third of the CRLC.

It is suggested that very infrequent extremely large flood, seismic, or volcanic events are the Columbia River's natural transport mechanisms for moving appreciable volumes of sand through the estuary and discharging it to the coast. It is also suggested that in a natural setting, regional processes affecting coastal erosion occur much more frequently 
than does the discharge of sand from the Columbia River to the coasts. In addition, numerous other locations along the U.S. Northwest Coast have exhibited accelerated rate of shoreline erosion within the last 2 decades. The SWCES study does not have reasonable evidence to attribute coastal erosion within the Study area to anthropogenic effects on the Columbia River system or estuary. If further consideration is needed on these topics, research should be undertaken within the context of a separate project.

Likewise, it is suggested that the SWCES focus on defining coastal processes that affect shoreline change: alongshore and cross shore response due to varying wave, wind, and current conditions, closure depth for varying degrees of environmental forcings, overland wave run-up and deposition, level of forcing expected from waves and currents, etc.

\section{USACE - Portland District Data Collection Offshore MCR}

Concurrent measurement of current, waves, C-T, and bottom suspended sediment transport at 4 location during 1997-1999. Joint EPA-USACE project. Status of data collection: Completed. Analysis of the data acquired during the above field data collection is on going.

Acquisition of bathymetry surveys at MCR, $19.3 \mathrm{~km}$ [12 miles] north, and $12.9 \mathrm{~km}$ [8 miles] south; coverage for water depths 7.6 to $54.9 \mathrm{~km}$ [25 to $180 \mathrm{ft}$ ]. Project sponsored in part by USGS-SWCES. Status: Completed.

Digital side-scan sonar (SSS) and bottom sediment back-scatter (Roxann) survey at proposed "deepwater" dredged material disposal site. Coverage is $10.4 \mathrm{~km}^{2}$ [4 square miles] in water depth of 61.0-91.5 m [200-300 ft]. Survey jointly sponsored by EPAUSACE. Status: Ongoing.

Sediment Trend Analysis covering entire MCR offshore region. More than 1,200 seabed surface sediment samples obtained. Survey jointly sponsored by EPA-USACE. Status: Ongoing.

\section{Future Partnerships And Funding Mechanisms}

Columbia River General Investigation Study: Start for FY 2001.

The Estuary Restoration Act of 2000: Senate Bill 835, to promote the restoration of estuary habitat; develop a national estuary habitat restoration strategy; provide Federal assistance for projects; and develop/enhance monitoring and research capabilities.

Regional Sediment Management: USACE sponsored program intended to develop federal-state-local partnerships to formulate long-term solutions for managing the beneficial uses of sediment dredged from federal navigation projects. 


\section{A REVIEW OF COLUMBIA RIVER DREDGING: PAST PRACTICES AND RECENT PROPOSALS}

George M. Kaminsky, Washington Department of Ecology

\section{CONCLUSIONS}

1) Currently proposed dredging activities (U.S. Army Corps of Engineers, 1999) in the Columbia River estuary (River Mile 3-30) and mouth (MCR) over the next 20 years would remove $12.2 \mathrm{Mm}^{3}\left(0.6 \mathrm{Mm}^{3} / \mathrm{yr}\right)$ [16 mcy $\left.(0.8 \mathrm{mcy} / \mathrm{yr})\right]$ of sand from RM 3-30 and $30-53 \mathrm{Mm}^{3}\left(1.5-2.6 \mathrm{Mm}^{3} / \mathrm{yr}\right)\left[40-70 \mathrm{Mm}^{3}(2-3.5 \mathrm{mcy} / \mathrm{yr})\right]$ of sand from MCR and dispose of this potential resource in the proposed Deep Water Site on the mid-shelf in 60-90 m [200-300 feet] water depth. Such large quantities of sand losses have quantifiable impacts to the nearshore and coastal environment, and would contribute to exacerbated erosion of the coast and nearshore zone.

2) In total over the next 20 years, the Corps has proposed to extract $47.7 \mathrm{Mm}^{3}$ [64.4 mcy] from the Columbia River via upland disposal, and between $42.8 \mathrm{Mm}^{3}$ [56 mcy] to $65.8 \mathrm{Mm}^{3}$ [86 mcy] via ocean disposal at a proposed Deep Water Site in 60-90 m [200300 feet] water depth. On average, the total annual amount of sand removed from the Columbia River, estuary, and nearshore system is equivalent to $5.1 \mathrm{Mm}^{3} / \mathrm{yr}$

$[6.7 \mathrm{mcy} / \mathrm{yr}]$. The estimated sand supply from the upland drainage basin to this system is approximately $1.5 \mathrm{Mm}^{3} / \mathrm{yr}[1.95 \mathrm{mcy} / \mathrm{yr}]$, therefore the net sand removal rate is $3.6 \mathrm{Mm}^{3} / \mathrm{yr}$ [4.75 mcy/yr], roughly 3.5 times the sand supply from the drainage basin.

3) Due to flow regulation and up-river dredging, the sand that is removed can not be replenished in the absence of a catastrophic, unmitigated event such as an extreme flood or debris flow from a volcanic eruption.

4) The net removal of sand from the system appears to be a practice that has been initiated only within the last 2 decades. Although the Corps' Environmental Impact Statement (EIS) documents do not provide data on the amount of previous upland disposal, Sherwood et al. (1990) suggests that 49.3 - $100.0 \mathrm{Mm}^{3}$ [64.5 - $130.8 \mathrm{mcy}$ ] has been disposed in upland sites since 1939. Over a period of 50 years, this amount is approximately $1.5 \mathrm{Mm}^{3} / \mathrm{yr}$ [2 mcy/yr]. Gelfenbaum et al. (1999) estimates that the river supply of sand during $1935-1958$ was $2.6 \mathrm{Mm}^{3} / \mathrm{yr}$ [3.4 mcy/yr], suggesting the annual upland disposal of sand was less than the annual supply. In terms of removal of sand from the system via deep-water ocean disposal, it appears that as little as $1.0 \mathrm{Mm}^{3}$ [1.3 mcy] was removed between 1904 and 1955. During 1956-1983, $25.2 \mathrm{Mm}^{3}$ [33 mcy] were disposed in deep water outside the littoral system, an annual rate of $0.9 \mathrm{Mm}^{3}$ / yr $[1.2 \mathrm{mcy} / \mathrm{yr}]$.

5) Following completion of MCR deepening to $16.7 \mathrm{~m}$ [55 feet] in 1984, deep-water ocean disposal of dredged sands became much more prevalent. From 1984 to 1998, 
$34.8 \mathrm{Mm}^{3}$ [45.5 mcy] were disposed in deep water ocean sites, an annual rate of $2.3 \mathrm{Mm}^{3} / \mathrm{yr}$ [3 mcy/yr], over 2.5 times the previous rate during 1956-1983. It is important to note that the net supply of river sand has decreased by a factor of 3 over the historical period, while the removal of sand has increased by a factor of 2.5 , resulting in a present situation of net sand extraction (deficit) from the system.

6) As the sand supply (that was historically derived from the Columbia River, estuary, mouth, and nearshore region) to the Long Beach Peninsula declines, the southern portion of the Peninsula is predicted to undergo net shoreline recession. Preliminary shoreline modeling results suggest that a net sand supply of $2.2 \mathrm{Mm}^{3} / \mathrm{yr}[2.9 \mathrm{mcy} / \mathrm{yr}]$ is required to avoid future erosion along the southern Long Beach Peninsula. A reduction in sand supply to $1.6 \mathrm{Mm}^{3} / \mathrm{yr}$ [2.1 $\mathrm{mcy} / \mathrm{yr}$ ] results in a gradient in shoreline recession ranging from $250 \mathrm{~m}$ [820 feet] just north of North Head, to no change at distance $7 \mathrm{~km}$ [4.5 miles] to the north by 2025 .

7) Unfortunately, a zero to negative littoral sand supply from the Columbia River is a plausible scenario due to the deficit of sand created by the removal of sand from the MCR and the estuary. Preliminary shoreline modeling results indicate that an elimination of sand supply to Long Beach Peninsula results in a gradient in shoreline recession ranging from $640 \mathrm{~m}$ [2100 feet] just north of North Head, to no change at a distance $12 \mathrm{~km}$ [7.5 miles] to the north by 2025. Moreover the Southwest Washington Coastal Erosion Study's beach morphology monitoring program has in fact revealed net shoreline recession along southern Long Beach Peninsula since the program began in summer 1997.

8) Because the rate of river sand extraction is suspected to be greater than the river sand supply, it could be assumed that the sand removed from the estuary is primarily sand that has entered through MCR from the littoral environment. If this assumption is correct, then the present rates of erosion of the littoral environment would increase in the future.

\section{ACCOMPLISHMENTS}

1) An analytical review of the U.S. Army Corps of Engineers, Portland District, Integrated Feasibility Report for Channel Improvements and Environmental Impact Statement, Columbia \& Lower Willamette River Federal Navigation Channel (U.S. Army Corps of Engineers, 1999) has been completed.

2) A report on the Columbia River dredging activities relative to the historical sediment budget is in progress.

\section{QUESTIONS}

1) Assuming that the Columbia River sand supply to the estuary (excluding the effects of dredging in the river) is $1.4 \mathrm{Mm}^{3} / \mathrm{yr}$ [1.8 mcy/yr], how much sand can be mechanically 
extracted from the Columbia River, estuary, and/or MCR without contributing to erosion (net removal of sand) within the littoral cell?

2) If all dredging in the Columbia River, estuary and MCR were terminated, would there be greater, equal, or less sand supply to the littoral cell?

3) If it is assumed that the mechanical extraction of sand from the Columbia River and estuary has no effect on the sand supply to the littoral cell; how much sand can be removed from MCR (via deep water disposal) without contributing to erosion (net removal of sand) within the littoral cell (ignoring that the littoral cell includes MCR)?

4) If it is assumed that net removal of sand (via dredging and deep water disposal) from the littoral cell can not be shown to cause immediate shoreline recession, should it also be assumed that there is no cause - effect relationship? If it is assumed there is a time lag in shoreline response to the net removal of sand from MCR and estuary, how long can the lag time be before a cause - effect relationship becomes questionable?

5) Assuming the sand supply from the estuary to the littoral cell is episodic, occurring only during large flood events that have a return period of several decades, is the sand inventory in the Columbia River and estuary essentially infinite, so that the amount removed via dredging is negligible? If the existing sand source is not essentially infinite, can these large floods replenish the supply of sand to the lower Columbia River and estuary, or will there be a net loss?

\section{ANALYSIS Introduction}

The beaches of southwest Washington have been built from sand supplied predominantly by the Columbia River. With the installation of the Columbia River jetties during 1889 to 1917, the southern Long Beach Peninsula accumulated a large quantity of sand due to the redistribution of sand eroded from the mouth of the Columbia River (MCR) and the adjacent nearshore region. Sand supply from the river has declined over the past several decades due to dam construction and river flow regulation. MCR and the adjacent nearshore region have continued to erode since the jetties were constructed. Benson Beach has lost $7.1 \mathrm{Mm}^{3}$ [9.3 mcy] of sand from 1958 to 1998 due to coastal erosion (Buijsman et al., in prep). Sand is a critical resource to the beaches of southwest Washington, and dredged sand from the Columbia River could be used to help mitigate this ongoing erosion.

\section{Historical Reduction in Sand Supply to the Estuary}

Human influence on the Columbia River flow cycle began as early as the 1840s with irrigation, followed by logging and then dam construction (Sherwood et al., 1990). The first major dam (Bonneville) was completed in 1933 and the last of the eleven major dams was completed in 1968. Sherwood et al. (1990) suggest that large-scale regulation of the flow cycle began in 1969, resulting in a substantial reduction in the variability of the monthly mean flows. The combined effect of the eleven major dams and over 200 smaller 
dams that were constructed throughout the Columbia River drainage basin during the mid1900s has significantly decreased the peak flows and reduced the sediment carrying capacity of the Columbia River (Sherwood et al., 1990; Gelfenbaum et al., 1999). The fluvial sand supply to the estuary has decreased from $4.3 \mathrm{Mm}^{3} / \mathrm{yr}[5.6 \mathrm{mcy} / \mathrm{yr}]$ for the period 1878-1934, prior to significant flow modification by dams, to $1.4 \mathrm{Mm}^{3} / \mathrm{yr}[1.8$ $\mathrm{mcy} / \mathrm{yr}$ ] for the period 1958-1997, a decrease by a factor of 3 during historical times (Gelfenbaum et al., 1999). Sand may also be directly trapped by some of the dams. For example, the sediment retention dam on the Cowlitz River, constructed for the sole purpose of retaining sediment resulting from the 1980 eruption of Mt St. Helens, has trapped an estimated $50 \mathrm{Mm}^{3}$ [65 mcy] of sediment since it was constructed.

It is possible that only rare flood events on the order of 400,000 cfs or higher are able to discharge beach-sized sand from the MCR into the littoral system. It could be hypothesized that because peak floods have been so reduced that the Columbia River has in effect already stopped supplying sand to the coast. The cumulative effect of removing large quantities of sand from the river increases the probability for this hypothesis. In the absence of extreme floods or unmitigated sediment supply from volcanic eruptions, it is unlikely that a significant quantity of sand can be supplied to the littoral system. The direct transfer of sand via dredging and disposal in the littoral zone is needed to mitigate sand deficits attributable to flow regulation and upland disposal of sand dredged from the navigation channel.

\section{Proposed Sand Extraction from the Columbia River}

The present Columbia River fluvial sand supply to the area proposed for channel deepening (RM 3-105.5) is estimated by the Corps to range between $0.15-0.46 \mathrm{Mm}^{3} / \mathrm{yr}$ [0.2 - $0.6 \mathrm{mcy} / \mathrm{yr}]$ suspended load and $0.08-0.31 \mathrm{Mm}^{3} / \mathrm{yr}[0.1-0.4 \mathrm{mcy} / \mathrm{yr}]$ bedload. [Note: The Corps assumes bedload transport occurs for sand grains greater than $0.18 \mathrm{~mm}$ diameter, and suspended transport occurs for sand finer than $0.15 \mathrm{~mm}$. The mean diameter of the beach sand along the Columbia River littoral cell is approximately $0.18 \mathrm{~mm}$ with a range from $0.10 \mathrm{~mm}$ to $2.0 \mathrm{~mm}$ ]. The Willamette River sand supply is estimated by the Corps to be $0.23 \mathrm{Mm}^{3} / \mathrm{yr}[0.3 \mathrm{mcy} / \mathrm{yr}]$, and the Cowlitz River sand supply is estimated by the Corps to be less than $0.76 \mathrm{Mm}^{3} / \mathrm{yr}$ [ $\left.1 \mathrm{mcy} / \mathrm{yr}\right]$. Therefore total fluvial sand supply to the estuary ranges between less than $1.2 \mathrm{Mm}^{3} / \mathrm{yr}[1.6 \mathrm{mcy} / \mathrm{yr}]$ to less than $1.8 \mathrm{Mm}^{3} / \mathrm{yr}$ [2.3 mcy/yr] an average of $1.5 \mathrm{Mm}^{3} / \mathrm{yr}$ [1.95 mcy/yr]. Gelfenbaum et al. (1999) have estimated the fluvial sand supply to the estuary to be $1.4 \mathrm{Mm}^{3} / \mathrm{yr}[1.8 \mathrm{mcy} / \mathrm{yr}]$ over the period 1958-1997. In summarizing the proposed 20-year dredged material disposal plan for the proposed 13.1-m [43-foot] navigation channel, $47.7 \mathrm{Mm}^{3}$ [62.4 mcy] will be disposed in upland sites, equivalent to a sand extraction rate of $2.3 \mathrm{Mm}^{3} / \mathrm{yr}$ [3.1 mcy/yr] over the initial 20 years of the project.

From the above estimates of fluvial sand supply and the amount of sand scheduled for removal from the Columbia River (excluding MCR and the estuary), the net extraction of sand ranges from $0.6-1.1 \mathrm{Mm}^{3} / \mathrm{yr}[0.8-1.5 \mathrm{mcy} / \mathrm{yr}]$, an average of $0.85 \mathrm{Mm}^{3} / \mathrm{yr}$ [1.1 mcy/yr] more than the fluvial supply rate. In addition, a presently unknown but significant amount of non-federal dredging and sand mining occurs in the area dredged by the Corps, which suggests that the net sand extraction may be closer to twice the fluvial 
supply. Similarly, the Corps maintenance dredging forecasts suggest that river supply will not replace the amount of sand dredged from the navigation channel. Over the first 20 years of the proposed 13.1-m [43-foot] navigation channel project, the annual maintenance dredging forecast declines from around $6.1 \mathrm{Mm}^{3} / \mathrm{yr}$ [8 $\mathrm{mcy} / \mathrm{yr}$ ] to approximately $2.3 \mathrm{Mm}^{3} / \mathrm{yr}$ [3 $\left.\mathrm{mcy} / \mathrm{yr}\right]$.

It is worth noting that the estimated fluvial supply rates by the Corps and by Gelfenbaum et al. (1999) are based on historical data, especially as related to peak river flows. Future Columbia River peak flows (based on monthly means during the June freshets) are predicted by JISAO (1999) to decline over the next several decades (due to various human inventions in the drainage basin), suggesting that the fluvial sand supply will further decline.

\section{Shoreline Change based on Sand Supply}

Shoreline change analysis by the Southwest Washington Coastal Erosion Study (Kaminsky et al., 2000; Buijsman et al., in prep.) indicates that a supply of $2.7 \mathrm{Mm}^{3} / \mathrm{yr}$ [3.5 mcy/yr] of sand was needed to account for net shoreline advance of the Long Beach Peninsula during 1958-1998. This sand is presumed to have been supplied from a combination of sources including erosion of Peacock Spit, erosion of the ebb-tidal delta, dispersal from disposal Site E, supply from the river during floods, and supply from erosion of the inner shelf. Continued supply of sand from Peacock Spit and the ebb-tidal delta (including the Clatsop inner shelf) is likely to be both limited and finite over the next few decades because these areas have eroded substantially since jetties were constructed in the early 1900s. As the sand supply to the Long Beach Peninsula declines, the southern portion of the Peninsula is predicted to undergo net shoreline recession. The coast can not maintain its existing configuration without the continued supply of sand. This phenomenon has been initiated at Benson Beach since the 1950s as the supply of sand from Peacock Spit declined due to its northward migration and dispersal.

Preliminary shoreline modeling results suggest that a net sand supply of $2.2 \mathrm{Mm}^{3} / \mathrm{yr}$ [2.9 mcy/yr] is required to avoid future erosion along the southern Long Beach Peninsula. However, this supply rate is probably not naturally sustainable in the future decades due to the ongoing reduction in potential sand supplies. A reduction in sand supply to $1.6 \mathrm{Mm}^{3}$ / $\mathrm{yr}[2.1 \mathrm{mcy} / \mathrm{yr}]$, results in a gradient in shoreline recession ranging from $250 \mathrm{~m}$ [820 feet] just north of North Head, to no change at distance $7 \mathrm{~km}$ [4.5 miles] to the north by 2025 . This future change represents an optimistic scenario in which most of the dredged sand placed at Site E feeds the beaches immediately to the north, rather than feeding other compartments in the littoral system, such as the mouth of the Columbia River (MCR), the estuary, the ebb-tidal delta, Peacock Spit, or the inner shelf. Since the nearshore region of Peacock Spit and the ebb-tidal delta have been eroding at a rate of $1.34 \mathrm{Mm}^{3} / \mathrm{yr}$ [1.74 mcy/yr] since 1958 (Buijsman et al., in prep.), the $0.76-1.76 \mathrm{Mm}^{3} / \mathrm{yr}[1-2.3 \mathrm{mcy} /$ yr] placed at Site E (the annual site capacity estimated by the Corps) may only help counterbalance these ongoing losses. The Corps estimates that $0.2-0.3 \mathrm{Mm}^{3} / \mathrm{yr}[0.3-0.4$ $\mathrm{mcy} / \mathrm{yr}]$ is needed to counterbalance the erosion of Benson Beach alone. The Corps notes that within the 1986 boundaries of Site E, a net loss of $0.24 \mathrm{Mm}^{3}$ [0.31 mcy] occurred during 1990-1997 despite the disposal of $3.9 \mathrm{Mm}^{3}[5.1 \mathrm{mcy}]$ at the site. 
A zero to negative littoral sand supply from the Columbia River is a plausible scenario. Future dredging at the MCR and disposal of the dredged sand in deep water will likely maintain an effective sand trap that accumulates sand from the surrounding littoral environment. The Corps has suggested that most of the sand dredged at MCR is sand is transported into the navigation channel from (the submerged area of) Clatsop Spit. The maintenance of the MCR sand trap may attract more sand from adjacent nearshore sand bodies than those sand bodies supply to the adjacent coast.

Preliminary shoreline modeling results indicate that an elimination of sand supply to Long Beach Peninsula results in a gradient in shoreline recession ranging from $640 \mathrm{~m}$ [2100 feet] just north of North Head, to no change at distance $12 \mathrm{~km}$ [7.5 miles] to the north by 2025. A sudden, complete elimination of sand supply in 2001 may not be realistic due to the continuing (although declining) supply of sand from Peacock Spit and the inner shelf. However, the effect is none the less certain, and net shoreline retreat along the southern Long Beach Peninsula would be inevitable in the coming decades.

The Southwest Washington Coastal Erosion Study's beach morphology monitoring program has in fact revealed net shoreline recession along southern Long Beach Peninsula since the program began in summer 1997. Beach profile data at the 4 southern transects (PC008, PC025, PC004, and CANBY) that cover the southern $8.5 \mathrm{~km}$ [5.3 miles] of the Long Beach Peninsula all display a consistent annual erosion trend, with the $3.0-\mathrm{m}$ contour retreating by 30.5-61 m [100-200 feet] since summer 1997 (Ruggiero and Voigt, 2000).

\section{Sand Trapping and Extraction at MCR and the Estuary}

The channel deepening and maintenance dredging of the Columbia River estuary may also create an effective sand trap for marine sand drawn in from the adjacent littoral environment. It has not been estimated how much of the sand dredged from the estuary is supplied from the adjacent marine environment. However, a deepened estuary will change the circulation patterns in a direction that enhances bottom transport of marine sand into the estuary. At issue is how much sand is removed from the estuary that could be used to supply sand to littoral system.

The Corps estimates that $12.2 \mathrm{Mm}^{3}$ [16 mcy] of sand will be removed from the estuary (RM 3-30) by construction $\left(5.4 \mathrm{Mm}^{3}\right.$ [7 mcy]) and maintenance $\left(6.9 \mathrm{Mm}^{3}\right.$ [9 mcy]) of the 13.1-m [43-foot] navigation channel over the next 20 years. All of this sand will be disposed of at the Deep Water Site in 60-90 m [200-300 feet] of water where it presumably can not return to the littoral environment. This quantity of sand is significant and could be used to reduce the effects of ongoing or exacerbated erosion of the adjacent nearshore areas and coasts. The Corps dredging estimates for MCR are $3.4 \mathrm{Mm}^{3} / \mathrm{yr}$ [4.5 mcy/yr]. The maximum combined capacity of the only nearshore disposal areas at Site E (1997expanded boundary) and along the North Jetty is $1.9 \mathrm{Mm}^{3} / \mathrm{yr}$ [ $\left.2.5 \mathrm{mcy} / \mathrm{yr}\right]$, therefore over a 20-year period, a minimum of $30.6 \mathrm{Mm}^{3}$ [40 mcy] of sand from MCR would be disposed of in the Deep Water Site. In fact, the Site E dispersive capacity might only be $0.76 \mathrm{Mm}^{3} / \mathrm{yr}[1 \mathrm{mcy} / \mathrm{yr}]$ based on the Corps' more conservative estimate, which would 
result in $53.5 \mathrm{Mm}^{3}$ [70 mcy] (rather than $30.6 \mathrm{Mm}^{3}$ ) of MCR sand disposed in the Deep Water Site within 20 years.

Combining the $12.2 \mathrm{Mm}^{3}$ [16 mcy] from the estuary with the $30.6-53.5 \mathrm{Mm}^{3}$ [40 70 mcy] from MCR to be disposed in the Deep Water Site results in sand extraction rates between $2.1-3.3 \mathrm{Mm}^{3} / \mathrm{yr}$ [2.8 - $4.3 \mathrm{mcy} / \mathrm{yr}$ ] over the 20 year proposed period, an average of $2.7 \mathrm{Mm}^{3} / \mathrm{yr}$ [3.5 mcy/yr]. This rate of sand extraction is comparable to the recent erosion rate for the MCR vicinity. The area comprised of Benson Beach, the inner ebbtidal delta, the Clatsop Spit nearshore, and the MCR inlet has eroded $129 \mathrm{Mm}^{3}$ [169 mcy] over the period 1958-1998, a rate of $3.2 \mathrm{Mm}^{3} / \mathrm{yr}$ [4.2 mcy/yr] (Buijsman et al., in prep.). Therefore, even if all of the sand currently proposed for deepwater disposal was placed in the littoral zone, it may only be enough to counterbalance the ongoing erosion occurring in the vicinity of MCR.

\section{Review of Historical and Proposed Ocean Disposal}

The Corps dredging records show that between 1904 and 1940, $6.3 \mathrm{Mm}^{3}$ [8.29 mcy], $0.56 \mathrm{Mm}^{3} / \mathrm{yr}(753,000 \mathrm{cy} / \mathrm{yr})$, was dredged from MCR. Of this material, the Corps assumes $4.4 \mathrm{Mm}^{3}[5.8 \mathrm{mcy}]$ was disposed at an area southwest of the South Jetty in water depths of $18.2 \mathrm{~m}$ [60 feet] (in the vicinity of the more recently designated Site A), and about $1.9 \mathrm{Mm}^{3}$ [2.5 mcy] was disposed in the estuary. Between 1941 and 1944 there was no dredging at MCR. Between 1945 and 1955, $9.9 \mathrm{Mm}^{3}\left(0.9 \mathrm{Mm}^{3} / \mathrm{yr}\right)[13 \mathrm{mcy}$ $(1.18 \mathrm{mcy} / \mathrm{yr})]$ was dredged from MCR. The Corps assumes $6.9 \mathrm{Mm}^{3}$ [9.1 mcy] was disposed in the vicinity of Site A, $2.0 \mathrm{Mm}^{3}$ [2.6 mcy] was disposed in the estuary, and $1.0 \mathrm{Mm}^{3}$ [1.3 mcy] was disposed in the vicinity of Site B. In total, between 1904 and $1955,15.3 \mathrm{Mm}^{3}$ [20 mcy] of the $16.3 \mathrm{Mm}^{3}$ [21.3 mcy] was disposed at sites that could be considered to be within the littoral system (the $1.0 \mathrm{Mm}^{3}$ [1.3 mcy] disposed near Site B is the exception).

Between 1956 and 1998, a total of $143.3 \mathrm{Mm}^{3}$ (3.26 Mm³/yr) [187.41 mcy (4.26 mcy/yr)] has been dredged from MCR and placed in-water at up to 7 sites (A,B,C,D,E,F, and G) located in both the estuary and ocean. Sites $\mathrm{C}$ and $\mathrm{D}$ are located within the estuary; Sites

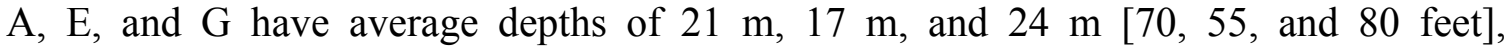
respectively; and Sites B and F are in deep water with average depths of $46 \mathrm{~m}$ and $38 \mathrm{~m}$ [150 and 125 feet], respectively. For the purposes of this analysis, we assume Sites A, C, $\mathrm{D}, \mathrm{E}$, and $\mathrm{G}$ to be within the littoral system and Sites B and F to be outside the littoral system.

Site B (deep water) has been used from 1956 to 1997 (not in 1998), but more extensively since 1984. It is instructive to separate the 1956-1998 period of dredged material disposal discussed above into two sub-periods, 1956-1983 and 1984-1998. During 1956-1983 Site B received $24.2 \mathrm{Mm}^{3}\left(0.86 \mathrm{Mm}^{3} / \mathrm{yr}\right)$ [31.6 mcy $\left.(1.13 \mathrm{mcy} / \mathrm{yr})\right]$ and Site F received 0.57 $\mathrm{Mm}^{3}\left(15,000 \mathrm{~m}^{3} / \mathrm{yr}\right)[0.75 \mathrm{mcy}(0.02 \mathrm{mcy} / \mathrm{yr})]$. Site G was used only once (in 1975) and received $45,000 \mathrm{~m}^{3}$ [0.06 mcy]. In total, $25.2 \mathrm{Mm}^{3}$ [33 mcy] were disposed outside the littoral system during 1956-1983, an annual rate of $0.9 \mathrm{Mm}^{3} / \mathrm{yr}$ [1.2 mcy/yr]. During $1984-1998,27.9 \mathrm{Mm}^{3}$ [36.5 mcy] were disposed at Site B and $6.9 \mathrm{Mm}^{3}$ [9 mcy] were disposed at Site F, a total of $34.8 \mathrm{Mm}^{3}$ [45.5 mcy], an annual rate of $2.3 \mathrm{Mm}^{3} / \mathrm{yr}$ [3 mcy/ 
yr]. Over the entire period of MCR dredging from 1904 to $1998,61.1 \mathrm{Mm}^{3}$ [79.9 mcy] out of $159.6 \mathrm{Mm}^{3}$ [208.7 mcy] of sand dredged have been removed from the littoral system, roughly 38 percent.

From the above figures, it is apparent that within the past two decades, the rate of sand extraction from the littoral system has increased by 2.5 times from the previous three decades. For the MCR the record of dredging from 1904 to $1983,26.2 \mathrm{Mm}^{3}$ [34.3 mcy] were removed from the littoral system via deep water disposal, equivalent to $0.3 \mathrm{Mm}^{3} / \mathrm{yr}$ [0.4 mcy/yr], compared to $2.3 \mathrm{Mm}^{3} / \mathrm{yr}$ [3 mcy/yr] since 1984 , an increase by a factor of 7.5. Because this jump in sand removal rates has been relatively recent, the effect on the adjacent beaches and nearshore area may not yet be fully realized.

\section{REFERENCES}

Buijsman, M.C., Sherwood, C.R., Gibbs, A.E., Gelfenbaum, G., Kaminsky, G.M., Ruggiero, P., and Franklin, J. in prep. Regional sediment budget of the Columbia River littoral cell, USA: Analysis of bathymetric- and topographic-volume change, U.S. Geological Survey Open-File Report.

Gelfenbaum, G., Sherwood, C.R., Peterson, C.D., Kaminsky, G.M., Buijsman, M., Twichell, D.C., Ruggiero, P., Gibbs, A.E., and Reed, C. 1999. The Columbia River littoral cell: A sediment budget overview, Proceedings of Coastal Sediments '99, ASCE, pp. 1660-1675.

JISAO/SMA Climate Impacts Group, University of Washington 1999. Impacts of climate variability and change, Pacific Northwest: a report of the Pacific Northwest Regional Assessment Group for the U.S. Global Change Research Program, 109 p.

Kaminsky, G.M., Buijsman, M.C., and Ruggiero, P. 2000. Predicting shoreline change at decadal scale in the Pacific Northwest, USA, Proceedings of the 27th International Conference on Coastal Engineering, Sydney, Australia, pp. 2400-2413.

Ruggiero, P. and Voigt, B. 2000. Beach monitoring in the Columbia River littoral cell, 1997-2000, Washington State Department of Ecology, Coastal Monitoring \& Analysis Program, Publication No. 00-06-26, 112 p.

Sherwood, C.R., Jay, D.A., Harvey, R.B., Hamilton, P., and Simenstad, C.A. 1990. Historical changes in the Columbia River estuary, Progress in Oceanography, 25, pp. 299-352.

U.S. Army Corps of Engineers 1999. Integrated Feasibility Report for Channel Improvements and Environmental Impact Statement, Columbia \& Lower Willamette River Federal Navigation Channel, Portland District, Portland OR, USA. 


\title{
HIGH RESOLUTION SEDIMENT DYNAMICS IN SALT-WEDGE ESTUARIES
}

\author{
Philip Orton, Department of Environmental Science and Engineering, Oregon \\ Graduate Institute \\ Douglas Wilson, Department of Environmental Science and Engineering, Oregon \\ Graduate Institute \\ David Jay, Department of Environmental Science and Engineering, Oregon \\ Graduate Institute \\ Annika Fain, School of Oceanography, University of Washington
}

\section{SUMMARY}

The Fraser and Columbia River estuaries switch between two extremes of mixing on very small horizontal scales; over as little as tens of meters, conditions can vary between that of a highly-stratified estuary and a well-mixed river. Over this transition zone, suspended particulate matter concentration $(C)$ and particle settling velocity $(W s)$ can also rapidly change. Understanding the sedimentological processes that occur within the transition zone requires measurements of sediment properties and transport on the same time and space scales as is now possible for physical oceanographic properties.

This paper discusses data primarily from the Fraser River estuary. The technologies and analysis procedures are applicable to the Columbia River estuary as well. Achieving such a high-resolution view of sedimentological processes requires a new measurement technique based on optics and acoustics. A two-stage inverse analysis (IA) approach has been developed to take advantage of (a) dynamical information available from $C$ profile shapes, and (b) the differing particle-size responses of optical and acoustical instrumentation. The output of this analysis is high spatial resolution $C$ and transport fields, expressed in terms of several discrete $W s$-classes. This approach may be applied during periods of strong turbulence and high $C$, typically problematic with conventional instrumentation. In an initial trial using Fraser data, resulting $C$ values compared well with in situ settling tube observations, typically within a factor of 2 .

\section{OBSERVATIONS}

A wealth of data sets are available from the Columbia River estuary (1995-1999), and the Fraser River estuary (1999-2000), typically with two vessels conducting simultaneous anchor stations and transects. For an initial trial, we have focused on 1999 estuarine anchor stations from the southern, main arm of the Fraser River estuary (Figure 1). River flow during the study was very high, approximately $9500 \mathrm{~m}^{3} \mathrm{~s}^{-1}$ (Water Survey of Canada, unpublished data). Tides in the Fraser are mixed semidiurnal, and the tidal range near station bD11 varies from 2 to $5 \mathrm{~m}$ over the neap-spring cycle. Acoustic backscatter (ABS) and velocity were measured continuously using a $300 \mathrm{kHz}$ acoustic Doppler current profiler (ADCP). Near-bed data is unavailable for angled-beam ADCPs, due to bedreflection effects. Optical backscatter (OBS), salinity, and temperature were profiled bihourly using an optical backscatter sensor and CTD on a weighted frame. Once every two 
hours, suspended particulate matter (SPM) concentration $(C)$ was measured using a pump sampler mounted on the frame, and particle settling velocity $(W s)$ was measured using a modified Owen tube (methods of Simenstad et al., 1994). Various ecological measurements were also made, including zooplankton counts; these showed that zooplankton could not provide comparable backscatter to suspended sediments, due to their low numbers (C. Simenstad, pers. comm.) and low-reflectivity species types (Stanton et al., 1998).

Observations during the Fraser 1999 study included currents of up to $4 \mathrm{~m} \mathrm{~s}^{-1}$, and $C$ maxima of up to and above $1 \mathrm{~g} \mathrm{~L}^{-1}$. Brackish waters were highly stratified; salinity gradients of $10 \mathrm{~m}^{-1}$ were not uncommon, and bedstress was rarely above $1 \mathrm{~Pa}$. Fresh waters were well-mixed, with bed stress maxima exceeding $10 \mathrm{~Pa}$. OBS and ABS were calibrated to $C$ in situ, using the pumped water samples. Observations from one ebb tide are summarized in Figure 1. In the bottom panel, note that acoustically- and opticallyderived $C$ time series differed substantially. This is consistent with expectations; the ABS responds primarily to sand and the OBS to fine sediment. This period was two days past neap tide, with a tidal range of $3.0 \mathrm{~m}$.

\section{METHODS}

A joint two-stage inverse analysis (IA) was applied to the OBS and ABS data. A schematic of this approach is shown in Figure 2. Stage 1 of the IA partitioned the backscatter between $W s$-classes, based on an assumed vertical SPM balance (as Fain, 2000 and Fain et al., 2001, but with an algebraic modification for stratification effects based on the gradient Richardson number). Figure $2 \mathrm{a}$ and $2 \mathrm{~b}$ show typical results for stage 1. The ABS and OBS data disagree on the distribution of $C$ over $W s$-classes because of their different response functions. This concept is summarized in Figure 2c, which shows the theoretical response of each instrument to a given sediment size distribution. To account for these differences, response coefficients were defined for each instrument and $W s$-class (these are essentially gain values). Applying mass conservation between the two instruments, a description of the SPM field can be written:

$$
\sum_{k=1}^{4} \Gamma_{k} C_{k}=\sum_{k=1}^{4} \gamma_{k} c_{k}
$$

Here, capital and lower case letters represent optical and acoustic quantities, respectively; $k$ represents the different $W s$-classes; and $\Gamma_{k}$ and $\gamma_{k}$ are the response coefficients for the OBS and ABS, respectively. Least-squares best-fit values were found for $\Gamma_{k}$ and $\gamma_{k}$ using all available data points from all three Fraser anchor stations. Using this approach, response coefficients were determined for each instrument and $W s$-class that minimized the differences between the ABS and OBS description of the SPM field. The output of this analysis was response-modified concentrations, $C_{k}{ }^{\prime}=\Gamma_{k} C_{k}$ and $c_{k}{ }^{\prime}=\gamma_{k} c_{k}$. The data set of most interest was $c_{k}{ }^{\prime}$, due to its high resolution. This data was de-spiked using a two standard deviation threshold, then smoothed using a 10-minute running average. 


\section{RESULTS}

Results are shown in Figure 3. In situ observations (diamonds) were similar to calculated concentrations, typically within a factor of 2 . The top plot shows the resulting concentration time-series of $W$ s-classes $\# 1$ and $\# 2$ at $1 \mathrm{~m}$ above the bed, along with shear velocity $U_{*}$. Concentrations of these sediments appear to rely more on salinity (bottom plot) than on $U_{*}$. This is a reasonable observation considering that pumped water samples also showed a strong correlation between fine sediment $C$ and salinity.

The middle plot shows the resulting $C$ time-series for the coarser sediments, $W s$-classes \#3 and \#4. As the salt-wedge retreated, increasing bed stresses lead to the passage of successive size-dependent erosion thresholds. This plot also includes the skin-friction shear velocity, $U *_{s f}$. This is an important parameter because echo soundings indicated the presence of sand waves averaging $1 \mathrm{~m}$ high, and $30 \mathrm{~m}$ wavelength. A comparison was made between theoretical threshold values of $U_{*_{s f}}$ for erosion and the observed $U_{*_{s f}}$ at the point of initial detection in the water column. These values were roughly equivalent to that expected from theory. A typical rule of thumb threshold for sediments to be carried as suspended load is $W S / 0.4 U_{*}<2$. Observed values showed that these coarse sediments appeared in suspension later than expected based on this concept. This may indicate that sediment suspension was being hindered by bedforms or by stratification.

\section{QUESTIONS}

Laser in situ particle size analyzer (LISST) data is available for the year 2000. How will these particle size observations be compared to $W s$-class based observations? Considering that instrument responses should not be time varying, can aggregation be monitored using the time-variability of $\Gamma_{k}$ and $\gamma_{k}$ ? In future analyses we intend to evaluate methodological sensitivity, utilize available multi-frequency acoustic data, and modify the IA stage 1 approach to include advection.

\section{ACKNOWLEDGEMENTS}

The authors would like to thank Denise Reed for her contributions with sediment analyses. This work was funded under National Science Foundation Grant OCE-9412928 (Columbia River Land-Margin Ecosystem Research Project).

\section{REFERENCES}

Fain, A.M.V. 2000. Suspended particulate dynamics in the Columbia River estuary, M.S. thesis, Oregon Graduate Institute, $97 \mathrm{p}$.

Fain A.M.V., Jay, D.A., Wilson, D.J., Orton, P.M., and Baptista, A.M. 2001. Seasonal, monthly and tidal patterns of particulate matter dynamics in a stratified estuary, submitted to Estuaries.

Simenstad, C.A., Reed, D.J., Jay, D.A., Baross, J.A., Prahl, F.G., and Small, L.F. 1994. Land-margin ecosystem research in the Columbia River estuary: Investigations of 
the couplings between physical and ecological processes within estuarine turbidity maxima, Changes in fluxes in estuaries: Implications from science to management, K.R. Dyer and R.J. Orth, editors, Olsen and Olsen, Fredensborg, pp. 445-450.

Stanton, T.K., Chu, D., and Wiebe, P.H. 1998. Sound scattering by several zooplankton groups II: Scattering models, J. Acoust. Soc. Am., 103, pp. 236-253. 

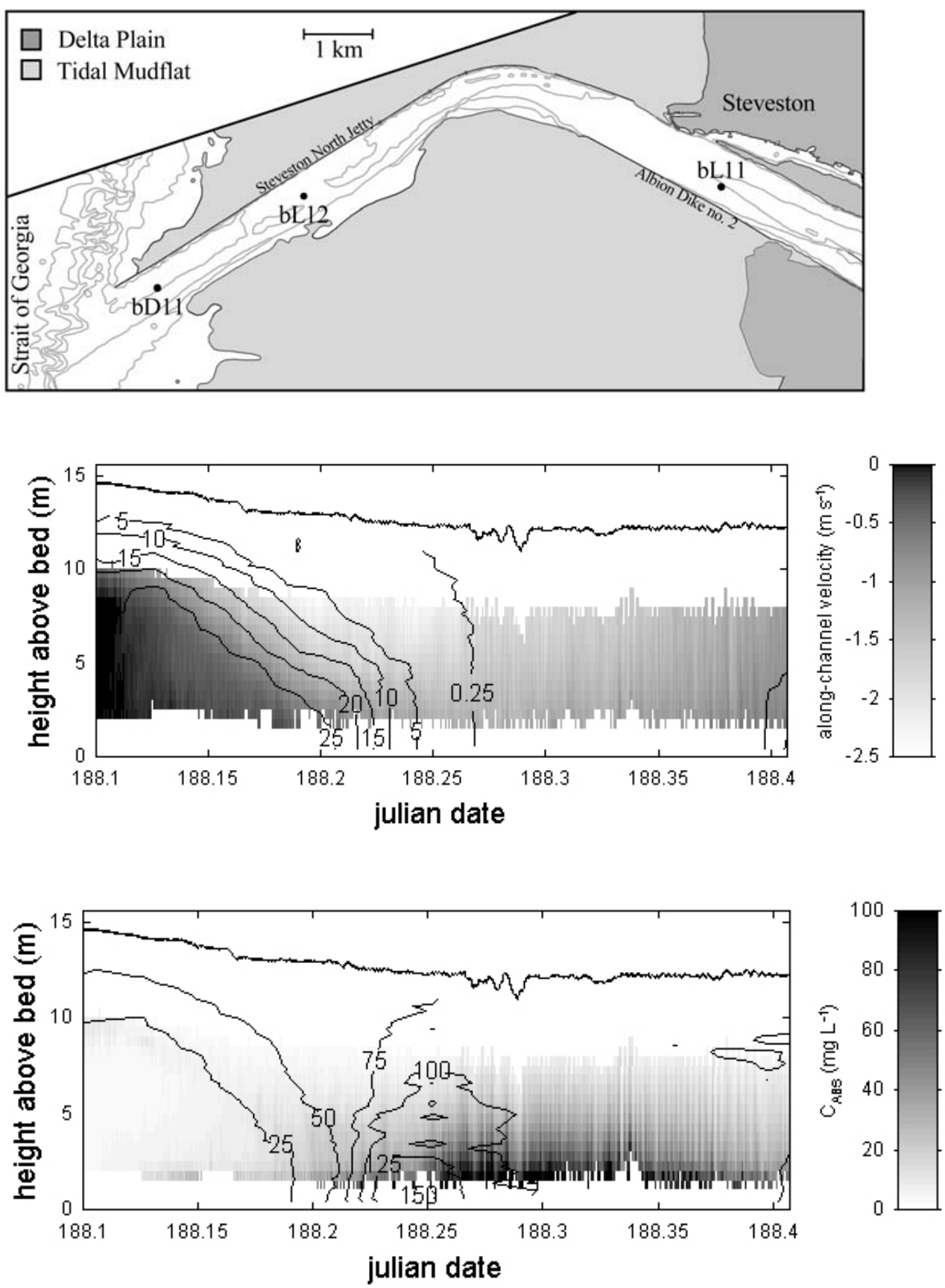

Figure 1. Observations. (top) Map of the southern, main arm of the Fraser River estuary, with select 1999 anchor stations. The middle and bottom plots focus on an ebb-tide salt wedge retreat, at station bD11, July 9th. (middle) Salinity contours on velocity shading. Note that there is no near-bed (within $\sim 1 \mathrm{~m}$ ) or near-surface (within $\sim 4 \mathrm{~m}$ ) data. (bottom) Observed suspended particulate matter concentrations, $C\left(\mathrm{mg} \mathrm{L}^{-1}\right)$, from optics (OBS; contours) and $300 \mathrm{kHz}$ acoustics (ABS; shading). ABS and OBS data disagree on shape and placement of $C$ maxima because of their different response functions; the $A B S$ responds primarily to sand and the OBS to fines. 
$\mathrm{C}_{\mathrm{OBS}} \quad \mathrm{C}_{\mathrm{ABS}}$

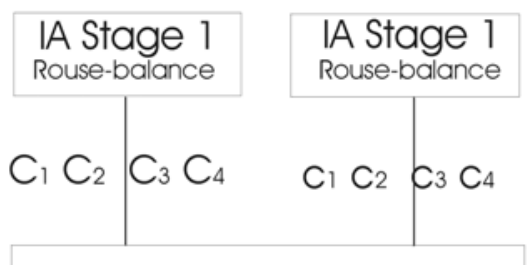

IA Stage 2 Mass conservation

$\Gamma_{1} \Gamma_{2} \Gamma_{3} \Gamma_{4}$

$\begin{array}{llll}\gamma_{1} & \gamma_{2} & \gamma_{3} & \gamma_{4}\end{array}$

Recalculate concentrations using response coefficients

$\mathrm{C}_{1}^{\prime} \mathrm{C}_{2}^{\prime} \mathrm{C}_{3}^{\prime} \mathrm{C}_{4}^{\prime} \quad \mathrm{Ci}_{1}^{\prime} \mathrm{C}_{2}^{\prime} \mathrm{C}_{3}^{\prime} \mathrm{C}_{4}^{\prime}$
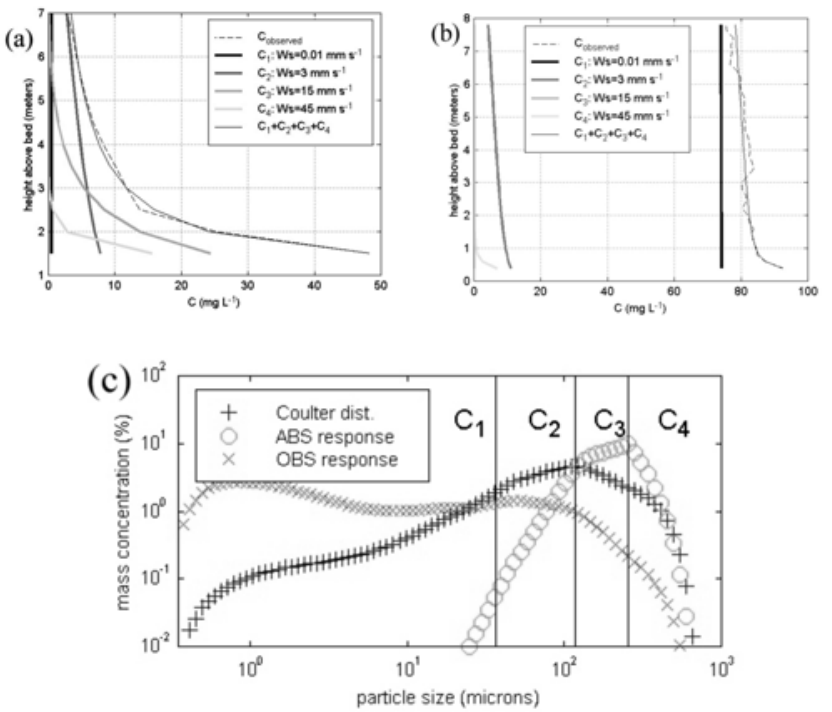

Figure 2. Inverse Analysis. (left) Schematic of inverse analysis (IA) approach. OBS variables are in caps, and ABS variables are in lower case. Plots to the right show IA results for (a) a typical ABS profile, and (b) a typical OBS profile. Plot (c) shows a Coulter counter size distribution (by size and $W s$-class $C_{k}$ ) for a sample $1 \mathrm{~m}$ above the bed at day 188.39, with $O B S$ and $A B S$ responses derived from scattering theory. 

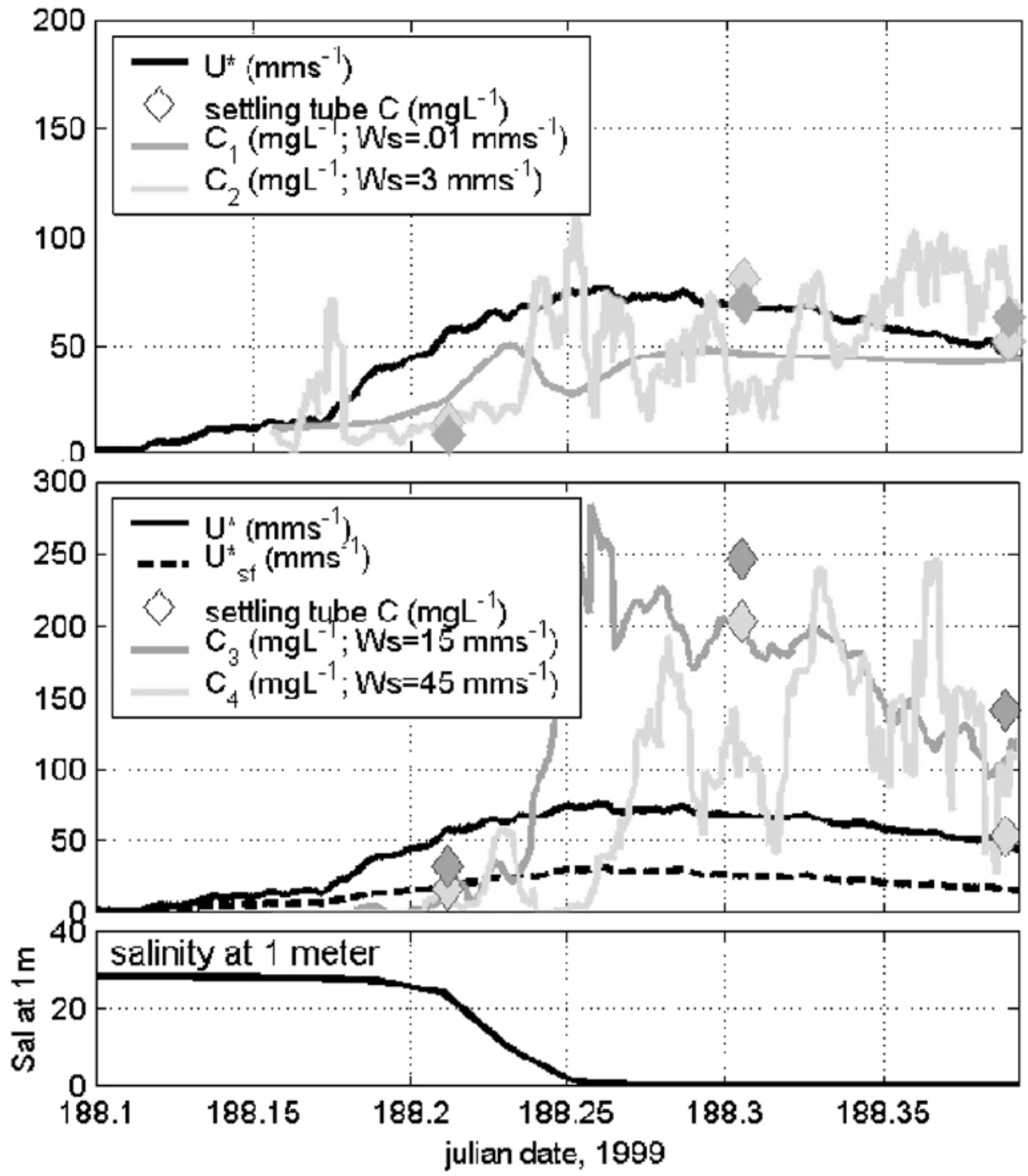

Figure 3. Results. Comparison of post-IA calculated concentrations with settling tube observations $\left(C_{k}\right.$ is actually $C_{k}^{\prime}$, the response-modified acoustically-derived $\left.C\right)$. (top) Results for Ws-classes \#1 and \#2. (middle) Results for Ws-classes \#3 and \#4, along with estimated total shear velocity $\left(U_{*}\right)$ and skin friction shear velocity $\left(U_{*} f\right)$. (bottom) Salinity at $1 \mathrm{~m}$ above the bed. 


\title{
ESTIMATION OF THE COLUMBIA RIVER VIRGIN FLOW
}

\author{
Pradeep K. Naik, Oregon Graduate Institute of Science and Technology \\ David A. Jay, Oregon Graduate Institute of Science and Technology
}

\section{CONCLUSIONS}

It is imperative to have a long-term estimate of the virgin flow of a river to provide a historical perspective of the water resources development, to allow the study of the anthropogenic and climate impacts on the water resources sector, and also to compare the current water use scenarios with those of the past decades. The Columbia River has historically been a major source of economic activity for the Pacific Northwest and is one of the heavily modified rivers in the United States today. Irrigation diversions and the post-1970 flow regulation in large reservoirs along the river have brought significant changes in its streamflow hydrology. Daily streamflow of the Columbia River at The Dalles is available from the U.S. Geological Survey (USGS) since June, 1878. The USGS has calculated a monthly averaged adjusted river flow at The Dalles for 1879-1999 that accounts for the effects of flow regulation. The Bonneville Power Administration (BPA, 1993) has estimated the monthly averaged virgin flow at The Dalles for 1929-1989, i.e., the flow in the absence of both flow regulation and irrigation depletion. We have estimated the virgin flow of the river at The Dalles for the missing years (1879-1928 and 1990-1999).

The effects of irrigation diversions, flow regulation, and climate change are evident in the Columbia River mean flow on the basis of the analyses of the long-term (1879-1999) virgin, adjusted and observed flows. The total reduction in the annual average flow (difference between the 1879-1899 virgin flow and 1945-1999 observed flow) is $957 \mathrm{~m}^{3} \mathrm{~s}^{-1}$ or 15.2 percent, of which $\sim 7.4$ percent is due to climate change, $\sim 7$ percent is due to irrigation withdrawal, and the discrepancy of $\sim 0.8$ percent arises from differences in averaging times. The 1970-1999 annual average loss due to water withdrawal for irrigation is $468 \mathrm{~m}^{3} \mathrm{~s}^{-1}$ or $\sim 7.4$ percent of the $19^{\text {th }}$ century virgin flow.

\section{ACCOMPLISHMENTS}

Simons (1953) has given estimates of the area under irrigation and the corresponding depletion (due to irrigation) for the Columbia River at The Dalles for 1860-1946. His estimates are for every ten years for 1860-1900, for every five years for 1900-1920 and on an annual basis for the subsequent years until 1946. Based on his data, irrigated areas were interpolated on an annual basis for the period 1860-1999 (Figure 1).

The difference between the published estimates of monthly virgin and adjusted flow gives the monthly depletion due to irrigation. When the monthly depletion values are divided by the area under irrigation for the corresponding years, an estimate of depletion per unit area in a month is obtained. These monthly values, when plotted for a year, give an annual cycle of depletion. Based on the examination of the annual depletion cycles defined by 
the period 1929-1946, the annual cycles for the five-year period 1929-1933 were averaged to define a depletion cycle that was assumed to also be typical for the period 1879-1928 (Figure 2). The monthly depletion rates thus obtained from this annual cycle were multiplied by the total area under irrigation in each year for the 1879-1928 period to obtain monthly depletion values. These monthly values were then added to the corresponding monthly adjusted flows to get the monthly virgin flows for the period 18791928. A similar methodology was adopted for estimating virgin flow for 1990-1999, using 1985-1989 as the base period.

Daily virgin flows were estimated using the interpolation technique. After 1940, the daily observed flows were filtered to remove the weekly effects of the hydropower peaking cycles. The difference between the monthly virgin and the observed flow was obtained for every month in a year and the values thus obtained were interpolated on a daily basis for the entire period. These daily interpolated values were then added to the daily observed flows to get virgin flows for the corresponding days (Figure 3).

\section{ANALYSIS}

There has been a steady growth of population and irrigated area in the Columbia River basin since 1860. Until the mid-1940s, about 70 percent of the irrigated areas of the Columbia River basin above The Dalles were found in the Snake River basin, while about 23 percent were above the mouth of the Snake River basin. The remainder (about 7 percent) were between the mouth of the Snake River basin and The Dalles (Figure 4). With the construction of several dams in the sixties, the irrigated areas in the middle reaches of the Columbia River rose quickly. Flow regulation became much more effective after 1970 when several major new dams high in the basin became fully operational.

The effects of post-1970 flow regulations are marked when the ratio of the annual average observed and the virgin flows are plotted for The Dalles (Figure 5). The period until 1970 mostly shows the effect of irrigation depletion, but after 1970, the net effects are both due to flow regulation (inter-annual transfer of water) and irrigation depletion. The difference between the adjusted flow and the observed flow gives an estimate of flow difference due to regulation, whereas the difference between the virgin flow and the adjusted flow gives an estimate of irrigation depletion. The net effect due to flow regulation and irrigation depletion is derived from the difference between the virgin flow and the observed flow. Figure 6 shows the effects of flow regulations and irrigation depletion in the Columbia River during the month of June (1879-1999). Figure 7 shows the annual depletion due to irrigation and the net effects of flow regulation and irrigation depletion for the entire 18791999 period.

\section{ACKNOWLEDGEMENTS}

The Bonneville Power Administration and the National Marine Fisheries Service supported this study. 


\section{REFERENCES}

Simons, W.D. 1953. Irrigation and streamflow depletion in Columbia River basin above The Dalles, Oregon, USGS Water-Supply Paper 1220.

Bonneville Power Administration (BPA) 1993. 1990 level modified streamflow (19281989), 279 p.

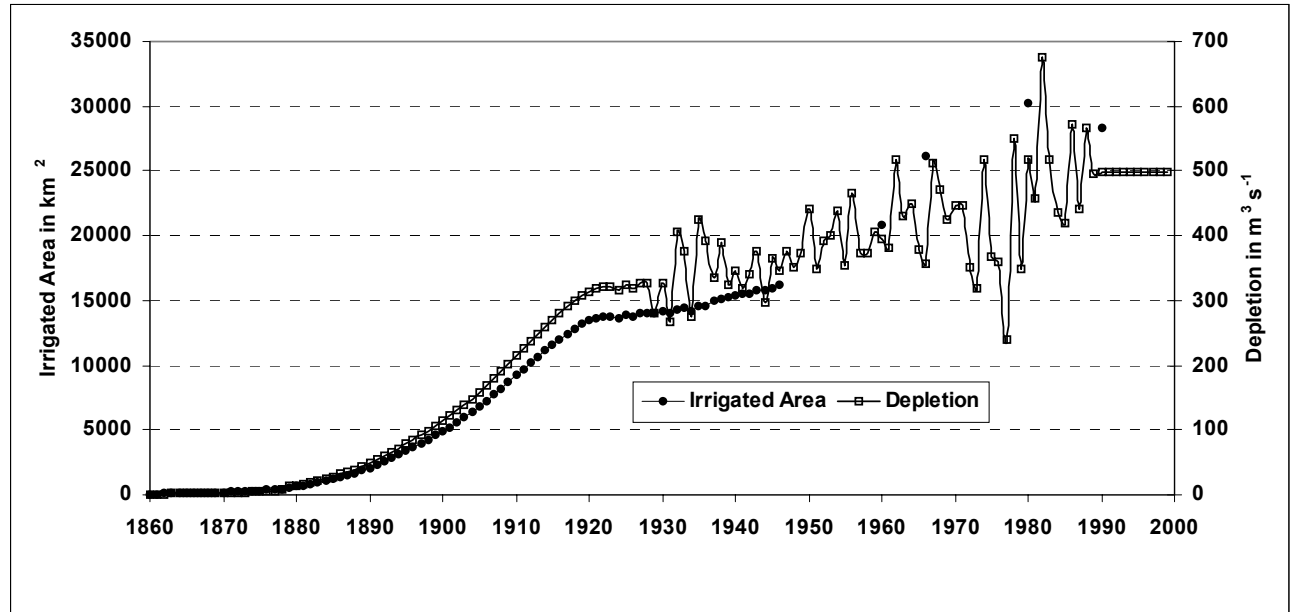

Figure 1. The Columbia River irrigated areas and the corresponding depletions (1860-1999).

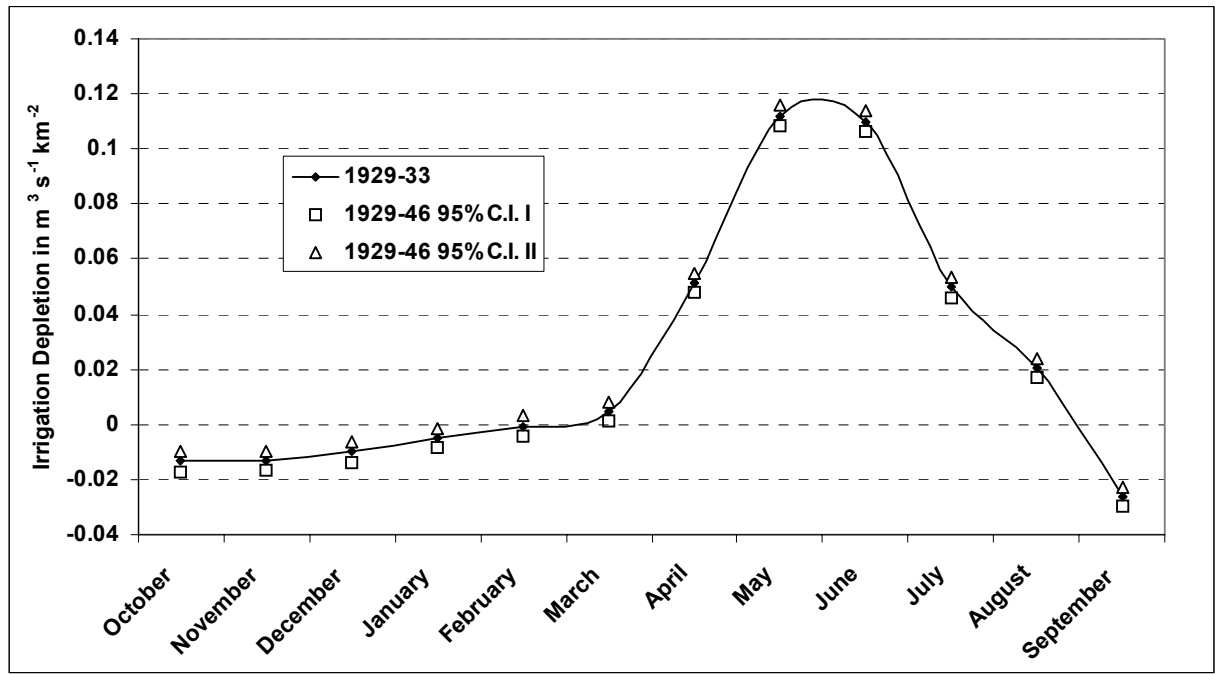

Figure 2. The 1929-1933 irrigation cycle of depletion with uncertainty range (95 percent confidence interval) for 1929-1946. 


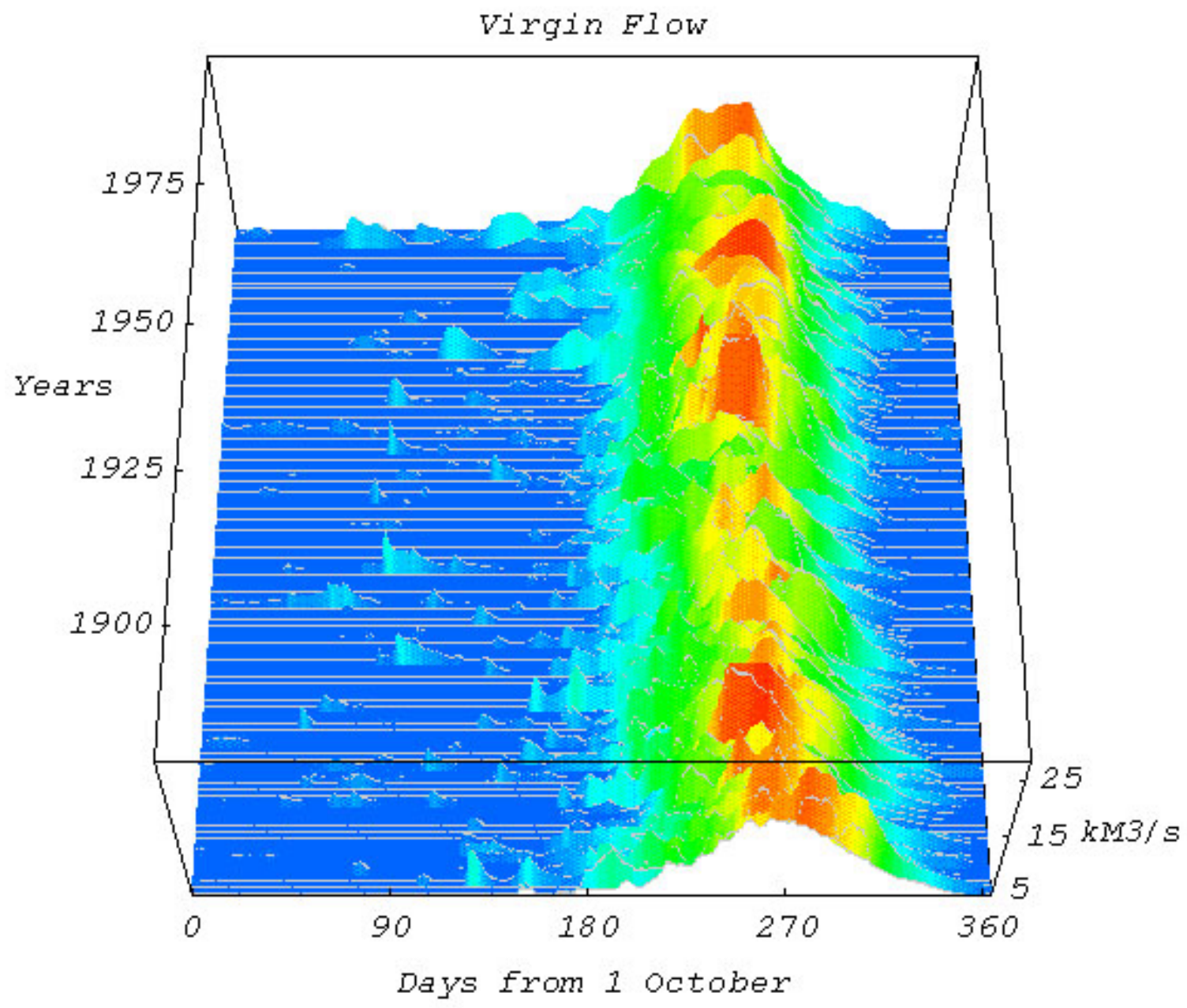

Figure 3. Estimated daily virgin Columbia River interior sub-basin flow at The Dalles, 18791999. The virgin flow is flow that would have occurred in the absence of human manipulation. Note the low winter flows throughout the record and the late spring freshet in the early part of the record. A floor has been set at $4,000 \mathrm{~m}^{3} \mathrm{~s}^{-1}$ to emphasize high flow periods. 


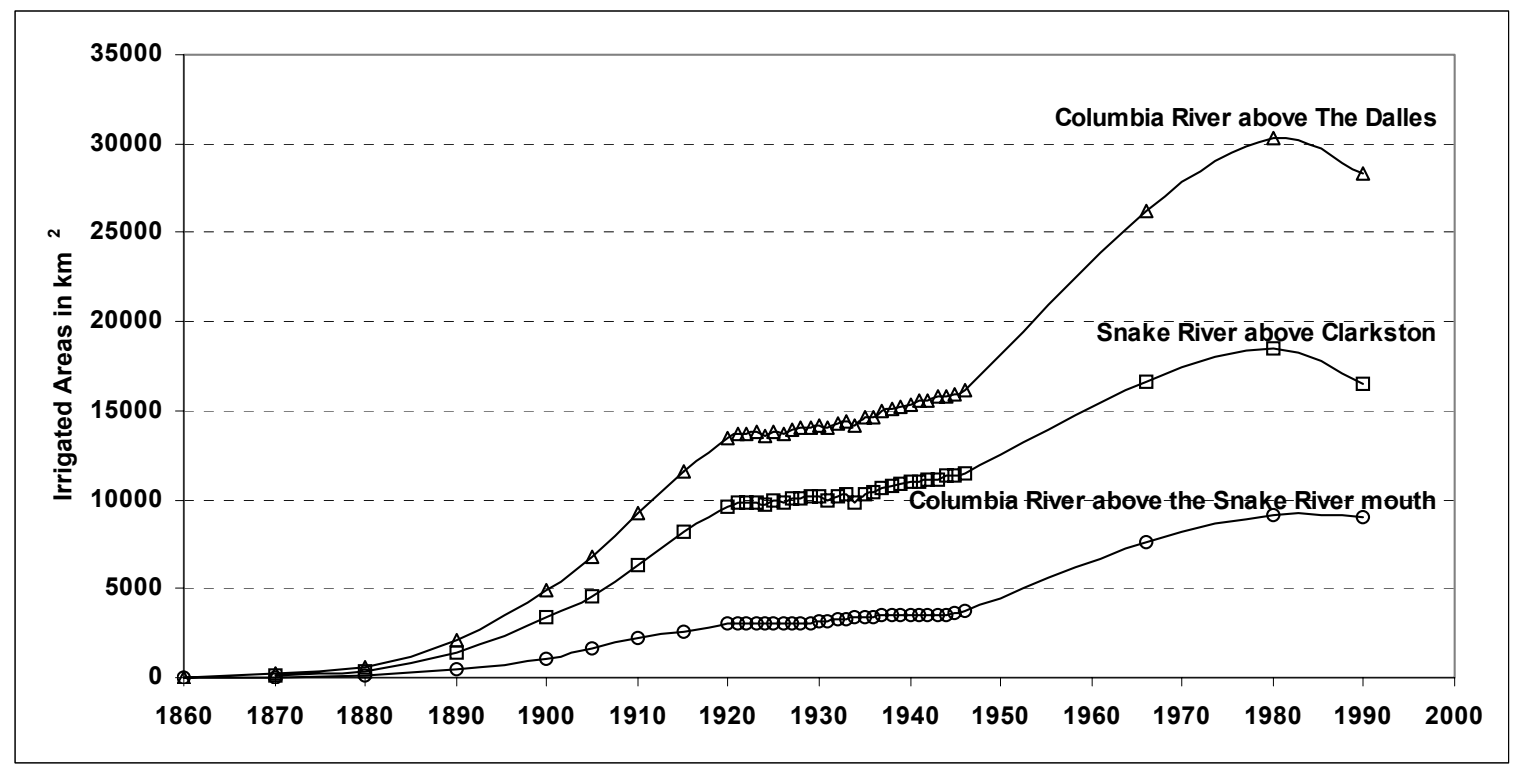

Figure 4. Irrigated areas in the Columbia River basin (1860-1990).

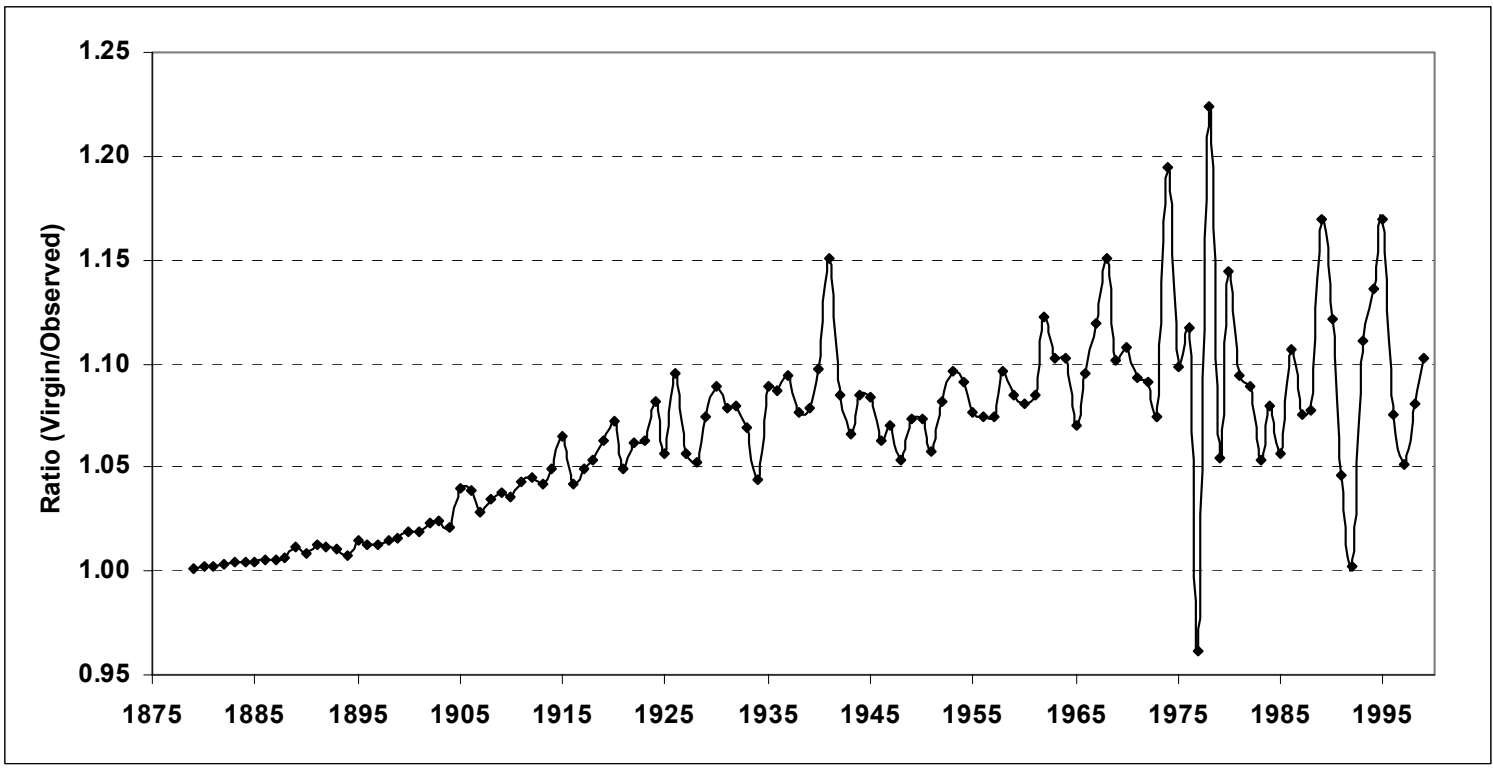

Figure 5. Ratio of the annual mean virgin flow to the observed flow at The Dalles (18791999). 


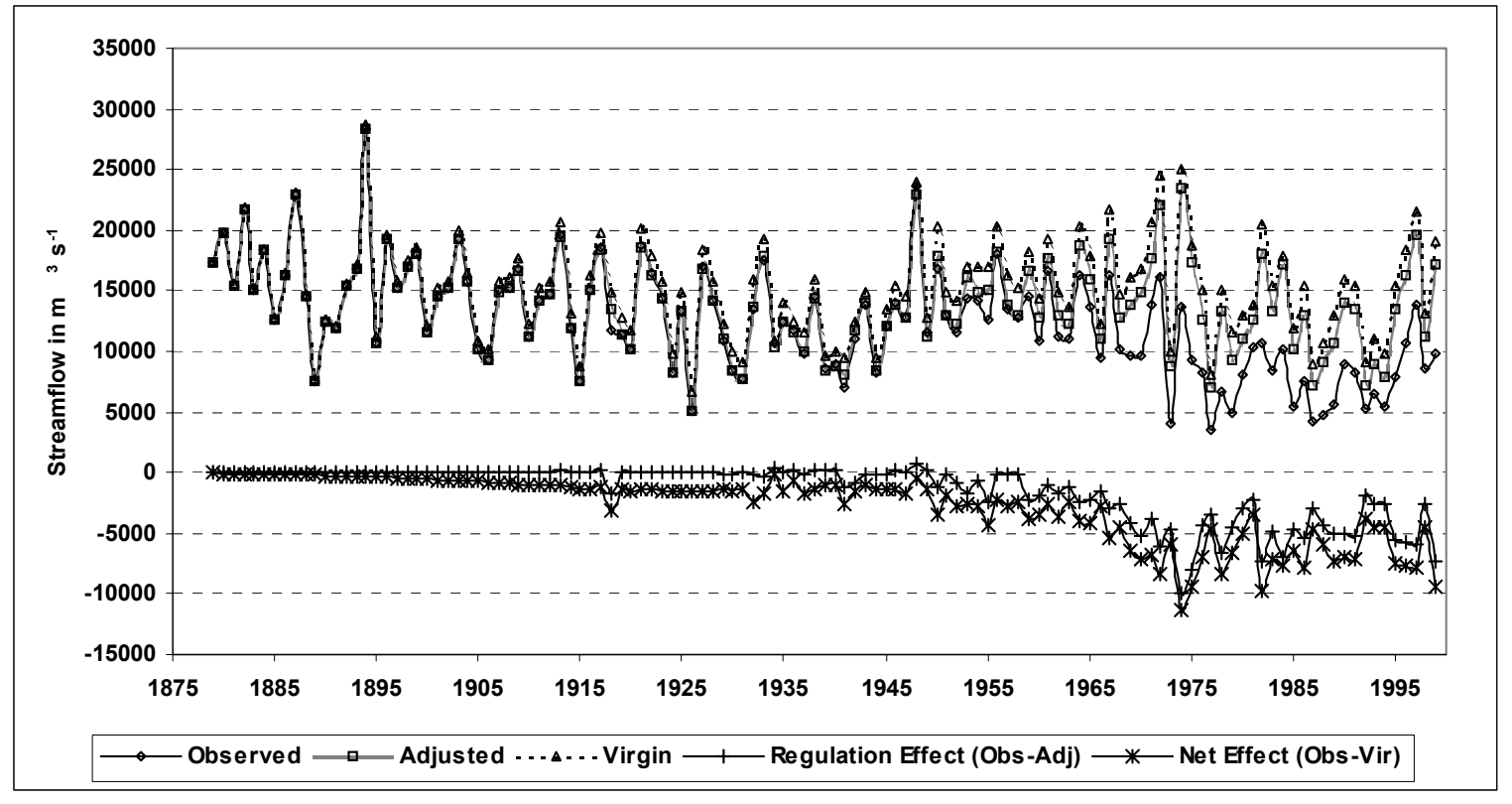

Figure 6. Effects of flow regulation and irrigation depletion in the Columbia River at The Dalles in June (1879-1999).

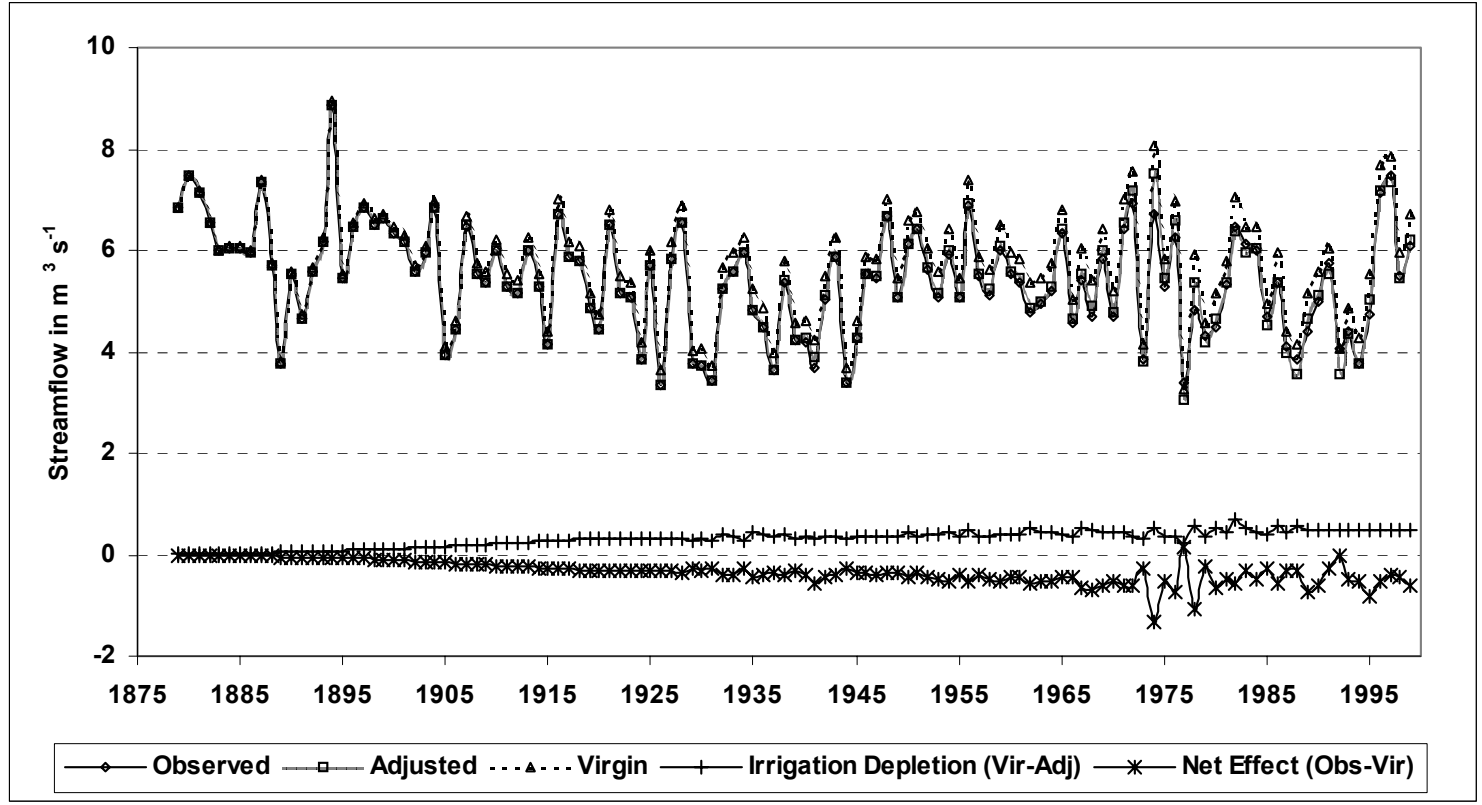

Figure 7. Effects of irrigation depletion and the net effect of flow regulation and irrigation depletion in the Columbia River at The Dalles (1879-1999). 


\section{Coastal Barriers \& Beaches}




\title{
CORRELATION OF SHOREFACE RETREAT SCARPS, FOREDUNE RIDGES, AND LATE-HOLOCENE SHORELINE AGES IN THE COLUMBIA RIVER LITTORAL CELL, WASHINGTON-OREGON, USA
}

\author{
Curt Peterson, Portland State University \\ Harry Jol, University of Wisconsin-Eau Claire \\ David Percy, Portland State University \\ James Phipps, Grays Harbor College \\ Frank Reckendorf, Reckendorf \& Associates \\ Sandy Vanderburgh, University College of the Fraser Valley \\ Lorraine Woxell, Portland State University
}

\begin{abstract}
ANALYSIS
Three independent data sets have been integrated to establish prehistoric shorelines (0$5 \mathrm{ka})$ in the progradative barrier-spits and beach-plains of the Columbia River littoral cell. The data sets include (1) catastrophic retreat scarps documented in ground penetrating radar (GPR) profiles, (2) foredune ridges based on airphoto and topographic coverages, and (3) radiocarbon dates of drift wood, charcoal, shells, basal peat, and/or paleotsunami deposits from geo-referenced core sites. All three data sets have previously been reported in different formats including: MS theses (Woxell, 1998; Schlichting, 2000), hardcopy handouts at Southwest Washington Coastal Erosion Study workshops (Peterson et al., 1999, and 2000), and on project web-pages (nwdata.geol.pdx.edu.coastal-studies/ ofr_2000/). A 300-m long GPR traverse (west of Loomis Lake) from the project web page $<$ ofr_2000/GPR $>$ is shown in Figure 1 with interpreted retreat scarps at $60 \mathrm{~m}$ and $200 \mathrm{~m}$ from the west end at figure left. The two scarps, A and B, are dated at 300 and 1,100 RCYBP respectively (Dolyle, 1996; Meyers et al., 1996), and can be traced throughout the four sub-cells (North Beach, Grayland Plains, Long Beach, and Clatsop Plains).
\end{abstract}

The integration of the three data sets was performed using a NOAA LIDAR coverage (provided by DOE) as a base map in ARCVIEW GIS. The southern several square kilometers (UTM grids) of the Long Beach barrier-spit are shown in Figure 2. White areas represent missing LIDAR data (incomplete coverage). Relative elevation is represented by contrast, i.e., lighter-shades corresponding to higher elevations $(1-10 \mathrm{~m})$ above sea level. Bedrock outcrops ( $>10 \mathrm{~m}$ elevation) anchoring the southern end of the spit are shown in blue (color) or black.

Shore-normal lines represent GPR profiles with lettered retreat scarps (A,B,C-I) corresponding to published Cascadia earthquake subsidence events at 300(A), 1,100(B), 1,300(C), 1,700(D), 2,500(E), 2,800(F), and 3,200(G) RCYBP (Atwater, 2000). Event I is tentatively dated at 4,200 RCYBP from a site at the east end of Joe Johns Rd, Ocean Park, WA (Meyers et al., 1996). The GPR profiles are widely separated alongshore (about $5 \mathrm{~km}$ spacing), and are restricted to existing across-spit roadways (light line coverage). Shoreparallel dark lines represent foredune-ridges corresponding to airphoto interpretations of linear dune-ridge crests between interdune valley wetlands. The LIDAR foredune ridges 
are offset from the mapped airphoto dune ridges. The offsets can result from data-set datum shifts, misinterpreted airphoto images, and inaccurate LIDAR ground elevations (vegetation bias). Work is underway to reconcile the foredune-ridge offsets between the airphoto and LIDAR data sets.

Although not shown on the Long Beach segment in Figure 2, radiocarbon dates constrain the ages of the third, fourth, and sixth foredune-ridge lines from the west. The third ridge (set 3A) is the first prehistoric foredune landward of the late 1800s shoreline, and its age is constrained by a radiocarbon date to the west (LOOMIS 1,100 RCYBP) and Cascadia paleotsunami deposits to the east (1,300 RCYBP) (Schlichting, 2000). The fourth ridge's age is constrained by a radiocarbon date to the west (CRAN 2,500 RCYBP), and the sixth ridge is constrained by a newly obtained radiocarbon date to the east $(5,000 \mathrm{RCYBP})$, i.e., the first onset of net shoreline accretion in the Columbia River littoral cell.

The integration of the three data sets, i.e., GPR, foredune-ridge, and C14 sample-ages, required several assumptions. The first assumption is that same retreat-scarp and same foredune-ridge correlation lines do not cross. The second assumption is that complete sequences of retreat-scarps or foredune-ridges can be patched together by overlapping sequence segments. The third assumption is that dated radiocarbon deposits, overlying basal peats, or distinctive paleotsunami deposits can be used to test scarp-ridge correlation, within and between the four sub-cells. By definition the scarp or ridge correlation lines must not cross timelines (minima or maxima dates) established by the C14 dating.

Preliminary results show an independently correlated sequence of shoreface progradation, retreat, and foredune-ridge development events throughout the Study area. The cause and effect relations of the geomorphic features are not fully understood. Nevertheless, the primary objective of establishing dated (prehistoric) shoreline positions throughout the littoral cell has been realized. Positional errors of the retreat scarps and foredune-ridge crests are on the order of several tens of meters. Age errors are on the order of several decades for the latest retreat scarp and up to several centuries for the older scarp/ridges.

Future work should include establishing (1) shoreface reflector gradients along GPR profiles, (2) statistics of foredune ridge and scarp relative position, and (3) comparisons of geomorphic expression, duration between events, event subsidence magnitude, and event rebound models. These relations should be useful in addressing questions about shoreline processes in the littoral cell.

For example, do steep reflector gradients follow large subsidence events? Do large foredune-ridges develop from small subsidence events and/or minimal rebound conditions? Do nearly-horizontal progradative shoreface reflectors represent rapid rebound conditions? Do foredune-ridges occur from pre-subsidence submergence, yielding two foredunes per earthquake cycle? How and when do foredune-ridge splays form at spit ends? How do these topographic features compare to associated subsurface reflector packages? What is the timing of subsequent spit elongation? What is the relative timing and origin of foredune-ridge truncations by drainage channels? Are the truncations 
sequence-correlated within or between the sub-cells, possibly representing catastrophic tsunami discharge or post-subsidence water-table rise? If the channels are isolated in time/space do they reflect net littoral drift directions, i.e., Connor Creek analogs?

In summary, the integration of the GPR, LIDAR, and C14-age data sets from the progradaing barrier spits and beach plains now allows investigation into numerous process questions based on specific event forcing, event timing, and shoreface response in the Columbia River littoral cell.

\section{REFERENCES}

Atwater, B., 2000, Handouts, Bruceport County Park, Pacific County Field Trip: Geological Society of America, Cascadia Tricentennial Penrose Conference, Seaside, Oregon, p. 3-4.

Dolyle, D. 1996. Beach response to subsidence following a Cascadia subduction zone earthquake along the Washington-Oregon coast, M.S. Thesis, Portland State University, Portland, Oregon, 113 p.

Meyers, R.A., Smith, D.G., Jol, H.M., and Peterson, C.D. 1996. Evidence for eight great earthquake-subsidence events detected with ground-penetrating radar, Willapa barrier, Washington, Geology, 24, pp. 99-102.

Peterson, C. Vanderburgh, S., Phillips, L., Herb, A., Twichell, D. 1999. Deep borehole at the Columbia River mouth, Southwest Washington Coastal Erosion Workshop Report 1998, U.S. Geological Survey Open-File Report 99-524, pp. 29.

Peterson, C., Reckendorf, F., Phipps, J., Percy, D, Vanderburgh, S., Woxell, L., Jol., H. 2000. Dune ridge correlation between the Clatsop Plains and the northern subcells of the Columbia River littoral cell: Late-Holocene paleo-shoreline reconstruction of Southwest Washington and Northwest Oregon, USA, Southwest Washington Coastal Erosion Workshop Report 1999, U.S. Geological Survey Open-File Report 00-439, pp. 33

Schlichting, R. 2000. Establishing the inundation distance and overtopping height of paleotsunami from the late-Holocene geologic record at open-coastal wetland sites, central Cascadia margin, M.S. Thesis, Portland State University, Portland, Oregon, $166 \mathrm{p}$.

Woxell, L.K., 1998. Prehistoric beach accretion rates and long-term response to sediment depletion in the Columbia River littoral system, USA, M.S. Thesis, Portland State University, Portland, OR, 206 p. 
W

$\mathrm{E}$

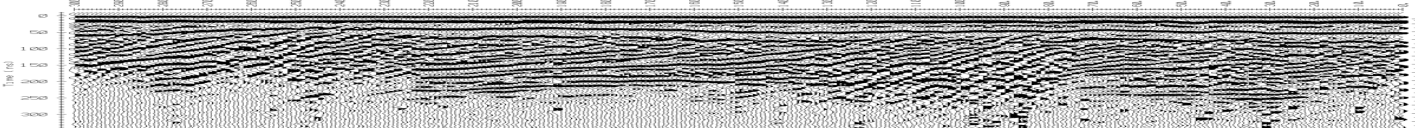

Figure 1. A 300-m long GPR traverse (west of Loomis Lake) from the project is shown with interpreted retreat scarps at $60 \mathrm{~m}$ and $200 \mathrm{~m}$ from the west end at figure left.

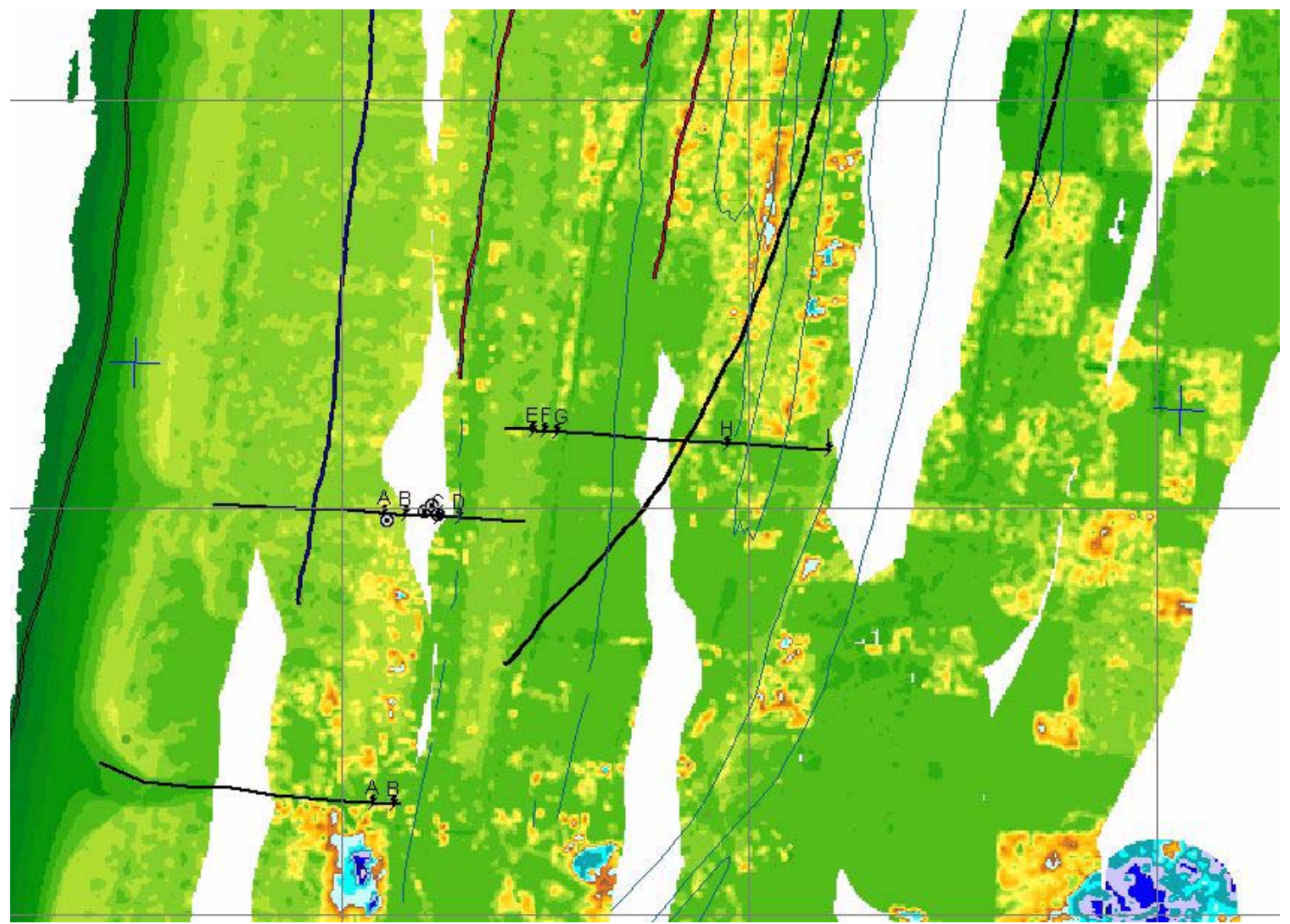

Figure 2. The southern several square kilometers (UTM grids) of the Long Beach barrier-spit are shown. White areas represent missing LIDAR data (incomplete coverage). 


\section{DATA INTEGRATION AND MODELING}

David C. Percy, Portland State University

Peter J. Cowell, University of Sydney

Curt D. Peterson, Portland State University

\section{CONCLUSIONS}

1) Teams of researchers need to work together in order to extract meaning from complex data.

2) Teams need to be composed of people with complementary skill sets that allow for a maximum level of cognitive discourse.

3) It is essential to have a data manager, though every team member should have good computer skills.

4) The data manager should have a solid background in the sciences and the scientific method. This makes the data manager aware of the importance of certain issues, such as resolution and error analysis.

5) GIS and web-based technologies are useful for integrating data.

6) Computer programming skills are necessary to accomplish tasks that the software was not designed to do, which much of the data integration requires.

7) Deadlines are necessary for accomplishing goals.

\section{ACCOMPLISHMENTS}

1) A large data set was integrated.

2) Data for shoreface-modeling was generated.

3) Teamwork model was tested.

4) Open-File Reports were generated and tested for efficacy.

\section{QUESTIONS}

How do we most effectively integrate three-dimensional data? How do we enable scientists to interact most efficiently with the data? How do we deliver data in an electronic form that still encourages interaction among researchers? Can we accomplish some of these tasks using "virtual" meetings? How often do meetings need to be held in 
order to keep data from becoming stagnant? How do we add value to data by including scientific interpretation?

\section{ANALYSIS}

One of the goals of amassing large amounts of data is to extract models. In a Hegelian sense, this is the reason for engaging in scientific inquiry (Mitroff and Turroff, 1973). Successful model extraction may allow us to replace voluminous data with models that are more parsimonious, being made up of equations needing only initial conditions and rates of input change. Sometimes, however, these models are not intended to replace, but to enhance existing data sets, even becoming data sets in their own right.

Another goal of generating and collecting large amounts of data is to enable true scientific breakthroughs. This is often possible only through teamwork where each person involved brings a complementary skill-set, with a "depth" in at least one area ("T-shaped" individuals). In this case, at least one of the team members needs to be steeped in data management. However, it is not enough to be simply a "data-geek". It is critical for the data manager to have a solid understanding of science and the scientific method. This allows the team to communicate at a significantly higher cognitive level. It also makes the data manager aware of the importance of certain issues, such as resolution and error analysis.

As an example of this a recent case in which the three authors worked together to generate a data set for shoreface modeling is presented. The goal was to enable modeling of beachresponse to sea-level transgression and earthquake events. What would the response be, and how could we use existing data to tune the model? The data sets were foredune ridge lines, ground penetrating radar (GPR), core logs, surface topography (LIDAR and DEM), depth to beach sand/shelf sand interface, and depth to ravinement (erosional surface from sea-level rise).

The authors gathered in a small room with a projector connected to a laptop loaded with data. This was one of the most successful examples of using the GIS and web tools. The projector showed the locations of various features in map view on the wall while allowing the authors to toggle over to displays of the sub-surface in logs and GPR. The investigators were able to determine the ideal location for cross-sections, using these tools. The criteria were that a maximum of applicable data exist nearby to the crosssectional location.

Subsequently, cross-sectional data was generated using ravinement data (Cross et al., 1998), topography (LIDAR; Daniels, 2001), and depth to beach sand interface (Herb, 2000). These data were then used by Cowell in a shoreface-modeling program (Cowell et al., this volume). This required truly integrating the data at a level that had not before been attempted. Simply, for a data interval along the transect, a value for each of our data sets was needed. This required getting all of the data at the same resolution, which entailed writing scripts to output coordinates of vertices along our cross-section, and then programatically assigning z-value data to each vertex from each layer of data. Foredune 
ridge locations were also plotted where they intersected the transect as a sharp spike downwards. Figure 1 shows an example of this collection of data.

Later, during other phases of the data integration and interpretation, the simple hard-copy output of maps proved to be the most useful tool. And, when used in conjunction with a web-browser pointed to the Open-File Report data, this was the key to mapping out the earthquake scarps (Peterson et al., this volume).

A GIS database now exists that allows for the investigation of the correlation between data sets. This was constructed in Arcview (ESRI) using standard web technologies (HTML) and server specific software (ArcIMS). Using georeferenced topography data (LIDAR and DEM), as well as GPR and core locations, reference maps were constructed that could be displayed on a computer monitor. The locations of the objects, such as GPR and cores, were placed onto an "imagemap" in a web page that referred to data files containing appropriately sampled images of these objects (USGS Open-File Reports in progress http://nwdata.geol.pdx.edu/coastal-studies/OFR_2000). Similar techniques can be implemented directly in the GIS database, but these were not used due to interpretability issues. There are still significant limitations in GIS, particularly in how 3-dimensional data are handled.

\section{ACKNOWLEDGEMENTS}

We would like to thank VeeAnn Cross for her quick response to our requests for offshore data!

\section{REFERENCES}

Cowell, P.J., Stive, M.J.F., Kaminsky, G.M., and Buijsman, M.C. this volume. Shoreface sand supply for barrier progradation, Southwest Washington Coastal Erosion Workshop Report 2000, U.S. Geological Survey Open-File Report.

Cross, V.A., Twichell, D.C., Parolski, K.F., and Harrison, S.E. 1998. Archive of boomer seismic reflection data collected aboard RV Corliss cruise CRLS97007 off northern Oregon and southern Washington inner continental shelf, U.S. Geological Survey Open-File Report 98-351, 2 CD-ROMs.

Daniels, R.D. 2001. Datum conversion issues with LIDAR spot elevation data, Photogrammetric Engineering \& Remote Sensing, Vol. 67, No. 6, pp. 735-740.

Herb, A. 2000. Holocene stratigraphy and sediment volumes for the Columbia River littoral cell, Pacific Northwest, USA, M.S. Thesis, Portland State University, Portland, Oregon, $186 \mathrm{p}$.

Mitroff, I.I., and Turoff, M. 1973. Technological Forecasting and Assessment: Science and/or Mythology?, Technological Forecasting and Social Change, 5, pp. 113-134. 
Peterson, C., Jol, H., Percy, D., Phipps, J., Reckendorf, F., Vanderburgh, S., and Woxell, L. this volume. Correlation of shoreface retreat scarps, foredune ridges, and late holocene shoreline ages in the Columbia River littoral cell, Washington-Oregon, USA, Southwest Washington Coastal Erosion Workshop Report 2000, U.S. Geological Survey Open-File Report.

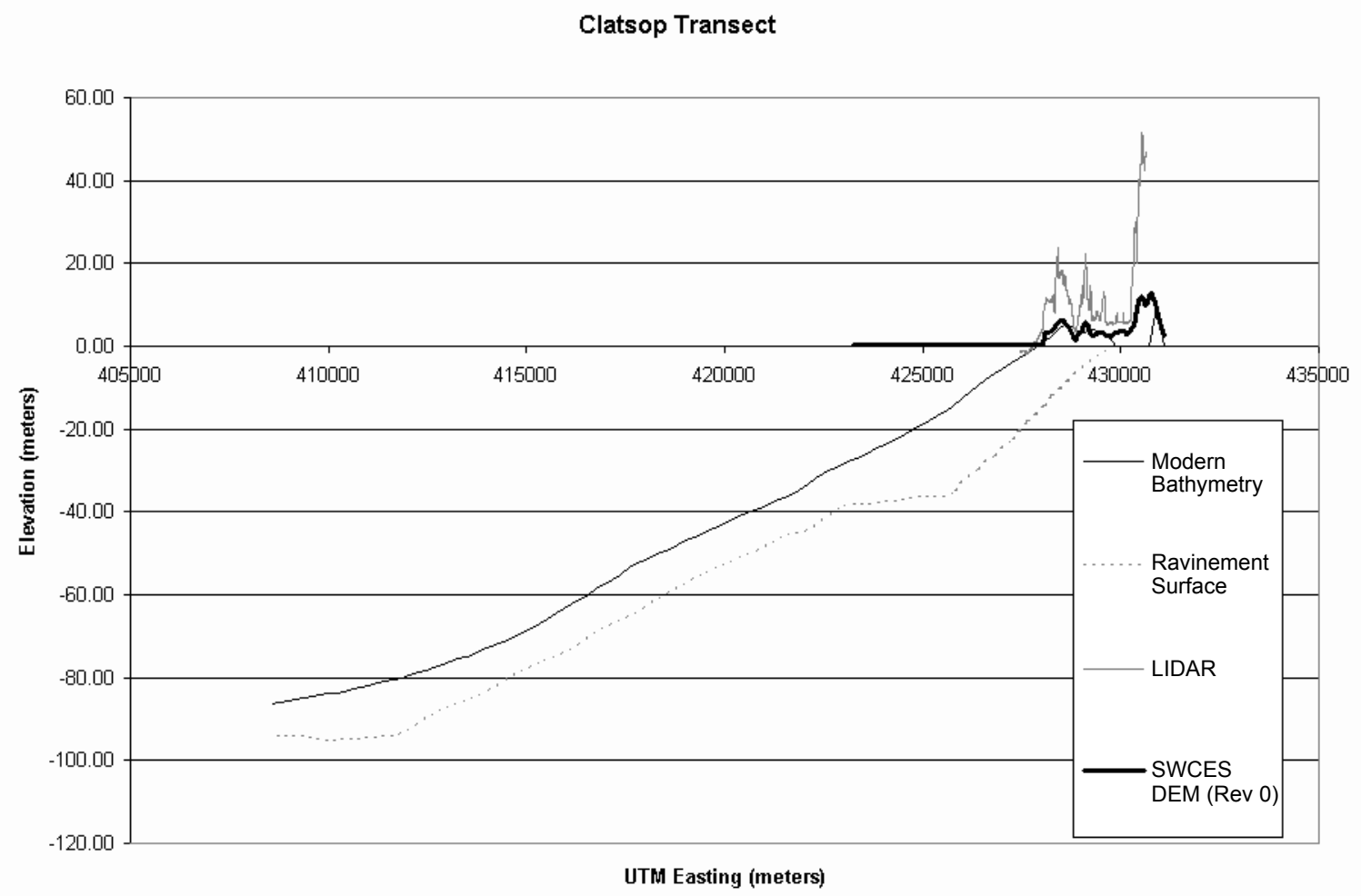

Figure 1. Example plot showing ravinement, bathymetry, DEM and LIDAR data. Not seen, but included, are locations of dune ridges (downward spikes in the LIDAR data). Later revisions include earthquake scarp locations. 


\section{SHOREFACE SAND SUPPLY FOR BARRIER PROGRADATION}

Peter J. Cowell, Coastal Studies Unit, University of Sydney

Marcel J.F. Stive, Department of Hydraulic Engineering, Delft Technical University

George M. Kaminsky, Washington Department of Ecology

Maarten C. Buijsman, Washington Department of Ecology

\section{CONCLUSIONS}

1) Barrier progradation has been attributed in part to shoreface sand supply to the barriers in the Columbia River littoral cell (CRLC) (Kaminsky et al., 1999). The possibility of sand supply from the shoreface to beaches was evaluated based on a variety of methods involving field data and modeling results obtained from five coasts on three continents representing a wide range of coastal environments. The field data include wave-current measurements, historical seabed soundings, and geological surveys. Cross-shore transport estimates from modeling on the annual time scale were compared against scaled-down inferences from the seabed-change and geological data. The results are all consistent with there being net onshore transport over the long term from the lower shoreface to beaches in each of the environments. These environments typify settings that occur commonly (probably predominantly) along the world's coasts. So net shoreface sand supply to beaches may be a widespread and common but little appreciated factor in coastal stability.

2) The effect of this net supply is to offset other factors causing shoreline recession, such as positive gradients in littoral transport. Moreover, shoreline progradation occurs if sand supply from the shoreface dominates over littoral sediment losses. Implications are clearly significant for coastal engineering and coastal management, despite the processes not being immediately apparent: long-term shoreface sand supply to beaches is masked by more rapid cyclical changes. Rates of shoreface sand supply to beaches indicated from various lines of evidence are typically on the order of $10^{0} \mathrm{~m}^{3} \mathrm{a}^{-1}$ per meter of shoreline. This volume corresponds to a lowering of the shoreface by only a few grain diameters per year.

\section{ACCOMPLISHMENTS}

1) A preliminary comparative analysis of various data from other coasts (in the USAAtlantic, Europe-North Sea and SE Australia), was undertaken to assess the general hypothesis that the lower shoreface supplies sand for barrier progradation.

2) Historical bathymetric-change data from the CRLC analyzed originally by Gibbs and Gelfenbaum (1999) was generalized selectively (i.e., in areas away from ebb-tidal deltas) to evaluate possible rates of sand supply for barrier progradation. 


\section{QUESTIONS}

Generally sand loss from beaches to the sea has been perceived as a key factor in worldwide trends toward shoreline recession (Bird, 1985). In principle however, shoreline movements on any stretch of beach on any time scale occurs due to the combined effects of cross-shore sediment movements and alongshore gradients in sediment-transport rates. The paper focuses on the cross-shore component of the problem for time scales of decades or longer. Changes on these time scales are especially important in coastal management because they relate to systematic trends in coastal change that may manifest themselves as chronic shoreline problems.

On annual time scales, movements in shoreline position due to cross-shore sand transport largely involve surfzone dynamics in which changes and movements in sand bars are key elements. These processes have been the subject of concerted effort in coastal research for half a century and, although knowledge of the processes involved remains far from definitive, surfzone morphodynamics is one of the best understood areas in coastal science. Shoreline movements associated with surfzone morphodynamics are circumscribed roughly by the annual closure depth for profile changes, as defined originally be Hallermeier (1981). More recent studies have shown that observable profile closure occurs at greater water depths as the time scale increases (Nicholls et al., 1998).

The questions addressed in this paper therefore are as follows:

1) Is there evidence that the shoreface acts as a sand supply to the beach, and, hence, a source of sands for barrier progradation?

2) What rates of cross-shore sand transport are evident from source and sink indicators, and are these rates plausible?

\section{ANALYSIS Introduction}

The perception that the shoreface is a sink for beach sand derives mainly from erosion events related to storms in which sand loss offshore can be observed directly through measurements of profile change. Although erosion events cause temporary sand displacements that may manifest as acute coastal-management problems, they are part of a cyclical process and, thus, not necessarily a cause of chronic coastal recession. Our recent work on the coasts of three continents suggests that more systematic (long-term) trends in shoreline movements, related to cross-shore sediment displacement, involve a coupling between the upper and lower shoreface (where the upper shoreface is defined as the seabed and beach landward of the annual closure depth).

Figure 1 illustrates this coupling in results obtained by applying the Shoreface Translation Model (Cowell et al., 1995) to the Tuncurry coast, $220 \mathrm{~km}$ north of Sydney. Sand supply from the lower to the upper shoreface, due to simulated shoreface deepening, averaged $1.1 \mathrm{~m}^{3} \mathrm{a}-{ }^{1}$ per meter of shoreline over a 6000 year period, forming 80 percent of the sand now in the strandplain. 
With the focus of research until now on bar movements and shoreline erosion-recovery cycles on the sub-decadal time scale, little is known about the sediment exchanges between the upper and lower shoreface, or the consequent shoreline responses over the long term (decades to centuries). Evidence is now emerging however that, on this time scale, the shoreface is a net sand source for beaches in many coastal environments, as illustrated in Figure 1. The effect of this net supply is to offset other factors causing shoreline recession, such as positive gradients in littoral transport (Stive et al., 1991). Moreover, shoreline progradation remains possible if sand supply from the shoreface dominates over littoral sediment losses. Implications are clearly significant for coastal engineering and coastal management, despite the processes not being immediately apparent; shoreface sand supply to beaches is masked by more rapid cyclical changes (Cowell et al., 1995).

Circumstantial evidence for long-term sand supply to beaches on the Ebro Delta in the Mediterranean Sea was presented recently by Stive et al. (1999). The evidence was obtained from a range of methods including detailed field measurements and modeling on several time scales. In this paper, we draw together further evidence that point toward the shoreface being a net source for beach sand on the time scale of decades to millennia in a wider range of coastal environments.

\section{Methods}

Indications that sand supply from the shoreface is widespread comes from i) bathymetric measurements spanning many decades, ii) measurements of sediment dynamics on the lower shoreface, iii) numerical modeling of shoreface sediment transport, iv) behavior modeling of sediment-transport regime and profile kinematics, v) the radiometric dating of strandplain development at sites where other sources of sand supply are limited, non existent, or can be estimated, vi) lower-shoreface sedimentology, and vii) regional sediment-budget analyses. As usual in coastal science, none of this evidence is conclusive and each has limitations in terms of accuracy, validation, or both. More specific details of methods are outlined in respective parts of the Results section. The following general considerations however are also relevant.

Direct measurement and modeled estimates: In principle, the most obvious way to resolve the question of shoreface sand-supply to beaches is through direct measurement of either cross-shore sand transport or of changes in bed elevations on the lower shoreface. In practice, however, both methods face serious shortcomings. Cross-shore transport of sand is difficult to measure in the field. Usually estimates are based on measurements of suspended-sand concentrations and horizontal water velocities that are combined via boundary-layer and sediment-transport models to yield sediment-flux (Wright, 1995). While estimates of gross oscillatory fluxes derived from such observations are problematical enough, the practical value of such estimates is diminished critically because what we actually need to know are the net fluxes averaged over the long term. Measurements are generally available for isolated periods only, over durations typically of months. Within such a measurement window it is impossible to capture anything like the full climatology of flows driving sand transport. Moreover, from the observations made so far it is clear that the variability in fluxes is large even during a single storm event; so 
long-term average net-flux estimates become indeterminate quantities over many cycles of storm and fair-weather conditions.

Sand supply from the lower shoreface should produce a lowering of the shoreface through time. Direct measurements of changes in shoreface elevation typically have a maximum accuracy of $\pm 0.3 \mathrm{~m}$ (Gibbs and Gelfenbaum, 1999). This limit of measurement underpins the formal definition of profile closure (Hallermeier, 1981). Long term (multi-decadal) data sets in which lower shoreface changes are greater than $0.3 \mathrm{~m}$ are not common. Moreover, earlier data sets (especially before about 1960) are less accurate and accuracy deteriorates with distance from the coast. This deterioration occurs because uncertainty in horizontal-position fixing, based on sight-line triangulation from landmarks, results in vertical accuracy no better than $\pm 2.5 \mathrm{~m}$ over the seaward part of the shoreface (Gibbs and Gelfenbaum, 1999). Thus, while comparison of recent bathymetric measurements with data from further back in time might be expected to encompass more detectable bed changes, the poorer accuracy from older records diminishes the value of this opportunity.

Indirect measurement and modeling: The alternative ways of addressing the problem all involve indirect methods, and each has its own shortcomings. Modeling cross-shore transport on the shoreface is notoriously unreliable, and, in any event, cannot be expected to yield reliable estimates of time-averaged net fluxes if we cannot be sure about our measurements of such fluxes for the purposes of model validation. So called behaviororiented modeling (de Vriend et al., 1993) of sediment-transport climatology and bedprofile kinematics addresses the problem on more appropriate space and time scales. This approach has the advantage of side-stepping uncertainties in scaling up sand-flux residuals. These residuals generally are much smaller than the gross oscillatory fluxes from which they derive, but cumulate through time to produce systematic morphological change. Behavior-oriented models, however, rely heavily on parameter fitting and thus require sound estimates of exogenous quantities including morphological change itself. These models, therefore, cannot be used in isolation but depend upon their application occurring in parallel with the other methods described herein.

Depositional features on coasts record the end product of sediment displacement from one place to another. Radiometric dating of such deposits can be used to constrain possible transport paths and sources, and to provide estimates for rates of sediment delivery. Strandplains (prograded barrier beaches) provide evidence of sand delivery from elsewhere, i.e., from further along the coast, local deltaic sources, or, possibly, from the lower shoreface. In coastal cells where deltaic or alongshore sources can be ruled out based on regional setting and sedimentological evidence, or where estimates of input volumes from these sources can be constrained reasonably well, the question of sand supply to beaches from the shoreface can be resolved by inference from the depositional volume. Rates of net sand supply can then be obtained by extrapolating down from radiometrically calibrated rates of strandplain development that occurs generally over centuries and millennia (e.g., Figure 2).

Such inferences are not so easy to draw from the source zone (i.e., the lower shoreface) because, by definition, it is an erosion surface. While here there is no counterpart to the 
depositional volume from which to infer rates of sediment displacement, the character of the sediments themselves may at least provide evidence that the lower shoreface is a deflationary surface and hence a sand source. This evidence takes the form of a lag deposit comprising sand that is coarser than the underlying deposits. The inference here is that the finer sand grains have been winnowed out and transported elsewhere, such as toward the coast where it might be redeposited in strandplains or dispersed alongshore and lost into estuaries. For surface lag deposits to form, a proportion of coarser sands must be present in the underlying parent material. A coarser sand fraction is not always available (e.g., when the parent material is itself a lower-shoreface or palaeo-dune deposit). Where the underlying surface comprises relict beach, tidal-inlet, or glacio-fluvial deposits, a coarser fraction is generally present in the parent material.

Estimates of sand source and sink relationships obtained from any of the above methods can be evaluated and constrained through an audit of regional sediment budgets. Such an exercise usually requires estimates of net sediment fluxes and depositional (or erosion) volumes obtained using any or all of the other methods outlined above. Sediment-budget analysis thus confers added value by cross checking the consistency between net-flux estimates derived by various means.

\section{Indicators from Field data and Modeling results}

Detailed long-term bathymetric measurements from the central Netherlands coast (Stive and de Vriend, 1995) and the U.S. Columbia River Pacific coast (Gibbs and Gelfenbaum, 1999) each reveal deepening of the lower shoreface over many decades, despite extreme contrasts in the oceanographic and morphologic character of these environments. It is not immediately obvious in these cases that sand removed from the lower shoreface was displaced onshore without reference to the other indicators, including sedimentology, sand-transport measurements, and modeling, as outlined below. In SE Australia barrier progradation under circumstances that exclude the possibility of other sand sources provides the most definitive evidence for sand supply from the lower shoreface during the last 6,000 years of stable, high-stand sea level.

Radiometric dating of Holocene strandplain development: Radiometric dating of subsurface samples from strandplains in SE Australia indicates that sand supplied to deeply embayed coastlines derives from the shoreface. Two well studied examples exist: Moruya Beach (Thom, 1984) and Tuncurry Beach (Roy et al., 1994), about $240 \mathrm{~km}$ south and 220 $\mathrm{km}$ north of Sydney respectively.

Studies of sediments and stratigraphy on the strandplains behind these beaches indicate that the lower shoreface was the only source for strandplain progradation during the past 6000 years. At Moruya, bedrock headlands protrude far enough to preclude littoral transport of sand into the Moruya embayment (Inset, Figure 2). The littoral partitioning of adjacent coastal cells is further evident in sedimentological indicators (Thom, 1984). Since the shoreface is the only possible source of significance for sand contained within the strandplain, the total volume of the strandplain infers a lowering of the shoreface by about $8 \mathrm{~m}$ during the past 6000 years (i.e., the period that has elapsed since relative sea level stabilized in the SE Australian region). The inferred rate of lowering averages 
$1.3 \mathrm{~mm} \mathrm{a} \mathrm{a}^{-1}$, i.e., less than 3 grain diameters, which seems feasible considering that Moruya is subject to a swell-dominated wave climate.

The Moruya data indicate a decreasing trend in the volume rate of progradation through time (Figure $3 \mathrm{~b}$ ). The data however clearly suggest that a mean-trend progradation still continues today (at about $3.3 \mathrm{~m}^{3} \mathrm{~m}^{-1} \mathrm{a}^{-1}$ ), but that the supply rate may be reducing as the shoreface trends toward equilibrium, or due to bed armouring by the surface lag deposit that has developed on the lower shoreface (depicted by the stippling in Figure 3a).

At the other study site, Tuncurry Beach, the net littoral transport of sand north toward the Tuncurry bedrock embayment was intercepted through loss offshore to form an inner-shelf sand body (Roy et al., 1994). Thus, the $1150 \mathrm{~m}$ wide Holocene strandplain has necessarily derived most of its sand from the shoreface immediately seaward of the beach. The total prograded volume is $26,000 \mathrm{~m}^{3} \mathrm{~m}^{-1}$ of coast which gives an upper estimate for the supply rate from the shoreface of $4.3 \mathrm{~m}^{3} \mathrm{~m}^{-1} \mathrm{a}^{-1}$.

Bathymetric-change measurements: Detailed long-term bathymetric measurements from the central Netherlands coast (Stive and de Vriend, 1995), and the U.S. Columbia River coast in the NW USA (Gibbs and Gelfenbaum, 1999) provide direct measurement of morphological changes on the lower shoreface. Both sets of survey data span from the late 19th through to the late 20th century (1897-1975 and 1870s-1999 for the Netherlands and Columbia-River coasts respectively, with additional surveys available for the latter from 1926, and 1958). The data are yet to be analyzed in their entirety, so the results presented here are preliminary. Both data sets can be expected to contain errors that are greatest for the older data sets, reducing to an estimated $\pm 0.3 \mathrm{~m}$ for the modern data for which radar or DGPS positioning was available and high resolution fathometers were used.

Error in depth soundings from the 18th century was estimated from detailed analysis as being less than $\pm 2 \mathrm{~m}$ for the Columbia-River coast (Gibbs and Gelfenbaum, 1999). The error sources could be systematic due to datum uncertainties, or random due to errors in soundings or horizontal-position fixing. Random errors were evaluated to be the dominant source. We attempt to minimize much of the random error in the Columbia River data by averaging the measured bathymetry alongshore within sub-cells for which homogeneity of profiles can be assumed.

The alongshore averaging for the Columbia River coast was performed by calculating the area between contours ( $1 \mathrm{~m}$ contour interval) along segments of beach ranging from 4 to $15 \mathrm{~km}$ in length, and then dividing the area by the shoreline-segment length to give average cross-shore distance between contours. In the case of the central Netherlands coast (offshore from Haarlem), depth data from only one representative transect were selected; so this example is less reliable. Measured depth changes are within the error bands for both examples so the data are by no means conclusive. In both cases, however, the apparent bathymetric change has been evaluated, via sediment-budget analyses (Stive et al., 1991; Kaminsky et al., 1999), against results from various complementary data 
sources and methods. The indicative changes in bathymetric data are consistent with other evidence in both cases.

In the Long Beach sub-cell of the Columbia River coast, accretion is indicated on the upper shoreface, consistent with observed historical and prehistorical shoreline progradation along this entire coastal cell. Shoreface lowering is indicated in the data for water depths ranging from $25-50 \mathrm{~m}$ below extreme low tide levels (Figure 4a). Further seaward, the entire continental shelf is aggrading due to sediment supply (primarily muds) from the Columbia River.

The less detailed data from the central Netherlands coast show similar tendencies, except here active progradation of the beach that occurred throughout the mid-Holocene is thought to have ceased about 2000 years ago (Beets et al., 1992), with a stable mean shoreline position prevailing during historical times (Stive et al., 1991). The rotational shoreface deepening evident from the central Netherlands coast increases in the seaward direction (Figure 5), and extends beyond the offshore limit of the survey, so the full extent of the deepening cannot be determined.

Sand eroded from the Netherlands lower shoreface is thought to be transported onshore and then alongshore into the estuaries (Stive et al., 1991). Development of progradational strandplains along the central Netherlands coast during the mid-Holocene (post 5-2 ka BP) has been analyzed in terms of the regional sand budget, and half the sand supply has been attributed possibly to a lower shoreface source (Beets et al., 1992; Stive and de Vriend, 1995). The annual rates of shoreface lowering, which range up to $7 \mathrm{~mm} \mathrm{a}^{-1}$ (Figure 5a), thus suggest a minimum supply rate of sand from the shoreface of about $4.6 \mathrm{~m}^{3}$ per meter of shoreline per year. Over the $120 \mathrm{~km}$ of the central Netherlands coast, the implication is that the annual supply from the shoreface to the beaches exceeds 0.5 million $\mathrm{m}^{3}$ of sand per year.

Similarly, sediment-budget analysis for the Columbia River coast indicates that only part of the progradation can be accounted for through direct sand supply from the river, or through the additional source attributed to degeneration of ebb-tidal deltas following construction of long rock jetties at the entrance of the Columbia River and Grays Harbor (inset, Figure 4); supply from the lower shoreface was deemed to be necessary to balance the budget (Kaminsky et al., 1999).

Overall, results from the historical seabed survey data from The Netherlands and the NW USA are consistent with the geological data from SE Australia (Figure 3b). The bathymetric-change data suggest shoreface lowering occurs at rates of only several sandgrain diameters per year (Figures $4 \mathrm{~b}$ and $5 \mathrm{~b}$ ), with the highest rates at the shallowest end of the lower shoreface where wave-induced bed stresses are greatest (Figure 4b).

Lower-shoreface sedimentology: The stippling beneath the modern shoreface in Figure 3a depicts a lag deposit of coarse surface sediments reported for lower shorefaces from many parts of the world, including Pacific and Atlantic coasts of the USA, the Netherlands North Sea coast, and along much of the coast in SE Australia (Cowell et al., 
1999). Careful sedimentalogical analysis of sands from this lag layer off Tuncurry in SE Australia has shown that there the coarser sediments are derived from the underlying parent sediment body (Roy et al., 1994). Coarse sediments with the same mineralogy and granulometric properties are found in the parent sediments but in much lower concentrations. It is apparent therefore that concentration of the coarser sands occurs through a lowering of the parent sediment body through erosion, with the finer sand fraction winnowed out.

Two additional indicators provide evidence for this process: a) the mineralogy of the finer fraction at Tuncurry is consistent with that of sediments composing the strandplain immediately inshore (Roy et al., 1994); and b) seismic records from the parent sediment body show truncated strata consistent with a lowering of the parent sediment body by several meters (Cowell et al., 1995).

Field measurements and numerical modeling of shoreface sediment dynamics: Our previous work on lower-shoreface sediment dynamics (summarized in Wright, 1995; see also Stive et al., 1999) provides evidence that onshore transport of the sand from the lower shoreface is at least possible. Measurements in $20 \mathrm{~m}$ of water in the Atlantic Bight, USA and SE Australia clearly showed that offshore transport, primarily due to storm-driven downwelling flows, is a dominant process under high energy conditions. Effects of swell in returning sand onshore under fair-weather conditions, however, are indeterminate because of a phase shift between measured sand-suspension concentrations and water velocities in response to the asymmetrical wave velocity field, i.e., the well known problem of vortex generation over sharp-crested, wave-induced bed ripples (Wright, 1995). On the other hand, the Atlantic Bight field campaigns provided evidence that substantial onshore transport of sand occurs under conditions of moderate wave energy during the waning stages of storms, when wind forcing and associated downwelling has abated, vortex ripples presumably having been destroyed during the peak of the storm (Wright, 1995).

Similarly, measurements off the Ebro Delta in the Mediterranean Sea under these types of conditions show onshore skewness in the near-bed velocity field, together with a phase shift between suspended-sand concentrations and velocity fluctuations that is consistent with onshore transport (Stive et al., 1999). None of these data sets from the USA, SE Australia, or the Mediterranean provide anything more than circumstantial evidence of onshore sand transport, especially in a net sense. The net fluxes depend upon the climatology driving cross-shore transport.

While wave climates can be reconstructed from long-term records of wave-rider buoys (where these exist, and subject to uncertainties related to inter-decadal, El Niño-type climate variations), and tidal-flow regimes can be modeled reasonably well, we remain a long way from being able to build representative climatologies of wind-induced flows over the shoreface. The problem is partly to do with the variability in storm source and tracking. Even worse, no reliable transform functions exist for converting the spectra of flows into estimates of net sand transport, especially for the cross-shore component. 
What we can conclude from measurements however is that there is more than enough hydrodynamic energy on the lower shoreface to permit the occurrence of onshore transport. That is, our data are not inconsistent with the possibility of net onshore transport. This possibility is given further support in modeling of the wave-tide flow climatology and resulting sediment transport over the lower shoreface on coast of The Netherlands (Roelvink and Stive, 1991). The modeling did not include representation of a downwelling climatology related to storm surges, which are significant on the Netherlands coast. The net onshore transport from the modeling is thus probably over estimated. Modeled net fluxes are compared in Table 1 to the fluxes inferred from Figure 5.

The ratio of modeled to inferred net fluxes is an excess potential-transport factor. The excess potential may in part reflect the exclusion of wind-generated downwelling flows from the modeling which would contribute to the offshore component of sand flux. The onshore fluxes inferred from Figure 5, however, are probably minima since the bed lowering evident is greatest at the seaward limit of the data, suggesting an even larger sediment yield from further offshore, and indicating that the over-estimation of modeled fluxes is not as large as implied in Table 1.

\section{Discussion}

Detailed analyses for sediment budgets for the Netherlands coast (Stive et al., 1991) and the Columbia River littoral cell (Kaminsky et al., 1999) both indicate that a sand supply from the shoreface is required to balance the budget, thus supporting the results presented here. More generally, however, sediment-budget analyses have widely differing implications for coastal management depending on whether or not the shoreface is included as a sand supply for beaches.

For example, gross analysis of the littoral sand-budget for the 'northern rivers' coastal cell, roughly 500-700 km north of Sydney on the E Australian coast, indicates a littoraltransport deficit of about 0.5 million $\mathrm{m}^{3} \mathrm{a}^{-1}$. The deficit arises because the net littoral transport is estimated to increase from zero to about 0.5 million $\mathrm{m}^{3} \mathrm{a}^{-1}$ over this $200 \mathrm{~km}$ stretch of coastline, with negligible sand contributions from coastal rivers (Roy and Thom, 1981). The alternative implications then are that a) the coastline is retreating at a rate averaged along the entire cell of up to $1 \mathrm{~m} \mathrm{a}^{-1}$ to make up the supply deficit, or b) if the shoreface supplies about $2.5 \mathrm{~m}^{3} \mathrm{~m}^{-1} \mathrm{a}^{-1}$, then the coastline may be in or near a dynamic equilibrium.

The northern-rivers coastal cell exhibits signs of erosion and systematic recession in many places and these are the subject of coastal management and engineering interventions. Sea level has been fairly stable for the last 6000 years and it seems unlikely that the coast has receded on the order of kilometers during this period, as the sediment budget might imply. On the other hand, there have been many large engineering interventions, such as construction of river-mouth training walls, that have caused shoreline realignments and erosion, although the downdrift extent of these impacts is not well understood. So the possibility exists that perceived problems of coastal recession are largely anthropogenic, and that a shoreface sand supply to beaches is sufficient to offset, in part or in full, the 
demand created by the alongshore transport gradient. Clearly, resolving this problem is crucial for sensible decision making in coastal management.

The inner shelf and shoreface fronting the northern-rivers coastal cell is much shallower than at Moruya, south of Sydney, where clear evidence exists for a shoreface sand supply to beaches (Figure 3). The northern-rivers shoreface is also more sand abundant, i.e., the area of bedrock outcrop on the sea floor is much less than off Moruya (Roy and Thom, 1981). On this basis we would expect a greater potential for sand supply from the shoreface along the northern rivers cell. Evidence for this supply, however, is absent onshore in the northern-rivers cell because any shoreface sand supplied to beaches feeds the littoral-transport demand rather than contributing to strandplain development.

Even at Moruya, however, where progradation of the Holocene strandplain attests to a shoreface supply, the annual addition of sand to the beach and resulting mean-trend shoreline change is undetectable on annual and even sub-decadal time scales. That is, the shoreface-supply volume is negligible compared to the volume of sand involved in beach erosion and recovery cycles (which is in the range $100-200 \mathrm{~m}^{3} \mathrm{~m}^{-1} \mathrm{a}^{-1}$ ). The annual net supply residual however is cumulative and would grow to exceed the beach-cut/fill volume after only several decades (about 30 to 60 years).

Overall, the convergent lines of evidence contained in the results point to a long-term relaxation of the lower shoreface toward a deeper equilibrium. The continuous progradation of strandplains over the past 6000 years in embayments closed to littoral sediment inputs in SE Australia indicates relaxation times on the order of $10^{3}$ years. Our work thus implies new imperatives and possibilities for pursuing further research into shoreface equilibrium relevant to practical coastal engineering.

\section{ACKNOWLEDGMENTS}

This paper is an outcome of the PACE project under the European Union Marine Science and Technology program (MAST-III contract MAS3-CT95-0002), and is funded by the Southwest Washington Coastal Erosion Study supported by the USGS and Washington Department of Ecology. Collaboration was funded by grants from Australian Department of Industry Science and Resources. The contribution of MJFS was funded by the Delft Cluster Project Coasts 03.01.03.

\section{REFERENCES}

Beets, D.J., van der Valk, L., and Stive, M.J.F. 1992. Holocene evolution of the coast of Holland, Marine Geology, 103, pp. 423-443.

Bird, E.C.F. 1985. Coastline Changes, Wiley Interscience, Chester, 219 p.

Cowell, P.J., Hanslow, D.J. and Meleo, J.F. 1999. The shoreface, In: Short, A.D. (ed.), Handbook of Beach and Shoreface Morphodynamics, Wiley, Chichester, pp. 3771. 
Cowell, P.J., Roy, P.S. and Jones, R.A. 1995. Simulation of LSCB using a morphological behaviour model, Marine Geology, 126, pp. 45-61.

de Vriend, H.J., Capobianco, M., Chester, T., de Swart, H.E., Latteux, B., and Stive, M.J.F. 1993. Approaches to long-term modelling of coastal morphology: a review, Coastal Engineering, 21, pp. 225-269.

Gibbs, A.E. and Gelfenbaum, G.R. 1999. Bathymetric change off the Washington Oregon Coast, Proceedings of Coastal Sediments '99, ASCE, pp. 1627-1642.

Hallermeier, R.J. 1981. A profile zonation for seasonal sand beaches from wave climate, Coastal Engineering, 4, pp. 253-277.

Kaminsky, G.M., Buijsman, M., Gelfenbaum, G.R., Ruggiero, P., Jol, H.M., Gibbs, A., and Peterson, C.D. 1999. Synthesizing geological observations and process-response data for modeling coastal change at a management scale, Proceedings of Coastal Sediments '99, ASCE, pp. 1708-1723.

Knoester, D. 1990. Morphology of the Holland coast, Rijkswaterstaat, Tidal Waters Division, Report GWAO-90.010 (in Dutch).

Nicholls, R.J., Birkemeier, W.A. and Lee, G-H. 1998. Evaluation of depth of closure using data from Duck, NC, USA, Marine Geology, 148, pp. 179-201.

Roelvink, J.A. and Stive, M.J.F. 1991. Sand transport in the shoreface of the Holland coast, Proc. 22nd Int. Conf. Coastal Eng, pp. 1909-1921.

Roy, P.S., and Thom. B.G. 1981. Late Quaternary marine deposition in New South Wales and southern Queensland - an evolutionary model, Journal of Geology Society of Australia, 28, pp. 471-89.

Roy, P.S., Cowell, P.J., Ferland, M.A. and Thom, B.G. 1994. Wave dominated coasts, In: Carter, R.W.G. and Woodroffe, C.D. (eds), Coastal Evolution: Late Quaternary Shoreline Morphodynamics, Cambridge University Press, Cambridge, pp. 121-86.

Stive, M.J.F. and de Vriend, H.J. 1995. Modelling shoreface profile evolution, Marine Geology, 126, pp. 235-248.

Stive, M.J.F., Roelvink, D.J.A. and de Vriend, H.J. 1991. Large-scale coastal evolution concept, Proceedings 22nd International Conference on Coastal Engineering, pp. 1962-1974.

Stive, M.J.F., Cloin, B., Jiménez, J. and Bosboom, J. 1999. Long-term cross-shoreface sediment fluxes, Coastal Sediments '99, pp. 505-518. 
Thom, B.G. 1984. Transgressive and regressive stratigraphies of coastal sand barriers in eastern Australia, Marine Geology, pp. 137-158.

Wright, L.D. 1995. Morphodynamics of Inner Continental Shelves, CRC Press, Boca Raton, $241 \mathrm{p}$.

Table 1. Comparison of net onshore sand fluxes on the central Netherlands shoreface estimated from sand transport modeling (Roelvink and Stive, 1991) and inferred from bathymetric changes in Figure 5.

\begin{tabular}{llll}
\hline \hline & \multicolumn{3}{c}{ onshore flux $\mathrm{m}^{3} \mathrm{~m}^{-1} \mathrm{a}^{-1}$} \\
water depth $(\mathrm{m})$ & modeled & inferred & modeled:inferred \\
\hline-6.0 & 19.5 & 4.6 & 4.26 \\
-7.0 & 17.5 & 4.4 & 4.01 \\
-7.9 & 15.7 & 3.8 & 4.16 \\
-10.0 & 11.3 & 3.1 & 3.64 \\
-10.4 & 10.6 & 0.7 & 14.68 \\
-10.5 & 10.2 & 0.2 & 41.30 \\
\hline
\end{tabular}

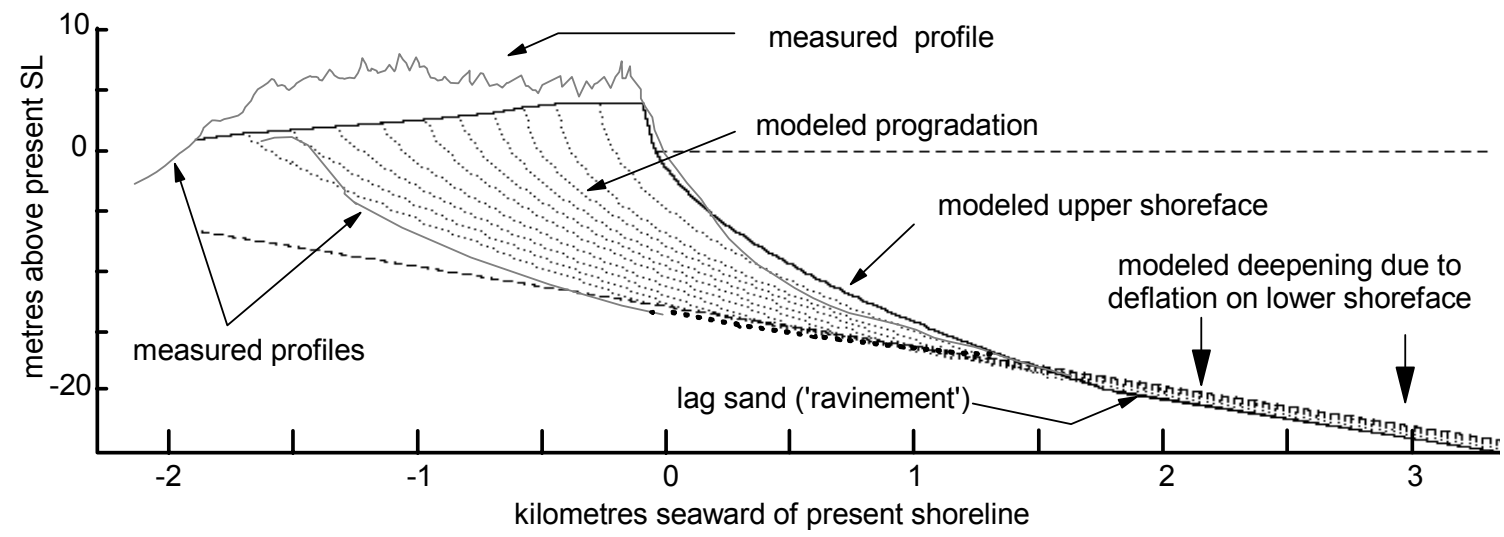

Figure 1. Simulated strandplain development with deepening of the lower shoreface, Tuncurry SE Australia. The simulation involved constant sea level for 6000 years, a constant littoral sand feed of $0.25 \mathrm{~m}^{3} \mathrm{a}^{-1} \mathrm{~m}^{-1}$, and a steady increase in landward depths of the lower shoreface at a rate of $0.002 \mathrm{~m} \mathrm{a}^{-1}$, decreasing linearly with distance through $10,000 \mathrm{~m}$ seawards. 


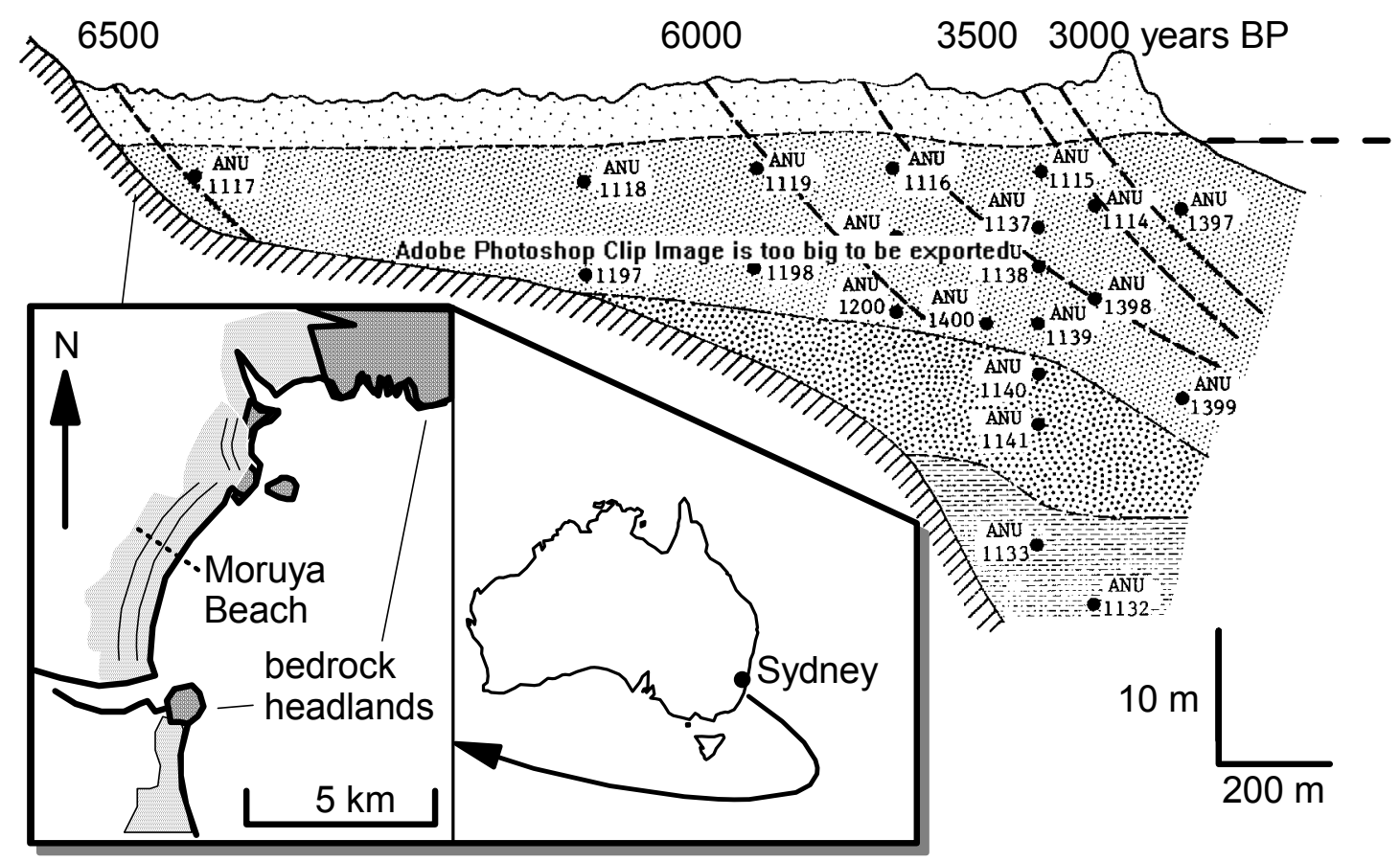

Figure 2. Strandplain progradation within a deeply embayed bedrock coastline (Inset) at Moruya Beach, SE Australia. The timelines, in years before present (BP), were interpolated from the radiocarbon dates obtained for sediment samples taken from the sub-surface locations shown by the dots (Thom, 1984). 

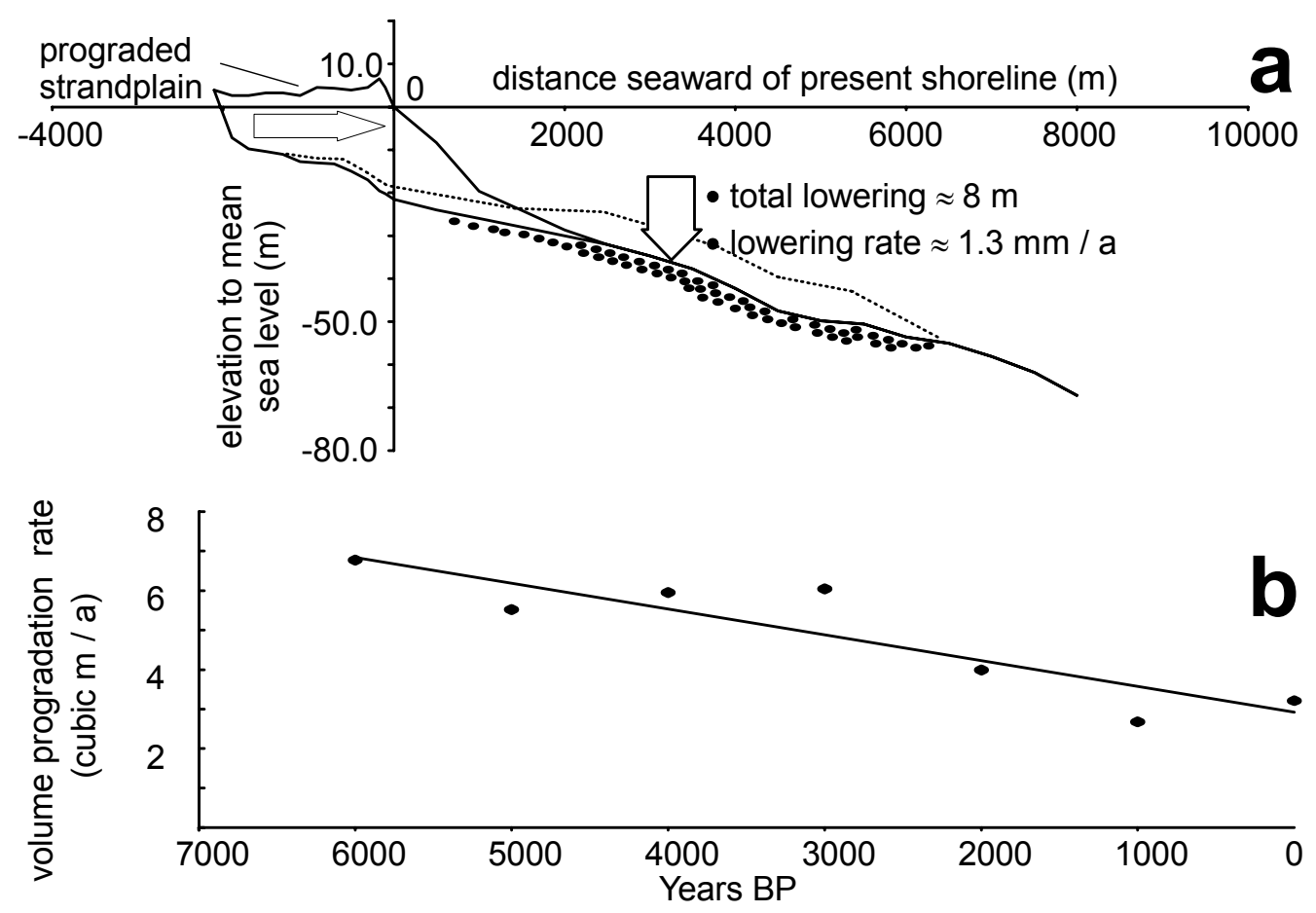

Figure 3. Strandplain progradation along the Moruya transect marked on insert in Figure 2: a) progradation determined from stratigraphic measurements and inferred shoreface lowering needed to provide the progradation volume, the dashed surface being the inferred seabed 6000 years ago, with the stippled pattern beneath the modern shoreface depicting a lag deposit of coarse surface sediments; b) sand volume added to the strandplain through time, determined from drillholes and ${ }^{14} \mathrm{C}$ dates on shell samples reported in Thom (1984). 


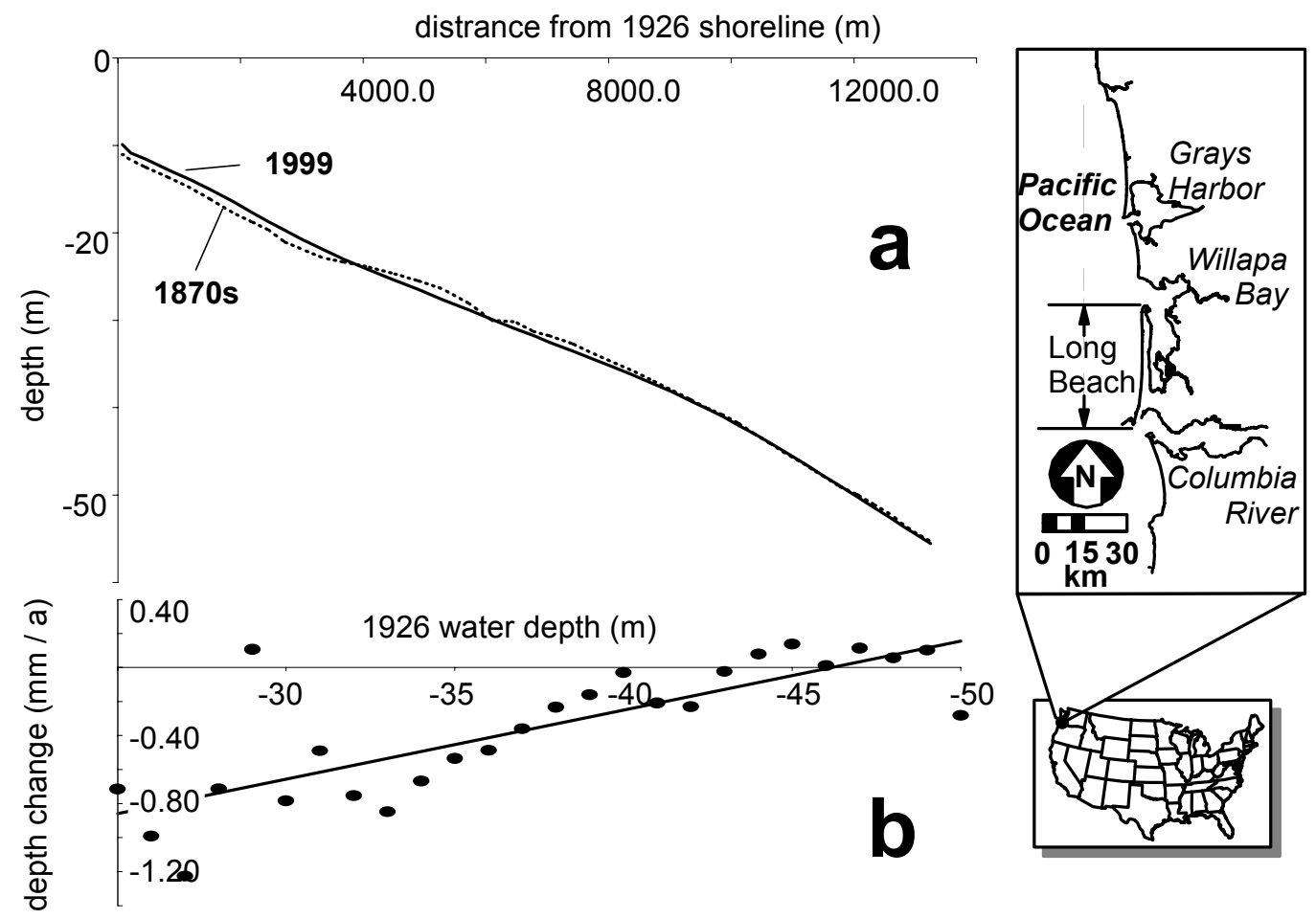

Figure 4. Bathymetric change measured over 73 years off Long Beach on the Columbia River coast, USA (based on data compiled by Gibbs and Gelfenbaum, 1999): a) alongshoreaveraged bed elevations; b) annual rate of bed change vs. initial water depth. Water depths are relative to NAVD88: extreme low water (tidal range of about $3 \mathrm{~m}$ ). 


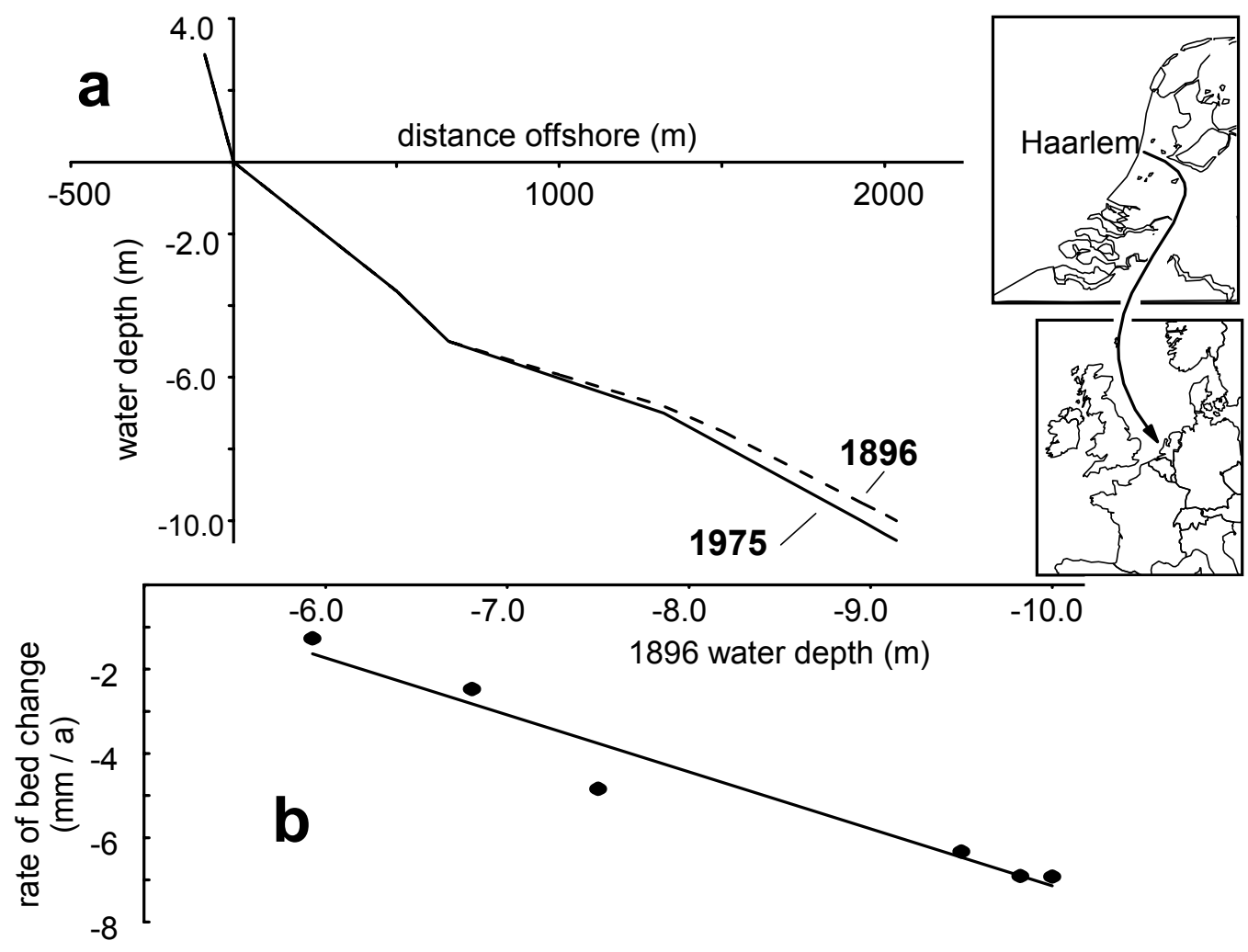

Figure 5. Bathymetric change measured over 79 years on the central Netherlands coast (Haarlem), from data presented in Stive and de Vriend (1995) based on Knoester (1990): a) Haarlem transect; b) annual rate of bed change vs. initial water depth. 


\section{HIGH RESOLUTION 2D AND 3D GROUND PENETRATING RADAR DATASETS}

Harry Jol, University of Wisconsin-Eau Claire

George M. Kaminsky, Washington Department of Ecology

\section{CONCLUSIONS}

1) High frequency ground penetrating radar (GPR) 2-D datasets utilizing 200, 225, and $450 \mathrm{MHz}$ were collected in the North Beach, Grayland Plains, and Long Beach subcells with depths of up to 7-8 $\mathrm{m}$. The resulting images showed detailed reflection patterns, which, in turn, provide a more enhanced perspective from which to interpret the coastal environment.

2) The 3D GPR image presented of Loomis Lake shows 3-D imaging to be an effective means of detailed stratigraphic analysis within this coastal environment. The 3-D rendering makes spatial associations and depositional patterns of an associated earthquake easier to visualize.

3) Some drawbacks to higher resolution data are too much detail, lack of penetration, and potentially more equipment in the field.

4) The GPR data show, with surprising clarity, that higher frequency datasets can provide details needed to aid in the interpretation of the coastal environments.

\section{ACCOMPLISHMENTS}

1) GPR data were collected across coastal barriers that have prograded by several meters per year over the last century. The resulting GPR datasets reveal the internal structure of the coastal deposits.

2) The data were collected using a pulseEKKO 100 and 1000 GPR system with antennae ranging from 200, 225 to $450 \mathrm{MHz}$ and $200-1000 \mathrm{~V}$ transmitters. Step sizes ranged from $0.5 \mathrm{~m}$ to $0.1 \mathrm{~m}$.

3) All data was processed and plotted using pulseEKKO software. Interpretations of the plotted GPR profiles are based on radar facies analysis.

4) A 3-D cube was assembled from a series of identical length 2-D GPR profiles running parallel to each other along an $\mathrm{x}-\mathrm{y}$ grid system. The 2-D GPR profiles were processed and then interpolated to create 3-D datasets using pulseEKKO and T3D software. 


\title{
QUESTIONS
}

1) Do higher frequency datasets have enough penetration and continuity of reflections to properly analyze coastal progradation and erosion?

2) How do aeolian features influence both the penetration of the radar signal and subsurface reflections?

3) Do the seaward inclined reflection signals represent major storm events, or yearly progradation?

4) Can signals of El Niño events be detected in the high resolution GPR datasets?

5) How can three-dimensional visualization aid in better understanding coastal processes such as those that develop earthquake scarps?

\begin{abstract}
ANALYSIS
Changing the center frequency of a GPR system permits selective enhancement of subsurface responses. These responses can aid in better understanding different geomorphic and geologic settings. Previous studies using GPR with geomorphology have generally used lower GPR antennae frequencies (25-200 MHz). These studies interpreted environments based on resolution, reflection continuity, patterns, and/or penetration depth (Davis and Annan, 1989; Jol, 1995; Smith and Jol, 1995). The wavelength of the GPR antennae corresponds to the minimum detectable layer thickness; therefore higher frequencies will allow greater resolution of the subsurface.
\end{abstract}

The data presented was collected using a pulseEKKO 100 and 1000 GPR system with antennae ranging from 200, 225 to $450 \mathrm{MHz}$, and $200-1000 \mathrm{~V}$ transmitters. Step sizes ranged from $0.5 \mathrm{~m}$ to $0.1 \mathrm{~m}$. All data were processed and plotted using pulseEKKO software. Interpretations of the plotted GPR profiles are based on radar facies analysis.

A component of the Southwest Washington Coastal Erosion Study is the investigation of late Holocene and historical evolution of barriers along the Washington coast. Extensive GPR surveys have been conducted to map the near surface stratigraphy and morphological change of prograded coastal barriers spanning time scales of years to millennia. Differences in the GPR reflection packages suggest changes in depositional processes. In particular, the high resolution GPR profiles can identify strata that allow for comparison of coastal changes with resolution up to an annual/biannual basis.

The data were collected across coastal barriers that have prograded by several meters per year over the last century (Peterson et al., 1999). The resulting GPR datasets reveal the internal structure of the coastal deposits. Figure 1 shows portions of 225 and $450 \mathrm{MHz}$ profiles across a typical section of the coastal barrier. The shallow dipping reflections with westward oriented shingle patterns suggest a prograding beachface. Figure 2 shows similar shallow dipping reflection patterns on the westward portion of this $225 \mathrm{MHz}$ profile between positions 34 and 36 . On the eastward portion the reflections become more 
undulating. Steeper dips and less continuous reflections patterns between positions 19-22 suggest an erosional truncation just westward of shallow dipping reflections. This reflection pattern is characteristic of major erosional events, earthquakes, and El Niño events that impact the Washington coastline on very different temporal and spatial scales (Meyers et al., 1996; Jol et al., 1998). Further details of how these erosional events influence coastal deposition can also be interpreted from the GPR reflection patterns. The reflection patterns have been noted in previous studies, but not in such detail as in this abstract (Meyers et al., 1996; Kaminsky et al., 1999; Smith et al., 1999). Through these studies we hypothesize that annual or biannual paleo-beach facies of a prograded shoreline can be identified.

A 3-D cube was assembled from a series of identical length 2-D GPR profiles running parallel to each other along a x-y grid system (Figure 3). All GPR transects were gathered using a pulseEKKO 1000 GPR system and spaced $0.25 \mathrm{~m}$ apart. The 2-D GPR profiles were processed and then interpolated to create 3-D datasets using pulseEKKO software. Visual rendering of the 3-D datasets was done using Fortner T3D. The data for the 3-D cube was acquired near Loomis Lake in Long Beach, Washington. The GPR transects were collected using $225 \mathrm{MHz}$ antennae along a $6 \mathrm{~m}$ x $30 \mathrm{~m}$ grid with a $0.10 \mathrm{~m}$ step. The image shows a series of dipping reflections (Figure 3 ), which are interpreted as an erosional scarp, caused by earthquake activity in the area. The GPR image presented show 3-D imaging to be an effective means of detailed stratigraphic analysis within this coastal environment. The 3-D rendering makes spatial associations and depositional patterns easier to visualize.

\section{ACKNOWLEDGMENTS}

Research was supported by the Office of University Research (University of WisconsinEau Claire), Washington Department of Ecology, and Sensors and Software. Thanks also to Brian Junck, Brian Thayer, and Diana McCandless for their help in the field.

\section{REFERENCES}

Davis, J.L., and Annan, A.P. 1989. Ground penetrating radar for high resolution mapping of soil and rock stratigraphy, Geophysical Prospecting, 27, pp. 531-551.

Jol, H.M. 1995. Ground penetrating radar antennae frequencies and transmitter powers compared for penetration depth, resolution and reflection continuity, Geophysical Prospecting, 43, pp. 693-709.

Jol, H.M., Junck, M.B., and Kaminsky, G. 2000. High resolution ground penetrating radar imaging $(225-900 \mathrm{MHz})$ of geomorphic and geologic settings: examples from Utah, Washington, and Wisconsin, Proceedings of the Eighth International Conference on Ground Penetrating Radar (GPR 2000), edited by D.A. Noon, G.F. Stickley, and D. Longstaff, May 23-26, Gold Coast, Australia, SPIE Vol. 4084, pp. 69-74. 
Jol, H.M., Peterson, C.D., Vanderburgh, S., and Phipps, J. 1998. GPR as a regional geomorphic mapping tool: shoreline accretion/erosion along the Columbia River littoral cell, GPR'98 International Meeting, Lawrence, KS, pp. 257-262.

Junck, M.B., and Jol, H.M. 2000. Three-dimensional investigations of geomorphic environments using ground penetrating radar, Proceedings of the Eighth International Conference on Ground Penetrating Radar (GPR 2000), edited by D.A. Noon, G.F. Stickley, and D. Longstaff, May 23-26, Gold Coast, Australia, SPIE Vol. 4084, pp. 314-318.

Kaminsky, G.M., Buijsman, M., Gelfenbaum, G.R., Ruggiero, P., Jol, H.M., Gibbs, A., and Peterson, C.D. 1999. Synthesizing geological observations and process-response data for modeling coastal change at a management scale, Proceedings of Coastal Sediments '99, ASCE, pp. 1708-1723.

Peterson, C.D., Gelfenbaum, G.R., Jol, H.M., Phipps, J.B., Reckendorf, F., Twichell, D.C., Vanderburg, S., and Woxell, L.K. 1999. Great earthquakes, abundant sand, and high wave energy in the Columbia Cell, USA, Proceedings of Coastal Sediments '99, ASCE, pp. 1676-1691.

Meyers, R.A., Smith, D.G., Jol, H.M., and Peterson, C.D. 1996. Evidence for eight great earthquake-subsidence events detected with ground-penetrating radar, Willapa barrier, Washington, Geology, 24, pp. 99-102.

Smith, D.G., and Jol, H.M. 1995. Ground penetrating radar: antennae frequencies and maximum probable depths of penetration in Quaternary sediments, Journal of Applied Geophysics, 33, pp. 93-100.

Smith, D.G., Meyers, R.A., and Jol, H.M. 1999. Sedimentology of an upper meso tidal $(3.7 \mathrm{~m})$ holocene barrier, Willapa Bay, SW Washington, U.S.A., Journal of Sedimentary Research, Section B: Stratigraphy and Global Studies, 69(6), pp. 1290-1296. 
W

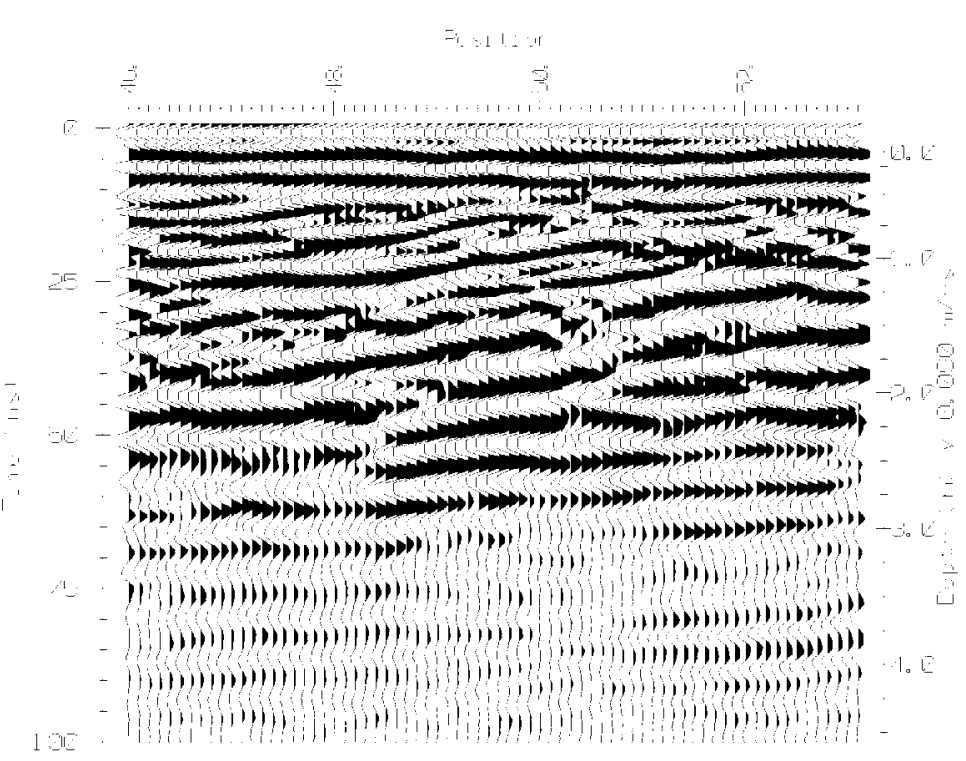

$\mathrm{E}$

W

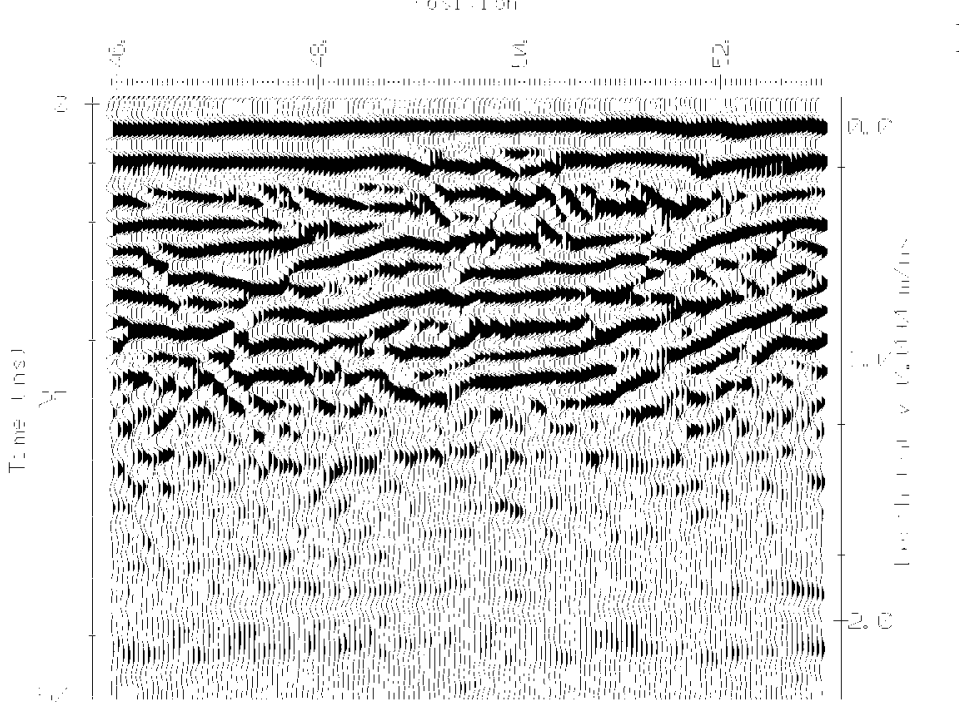

Figure 1. Upper: $225 \mathrm{MHz}$ GPR profile (W-E, 0-100 ns) shot to show the typical dipping foresets of the coastal deposits. Lower: $450 \mathrm{MHz}$ GPR profile (0-50 ns) shot over the same site showing higher resolution stratigraphy with less depth of penetration (Jol et al. 2000). 


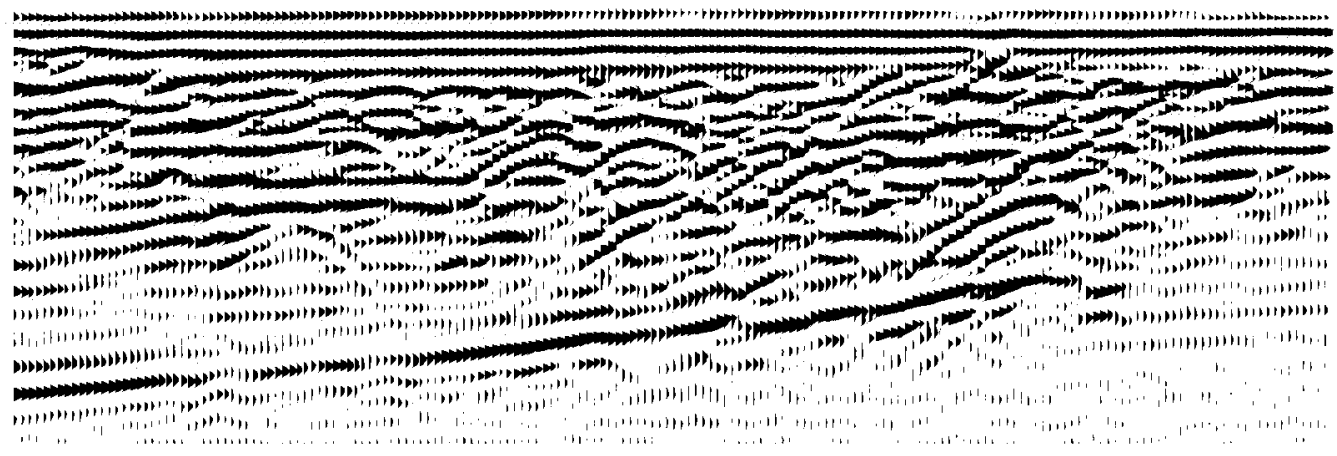

Figure 2. $225 \mathrm{MHz}$ GPR profile (W-E) shot along Warrenton-Carrenry Road in the southern Grayland Plains. Shallow dipping reflection patterns become steeper and more undulating as one moves eastward along the profile. Between 19-22 $\mathrm{m}$ erosional truncations are apparent before shallow dipping reflections occur again. This pattern is similar to other interpreted erosional events along the Washington coast (Jol et al., 2000).

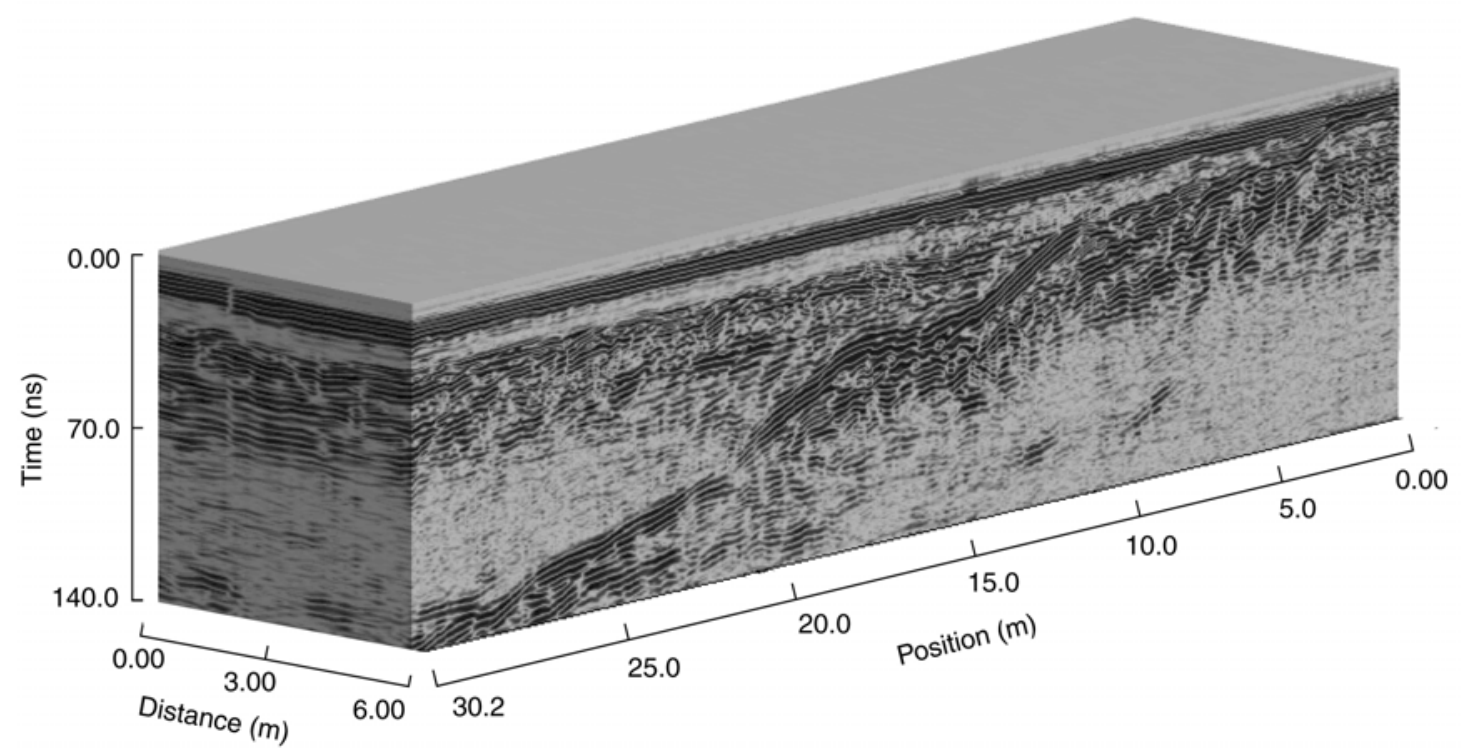

Figure 3. A 3D GPR image of the Loomis Lake research site in southwest Washington. Data were collected using $225 \mathrm{MHz}$ antennae with a $200 \mathrm{~V}$ transmitter. The image shows reflections to $140 \mathrm{~ns}$ (approximately $7 \mathrm{~m}$ ). The transactions follow a $6 \mathrm{~m} \times 30 \mathrm{~m}$ grid, using an odometer set to a 0.10 step (Junck and Jol, 2000). 


\title{
EXPLORING CORRELATIONS BETWEEN SHORELINE PROGRADATION AND CLIMATE INDICES, SOUTHWEST WASHINGTON
}

\author{
Laura Moore, U.S. Geological Survey and University of South Florida \\ Harry Jol, University of Wisconsin-Eau Claire \\ George M. Kaminsky, Washington Department of Ecology
}

\section{CONCLUSIONS}

1) Preliminary counts of GPR reflections along Taurus Boulevard in the North Beach subcell of the Columbia River littoral cell suggest that $200 \mathrm{MHz}$ GPR reflections represent annual shoreface position.

2) Anomalous reflections identified on a $100 \mathrm{MHz}$ transect might be coincident with El Niño and La Niña events from the late 1800s to mid-1900s.

3) Progradation rates (vertical distance between reflections) correlate with SOI and Columbia River discharge at Beaver, Oregon such that higher progradation rates are associated with El Niño events and high discharge.

4) El Niño and La Niña events, along with river discharge events (or more likely, processes contemporaneous with river discharge events) appear to leave detectable sedimentological signals in the stratigraphic record of a rapidly prograding coastline. The processes responsible for these relationships will be the focus of future work.

\section{ACCOMPLISHMENTS}

One approach toward predicting the effect of future climate variability on coastal change is to examine the past. Since many modern coastlines are erosional in nature, this is often a difficult task that can only be accomplished for the last several decades where aerial photography and ground surveys are available. Unlike many coastlines, large portions of the southwest Washington coastline have been progradational (i.e., accreting seaward) for several thousand years. A record of this seaward progradation is preserved in the subsurface as highly reflective, seaward dipping, subsurface layers. These subsurface layers are visualized using ground penetrating radar (GPR) and are interpreted as beachface and upper shoreface deposits (Jol et al., 1998). The data used in this study were collected using a pulseEKKO $100 \mathrm{GPR}$ system with $100 \mathrm{MHz}$ and $200 \mathrm{MHz}$ antennae (Figure 1). As the GPR system is stepped along the shore-perpendicular path (Taurus Boulevard), the system emits electromagnetic waves that reflect off of structures and lithologic changes in the subsurface sediments to produce a record of GPR reflections. Such high-resolution GPR records for prograded coastal barriers are hypothesized to reveal patterns of coastal change with individual subsurface layers representing interannual to annual shoreline locations, depending on the rate and persistence of progradation. Truncated seaward dipping reflectors suggest erosional periods, some of which can be associated with known earthquake or storm events or otherwise dated to 
provide time control (Peterson et al., 1999; Kaminsky et al., 1999). Thus, a record of shoreline behavior through time is preserved in the subsurface of the barriers throughout much of southwest Washington. The spatial and temporal variability in these subsurface patterns may have a relationship to climate fluctuations.

To test the feasibility of relating records of shoreline progradation with climate variability for the prehistorical and historical past, patterns recorded by GPR for the North Beach sub-cell of the Columbia River littoral cell are interpreted. Along a $200 \mathrm{MHz}$ interpreted transect across Taurus Boulevard (an area with a historically high rate of progradation, Peterson et al., 1999) a count of reflections suggests that the seaward dipping markers represent annual shoreline positions through time (Figure 2). Along a corresponding 100 $\mathrm{MHz}$ GPR transect for Taurus Boulevard, processed using constant gain control, several reflections are anomalously strong and extend deep into the subsurface. To test the hypothesis that the sedimentological signal responsible for these anomalous reflections is produced by coastal storms associated with El Niño and/or La Niña events, the annual signal in the $200 \mathrm{MHz}$ GPR transect is used to assign dates to the strong reflections in the $100 \mathrm{MHz}$ transect. The resulting dates for the anomalous reflections match the timing of strong El Niño and La Niña events and suggest that the sedimentological effects of severe winter storms occurring during these climate events are preserved in the stratigraphic record of a rapidly prograding coast as layers with higher concentrations of heavy minerals (Figure 3, Table 1). This provides further evidence that the reflections are annual and suggests that in stormier years sedimentary layers containing higher concentrations of heavy minerals may be deposited.

In addition to linking El Niño and La Niña events to the stratigraphic record at Taurus Boulevard, spacings between the highly reflective layers are quantified to determine progradation rates. These rates and patterns are compared with climate indices including the Southern Oscillation Index (SOI) (Allan et al., 1991; Mantua et al., 1997; Trenberth and Hurrell, 1994) and estimated river discharge for the Columbia River (Figure 4). Each significant positive peak in progradation rate correlates with either an El Niño event or a major discharge event. The converse is true for all significant negative peaks in the progradation rate. The presence of fewer positive peaks in the later part of the progradation record appears to be linked with decreased discharge from the Columbia River due to severe drought conditions in North America at that time.

\section{FUTURE WORK}

1) Ground truth $200 \mathrm{MHz}$ reflections to determine if they represent an annual signal.

2) Further explore the process explanation for the relationship between progradation, SOI and discharge.

3) Explore alongshore relationships between progradation, SOI, and discharge.

4) Perform this analysis at other sites along the southwest Washington coastline in an attempt to reproduce results. 
5) Perhaps use changes in progradation rates to reconstruct SOI back in time in rapidly prograding areas.

\section{REFERENCES}

Allan, R.J., Nicholls, N., Jones, P.D., and Butterworth, I.J. 1991. A further extension of the Tahiti-Darwin SOI, early ENSO events and Darwin pressure, J. Climate, 4, pp. 743-749.

Jol, H.M., Peterson, C.D., Vanderburgh, S., and Phipps, J. 1998. GPR as a regional geomorphic mapping tool: shoreline accretion/erosion along the Columbia River littoral cell, GPR'98 International Meeting, Lawrence, KS, pp. 257-262.

Kaminsky, G.M., Buijsman, M., Gelfenbaum, G.R., Ruggiero, P., Jol, H.M., Gibbs, A., and Peterson, C.D. 1999. Synthesizing geological observations and process-response data for modeling coastal change at a management scale, Proceedings of Coastal Sediments '99, ASCE, pp. 1708-1723.

Mantua, N.J., Hare, S.R., Zhang, Y., Wallace, J.M., and Francis, R.C. 1997. A Pacific interdecadal climate oscillation with impacts on salmon production, Bulletin of the American Meteorological Society, 78(6), pp. 1069-1079.

Peterson, C.D., Gelfenbaum, G.R., Jol, H.M., Phipps, J.B., Reckendorf, F., Twichell, D.C., Vanderburg, S., and Woxell, L.K. 1999. Great earthquakes, abundant sand, and high wave energy in the Columbia Cell, USA, Proceedings of Coastal Sediments '99, ASCE, pp. 1676-1691.

Trenberth, K.E., and Hurrell, J.W. 1994. Decadal atmosphere-ocean variations in the Pacific, Climate Dynamics, 9, pp. 303-319. 


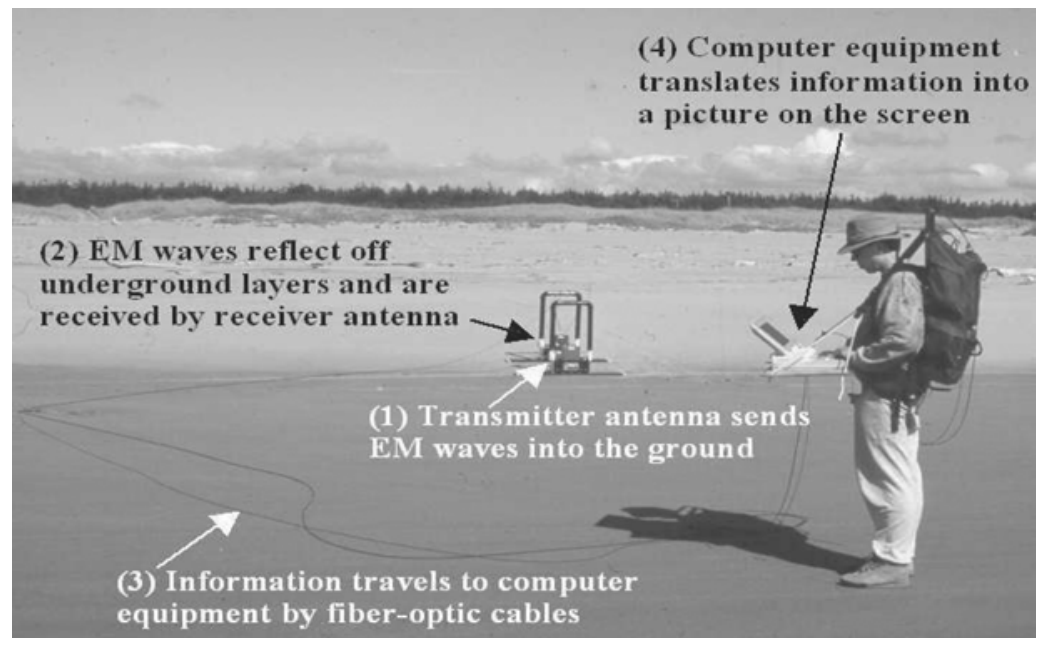

Figure 1. A pulseEKKO $1000 \mathrm{GPR}$ system with $100 \mathrm{MHz}$ and $200 \mathrm{MHz}$ antennae was stepped along Taurus Boulevard to produce the data used in this study. As the system is stepped perpendicular to the shoreline, it emits electromagnetic waves that reflect off of structures and lithologic changes in the subsurface to produce a record of reflections. On a rapidly prograding coast, these reflections represent annual shorefaces. 


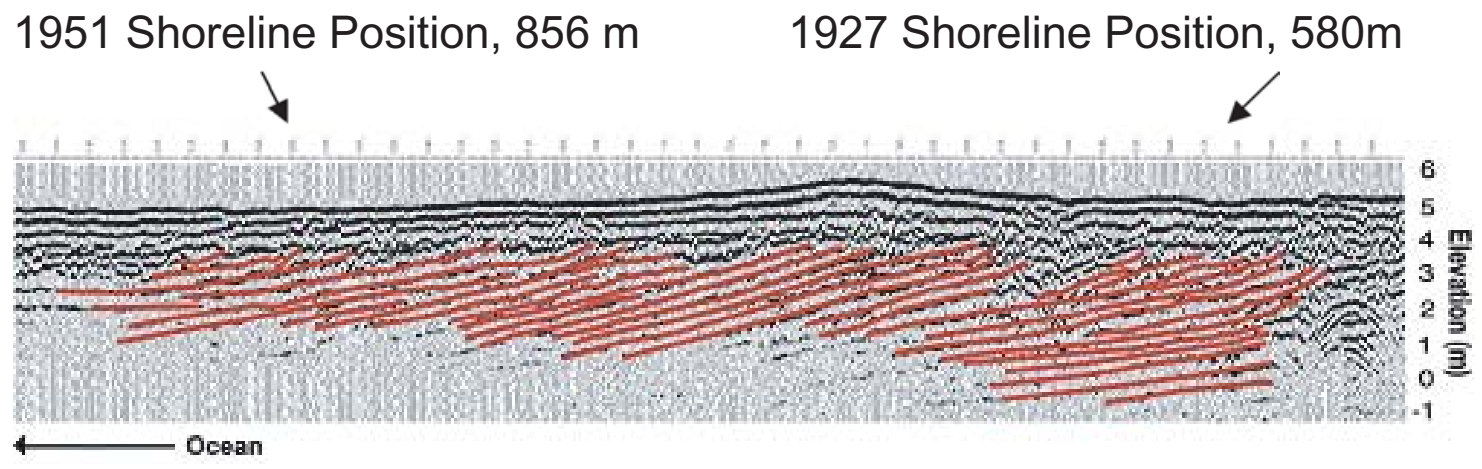

Figure 2. A portion of the $200 \mathrm{MHz}$ Taurus Boulevard Transect. Reflections interpreted as annual shorefaces are shown in red. Timing is provided by known 1951 and 1927 surface shoreline positions determined from historic t-sheets and aerial photos.

* El Nino

**EI Nino or La Nina +/-1 Year

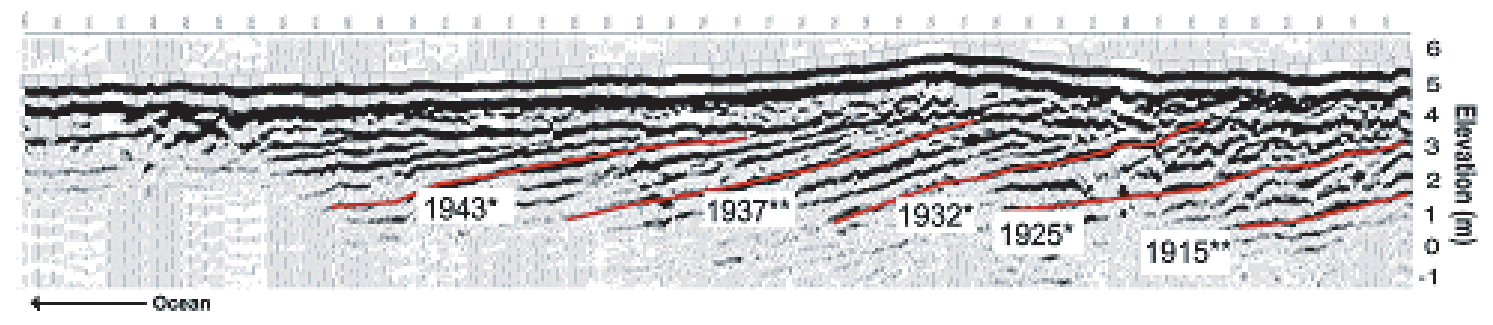

Figure 3. A portion of the $100 \mathrm{MHz}$ Taurus Boulevard Transect. Anomalously strong continuous and deep reflections are highlighted in red. All 9 anomalous reflections (only 5 shown) fall within 1 year of an El Niño or La Niña event. 


\section{Progradation, Negative SOI and River Discharge}

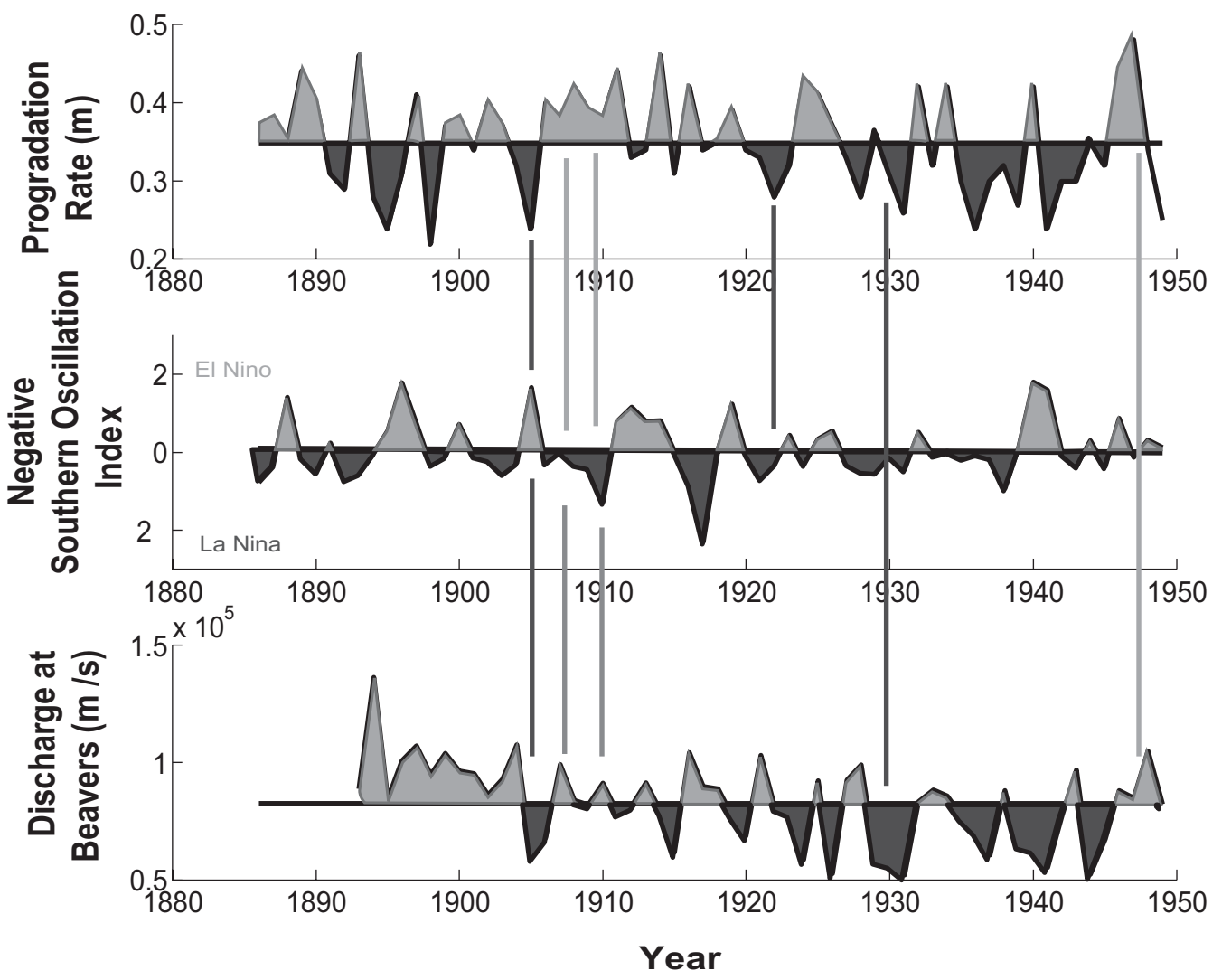

Figure 4. Progradation rate at Taurus Boulevard is plotted with Negative SOI (ftp:/l daac.gsfc.nasa.gov/data/inter_disc/surf_temp_press/soi/so_osc_indx/, Data from EOS Distributed Active Archive Center) and Columbia River discharge at the Beavers (Data courtesy of David Jay and Pradeep Nadik, Oregon Graduate Institute). Each significant positive peak in progradation rate correlates with either an EI Niño event or a major discharge event. The converse is true for all significant negative peaks in progradation rate. 
Table 1. All but one of the anomalous reflections identified on the $100 \mathrm{MHz}$ GPR profile appear to lie within 1 year of either an EI Niño or La Niña event. This provides further evidence that the reflections are annual and suggests that in stormier years sedimentary layers with higher concentrations of heavy minerals may be deposited.

\begin{tabular}{cccc}
\hline Location $(\mathbf{m})$ & Reflection \# & Year & JMA - SSTA Index \\
\hline 70 & 10 & 1896 & El Nino \\
\hline 110 & 14 & 1900 & El Nino (1899) \\
\hline 160 & 18 & 1904 & El Nino \\
\hline 270 & 24 & 1910 & El Nino (1911) \\
\hline 350 & 29 & 1915 & La Nina (1916) \\
\hline 560 & 39 & 1925 & El Nino \\
\hline 630 & 46 & 1932 & Neutral \\
\hline 710 & 51 & 1937 & La Nina (1938) \\
\hline 795 & 57 & 1943 & La Nina (1944) \\
\hline
\end{tabular}




\title{
HISTORICAL BATHYMETRIC AND TOPOGRAPHIC CHANGE ANALYSIS - AN OVERVIEW
}

\author{
Maarten Buijsman, Washington Department of Ecology
}

\section{CONCLUSIONS}

1) Human influences largely affected the morphology of the coasts and estuaries in the Columbia River littoral cell (CRLC) during the last century.

2) The time-scales of these morphological changes are very long, on the order of 50 to 100 years, $\mathrm{O}(50-100$ years). The initial morphological changes were large, but declined through time.

3) The barriers of Long Beach, north of the Columbia River (CR) ebb-tidal delta, and North Beach, north of the Grays Harbor $(\mathrm{GH})$ ebb-tidal delta, were affected most and are still affected by the changing $\mathrm{CR}$ and $\mathrm{GH}$ delta morphologies.

4) The bathymetric analysis reveals shoreface rotation (offshore erosion and nearshore accretion) along most of the CRLC.

5) The active depth of shoreface scour derived from the bathymetric analysis is different for each sub-cell. Long Beach has the largest active depth. Clatsop Plains and Grayland Plains have the smallest active depths.

6) Uncertainties in vertical datum, tide correction, and horizontal positioning have a significant effect on the results of the bathymetric and topographic change analysis.

7) The limited data coverage complicates a regional sediment budget analysis.

\section{ACCOMPLISHMENTS}

The bathymetric and topographic analysis is comprised of the Columbia River and Grays Harbor entrance and adjacent coasts. Bathymetric surfaces were derived for the following locations and times (most surfaces are comprised of various data-sets from different years):

Columbia River entrance: 1868, 1926, 1958, 1994, 1998

Grays Harbor entrance: 1887, 1900, 1926, 1954, 1974, 1998

The following U.S. Army Corps of Engineers Annual Surveys of the Grays Harbor ebbtidal delta were digitized: years 1900, 1927, 1954, and 1974. 
The bathymetric and topographic analysis was used for the following papers: Kaminsky et al. (1999), Gelfenbaum et al. (1999), Kaminsky et al. (2000), and the USGS-DOE Factsheet: "Jetty Construction and Rehabilitation at Grays Harbor, Washington; Do They Cause Shoreline Change?" (in review).

\section{QUESTIONS}

The following research questions remain unanswered:

1) Is the "one time" accretion of Grayland Plains between 1887 and 1927 correlated with the erosion of the shelf offshore Grayland Plains?

2) When will the morphological effects caused by jetty construction be no longer measurable?

3) Why do the Long Beach and North Beach sub-cells continue to accrete with higher than prehistoric rates?

4) What is the contribution of cross-shore feeding? Has this process changed as a result of human induced morphological changes?

5) What is the explanation of the differences in active depth?

6) Is it possible to correct errors in the 1920s and 1950s bathymetric data?

7) What are the bathymetric changes in the CR estuary between 1958-1998?

8) Is it possible to model the human-induced morphology changes at the entrance areas with an advanced morphological computer model (e.g., Delft 3D)?

\section{ANALYSIS Introduction}

Human influences such as jetty construction at the entrances to the Columbia River (1885-1917) and Grays Harbor (1898-1916), and dam construction and flow regulation in the Columbia River drainage basin largely affected the morphology of the coasts and estuaries in the Columbia River littoral cell during the last century. Channel migration to the north in the entrance to Willapa Bay (WB) caused morphological changes similar in scale to those for the Columbia River and Grays Harbor. The time-scales of the morphological changes are very long, $\mathrm{O}(50-100$ years); the morphological system is still adjusting to the modifications made in the beginning of the century. During the last century the $\mathrm{CR}$ and GH ebb-tidal deltas moved farther offshore. The inlets and inner deltas eroded, and the adjacent coasts accreted. The adjacent coasts were affected 10 to 30 $\mathrm{km}$ away from the entrances. The coastline of Grayland Plains stabilized after 1927 and the coastline of Clatsop Plains showed minimal accretion after the 1950s. The coasts of 
the Long Beach and North Beach sub-cells have continued to accrete until now, showing minimal decline in the shoreline change rates over the last 50 years.

\section{Methodology}

Topographic and bathymetric change analyses were merged to obtain historical volumes of the CR estuary, entrance, and adjacent coasts, and the GH entrance and adjacent coasts. The topographic change analysis was done in ARC/INFO using a Digital Elevation Model (DEM) of the adjacent coasts and the bathymetric change analysis was performed in Surfer. The volume changes in the CR estuary between 1868 and 1958 were derived from Sherwood et al. (1990).

The topographic volumes were calculated between the shorelines and above the high water (HW) line. The height of the HW line approximates $+3 \mathrm{~m}$ NAVD88. The DEM volumes above the HW line were calculated assuming a constant shape of the beach profile. The DEM is derived from the 1998 beach and dune topography; no digital elevation model is available for the earlier periods. The DEM was used for the volume change calculations of all periods; this assumes that the horizontal changes were larger than the vertical changes. The alongshore length of the boxes, for which the volumes were calculated, approximates about $5 \mathrm{~km}$.

The bathymetric data sets were gridded relative to NAVD88, using triangulation with linear interpolation or kriging. The grid size used for the differencing is equal to $25 \mathrm{~m}$. Figure 1 shows an example of how the volumes are calculated between shorelines (in this example: the 1926 and 1958 shorelines). The topographic volume V1 is calculated above +3 m NAVD88 using the DEM; volume V2 is calculated by subtracting the 1926 bathymetry from the $+3 \mathrm{~m}$ NAVD 88 plane, and volume V3 is calculated by subtracting the 1926 bathymetry from the 1958 bathymetry. In the case where no nearshore bathymetry is available, volumes V2 and V3 are calculated by multiplying the horizontal accreted area between the shorelines with an active depth. This active depth is not depth related, but volume related and is calculated in areas where nearshore bathymetry is present. In this case, the active height is calculated by dividing the accreted volume (V1, V2, and V3) by the horizontal area between the shorelines. Subsequently the active depth is derived by subtracting the average dune height above MHW from the active height. This active depth is then used in nearshore areas within the same sub-cell without bathymetric coverage.

\section{Uncertainties}

The bathymetric and topographic analysis is affected by the following uncertainties (Gibbs and Gelfenbaum, 1999):

1) Surveying errors: vertical datum, tide correction, and horizontal positioning.

2) Estimated vertical error in the DEM is $+/-0.5 \mathrm{~m}$.

3) Horizontal error and vertical error in shoreline position (latter is neglected in this analysis). 
4) Vertical accretion of the dunes is not incorporated.

5) Errors related to the volume calculations (e.g., gridding routine).

Errors related to vertical datum, tide correction, and horizontal positioning have the largest influence on the bathymetric change analysis. The largest of these errors are in the $1870 \mathrm{~s}$, 1920 s, and 1950s data sets.

\section{Results}

The bathymetric analysis for the Columbia River entrance covers three periods: 18681926, 1926-1958, and 1958-1998. The bathymetric changes at the Grays Harbor entrance are described for the periods 1887-1926 and 1926-1998.

Columbia River 1868-1926: Both the 1868 and 1926 data sets of the Columbia River entrance are characterized by many anomalies. Only the areas that showed large and consistent change were used for the analysis. Between 1868 and 1926 large morphological changes occurred. Because of jetty construction (South Jetty: 1885-1895; North Jetty: 1913-1917) tidal flow patterns changed and the Columbia River delta shifted to the north. The old delta lobe south of the South Jetty, inlet, and inner delta eroded $5.5 \mathrm{Mm}^{3} / \mathrm{yr}$ (including accretion of Clatsop Spit and Peacock Spit) feeding the Clatsop Plains coast $\left(0.9 \mathrm{Mm}^{3} / \mathrm{yr}\right)$, and the new ebb-tidal delta $\left(3.0 \mathrm{Mm}^{3} / \mathrm{yr}\right)$. The net change over the entrance area was $-2.4 \mathrm{Mm}^{3} / \mathrm{yr}$. Sand from the entrance may have accreted the flood tidal delta (1.6 Mm $3 / y r$; Sherwood et al., 1990). Little shoreline change occurred along Long Beach in the period 1868-1926 (0.5 Mm³ $/ \mathrm{yr})$. Most likely the sand that fed Long Beach came from the Columbia River or from cross-shore feeding. The net change over the estuary was $3.2 \mathrm{Mm}^{3} / \mathrm{yr}$. All results are presented in Table 1.

Columbia River 1926-1958: Because of different measurement techniques in water deeper than $20 \mathrm{~m}$, the offshore regions of the 1926 bathymetry have more uncertainty. During the period from 1926 to 1958 the morphology at the Columbia River entrance continued to adjust to jetty construction. The new outer bar continued to move farther offshore $\left(3.3 \mathrm{Mm}^{3} / \mathrm{yr}\right.$, Table 2$)$ and the inner delta and inlet continued to erode $\left(1.9 \mathrm{Mm}^{3} / \mathrm{yr}\right)$. The net change over the entrance area was $1.4 \mathrm{Mm}^{3} / \mathrm{yr}$. The estuary and the flood-tidal delta accreted $2.4 \mathrm{Mm}^{3} / \mathrm{yr}$. Incorporating dredging and omission of land in the estuary, the estuary as a whole accreted $4.6 \mathrm{Mm}^{3} / \mathrm{yr}$. Long Beach and Clatsop Plains accreted 1.7 and $2.1 \mathrm{Mm}^{3} / \mathrm{yr}$, respectively, an increase compared to the previous period.

Columbia River 1958-1998: The coverage for this time frame is limited; no bathymetric change is available for the Columbia River estuary. Between 1958 and 1998 the outer bar continued its offshore movement $\left(0.8 \mathrm{Mm}^{3} / \mathrm{yr}\right)$, while the inner delta eroded $\left(1.9 \mathrm{Mm}^{3} / \mathrm{yr}\right.$; the net change of the entrance over the delta was $\left.-0.8 \mathrm{Mm}^{3} / \mathrm{yr}\right)$. The coast of Long Beach accreted $2.6 \mathrm{Mm}^{3} / \mathrm{yr}$, whereas Clatsop Plains showed a decline in the accretion rate to 0.7 $\mathrm{Mm}^{3} / \mathrm{yr}$. The shelf off Clatsop Plains continued to erode, but this erosion might be due to inconsistencies in the 1926 and 1958 data. The bathymetric change for this period is presented in Figure 1. 
Grays Harbor 1887-1926: Similar changes occurred in the Grays Harbor delta. Jetty construction (South Jetty: 1898-1902; North Jetty: 1907-1916) triggered large morphological changes. The outer delta moved offshore $\left(0.6 \mathrm{Mm}^{3} / \mathrm{yr}\right)$, and the inlet and inner delta eroded $\left(2.5 \mathrm{Mm}^{3} / \mathrm{yr}\right.$; including the accretion of the southern spit at North Beach). This sand and the erosion of the shelf off Clatsop Plains $\left(-1.4 \mathrm{Mm}^{3} / \mathrm{yr}\right)$ fed the beaches of Grayland Plains $\left(1.6 \mathrm{Mm}^{3} / \mathrm{yr}\right)$ and Long Beach $\left(0.4 \mathrm{Mm}^{3} / \mathrm{yr}\right)$. The bathymetric changes are presented in Table 4.

Grays Harbor 1926-1998: In this period the outer delta accreted $1.2 \mathrm{Mm}^{3} / \mathrm{yr}$, and the inner delta and inlet eroded $2.3 \mathrm{Mm}^{3} / \mathrm{yr}$ (see Table 5 and Figure 2). The accretion of the Grayland Plains was virtually zero, and the accretion along North Beach averaged 1.8 $\mathrm{Mm}^{3} / \mathrm{yr}$. The shelf off the Grayland Plains eroded less, $0.4 \mathrm{Mm}^{3} / \mathrm{yr}$. Huge changes occurred at the entrance to Willapa Bay. Because of the northern migration of the North Channel the Willapa Bay delta shifted to the north. The net change over the area covered with data was $1.5 \mathrm{Mm}^{3} / \mathrm{yr}$.

Figure 3 and Table 6 show the topographic and nearshore volume change (Methodology section) along the CRLC for three time periods: 1870s-1926, 1926-1950, and 1950-1995. All accumulation rates are relative to the start of jetty construction (CR: 1885 and GH: 1898). The accumulation rates for the barriers comprise all spits, except Peacock Spit. Following jetty construction, the accumulation rates for all sub-cells, except Long Beach are about $2 \mathrm{Mm}^{3} / \mathrm{yr}$. Subsequently all rates are higher in the second period, except for the Grayland Plains. In the last period (1950-1995) only Long Beach shows high accumulation rates.

\section{Discussion}

Between jetty construction and 1926 the southern flank of the CR and GH deltas partially moved onshore causing the accretion of the Clatsop and Grayland barriers. At Clatsop Plains the largest accretion occurred in the north, near the eroding south flank of the CR delta, whereas Grayland Plains accreted uniformly. The bathymetric analysis reveals large erosion along the whole shelf off of Grayland Plains. Possibly, feeding from the shelf contributed to the uniform accretion of the Grayland Plains. If cross-shore feeding is plausible, why did it occur? Or does the 1887 bathymetric data have a large vertical error? In the following periods the Grayland shelf continued to erode but at a smaller rate (18871926: $1.4 \mathrm{Mm}^{3} / \mathrm{yr}$ vs. 1926-1998: $0.4 \mathrm{Mm}^{3} / \mathrm{yr}$ ). In these years the accretion of the Grayland Plains was less as well. Both Long Beach and North Beach have accreted longer and more than Clatsop Plains and Grayland Plains. Possibly, the northward shelf transport was able to supply sand from south of the CR and GH ebb-tidal deltas.

Where there was no nearshore bathymetry available an active depth was used which was derived from areas with nearshore coverage (Methodology section). The active depths below NAVD88 for each sub-cell are: Clatsop Plains: 6-7 m, Long Beach: $10 \mathrm{~m}$, Grayland Plains: 4-6 m, and North Beach 6-7 m. The following hypothesis is posed: as shoreface rotation increases the active depth based on bathymetry calculations becomes shallower. The progradation along Long Beach obviously occurred with the least change in beach profile shape. Looking at the bathymetric change, the sub-cells with the smallest active 
depths (Clatsop Plains and Grayland Plains) show offshore shelf erosion. The smaller depths (now 6-7 m; the overall standard was $10 \mathrm{~m}$ ) along North Beach will affect the UNIBEST model runs (Methodology section). At the time of this abstract the outcome of the bathymetric analysis had not been double-checked.

This work is the foundation of the regional sediment budget analysis, which is not discussed here. The sediment budget analysis shows that the budget can only be balanced with sediment supplied from the shoreface. However, most offshore changes are within the error bounds of the change analysis.

\section{ACKNOWLEDGEMENTS}

My appreciation goes to Jerry Franklin (DOE; DEM volume calculations), Bob Huxford, Diana McCandless, and Rich Daniels (DOE; for digitizing shorelines and bathymetric data, GIS work), Eric Nelson (USACE Seattle District) and Rod Moritz (USACE Portland District; for providing USACE Annual Surveys), and Ann Gibbs (USGS; for providing USC\&GS bathymetric surveys).

\section{REFERENCES}

Gelfenbaum, G., Sherwood, C.R., Peterson, C.D., Kaminsky, G.M., Buijsman, M., Twichell, D.C., Ruggiero, P., Gibbs, A.E., and Reed, C. 1999. The Columbia River littoral cell: A sediment budget overview, Proceedings of Coastal Sediments '99, ASCE, pp. 1660-1675.

Gibbs, A.E., and Gelfenbaum, G.R. 1999. Bathymetric change off the Washington Oregon Coast, Proceedings of Coastal Sediments '99, ASCE, pp. 1627-1642.

Kaminsky, G.M., Buijsman, M., Gelfenbaum, G.R., Ruggiero, P., Jol, H.M., Gibbs, A., and Peterson, C.D. 1999. Synthesizing geological observations and process-response data for modeling coastal change at a management scale, Proceedings of Coastal Sediments '99, ASCE, pp. 1708-1723.

Kaminsky, G.M., Buijsman, M.C., and Ruggiero, P. 2000. Predicting shoreline change at decadal scale in the Pacific Northwest, USA, Proceedings of the 27th International Conference on Coastal Engineering, Sydney, Australia, pp. 2400-2413.

Sherwood C.R., and Creager J.S. 1990. Sedimentary geology of the Columbia River estuary. Progress in Oceanography, 25, pp. 15-79. 


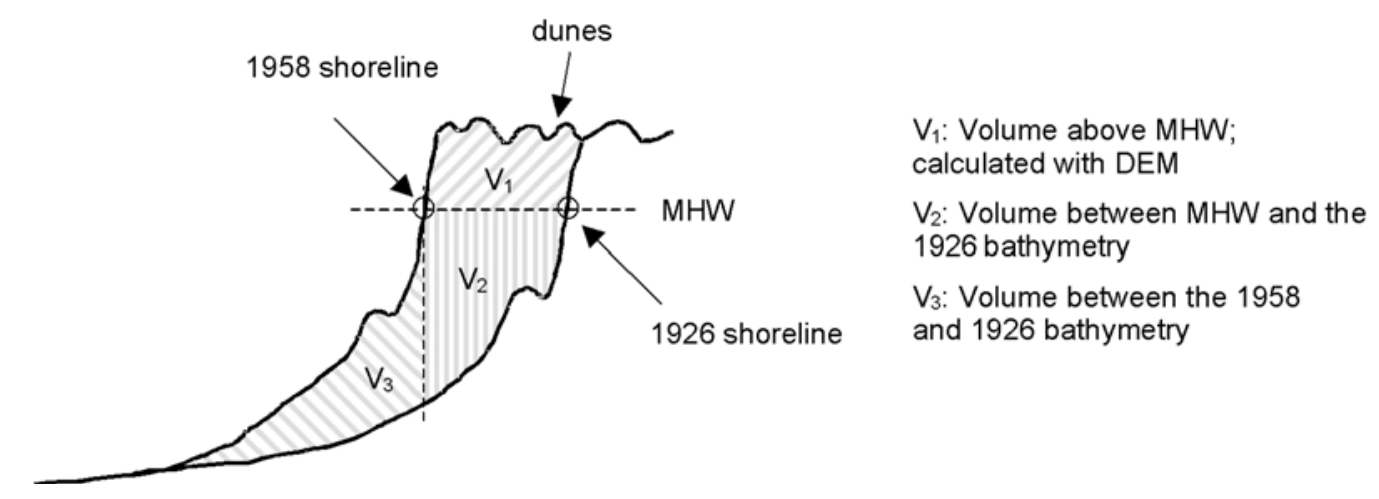

Figure 1. Topographic and bathymetric volume calculations, 1926 to 1958.

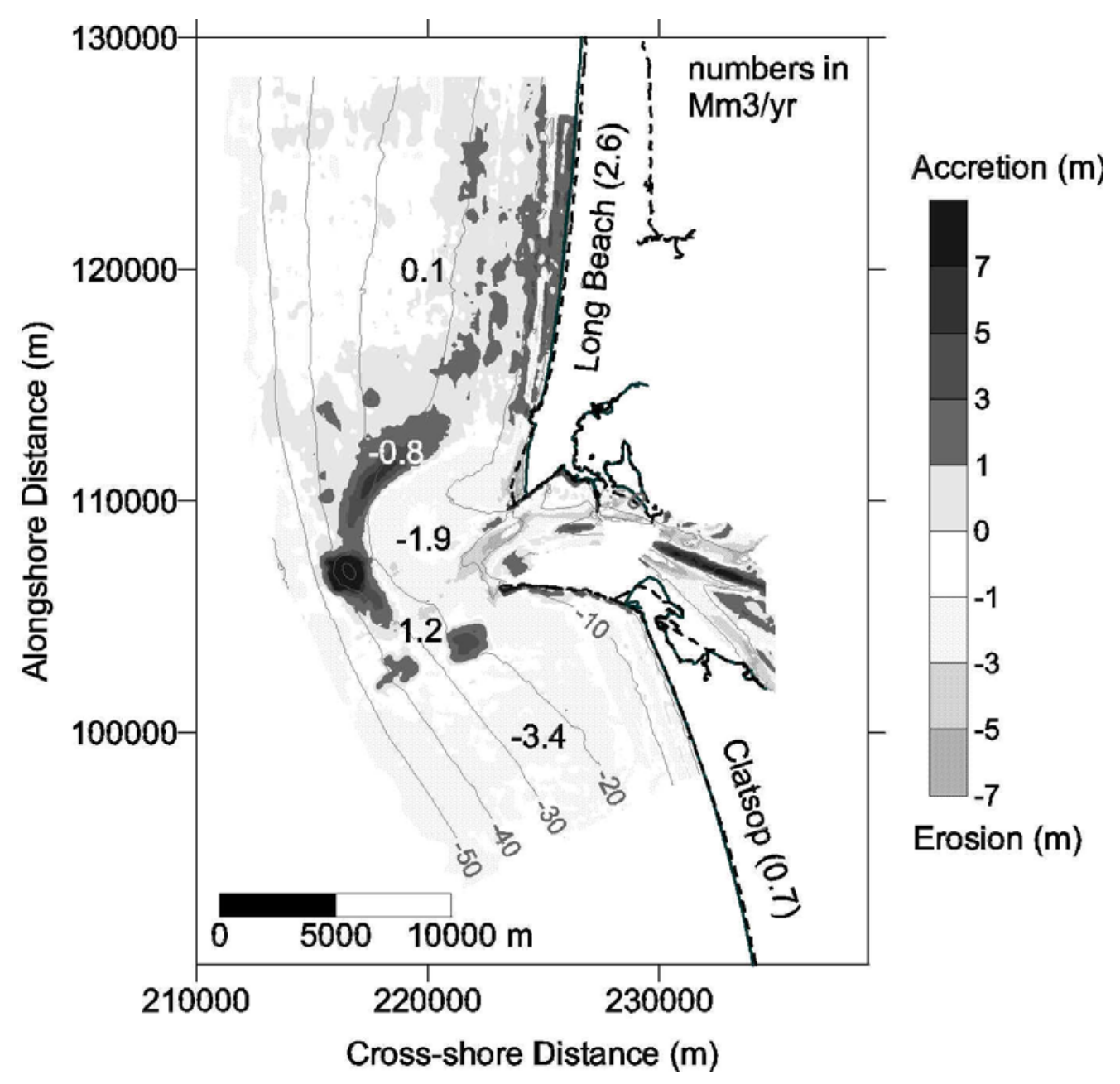

Figure 2. Volume changes at the entrance to the Columbia River, 1958 to 1998. 


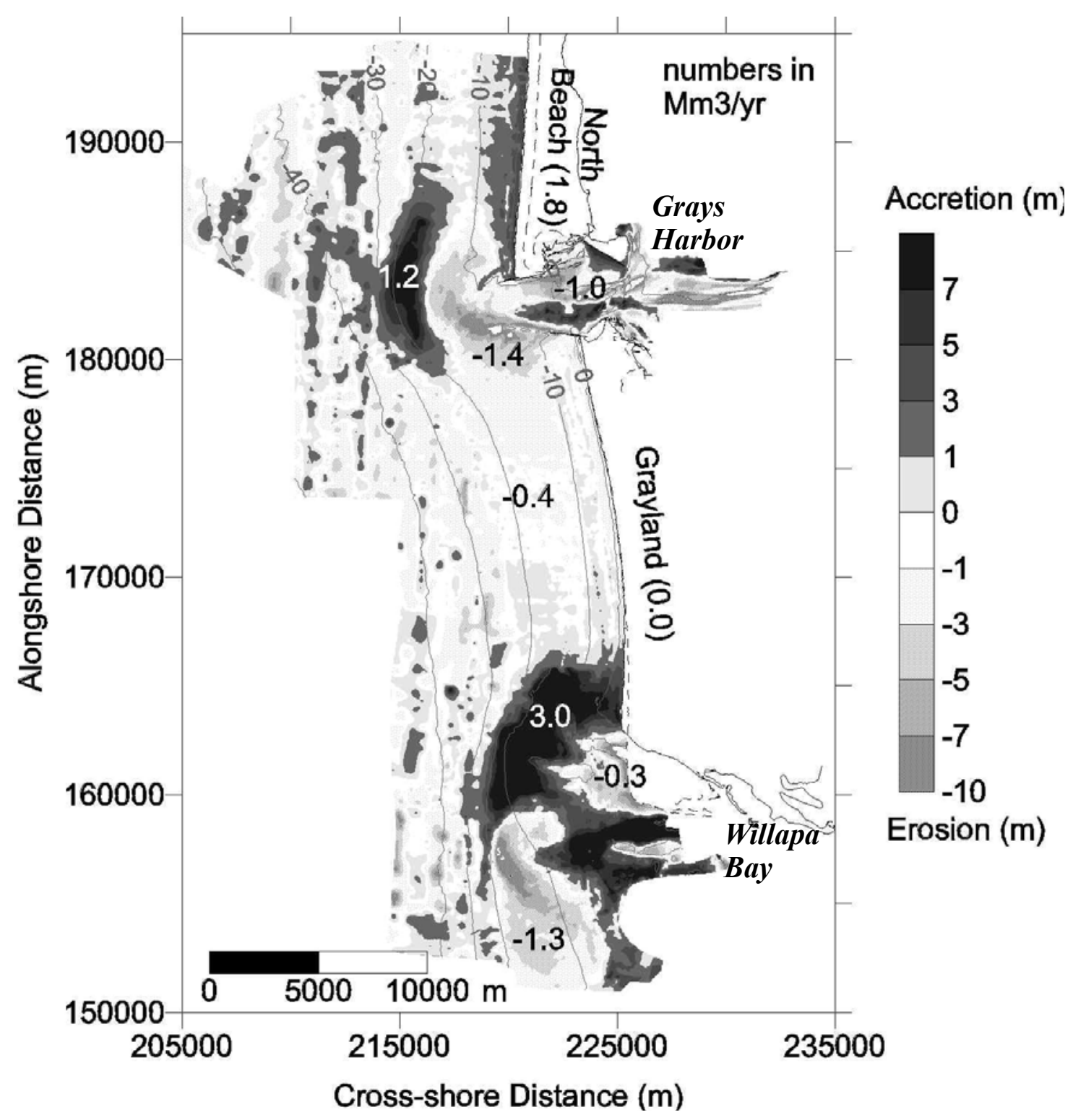

Figure 3. Volume changes at the entrance to Grays Harbor, 1926 to 1998. 


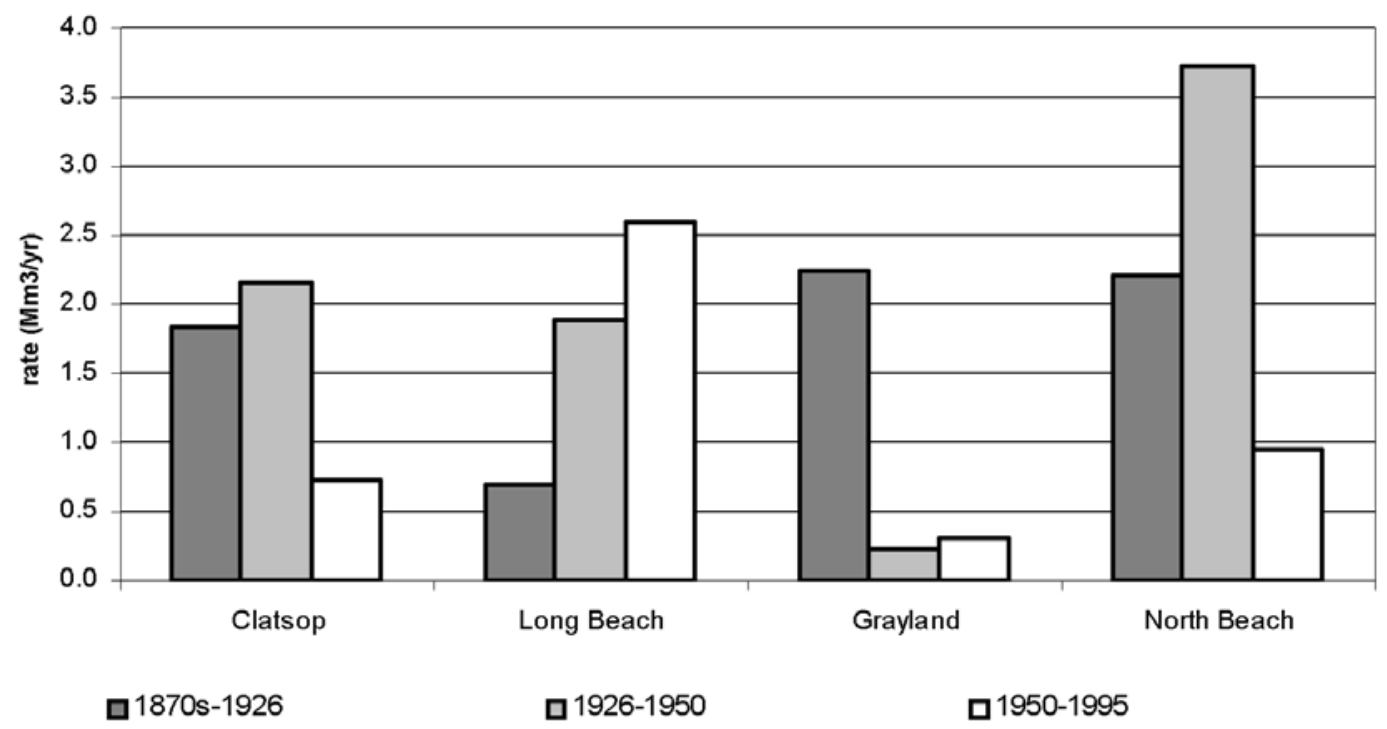

Figure 4. Topographic and nearshore accumulation rates along the CRLC.

Table 1. Volume changes at the entrance to the Columbia River, 1868 to 1926.

\begin{tabular}{lcc}
\hline & Volume change $\left(\mathrm{Mm}^{3}\right)$ & Rate \\
\hline Long Beach coast & 28.2 & 0.5 \\
& & \\
Outer delta & 175.8 & 3.0 \\
Inner delta and inlet & -316.6 & -5.5 \\
\hline Sum CR delta & -140.8 & -2.4 \\
& & \\
Flood tidal delta & 91.7 & 1.6 \\
Estuary (rest) & 96.6 & 1.7 \\
\hline Sum estuary & 188.4 & 3.2 \\
& & \\
Clatsop coast & 52.3 & 0.9 \\
Clatsop shelf & -24.4 & -0.4 \\
\hline
\end{tabular}


Table 2. Volume changes at the entrance to the Columbia River, 1926 to 1958.

\begin{tabular}{lcc}
\hline CR entrance 1926-1958 & Volume change $\left(\mathbf{M m}^{3}\right)$ & Rate $\left(\mathbf{M m}^{3} \mathbf{y r}\right)$ \\
\hline Long Beach coast (north) & -25.8 & -0.8 \\
Long Beach coast (south) & 80.4 & 2.5 \\
\hline Sum Long Beach & 54.6 & 1.7 \\
& & \\
Outer delta & 106.6 & 3.3 \\
Inner delta and inlet & -60.5 & -1.9 \\
\hline Sum CR delta & 46.1 & 1.4 \\
Flood tidal delta & & \\
Estuary (rest) & 33.5 & 1.0 \\
Omission and dredging & 41.3 & 1.3 \\
\hline Sum estuary & 71.9 & 2.2 \\
\hline Clatsop coast & 146.8 & 4.6 \\
Clatsop shelf & & \\
\hline
\end{tabular}

Table 3. Volume changes at the entrance to the Columbia River, 1958 to 1998.

\begin{tabular}{lcc}
\hline CR entrance 1958-1998 & Volume change $\left(\mathbf{M m}^{3}\right)$ & Rate $\left(\mathbf{M m}^{3} / \mathbf{y r}\right)$ \\
\hline Long Beach coast & 103.9 & 2.6 \\
Long Beach shelf & 3.2 & 0.1 \\
Outer delta & 33.0 & 0.8 \\
Inner delta & -75.6 & -1.9 \\
Dredge disposal & 47.5 & 1.2 \\
\hline Sum CR delta & 5.0 & 0.1 \\
Clatsop coast & & \\
Clatsop shelf & 29.3 & 0.7 \\
\hline
\end{tabular}

Table 4. Volume changes at the entrance to Grays Harbor, 1887 to 1926.

\begin{tabular}{lcc}
\hline GH entrance 1887-1926 & Volume change $\left(\mathrm{Mm}^{3}\right)$ & Rate $\left(\mathrm{Mm}^{3} / \mathrm{yr}\right)$ \\
\hline North Beach coast & 15.0 & 0.4 \\
& & \\
Outer delta & 16.8 & 0.6 \\
Inner delta & -27.4 & -1.2 \\
Inlet & -33.3 & -1.3 \\
\hline Sum Grays Harbor entrance & -44.0 & -1.9 \\
& & \\
Grayland coast & 62.7 & 1.6 \\
Grayland shelf & -54.4 & -1.4 \\
\hline
\end{tabular}


Table 5. Volume changes at the entrance to Grays Harbor and Willapa Bay, 1926 to 1998.

\begin{tabular}{lcc}
\hline GH entrance 1926-1998 & Volume change $\left(\mathbf{M m}^{3}\right)$ & Rate $\left(\mathbf{M m}^{3} / \mathbf{y r}\right)$ \\
\hline North Beach coast & 132.2 & 1.8 \\
Outer delta & 86.7 & 1.2 \\
Inner delta & -97.7 & -1.4 \\
Inlet & -71.4 & -1.0 \\
\hline Sum Grays Harbor entrance & -82.4 & -1.1 \\
Grayland coast & 0.9 & 0.0 \\
Grayland shelf & -25.8 & -0.4 \\
Willapa Bay delta (new) & & \\
Willapa Bay delta (old) & 218.9 & 3.0 \\
Channel & -93.5 & -1.3 \\
\hline Sum Willapa Bay entrance & -18.2 & -0.3 \\
\hline
\end{tabular}

Table 6. Accumulation rates along the CRLC ( $\left.\mathrm{Mm}^{3} / \mathrm{yr}\right)$.

\begin{tabular}{lcccc}
\hline & Clatsop & Long Beach & Grayland & North Beach \\
\hline $\mathbf{1 8 7 0 s - 1 9 2 6}$ & 1.8 & 0.7 & 2.2 & 2.2 \\
$\mathbf{1 9 2 6 - 1 9 5 0}$ & 2.2 & 1.9 & 0.2 & 3.7 \\
$\mathbf{1 9 5 0 - 1 9 9 5}$ & 0.7 & 2.6 & 0.3 & 1.0 \\
\hline
\end{tabular}




\title{
AGGREGATING BEACH MONITORING DATA TO INFORM MANAGEMENT SCALE PREDICTIVE MODELLING
}

\author{
Peter Ruggiero, Washington Department of Ecology \\ George M. Kaminsky, Washington Department of Ecology \\ Guy Gelfenbaum, U.S. Geological Survey \\ David Thompson, University of Delaware \\ Etienne Kingsley, Washington Department of Ecology
}

\section{CONCLUSIONS}

1) The seasonal exchange of sediment between onshore and offshore is large within the Columbia River littoral cell (CRLC). The CRLC beaches lower approximately $0.5 \mathrm{~m}$ during the winter season and retreat horizontally between 20 and $30 \mathrm{~m}$. This seasonal change is primarily due to the large winter wave climate and seasonal variability of wave direction and water levels in the Pacific Northwest. During the high wave conditions of the winter season, sediment is transported northward and offshore while during the low wave conditions of the summer season, sediment is transported back onshore and southward. As a result, the net change over the full annual cycle is small relative to the seasonal variability. However, the interannual variability within the CRLC is still quite large (many beaches changed by more than $10 \mathrm{~m} / \mathrm{year}$ during the first three years of the monitoring program), and can mask short- to medium-term shoreline change trends.

2) The 1997/1998 El Niño was one of the strongest on record and had a regional effect on the CRLC beaches. Associated with the El Niño were higher than typical water levels and wave heights and waves approaching from a more acute angle from the south. The impact of this event was evident in the annual response of the beaches, as El Niño conditions resulted in higher net northward sediment transport and accumulation in each sub-cell. Some of the highest net beach accretion rates during 1997-1998 occurred at the northern-most section in each sub-cell (Clatsop Spit, Leadbetter Point, Westport, and Point Grenville).

3) Approximately 85 percent of the beach profile sites, and all of the 16 surface map sites, experienced erosion during the winter of 1997/1998, averaging $25 \mathrm{~m}$ of shoreline recession. By summer 1998, approximately 55 percent of the beach profiles had not recovered beyond the 1997 baseline, resulting in an average recession rate of $1.2 \mathrm{~m} / \mathrm{yr}$, as measured by the retreat of the $2.0-\mathrm{m}$ contour.

4) The La Niña of 1998/1999 also had a strong effect on the region's beaches. While water levels were not as high as during the 1997/1998 El Niño, wave heights were more extreme, with monthly averages more than $1.0 \mathrm{~m}$ above normal during the winter months. By summer 1999, the end of the 2nd year of the monitoring program, 62 percent of the beach profiles had experienced net recession, and the average rate of 
change during this two-year period for all profiles was approximately $1.8 \mathrm{~m} / \mathrm{yr}$ of shoreline recession.

5) The largest wave event on record in the Pacific Northwest occurred during the La Niña winter, (3 March 1999), with deep-water significant wave heights measuring over $10 \mathrm{~m}$ and an associated storm surge measuring approximately $1.4 \mathrm{~m}$. This major storm caused widespread erosion and flooding throughout the CRLC and destroyed a restroom facility in the City of Ocean Shores (WA).

6) By summer 2000, the end of the 3rd year of the monitoring program, 64 percent of the beach profiles had experienced net accretion, and the average rate of change during this three-year period for all profiles was approximately $4.5 \mathrm{~m} / \mathrm{yr}$ of shoreline progradation. After these three years 63 percent of the beach surface maps had also experienced accretion averaging close to $2.3 \mathrm{~m} / \mathrm{yr}$ of progradation. As compared to the El Niño year of 1997/1998 and the La Niña year of 1998/1999 the winter of 1999/2000 was relatively mild with water levels, wave heights and wave periods being very close to the long-term averages. Although the majority of beaches reveal a trend of accretion, several sites did exhibit an erosion trend during the three years of observations. The Grayland Plains eroded at a rate of over $8 \mathrm{~m} / \mathrm{yr}$ and the southern Long Beach Peninsula eroded at $10 \mathrm{~m} /$ yr.

7) Nearshore morphology among the four sub-cells of the CRLC is strikingly different. Nearshore morphologic features (such as sandbars) along Long Beach were large and three-dimensional in 1999 while along the Grayland Plains the bars were more linear and much smaller in magnitude. Both the North Beach and the Clatsop Plains sub-cells have substantial nearshore morphologic variability.

8) Some of the largest sandbars ever observed were found along the Long Beach Peninsula during summer 1999. The maximum observed sandbar height was $6.0 \mathrm{~m}$ as measured from crest to trough. The mean height of the outer sandbar was approximately $4.0 \mathrm{~m}$ over an alongshore distance of $20 \mathrm{~km}$. Initial evidence suggests that there may be a strong connection between sandbar characteristics, such as size and distance from the shoreline, and the susceptibility of the shoreline to erosion.

9) Initial analysis of nearshore bathymetry data collected in summer 2000 suggests a clear lowering and onshore migration of the majority of outer bars in the littoral cell. This behaviour appears to be linked with the beach progradation observed throughout the cell between 1999 and 2000.

10) Monitoring data is helping to refine and verify process-based shoreline change models, as well as to assess the flooding potential of upland properties. Shoreline variance is being used to define the zone of possible shorelines that bracket predictions.

11) An observation with implications for shoreline change predictive modeling is that the annual limit of measurable cross-shore profile change from 1998 to 2000 ranges from 6 to 12 m (NAVD 88). 
12) The mean beach sand grain size in the CRLC is approximately $0.18 \mathrm{~mm}$ with median grain sizes ranging from 0.1 to $1.0 \mathrm{~mm}$ throughout the littoral cell. There is a regional gradient in sediment size with grain sizes decreasing (finer sand) with increasing distance from the Columbia River. This trend is interrupted near the mouth of Grays Harbor, where coarse sediment deposits exist on the beach.

13) The sand size gradient is roughly mirrored by a gradient in beach slope with slopes decreasing with distance from the Columbia River. The northern portion of the North Beach sub-cell exhibits the lowest sloping beaches in the CRLC. The mean beach slope, measured between the $1.0 \mathrm{~m}$ and $3.0 \mathrm{~m}$ elevation contours (NAVD 88), in the CRLC is approximately $0.022(1: 45)$ and ranges from $0.008(1: 125)$ to $0.1(1: 10)$.

14) The highest sand dunes in the CRLC can be found in the Clatsop Plains sub-cell, with dunes measuring as high as $15 \mathrm{~m}$. The smallest dunes in the littoral cell are between Moclips and Point Grenville, WA, where small incipient dunes have formed in front of the backing sea cliffs and bluffs.

15) The beach monitoring program data is currently being used by a variety of resource agencies for permitting, project review and long-range planning. Monitoring data is also being used by coastal engineers for project design.

\section{ACCOMPLISHMENTS}

The first major accomplishment associated with the beach monitoring program was the completion of the Washington Coastal Geodetic Control Network. In order to reference all beach monitoring data to consistent horizontal and vertical datums, a dense network of 76 geodetic control monuments was established during the summer of 1997. Monuments are spaced approximately 3-4 km apart throughout the littoral cell. The network has been referenced to the Washington State Plane (South) North American Datum of 1983 (NAD 83) and the land-based North American Vertical Datum of 1988 (NAVD 88) (Daniels et al., 1999).

\section{Data Sets Collected}

Following the completion of the control network a nested beach morphology monitoring program was designed and initiated. By summer 2000, three complete years of the monitoring program have been completed. Table 1 illustrates the range of data collected and the number of data sets in each category. The table represents an exhausting amount of walking (over $200 \mathrm{~km}$ of cross-shore topographic beach profiles have been measured), driving (over $4,000 \mathrm{~km}$ of beach surface has been mapped with the CLAMMER), and boating (over $800 \mathrm{~km}$ of nearshore bathymetry data has been collected with the Coastal Profiling System). Several papers, reports and abstracts have been completed that include results and data from the beach monitoring program.

\section{Monitoring Program Publications}

Côté, J.M., Holman, R.A., Stanley, J., Ruggiero, P. and Beach, R.A. in prep. Development and accuracy of the Coastal Profiling System, Journal of Coastal Research. 
Kaminsky, G.M., Ruggiero, P., and Gelfenbaum, G.R. 1998. Monitoring coastal change in southwest Washington and northwest Oregon during the 1997/98 El Niño, Shore and Beach, Vol. 66, 3, pp. 42-51.

Ruggiero, P., Gelfenbaum, G., Thompson, D., and Kaminsky, G.M. 2001. Exploring the relationship between nearshore morphology and shoreline change, Proceedings of the 4th Conference on Coastal Dynamics, Lund, Sweden, pp. 627-636.

Komar, P.D., Allan, J., Dias-Mendez, G.M., Marra, J.J., and Ruggiero, P. 2000. E1 Niño and La Niña: Erosion processes and impacts, Proceedings of the 27th International Conference on Coastal Engineering, Sydney, Australia, pp. 2414-2427.

Ruggiero, P., Voigt, B., and Kaminsky, G. 2000. Beach monitoring for enhanced decision making, Proceedings of the 17th International Conference of The Coastal Society, Portland, OR, pp. 516-524.

Voigt, B., Ruggiero, P., and Kaminsky, G. 2000. Towards the development of a decision support system for the Columbia River littoral cell, Proceedings of the 17th International Conference of The Coastal Society, Portland, OR, pp. 525-532.

Marra, J.J., Komar, P.D., Diaz-Mendez, G., Allan, J.C., and Ruggiero, P. 2000. El Niño versus La Niña along the Oregon coast, Proceedings of the 17th International Conference of The Coastal Society, Portland, OR, pp. 776-787.

Ruggiero, P., Côté, J., Kaminsky, G.M., and Gelfenbaum, G.R. 1999. Scales of variability along the Columbia River littoral cell, Proceedings of Coastal Sediments '99, ASCE, pp. 1692-1707.

Ruggiero, P., Kaminsky, G.M., Komar, P.D., and Plant, N. 1998. Coastal morphologic variability of high energy dissipative beaches, Proceedings of the 26th International Conference on Coastal Engineering, ASCE, pp. 3258-3251.

Ruggiero, P., Kaminsky, G.M., Komar, P.D., and McDougal, W.G. 1997. Extreme waves and coastal erosion in the Pacific Northwest, Proceedings of Waves '97, ASCE, pp. 947-961.

\section{Published Abstracts}

Gelfenbaum, G., Ruggiero, P., and Thompson, D. 2000. "Is there a relationship between bar morphology and shoreline change?" Abstract, EOS, Transactions, AGU Fall Meeting, Vol. 81, No. 48, Supplement, p. F673.

Ruggiero, P., Gelfenbaum, G., Kaminsky, G., and MacMahan, J. 1999. Medium- largescale nearshore variability of high energy dissipative beaches, Abstract, EOS, Transactions, $A G U$ Fall Meeting, Vol. 80, No. 46, Supplement, p. F547. 
Ruggiero, P., and Kaminsky, G. 1999. Morphology monitoring of the Columbia River littoral cell, Association of American Geographers, 95th Annual Meeting, Honolulu, HI, Abstract on CD-ROM.

Ruggiero, P., and Kaminsky, G.M. 1998. Morphologic length scales on high energy dissipative beaches, Abstract, EOS, Transactions, AGU Fall Meeting, Vol. 79, No. 45, Supplement, p. F445.

Oltman-Shay, J., Smith, F., Secan, J., Ruggiero, P., Pruis, M., Putrevu, U., Kaminsky, G., Echert, D., Cooksan, A., Côté, J., Boss, E., and Bussey, R. 1999. Infragravityfrequency-band waves and currents on a Washington coast beach, Abstract, EOS, Transactions, AGU Fall Meeting, Vol. 79, No. 45, Supplement, p. F446.

Côté, J.M., Holman, R.A., and Ruggiero, P. 1998. Nearshore bathymetry within the Columbia River littoral cell, Poster, EOS, Transactions, AGU Fall Meeting, Vol. 79, No. 45, Supplement, p. F450.

\section{Reports}

Côté, J.M. 1999. The measurement of nearshore bathymetry on intermediate and dissipative beaches, M.S. Thesis, Oregon State University, Corvallis, Oregon, $102 \mathrm{p}$.

Ruggiero, P., and Voigt, B. 2000. Beach monitoring in the Columbia River littoral cell, 1997-2000, Washington State Department of Ecology, Coastal Monitoring \& Analysis Program, Publication No. 00-06-26, 112 p.

Daniels, R.C., Ruggiero, P., and Weber, L.E. 1999. Washington geodetic control network: Report and station index, Washington State Department of Ecology, Coastal Monitoring \& Analysis Program, Publication No. 99-103, 268 p.

Kaminsky, G.M., Ruggiero, P., McCandless, D., Daniels, R., McInnis, J., and Lindstrum, E. 1999. Shoreline change at Fort Canby State Park, Report to the Washington State Parks and Recreation Commission.

Kaminsky, G.M., Ruggiero, P., McCandless, D., Lindstrum, E., McInnis, J., and Daniels, R., 1999. Road wash-outs and shoreline change at Damon Point, Washington, Report to the Washington State Parks and Recreation Commission.

\section{QUESTIONS}

The following are some of the major unresolved questions that future efforts and continued monitoring will attempt to address:

1) Can existing models predict the observed spatial variability and temporal evolution of nearshore morphology? 
2) What process(es) are responsible for 4-6 $\mathrm{m}$ high bars $1000 \mathrm{~m}$ from the shoreline?

3) What are the relationships between nearshore morphometric parameters (number of bars in the cross-shore, bar height, cross-shore position of bars, etc.) and shoreline variability, i.e., beach erosion, accretion, and dynamic stability?

4) What are the mechanisms and morphologic pathways associated with winter erosion and summer accretion? What is the role of swash bars during beach recovery?

5) Can beach monitoring data be used at the local level to inform coastal management decision making?

6) Where will the shoreline be in the future?

\section{ANALYSIS}

In order to quantify coastal change, enhance predictive capabilities, and enable informed decision-making, a regional beach morphology monitoring program was initiated in summer 1997 as one component of the Study (Ruggiero et al., 1998 and 1999). The data from the monitoring program are being integrated with other data sets, including those that document the long-term coastal evolution and geological framework of the CRLC, to develop conceptual and predictive models of coastal evolution at scales relevant to the planning and decision-making process of coastal managers.

The primary goals of the monitoring program are to:

1) Quantify the short- to medium-term (event-seasonal-interannual) beach change rates and morphologic variability along the Columbia River littoral cell.

2) Collect beach state parameter (i.e., grain size, beach slope, and dune height) data to enhance the conceptual understanding of CRLC functioning and refine predictions of future coastal change.

3) Compare and contrast the scales of environmental forcing and beach change with other coastlines of the world.

4) Provide relevant beach change data in an appropriate format to coastal decision-makers.

Components of the monitoring program include:

- Geodetic control,

- Beach profiles,

- Sediment size distributions, 
- Three-dimensional beach surface maps,

- Shoreline reference feature mapping,

- Nearshore bathymetry, and

- Waves and water levels.

\section{Monitoring Program Design}

A nested sampling scheme began in 1997 in which multiple techniques are being used to measure beach change over a variety of time and space scales (Figure 1). The evolution of the sub-aerial beach is often of principal interest in coastal management due to its proximity to valuable upland properties and community infrastructure. The sub-aerial beach is one of the most dynamic places within the active coastal zone where tens of meters of horizontal shoreline recession can occur in just a few hours as a result of a major storm. Fortunately, this portion of the active coastal zone is readily available for measurement, and as a result, most beach monitoring programs focus on measuring the temporal variability of the visible beach. The sub-aerial beach, however, comprises only a small percentage of the active coastal zone. In order to develop reliable predictive capabilities of shoreline change, an understanding of the sub-aqueous beach variability is also necessary (Figure 1). Since offshore sandbars dissipate wave energy and provide a buffering capacity that protects the sub-aerial beach, the temporal variability of nearshore morphology (i.e., position and height of sandbars and overall beach slope) may affect the susceptibility of the shoreline to the erosive power of waves. Most of the world's beaches are inherently three-dimensional. This implies that knowledge of the alongshore variability of the coastal planform is also important to coastal decision-makers. Figure 1 illustrates the relationships between the temporal and spatial scales of morphologic change across the coastal planform (Ruggiero et al., 2000).

\section{Aggregating to Management Scale}

A primary goal of the Southwest Washington Coastal Erosion Study is understanding and predicting coastal change at a management scale of tens of kilometers (spatially) and decades (temporally). Historical morphological changes are being viewed in context with coastal change over several centuries prior to human influence as well as with recent data collected by the beach monitoring program that quantifies morphologic response to forcing conditions. These multi-scale data sets are being used to inform process-based modeling that simulates historical changes and predicts the evolution of the coast several decades into the future.

The figures below summarize some of the major accomplishments of the monitoring program.

\section{ACKNOWLEDGEMENTS}

We would like to thank a number of individuals who helped with the design and implementation of the beach monitoring program. Diana McCandless has miraculously 
managed to keep the equipment and fleet of vehicles that are used in the monitoring program running smoothly (more or less) and always is eager to go to the field. None of the data presented in this report would be possible without the hard and dedicated work of numerous field scientists who worked tirelessly under what could euphemistically be termed "adverse" conditions. Emily Lindstrum, Josh McInnes, and Troy Warnick collected the bulk of the data and made surveying in the rain at 4:00 AM fun. Jessica Côté and Jamie MacMahan contributed significantly to the nearshore bathymetry campaigns of 1998 and 1999. Many others, including Brian Voigt, Maarten Buijsman, Steve Eykelhoff, Rich Daniels, Bob Huxford, and Peter Wald were always available when necessary to make sure that we "got the data."

Table 1. Data sets collected as part of the beach morphology monitoring program.

\begin{tabular}{ccccccc}
\hline $\begin{array}{c}\text { Field } \\
\text { Campaign }\end{array}$ & $\begin{array}{c}\text { Beach } \\
\text { Profiles }\end{array}$ & $\begin{array}{c}\text { Beach } \\
\text { Surface } \\
\text { Maps }\end{array}$ & $\begin{array}{c}\text { Sediment } \\
\text { Samples }\end{array}$ & $\begin{array}{c}\text { Scarp } \\
\text { Walks }\end{array}$ & $\begin{array}{c}\text { Nearshore } \\
\text { Bathymetry } \\
\text { Profiles }\end{array}$ & $\begin{array}{c}\text { Nearshore } \\
\text { Sediment } \\
\text { Samples }\end{array}$ \\
Winter 1997 & --- & --- & --- & 4 & --- & --- \\
Summer 1997 & 47 & 16 & 47 & --- & --- & --- \\
Winter 1998 & 47 & 19 & 47 & 5 & --- & --- \\
Summer 1998 & 47 & 24 & 47 & --- & 101 & 2 \\
Fall 1998 & 47 & --- & --- & --- & --- & --- \\
Winter 1999 & 47 & 20 & --- & 3 & --- & --- \\
Spring 1999 & 47 & --- & --- & --- & --- & --- \\
Summer 1999 & 47 & 23 & 47 & --- & 235 & 17 \\
Fall 1999 & 47 & --- & --- & --- & --- & --- \\
Winter 2000 & 47 & 21 & --- & 5 & --- & --- \\
Spring 2000 & 47 & --- & --- & --- & --- & -- \\
Summer 2000 & 47 & 21 & 47 & --- & 237 & 97 \\
Totals & $\mathbf{5 1 7}$ & $\mathbf{1 4 4}$ & $\mathbf{2 3 5}$ & $\mathbf{1 7}$ & $\mathbf{5 7 3}$ & $\mathbf{1 1 6}$ \\
\hline
\end{tabular}




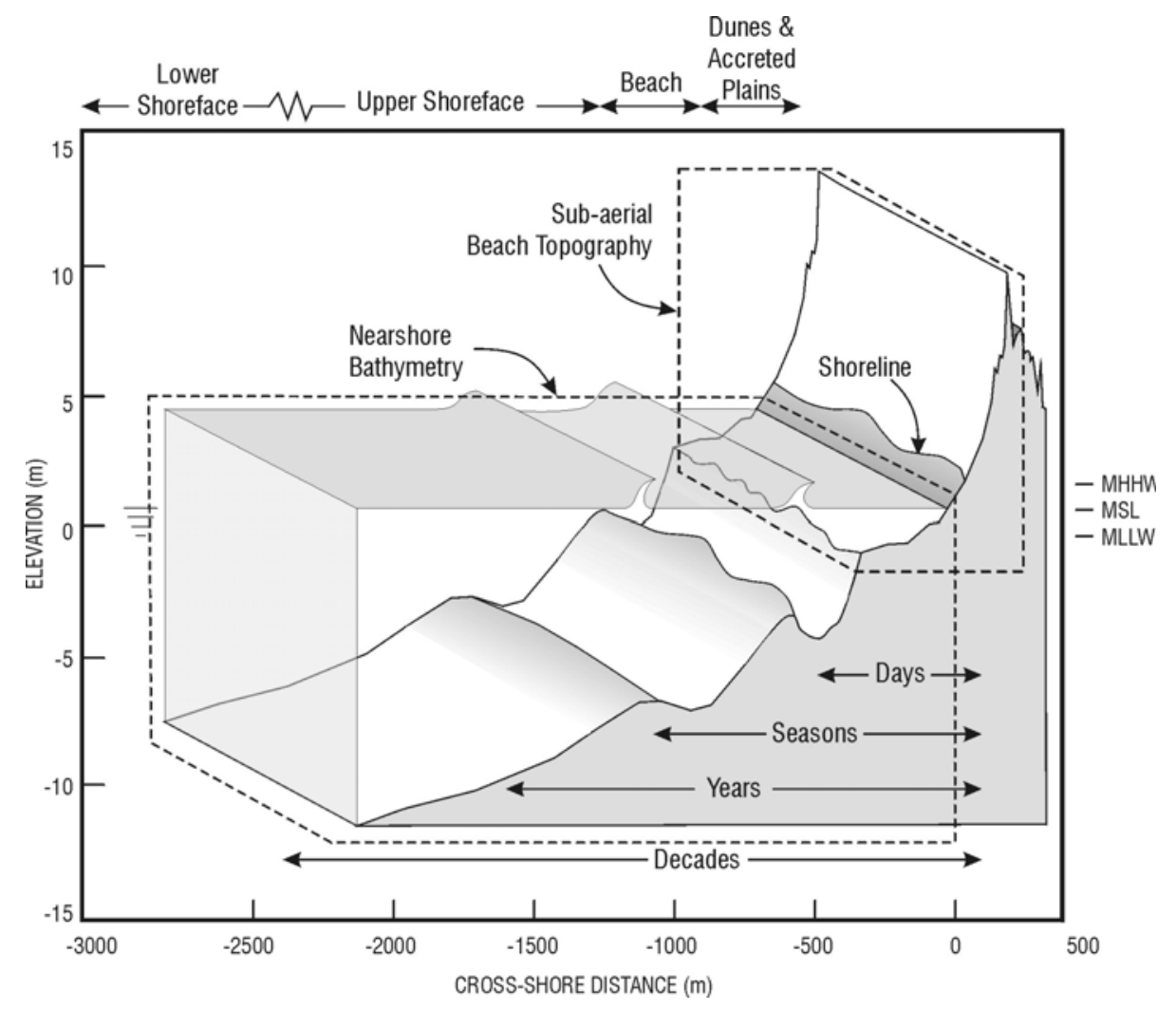

Figure 1. Conceptual diagram illustrating the motivation for a nested sampling scheme for monitoring beach change. The evolution of the shoreline is of primary interest from a coastal management perspective. However, for accurate predictions of shoreline evolution, nearshore bathymetry and the inherent three-dimensionality of the coastal system must also be considered. The horizontal arrows represent time scales for cross-shore morphologic change. 


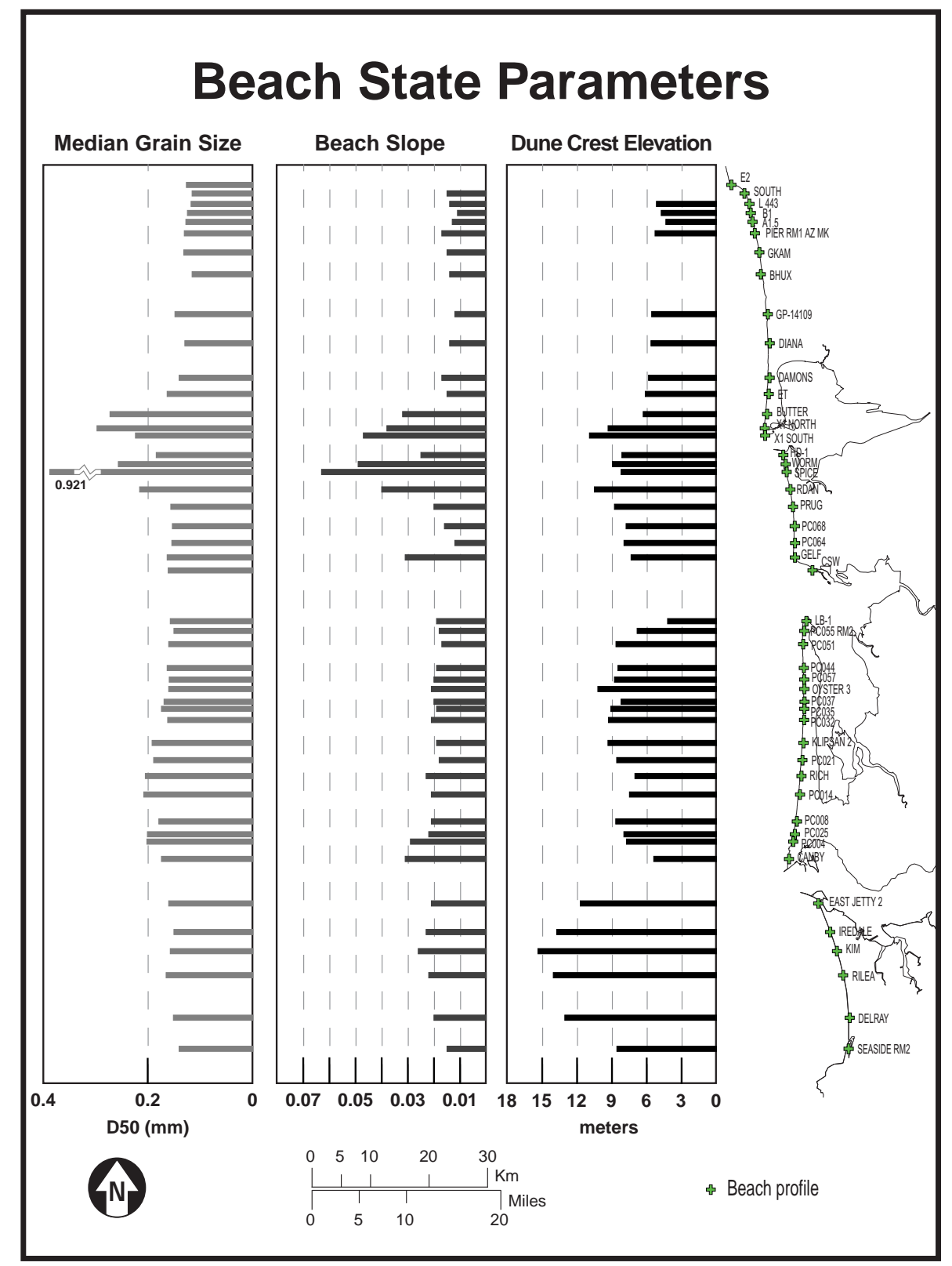

Figure 2. Beach state parameters. A regional inventory of physical parameters that help to define the 'state' of the beach includes the average sediment size, beach slope, and dune crest elevation at each profile. The average median grain size from samples collected at approximately MHW during both the summer 1998 and summer 1999 survey are shown. The slope of the sub-aerial beach is defined as the gradient between the 1.0- and $3.0-\mathrm{m}$ elevation contours on the profile. Slope values have been averaged for the 9 surveys that have been collected since 1997 at each of the 47 beach profile locations. The primary dune crest elevation is also given relative to NAVD 88. 


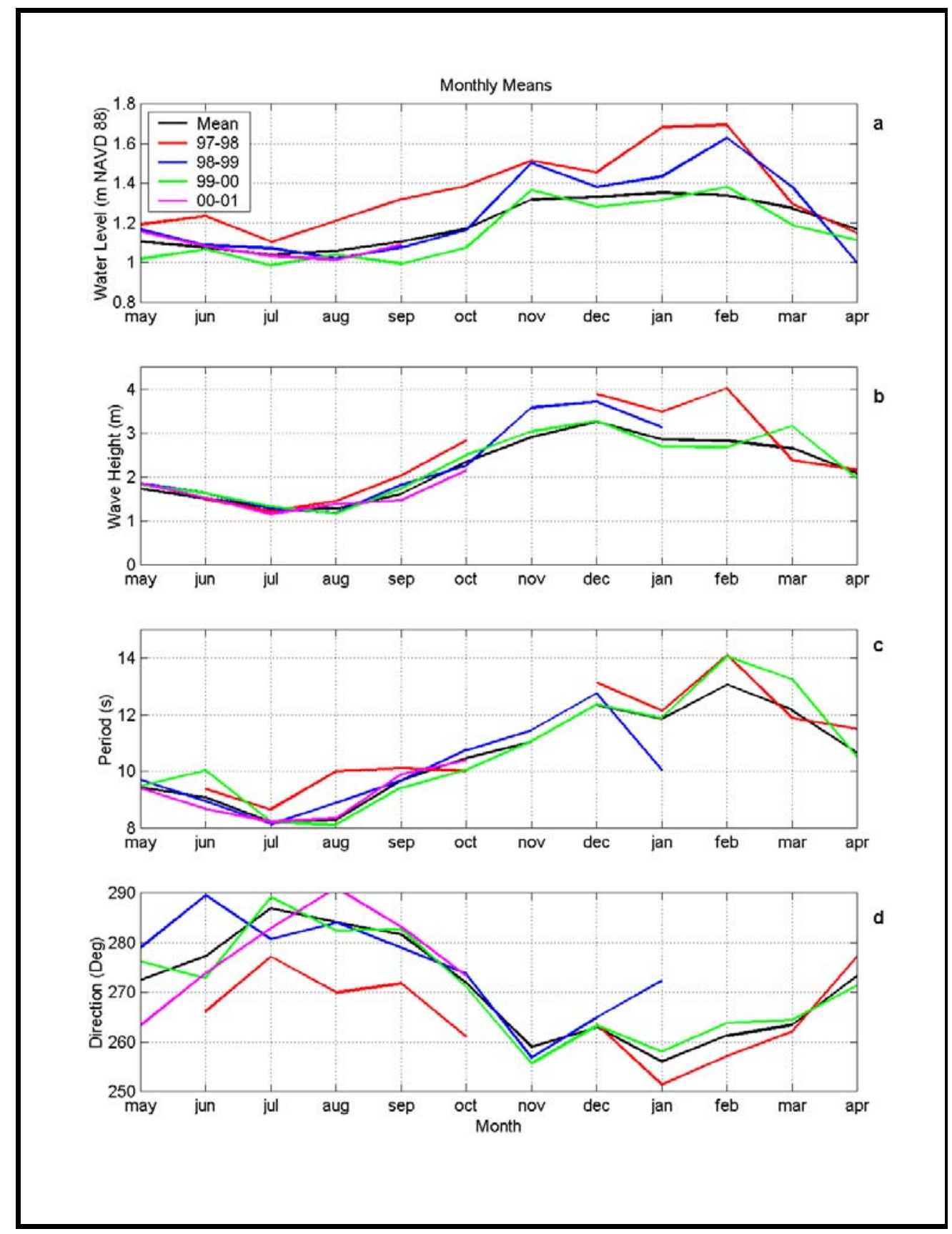

Figure 3. Monthly mean a) water level from the Toke Point tide gage (NAVD 88), b) significant wave height, c) period, and d) direction from the Grays Harbor buoy. The solid black line represents long-term means beginning in 1980 for water levels, 1981 for wave heights and periods and 1993 for wave direction. 


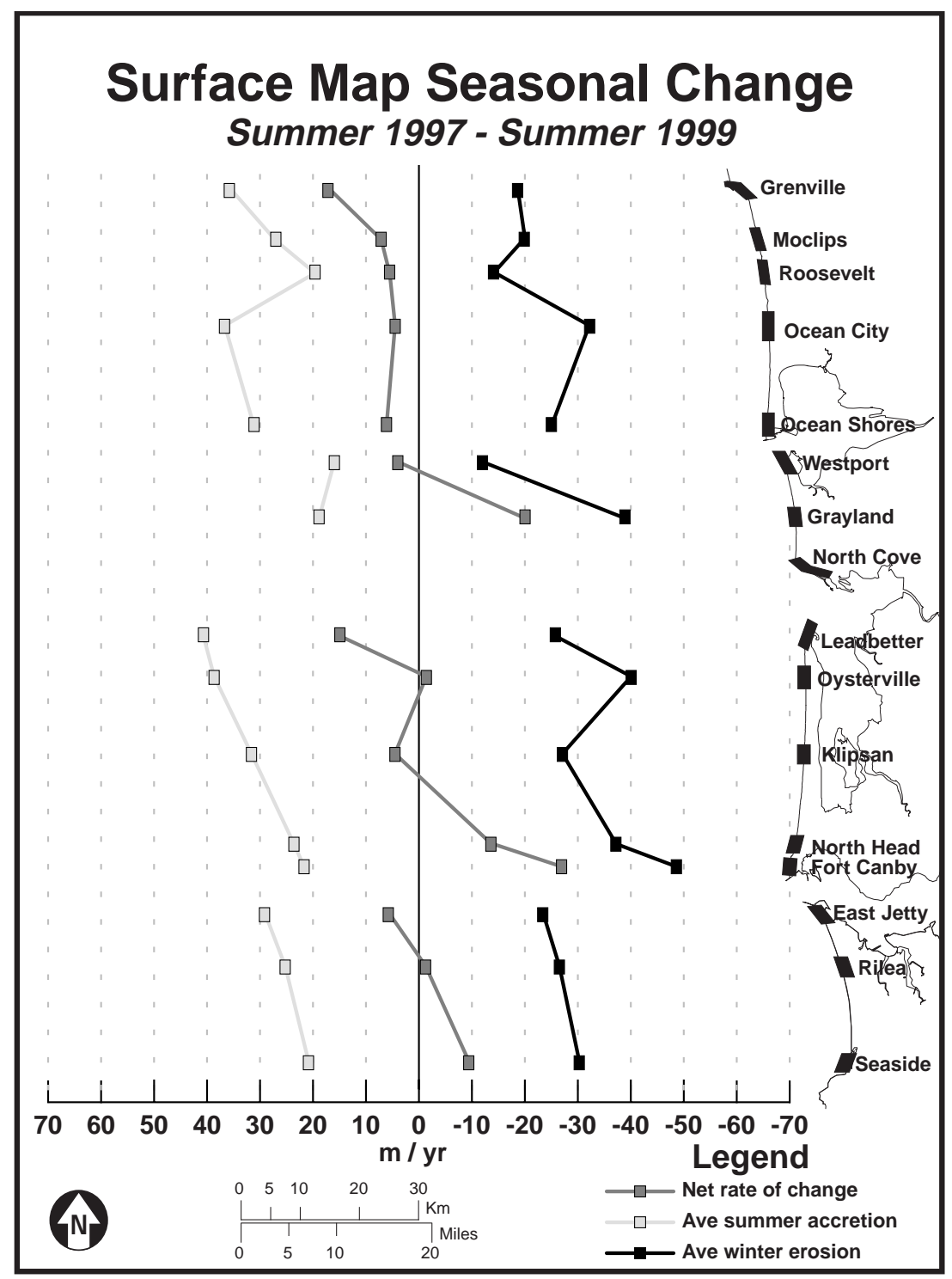

Figure 4. Seasonal variability of the $2.0-\mathrm{m}$ contour line. This figure demonstrates the seasonal variability of shoreline change along the CRLC. The average winter erosion and average summer accretion observed during the first two years of the monitoring program are presented. These large shoreline change rates tend to balance each other to produce the lower net annual shoreline change rates that are also plotted on the figure. Many of the surface map sites experienced significant net change over this two-year period, e.g., $6 \mathrm{~m} / \mathrm{yr}$ of net progradation at the East Jetty site and $13 \mathrm{~m} / \mathrm{yr}$ of net recession at the North Head site. Each sub-cell shows maximum net erosion or minimum net accretion at the southern end of the sub-cells (except in the North Beach sub-cell where these extremes occur closer to the middle) and maximum net accretion at the northern sub-cell boundaries. These data suggest that the sub-cell shorelines have realigned themselves in response to the acute southerly wave directions associated with the 1997/1998 El Niño. 


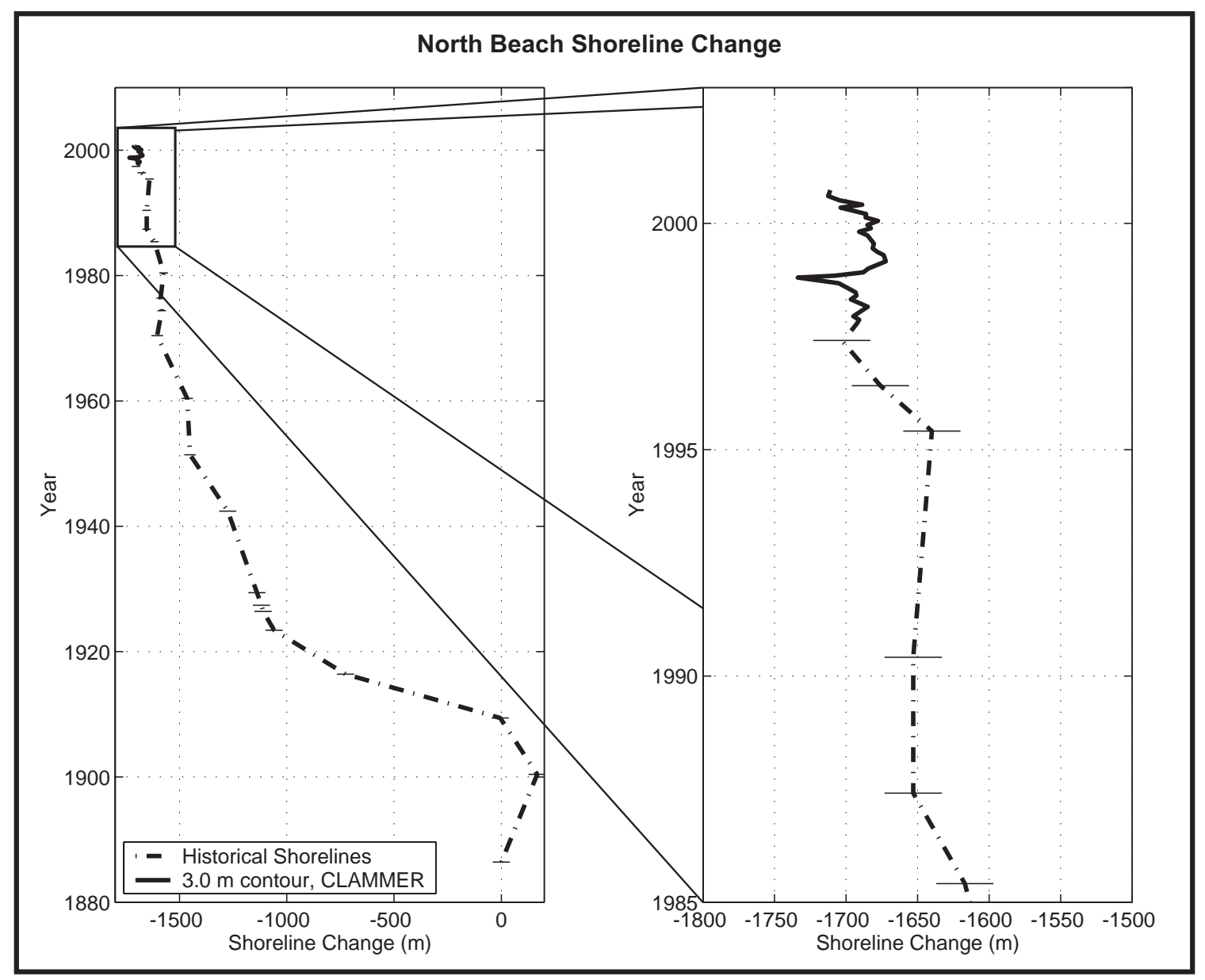

Figure 5. Bulk parameters of shoreline and profile change are being derived to compare short-term variability with decadal-scale regional trends. By documenting the range of spatial and temporal variability of the coastal system it becomes possible to assess the susceptibility of the coast to adverse impacts of morphologic change. In particular, separation of the variance from the mean trend in shoreline position is important in management scale predictions because the variance can be used to define the zone of possible shorelines that bracket the predicted shoreline position. 

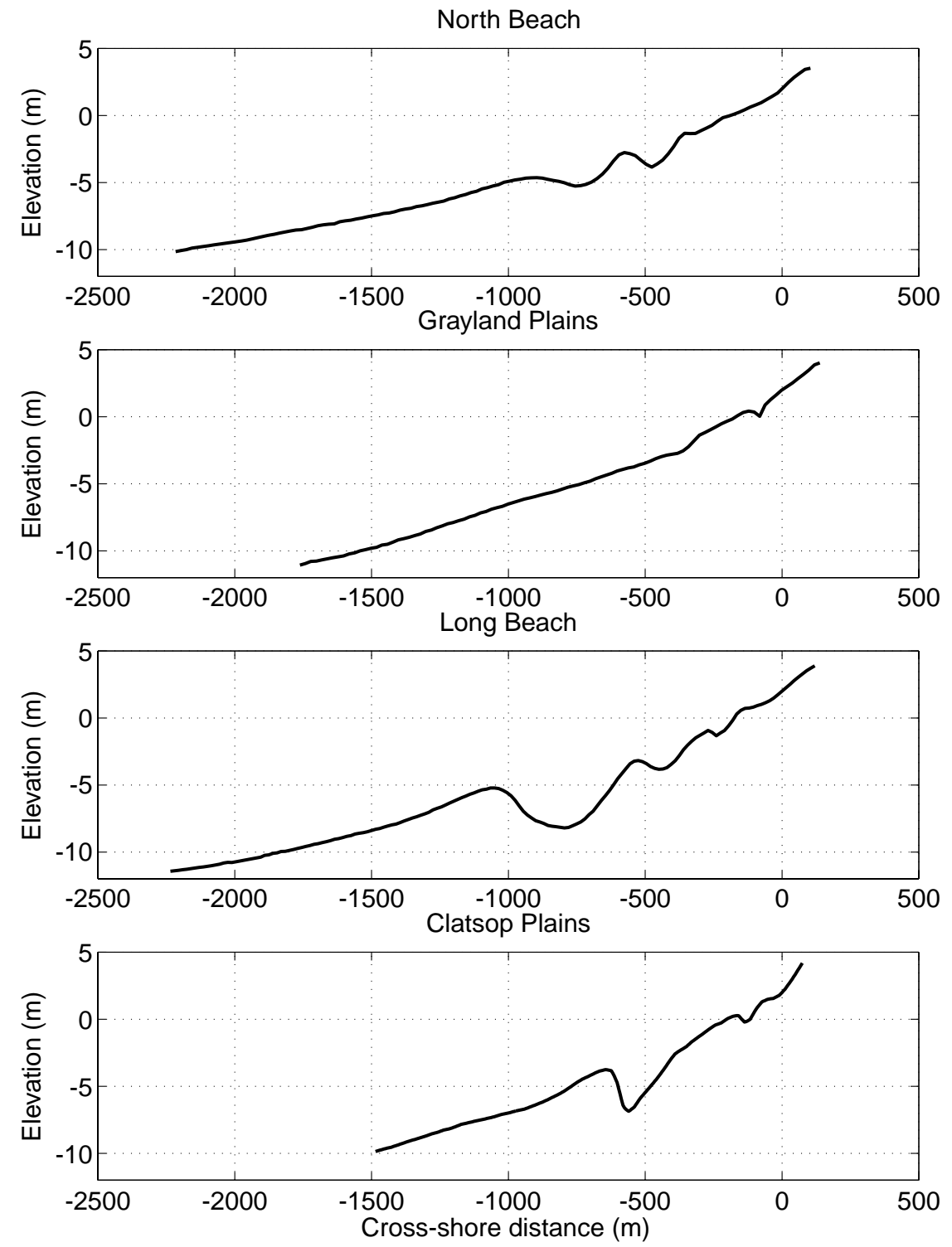

Figure 6. Nearshore beach profiles for each of the 4 sub-cells within the CRLC collected in 1999. These profiles reveal the variability in morphology observed among the four subcells. The slope for these profiles is measured from the 2.0-m elevation contour (NAVD 88) offshore to the $-10.0-\mathrm{m}$ contour. The North Beach profile $(\mathrm{km} \mathrm{137)}$ is relatively low sloping $(0.0055,1: 181)$ and features 3 sandbars. The profile collected in the Grayland Plains $(\mathbf{k m}$ 102) shows small sandbar features and a much steeper slope $(0.0078,1: 128)$. The Long Beach profile $(\mathrm{km} \mathrm{69})$ has four sandbars with a larger outer sandbar (approximately $3.0-\mathrm{m}$ high) than each of the other three profiles. The slope of the Long Beach profile is 0.0065 (1:153). The Clatsop Plains profile ( $\mathrm{km} \mathrm{22)}$ has a distinct outer bar approximately $2.0-\mathrm{m}$ in height and a slope similar to that of the Grayland Plains profile, 0.0080 (1:125). 


\section{ASSESSING COASTAL SUSCEPTIBILITY IN THE COLUMBIA RIVER LITTORAL CELL}

Brian Voigt, Washington Department of Ecology

Peter Ruggiero, Washington Department of Ecology

\section{CONCLUSIONS}

1) Declining productivity of the natural system (timber, fishing) has resulted in a reliance on significant economic contributions from tourism and related development. The upsurge in coastal development, while economically beneficial over the short term, may prove costly in the long run if the evolution of the coastal system and seasonal fluctuations in physical beach condition are not considered.

2) Planning efforts for future coastal development, recreational opportunities and economic and environmental sustainability in the Columbia River littoral cell can be strengthened by incorporating a scientific understanding of the coastal system.

3) It is critical that Study investigators work in cooperation with the management community to ensure the development of useful products which address relevant issues and priority planning efforts.

4) Employing knowledge of the physical system to develop a susceptibility profile for coastal communities will facilitate the development of coastal policies and management decisions that pursue desired outcomes (economic, social, environmental) with respect to scientifically-based scenarios of future physical coastal conditions.

5) One of the greatest challenges to the process of deriving a susceptibility rating lies in the uncertainties that will ultimately affect decision-making outcomes. As a result, the development and implementation of a susceptibility rating as a decision support tool relies heavily on the expert knowledge resulting from the SWCES research.

6) Information on vulnerable coastal areas needs to be developed to mitigate coastal hazards, guide land-use planning, and enable fiscally responsible investments in community infrastructure (Kaminsky and Gelfenbaum, 2000).

7) The integration of multi-disciplinary data sets will facilitate science-based management that addresses community issues and identifies priority areas for planning consideration based on acceptable levels of risk.

8) The Study is continuing to develop informational products to facilitate the integration of scientific knowledge with the decision-making process of coastal mangers (Voigt, 1998). 
9) There is not a single management support tool that will address all the needs of diverse coastal communities. Management support tools are most successfully developed in cooperation with local communities to address local needs. Examples of support tools produced by the SWCES to date include static paper maps, digital databases, an Internet site, and GIS data and documentation.

\section{ACCOMPLISHMENTS}

Financial support through Coastal Zone Management (CZM) 306 "Special Project" funding was awarded during FY 2000. The project will determine local community information needs for coastal management activities and develop modern decision-support tools to improve the integration of scientific knowledge with the local management framework. A principal goal of this effort is to collaborate with local governments to develop interactive map-based products to enable better long-term planning and management of coastal resources. A survey questionnaire has been developed to assess the technical capacity and planning horizon of local communities. The outcomes of this project will improve the ability of local governments to access baseline data and assess potential risks and impacts of current and future development based on the results from a variety of natural hazard scenarios.

\section{QUESTIONS}

1) How can the knowledge base developed by SWCES research best be transferred to coastal communities for integration with planning and decision-making processes?

2) How can geological scale research results be integrated into susceptibility analysis?

3) What type of management approach(es) for dealing with impacts of current and future coastal development will be politically acceptable to diverse interest groups (local governments, environmental advocates, statewide beach users) while at the same time accomplish the objectives of state and federal environmental legislation? How can an improved understanding of the physical processes of the CRLC be employed to support selected management approaches?

\footnotetext{
ANALYSIS

An initial attempt at applying this susceptibility framework and developing management products has begun for an 8-km stretch of the southern Long Beach Peninsula. The case scenario examines shoreline change over a 25-year period (1995-2020) coupled with the seasonal variability of beach state parameters and the impacts associated with predicted wave run-up (dune toe impact and dune crest overwash). Future shoreline position is presented as a range of values incorporating uncertainty in data sets and model formulation as well as short-term seasonal variability. Integrated data and model results are plotted on an orthophoto base map to illustrate potential conflicts between the predicted future shoreline positions and existing coastal development.
} 
Figure 2a displays the alongshore variability of dune toe and dune crest elevations. The mean dune toe and dune crest elevations for this $8-\mathrm{km}$ stretch of coast measure $4.7-\mathrm{m}$ (NAVD 88) and 7.8-m (NAVD 88), respectively. Beach slope, as calculated between the 1.0 and 3.0-m contours averages 0.025 (1:40). An assessment of the frequency of dune toe impact and wave overwash has been performed utilizing a probabilistic total water level model (Ruggiero et al., 1996), and the results are displayed in Figure 2b. Although dune overwash is an infrequent occurrence, wave impact at the dune toe is problematic along the southern end of the Study area, with 7 locations (denoted by asterisks) experiencing more than 75 hours of wave impact per year. Figure $2 \mathrm{c}$ displays predicted shoreline change for the time period 1995-2020 derived from the processes-based shoreline change model UNIBEST (Delft Hydraulics, 1994). Results indicate larger shoreline retreat at the southern end of the case study tapering off to the north. Figure $2 \mathrm{~d}$ maps a scenario of potential future impact that reveals several kilometers of shoreline susceptible to coastal change with increased potential for dune erosion and coastal flooding along the southern extent of the case example.

While mapped output may be useful over the short-term, the static nature of a printed map may limit its utility into the future. Ideally, decision support is provided as a GIS tool that enables a range of scenarios to be tested, allowing local communities to determine specific boundary conditions and objective evaluation measures, combined with their associated probabilities, uncertainties and levels of risk to facilitate the adoption of scientificallybased, publicly-acceptable coastal management plans.

\section{REFERENCES}

Delft Hydraulics 1994. UNIBEST, A software suite for the simulation of sediment transport processes and related morphodynamics of beach profiles and coastline evolution, Delft Hydraulics, Delft, The Netherlands.

Kaminsky, G.M., and Gelfenbaum, G. 2000. The Southwest Washington Coastal Erosion Study: A scientific research project to address management-scale objectives, Proceedings of the 17th International Conference of The Coastal Society, Portland, OR, pp. 505-515.

Ruggiero, P., Komar, P., McDougal, W. and Beach, R. 1996. Extreme water levels, wave run-up and coastal erosion, Proceedings 25th International Conference on Coastal Engineering, pp. 2793-2805.

Voigt, B. 1998. Merging coastal research and policy for improved coastal hazard management, Poster, Proceedings of the 16th International Conference of The Coastal Society, Williamsburg, VA, pp. 160a. 


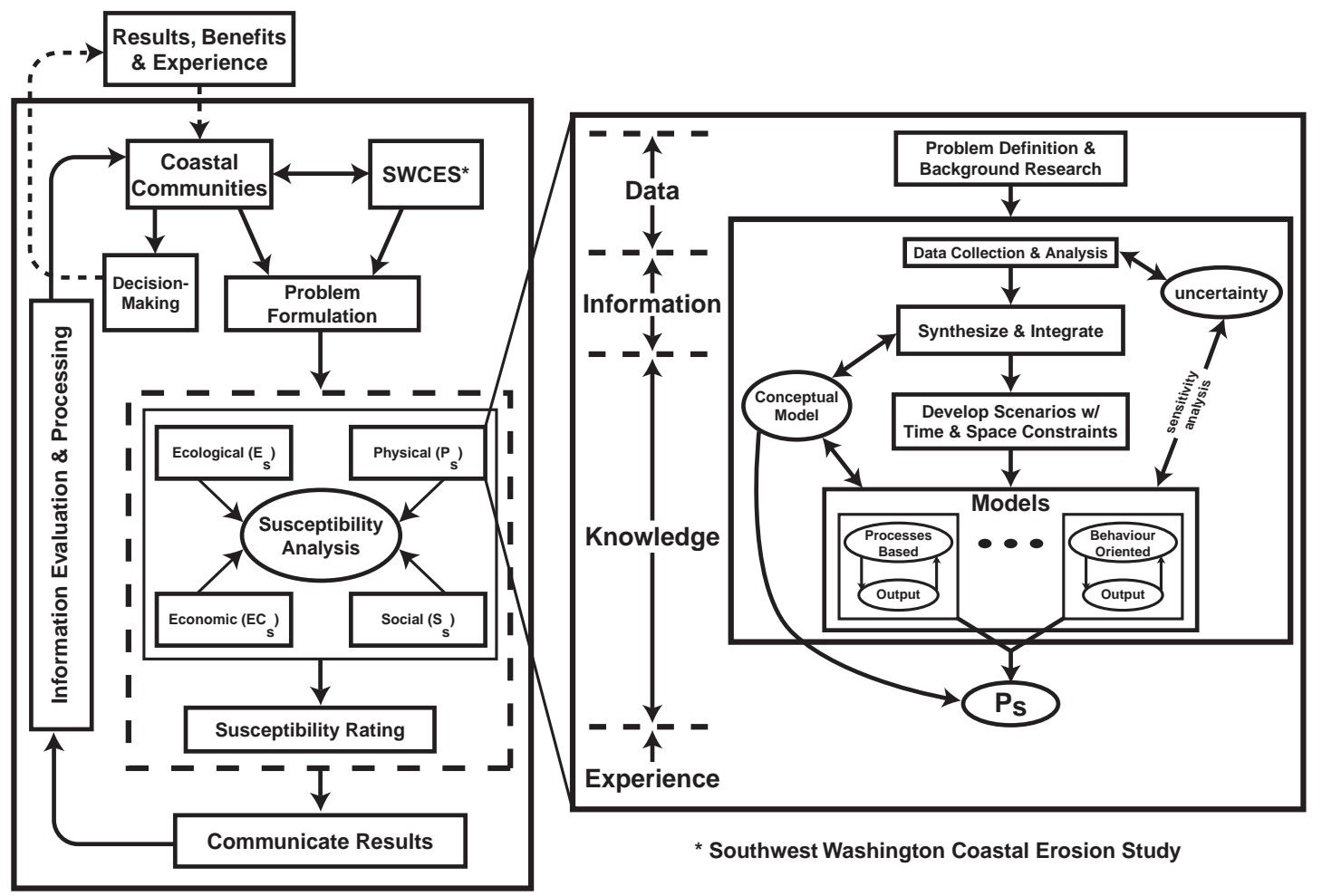

Figure 1. Flow diagram for information transfer between the scientific and management communities and a physical susceptibility framework. The left panel depicts the information flow from coordinated problem formulation to local decision-making. The right panel illustrates a framework for deriving physical susceptibility to coastal change. The physical susceptibility (Ps) is integrated with ecological, social, and economic susceptibilities to derive a susceptibility rating. As decisions are made and evaluated over time, communities benefit from past experience. 


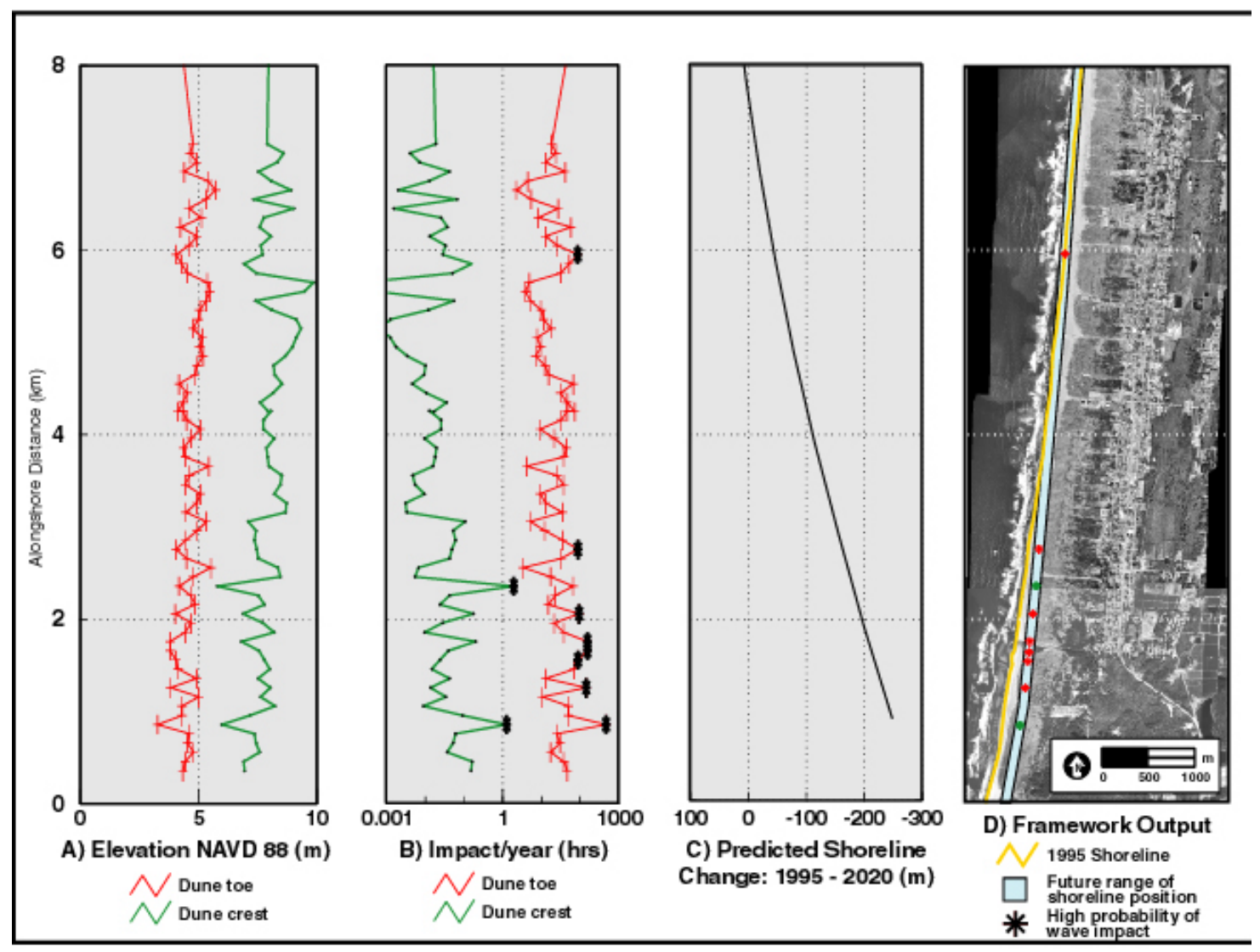

Figure 2. A) dune toe and crest elevations, B) annual hours of dune toe impact and dune crest overwash, C) shoreline change prediction, D) susceptibility analysis output mapped on southern Long Beach peninsula orthophoto; asterisks denote significant dune erosion and coastal flooding potential. 


\section{PREDICTING SHORELINE CHANGE AT MANAGEMENT SCALE}

George M. Kaminsky, Washington Department of Ecology

Maarten C. Buijsman, Washington Department of Ecology

Peter Ruggiero, Washington Department of Ecology

\section{CONCLUSIONS}

1) Preliminary shoreline change model results suggest that the present shoreline configuration in each of the sub-cells is undergoing change in response to reductions in sediment supply, especially from the ebb-tidal deltas at the entrances to the Columbia River and Grays Harbor. Consequently, it is suspected that the shoreline in each subcell will re-adjust towards a new equilibrium configuration over the next few decades.

2) A sensitivity analysis has revealed that shoreline calibrations using UNIBEST (Delft Hydraulics, 1994) are most sensitive to wave direction and that predictions are most dependent on sediment budget estimates. The shoreline change simulations were moderately sensitive to changes in wave height, large changes in duration, and fall velocity. The INIBEST model may be sensitive to alongshelf currents, but this has not been fully evaluated.

3) Preliminary shoreline change predictions based on a range of sediment budget estimates for each of the sub-cells suggest the following orders of magnitude changes over the next two decades:

a) The southern Long Beach shoreline may retreat, within $5 \mathrm{~km}$ north of North Head (located $4 \mathrm{~km}$ north of the Columbia River entrance), by up to $200 \mathrm{~m}$. The shoreline along the northern part of the Long Beach sub-cell may advance by as much as $150 \mathrm{~m}$.

b) In the Grayland sub-cell the shoreline may retreat on the order of $150 \mathrm{~m}$ at the Grays Harbor South Jetty, and a gradual shoreline rotation along the southern 10$\mathrm{km}$ of the sub-cell may result in advance about $40 \mathrm{~m}$ near the northward migrating Willapa Bay entrance. These model results are very preliminary.

c) The North Beach sub-cell may undergo about 10 to $100 \mathrm{~m}$ of shoreline retreat within $5 \mathrm{~km}$ north of the Grays Harbor North Jetty and up to $80 \mathrm{~m}$ of shoreline advance approximately $15 \mathrm{~km}$ north of the North Jetty. These results are highly dependent upon the sediment budget.

4) Preliminary model results suggest that net sediment transport is directed away from the stabilized entrances of Grays Harbor and the Columbia River. This suggests that most of the sand must be supplied by (or bypassed across) the ebb-tidal deltas (or the Columbia River for the Long Beach and Clatsop sub-cells) in order to maintain the present shoreline configuration. In each case, the magnitude of future shoreline retreat 
is expected to decrease with alongshore distance from the jetties at the Columbia River and Grays Harbor inlets, and result in shoreline advance at a greater distance. The shoreline along southern North Beach and southern Long Beach is anticipated to approach toward a new equilibrium over a time scale of several decades.

5) The results of shoreline modeling and morphodynamic analyses suggest that the net sediment transport along the upper shoreface and coast is directed away from the jettied estuary entrances. In contrast, the net regional sediment transport along the lower shoreface appears to be both northerly and onshore over decadal to century time scales throughout the entire littoral cell. Future shoreline position will likely be governed by a combination of sediment supply from the Columbia River, the ebb-tidal deltas, and the lower shoreface.

6) Future work to improve the predictions of shoreline change will also involve:

a) verifying and calibrating the wave model with field experiment data;

b) using the calibrated wave model results to drive the sediment transport and shoreline change modeling;

c) developing data and models of inner-shelf sediment transport;

d) continued monitoring to calibrate and verify shoreline change predictions;

e) integrating the shoreline modeling results with other data and models, including 3-dimensional morphological modeling efforts; and

f) continuing detailed investigations of the other agents driving coastal change at scales relevant to coastal management.

\section{ACCOMPLISHMENTS}

1) Shoreline change modeling using UNIBEST has been attempted for each of the subcells in the Columbia River littoral cell, using shoreline data from the 1950s, 1970s, and 1995. Two modules in UNIBEST have been applied, UNIBEST-LT (longshore transport) and UNIBEST-CL (coastline change). In UNIBEST-CL, the cross-shore profiles are defined. For each cross-section the sediment transport $\left(S\left[\mathrm{~m}^{3} / \mathrm{yr}\right]\right)$ is calculated as a function of the coast angle ( $q$ [degrees]). In UNIBEST-LT the dynamics of the coastline are considered through time. In this module the initial coastline, boundary conditions, sources and sinks, jetties, and revetments are defined. Changes in coast angle cause changes in sediment transport. The sediment transport is calculated using the $S(q)$ curve determined in UNIBEST-CL. UNIBEST-LT is a one-line model. All the horizontal changes are averaged over the active height. The sediment transport formulas of Van Rijn and Bijker (Delft Hydraulics, 1994) have been applied. 
2) To apply the shoreline change model, a sediment budget, including compartment volumes and net sediment flux has been derived for the period 1950s to 1999. This effort has been primarily based on regional bathymetric and topographic change analysis for the inner shelf and coastal barriers, respectively. The active profile depth, or depth of no net bed change, is typically $13 \mathrm{~m} \mathrm{MSL}$ and the total active height ranges between 15-19 $\mathrm{m}$.

3) A preliminary sensitivity analysis has been accomplished to evaluate the relative importance of the following parameters: wave height, wave period, wave direction, wave duration, number of waves, sediment source, depth of closure, boundary conditions, water level, sediment size, fall velocity, current velocity, bottom roughness, and calibration variables in the sediment transport formulas.

4) Simulated shoreline change has been compared to the 1995 shoreline position by means of a RMS error analysis.

5) The time series from the Grays Harbor waverider buoy (41.5 m water depth) from 1994 to 1999 was used to derive a wave climate for most of the model runs. In some cases the time series from the Columbia River buoy (128 $\mathrm{m}$ water depth) was used to fill data gaps from the Grays Harbor buoy. The model wave climatology is based on the approach of Chesher and Miles (1992), where a number of direction bins are defined and a representative wave height is calculated on the basis of the weighting algorithm:

$$
H_{\phi}=\left[\sum\left(f H^{n}\right) / \sum f\right]^{1 / n}
$$

where $H$ is the wave height, $f$ the frequency of occurrence and $n$ the exponent of the wave height in the sand transport formula. In this case $n$ is equal to $5 / 2$. Because sediment transport is more sensitive to higher (storm) waves, two representative wave heights have been derived per bin, one for waves higher than $4.5 \mathrm{~m}$ and one for waves lower than $4.5 \mathrm{~m}$. The entire wave climate is normalized on a one-year basis.

6) The schematized wave climate has been used as input to the SWAN model (Booij et al., 1999). In some cases, linear refraction has been applied rather than SWAN (the SWAN model is still being calibrated by others in the Study - see Palmsten, this volume). The waves have been shoaled and refracted towards a depth where they are imported in UNIBEST at the depth of closure (offshore boundary). The waves are shoaled from this boundary to the shore using linear refraction.

7) An integrated processes and modeling approach has been developed and applied, however additional work is needed in applying coastal currents and the shoreline variability to the shoreline model.

8) A paper on this topic has been submitted to the Proceedings of the 27th International Conference on Coastal Engineering (Kaminsky et al., 2000). Some of the contents of this abstract appear in this proceedings paper. 


\section{QUESTIONS}

1) Can shoreline change be accurately predicted considering the uncertainty of the time scale and spatial distribution of the shoreline response to a change in sediment source?

2) How accurate can wave refraction and shoaling patterns over the ebb-tidal deltas be modeled and how well can we estimate sediment supply and bypassing?

\section{ANALYSIS \\ Modeling Approach}

A principal goal of the Southwest Washington Coastal Erosion Study is the prediction of shoreline change at a scale of decades (temporal) and tens of kilometers (spatial). The intent of this goal is to provide a basis for coastal management decisions that require anticipation of long-term regional scale change for land-use planning and hazard mitigation.

Quantitatively accurate prediction of coastal change is generally regarded as inherently difficult at any scale (de Vriend, 1998). Determining correct process-response relationships is confounded by time-dependent initial conditions, variable sensitivities, time lags, non-linear responses, and variable duration of transient periods between states. Long-term regional scale predictions may also remain elusive due to the fact that natural phenomenon such as the magnitude and frequency of storms, climatic fluctuations, and tectonic events that drive coastal change are stochastic processes, i.e., they depend on random variables that can not be predicted with certainty. However, an integrated multiscale approach to the problem can help determine a range of possible outcomes that may be linked to probabilities or levels of uncertainty.

One of the more difficult aspects of prediction is accurately determining the time scale and spatial distribution of the shoreline response to a change in sediment source. For example, the elimination of sediment supply from the Columbia River would not be expected to have an immediate effect on the shoreline because sediment may be supplied for some time from other available sources such as the ebb-tidal shoals or the lower shoreface. In fact, human interventions (jetties, dams, and dredging) caused changes in sediment distribution and storage patterns that have resulted in a simultaneous reduction in sediment supply from the Columbia River and a rapid advance of the shoreline.

The relationship between shoreline behaviour and shoreface morphodynamics is still a subject of active research and it is presently unclear what combinations of geometric and physical process parameters regulate the potential of the lower shoreface (i.e., deeper than the annual closure depth) as a sediment source to the upper shoreface. Natural sediment supply from the lower shoreface can not be directly measured and must be inferred from long-term bathymetric changes and shoreface behaviour models (Cowell et al., 2000). In most cases, the historical bathymetric data suggest that such cross-shore transfers of sediment are small relative to the survey accuracy, so these data must be used with caution. 
Predictive modeling of shoreline change at scales of decades and tens of kilometers may be most reliable and informative when accomplished within the context of anticipated change at both smaller and larger scales. The fundamental principle applied here is that small scale fluctuations can be aggregated to define larger scale changes, and similarly, these intermediate scale changes may be constrained by factors that influence coastal evolution at an even larger scale. In terms of decadal scale shoreline prediction, a principal objective is to define both regional trends and variability of the shoreline. Geological investigations are used to obtain estimates of larger scale trends in shoreline evolution, and determine the most fundamental basis for large scale coastal behaviour. Figure 1 depicts three major coastal system scales relevant to predicting management scale coastal change.

Within the context of research results over these three major time scales of morphological change, a suite of analyses and models are systematically employed to predict shoreline change at decadal scale (Figure 2). The analyses of morphodynamic constituents such as waves, currents, bathymetry, topography, and sediment characteristics yield fundamental outputs such as the sediment budget and shoreline variability that must be used to inform and constrain the shoreline change model. Similarly, specific models that represent the fluid forcing acting on the coastal planform must also be used as the process drivers of the shoreline change model. The shoreline change model itself integrates the transfer functions between fluid motion and seabed to drive both sediment transport and resulting shoreline position. Both the sediment budget and the spatial and temporal variability of the shoreline are used in iteration with the model results.

The modeling tools applied in this study include the process-based shoreline change model, UNIBEST and the wave propagation model, SWAN (Delft University of Technology). In addition, results of the hydrodynamic model ADCIRC (Luettich et al., 1992) provided by the U.S. Army Corps of Engineers were used to represent the tidal forcing. The UNIBEST (Uniform Beach Sediment Transport) model incorporates the initial shoreline position, waves, beach profiles, sediment grain size, tidal currents, and sediment volume flux to calculate longshore sediment transport and shoreline change. The SWAN (Simulating Waves Nearshore) model is used to estimate wave conditions in shallow water coastal regions with barrier islands, tidal flats, local wind and ambient currents. ADCIRC (ADvanced CIRCulation) is a long-wave hydrodynamic model applied for simulating water surface elevation and vertically averaged circulation (2DH).

\section{Model Results}

Model calibrations and predictions are presented here for the Long Beach and North Beach sub-cells. The results of these preliminary predictions apply to the period 1995 to 2020. Shoreline variability has not been included, as the intent here is to present only order of magnitude estimates of shoreline change based on a preliminary range of sediment budget scenarios. Predicted shoreline positions vary more given the potential range of possible sediment budget values than they do given the potential range in shoreline variability. The shoreline change modeling of the Grayland Plains and Clatsop Plains is in its initial stages and is only briefly discussed herein. 


\section{Long Beach}

The model calibration of Long Beach for the period 1955 to 1995 is shown in Figure 3a. The cross-shore feeding from the shoreface was equal to $1.1 \mathrm{Mm}^{3} / \mathrm{yr}$, distributed along the 35-km length of the modeled shoreline. The littoral supply entering the southern boundary was $2.7 \mathrm{Mm}^{3} / \mathrm{yr}$ and the output in the north was $1.4 \mathrm{Mm}^{3} / \mathrm{yr}$, including $0.3 \mathrm{Mm}^{3} / \mathrm{yr}$ representing the spit accumulation at Leadbetter Point that was not included in the modeled shoreline. The Long Beach barrier excluding Leadbetter Point accumulated $2.3 \mathrm{Mm}^{3} / \mathrm{yr}$ during this period.

The Long Beach model prediction for 1995 to 2020 is shown in Figure 3b. The crossshore feeding remained the same as in the model calibration but the input in the south decreased to $1.3 \mathrm{Mm}^{3} / \mathrm{yr}$ and the output in the north decreased to $1.0 \mathrm{Mm}^{3} / \mathrm{yr}$, including $0.2 \mathrm{Mm}^{3} / \mathrm{yr}$ accumulation of Leadbetter Point. This scenario resulted in shoreline retreat within $5 \mathrm{~km}$ north of North Head (located $4 \mathrm{~km}$ north of the Columbia River entrance) by up to $200 \mathrm{~m}$. The shoreline along the northern part of Long Beach advanced by as much as $150 \mathrm{~m}$, partially attributed to the lower calculated alongshore sediment transport of 1.0 $\mathrm{Mm}^{3} / \mathrm{yr}$ just south of Leadbetter Point. These results suggest a regional trend of shoreline rotation occurring over the next two decades.

\section{North Beach}

In the North Beach sub-cell, the shoreline model was calibrated based on the sediment budget shown in Figure $4 \mathrm{a}$ over the southern $22 \mathrm{~km}$ of the sub-cell. The historical shoreline changes of the remaining northern $20 \mathrm{~km}$ of the sub-cell were minor over this period so this shoreline reach was excluded from the model calibration. However, it was assumed that $0.1 \mathrm{Mm}^{3} / \mathrm{yr}$ could disperse northward to account for modern trends of beach accumulation along this northern reach.

The model calibration of North Beach for the period 1950 to 1995 is shown in Figure 4a. The input consists of cross-shore sediment supply of $0.3 \mathrm{Mm}^{3} / \mathrm{yr}$ from the shoreface evenly distributed over the southern $11 \mathrm{~km}$, based on the shoreface morphology and sand distribution along the North Beach shelf. The littoral feeding of $1.0 \mathrm{Mm}^{3} / \mathrm{yr}$ from the delta/inlet/bypassing was evenly distributed over the southern $8 \mathrm{~km}$ based on the morphology of the ebb-shoal and shoreline configuration.

A North Beach model prediction for 1995 to 2020 is shown in Figure 4b. During this period the cross-shore feeding remained constant but the feeding from the delta/inlet/ bypassing was reduced to $0.4 \mathrm{Mm}^{3} / \mathrm{yr}$. The results show slight shoreline retreat directly north of the Grays Harbor North Jetty and up to $80 \mathrm{~m}$ of shoreline advance approximately $15 \mathrm{~km}$ north of the jetty. These results suggest a regional adjustment of the shoreline towards a more flattened curvature over the next two decades. Other calibrated model runs with sediment supply from the south lower than $1.0 \mathrm{Mm}^{3} / \mathrm{yr}$ suggest greater shoreline retreat near the jetty.

In another case shown in Figure 5, it is assumed there is no feeding from the ebb-tidal delta (i.e., either direct supply or bypassing) after 1995. Assuming continued feeding 
from the shoreface results in a minimum shoreline retreat of $85 \mathrm{~m}$ at the North Jetty. With no shoreface supply of sand, shoreline recession is even greater.

\section{Grayland Plains}

In the Grayland sub-cell (length $18 \mathrm{~km}$ ) minor net beach accretion of $3 \mathrm{Mm}^{3}$ occurred between 1951 and 1974, while Grayland accreted 17 million $\mathrm{m}^{3}$ between 1974 and 1995 . Model results indicate net southerly sediment transport along Grayland on the order of $300,000 \mathrm{~m}^{3} / \mathrm{yr}$, which is small relative to the gross transports. Shoreline data indicates southerly transport, but not along the whole sub-cell. South of the South Jetty, the shoreline area rapidly eroded between 1950 and 1995, while deposition occurred farther south, shown in Figure 6. Central Grayland, south of this area of erosion and deposition remained fairly stable. The southern part of Grayland accreted between 1951 and 1995, mostly because of the northerly advance of the Willapa Bay ebb-tidal delta south of Grayland. Assuming no sediment feeding after 1995 at the northern boundary and 0.5 million $\mathrm{m}^{3} / \mathrm{yr}$ net loss at the southern boundary results in a maximum shoreline retreat of about $150 \mathrm{~m}$ at the Grays Harbor South Jetty to 2020. A gradual shoreline rotation along the southern $10-\mathrm{km}$ of the sub-cell within this period achieves a maximum advance of 40 $\mathrm{m}$ near the northward migrating Willapa Bay entrance.

\section{Clatsop Plains}

The UNIBEST runs with linearly shoaled waves performed for Clatsop were not satisfactory and are not presented here. Following jetty construction Clatsop spit accreted and became supratidal. Between 1926 and 1950 the shoreline along Clatsop Spit retreated, while southern Clatsop Plains accreted, indicating southerly transport of sand. After the 1950s the northern shoreline stabilized while the shoreline in the south continued to advance, but at a slower pace. Figure 7 shows shoreline change at Clatsop between $1868 / 74$ and 1995. No major changes in regional shoreline orientation are expected in the near future. Moderate to low net shoreline recession or stability is anticipated in the future decades.

\section{ACKNOWLEDGEMENTS}

The authors appreciate the data contributions made by many study investigators. Mary Cialone of the USACE provided ADCIRC model results. Eric Nelson and Rod Moritz of the USACE provided bathymetric data.

\section{REFERENCES}

Booij, N., Ris, R.C., and Holthuijsen, L.H. 1999. A third-generation model for coastal regions, 1. Model description and validation, Journal of Geophysical Research 104 (C4), pp. 7649-7666.

Cheser, T.J., and Miles, G.V. 1992. The concept of a single representative wave, in: R.A. Falconer, S.N. Chandler-Wilde and S.Q. Liu (Editors), Hydraulic and Environmental Modelling; Coastal Waters, Ashgate Brookfield, VT, pp. 371-380. 
Cowell, P.J., Stive, M.J.F., Roy, P.S., Kaminsky, G.M., Buijsman, M.C., Thom, B.G., and Wright, L.D. 2000. Shoreface sand supply to beaches, Proceedings of the 27th International Conference on Coastal Engineering, pp. 2495-2508.

Delft Hydraulics 1994. UNIBEST, A software suite for the simulation of sediment transport processes and related morphodynamics of beach profiles and coastline evolution, Delft Hydraulics, Delft, The Netherlands.

de Vriend, H.J. 1998. Large-scale coastal morphological predictions: a matter of upscaling?, Proceedings of the 3rd International Conference on Hydro Science and Engineering, Cottbus/Berlin, Germany, paper on CD-ROM (Cyber Proceedings), ISBN 0-937099-09-0.

Kaminsky, G.M., Buijsman, M.C., and Ruggiero, P. 2000. Predicting shoreline change at decadal scale in the Pacific Northwest, USA, Proceedings of the 27th International Conference on Coastal Engineering, Sydney, Australia, pp. 2400-2413.

Kaminsky, G.M., Buijsman, M.C., Ruggiero, P., and Gelfenbaum, G. this volume. An integrated contemporary sediment budget for the Columbia River littoral cell, Southwest Washington Coastal Erosion Workshop Report 2000, U.S. Geological Survey Open-File Report.

Luettich, R.A., Westerink, J.J., and Scheffner, N.W. 1992. ADCIRC: An advanced threedimensional circulation model for shelves, coasts, and estuaries; Report 1, Theory and methodology of ADCIRC-2DDI and ADCIRC-3DL, Technical Report DRP92-6, U.S. Army Engineer Waterways Experiment Station, Vicksburg, MS, USA. 


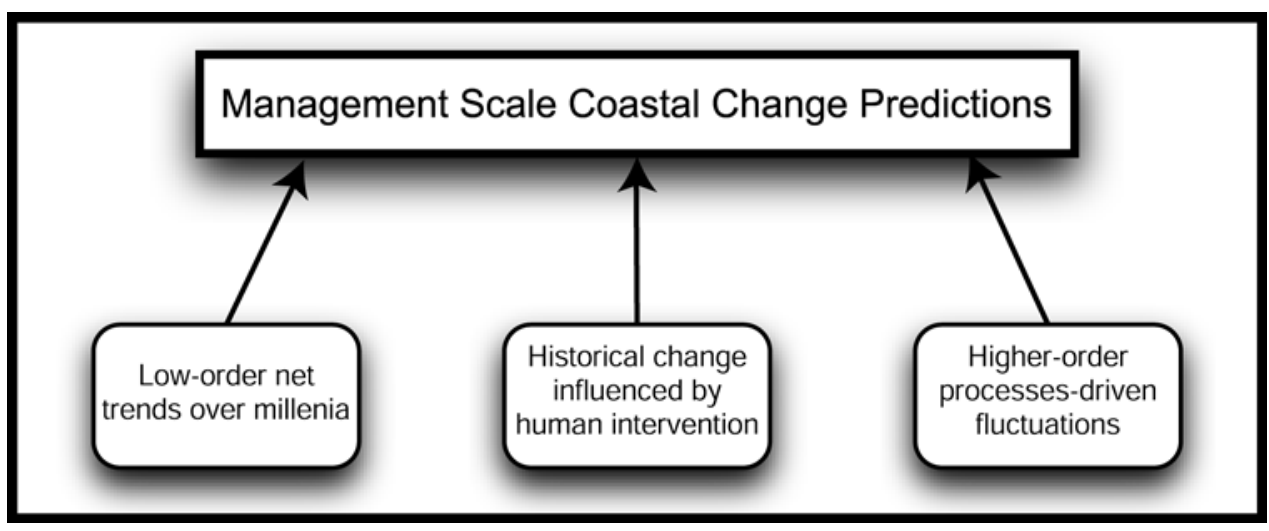

Figure 1. Schematic representation of the SWCES approach to develop predictive models of the Columbia River littoral cell. The trends, patterns, and variability of coastal change are determined based on the combined influences of: a) the inherited geological framework and processes that govern long-term trends; b) century-scale perturbations (often humaninduced) that affect regional changes in coastal configuration; and c) interannual-scale morphodynamic behaviour driven by short-term, small-scale processes.

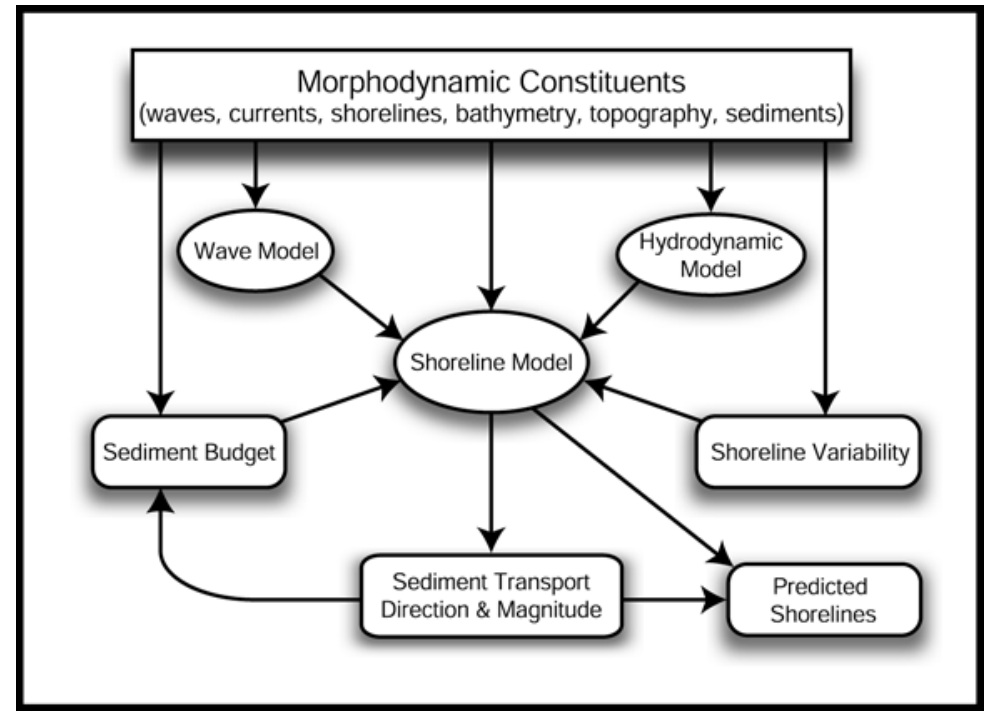

Figure 2. Integrated analyses and modeling approach to predict shoreline change. 

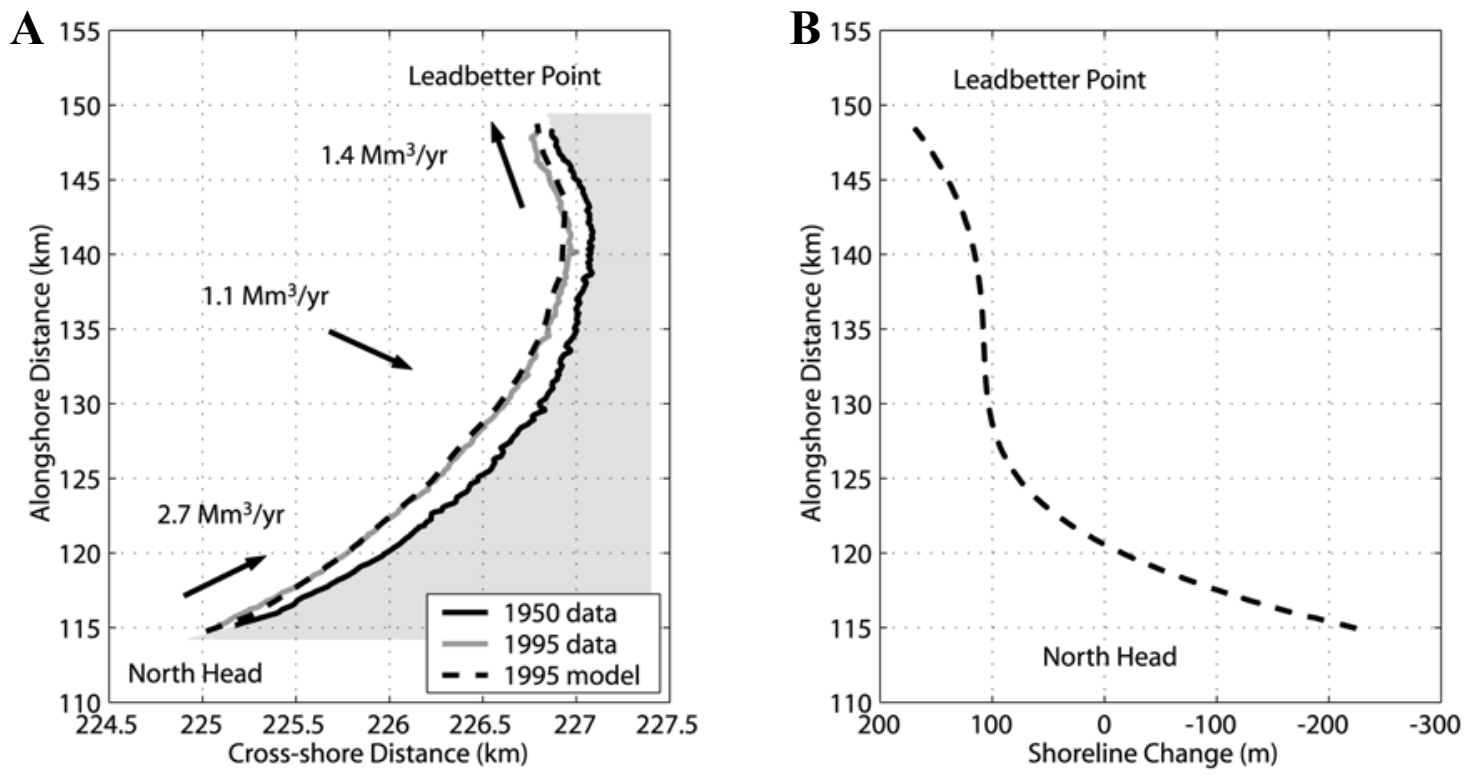

Figure 3. a) Long Beach model calibration based on sediment budget shown (Kaminsky et al., this volume). RMS error is 17 percent of the average observed change. b) 2020 shoreline change prediction relative to the 1995 shoreline position and based on a sediment supply at the southern boundary of $1.3 \mathrm{Mm}^{3} / \mathrm{yr}$, shoreface supply of $1.1 \mathrm{Mm} / \mathrm{yr}$, and 1.0 $\mathrm{Mm}^{3} / \mathrm{yr}$ exiting at the northern boundary. 

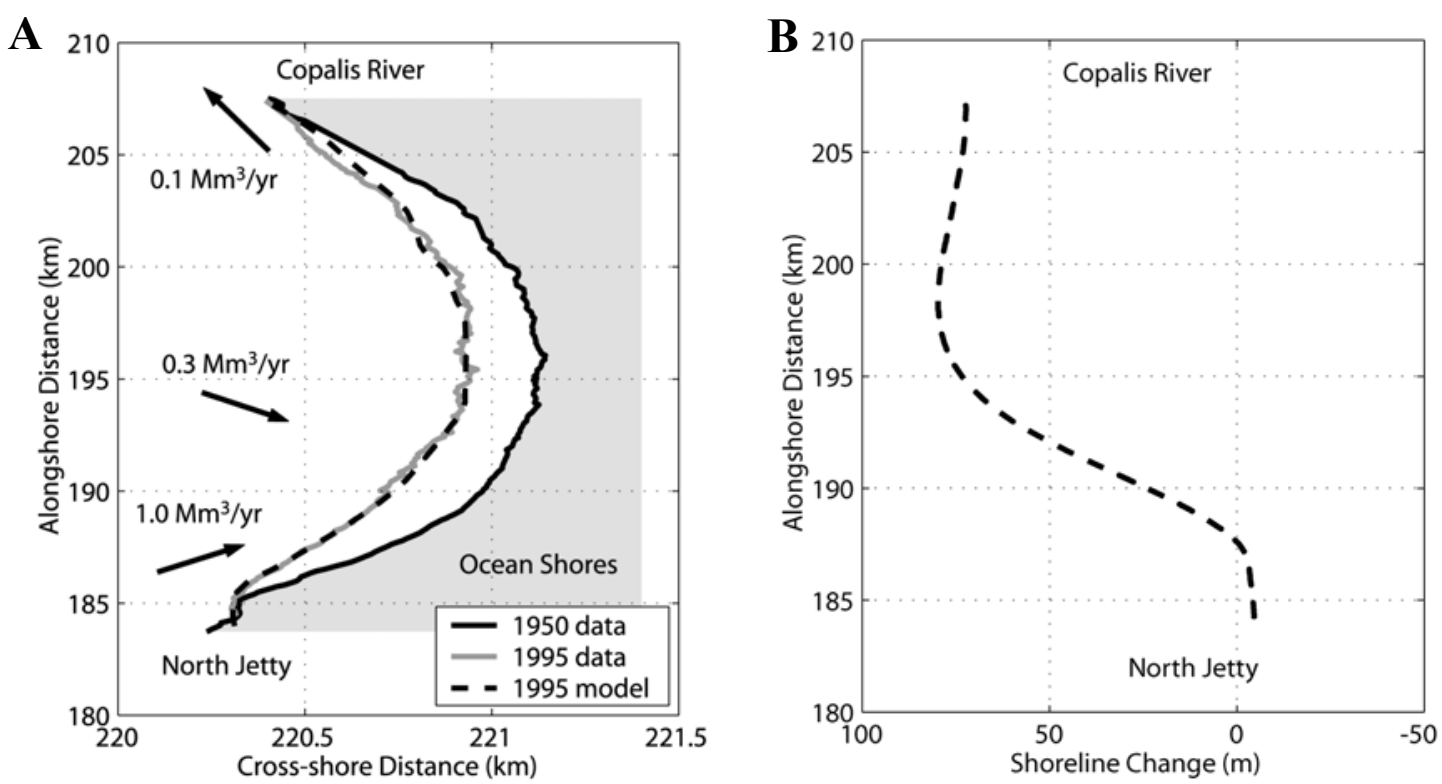

Figure 4. a) North Beach model calibration based on the sediment budget shown (Kaminsky et al., this volume). RMS error is 12 percent of the average observed change. b) 2020 shoreline change prediction relative to the 1995 shoreline position and based on $0.4 \mathrm{Mm} / \mathrm{yr}$ sediment supply at the southern boundary, $0.3 \mathrm{Mm}^{3} / \mathrm{yr}$ shoreface supply.

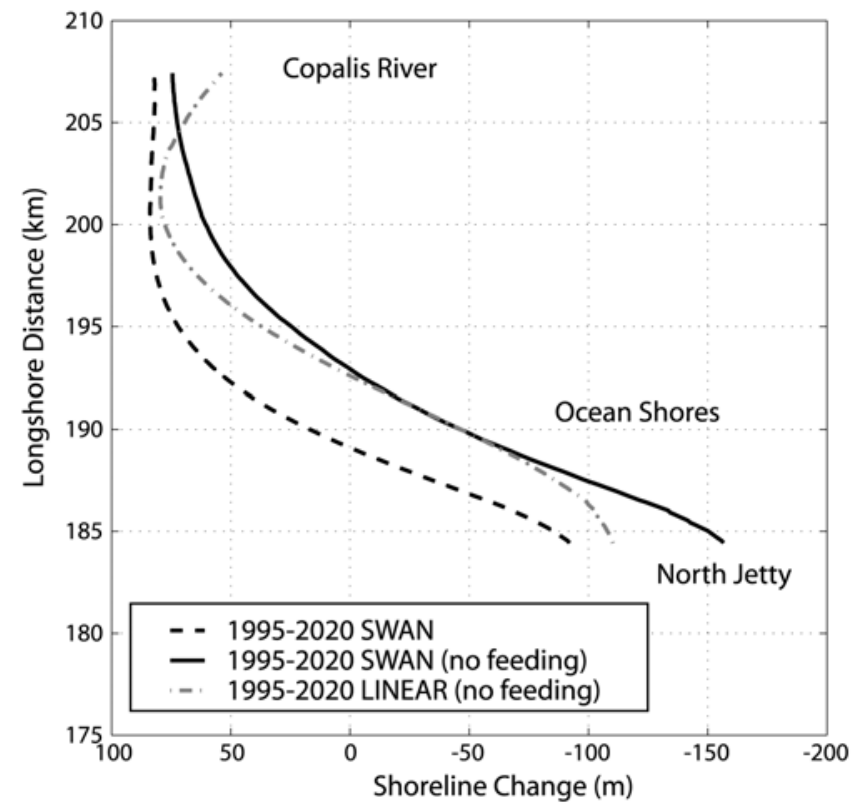

Figure 5. Future shoreline change in North Beach with no supply at the southern boundary. A minimum shoreline retreat of $85 \mathrm{~m}$ at the North Jetty is predicted. 


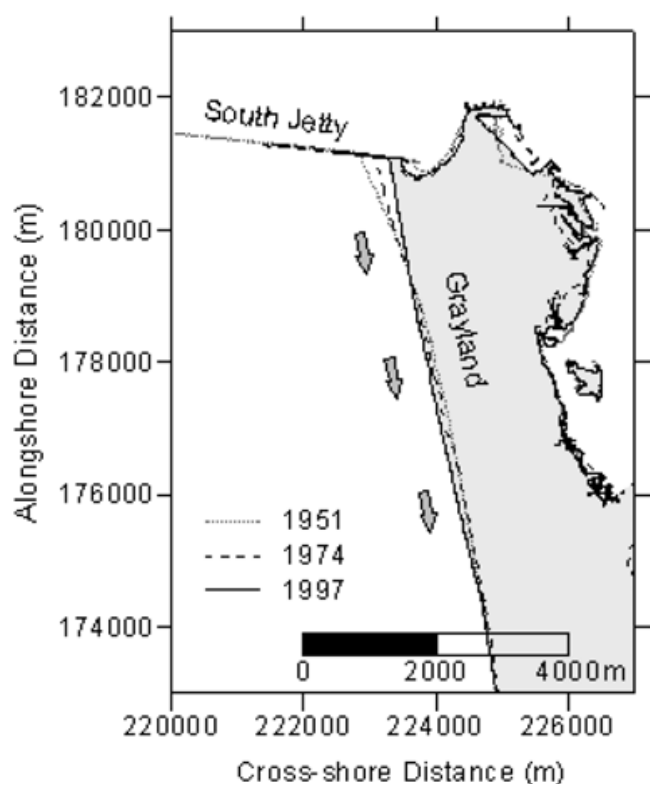

Figure 6. Shoreline change and net sediment transport along the northern Grayland Plains.

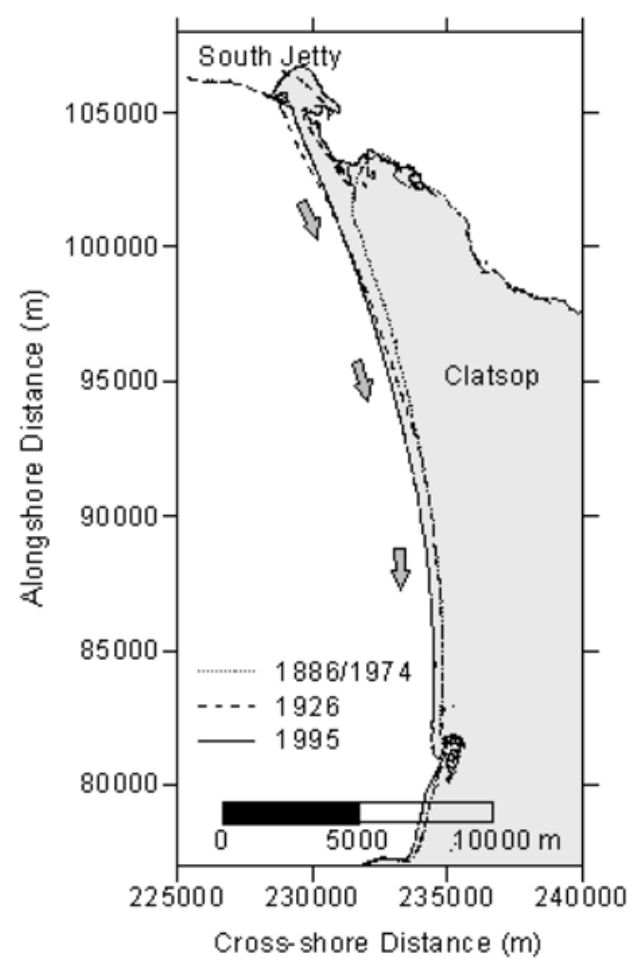

Figure 7. Regional shoreline change and direction of net sediment transport along the shoreline of Clatsop Plains. 


\title{
HISTORICAL SHORELINE CHANGE RATES FOR THE COLUMBIA RIVER LITTORAL CELL
}

Richard C. Daniels, Washington Department of Ecology

Diana McCandless, Washington Department of Ecology

Robert H. Huxford, Washington Department of Natural Resources

\begin{abstract}
ANALYSIS
A chronological set of historical shoreline positions have been compiled for the Columbia River littoral cell (CRLC) by the Washington Department of Ecology (Ecology) in support of the Southwest Washington Coastal Erosion Study. The shoreline positions were derived for the CRLC from historical maps and charts, air photo mosaics, orthophotography, and Light Detection and Ranging data (LIDAR). These data were used to calculate shoreline change rates for the entire littoral cell. This paper presents these change rates at 1-kilometer intervals for the period 1870 through 1999.

The Southwest Washington Coastal Erosion Study is an integrated research project funded and coordinated by Ecology and the U.S. Geological Survey (USGS) Coastal and Marine Geology Program to study coastal processes within the CRLC (Kaminsky et al., 1997, Kaminsky et al., 1999). The CRLC extends 32-km south from the mouth of the Columbia River to Tillamook Head, Oregon and northward 132-km to Point Grenville, Washington (Figure 1).
\end{abstract}

\section{SHORELINE DATA}

This assessment required the collection and detailed analysis of shoreline position data from the last century. As such, Ecology has been instrumental in digitizing and compiling shorelines for Washington and the northwest coast of Oregon. Shorelines prior to 1960 were digitized by Ecology from National Ocean Service (NOS) Topographic Sheets (Tsheets) or U.S. Army Air Corps mosaics (Daniels and Huxford, 2001). Shorelines for periods between 1960 and 1999 were digitized from orthorectified aerial photography (Kaminsky et al., 1999). In addition, shorelines for 1997 and 1998 were derived from LIDAR data collected by the Airborne LIDAR Assessment of Coastal Erosion (ALACE) Project (Sallenger et al., 1999).

The term shoreline as used here refers to the average high water line (AHWL) as determined by physical cues and as seen on the ground or in aerial photography. Specifically, in the Pacific Northwest where there are two high tides a day the location of the AHWL would be between the higher high tide line and the last lower high tide. In practice this line is taken to be between the current dewatering line, assuming the photographs were not taken during higher high tide, and the drift or rack line formed by the last higher high tide. A review of available literature (Ellis, 1978; Shalowitz, 1964) indicates that the mean high water line (MHW) as depicted on NOS T-sheets utilized 
similar cues and that the NOS MHW line is comparable to AHWLs digitized from orthophotography.

A digitization repeatability experiment was carried out to determine the ability of the analysts to reproduce the interpreted AHWL from orthophotography. In the experiment two analysts were asked to repeatedly digitize the AHWL from six orthorectified photographs, presented in random order, at three different sessions. To minimize the ability of the analysts to remember what they had digitized in the past, the analysts was required to wait 24 hours between digitizing sessions. The experiment obtained a within analyst mean difference between the location of the AHWL of $0.22 \mathrm{~m}$ with a standard deviation of $5.22 \mathrm{~m}$ over the $18 \mathrm{~km}$ of AHWL digitized. The between analyst mean difference in the location of the AHWL was $12.44 \mathrm{~m}$ with a standard deviation of $8.76 \mathrm{~m}$. The second analyst digitized the AHWL consistently $10 \mathrm{~m}$ further seaward than the first; this indicates that the differences between the two analysts may be reduced with further training to about $5 \mathrm{~m}$ (Daniels et al., 2000).

The experiment described above demonstrated that the AHWL, as digitized from orthophotography, and by extension from NOS T-sheets, would be within $10 \mathrm{~m}$ of the true location on the ground at the time of survey. This qualification is important, as the location of the AHWL migrates daily based on wave and tide levels. On the high energy coasts of the Pacific Northwest it has been shown that the AHWL can migrate by as much as 50 to $100 \mathrm{~m}$ between summer and winter (Komar 1997). To minimize the effects of seasonal changes in the AHWL a majority of the data selected for inclusion in this study (except for a few of the 1870 era T-sheets) were collected between April and September.

\section{Shoreline Uncertainty}

Tables 1 and 2 were developed to show the relative accuracy of each shoreline data set based on the accuracy assessments described above and additional analyses conducted for the NOS T-sheets (Daniels and Huxford, 2001) and LIDAR data (Daniels, 2001). These data were used to calculate the extreme bound of possible uncertainty as well as the root mean square (RMS) uncertainty for each shoreline. Note that the term uncertainty as used here includes both "error" in the traditional sense (e.g., from registration or digitizer error) as well as an estimate of the variability of the shoreline from short-term variations in water levels (i.e., daily to monthly). As such, the uncertainty value shown here should be seen as a conservative estimate of the "error" associated with each shoreline position.

The uncertainty values shown in Tables 1 and 2 may be used to determine the critical rate of change that must occur between two different shorelines for the change to be significant.

The uncertainty values are seen as additive between any two shorelines being compared. However, the uncertainty is averaged over the time period between the two shorelines. For example, in Oregon the 1926 and 1942 AHWL had a RMS of $16.0 \mathrm{~m}$ and $18.8 \mathrm{~m}$, respectively, for a maximum uncertainty of $34.8 \mathrm{~m}$ or $2.16 \mathrm{~m} / \mathrm{yr}$ and a RMS uncertainty of $24.7 \mathrm{~m}$ or $1.53 \mathrm{~m} / \mathrm{yr}$. Thus, the shoreline change rate in Oregon between the 1926 and 1942 AHWL must be larger than $\pm 1.53 \mathrm{~m} / \mathrm{yr}$ (i.e., larger than the RMS) to be significant. 


\section{Shoreline Change}

The CRLC has been accreting throughout most of its $165-\mathrm{km}$ length for the last several thousand years. To describe how the shoreline has changed through historic times (1870 to present), change rates have been calculated for each $100-\mathrm{m}$ section of the coast based on the methods described in Daniels (2001) and Daniels and Huxford (1998). For this paper, 141 transects were taken at one kilometer intervals along the 1995 shoreline. These transects were drawn perpendicular to the coastline as of 1995 (i.e., shore-normal) and overlayed onto the data sets containing the change rate data to extract the change rates. Rates were obtained for each transect, for each time period analyzed, and are shown in Tables 3 through 7 .

The CRLC has four major concave-shaped, offset sections of shoreline separated by the Columbia River and two large estuaries, Willapa Bay and Grays Harbor. These estuaries divide the region into four distinct sub-cells, Clatsop Plains (Figure 2), Long Beach (Figure 3), Grayland Plains (Figure 4), and North Beach (Figure 5). Tables 3 through 6 present the change rates for each of these sub-cells. Table 7 contains the bulk (minimum, mean, and maximum) change rates for each sub-cell for each time period analyzed. Figure 6 shows the long-term historical change rate for each transect.

\section{REFERENCES}

Daniels, R.C. 2001. Calculating coastal change rates for northwest Oregon and southwest Washington, Proceedings of the 2nd Biennial GeoTools Conference, Charleston, $\mathrm{SC}$, Abstract on CD-ROM.

Daniels, R.C. 2001. Datum conversion issues with LIDAR spot elevation data, Photogrammetric Engineering \& Remote Sensing, Vol. 67, No. 6, pp. 735-740.

Daniels, R.C. and Huxford, R.H. 2001. An error assessment of vector data derived from scanned National Ocean Service Topographic Sheets, Journal of Coastal Research, vol. 17, no. 3, pp. 611-619.

Daniels, R.C., Huxford, R.H., and McCandless, D. 1998. Coastline mapping and identification of erosion hazard areas in Pacific County, Washington, ESRI 1998 User Conference, San Diego, CA.Daniels, R.C., P. Ruggiero, and D. McCandless 2000. Interpretation of the average high water line from air photography: variability and repeatability, Southwest Washington Coastal Erosion Workshop Report 1999, U.S. Geological Survey Open-File Report 00-439.

Ellis, M.Y. 1978. Coastal Mapping Handbook, U.S. Department of Commerce, National Ocean Service.

Kaminsky, G.M., Daniels, R.C., Huxford, R., McCandless, D., and Ruggiero, P. 1999. Mapping erosion hazard areas in Pacific County, Washington, Journal of Coastal Research, Special Issue \#28, pp. 158-170. 
Kaminsky, G.M., Ruggiero, P., Gelfenbaum, G., and Peterson, C. 1997. Long-term coastal evolution and regional dynamics of US Pacific Northwest littoral cell, Proceedings of Coastal Dynamics '97, ASCE, pp. 614-623.

Komar, P.D. 1997. The Pacific Northwest: Living with the Shores of Oregon and Washington, Duke University Press, Durham, NC.

Sallenger, A.H., Krabill, W., Brock, J., Swift, R., Jansen, M., Manizade, S., Richmond, B., Hampton, M., Eslinger, D. 1999. Airborne laser study quantifies El Niño-induced coastal change. EOS, Trans. Am. Geophysical Union, 80 (8), pp. 89, $92-93$.

Shalowitz, A.L. 1964. Shore and Sea Boundaries, Volume 2, U.S. Department of Commerce, Coast and Geodetic Survey, Washington, DC.

Table 1. Shoreline accuracy assessment for historical average high water lines collected for the Washington portion of the Columbia River littoral cell (values in meters).

\begin{tabular}{|c|c|c|c|c|c|c|}
\hline \multicolumn{7}{|c|}{ Washington } \\
\hline $\begin{array}{l}\text { Decimal } \\
\text { Year }\end{array}$ & $\begin{array}{l}\text { Shoreline } \\
\text { Source }\end{array}$ & $\begin{array}{l}\text { Shoreline } \\
\text { Repeatability }\end{array}$ & $\begin{array}{l}\text { Shoreline } \\
\text { Variability }\end{array}$ & $\begin{array}{l}\text { Source } \\
\text { Accuracy }\end{array}$ & $\begin{array}{l}\text { Maximum } \\
\text { Error }\end{array}$ & $\begin{array}{l}\text { RMS } \\
\text { Error }\end{array}$ \\
\hline 1999.3 & 3 Ortho & 5 & 13 & 3 & 21 & $\overline{14.2}$ \\
\hline 1998.2 & 5 Lidar & 2.5 & 12 & 1.5 & 16 & 12.3 \\
\hline 1997.5 & 8 Lidar & 2.5 & 16.2 & 1.5 & 20.2 & 16.5 \\
\hline 1995.6 & 7 Ortho & 5 & 17.6 & 3 & 25.6 & 18.5 \\
\hline 1988.5 & 0 Ortho (Long Beach) & 5 & 15 & 3 & 23 & 16.1 \\
\hline 1987.4 & $\begin{array}{l}2 \text { Ortho (Grayland \& North } \\
\text { Beach) }\end{array}$ & 3 & 14 & 3 & 20 & 14.6 \\
\hline 1986.3 & 3 Ortho (Leadbetter Point) & 3 & 13 & 3 & 19 & 13.7 \\
\hline 1974.4 & 2 Ortho & 5 & 14 & 3 & 22 & 15.2 \\
\hline 1957.5 & 8 Ortho (Long Beach) & 5 & 16.2 & 4 & 25.2 & 17.4 \\
\hline 1953.4 & 2 T-Sheet & 5 & 14 & 6 & 25 & 16.0 \\
\hline 1942.5 & 0 Mosaic & 5 & 15 & 10.16 & 30.16 & 18.8 \\
\hline 1926.58 & 8 T-Sheet & 5 & 16.2 & 6 & 27.2 & 18.0 \\
\hline 1886.8 & 3 T-Sheet & 5 & 20 & 12 & 37 & 23.9 \\
\hline 1868.8 & 3 T-Sheet & 5 & 20 & 12 & 37 & 23.9 \\
\hline
\end{tabular}


Table 2. Shoreline accuracy assessment for historical average high water lines collected for the Oregon portion of the Columbia River littoral cell (values in meters).

\begin{tabular}{|c|c|c|c|c|c|c|}
\hline $\begin{array}{l}\text { Oregon } \\
\text { Decimal } \\
\text { Year }\end{array}$ & $\begin{array}{l}\text { Shoreline } \\
\text { Source }\end{array}$ & $\begin{array}{l}\text { Shoreline } \\
\text { Repeatability }\end{array}$ & $\begin{array}{l}\text { Shoreline } \\
\text { Variability }\end{array}$ & $\begin{array}{l}\text { Source } \\
\text { Accuracy }\end{array}$ & $\begin{array}{l}\text { Maximum } \\
\text { Error }\end{array}$ & $\begin{array}{l}\text { RMS } \\
\text { Error }\end{array}$ \\
\hline 1999.33 & 3 Ortho & 5 & 13 & 3 & 21 & $\overline{14.2}$ \\
\hline 1998.25 & 5 Lidar & 2.5 & 12 & 1.5 & 16 & 12.3 \\
\hline 1997.58 & 3 Lidar & 2.5 & 16.2 & 1.5 & 20.2 & 16.5 \\
\hline 1995.42 & Ortho & 5 & 14 & 3 & 22 & 15.2 \\
\hline 1986.58 & 3 Ortho (Jetty) & 5 & 16.2 & 3 & 24.2 & 17.2 \\
\hline 1986.42 & Ortho & 5 & 14 & 3 & 22 & 15.2 \\
\hline 1973.75 & Ortho & 5 & 17.6 & 3 & 25.6 & 18.5 \\
\hline 1957.00 & T-Sheet & 5 & 22 & 6 & 33 & 23.3 \\
\hline 1955.42 & T-Sheet (North Jetty) & 5 & 14 & 6 & 25 & 16.0 \\
\hline 1948.92 & T-Sheet (south) & 5 & 22 & 6 & 33 & 23.3 \\
\hline 1942.50 & Mosaic & 5 & 15 & 10.16 & 30.16 & 18.8 \\
\hline 1926.42 & T-Sheet & 5 & 14 & 6 & 25 & 16.0 \\
\hline 1874.42 & T-Sheet & 5 & 14 & 12 & 31 & 19.1 \\
\hline 1868.83 & 3 T-Sheet (South Jetty) & 5 & 20 & 12 & 37 & 23.9 \\
\hline
\end{tabular}


Table 3. Historical shoreline change rates for the Clatsop Plains sub-cell (values in meters per year). Values are considered significant if they are greater (or less than) the critical rate shown in the table.

\begin{tabular}{|c|c|c|c|c|c|c|c|c|}
\hline Transect & & & $\begin{array}{l}1926 \text { to } \\
1942\end{array}$ & $\begin{array}{l}1942 \text { to } \\
1973\end{array}$ & $\begin{array}{l}1973 \text { to } \\
1986\end{array}$ & $\begin{array}{l}1986 \text { to } \\
1995\end{array}$ & $\begin{array}{l}1995 \text { to } \\
1999\end{array}$ & $\begin{array}{l}187 x \text { to } \\
1998 \\
\end{array}$ \\
\hline & 1 & 0.01 & 0.00 & 0.00 & 0.00 & 0.01 & 0.00 & 0.00 \\
\hline & 2 & -0.04 & 0.00 & 0.00 & 0.97 & 0.09 & -1.46 & 0.02 \\
\hline & 3 & 0.38 & 4.28 & 0.97 & -0.90 & 10.49 & -16.66 & 1.07 \\
\hline & 4 & -0.29 & 7.17 & 0.88 & -2.40 & 12.14 & -16.70 & 1.20 \\
\hline & 5 & -1.04 & 10.86 & 0.54 & -2.97 & 0.30 & 7.72 & 1.08 \\
\hline & 6 & -1.31 & 7.06 & 0.57 & 1.61 & -1.97 & 2.56 & 2.47 \\
\hline & 7 & -0.49 & 8.43 & 1.82 & 1.67 & 6.94 & -10.65 & 1.90 \\
\hline & 8 & -0.63 & 10.12 & 1.69 & 0.50 & 5.90 & -7.07 & 1.94 \\
\hline & 9 & -0.45 & 10.26 & 1.98 & 0.73 & 7.10 & -9.69 & 2.06 \\
\hline & 10 & 0.01 & 11.37 & 2.14 & 1.00 & 4.19 & -3.37 & 2.46 \\
\hline & 11 & 0.04 & 12.45 & 1.89 & 1.58 & 5.27 & -4.75 & 2.56 \\
\hline & 12 & 0.14 & 12.23 & 2.46 & 1.19 & 5.68 & -3.17 & 2.71 \\
\hline & 13 & 0.32 & 10.33 & 3.85 & 0.15 & 5.84 & -5.15 & 2.84 \\
\hline & 14 & 0.50 & 10.96 & 3.37 & 0.21 & 7.11 & -6.33 & 2.95 \\
\hline & 15 & 0.19 & 13.72 & 2.97 & -0.51 & 5.63 & -5.77 & 2.90 \\
\hline & 16 & -0.09 & 15.66 & 2.93 & -0.12 & 5.24 & -6.53 & 2.93 \\
\hline & 17 & 0.11 & 17.81 & 2.42 & -0.26 & 4.62 & -7.66 & 3.24 \\
\hline & 18 & 1.37 & 13.75 & 3.24 & -1.08 & 5.65 & -6.46 & 3.54 \\
\hline & 19 & 3.08 & 11.72 & 2.71 & -1.05 & 4.98 & -4.37 & 3.71 \\
\hline & 20 & 5.02 & 5.68 & 4.23 & -0.28 & 3.21 & -1.71 & 4.03 \\
\hline & 21 & 6.03 & 5.15 & 1.68 & 2.13 & 1.43 & -5.02 & 3.99 \\
\hline & 22 & 7.15 & 2.93 & 1.84 & 2.41 & -0.64 & -1.30 & 4.35 \\
\hline & 23 & 7.81 & 7.07 & -0.11 & 0.51 & 0.83 & -2.43 & 4.39 \\
\hline & 24 & 8.52 & 5.46 & -1.71 & 0.32 & 1.58 & -2.39 & 4.20 \\
\hline 2 & 25 & 10.06 & 4.60 & -2.43 & 1.08 & 1.56 & -6.61 & 4.63 \\
\hline 2 & 26 & 11.72 & -0.44 & -1.73 & -1.43 & 2.92 & -7.31 & 4.74 \\
\hline 2 & 27 & 4.18 & -2.50 & -1.29 & -2.69 & 2.52 & -2.76 & 7.88 \\
\hline 2 & 28 & 20.79 & -7.79 & -1.03 & -4.25 & 0.48 & -1.45 & 13.02 \\
\hline & 29 & 37.76 & -12.12 & -21.37 & 1.23 & -0.21 & 3.42 & 19.05 \\
\hline CR Jetty 3 & & 51.16 & -13.15 & -0.95 & -7.88 & -1.74 & -2.35 & No Data \\
\hline & 31 & 74.42 & -12.64 & 26.24 & 2.26 & -33.10 & 28.05 & No Data \\
\hline & 32 & 57.79 & -2.82 & 24.62 & -1.08 & -2.67 & -12.46 & No Data \\
\hline $\begin{array}{l}\text { Critical } \\
\text { Rate }\end{array}$ & & \pm 1.14 & \pm 2.16 & \pm 1.19 & \pm 2.64 & \pm 3.66 & \pm 7.52 & \pm 0.32 \\
\hline
\end{tabular}


Table 4. Historical shoreline change rates for the Long Beach sub-cell (values in meters per year). Values are considered significant if they are greater (or less than) the critical rate shown in the table.

\begin{tabular}{|c|c|c|c|c|c|c|c|}
\hline Transect & $\begin{array}{l}187 x \text { to } \\
192 X\end{array}$ & $\begin{array}{l}192 X \text { to } \\
195 X\end{array}$ & $\begin{array}{l}195 X \text { to } \\
1974 \\
\end{array}$ & $\begin{array}{l}1974 \text { to } \\
198 X \\
\end{array}$ & $\begin{array}{l}198 X \text { to } \\
1995 \\
\end{array}$ & $\begin{array}{l}1995 \text { to } \\
1999 \\
\end{array}$ & $\begin{array}{l}187 x \text { to } \\
1998 \\
\end{array}$ \\
\hline CR Jetty 33 & 40.48 & -2.26 & -2.48 & -2.54 & 0.83 & -1.09 & 16.46 \\
\hline 34 & 24.45 & 13.09 & -12.72 & -5.35 & -18.83 & -16.06 & 9.34 \\
\hline 35 & 5.16 & 21.78 & -4.42 & -6.67 & 3.19 & -19.02 & 4.14 \\
\hline 36 & 1.23 & 7.87 & 1.46 & -4.12 & 5.80 & -15.85 & 1.19 \\
\hline North H. 37 & 0.11 & -0.62 & 0.36 & -0.52 & 4.59 & -5.64 & 0.03 \\
\hline 38 & 0.09 & 6.83 & 2.76 & -0.56 & 6.03 & -2.81 & 1.92 \\
\hline 39 & 1.19 & 13.49 & 5.08 & 3.33 & 4.57 & -5.94 & 5.15 \\
\hline 40 & 1.72 & 14.52 & 3.72 & 1.09 & 7.32 & -10.49 & 5.34 \\
\hline 41 & 2.44 & 12.85 & 4.39 & 2.76 & 4.98 & -4.96 & 5.82 \\
\hline 42 & 1.96 & 12.44 & 5.40 & 1.28 & 8.68 & -13.76 & 5.46 \\
\hline 43 & 1.54 & 11.34 & 5.33 & 4.33 & 6.15 & -2.27 & 5.21 \\
\hline 44 & 1.25 & 10.54 & 4.25 & 5.72 & 6.65 & 0.61 & 5.11 \\
\hline 45 & 1.41 & 9.16 & 5.43 & 5.75 & 7.30 & -3.48 & 4.74 \\
\hline 46 & 0.79 & 9.50 & 4.43 & 5.79 & 5.84 & 0.88 & 4.54 \\
\hline 47 & 0.67 & 7.59 & 5.66 & 5.91 & 4.45 & 0.93 & 4.22 \\
\hline 48 & 0.74 & 7.30 & 3.19 & 7.57 & 5.52 & 1.22 & 3.87 \\
\hline 49 & 1.03 & 5.50 & 5.09 & 6.19 & 6.85 & -1.09 & 3.77 \\
\hline 50 & 0.60 & 6.13 & 2.47 & 6.55 & 6.48 & 0.52 & 3.36 \\
\hline 51 & 0.67 & 4.22 & 3.81 & 6.23 & 6.42 & 0.48 & 2.96 \\
\hline 52 & 0.77 & 3.12 & 4.46 & 5.68 & 5.20 & 0.60 & 2.85 \\
\hline 53 & 0.71 & 3.06 & 3.48 & 4.79 & 5.21 & -1.22 & 2.52 \\
\hline 54 & 0.76 & 1.18 & 3.85 & 5.97 & 4.15 & 3.64 & 2.21 \\
\hline 55 & 1.55 & 0.71 & 3.50 & 4.86 & 3.48 & -1.14 & 2.21 \\
\hline 56 & 1.57 & 0.56 & 3.01 & 5.18 & 2.10 & -1.05 & 2.03 \\
\hline 57 & 1.61 & 0.68 & 2.20 & 5.11 & 3.77 & -4.12 & 1.95 \\
\hline 58 & 1.73 & -0.12 & 2.15 & 3.63 & 5.75 & -1.86 & 1.82 \\
\hline 59 & 1.78 & -0.99 & 1.86 & 4.01 & 2.40 & -3.54 & 1.53 \\
\hline 60 & 1.50 & 0.42 & 1.23 & 2.23 & 4.32 & -0.62 & 1.50 \\
\hline 61 & 1.79 & -1.96 & 1.62 & 3.31 & 3.05 & 1.77 & 1.45 \\
\hline 62 & 2.15 & -3.03 & 1.40 & 3.13 & 4.19 & -1.98 & 1.29 \\
\hline 63 & 2.02 & -3.16 & 1.88 & 0.84 & 3.92 & 1.32 & 1.02 \\
\hline 64 & 1.37 & -3.31 & 3.07 & 0.22 & 2.94 & -0.36 & 0.81 \\
\hline 65 & 0.17 & -2.46 & 2.70 & -1.32 & 6.27 & 0.80 & 0.35 \\
\hline 66 & 0.33 & -4.97 & 3.35 & -0.26 & 6.29 & 1.66 & 0.33 \\
\hline 67 & 0.01 & -5.94 & 3.20 & 0.28 & 5.27 & 4.05 & 0.00 \\
\hline 68 & -0.34 & -7.19 & 3.08 & 0.32 & 5.20 & 5.02 & -0.47 \\
\hline 69 & -0.76 & -8.59 & 4.17 & -0.56 & 5.66 & 1.73 & -0.85 \\
\hline 70 & -2.32 & -6.65 & 4.15 & -3.68 & 6.00 & 10.71 & -1.18 \\
\hline 71 & -3.16 & -5.34 & 3.26 & -1.15 & 1.25 & 22.25 & -1.22 \\
\hline 72 & -1.02 & -5.65 & 3.21 & 0.31 & 1.38 & 17.22 & -0.47 \\
\hline 73 & 0.68 & -3.97 & 4.70 & -0.09 & 3.12 & 1.61 & 0.60 \\
\hline 74 & 2.02 & -2.95 & 8.73 & 6.12 & 7.35 & 0.76 & 3.27 \\
\hline 75 & 3.44 & -14.17 & 16.64 & 23.58 & 16.19 & 20.17 & 6.90 \\
\hline $\begin{array}{r}\text { Willapa Bay } \\
76\end{array}$ & No Data & No Data & No Data & 48.27 & 28.32 & 33.12 & 9.40 \\
\hline Critical Rate & \pm 1.14 & \pm 1.32 & \pm 1.94 & \pm 2.62 & \pm 3.66 & \pm 8.93 & \pm 0.32 \\
\hline
\end{tabular}


Table 5. Historical shoreline change rates for the Grayland Plains sub-cell (values in meters per year). Values are considered significant if they are greater (or less than) the critical rate shown in the table.

\begin{tabular}{|c|c|c|c|c|c|c|c|}
\hline Transect & $\begin{array}{l}187 x \text { to } \\
192 X\end{array}$ & $\begin{array}{l}192 X \text { to } \\
195 X\end{array}$ & $\begin{array}{l}195 X \text { to } \\
1974\end{array}$ & $\begin{array}{l}1974 \text { to } \\
198 X\end{array}$ & $\begin{array}{l}198 X \text { to } \\
1995\end{array}$ & $\begin{array}{l}1995 \text { to } \\
1999\end{array}$ & $\begin{array}{l}187 x \text { to } \\
1998\end{array}$ \\
\hline $\begin{array}{r}\text { Willapa Bay } \\
77\end{array}$ & -1.29 & 1.92 & -0.45 & No Data & No Data & No Data & -28.07 \\
\hline 78 & -7.22 & -34.51 & -27.30 & -23.74 & -9.50 & -19.28 & -29.25 \\
\hline 79 & -7.77 & -40.67 & -30.24 & -20.83 & -13.24 & -20.58 & -26.80 \\
\hline $\begin{array}{r}\text { North Cove } \\
80\end{array}$ & 3.21 & 7.07 & -18.45 & 7.97 & -36.00 & -28.74 & -5.52 \\
\hline 81 & 3.71 & 7.39 & 4.07 & 11.40 & -13.25 & -31.99 & 3.27 \\
\hline 82 & 7.76 & 5.38 & 2.70 & 4.70 & 8.60 & 76.15 & 7.92 \\
\hline 83 & 8.25 & 2.20 & 3.64 & 0.20 & 10.77 & 32.83 & 5.53 \\
\hline 84 & 7.66 & 1.73 & 1.87 & -0.98 & 13.75 & 5.07 & 4.28 \\
\hline 85 & 7.10 & 1.30 & 1.93 & 0.36 & 7.34 & -2.89 & 4.01 \\
\hline 86 & 7.20 & 0.96 & 0.72 & 0.83 & 8.38 & -6.62 & 3.57 \\
\hline 87 & 7.42 & 0.33 & -0.75 & 1.47 & 6.69 & -6.90 & 3.25 \\
\hline 88 & 7.08 & 1.46 & -0.87 & 0.22 & 6.98 & -7.65 & 3.14 \\
\hline 89 & 8.12 & 0.67 & -0.70 & -0.35 & 7.49 & -9.13 & 3.37 \\
\hline 90 & 7.37 & 0.14 & -1.27 & 1.32 & 4.17 & -7.53 & 2.69 \\
\hline 91 & 8.60 & -0.48 & -1.88 & 1.52 & 4.61 & -8.60 & 3.00 \\
\hline 92 & 8.09 & -1.13 & -1.74 & 2.13 & 3.21 & -4.07 & 2.88 \\
\hline 93 & 8.10 & -0.79 & -1.46 & 2.37 & 6.26 & 3.95 & 3.39 \\
\hline 94 & 8.12 & -1.75 & -0.24 & 2.97 & 9.76 & -5.50 & 3.75 \\
\hline 95 & 7.65 & -4.08 & 2.68 & 3.18 & 3.80 & -3.60 & 3.17 \\
\hline 96 & 6.64 & -4.46 & 2.86 & 3.72 & 0.15 & -0.24 & 2.38 \\
\hline 97 & 5.21 & -2.93 & 2.77 & 0.55 & -4.18 & 8.36 & 1.65 \\
\hline GH Jetty 98 & 6.21 & 3.06 & -1.89 & -1.91 & -12.52 & 3.83 & 1.16 \\
\hline Critical Rate & \pm 1.14 & \pm 1.32 & \pm 1.94 & \pm 2.62 & \pm 3.66 & \pm 8.93 & \pm 0.32 \\
\hline
\end{tabular}


Table 6. Historical shoreline change rates for the North Beach sub-cell (values in meters per year). Values are considered significant if they are greater (or less than) the critical rate shown in the table.

\begin{tabular}{|c|c|c|c|c|c|c|c|}
\hline Transect & $\begin{array}{l}187 x \text { to } \\
192 x\end{array}$ & $\begin{array}{l}192 X \text { to } \\
195 X\end{array}$ & $\begin{array}{l}195 X \text { to } \\
1974\end{array}$ & $\begin{array}{l}1974 \text { to } \\
198 X\end{array}$ & $\begin{array}{l}198 X \text { to } \\
1995\end{array}$ & $\begin{array}{l}1995 \text { to } \\
1999\end{array}$ & $\begin{array}{l}187 x \text { to } \\
1998\end{array}$ \\
\hline GH Jetty 99 & 46.53 & 17.58 & -1.91 & 2.51 & -1.39 & 4.91 & 23.36 \\
\hline 100 & 34.02 & 15.51 & 0.24 & 0.72 & 1.08 & 3.14 & 20.24 \\
\hline 101 & 34.84 & 14.20 & 3.07 & 3.53 & 0.82 & 10.10 & 17.32 \\
\hline 102 & 25.70 & 13.06 & 5.54 & 5.02 & -1.25 & 8.78 & 14.58 \\
\hline 103 & 18.20 & 11.71 & 6.20 & 5.47 & 1.06 & 12.88 & 12.11 \\
\hline 104 & 12.89 & 11.03 & 7.48 & 6.51 & -0.19 & 15.25 & 10.33 \\
\hline 105 & 9.89 & 11.05 & 7.73 & 3.71 & 1.26 & 18.99 & 9.35 \\
\hline 106 & 8.00 & 10.40 & 6.88 & 1.27 & 2.96 & 18.44 & 8.10 \\
\hline 107 & 5.38 & 12.46 & 5.26 & 3.86 & 1.02 & 13.37 & 7.10 \\
\hline 108 & 3.18 & 13.17 & 4.92 & 3.97 & -1.33 & 22.11 & 6.54 \\
\hline 109 & 2.54 & 13.25 & 4.89 & 1.35 & 4.44 & 18.25 & 6.36 \\
\hline 110 & 2.33 & 13.33 & 3.01 & 3.80 & 4.99 & 22.46 & 5.86 \\
\hline 111 & 1.35 & 12.97 & 3.58 & 4.59 & 6.96 & 15.48 & 5.71 \\
\hline 112 & 1.08 & 12.88 & 1.71 & 5.11 & 6.68 & 12.77 & 5.20 \\
\hline 113 & 4.89 & 10.96 & 2.62 & 3.71 & 5.85 & 14.32 & 5.73 \\
\hline 114 & 0.47 & 10.84 & 2.49 & 3.63 & 8.16 & 10.93 & 4.68 \\
\hline 115 & 0.04 & 10.21 & 1.43 & 3.54 & 10.33 & 8.49 & 4.06 \\
\hline 116 & -0.52 & -5.33 & 2.60 & -10.96 & 13.28 & 12.25 & 4.03 \\
\hline 117 & 1.41 & 6.73 & 2.27 & 2.98 & 11.41 & 6.70 & 3.85 \\
\hline 118 & -0.18 & 7.43 & 1.42 & 3.22 & -1.09 & 23.42 & 3.33 \\
\hline 119 & 1.00 & 7.29 & 0.52 & 0.99 & 10.92 & 2.48 & 2.27 \\
\hline 120 & -3.38 & 0.67 & 2.62 & -13.94 & 8.75 & 8.66 & 3.53 \\
\hline Copalis 121 & -0.76 & -1.70 & -6.33 & 0.49 & 7.30 & 4.75 & 2.20 \\
\hline 122 & -1.22 & 7.82 & -2.50 & -19.96 & -0.92 & -10.38 & -2.21 \\
\hline 123 & 0.66 & 2.97 & -1.78 & -0.30 & 2.05 & -3.69 & 0.23 \\
\hline 124 & -0.27 & 4.15 & -0.27 & -4.00 & 3.95 & 9.33 & 0.96 \\
\hline 125 & -0.57 & 3.72 & -0.59 & -2.31 & 1.76 & 8.54 & 0.87 \\
\hline 126 & 0.12 & 3.58 & -0.89 & -2.94 & 2.94 & 9.68 & 0.81 \\
\hline 127 & 0.89 & 2.88 & -0.95 & -3.22 & 5.52 & 5.84 & 0.79 \\
\hline 128 & -0.25 & 3.20 & -2.69 & -0.49 & 7.08 & 5.39 & 0.24 \\
\hline 129 & 0.20 & 3.22 & -0.46 & -2.31 & 3.48 & 6.03 & 0.69 \\
\hline 130 & -10.94 & 3.77 & 0.03 & -2.27 & 3.08 & 13.13 & 0.97 \\
\hline 131 & 0.14 & 3.17 & -0.43 & -1.53 & 2.16 & 12.33 & 1.00 \\
\hline 132 & 0.40 & 1.39 & -0.22 & -0.60 & No Data & No Data & 0.76 \\
\hline 133 & -4.85 & 4.56 & -1.90 & -9.73 & 2.32 & 20.96 & 0.26 \\
\hline 134 & -0.58 & No Data & No Data & 0.07 & 3.20 & 13.08 & 0.39 \\
\hline 135 & -0.90 & No Data & No Data & 0.53 & 0.84 & 14.46 & 0.73 \\
\hline 136 & -0.01 & No Data & No Data & 0.55 & -0.44 & 22.38 & 1.09 \\
\hline 137 & 0.18 & No Data & No Data & -0.69 & 0.10 & 25.40 & 0.99 \\
\hline 138 & 0.91 & No Data & No Data & 2.28 & -4.76 & 16.30 & 1.06 \\
\hline 139 & 0.23 & No Data & No Data & 2.18 & -2.64 & 18.13 & 1.17 \\
\hline 140 & -0.33 & No Data & No Data & 2.38 & -6.38 & 8.55 & 0.57 \\
\hline $\begin{array}{l}\text { Point } \\
\text { Grenville141 }\end{array}$ & -0.77 & No Data & No Data & -0.28 & -1.18 & 4.43 & -0.41 \\
\hline Critical Rate & \pm 1.14 & \pm 1.32 & \pm 1.94 & \pm 2.62 & \pm 3.66 & \pm 8.93 & \pm 0.32 \\
\hline
\end{tabular}


Table 7. Bulk shoreline change rates for each sub-cell within the Columbia River littoral cell. Values shown are in meters per year (negative values indicate erosion).

\begin{tabular}{l|rrr}
\hline Sub-cell & Minimum & \multicolumn{3}{c}{ Mean } & Maximum & Time Period \\
\hline North Beach & -10.94 & 4.46 & $46.53187 x$ to 1926 \\
& -5.33 & 7.83 & 17.581926 to $195 x$ \\
-6.33 & 1.59 & $7.73195 x$ to 1974 \\
& -19.96 & 0.06 & 6.511974 to 1987 \\
-6.38 & 2.96 & 13.281987 to 1995 \\
Grayland Plains & -10.38 & 11.64 & 25.401995 to 1999 \\
& -7.77 & 5.33 & $8.60187 x$ to 1926 \\
& -40.67 & -2.60 & 7.391926 to $195 x$ \\
Long Beach & -30.24 & -2.91 & $4.07195 x$ to 1974 \\
& -23.74 & -0.14 & 11.401974 to 1987 \\
& -36.00 & 0.63 & 13.751987 to 1995 \\
& -31.99 & -1.56 & 76.151995 to 1999 \\
& -3.16 & 2.46 & $40.48187 x$ to 1926 \\
& -14.17 & 2.34 & 21.781926 to $195 x$ \\
& -12.72 & 3.12 & $16.64195 x$ to 1974 \\
& -6.67 & 3.72 & 48.271974 to 1986 \\
& -18.83 & 5.13 & 28.321986 to 1995 \\
& -19.02 & 0.29 & 33.121995 to 1999 \\
& & & \\
& -1.31 & 9.51 & $74.42187 x$ to 1926 \\
& -13.15 & 5.24 & 17.811926 to 1942 \\
& -21.37 & 2.01 & 26.241942 to 1973 \\
& -7.88 & -0.23 & 2.411973 to 1986 \\
& -33.10 & 2.23 & 12.141986 to 1995 \\
& -16.70 & -3.75 & 28.051995 to 1999 \\
\hline
\end{tabular}
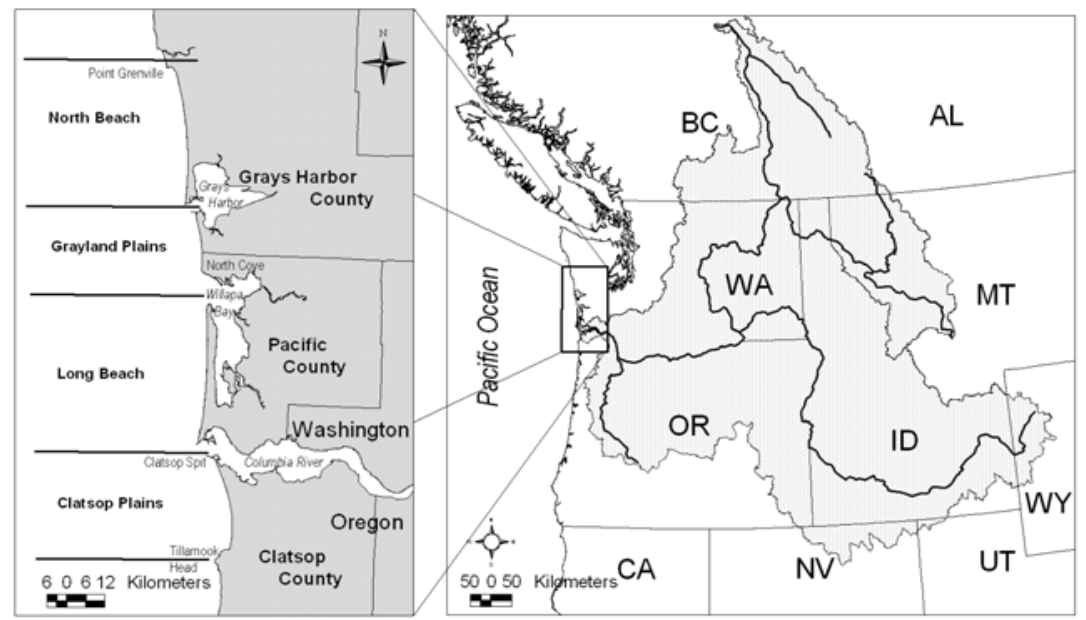

Figure 1. Relative size of the Columbia River basin (right) in relation to the Columbia River littoral cell (left). 


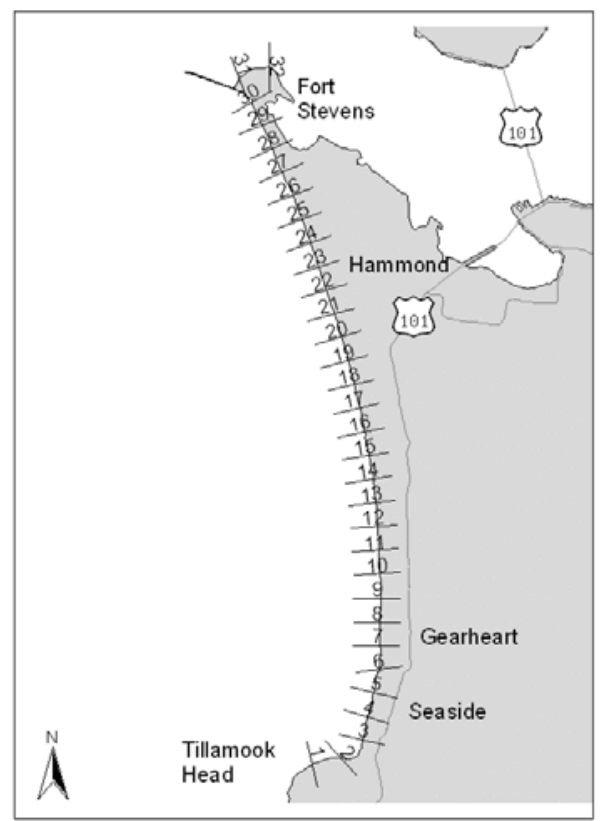

Figure 2. Transect locations within the Clatsop Plains sub-cell of the Columbia River littoral cell.

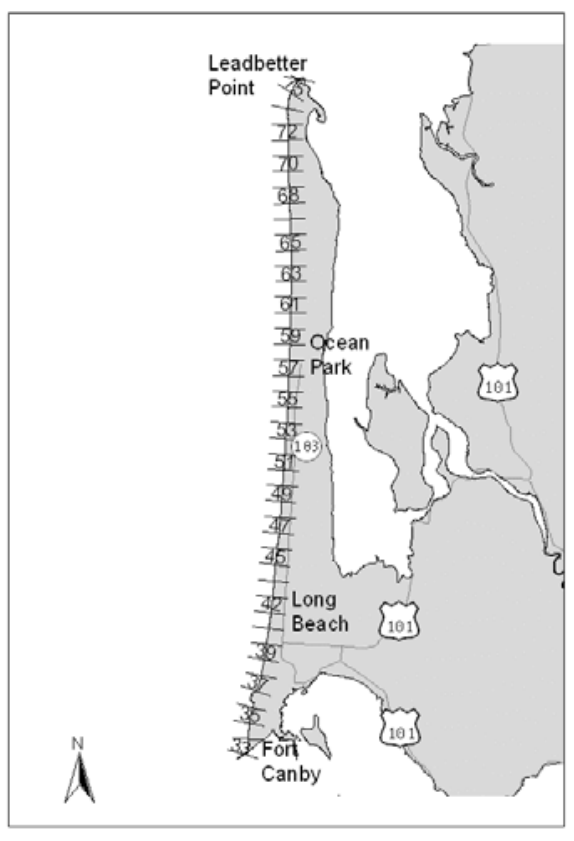

Figure 3. Transect locations within the Long Beach sub-cell of the Columbia River littoral cell. 


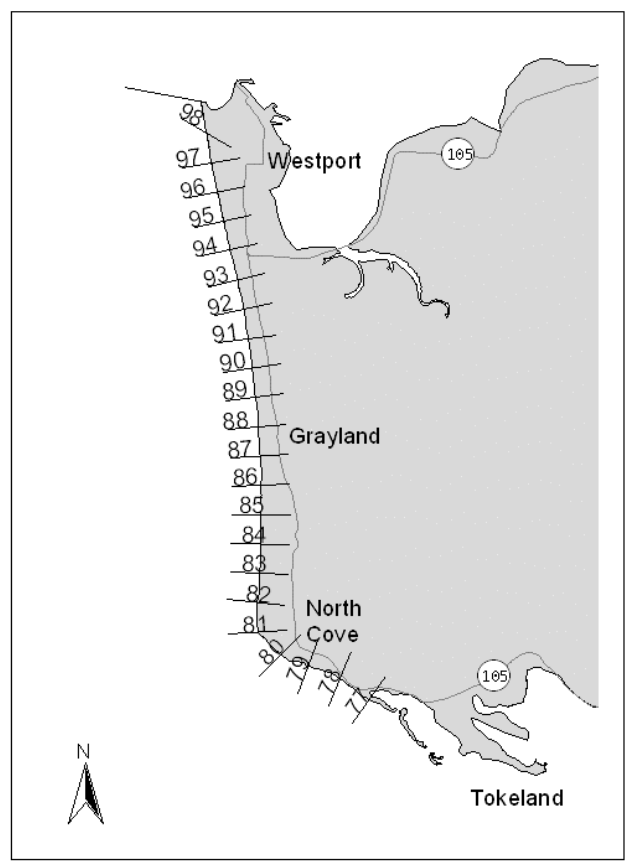

Figure 4. Transect locations within the Grayland Plains sub-cell of the Columbia River littoral cell.

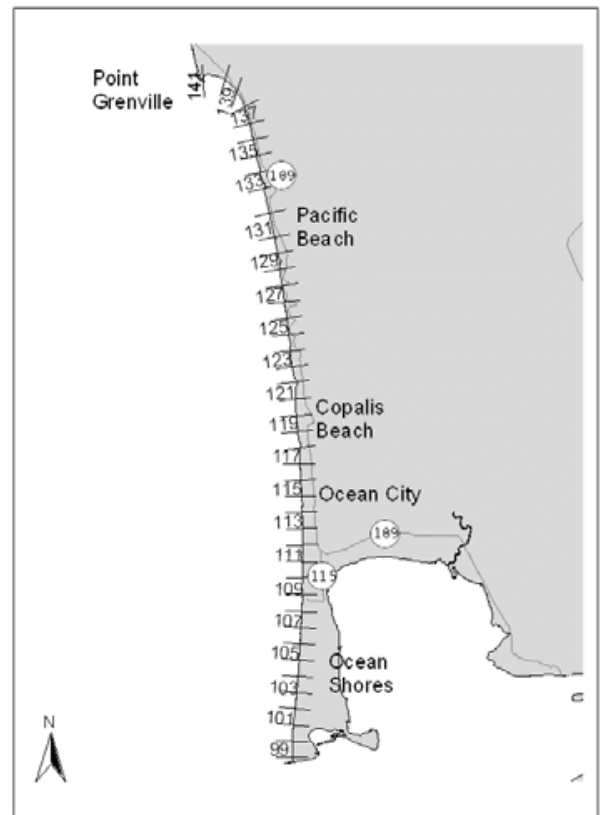

Figure 5. Transect locations within the North Beach sub-cell of the Columbia River littoral cell. 


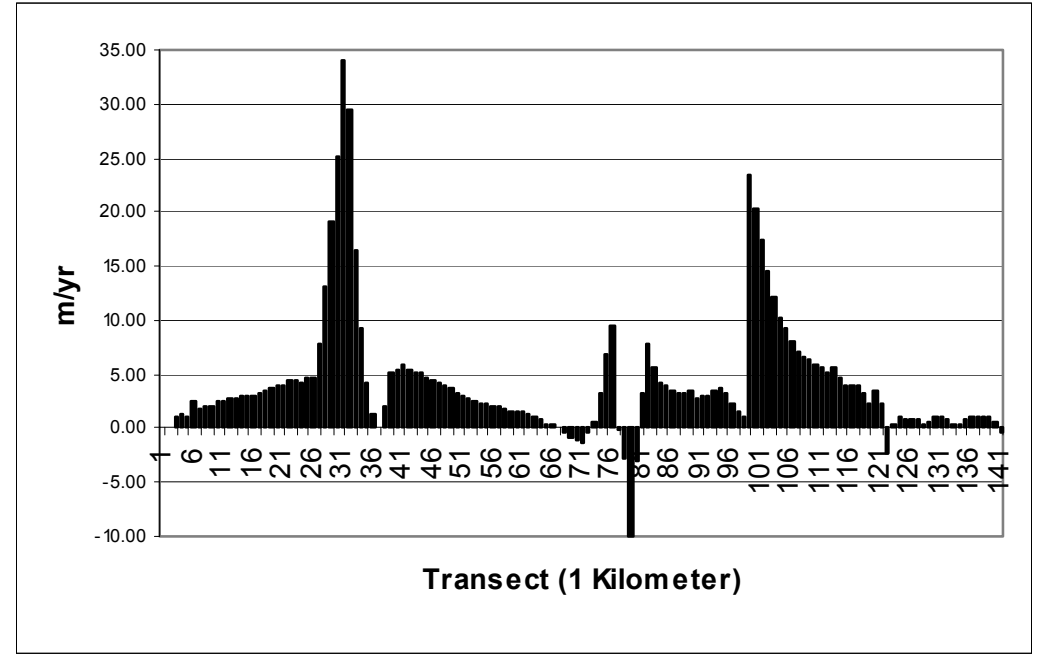

Figure 6. Long-term (1870 to 1998) shoreline change rates for the Columbia River littoral cell. Note that the Columbia River, Willapa Bay, and Grays Harbor entrances are located between transects $32-33,76-77$, and $98-99$, respectively. 


\title{
DIGITIZING SHORELINES FROM AERIAL PHOTOGRAPHY
}

\author{
Diana C. McCandless, Washington Department of Ecology \\ Richard C. Daniels, Washington Department of Ecology
}

\section{INTRODUCTION}

The 1870, 1926, and 1955 shorelines for the entire study area were digitized from National Ocean Service Topographic Sheets. The 1942, 1963-1967, 1974, 1987, 1995, and 1999 shorelines were digitized from aerial photographs.

In addition to these "whole study area" shorelines, there are additional aerial photography shorelines for various locations, such as Ocean Shores, Damon Point State Park, and Fort Canby State Park (Table 1). Not shown in the table are the shorelines for Grays Harbor (Ocean Shores and Westport) that have been digitized from Corps of Engineers bathymetry charts $(1898,1900,1902,1904,1906,1909,1916,1923,1926,1927,1929$, 1934, 1940, 1941, 1942, 1946, 1948, 1951, 1954, and 1960).

This paper does not describe an analysis of the data, but rather details the methodology of collecting that data. Digitization of the shorelines from these aerial photographs requires a tremendous burden of proof in order to justify where any particular shoreline arc is placed, therefore, a rigorous process is required to minimize the very subjective nature of the exercise.

\section{CONCLUSIONS}

Several tests were conducted: two tests for intra-season shoreline variability, two repeatability tests, and three tests for shoreline elevation and elevation consistency. The intra-season shoreline variability test consisted of digitizing photography from Ocean Shores taken on May 26, 1999, and aerial photography taken on June 27, 1999, and also digitizing photography from Klipsan Beach taken on May 26, 1999, and aerial photography taken on September 21, 1999. The repeatability test consisted of the authors digitizing the same randomized assortment of aerial photographs, in random order, and comparing the lines digitized by each to each other. The shoreline elevation and elevation consistency analysis consisted of comparing a formally digitized shoreline to the elevation map collected with Global Positioning Systems (GPS) within three days of the day that the aerial photography missions were flown. The shoreline reference feature was found to be consistently approximated by the 3.0-meter contour as determined by the GPS-derived beach surface elevation maps (Daniels et al., 2000). 


\section{ACCOMPLISHMENTS}

Table 1 provides a list of most of the Study's shorelines. Some shorelines used data sources (photography or topographic charts) from a number of years. For instance, a "1870 shoreline", a single continuous shoreline, was digitized from T-sheets dated 1868, $1869,1871,1872$, and 1873. Similarly, the surveys for the "1926" shoreline spanned over a year; T-sheets are dated 1926 and 1927. The "1950 shoreline" was derived from Tsheets dated 1948, 1950, 1951, and 1954 and a data gap was filled with aerial photography from 1957. The "1986" shoreline comes from photography from 1986, 1987, and 1988, depending on the sub-cell.

Some of the many possible change rates, as determined by subjecting different shorelines to a customized change rate program, are shown in Daniels et al. (this volume). The 19951999 change rates were graphically displayed at the 2000 Southwest Washington Coastal Erosion Workshop, on maps with the 1999 color photography as a background.

\section{Methodology}

Aerial photographs were procured from a variety of sources: some missions were flown by the Department of Natural Resources, some were flown by the respective counties, and some recent ones were contracted by the Washington Department of Ecology. The photos were provided in paper form (except for the 1995 NOAA photographs, which are diapositives).

At the edge of the photographs are the fiducial points of the camera, and these are used in conjunction with the Camera Calibration Report and the Erdas Imagine software to calculate a geometric correction to the image for lens distortion. In addition to this correction for lens distortion, there is also distortion of the image due to changes in elevation throughout the photograph. These are corrected through orthorectification by applying a digital elevation model to the rectified image. In the elevation correction process, portions of the photo that correspond to higher elevations are moved closer to the center of the image to correct for the fact that they appear to lean outward in the raw image. The intermediate step between correcting for camera lens distortion and elevation distortion is the process of triangulating, where the entire photograph is registered to realworld coordinates. This is done by forcing certain features in the photograph, such as a sidewalk corner, to have real-world coordinates as captured by Global Positioning Systems (GPS).

Having ortho-rectified the images as described above, mosaic images are created, three or four per sub-cell. Since each photograph has a 60 percent overlap with the next one in the flightline, the mosaic images tend to use only the center 50 percent. The resultant mosaic can be from 0.5 to 1.4 gigabytes each. The Mr. Sid compression software allows us to turn a 1.4-gigabyte mosaic (Clatsop) into a 38 megabyte Sid-format. These compressed versions are being provided on CD-ROM.

Once the mosaic has been created, it is ready to be digitized. The industry-standard Unixbased Arc/Info GIS software was used to digitize three lines: the vegetation line, the shoreline, and the instantaneous water line. The "shoreline" has several names, which are 
used interchangeably; "average high water", "shoreline" and "scrf" are all used to describe the average high water line. The term "scrf" is an acronym for "shoreline change reference feature". All arcs (line segments) have an attribute associated with them called "qa_scrf", and only those lines that represent the "average high water" are given a value greater than 0 for "qa_scrf". The vegetation line is intended to represent the line where the dominant, permanent vegetation (usually one of the beachgrasses) dwindles to 50 percent coverage, the other 50 percent being sand. It is occasionally called "the erf line;" erf is an acronym for "erosion reference feature". Every arc has an attribute called "qa_erf" associated with it, but only those arcs that comprise the vegetation line are given a "qa_erf" greater than zero.

The third line that is digitized is the instantaneous water line. The attribute that differentiates this line from the others is "dewater." Though a misnomer, the name has been kept so that Arc/Info coverages could continue to be appended, an action that requires consistency in the names of the attributes.

\section{The Erosion Reference Feature}

The landward-most of the three lines is the "erosion reference feature" (ERF), called so because it defines the location of storm high water, typically where erosion takes place. These features are identified by scarps, where an unusually high water level cuts into land that was previously above all salt-water levels. In cases where there is no erosion scarp, or where a previously active scarp is recovering with accreting sands at its toe, the "erosion reference feature" is the "vegetation line" where the dominant, permanent vegetation transitions from more than 50 percent coverage to less than 50 percent coverage. The lines that compose the erosion reference feature can be identified by choosing those arcs that satisfy the condition of having the attribute "qa_erf" greater than zero (arcedit: sel qa_erf $>0)$. Each arc thus selected will have a code in the qa_erf attribute that indicates what visible cue in the photograph was used to determine its placement. The codes are:

$0=$ this particular arc is not part of the erosion reference feature

$1=$ vegetation line, grass

$2=$ vegetation line, woodland

$3=$ vegetation line, estimated (broken vegetation line)

$4=$ cliff edge

$5=$ berm or scarp edge (indicator of active erosion)

$6=$ center (top) of the seaward most dune line (i.e., there is neither scarp nor vegetation on the dune)

$7=$ ERF not visible, best guess

$8=$ seawall or other anthropogenic feature

$9=$ ERF obliterated by stream or anthropogenic feature, location estimated based on widely spaced dunes and vegetation.

\section{The Shoreline Reference Feature}

The most important line digitized is formally called the shoreline change reference feature (SCRF); it is also called the average high water line. This line moves seaward and landward much more quickly than the vegetation line, because while a newly accreting 
dune will cause the high water line to be further seaward, vegetation will not immediately take hold on this newly reclaimed land. The lines that compose the shoreline reference feature can be identified by choosing those arcs that satisfy the condition of having the attribute "qa_scrf" greater than zero (arcedit: sel qa_scrf $>0$ ). Each arc thus selected will have a code in the qa_scrf item of the arc attribute table (arcedit: list qa_scrf) that indicates what visible cue in the photograph was used to determine its placement. The codes are:

$0=$ this particular arc is not part of the shoreline change reference feature

$1=\mathrm{SCRF}$ was visible, the sand darkened by recent high water

$2=$ SCRF partially visible, location estimated

$3=$ SCRF not visible, location estimated based on drift line

$4=$ SCRF located at bluff, scarp, or cliff (may be co-located with the ERF)

$5=$ non-SCRF shoreline added for completeness (non-oceanside bays where the beaches tend to be steeper, narrower and change less)

$7=$ SCRF not visible, best guess

$8=$ seawall or other anthropogenic feature

$9=$ SCRF obliterated by stream or anthropogenic feature, location estimated

\section{The Instantaneous Water Line}

The third line is the instantaneous water line at the time the photo was taken. In the arc attribute table, this line is coded by "dewater." The instantaneous water line is designated with the code "dewater $>0$ ". The codes that relate to the item "dewater" are:

$0=$ this particular arc is not an instantaneous water line

$1=$ the arc is an instantaneous water line, all by itself

$2=$ the arc is both instantaneous water line and also the "shoreline" (i.e., the tide is high and the current water level is thought to be mean high water.)

Often, when moving from one photo to the next photo in the series, this instantaneous water line is discontinuous, because the swash has either moved landward or seaward in the 6 seconds intervening between the two photos. In such cases, the arcs are intentionally left dangling, coded with "notes = 'intent. dangle'."

\section{Combined Lines}

In some cases, rather than three parallel lines, there will be only one or two. In a few cases the reason is because the photograph did not cover the feature (i.e., the edge of the photograph cut off the instantaneous water line). In most cases it is because two or more of the lines were co-spatial. For example, if a photo was taken at high tide, the instantaneous water line will be in the same place as the average high water line. If there is an erosional scarp and an extremely lowered beach, or equivalently a bulkhead, the average high water line might be right up against the scarp; therefore, the erosion reference feature (vegetation line) would be in the same place as the shoreline. In these cases, a single arc would have codes greater than zero for more than one of the three lines (i.e., qa_erf $=5$, qa_scrf $=4$, dewater $=2$ ). 


\section{Attribute Information (associated with each arc)}

In addition to the seven attribute items that are automatically assigned to each arcedit coverage (fnode\#, tnode\#, lpoly\#, rpoly\#, length, shore1995r6\#, and shore1995r6-id) there are twenty other attribute items. For example, the arc attribute item formats of the "shore1995r6" coverage follow:

\begin{tabular}{|c|c|c|c|c|c|}
\hline Column & Item_Name & Width & Output & Type & \#Decimals \\
\hline 1 & Fnode\# & 4 & 5 & $B$ & - \\
\hline 5 & Tnode\# & 4 & 5 & $B$ & - \\
\hline 9 & LPoly\# & 4 & 5 & $B$ & - \\
\hline 13 & RPoly\# & 4 & 5 & $B$ & - \\
\hline 17 & Length & 4 & 18 & $\mathrm{~F}$ & 5 \\
\hline 25 & shore1995r6\# & 8 & 5 & B & - \\
\hline 29 & shore1995r6-id & 4 & 5 & $B$ & - \\
\hline 33 & qa_erf & 4 & 4 & I & - \\
\hline 37 & qa_scrf & 4 & 4 & I & - \\
\hline 41 & year & 4 & 5 & $\mathrm{~N}$ & 0 \\
\hline 46 & month & 5 & 3 & $\mathrm{~N}$ & 0 \\
\hline 49 & erf_sym & 3 & 3 & I & - \\
\hline 52 & day & 3 & 3 & I & - \\
\hline 55 & time & 8 & 8 & I & - \\
\hline 63 & tidal_elev & 8 & 8 & $\mathrm{~F}$ & 1 \\
\hline 71 & mhhw & 8 & 8 & $\mathrm{~F}$ & 2 \\
\hline 79 & days_since & 4 & 4 & I & - \\
\hline 83 & photo\# & 6 & 6 & C & - \\
\hline 89 & breakerwidth & 5 & 5 & I & - \\
\hline 94 & dewater & 4 & 4 & I & - \\
\hline 98 & undularity & 4 & 4 & I & - \\
\hline 102 & notes & 15 & 15 & $\mathrm{C}$ & - \\
\hline 117 & tidal_motion & 12 & 12 & C & - \\
\hline 129 & uncertain_landwa & 4 & 4 & I & - \\
\hline 133 & uncertain_seawar & 4 & 4 & I & - \\
\hline 137 & reason ${ }^{-}$ & 13 & 13 & $\mathrm{C}$ & - \\
\hline 150 & scrf_elev_est & 4 & 4 & $\mathrm{~F}$ & 1 \\
\hline
\end{tabular}

"qa_erf" is a code that designates whether or not an arc is part of the erosion reference feature, and if so, is representative of the visual cue used to determine its position. See "The Erosion Reference Feature."

"qa_scrf" is a code that designates whether or not an arc is part of the shoreline change reference feature, and, if so, is representative of the visual cue used to determine its position. See "The Shoreline Change Reference Feature."

"year" is the year during which the aerial photograph was taken, from which the particular arc was digitized. 
"month" is the month number during which the aerial photograph was taken (i.e., 03 is March).

"erf_sym" will always equal zero. It is a place-holder which allows the arc attribute table to be identical (and thus appendable) to the Topographic-sheet shoreline coverages.

"day" is the day of the month on which the aerial photograph was taken.

"time" is the time of day, in military hours (i.e., $130000=1: 00 \mathrm{pm}$ ) during which the aerial photograph was taken. In some cases it is printed to the nearest second on the photograph itself. In other cases it is printed on the photographs at the beginning and ending of each flight line to the nearest minute. In many cases it is estimated to the nearest half-hour by analyzing shadows in the photograph.

"tidal_elev" is the tidal elevation, in feet at the time the photo was taken. It was derived by entering the date and (estimated) time into the Windows program "Tides and Currents" produced by Nautical Software. For shorelines in Oregon and on the Long Beach Peninsula, the "Columbia River Entrance-North Jetty" tidal station was used. For shorelines in North Cove, Grayland Plains, Westport, Ocean Shores, and North Beach to Tahola, the "Point Brown (Grays Harbor)" tidal station was used. Each tidal station has a different zero point elevation in NAVD-88, and also a different tidal range. Mean higher high water (MHHW) elevation is included for each case to give perspective to each tide. For instance, at the Columbia River Entrance tidal station, the Tides and Currents program lists mean higher high water as $7.5 \mathrm{ft}$, mean range as $5.6 \mathrm{ft}$, and mean tide as $4.0 \mathrm{ft}$. Inferring that mean lower low water is 0.0 , mean high water was extrapolated to have been $6.8 \mathrm{ft}$. Similarly, if the Tides and Currents program lists the following for the Point Brown (Grays Harbor) station: mean higher high water is $9.38 \mathrm{ft}$, mean tide is $5.0 \mathrm{ft}$ and mean range is $7.2 \mathrm{ft}$ inferring that mean lower low water is 0.0 , it is extrapolated that mean high water would be about $8.6 \mathrm{ft}$. Therefore, one must not only look at the "tidal_elev" attribute for the arc but also the "mhhw" attribute.

"mhhw" is in feet above mean lower low water. Please see "tidal elev".

"days_since" is the integer number of days that elapsed between the day on which the photo was taken and the most recent high tide that was within two-tenths of a foot elevation of mean higher high water. The intent was to give the person digitizing a qualitative idea of how many days had passed since the upper beachface had been smoothed by a high tide and then subsequently exposed to the rippling effects of wind. It was useful in differentiating the inter-tidal portion of the beachface from the portion of the beachface that rarely gets wetted during the summer (when aerial photo missions are flown). For instance, when digitizing certain photos, it had been 13 days since the last tide was near mean higher high water. Thus, the photo was taken at the end of a neap tide cycle and all of the beachface landward of the recent lower-high tides will look the same (wind-blown, footprint-dented, and litter-strewn) but recent tides had not been very high. It is crucial to know recent tidal action when determining the location of the "average high water line". 
"photo\#" is a character field that may be a four digit number (i.e., 1995 NOAA photos), a flight line number and a photo number combined, or pure text, i.e., "mosaic" or "seaview" (which means the "seaview" mosaic was used). Photo\# is included to facilitate reassessment of the digitized product.

"breakerwidth" is the distance, in meters, from the seaward-most occurrence of white breakers to the instantaneous water line. It is only non-zero for arcs that make up the instantaneous water line. The width of the breakers is dependent on the wave height, which is both variable and undetermined, as well as the steepness of the beach, orientation and tidal elevation (which determines the depth of offshore sandbars). Since so many factors are unquantified, no analysis should hinge on this number. It is only intended to be a matter of interest. If an arc is part of the instantaneous water line, but "breakerwidth" is not applicable, the value in "breakerwidth" is 1.

"dewater" is a code that designates whether or not an arc is part of the instantaneous water line. An arc has dewater $=0$ if it is not part of the instantaneous water line, dewater $=1$ if it is, and dewater $=2$ if the arc is both part of the instantaneous water line and also the shoreline. See "Combined Lines".

"undularity" is another highly subjective, unconstrained feature, included only for the digitizer's own interest. It is a two-digit number, the first digit representing the undularity of the beach in the cross-shore direction (x-axis), and the second number representing the undularity of the beach in the alongshore direction (y-axis). The cross-shore undularity value was based on the existence of visible sandbars above the waterline and also based on the existence (or lack thereof) of discontinuities in the breakers (caused by sandbars and troughs below the waterline). The alongshore undularity value was based on the size of cusps at the shoreline. Both values vary from one to three. It is only non-zero for arcs that make up the instantaneous water line. If an arc is part of the instantaneous water line, but "undularity" is not applicable, the value in "undularity" is -1 .

"notes" is an opportunity to associate a short note with an arc. Since it is only 15 characters wide, these are not verbose notes, but rather standard catch phrases. Examples are:

notes $=$ 'river boundary' designates arcs that border an "old" river or creek that has a gentle enough slope to allow salt water intrusion (i.e., has an estuary). As opposed to "creek boundary", where only one line is digitized to represent the creek, in "river boundary" both sides of the river are digitized, suggestive of the fact that both salt water and fresh water flow inward and outward of the river.

notes $=$ 'creek boundary' designates dangling arcs (i.e., do not merge with the shoreline) that depict a small creek into which salt water does not flow at high tide. Since fresh water flows down the creek in one direction, only one line is digitized down the middle to represent the creek. 
notes = 'intent. dangle' designates arcs that were intentionally left dangling, either because it ran to the edge of the photo, or in the case of the instantaneous water line, the line cannot be expected to be continuous. This code is used to remove intentional dangles from the list of problematic dangles when searching for dangling arcs.

notes $=$ 'dry streambed' like a creek, consists of only one line down the middle.

notes = 'SR 105 road' occurs once, near North Cove. The road was digitized as a reference.

notes $=$ 'blind guess' means that the relevant arcs were digitized with no photo in the background, as a link from one dangling arc to another. This method was used either for short arcs when the original arc had already been digitized but was accidentally deleted during editing, or when a gap of "no data" between two photos was small enough to justify the assumption that the intervening shoreline was relatively smooth between the two dangling arcs. The practice of doing a "blind guess" was only done when the digitizer had a very high confidence level in placing the arcs. Otherwise, the arcs were left dangling (when there was a gap in data) or time was taken to reload the photos (if photos that cover the area in question exist).

notes $=$ 'perfect tide' indicates that either the previous tide or the instantaneous tide level were inferred to be exactly the elevation of mean higher high water. Such a case adds confidence to the shoreline placement.

"tidal_motion" is a character field describing what direction the tide was thought to be headed. Possible values are: 'flooding', 'slack high', 'ebbing', or 'slack low'.

"uncertain_landwa" is the largest distance in the landward direction, in meters, between where the shoreline was digitized and where it might also have been placed if following a different signal on the shoreface. This value is only filled in for arcs that represent the shoreline. If it is equal to zero for an arc, that arc is not part of the shoreline (it is either the vegetation line or the instantaneous water line). The smallest uncertainty for a shoreline arc is 1 , next 3 , then 5 , followed by increments of 5. A value of "-999" means that the uncertainty was too hard to assess.

"uncertain_seawar" is the largest distance in the seaward direction, in meters, between where the shoreline was digitized and where it might also have been placed if following a different signal on the shoreface. If it is equal to zero for an arc, that arc is not part of the shoreline (it is either the vegetation line or the instantaneous water line). The smallest uncertainty for a shoreline arc is 1 , next 3 , then 5 , followed by increments of 5 . A value of "-999" means that the uncertainty was too hard to assess.

"reason" is a short character field that is meant to provide insight as to why the digitizer felt uncertain about the placement of the shoreline change reference feature. It is almost 
always filled in when "qa_scrf" has a non-zero code. (i.e., it is only associated with arcs that depict the "shoreline" proper). The arc attribute item "reason", when not left blank, is one of the following choices:

reason $=$ 'cusps' Implies there were undulating cusps along the shoreline. Technically, the shoreline could have been digitized as a curvy line following these cusps, but since they are so ephemeral, the shoreline was instead digitized right down the middle with an attempt to have the undulations be equal and opposite on either side of the shoreline.

reason $=$ 'appropt doubt' (equivalently 'genuine doubt') is usually associated with smaller uncertainties (on the order of 3-15 meters). This code reflects the fact that there are just intrinsic uncertainties in the placement of the shoreline, even when conditions and visual cues are ideal.

reason $=$ 'coaxial' was usually associated with larger uncertainties (over 40 meters). This cryptic message was meant to indicate that the uncertainty in the placement of the shoreline is 'coaxial' (parallel) with the shoreline, as opposed to perpendicular to it, which is normally the case. The code 'coaxial' applies only to two specific circumstances. The first is river estuaries, it was not obvious what portion of the visible water was salt and what portion of it was fresh. The other circumstance is one where a web of long, narrow drainage waterways provide drainage for a large mud flat. In these cases it was not easy to discern the difference between the landward extent of the intruding salt water wedge associated with an ordinary high tide and dark, murky vegetation. In these cases, the user of the information should not be dismayed at the large value in the shoreline uncertainty.

reason $=$ 'several lines' This code was to indicate that there were several candidate features for the "shoreline". Sometimes the drift line and wetting line was visible for several recent tides, making it hard to decide which line was the closest to "average high water".

reason $=$ 'lower than $\mathrm{MHW}$ (mean high water) The most recent high tide (at the time the photo was taken) was inferred to have been lower than the mean high water elevation. In such cases it was thought that the previous high tide would have left a driftline seaward of other driftlines, thus contributing to uncertainty in the placement of the 'shoreline'. In such cases the placement of the average high water line was adjusted to be slightly landward of the tide mark that was thought to be 'lower than MHW'.

reason = 'higher than MHW' The most recent high tide (at the time the photo was taken) was inferred to have been higher than the mean high water elevation. In such cases it was thought that the previous high tide had moved the drift line landward, thus contributing to uncertainty in the placement of the 'shoreline'. In 
such cases the placement of the average high water line was adjusted to be slightly seaward of the tide mark that was thought to be 'higher than MHW'.

reason = 'marshy ambiguity' was associated with back bay marshes, away from the high-energy wave side of the coast. It was usually associated with higher uncertainties. Often the vegetation in these marshes has much variety in color, and with many different types of plants that survive in salt water. They often form layers of peat on top of the sand. All these factors combined make it hard to discern what portion of the bay or inlet was wetted by tidal waters, versus being dark for another reason, such as peat layers from salt-water vegetation. As in the case of "coaxial", the user should not be dismayed at the large values in the uncertainty fields.

"scrf_elev_est" is an estimate of the elevation of the previous high tide (within the last 12 hours). It is in feet above mean lower low water for the tidal station (either Columbia River Entrance or Point Brown stations, see "tidal_elev"). It is the elevation of the most recent high tide that was suitable for digitizing. If the previous high tide was considerably lower than MHW (i.e., 2.4 feet lower), an earlier high tide whose drift line was still visible was used to digitize the shoreline. For example, when digitizing the shoreline in Westport, the Point Brown tidal station predictions were used, where mean high water is about $8.6 \mathrm{ft}$. The relevant pictures near the jetty were taken on August 8, 1995, at 1:51 pm, when the tide was retroactively predicted to have been 3.7 feet, ebbing. At 9:39 am that morning, there was a 6.2 foot high tide, but this would have been 2.4 feet below the targeted 8.6 foot mean high water. This value is occasionally zero for a shoreline arc, because the item "scrf_elev_est" was added only recently, while reviewing shorelines. If a particular shoreline arc has a zero value for this attribute, looking at nearby arcs, whose value may have been updated after having added this attribute, may help.

\section{REFERENCES}

Daniels, R.C., McCandless, D., and Huxford, R.H. this volume. Historical shoreline change rates for the Columbia River littoral cell, Southwest Washington Coastal Erosion Workshop Report 2000, U.S. Geological Survey Open-File Report.

Daniels, R.C., Ruggiero, P., and McCandless, D. 2000. Interpretation of the average high water line from aerial photography: Variability and repeatability, Southwest Washington Coastal Erosion Workshop Report, 1999, U.S. Geological Survey Open-File Report 00-439, pp. 58-74. 
Table 1. Shorelines digitized by the Washington Department of Ecology in support of the Southwest Washington Coastal Erosion Study.

Coding:

C = Completed $\quad F=$ Will have in the Future (after 2000 workshop)

\begin{tabular}{|c|c|c|c|c|c|c|c|c|c|c|c|c|c|c|c|c|c|c|c|c|c|c|c|c|c|c|}
\hline & 187 & 927 & & $\begin{array}{l}51- \\
57\end{array}$ & $63-$ & 70 & 74 & 7 & & 77 & 78 & 80 & 81 & 85 & 86 & 87 & 88 & 90 & 93 & 95 & 96 & 97 & 98 & $\begin{array}{l}05 / \\
99\end{array}$ & $\begin{array}{l}071 \\
99\end{array}$ & $\begin{array}{l}09 / \\
99\end{array}$ \\
\hline $\begin{array}{l}\text { North Beach } \\
\text { Subcell }\end{array}$ & C & C & C & C & $F$ & & ( & & & & & & & & & C & & & & C & & C & & C & & \\
\hline $\begin{array}{l}\text { Ocean } \\
\text { Shores }\end{array}$ & c & c & c & C & $F$ & $c$ & & & c & & & c & & c & & c & & c & & c & c & c & $F$ & c & c & \\
\hline $\begin{array}{l}\text { Damon } \\
\text { Point }\end{array}$ & & & & & C & & & & & C & & & c & C & & & & C & & C & & C & C & $F$ & $F$ & \\
\hline $\begin{array}{l}\text { Westport \& } \\
\text { Grayland }\end{array}$ & C & c & C & C & $F$ & & ( & & & & & & & & & C & & & & C & & c & & C & $F$ & \\
\hline North Cove & C & c & c & c & $F$ & & ( & & & & & & & & & c & & & & c & & & & c & & \\
\hline $\begin{array}{l}\text { Long Beach } \\
\text { Peninsula }\end{array}$ & C & C & C & c & $F$ & & ( & & & & & & & & c & & & & & & & & & c & & \\
\hline $\begin{array}{l}\text { "Klipsan" } \\
\text { section of } \\
\text { Long Beach }\end{array}$ & C & c & C & C & $F$ & & ( & & & & & & & & c & & & & & C & & & & c & & C \\
\hline Fort Canby & c & c & c & C & $F$ & $c$ & & & & & c & & & & & & c & & C & C & & & & C & & \\
\hline $\begin{array}{l}\text { Clatsop } \\
\text { Plains, OR }\end{array}$ & C & C & C & c & & & & & & & & & & & c & & & & & c & & & & c & & \\
\hline
\end{tabular}




\section{Willapa Bay \& Grays Harbor}




\title{
BAY CENTER CHANNEL AND WILLAPA NAVIGATION STUDIES
}

\author{
David Simpson, Pacific International Engineering
}

\section{CONCLUSIONS}

1) A sand spit extending from Cape Shoalwater undergoes cycles of elongation, dissection, migration, and welding to an island in the entrance of Willapa Bay. The cycles have an average length of a decade. Spit and shoal migration causes sedimentation in the navigation channel and forces the channel into different configurations, which are detrimental to commercial shipping.

2) Occurrences of El Niños have been linked to phasing in the cycling of geomorphic features and channel configuration. Bathymetric changes coinciding with the El Niño of 1997-98 are consistent with the observations made from historical charts. Detailed bathymetry surveyed since 1997 indicate that the breaching of the elongated Cape Shoalwater spit during El Niño events may be linked more to increased ebb flow speeds, although wave attack at the ocean side of the spit could also be a factor. The implication is that the hydraulics of ebb flows, and not wave-driven transport on the seaward slope, could be the major factor in spit dissection.

3) The northward movement of the North Channel, which is typical especially at the current phase in the geomorphic cycle, has been impeded. The SR 105 underwater dike appears to be responsible for interrupting the normally accelerated rate of North Cove erosion.

4) Monitoring of the Bay Center Entrance Channel in the pre-dredge condition revealed that the bottom sediment surface can erode as much as $10 \mathrm{~cm}$ during a single ebb flow, and accrete a similar amount at the end of the ebb in each tide cycle during a spring tide sequence.

\section{ACCOMPLISHMENTS}

Participants at the first SWCES workshop discussed the dynamics of the Willapa Bay entrance and the rapid erosion rate at North Cove. Dynamics of spits, shoals, and islands were evident from comparison of historical navigation charts. In the past five years, more detailed measurements have allowed a more precise description of entrance and channel behavior to be made. Surveys in the last year have shown a continuation of the previously identified morphological cycling of the growth and dissection of the spit extending from Cape Shoalwater, and the growth and movement of the island and shoal on the south side of the North Channel (Hands, this volume).

\section{Entrance Morphodynamics}

A very strong El Niño occurred in 1997-98, which provided the opportunity to closely observe in the hydrographic surveys the morphodynamic processes thought to be 
associated with El Niños. Previous analyses had linked the incidence of a strong El Niño with the initiation of breaching of the spit near its northern, proximal end (Hands, this volume). Bathymetric changes in 1998 - 2000 verified that the breach is developing, as well as provided the details to observe that breaching is progressing from east to west (from the bay side of the spit toward the ocean side). Breaching from the bay side suggests that channel hydraulics including wave-current interaction, more than ocean wave forces directly, might be the major contributor in the spit dissection process.

\section{Corps of Engineers Study of Navigation Feasibility}

The Corps of Engineers, with participation by contractors, is conducting a feasibility study of reestablishing a commercial navigation channel across the bar and entrance. Prototype wave, current, water level, conductivity, and temperature data were collected and analyzed to support numerical modeling tasks. Bathymetry of the bar, entrance and North Channel areas was collected repeatedly. Data were used for model grid development as well as quantifying trends in channel migration and the effect of that migration on costs of initial dredging of navigation channel alternatives. Phase 1 of the navigation feasibility study was conducted in 1998-1999, and developed 17 alternative channel concepts, consisting of two different depths, and locations and configurations in the North, Middle, and South Channels. Screening and analysis reduced the number of alternatives to five, which are being analyzed in more detail in Phase 2 of the study, which will be concluded in 2001. Observations in the vicinity of the SR 105 underwater dike indicate that the North Channel is still responding to the construction of the dike. A deeper thalweg and straighter alignment are continuing to form westward from the dike location. The final form of this channel adjustment is critical to the selection of a channel design for the navigation study.

The underwater dike of the SR 105 project appears to have significantly slowed the northern migration of the North Channel for a distance of about one mile both east and west from the structure. Some sections show that the thalweg has moved southward from its former location, supposedly in response to the hydraulics created by the presence of the dike. As the North Channel west of the dike develops a straighter alignment and shifts slightly south of the pre-dike thalweg, the northern edge of Dead Man Island continues to move northward. These actions are accompanied by a steepening of the south side of the North Channel and a deepening of the channel bottom, as it is squeezed from the south and stabilized on the north.

\section{Bay Center Entrance Channel Dredging}

Phase 2 of the navigation feasibility study has focused on research of environmental and regulatory issues associated with dredging and especially disposal, technicalities of Corps authorities under which project features could be accomplished, economic analysis, and validation of the ADCIRC model of circulation and transport. The necessity for dredging of the Bay Center Entrance Channel provided the opportunity to collect pre- and postdredging hydrodynamic and transport data in a confined and quite dynamic area with which to compare simulations of the ADCIRC model. This validation exercise will increase the confidence in results of modeling the larger domain when used for evaluating 
sediment infill rates and navigation safety of the alternative channel designs. Those evaluations will be completed later.

Although not connected directly with navigation in Bay Center Channel, dredging of approximately $209,000 \mathrm{~m}^{3}[160,000 \mathrm{cu}$ yd] of clean sand from that site in OctoberNovember 2000 did provide the opportunity for beneficial re-use of dredged material as a feeder berm at the Shoalwater Tribal property. Material was bottom-dumped in depths from 1.5 to $6 \mathrm{~m}$ [5 to $20 \mathrm{ft}$ ] below mean lower low water (MLLW) near a breach in a spit that protected the Tribal Community from wave overwash.

\section{QUESTIONS}

Continued monitoring of bathymetry of the bar, entrance, and North Channel is required to determine the final state of North Channel when it becomes adjusted to the presence of the SR 105 underwater dike. Monitoring will also reveal the pattern of movement of material placed in the beach fill near the SR 105 groin and the feeder berm along the shoreline of North Cove. Monitoring of currents, bathymetric changes, and sediment transport in the vicinity of the Bay Center Entrance Channel will reveal details of the system response to channel dredging from a bottom depth of $0.3-0.6 \mathrm{~m}[1-2 \mathrm{ft}]$, to $4.6 \mathrm{~m}[15 \mathrm{ft}] \mathrm{depth}$.

\section{ANALYSIS}

Data analyzed to support the conclusions stated above are contained in the Corps of Engineers' Engineer Research and Development Center (ERDC) report published in April 2000, Study of Navigation Channel Feasibility, Willapa Bay, Washington. A follow-on report is currently being drafted. A series of monitoring reports have been produced for the Washington State Department of Transportation by Pacific International Engineering. The latest report, number 18, was published in September 2000.

\section{ACKNOWLEDGEMENTS}

We appreciate the technical collaboration and good working relationships with individuals in the coastal communities of Southwest Washington, and in the Corps of Engineers' Seattle District, Navigation Section, and the Engineer Research and Development Center, Waterways Experiment Station. We have all benefited from the support for the work and the analysis offered from the unique perspective of each.

\section{REFERENCES}

Hands, E.B. this volume. Linking equatorial SST and hydrodynamics off SW Washington, USA, Southwest Washington Coastal Erosion Workshop Report 2000, U.S. Geological Survey Open-File Report. 


\title{
LINKING EQUATORIAL SST AND HYDRODYNAMICS OFF SW WASHINGTON, USA
}

\author{
Edward B. Hands, U.S. Army Engineer Waterways Experiment Station, Coastal and \\ Hydraulics Laboratory
}

\section{CONCLUSIONS}

At the entrance to Willapa Bay, 10 large-scale channel migration episodes occurred over the last 148 years. All began during El Niños. Entrance shoal breaching and initiation of new channel migration trends are evidently more likely during El Niño episodes, but why? Sea surface temperature (SST) in the southeastern Pacific is a widely cited index to El Niños (Figure 1). When SST was warm south of the equator, storm frequency and duration tended to increase off Willapa Bay (Table 1), sea level was higher, waves tended to be larger and more powerful, and wind stress stronger (Figures 2 and 3). Wind and wave vectors also tended to shift slightly south of shore normal. An increase in longshore transport potential toward the north was especially evident during the 1997-98 El Niño (Figure 2). Perturbations in wave parameters were identifiable in measurements from several buoys, but were not discernible in the 20-yr hindcast record. Mean sea level tended to rise and then return to normal during El Niños, and also to fall and return to normal during La Niñas. These and other related processes revealed varying degrees of correlation with SST and therefore El Niño. In contrast, freshwater discharge into Willapa Bay showed no correlation with El Niño (Figure 3).

These empirical correlations which show subtle, but measurable, El Niño components buried in several coastal processes strengthen the hypothesis that long-term climate cycles can trigger major disruptions in channel trends and shoal morphology.

\section{ACCOMPLISHMENTS AND ANALYSIS}

Wave, wind, water level, and stream runoff data were assembled from multiple stations relevant to sediment transport variations at the Willapa Bay entrance. Transport processes presumably respond synchronously with El Niño based on the correlation of El Niño with major geomorphic changes on the Willapa ebb shoal. Four transport-related processes were converted to about 40 hydrodynamic and wind parameters. A procedure was developed to initially screen all 40 parameters by subjecting them to identical analysis regardless of differences in measurement frequency, completeness, dimension, or duration, while allowing for flexibility to focus on either common or storm conditions during each month. This procedure benefits from the robustness with which percentiles represent distributions that may be incomplete or contaminated with spikes.

Some indications of spatial coherence and intergage confirmation were obtained by comparing data from several stations for each transport process. Wind and hydrodynamic forces fluctuate widely on many time scales. The channel cycle that motivated this investigation ranged from 5 to 27 years in duration, based on annual hydrographic 
surveys, but El Niño perturbations at the latitude of Willapa Bay can be briefer than 1 year. Perturbations lasting less than several weeks, however, probably do not contribute to channel instability. Therefore, monthly intervals were adopted as a reasonable frequency for representing perturbations in transport processes. Representative monthly values for all of these processes have strong seasonal variations. To examine longer-term correlations with SST, process measurements were converted to anomalies by removing their estimated seasonal variations. The median, or 50th percentile, anomaly was chosen to represent typical monthly conditions of runoff, water level, and SST. The 95th percentile was chosen to represent the storm conditions for monthly wind and wave anomalies.

\section{QUESTIONS}

Monthly anomalies of local parameters are occasionally synchronized with subequatorial SST during El Niño-Southern Oscillation (ENSO) extremes. Water level anomalies have the highest correlation. El Niño periods are clearly stormier. None of the local parameters, however, are so distinctly correlated to SST as to stand out as the exclusive process explaining how El Niños trigger channel instabilities.

Modeling may help determine which combination of processes really triggers ebb shoal breaching and channel switching. Greater correlation between transport processes and climate could be obtained if one of the North Pacific climate indices were substituted for southern hemisphere SST. The correlation could also be increased by restricting analysis to a subset of the data representative of times when the climate cycle is strong and large quantities of sediment are moving (e.g., winter months during extremes in the climate cycle). Usually, local processes are not correlated with Southern Hemisphere SST, which makes the present results based on the uncensored data relatively convincing as to the existence of a episodic climate link, but unclear as to the specific mechanism. Additional analyses, e.g., contingency testing and empirical orthogonal functions, may clarify the linkage. Quantification of channel geometry and hydrodynamics during documented breaches is needed to determine the range of channel conditions susceptible to the El Niño-triggered disruption of long-term trends. This would provide the basis for predicting ebb-shoal breaching and thereby improve management of the channel.

Table 1. Storms $(H>6 \mathrm{~m} \& T>9 \mathrm{sec})$ identified in the merged data from CDIP-03601, NDBC46029 , and NDBC-46010 wave gages.

\begin{tabular}{lcccc}
\hline \hline ENSO Phase & $\begin{array}{l}\text { No. of Episodes } \\
1950 \text { to } 2000\end{array}$ & No. of Storms & $\begin{array}{l}\text { Normalized Frequency } \\
\text { of Storms by Phase }\end{array}$ & $\begin{array}{l}\text { Ave. }{ }^{*} \text { Storm Duration, } \\
\text { hours }\end{array}$ \\
\hline El Niño & $\mathbf{5}$ & $\mathbf{6 1}$ & $\mathbf{2 . 2}$ & $\mathbf{1 5 . 1}$ \\
Neutral & $\mathbf{8}$ & $\mathbf{7 6}$ & $\mathbf{1}$ & $\mathbf{1 1 . 8}$ \\
La Niña & $\mathbf{1 7}$ & $\mathbf{1 7}$ & $\mathbf{1 . 2}$ & $\mathbf{1 1 . 1}$ \\
Total & $\mathbf{1 7}$ & $\mathbf{1 5 4}$ & -- & $\mathbf{3 7 . 9}$ \\
* Third decimal place easily justified by the large number of storms whose individual durations are known \\
to the nearest hour.
\end{tabular}




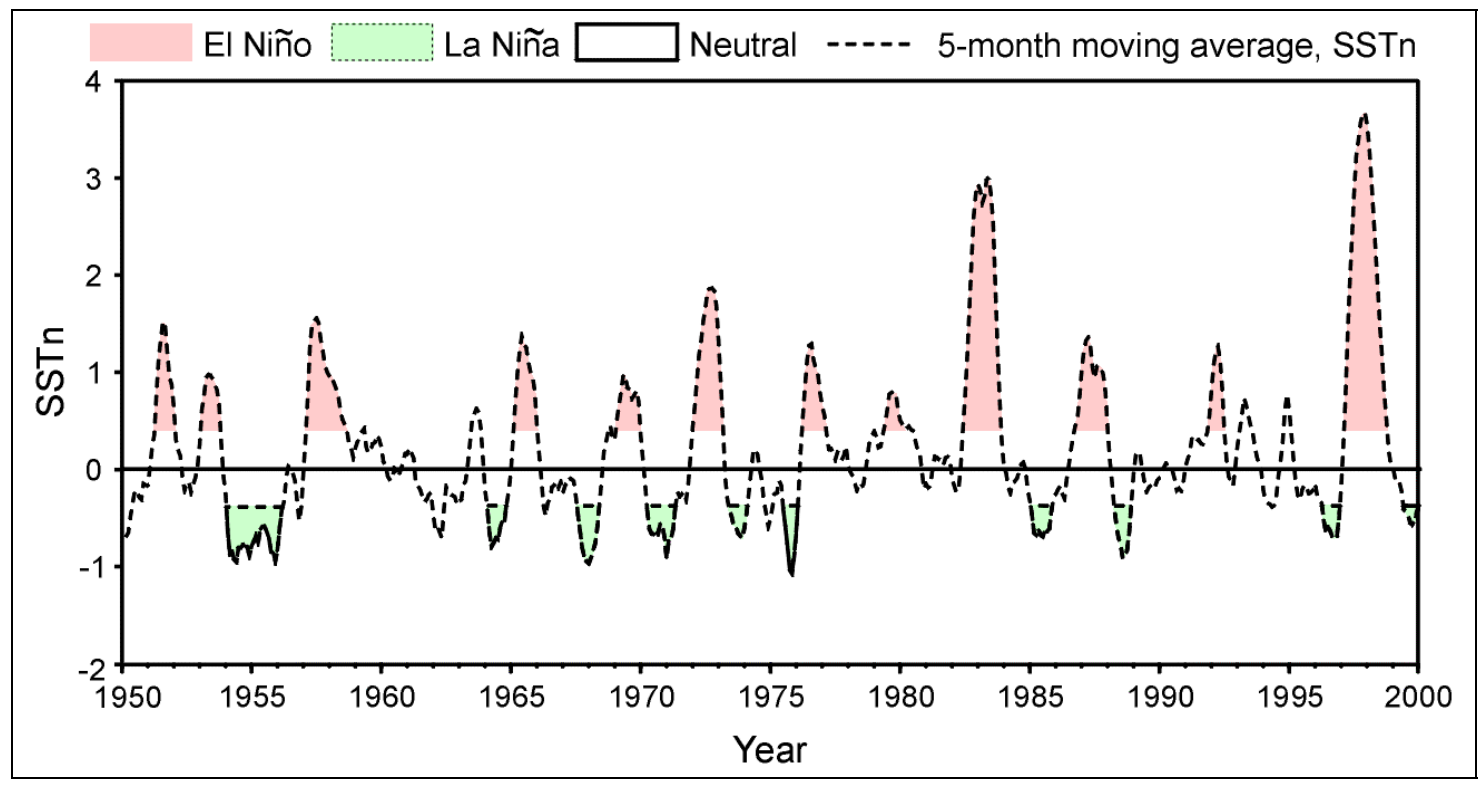

Figure 1. SST anomalies define EI Niño and La Niña phases. 

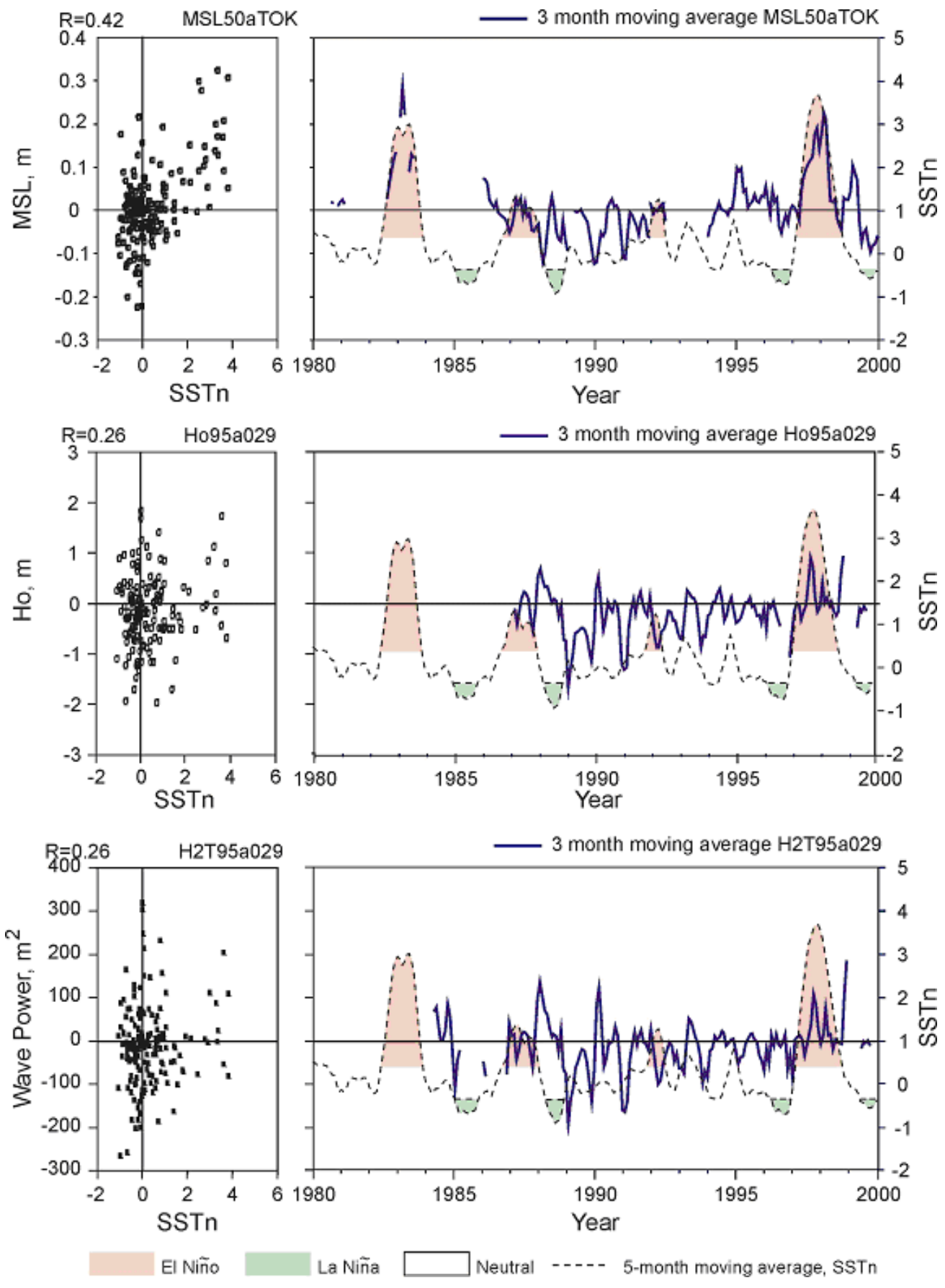

Figure 2. Anomalies in sea level, wave height, and wave energy flux, reveal some positive correlations with SST anomalies. 

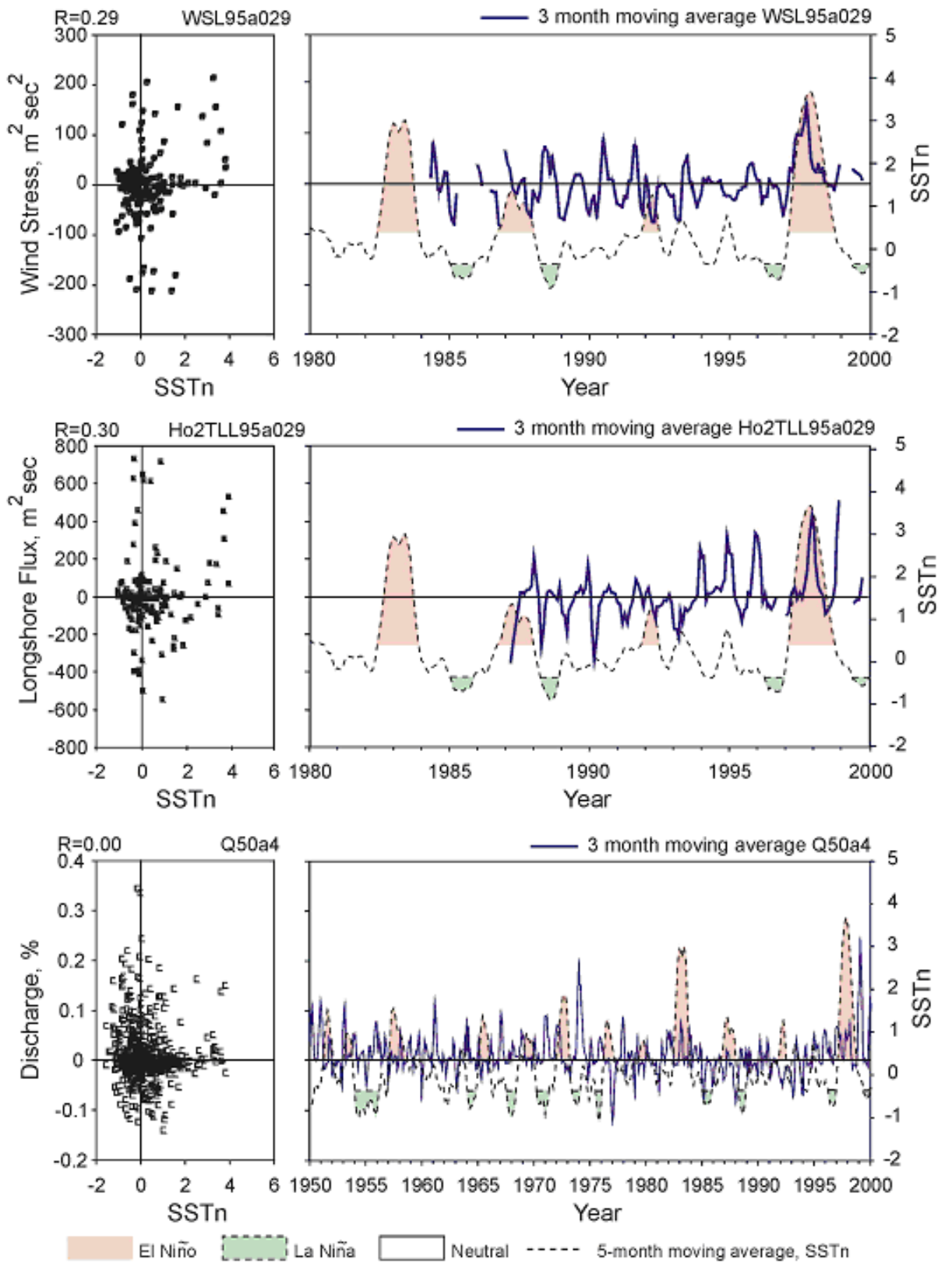

Figure 3. Anomalies in the wind stress and the longshore component of dominant wave energy flux (north positive, south negative) also show some correlation with SST, but fresh water discharge into Willapa Bay does not. 


\title{
EVIDENCE OF LARGE-SCALE, LONG-TERM CYCLES OF BEACH DEPOSITION AND EROSION, NORTH WILLAPA BAY
}

\author{
Robert A. Morton, U.S. Geological Survey \\ Noreen Purcell, U.S. Geological Survey \\ David Qualman, Portland State University \\ Jeff Heeren, Portland State University
}

\section{ABSTRACT}

The primary purposes of this study were to determine the periods of optimum beach sand transport and storage in north Willapa Bay, and to reconstruct the late Holocene geologic history of the area. Key scientific issues relate to the timing and conditions that cause (1) large-scale lateral migration of the entrance channel, (2) sediment redistribution at the mouth of the bay, and (3) transfer of sand to tidal flats within the bay. Some unanswered questions are: What paleo-climatic or oceanographic conditions promoted southerly transport and deposition of sand at the entrance to Willapa Bay?, and Have threshold conditions been surpassed so that the entrance channel at North Cove will erode beyond its previous northerly limit?

To answer those and other questions, 26 field sites were selected to obtain shallow $(<6 \mathrm{~m})$ hand auger cores and vibracores. In addition, about 50 water-well and borehole records were examined to determine the gross lithologic units underlying Tokeland Spit and Washaway Beach at moderate depths $(30-60 \mathrm{~m})$. Historical maps and aerial photographs were also examined to understand the morphological changes in the vicinity of North Cove and Empire Spit as Cape Shoalwater retreated.

Preliminary results of the study are: (1) The modern shoreline and the mid-Holocene shoreline of maximum transgression delineate a wedge of sediment that decreases in width northward from the Columbia River to the Copalis River, which represents a pivot point. At the present highstand in sea level, most of the sand from the Columbia River deposited in beach and estuarine environments is in the Long Beach Peninsula-Willapa Bay complex. Progressively less sand from the Columbia is available for beach construction and estuarine fill northward to the mouth of the Copalis River, where the beach abuts against the upland sea cliffs, and the shoreline of maximum transgression still has not reached its landward limit. (2) Morphological and sedimentological evidence indicates that both Kindred Island and Tokeland Spit are beach deposits without significant dune ornamentation. (3) The dense marsh in the North Cove embayment is a recent product of vegetation colonization and mud aggradation. These processes accelerated as the precursors of Empire Spit formed about 1928. Mud beneath the modern North Cove marsh extends to depths well below mean low water. The stratigraphic position of this mud section suggests that it is probably the fill (upward fining succession) of the abandoned entrance channel. (4) Local sinking of the tide gauge at Tokeland is not a reasonable explanation for the recorded relative rise in sea level. From a geological perspective, the gauge record should be valid and the most accurate source of fluctuations 
and trends in water level for the past few decades. Like other gauges around the world, the historical rate of sea-level rise at the Tokeland gauge $(\sim 2.8 \mathrm{~mm} / \mathrm{yr}$, Ann Gibbs, personal comm., 2000) greatly exceeds the geological rate of sea level rise. 


\section{RECENT SEA-LEVEL HISTORY IN THE CRLC AS DETECTED FROM TIDE GAUGE RECORDS}

Ann E. Gibbs, U.S. Geological, Survey

Holly F. Ryan, U.S. Geological Survey

\section{CONCLUSIONS}

1) Correlation between tidal components as recorded at Tongue Point, Astoria and Toke Point, Tokeland (Willapa Bay) is high, suggesting both gauges are stable and measuring similar physical conditions. Mean Sea Level (MSL) is, on average, 8-cm higher at Toke Point relative to the Astoria station.

2) The long-term trend of relative sea-level rise (RSLR), as indicated by the tide gauge at Astoria (1925 to 2000), is $-0.01 \mathrm{~cm} / \mathrm{yr}$. Between 1925 and 1977, the trend of RSLR at Astoria averaged $-0.19 \mathrm{~cm} / \mathrm{yr}$, but increased to $+0.24 \mathrm{~cm} / \mathrm{yr}$ between 1977 and 2000 . This rate is the same as the RSLR measured at Toke Point between 1977 and 2000 (Figures 1 and 2).

3) This apparent increase in the rate of RSLR corresponds to the 1977 (positive) polarity reversal in the Pacific Decadal Oscillation (PDO) and associated warming of ocean waters along the West Coast of North America (e.g., Mantua et al., 1997). Similar changes in RSLR were not observed during the previous (negative) polarity reversal in 1947.

4) Preliminary trend analysis of individual tidal components suggests the overall tidal range has increased at Astoria since 1925, along with relative elevations of mean high water (MHW) and mean higher high water (MHHW). Relative elevations of mean low water (MLW) and mean lower low water (MLLW) have decreased. Similar trends are also observed at stations around the U.S. and Pacific Islands (Flick et al., 1999; Figure 3).

5) Up to $60 \mathrm{~cm}$ excursions of MSL from the annual mean are observed at both Astoria and Toke Point stations. Positive excursions are commonly coincident with El Niño years, while negative and low excursions tend to be coincident with La Niña years (Figure 4).

\section{ACCOMPLISHMENTS}

- Preliminary analysis of monthly means of tidal constituents for Tongue Point and Toke Point have been completed.

- Hourly water levels between 1925 and 2000 for Astoria have been obtained in digital format. 
- Hourly water levels between 1925 and 2000 for Toke Point have been obtained in analog and digital format.

\section{QUESTIONS}

1) What is the influence of river discharge on water levels at Astoria (timing, volume, magnitude)?

2) Can we expect RSLR to continue at the current rate, or will the postulated negative shift in the PDO in 1999 reduce/change that rate?

3) What is the relative importance of seasonal excursions in the water level (e.g., El Niño/ La Niña) versus long-term sea-level rise?

4) What are the causes of the apparent rise in the mean elevation of high water? The decrease in low-water or tidal-range? Can we identify other trends in the data?

\section{ANALYSIS}

Monthly mean sea level (MSL) values at Tongue Point (hereafter referred to as Astoria) were derived from hourly water level data referenced to the MLLW datum (1960-1978 epoch) established at Astoria, the reference station for the region. Monthly MSL at Toke Point, and means of other tidal components at both Astoria and Toke Point (e.g., MHW, MHHW, MLW, MLLW), were obtained from the NOAA, NOS, CO-OPS web site. These data were obtained relative to both the individual station datum and the Astoria MLLW datum. The station datum at Astoria is $0.713-\mathrm{m}$ lower than the MLLW datum. The station datum at Toke Point is 1.403-m lower than the MLLW datum.

The Astoria tide gauge record extends back to 1925 and is mostly complete, except for a period between August 1945 and 1946. The Toke Point gauge initially started recording in October 1968. Because of questionable/inconsistent vertical datum references between 1968 and 1970, and the lack of any data between 1970 and 1973, only data acquired after 1973 were included in our data set.

The annual mean of MSL at each station was removed from the data set in order to allow direct comparison between the two stations, to show the monthly deviation from the annual mean, and to more easily identify water level excursions not related to seasonal cycles (Figure 3). The annual means for Toke Point (1973-2000), Astoria (1925-2000), and Astoria (1973-2000; coincident years relative to Toke Point) are presented in Figure 5. Note that monthly MSL at Toke Point is higher (mean 8-cm) than at Astoria. There is also an excursion from a symmetrical curve at Astoria between April and August. This excursion may be a response to spring freshets on the Columbia River, which have likely decreased in magnitude as a result of dam emplacement and/or climate change. 


\section{REFERENCES}

Flick, R.E., Murray, J.F., and Ewing, L.C. 1999. Trends in U.S. Tidal datum statistics and tide range; A data report atlas, SIO Reference Series No. 99-20.

Mantua, N.J., Hare, S.R., Zhang, Y., Wallace, J.M., and Francis, R.C. 1997. A Pacific interdecadal climate oscillation with impacts on salmon production, Bulletin of the American Meteorological Society, 78(6), pp. 1069-1079.
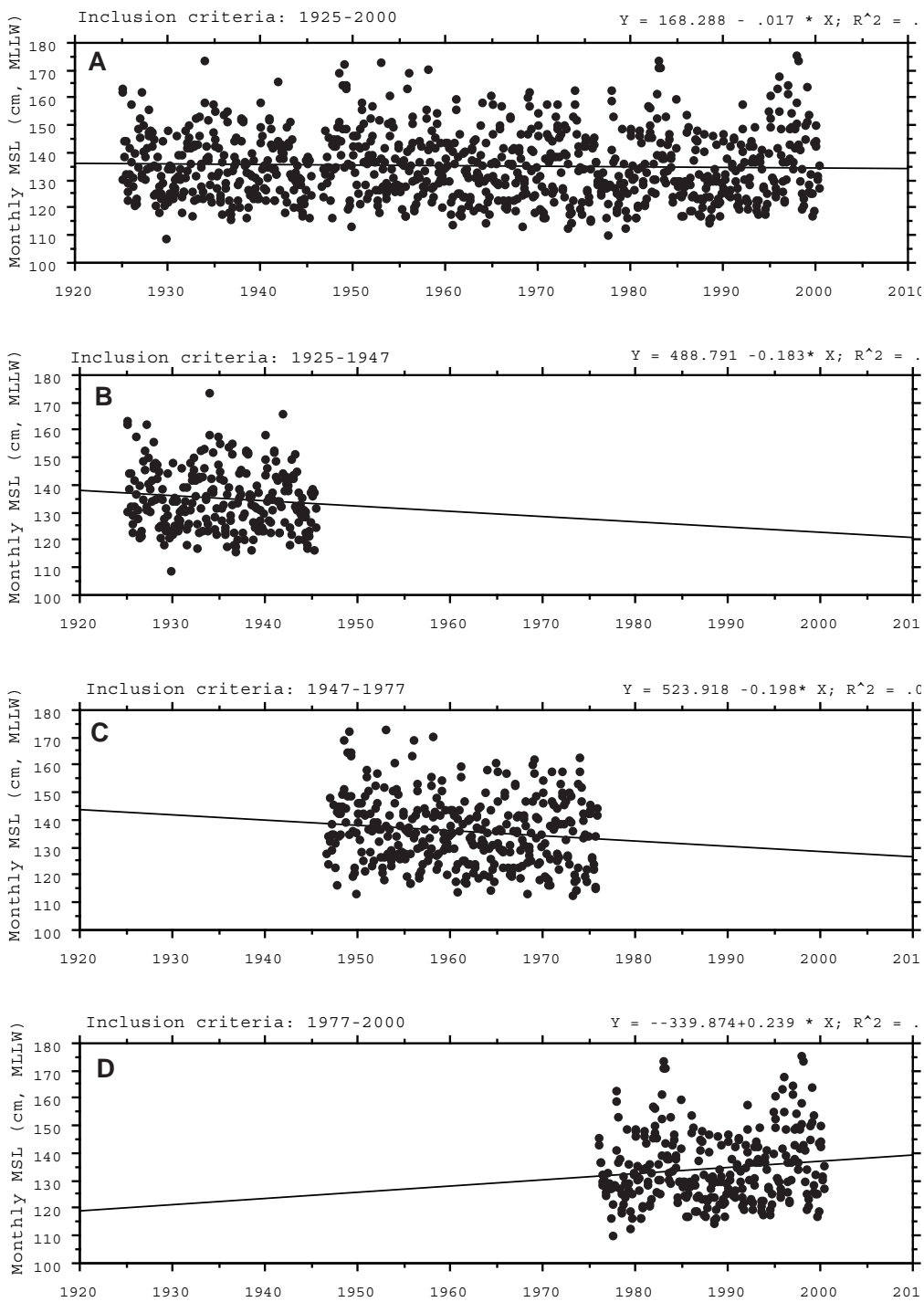

Figure 1. Monthly mean sea level elevation and rates of relative sea-level rise as measured at Tongue Point, Astoria. A) $\mathbf{- 0 . 0 1 7} \mathrm{cm} / \mathrm{yr}$ over the entire record length (1925 to 2000);

B) $-0.183 \mathrm{~cm} / \mathrm{yr}$ from 1925 to 1947 ; C) -0.198 from 1947 to 1977 ; and D) +0.239 from 1977 to 2000. The time divisions correspond to reversals in the polarity of the Pacific Decadal Oscillation (PDO). 


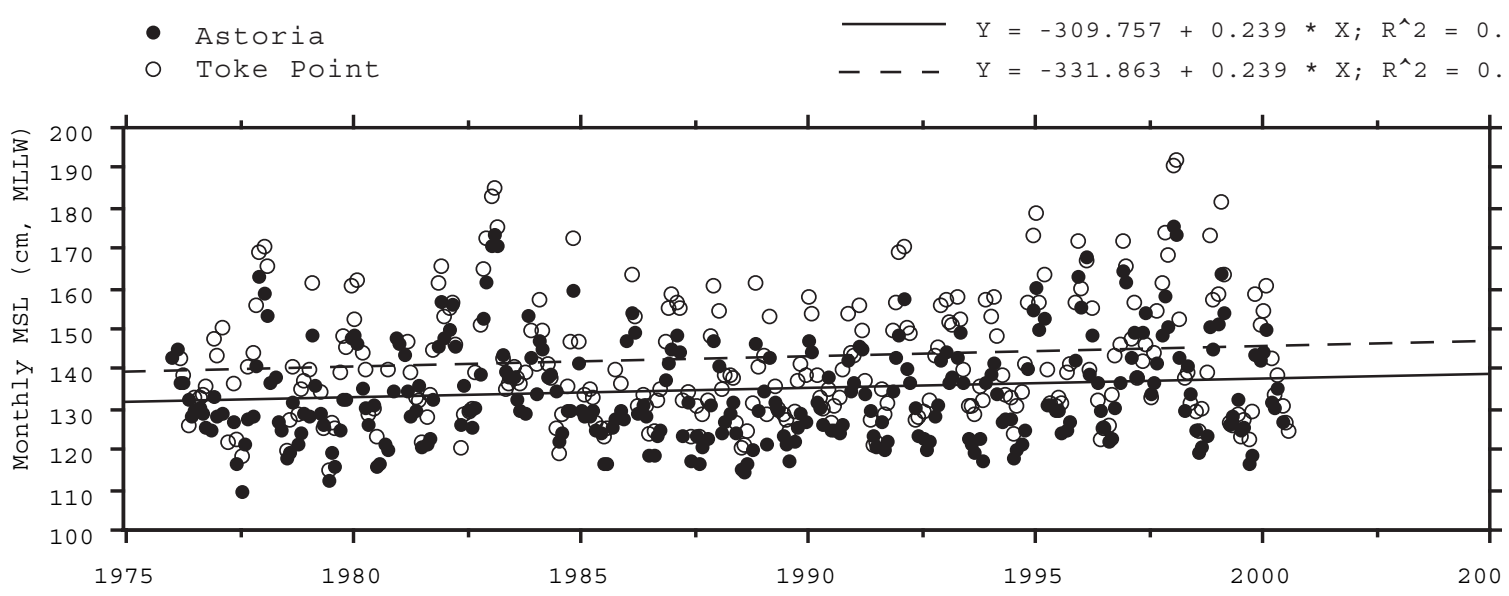

Figure 2. Monthly mean sea level elevation and rates of relative sea-level rise as measured at Tongue Point, Astoria and Toke Point, Tokeland (Willapa Bay), between 1977 and 2000. Note that the rate of relative sea-level rise is identical for both records $(+0.239 \mathrm{~cm} / \mathrm{yr})$, although the elevation of Toke Point MSL is about 8-cm higher. 

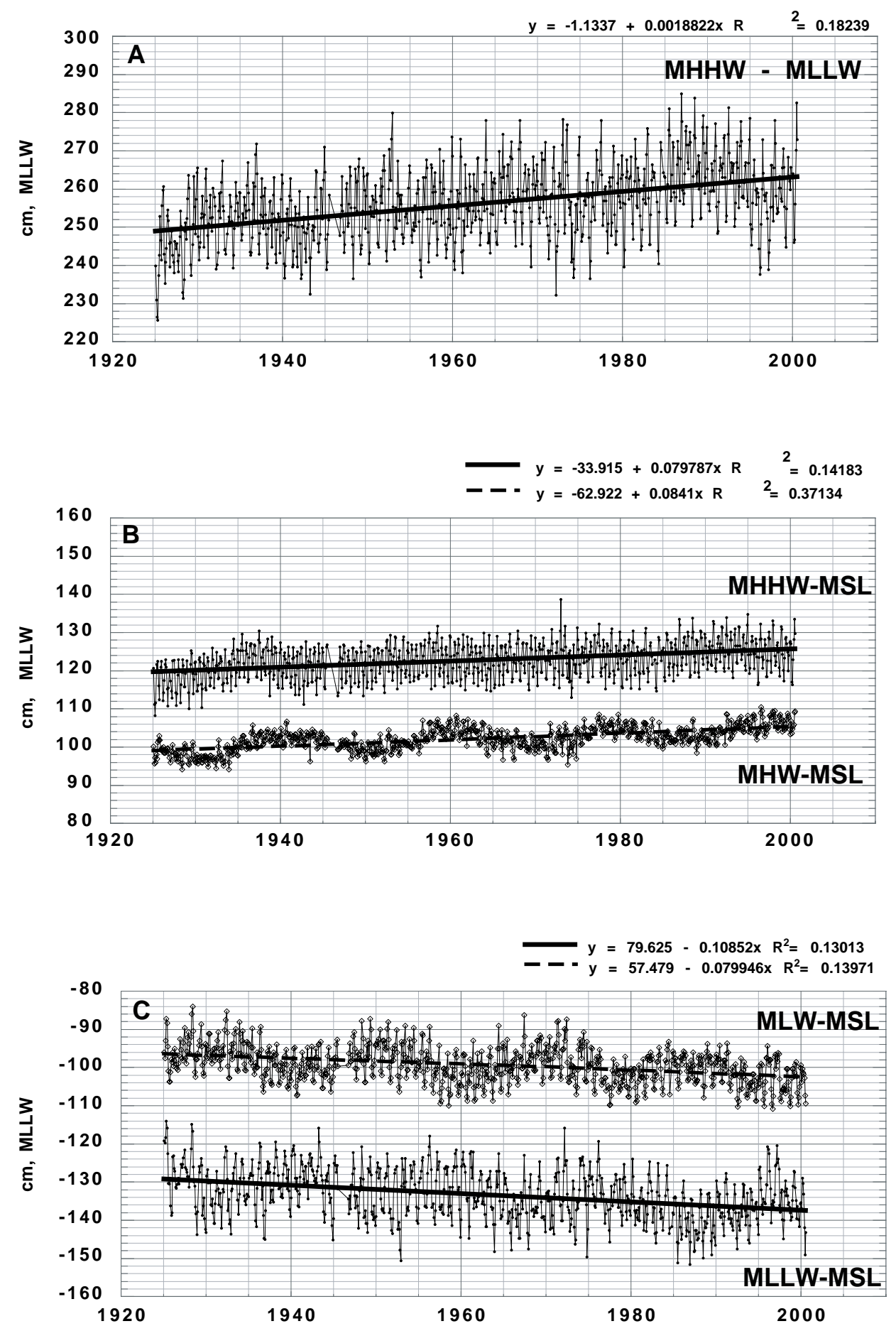

Figure 3. Monthly mean values of A) MHHW-MLLW (tidal range); B) MHHW and MHW minus the long-term trend in sea-level rise; and C) MLLW and MLW minus the long-term trend in sea-level rise at Tongue Point, Astoria. Note that the tidal range and high water are increasing, while low water is decreasing. The 18.6-year lunar nodal cycle is also apparent in these tidal components. 

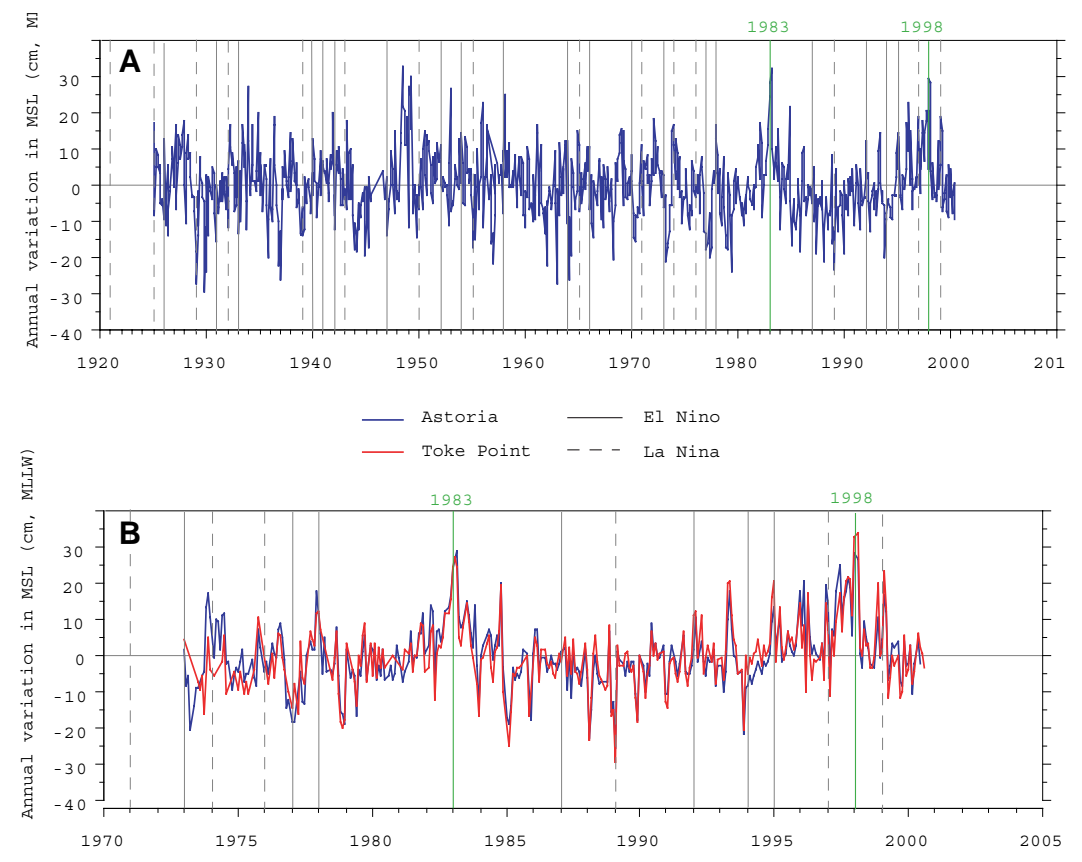

Figure 4. Monthly excursion from annual MSL (monthly means with annual mean removed) for A) Tongue Point Astoria, 1925 to 2000; and B) Astoria and Toke Point, 1973 to 2000. Note that positive excursions from the mean are commonly associated with EI Niño years, while negative or small excursions coincide with La Niña years. 


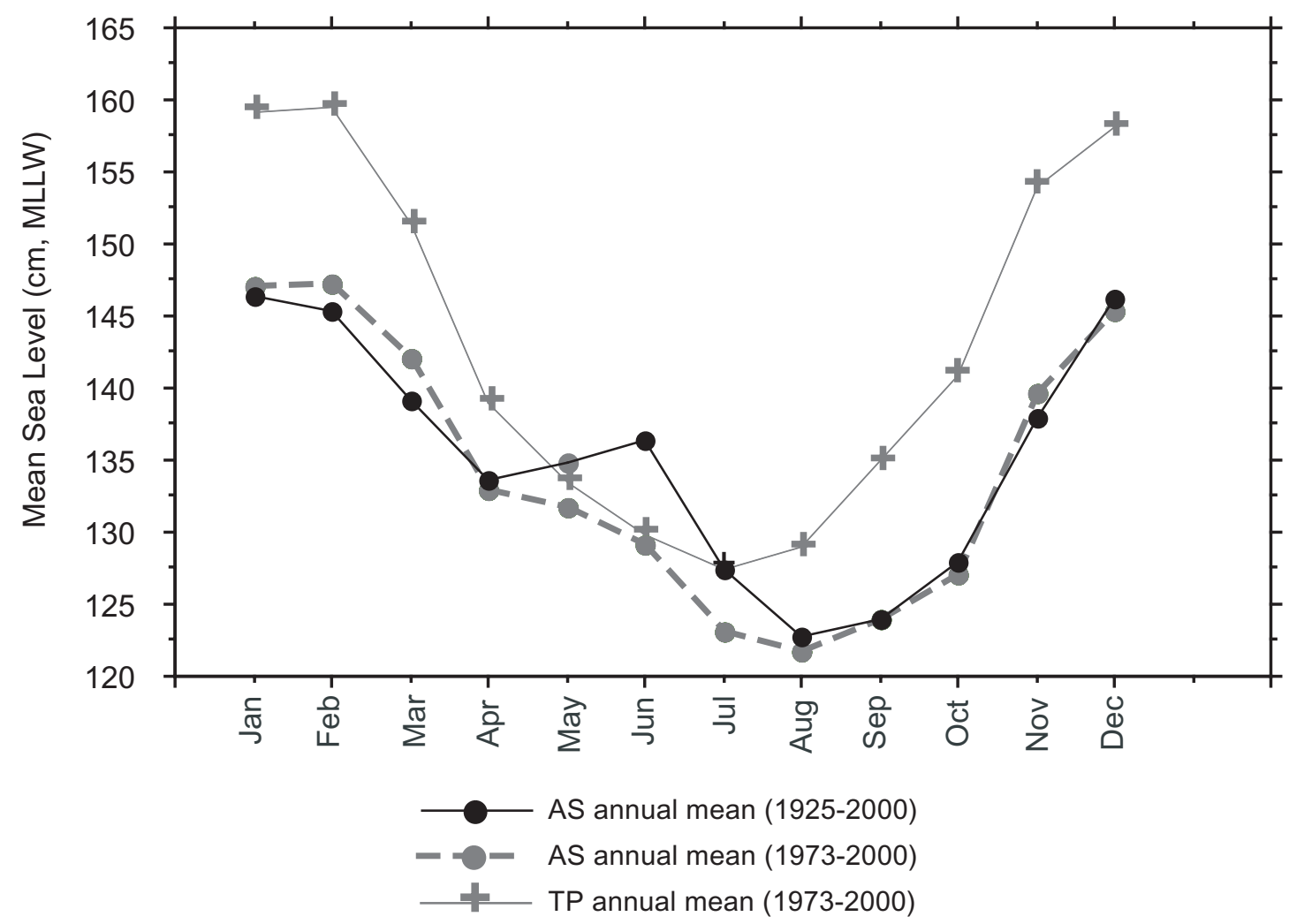

Figure 5. The annual cycle, or monthly mean of MSL, at Toke Point (1973-2000), Astoria (1973-2000), and Astoria (1925-2000). Note that monthly MSL at Toke Point is higher (mean $8-\mathrm{cm}$ ) than at Astoria. There is also an excursion from a symmetrical curve at Astoria, between April and August. This excursion may be a response to spring freshets on the Columbia River, which have likely decreased in magnitude as a result of dam emplacement and/or climate change. 


\section{VALIDATION OF NUMERICAL MODELS: GRAYS HARBOR, WASHINGTON}

Mary A. Cialone, U.S. Army Engineer Research and Development Center, Coastal and Hydraulics Laboratory

Nicholas C. Kraus, U.S. Army Engineer Research and Development Center, Coastal and Hydraulics Laboratory

Hiram T. Arden, U.S. Army Engineer District

Robert M. Parry, U.S. Army Engineer District

David B. Hericks, Pacific International Engineering

\section{CONCLUSIONS}

As part of a U.S. Army Corps of Engineers navigation study, field data were collected at seven locations extending from seaward of Grays Harbor and through the entrance to record surface wave propagation and current through the inlet (Figure 1). These measurements captured tidal flow and change of water level by tide and wind, as well as wave transformation through the inlet and into the bay. Waves and currents transport sediment into the navigation channel and over oyster-grounds leasing areas. Numerical models of waves and currents were also established for the entrance and bay at Grays Harbor. This abstract describes wave and current measurements and model simulations to examine surface wave propagation through the inlet, including the modification of the waves by the tidal current and water level.

\section{ACCOMPLISHMENTS}

The data-collection program consisted of: 1) bathymetry surveys in the offshore and along maintained and natural channels, 2) a Light Detection and Ranging (LIDAR) survey and controlled aerial photography of land and tidal flats during low tide in the bay,

3) measurement of water level at five locations around the periphery of the bay, wind and barometric pressure on a nearshore tower, and 4) waves, water level, tidal current through the water column, and suspended sediment at seven bottom-residing tripods. The tripod deployment interval of mid-September to mid-November 1999 spanned two lunar months. The tripods were deployed along or near the navigation channel (Figure 1). Stations 1 through 6 extended from the entrance, through the inlet, and into the bay. Each tripod was configured with a SonTek Hydra functioning as a directional wave gauge and an uplooking 1,500-kHz acoustic-Doppler profiler (ADP) (Figure 2). The Hydras contained a down-looking acoustic-Doppler velocimeter Ocean Probe, a high-resolution resonant pressure transducer, and two optical backscatterence sensors. This instrument suite documented the waves, current near the bottom, water level, current through the water column in $0.5-\mathrm{m}$ bins, and the suspended-sediment concentration through the inlet entrance. Station 0 (the seaward-most location) was configured with an Ocean Probe and an RDI Sentinel acoustic Doppler current profiler (ADCP) with directional wave-spectra firmware to determine if comparable data are derived from the two different measurement methods. Three tidal cycles of the velocity profile obtained by the ADP at Station 1 are shown in Figure 3, with maximum current speed of $170 \mathrm{~cm} / \mathrm{sec}$. The measurements are 
documented in the final data report "Grays Harbor Estuary Physical Dynamics Study, Final Data Report: Sep. 11, 1999-Nov. 17, 1999," produced by Pacific International Engineering (Hericks and Simpson, 2000).

Computational grids were developed for the tidal circulation model ADCIRC (Luettich et al., 1992) and the spectral wave model STWAVE (Smith et al., 1999). Representation of the significant flooding and drying in Grays Harbor was necessary in this study, and the ADCIRC model performed well. STWAVE computes nearshore wind-wave growth and propagation. The Grays Harbor data set provides an opportunity to rigorously examine representation of the wave-current interaction through the wave-action equation, currentinduced breaking, wave blocking by a current, and diffraction. Coupling of the two models requires exchange of the wave radiation stresses and other information in an iterative approach performed through a steering module.

\section{QUESTIONS}

Research questions that require further study include the significance of wave-current interaction in an inlet environment for varying physical conditions. For example, how do tide range, water level, current speed, wave height, period, direction, jetty permeability, and diffraction modify the current and the wave-current interaction for practical engineering calculations?

\section{ANALYSIS}

Evaluation of model performance is ongoing. Comparison between measurements for the first month of field data collection and calculations of wave height with the STWAVE model at Inlet Station 2 (see Figure 1) shows good agreement (Figure 4). Results at other stations are of similar quality. Comparison between measurements for the first month of field data collection and calculations of water level at Bay Station 2 (see Figure 1) shows good agreement (Figure 5).

\section{ACKNOWLEDGEMENTS}

Permission was granted by Headquarters, U.S. Army Corps of Engineers (USACE), to publish this information. This work was supported by the Seattle District, USACE. The cooperation of instrument manufacturers named in this work is acknowledged, but no endorsement of equipment is implied.

\section{REFERENCES}

Hericks, D.B. and Simpson, D.P. 2000. Grays Harbor Estuary Physical Dynamics Study, Final Data Report: Sep 11, 1999-Nov 17, 1999, Pacific International Engineering, Edmonds, WA.

Luettich, R.A., Westerink, J.J., and Scheffner, N.W. 1992. ADCIRC: An advanced threedimensional circulation model for shelves, coasts, and estuaries; Report 1, Theory 
and methodology of ADCIRC-2DDI and ADCIRC-3DL, Technical Report DRP92-6, U.S. Army Engineer Waterways Experiment Station, Vicksburg, MS, USA.

Smith, J.M., Resio, D.T., and Zundel, A.K. 1999. STWAVE: Steady-State Spectral Wave Model, Report 1, User's Manual for STWAVE Version 2.0.

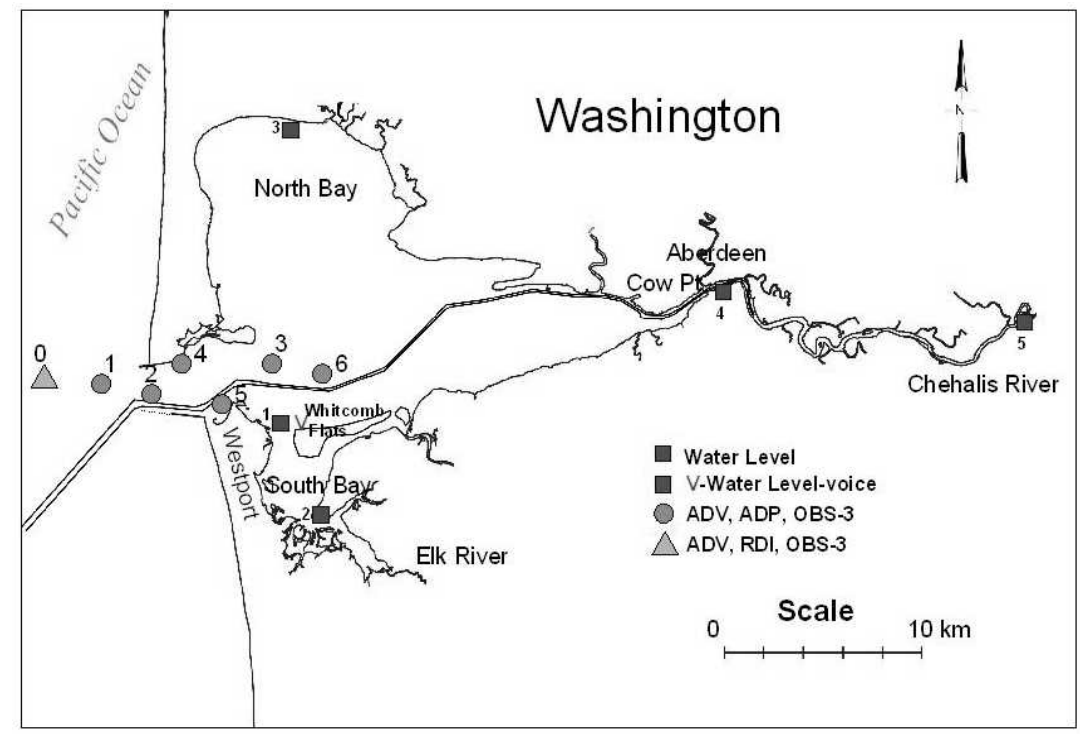

Figure 1. Measurement station location map. 


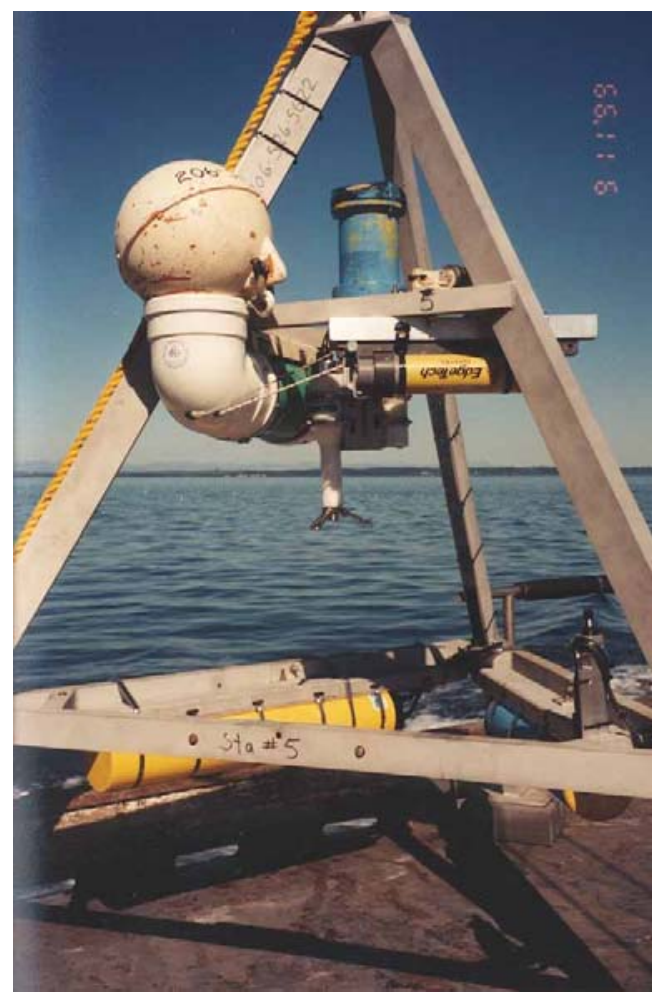

Figure 2. Tripod configuration.

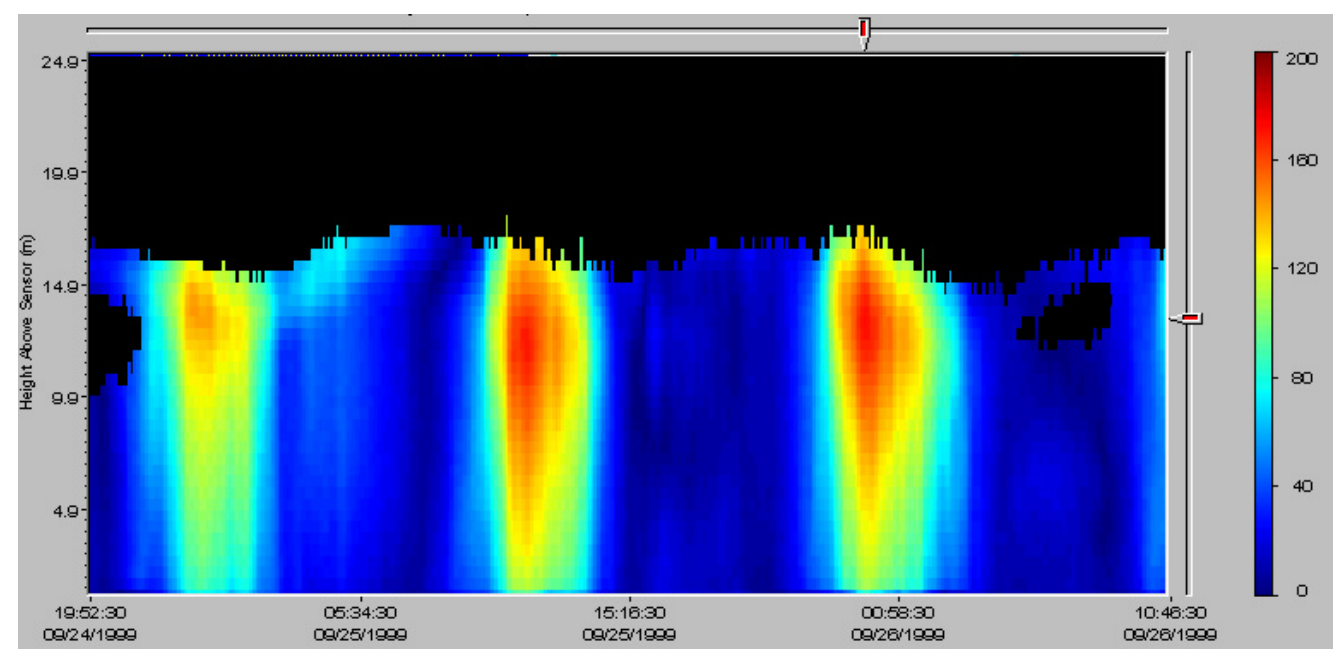

Figure 3. ADP Station 1 sample output of current speed $(\mathrm{cm} / \mathrm{sec})$ for three tidal cycles. 


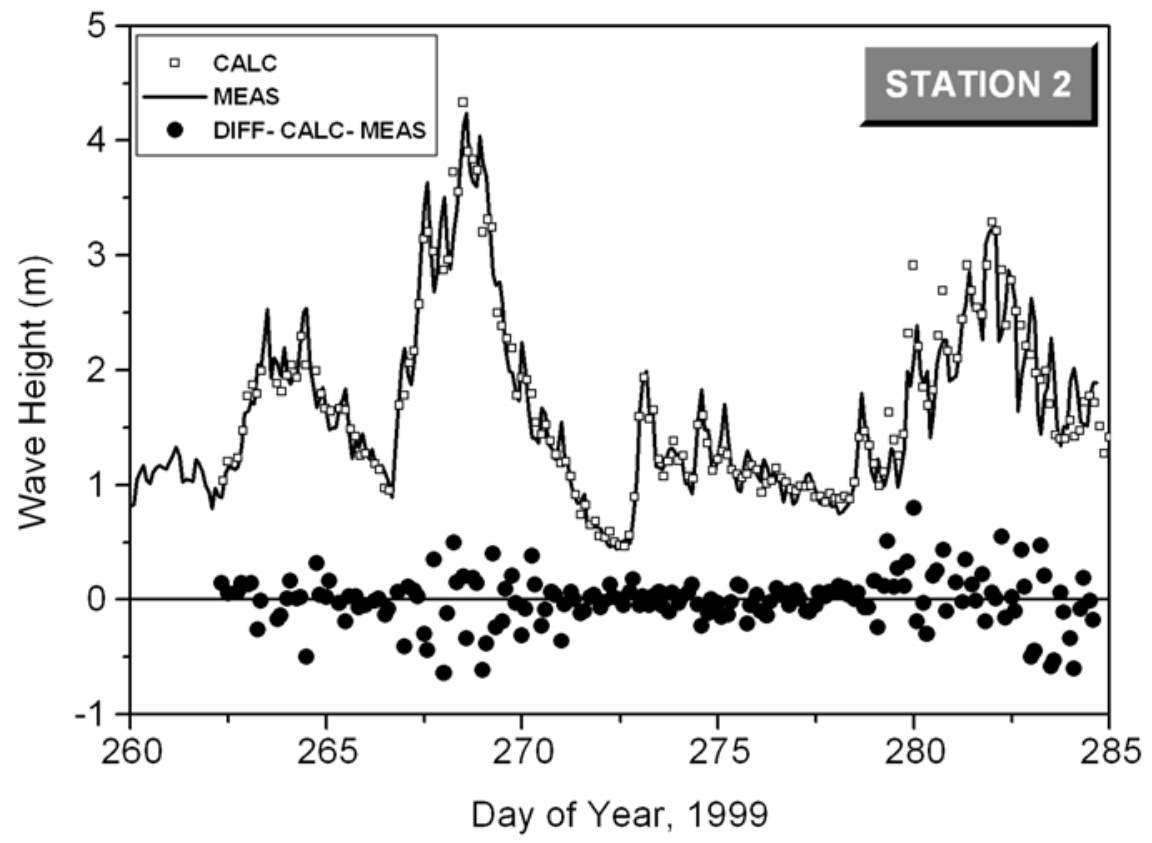

Figure 4. Measurement and calculation of wave transformation at Inlet Station 2.

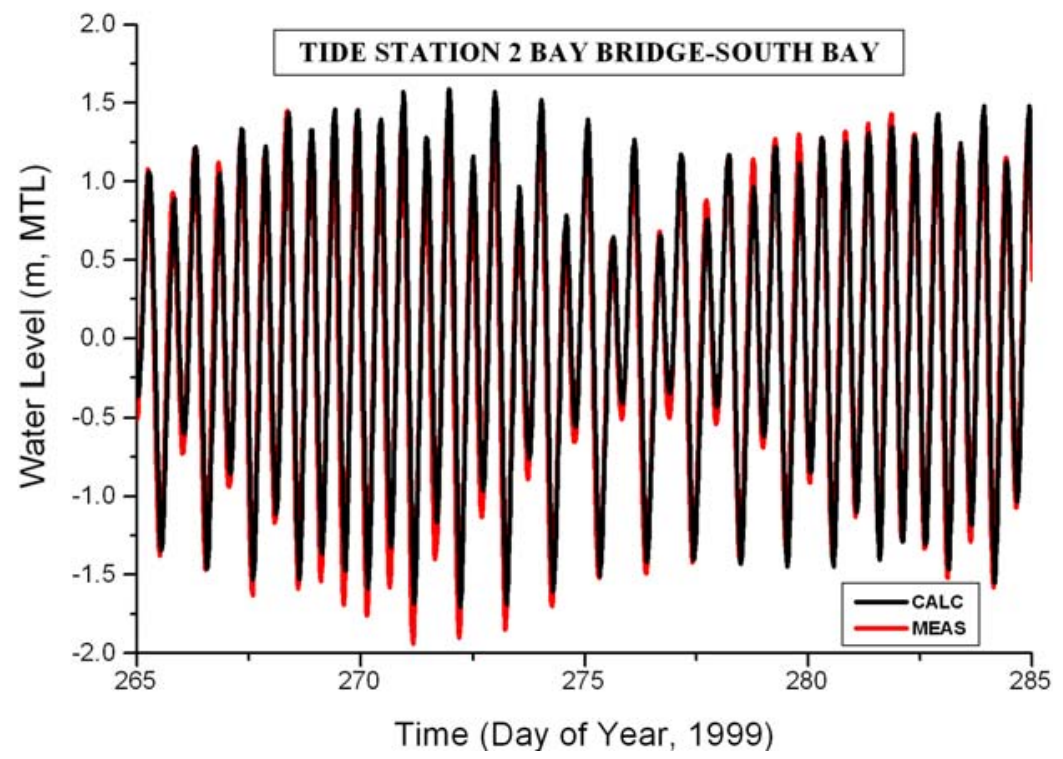

Figure 5. Measurement and calculation of water level at Bay Station 2. 


\title{
THE RELATION BETWEEN JETTY CONSTRUCTION/REHABILITATION AND SHORELINE CHANGE AT THE ENTRANCE TO GRAYS HARBOR
}

\author{
Maarten Buijsman, Washington Department of Ecology
}

\section{CONCLUSIONS}

1) The length and height of the jetties at the entrance to Grays Harbor and the availability of sand appear to determine the shoreline response near the entrance.

2) Compared to jetty construction, deterioration and subsequent rehabilitation of the jetties resulted in smaller changes of the bar and adjacent shoreline.

3) During the rehabilitations in the 1930s and 1940s the jetties were raised to $6 \mathrm{~m}$ above mean lower low water (MLLW). The higher jetty heights prevented sand transport across the jetties into the harbor, affecting the spits and beaches.

4) The effects of the second jetty rehabilitation in 1966 and 1976 on the shorelines at both South Beach and North Beach were minimal.

5) Because of the limited offshore source of sand, it is expected that further rehabilitation of the jetties would not result in significant shoreline advance.

\section{ACCOMPLISHMENTS}

A large number of North Beach and Grays Harbor shorelines were digitized from USACE Annual Surveys: 1898, 1900, 1902, 1904, 1906, 1909, 1916, 1923, 1926, 1927, 1929, 1934, 1940, 1941, 1942, 1946, 1948, 1951, 1954, and 1960 (North Beach), and 1898, 1900, 1902, 1904, 1906, 1909, 1916, 1923, 1926, 1927, 1929, 1934, 1940, 1941, 1942, 1946, 1948, 1951, 1954, and 1960 (Grayland).

All work presented in this abstract will be presented in the USGS-DOE Factsheet: "Jetty Construction and Rehabilitation at Grays Harbor, Washington; Do They Cause Shoreline Change?" (in review).

\section{QUESTIONS}

The following research questions remain unanswered:

1) Would a longer North Jetty lead to more accretion of North Beach?

2) In the case of lengthening, what would happen with the outer ebb-tidal delta?

3) How can we further test the hypothesis that the "source of sand" will diminish? 
4) When will the "source of sand" be diminished?

5) Is the shoreline at both sides of the North Jetty and South Jetty in "dynamic equilibrium" (with the jetty)?

\section{ANALYSIS Introduction}

Beach erosion is threatening homes near the entrance to Grays Harbor, a large bay on the Washington coast (Figure 1). The general assumption has been that rehabilitation of two jetties flanking the entrance to Grays Harbor will cause adjacent beaches to accumulate sand (accrete), and that deterioration of the jetties will cause the beaches to lose sand (erode). The validity of this relationship has been investigated by scientists from the Washington Department of Ecology and the USGS as part of the Southwest Washington Coastal Erosion Study (SWCES) in cooperation with the USACE - Seattle District. Jetty rehabilitation is costly (10s of millions of dollars), and this analysis should help coastal communities and the USACE better manage Washington's beaches and resources. Research results indicate that there are at least three key factors that relate jetty rehabilitation to shoreline changes. These factors include the height of the jetty relative to MLLW (mean lower low water, the average height of the lower low waters over a 19-year period), the available sand source, and waves and currents needed to transport available sand. Initially, sand from a large nearshore shoal (bar) enabled the nearby beaches to accrete following jetty construction. However, jetty rehabilitation projects have had successively less impact on the adjacent shorelines because of an overall decrease in the amount of sand available to nourish nearby beaches. It is expected that future rehabilitation of the jetties will not cause significant shoreline advance, since the supply of sand from the bar, that previously provided for shoreline advance, has significantly diminished.

\section{South Jetty construction 1898-1935}

The USACE constructed the South Jetty between May 1898 and September 1902 to improve navigation across the Grays Harbor bar (see Table 1, the chronology of jetty construction and rehabilitation). The purpose of this jetty was to confine outgoing ebbtidal currents and deepen (scour) the bar and entrance channel. At the time of construction the jetty was 4,200 meters (m) [13,700 feet (ft)] long and had an elevation of $2.4 \mathrm{~m} \mathrm{[8 \textrm {ft } ]}$ above MLLW. In the pre-jetty condition the net movement of sand on the bar was near zero; ebb-tidal currents pushed sand offshore and waves pushed sand onshore. Following construction, the tidal currents were constricted to the entrance channel north of the South Jetty. The ebb-currents scoured the entrance channel and bar, pushing large amounts of sand offshore. South of the South Jetty the balance between waves and currents was disturbed, and waves pushed sand onshore (Figure 2). The South Jetty effectively trapped sand supplied from the bar and from northerly alongshore transport, and the south shoreline began to advance at unprecedented rates (Figure 3a). By 1909 the south shoreline advanced seaward, up to $1,000 \mathrm{~m}[3,300 \mathrm{ft}]$ at a location $400 \mathrm{~m}[1,300 \mathrm{ft}]$ south of the jetty. 
Intense waves and currents began to erode the South Jetty soon after its construction. By 1933 the South Jetty had lowered to an average elevation of 1.5 to $3 \mathrm{~m}$ [5 to $10 \mathrm{ft}$ ] below MLLW over the outer 3,900 $\mathrm{m}[13,000 \mathrm{ft}]$ (the distance between the tip of the jetty and the shoreline position at that time). Between 1909 and 1929 the shoreline within $5 \mathrm{~km}$ [3 miles] south of the South Jetty retreated. At the same time the northern tip of Pt. Chehalis (Figure 1) advanced northward by $350 \mathrm{~m}$ [1,200 ft]. A possible explanation is that the deteriorated jetty with its reduced height allowed currents to pass over the jetty. The currents eroded the beaches to the south, carried sand over the jetty and fed the spit at Pt. Chehalis.

\section{South Jetty 1st rehabilitation 1935-1966}

Rehabilitation of the South Jetty first occurred between August 1935 and May 1940. To prevent currents from passing over the South Jetty, the elevation over the outer 3,900 m $[13,000 \mathrm{ft}]$ was raised to $6 \mathrm{~m}$ [20 ft] above MLLW. In the following two decades the shoreline within 2,000 $\mathrm{m}[6,600 \mathrm{ft}]$ south of the jetty advanced, but the beach farther south remained stable (Figure 3b). After the rehabilitation, the spit at Pt. Chehalis began eroding, and by 1946 Halfmoon Bay began to form (Figure 3, b and c). These observations suggest that the height of the jetty prevented northward transport of sand across the jetty, accreting the beach to the south. North of the jetty, the absence of a supply of sand from the south allowed waves and currents to erode Pt. Chehalis and to form Halfmoon Bay.

The South Jetty deteriorated again, and by 1962 the outer 2,300 m [7,500 ft] had an average elevation of MLLW, whereas the rest of the jetty remained intact. Around 1960, the shoreline within 2,000 $\mathrm{m}[6,600 \mathrm{ft}]$ south of the South Jetty had again begun to retreat.

\section{South Jetty 2nd rehabilitation 1966-present}

In 1966 the $1,200 \mathrm{~m}[4,000 \mathrm{ft}]$ section of the deteriorated jetty closest to the existing

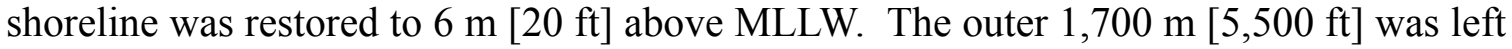
in its degraded condition. The shoreline within $2,000 \mathrm{~m}[6,600 \mathrm{ft}]$ south of the jetty continued to erode, and the shoreline south of that continued to accrete (Figure $3 \mathrm{c}$ ). This pattern of shoreline change suggests that the sediment was moving to the south. The shoreline $5 \mathrm{~km}$ [3 miles] south of the jetty remained relatively stable.

Since 1966 the rehabilitated portion of the South Jetty has remained in good condition. The outer submerged $1,700 \mathrm{~m}[5,500 \mathrm{ft}]$ has continued to deteriorate, reaching depths between 3 and $6 \mathrm{~m}$ [10 and $20 \mathrm{ft}$ ] below MLLW. The inner portion that was exposed by the retreating shoreline continued to deteriorate as well. After 1987, beach erosion within $2,500 \mathrm{~m}[8,200 \mathrm{ft}]$ south of the South Jetty accelerated, whereas the beach continued to accrete farther south. In December 1993 a breach occurred between the ocean and Halfmoon Bay, and the USACE filled the breach and nourished the eroding beach with dredged material in 1994. A March 1999 storm lowered a $60 \mathrm{~m}$ [200 ft] portion of the jetty to approximately $2.7 \mathrm{~m}$ [9 ft] above MLLW and damaged the jetty where it intersected with the shoreline. During the year 2000 rehabilitation, the USACE repaired the South Jetty over a $1,000 \mathrm{~m}[3,300 \mathrm{ft}]$ section seaward of the shoreline. The rehabilitated section has a height of $7 \mathrm{~m}[23 \mathrm{ft}]$ above MLLW. 


\section{North Jetty construction 1908-1941}

To further enhance the scouring effect of the outgoing ebb-tidal currents over the Grays Harbor bar the North Jetty was constructed between May 1908 and January 1916. Its length was 5,200 m [17,200 ft] and, like the South Jetty, it had an initial elevation of $2.4 \mathrm{~m}$ [8 ft] above MLLW. Because of jetty construction, tidal currents were constricted to the entrance channel between the jetties, and waves began eroding the shoals north of the North Jetty. Sand from the eroding shoals was pushed onshore by wave action and was trapped behind the jetty, resulting in massive shoreline advance along North Beach. Most of the accretion occurred directly north of the North Jetty, with the shoreline advancing seaward about 1,700 $\mathrm{m}[5,600 \mathrm{ft}]$ by 1923 . Farther to the north the beaches accreted at a slower rate (Figure 4a).

Following the construction of the North Jetty, waves and currents eroded the jetty. By 1934 the outer $2,400 \mathrm{~m}[8,000 \mathrm{ft}]$ of the North Jetty between the shoreline and the tip of the jetty had lowered to approximately $0.5 \mathrm{~m}[1.5 \mathrm{ft}]$ below MLLW. The shoreline within 2,000 m [6,600 ft] north of the North Jetty retreated between 1923 and 1942, while the shoreline north of this stretch continued to advance. During the same period, a large spit developed in the entrance, extending eastward $1,500 \mathrm{~m}[4,900 \mathrm{ft}]$ into the bay. The shoreline retreat north of the jetty and the rapid growth of the spit support the hypothesis that currents passed over the deteriorated jetty, carrying sand into the inlet. Most likely, this sand eroded from the immediate area north of the jetty to accrete the spit south and east of the jetty.

\section{North Jetty 1st rehabilitation 1941-1976}

The North Jetty was rehabilitated between February 1941 and May 1942 over the most

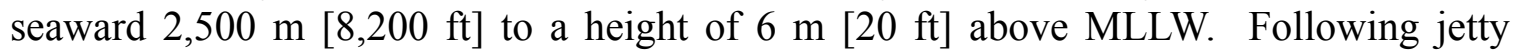
rehabilitation the shoreline within $2,000 \mathrm{~m}[6,500 \mathrm{ft}]$ north of the jetty started to advance again, whereas farther north a trend of moderate accretion continued (Figure $4 \mathrm{~b}$ ). The entrance spit eroded and became an island by 1943. Most likely the increased height of the jetty blocked the transport of sand across the jetty into the inlet, and the beach to the north started to accrete. Lacking any sand supply from the north, waves and currents eroded the spit in the inlet. During the 1950s the shoreline stabilized within 1,500 m $[4,900 \mathrm{ft}]$ north of the jetty. Possibly, the jetty length, in combination with the current and wave conditions, did not allow for more accretion of this stretch, whereas farther north shoreline advance continued, but slowed during the following decades.

The North Jetty once again continued to deteriorate, and by 1974 the section $400 \mathrm{~m}[1,300$ $\mathrm{ft}]$ seaward of the shoreline averaged between 0.9 and $4.3 \mathrm{~m} \mathrm{[3}$ and $14 \mathrm{ft}]$ above MLLW. The jetty seaward of this section deteriorated to below MLLW. The deterioration of the North Jetty did not have any noticeable effects on the regional shoreline change trends.

\section{North Jetty 2nd rehabilitation 1976-present}

During the rehabilitation of the North Jetty in 1976, the inner $1,800 \mathrm{~m}[6,000 \mathrm{ft}]$ of the

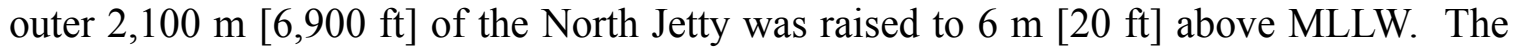
1976 rehabilitation did not significantly affect the shoreline change trends for North Beach 
(Figure 4c). The shoreline remained stable within 2,000 $\mathrm{m}[6,500 \mathrm{ft}]$ north of the jetty, but slow net shoreline advance continued farther north.

A 1996 survey of the North Jetty showed that the section that was rehabilitated in 1976 was still intact. The portion landward of the shoreline was lower than the original construction height, and in some places low-lying gaps permitted wave overtopping. The year 2000 rehabilitation consisted of rehabilitating the portion of the jetty landward of the shoreline to prevent wave overtopping and to limit the risk of coastal flooding. The section seaward of the shoreline was not rehabilitated.

Table 1. Chronology of jetty construction and rehabilitation at the Grays Harbor entrance.

\begin{tabular}{|c|c|c|}
\hline Year & Phase & Characteristics \\
\hline $1898-1902$ & $\begin{array}{l}\text { South Jetty } \\
\text { construction }\end{array}$ & $\begin{array}{l}\text { Length: } 4,200 \mathrm{~m}(13,700 \mathrm{ft}) \text {, height: }+2.4 \mathrm{~m}(8 \mathrm{ft}) \\
\text { MLLW }\end{array}$ \\
\hline $1908-1916$ & $\begin{array}{l}\text { North Jetty } \\
\text { construction }\end{array}$ & $\begin{array}{l}\text { Length: } 5,200 \mathrm{~m}(17,200 \mathrm{ft}) \text {, height: }+2.4 \mathrm{~m}(8 \mathrm{ft}) \\
\text { MLLW }\end{array}$ \\
\hline $1935-1940$ & $\begin{array}{l}\text { South Jetty } \\
\text { rehabilitation }\end{array}$ & $\begin{array}{l}\text { Raised to }+6 \mathrm{~m}(20 \mathrm{ft}) \text { MLLW over outer } 3,900 \mathrm{~m} \\
(13,000 \mathrm{ft})\end{array}$ \\
\hline $1941-1942$ & $\begin{array}{l}\text { North Jetty } \\
\text { rehabilitation }\end{array}$ & $\begin{array}{l}\text { Raised to }+6 \mathrm{~m}(20 \mathrm{ft}) \text { MLLW over inner } 2,500 \mathrm{~m} \\
(8,200 \mathrm{ft}) \text { of outer } 2,700 \mathrm{~m}(8,900 \mathrm{ft})\end{array}$ \\
\hline 1966 & $\begin{array}{l}\text { South Jetty } \\
\text { rehabilitation }\end{array}$ & $\begin{array}{l}\text { Raised to }+6 \mathrm{~m}(20 \mathrm{ft}) \text { MLLW over inner } 1,200 \mathrm{~m} \\
(4,000 \mathrm{ft}) \text { of outer } 2,900 \mathrm{~m}(9,500 \mathrm{ft})\end{array}$ \\
\hline 1976 & $\begin{array}{l}\text { North Jetty } \\
\text { rehabilitation }\end{array}$ & $\begin{array}{l}\text { Raised to }+6 \mathrm{~m}(20 \mathrm{ft}) \text { MLLW over inner } 1,800 \mathrm{~m} \\
(6,000 \mathrm{ft}) \text { of outer } 2,100 \mathrm{~m}(6,900 \mathrm{ft})\end{array}$ \\
\hline 2000 & $\begin{array}{l}\text { South Jetty } \\
\text { rehabilitation }\end{array}$ & $\begin{array}{l}\text { Raised to }+7 \mathrm{~m}(23 \mathrm{ft}) \text { MLLW over inner } 1,000 \mathrm{~m} \\
(3,300 \mathrm{ft}) \text { seaward of } 2000 \text { shoreline position }\end{array}$ \\
\hline 2000 & $\begin{array}{l}\text { North Jetty } \\
\text { rehabilitation }\end{array}$ & $\begin{array}{l}\text { Raised to }+7 \mathrm{~m}(23 \mathrm{ft}) \text { MLLW over } 1,500 \mathrm{~m}(5,000 \mathrm{ft}) \\
\text { landward of } 2000 \text { shoreline position }\end{array}$ \\
\hline
\end{tabular}



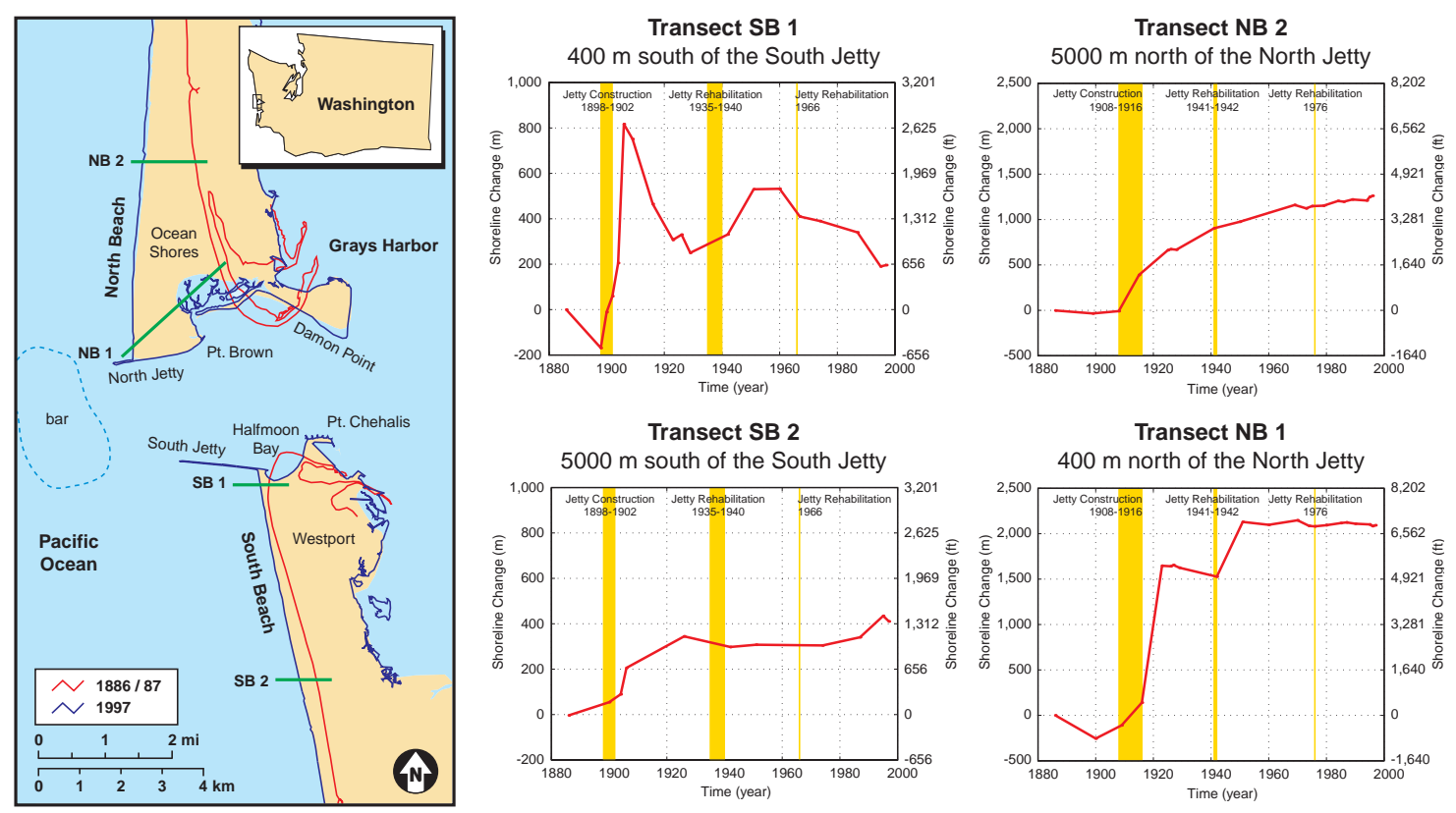

Figure 1. North Beach and South Beach adjacent to the entrance to Grays Harbor accreted significantly after construction of the North Jetty and South Jetty. These trends are presented in graphs that show shoreline change from 1886 to 1997 at transects SB 1, SB 2, NB 1 and NB 2 (transect locations shown on map left; land area defined by 1995 shoreline). The graphs illustrate that the beaches closest to the jetties - and the source of sand - have the fastest and largest response (accretion is positive). Following jetty construction, the shorelines at SB 1 and NB 1 rapidly accreted, whereas farther away the accretion was smaller and slower. Deterioration of the jetties below MLLW allowed currents to pass over the jetties, eroding sand from the beaches at SB 1 and NB 1 and feeding the inner harbor spits at Pt. Chehalis and Pt. Brown. Jetty rehabilitation in the 1930s and 1940s caused accretion only at SB 1 and NB 1, whereas at SB 2 and NB 2 the shoreline change trends remained unaffected. At transect SB 1, the shoreline started to retreat in the 1950s. The second rehabilitation of each jetty did not have a significant effect on the shoreline. 

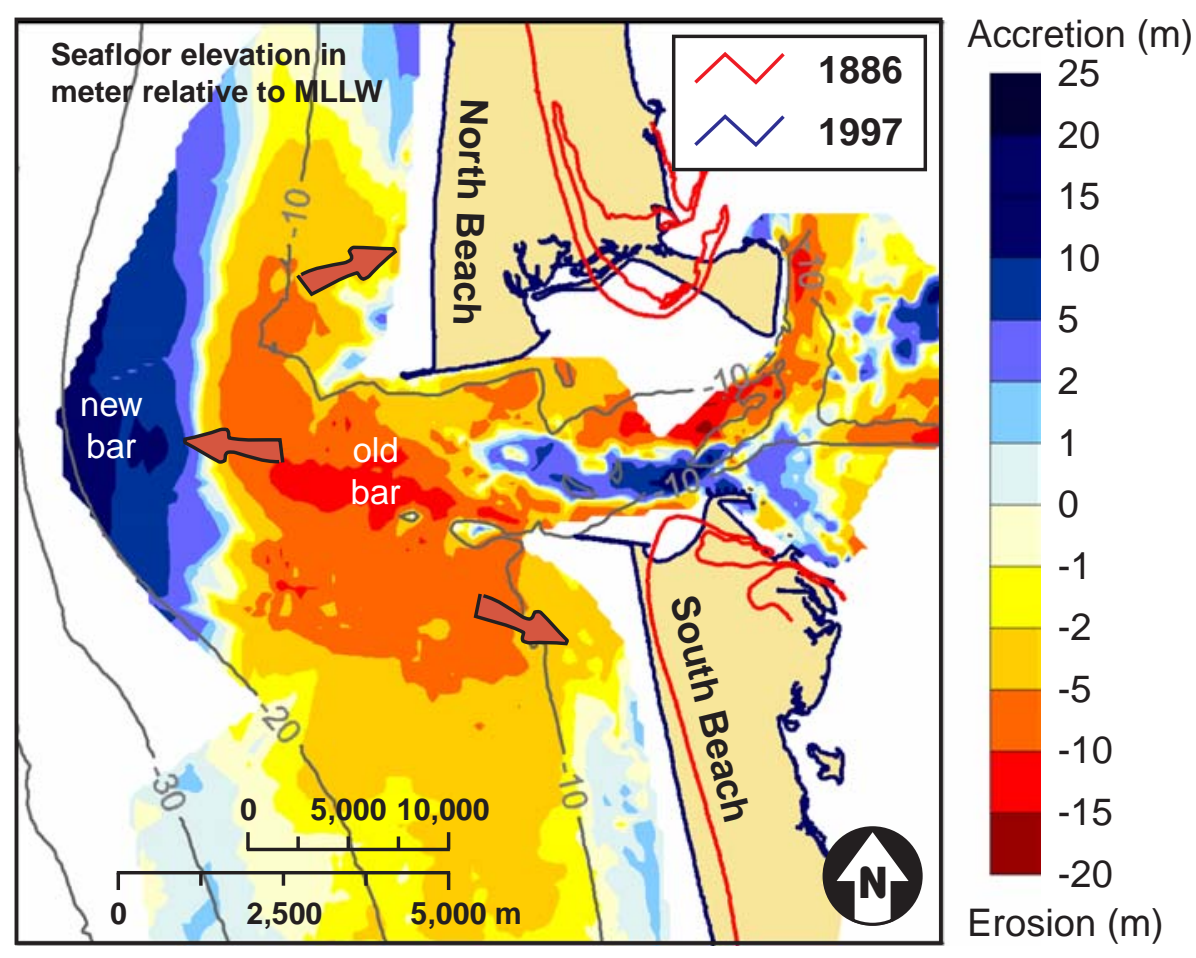

Figure 2. Bathymetric (sea-floor elevation) change between 1900 and 1999 at the Grays Harbor entrance shows erosion (red and yellow) of the bar in front of the inlet, and accretion (blue) of a new bar in deeper water. Part of the sand that eroded from the entrance channel and bar contributed to the accretion of North Beach and South Beach. Eventually, the increased water depths north and south of the entrance allowed higher waves to reach the coast, making the beaches more susceptible to erosion. 

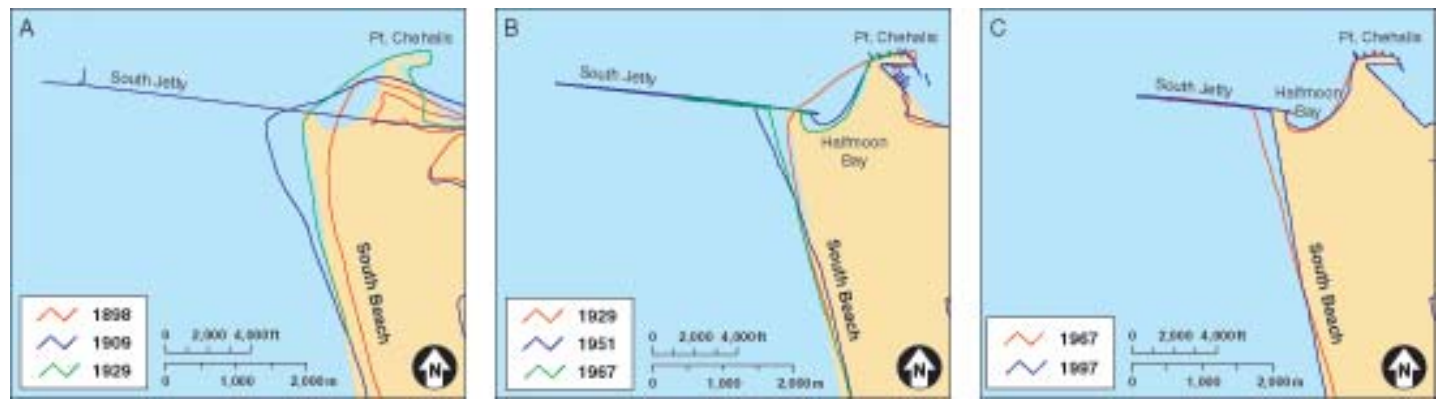

Figure 3. A) The initial construction of the South Jetty (1898-1902) caused South Beach to accrete. When the South Jetty deteriorated below MLLW, currents were able to cross the jetty, eroding the beach adjacent to the jetty and causing the growth of the spit at Pt. Chehalis. B) During rehabilitation from 1935 to 1940, the South Jetty was raised to $6 \mathrm{~m}$ [20 ft] above MLLW. The higher jetty blocked the currents, and resulted in beach accretion south of the South Jetty. The decrease in sand supply caused the erosion of Pt. Chehalis and the formation of Halfmoon Bay. During the 1950s the shoreline immediately south of the jetty started to retreat, while about $2 \mathrm{~km}[6,600 \mathrm{ft}]$ south of the South Jetty, the beach accreted, indicating southerly transport of sand. C) The 1966 rehabilitation could not halt the erosion of the beach south of the South Jetty.
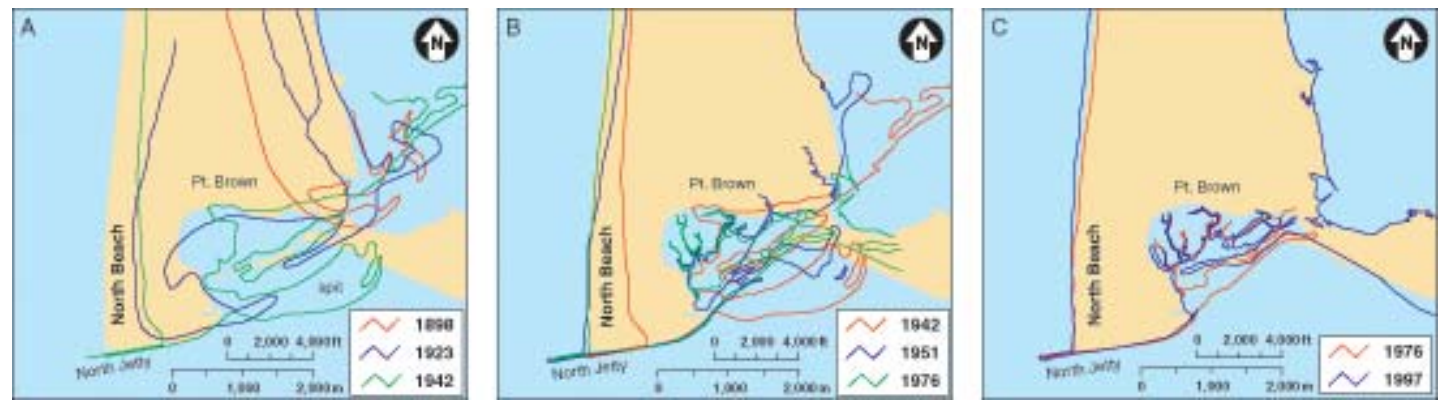

Figure 4. A) The North Jetty was constructed between 1908 and 1916. North Beach rapidly accreted until the 1920s. The deteriorated jetty allowed sand transport into the entrance, feeding a large spit. B) The first rehabilitation of the North Jetty raised the elevation to $6 \mathrm{~m}$ above MLLW, preventing eastward sand transport into the harbor. Subsequently the spit eroded. The shoreline advanced for a period of about a decade until it stabilized in the 1950s. Farther north, the accretion gradually decreased. C) The 1976 rehabilitation did not affect the shoreline change trends. 


\section{Ebb-Tidal Deltas \& Inner Shelf}




\title{
LATEST HOLOCENE EVOLUTION OF THE SW WASHINGTON SHELF AND COASTAL SYSTEM
}

\author{
David Twichell, U.S. Geological Survey \\ VeeAnn Cross, U.S. Geological Survey \\ Curt Peterson, Portland State University \\ Dave Percy, Portland State University \\ Sandy Vanderburgh, University College of the Fraser Valley \\ Jim Phipps, Grays Harbor Community College \\ April Herb, Portland State University (graduated)
}

\section{CONCLUSIONS}

Integration of a wide variety of offshore, beach, and bay data sets into a geographic information system (GIS) was needed to reconstruct the last 4000 years of this coastal system. Conclusions include:

- The total volume of sediment that has accumulated in the Study area since the onset of the Holocene transgression is $124 \times 10^{9} \mathrm{~m}^{3}$. This volume will increase once the remainder of the Columbia River estuary is included.

- Rates of sediment deposition on the shelf and in the bays have decreased through the Holocene.

- No beach deposits appear to have been preserved prior to 5,000 yr BP.

- During the last 5,000 years $32 \times 10^{9} \mathrm{~m}^{3}$ of sediment were deposited on the shelf, and $6 \times 10^{9} \mathrm{~m}^{3}$ in the bays, while beach deposits only account for $1.5-3.9 \times 10^{9} \mathrm{~m}^{3}$ during this time interval.

\section{QUESTIONS}

Several assumptions needed to be made for this analysis, resulting in the following concerns:

- The velocity of sound used to convert the offshore seismic data to depths was $1,500 \mathrm{~m} / \mathrm{sec}$ which probably is low.

- Shelf sedimentation rates are derived from the holes drilled on the beach, and are assumed to be constant through the Holocene.

- The boundaries between shelf, beach, and bay deposits may need to be modified.

- How should the remainder of the Columbia River estuary be incorporated into this GIS? 
- What should be in the final GIS, and how should it be made available to users?

\section{ANALYSIS}

A large volume of sediment derived from the Columbia River during the Holocene has been deposited on the Washington and Oregon shelf, the adjacent bays and on the coastal barrier-beach systems. Offshore seismic reflection profiling results, drilling results from the beaches, and seismic and drilling results from the bays and the lower Columbia River (west of Astoria, OR) have been integrated into a GIS. This has been used to quantify the volume of sediment deposited in this coastal and shelf (shallower than $200 \mathrm{~m}$ ) area during the last rise in sea level. The Holocene deposit has been subdivided into three depositional environments: bay, barrier-beach, and shelf. A revised sea level curve for the Study area in conjunction with the GIS have been used to show the partitioning of sediment between these three depositional environments during the last 10,000 years.

Computing volume estimates first required mapping the Holocene stratigraphy of the area. Two erosional surfaces were identified on seismic profiles (Figure 2) and in drill holes (Herb, 2000). One of these erosional surfaces, here referred to as the lowstand surface, was cut during the last lowstand of sea level, and the second, the ravinement surface, developed as sea level rose and the shoreline transgressed the lowstand shelf. The lowstand surface marks the base of the Holocene deposits and shows paleo-river valleys extending across the shelf from both the Columbia River mouth and Grays Harbor (Figure 3A). Willapa Bay does not appear to have had a large river draining it; however, the bay does occupy a broad depression in the lowstand surface. The ravinement surface coincides with the lowstand surface on parts of the shelf, but the seismic data show that the river valleys and depressions were nearly filled with sediment prior to flooding during the transgression (Figure 2), and here the two surfaces diverge. The ravinement surface is smoother than the lowstand surface on seismic reflection profiles (Figure 3B). The deposits that occupy the depressions in the lowstand surface tend to be narrow, thick ( $>$ $100 \mathrm{~m}$ ), elongate, and in two cases trend perpendicular to the coast (Figure 4A). We interpret the elongate depressions as paleo-river valleys cut during falling sea level. Drill information from the mouth of the Columbia River and from Grays Harbor indicates that these paleo-valleys were primarily filled with fluvial and estuarine deposits (Peterson and Phipps, 1992; Herb, 2000). The deposit above the ravinement surface (Figure 4B) is a broad deposit with its long axis oriented roughly parallel to the coast. This deposit reaches $50 \mathrm{~m}$ in thickness off the mouth of the Columbia River, but away from this area much of the deposit is less than $20 \mathrm{~m}$ thick. Drill holes along the barriers show that the sediments above the ravinement surface are shelf, beach, or dune deposits (Herb, 2000). Thus sediment below the ravinement surface is interpreted to be fluvial or estuarine while sediment above this surface is of either shelf or beach-barrier origin. Much of the mapping was based on seismic data, and a velocity of $1500 \mathrm{~m} / \mathrm{sec}$ through water and sediment was used to compute Holocene sediment thickness. Using this velocity, the volume of sediment contained between the lowstand surface and the ravinement surface (estuarine or bay deposits) is $32 \times 10^{9} \mathrm{~m}^{3}$, and the volume above the ravinement surface (shelf and beach-barrier deposits) is $92 \times 10^{9} \mathrm{~m}^{3}$. The total volume that has accumulated on the shelf, the beach-barriers, and bays during the Holocene is $124 \times 10^{9} \mathrm{~m}^{3}$. As more 
data becomes available, the $1500-\mathrm{m} / \mathrm{sec}$ velocity appears to be low, and therefore the volumes based on the seismic data should be viewed as minimum estimates.

This integrated data set was also used in concert with a revised sea level curve for the Study area (Peterson, personal communication) and assumptions on sedimentation rates, to show the evolution of this coastal area. Shelf sedimentation rates were assumed to have been constant throughout the Holocene. There are no long cores from the shelf, so this remains an untested assumption. Dates from cores that contain shelf sediments underlying the barriers suggest sedimentation rates of 4-7 m/1000 yr (Herb, 2000). These sedimentation rates are sufficient to account for the $50 \mathrm{~m}$ of sediment that has accumulated on parts of the shelf during the last 10,000 years. In the bays, sediment accumulation was assumed to be a function of accommodation space, and thus was controlled by sea level. As a first-order estimate, the bays were assumed to fill to the sea level of the time or to the modern bathymetry, whichever was deeper. For the barriers, radiocarbon dates and subaerial dune ridges were used to construct the outline of the barrier at different times. Prior to 5,000 yr BP, the shoreline moved rapidly across the shelf, and the only preserved deposits were the shelf and bay facies. Between 10,000 and 5,000 yr BP, the volume of sediment deposited on the shelf was $56 \times 10^{9} \mathrm{~m}^{3}$ and the volume of sediment deposited in the bays was $26 \times 10^{9} \mathrm{~m}^{3}$. Starting 5,000 yr BP, some of the beaches started to accrete. Between 5,000 yr BP and the present, the volume of sediment deposited on the shelf decreased to $32 \times 10^{9} \mathrm{~m}^{3}$, the volume in the bays decreased to $6 \times 10^{9} \mathrm{~m}^{3}$, and beach volumes ranged from 1.5-3.9 $\times 10^{9} \mathrm{~m}^{3}$ depending on where the base of the beach deposits is picked.

In addition to using this integrated data set to calculate sediment volumes, it also has been used to show how this coastal system has likely changed through the Holocene. Figure 5 shows this coastal area at four different time intervals. In addition to showing changes in the location of the shoreline through time, it also shows how the distribution of the different depositional environments changes through time. These interpretive maps suggest that shelf sediments were deposited on the floor of Willapa Bay and under what now are the coastal barriers until about 4,000 yr BP. This time appears to mark the maximum shoreward extent of shelf deposits for the part of the Study area south of Grays Harbor. North of Grays Harbor the coast continued to recede until about 1,500 yr BP (Herb, 2000; Peterson et al., 1999) while south of Grays Harbor the barrier beaches started to form and accrete after 4,000 yr BP.

\section{REFERENCES}

Cross, V.A., Twichell, D.C., Parolski, K.F., and Harrison, S.E. 1998. Archive of boomer seismic reflection data collected aboard RV Corliss cruise CRLS97007 off northern Oregon and southern Washington inner continental shelf, U.S. Geological Survey Open-File Report 98-351, 2 CD-ROMs.

Gates, E.B., 1994. The Holocene sedimentary framework of the lower Columbia River basin, M.S. Thesis, Portland State University, Portland, Oregon, 210 p. 
Herb, A. 2000. Holocene stratigraphy and sediment volumes for the Columbia River littoral cell, Pacific Northwest, USA, M.S. Thesis, Portland State University, Portland, Oregon, $186 \mathrm{p}$.

Peterson, C.D., and Phipps, J.B. 1992. Holocene sedimentary framework of Grays Harbor Basin, Washington, USA, in Fletcher, C.H., and Wehmiller, J.F., eds., Quaternary Coasts of the United States: Marine and Lacustrine Systems, SEPM Special Publication No. 48, pp. 273-285.

Peterson, C.D., Gelfenbaum, G.R., Jol, H.M., Phipps, J.B., Reckendorf, F., Twichell, D.C., Vanderburg, S., and Woxell, L.K. 1999. Great earthquakes, abundant sand, and high wave energy in the Columbia Cell, USA, Proceedings of Coastal Sediments '99, ASCE, pp. 1676-1691.

Wolf, S.C., Hamer, M.R., and McCrory, P.A. 1997. Quaternary geologic investigations of the continental shelf offshore southern Washington and northern Oregon, U.S. Geological Survey Open-File Report 97-677.

Wolf, S.C., McCrory, P.A., and Hamer, M.R. 1998. Investigations of late quaternary geologic features in Willapa Bay, Washington, U.S. Geological Survey Open-File Report 98-589. 


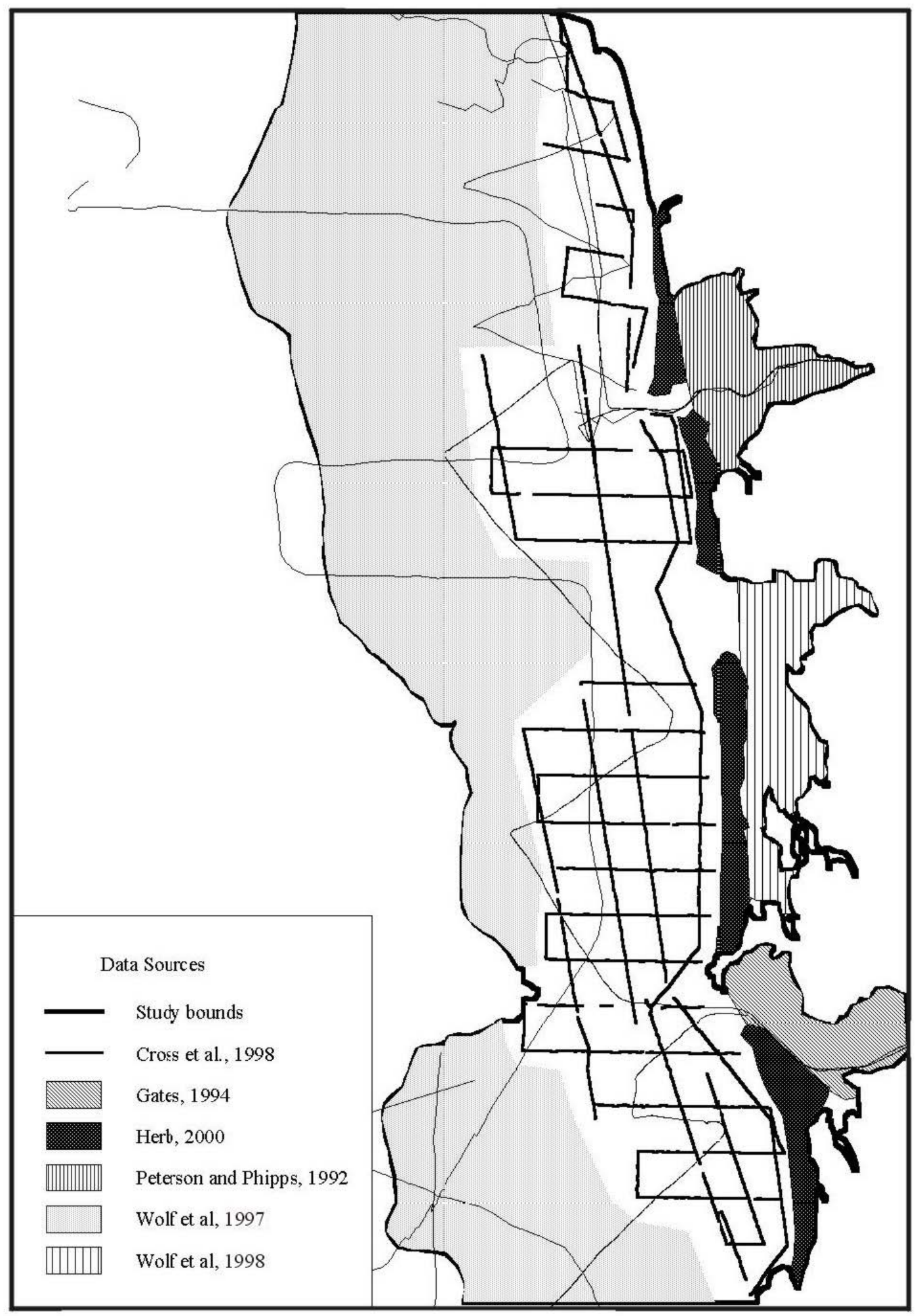

Figure 1. Map showing sources of the data used in this abstract. 


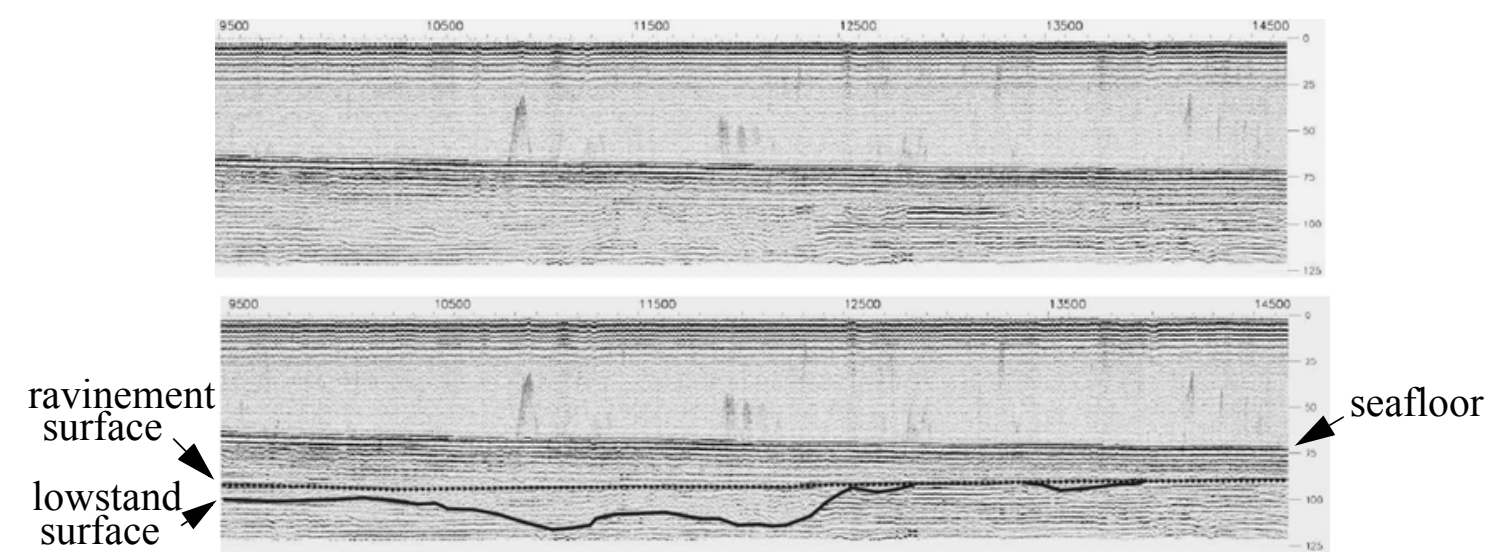

Figure 2. Seismic profile across the paleo-Columbia River valley in water depths of about $50 \mathrm{~m}$. The upper panel shows an uninterpreted profile and the lower panel shows the interpretation. The lowstand surface is shown as the solid line and the ravinement surface is the dotted line. The ravinement surface is nearly flat from the flanks to the middle of the valley which suggests that the valley was completely filled with sediment prior to cutting of the ravinement surface.

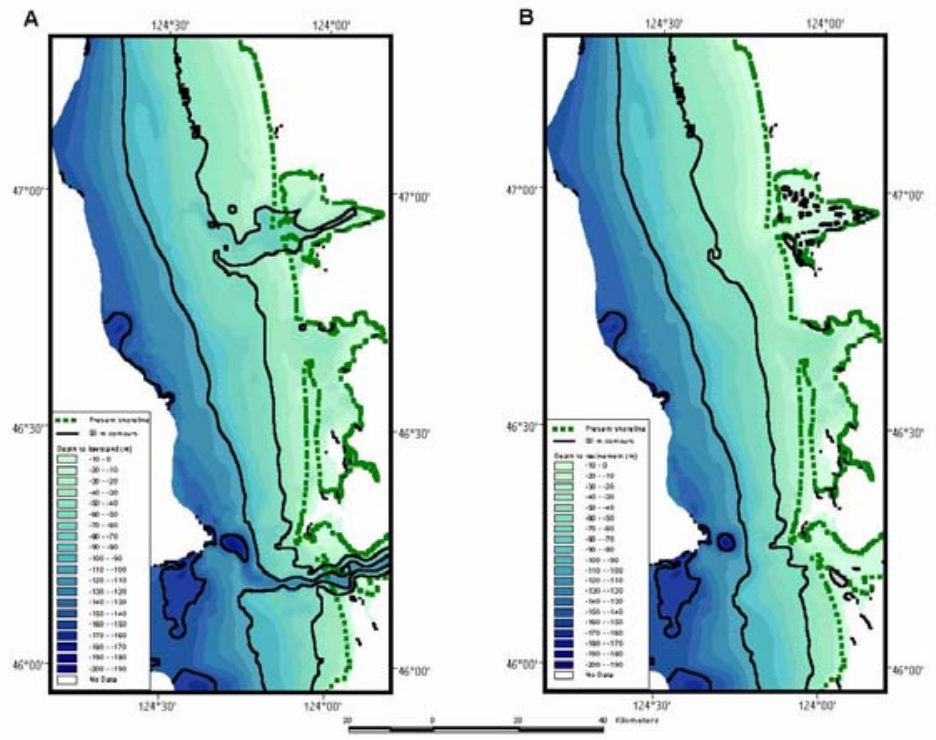

Figure 3. Maps showing depth to the lowstand surface (A) and the ravinement surface (B) in meters assuming a velocity of sound of $1500 \mathrm{~m} / \mathrm{sec}$ for the seismic data (water column and sediment). The present shoreline is superimposed on these maps to show the extent of the Study area relative to the modern coast. The lowstand surface shows paleoriver valleys extending from Grays Harbor and the Columbia River, but none from Willapa Bay. The ravinement surface shows that the valleys in the lowstand surface were nearly filled prior to the transgressing shoreline crossing them. 


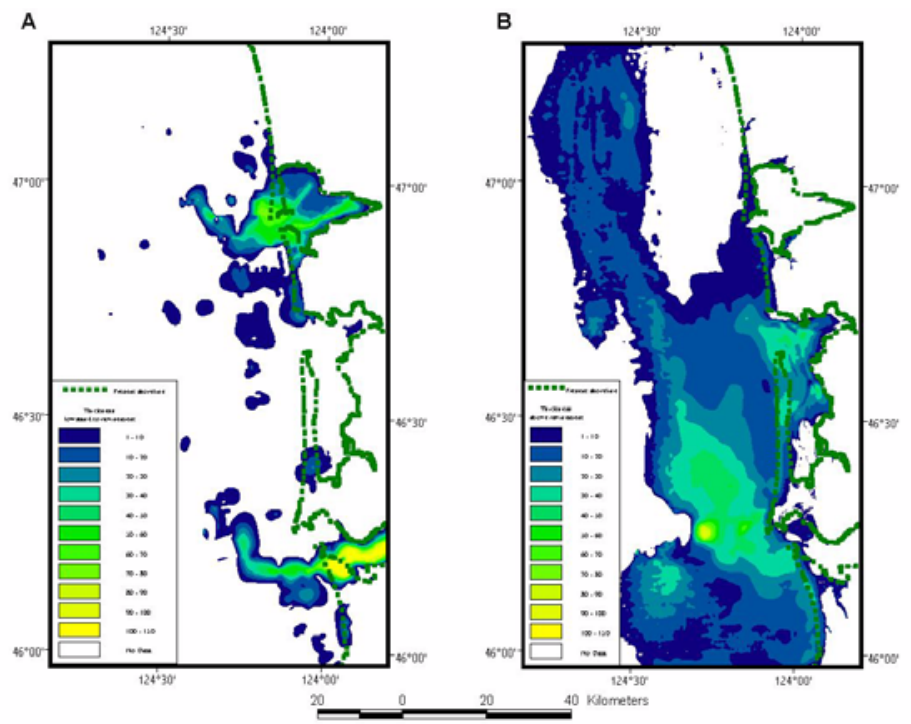

Figure 4. Maps showing the thickness of sediment between the lowstand and ravinement surfaces (A) and above the ravinement surface (B). The sediment below the ravinement surface (shown in $A$ ) is interpreted to be primarily fluvial and estuarine deposits. The sediment deposited above the ravinement is interpreted to be either shelf or barrier/beach deposits.

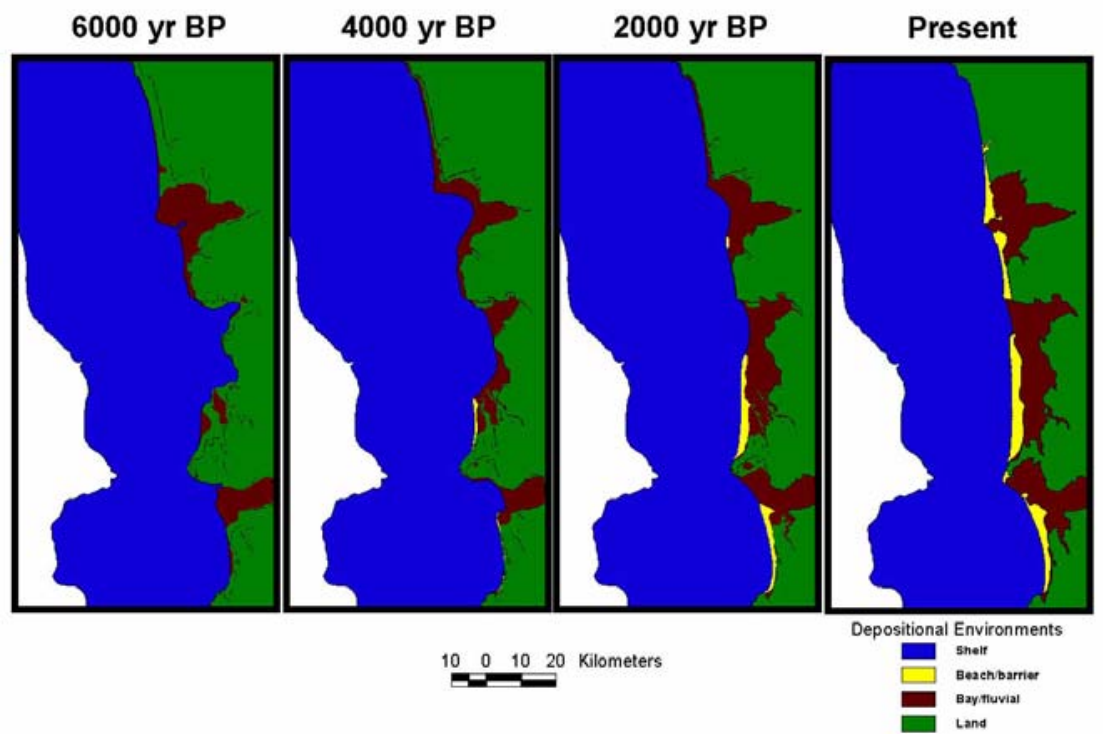

Figure 5. Evolution of the Southwestern Washington and Northern Oregon coast during the last 6,000 years. The distribution of depositional environments is shown as well. Prior to $4,000 \mathrm{yr}$ BP the coast retreated as sea level rose, but at 4,000 yr BP barriers started to form, and the coast started to accrete. 


\title{
RESULTS FROM A MULTIBEAM SONAR SURVEY ON THE INNER SHELF OFF GRAYS HARBOR: RELEVANCE TO THE SOUTHWEST WASHINGTON COASTAL EROSION STUDY
}

\author{
Vicki Lynn Ferrini, Marine Sciences Research Center, SUNY Stony Brook \\ Roger D. Flood, Marine Sciences Research Center, SUNY Stony Brook
}

\section{CONCLUSIONS}

1) High-resolution bathymetry and backscatter data were acquired on the inner shelf near Grays Harbor using an EM 3000D multibeam sonar system $(300 \mathrm{kHz})$.

2) A broad characterization of this environment was developed from preliminary analysis of multibeam data and further analysis has yielded the identification of large-scale seafloor patterns which can be used to describe the system in more detail.

3) Nearshore gravel-filled depressions south of the South Jetty at Grays Harbor which are oriented NE-SW may be related to hydrodynamics associated with the jetties.

a) The troughs are along subtle topographic features identified through the analysis of bathymetric data. The troughs are located on areas of SE-facing seabed and are separated by areas of NW-facing seabed.

b) The axes of the troughs rotate counter-clockwise closer to the South Jetty.

c) Oscillation ripples within the troughs were identified in backscatter imagery suggesting that there are very strong bottom flows in the region south of the jetty. These ripples probably form during large wave events, and are preserved during quiescent periods.

d) These features are evidence of the variable preferential removal of sandy sediment.

4) A cross-shelf trending feature north of Grays Harbor is evidence for mass movement of sediment and may be the surface expression of a fault.

a) This feature is a bathymetric depression bounded by what appears to be a scarp. It is characterized by high-backscatter and was found to contain gravel.

b) Broad and complex in the offshore region, this feature narrows as it approaches the shore. The nearshore limit of this feature has migrated $1 \mathrm{~km}$ shoreward since 1998 , based on previous side scan imagery.

c) There is evidence of mass wasting within this feature. The authors believe that it is a conduit for offshore sediment transport via gravity flows. 
5) Backscatter patterns can be used to identify areas of significant sediment transport processes. Distinct backscatter patterns are discussed here, but other backscatter patterns that are not yet understood may also be significant.

6) Repeat surveys of the inner shelf would help to determine the stability and importance of features identified through this research.

\section{ACCOMPLISHMENTS}

Data collected during a multibeam sonar survey between August 27 and September 10, 1999 have revealed many morphologic and textural features on the inner shelf off Grays Harbor (Flood et al., 1999). The survey resulted in a high-density data set with one depth measurement at least every meter along track and $5 \mathrm{~m}$ across track, and with higher sounding densities in shallower water. The bathymetric data are accurate to about $5-10 \mathrm{~cm}$ (vertically), and navigation accuracy is estimated to be within $1 \mathrm{~m}$ (horizontally). 100 percent coverage was achieved from $12 \mathrm{~m}$ to $30 \mathrm{~m}$ water depth, nearly 50 percent coverage to $40 \mathrm{~m}$ water depth, and isolated tracks to $60 \mathrm{~m}$ water depth. The data have been used to identify large-scale bathymetric patterns in the region including the morphology of the ebb-tidal shoals at the entrances to Grays Harbor and Willapa Bay. Other features identified are indicators of more localized processes which may contribute to large-scale sediment transport on the inner shelf. Temporal variability has been identified by comparing results with side-scan sonar data collected in 1997 (Twichell et al., 2000).

\section{QUESTIONS}

Continued analysis of multibeam data and other historical data is required to address the following questions:

1) What is the origin of the nearshore gravel-filled troughs?

2) Can the morphologic evolution of the troughs be deduced through the analysis of historical bathymetric data?

3) What is the nature of the offshore-trending feature north of Grays Harbor?

4) How might all of these features affect sediment transport processes and impact coastal erosion?

\section{ANALYSIS}

Viewing high-resolution bathymetric and backscatter data has enabled the identification of features that may affect sediment dynamics on the inner shelf. Investigation of the slope and aspect (directionality of the slope) of the multibeam depth soundings has enabled the identification of large-scale bathymetric patterns. ArcView GIS has been used to combine 
our data set with historical data including side-scan sonar records collected in 1997 and 1998 (Twichell et al., 2000).

The general morphology of the inner shelf can be easily identified through the analysis of multibeam imagery. One obvious feature is the ebb-tidal shoal at the mouth of Grays Harbor. It is broad and extends to $5 \mathrm{~km}$ beyond the tip of the southern jetty at the harbor entrance. The seaward edge of the shoal is at approximately $24 \mathrm{~m}$ water depth with bottom slopes ranging from $0.7-1.25^{\circ}$. The slope we calculate for the seaward edge of this feature is consistent with slopes calculated for other inlets, and the depth of the ebb-tidal shoal crest should therefore be directly related to wave height and tidal range (Buonaiuto et al., 2000).

Northeast-southwest trending depressions south of the submerged South Jetty at Grays Harbor may be important with respect to nearshore sediment transport (Figure 1). The most prominent depressions are within $3 \mathrm{~km}$ of the jetty at water depths of 10-16 meters, and are associated with high backscatter (Flood et al., 1999). These depressions are up to $2 \mathrm{~m}$ deep, are bounded on all sides by slopes on the order of $2-3^{\circ}$, and contain gravel molded into shore-parallel oscillatory ripples. Although the backscatter data suggest that these features are localized, analysis of the aspect of the bathymetry demonstrates that these features are in fact reflective of widespread subtle bathymetric features (Figure 2). The aspect of the seabed reveals an alternating pattern of SE-E facing seabed and NW-W facing seabed. All of the gravel-filled troughs identified coincide with areas of seabed that gently slopes toward the SE-E. They are also separated by areas of NW-W facing seabed that is composed of sandy sediment. It is important to note that not all SE-E facing areas of seabed correspond with gravel-filled depressions. One similar high backscatter feature that was identified during previous studies (Twichell et al., 2000) was located in an area of SE-E facing seabed, but no gravel-filled trough was present at the time of our 1999 survey. Therefore, it is believed that these subtle bathymetric features are periodically stripped of sandy sediment, revealing the underlying gravels that can then be mobilized and reworked. Bathymetric change analysis has shown that this area has been subject to erosion of at least $1.5 \mathrm{~m}$ since the early 1900s (Gibbs, 1999). Although the origin of these features is not clear, further analysis of historical bathymetric data may allow us to trace their morphologic evolution.

Another broad area of high backscatter exists north of Grays Harbor (Figure 3). The southern edge of this backscatter feature has a more distinct boundary than the northern edge, which appears somewhat diffuse in places. Like the nearshore gravel troughs this feature has a bathymetric expression, is 1-2 meters deeper than the surrounding seabed, and is bounded by relatively steep bottom slopes on the order of $1-4^{\circ}$. However, this feature is much larger than the nearshore troughs and is narrow at its nearshore limit. It has a width of 20-40 m at a depth of $10 \mathrm{~m}$, and broadens to at least $2 \mathrm{~km}$ with increasing water depth. The aspect of the depth data shows that this feature is bounded by S-facing seabed to the north, and $\mathrm{N}$-facing seabed to the south, as though it has sunken below the surrounding seabed, or that sediments are being funneled offshore through this feature. As the backscatter patterns suggest, the southern edge of this feature has a more distinct bathymetric expression, and is generally steeper than the northern edge. This asymmetry 
of backscatter may be an indication of northward transport of gravels. The backscatter imagery also provides evidence of offshore transport of sediments via mass wasting events, and individual mounds and pinnacles are evidence of extruded/deformed seabed. The high backscatter characterizing this feature is attributed to the preferential removal of sand revealing underlying gravels, which may be an indication of bedload divergence. A single pass over this feature with side-scan sonar in 1997 (Twichell et al., 2000) showed what appears to be the nearshore limit located $1 \mathrm{~km}$ further offshore than we found in 1999 (Figure 4). Furthermore, the width of this feature was $90 \mathrm{~m}$ (across-shelf) in the side-scan data (1997) in an area where the backscatter data show it to be $400 \mathrm{~m}$ wide. Based on these morphological and textural patterns, it is clear that some active process has caused the feature to widen and extend shoreward since the side-scan studies in 1997.

\section{REFERENCES}

Buonaiuto, F.S., Kraus, N.C., Bokuniewicz, H. 2000. Limiting slopes and depth of ebbtidal shoal features, Proceedings 10th International Biennial Conference on Physics of Estuaries and Coastal Seas, SRAMSOE Report No. 366.

Flood, R.D., Ferrini, V.L., Giosan, L., and Zaleski, L. 1999. Preliminary results of a multibeam bathymetry and backscatter survey, Southwest Washington Coastal Erosion Workshop Report, 1998, U.S. Geological Survey Open-File Report 99524 , pp. 81-83.

Gibbs, A. 1999. Bathymetric volume change: Data and analysis, Southwest Washington Coastal Erosion Workshop Report, 1998, U.S. Geological Survey Open-File Report 99-524, pp. 75-80.

Twichell, D.C., Cross, V.A., and Parolski, K.F. 2000. Sidescan sonar imagery, surface sediment samples, and surficial geologic interpretation of the southwestern Washington inner continental shelf based on data collected during Corliss cruises 97007 and 98014, U.S. Geological Survey Open-File Report 00-167, 28 p. and 1 CD-ROM. 


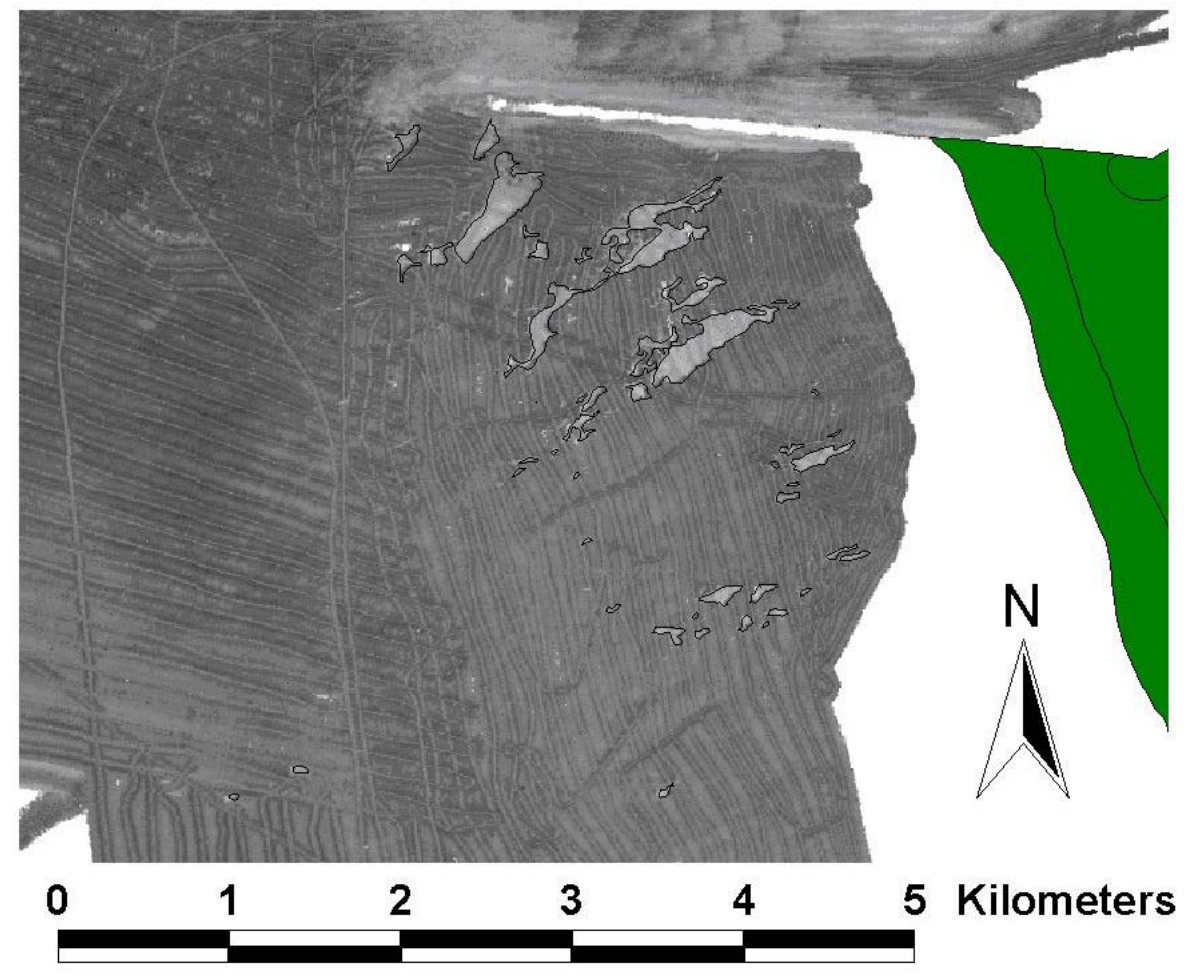

Figure 1. Backscatter imagery $(300 \mathrm{kHz})$ of nearshore gravel-filled troughs. Light areas correspond to high backscatter and dark areas correspond to low backscatter. 

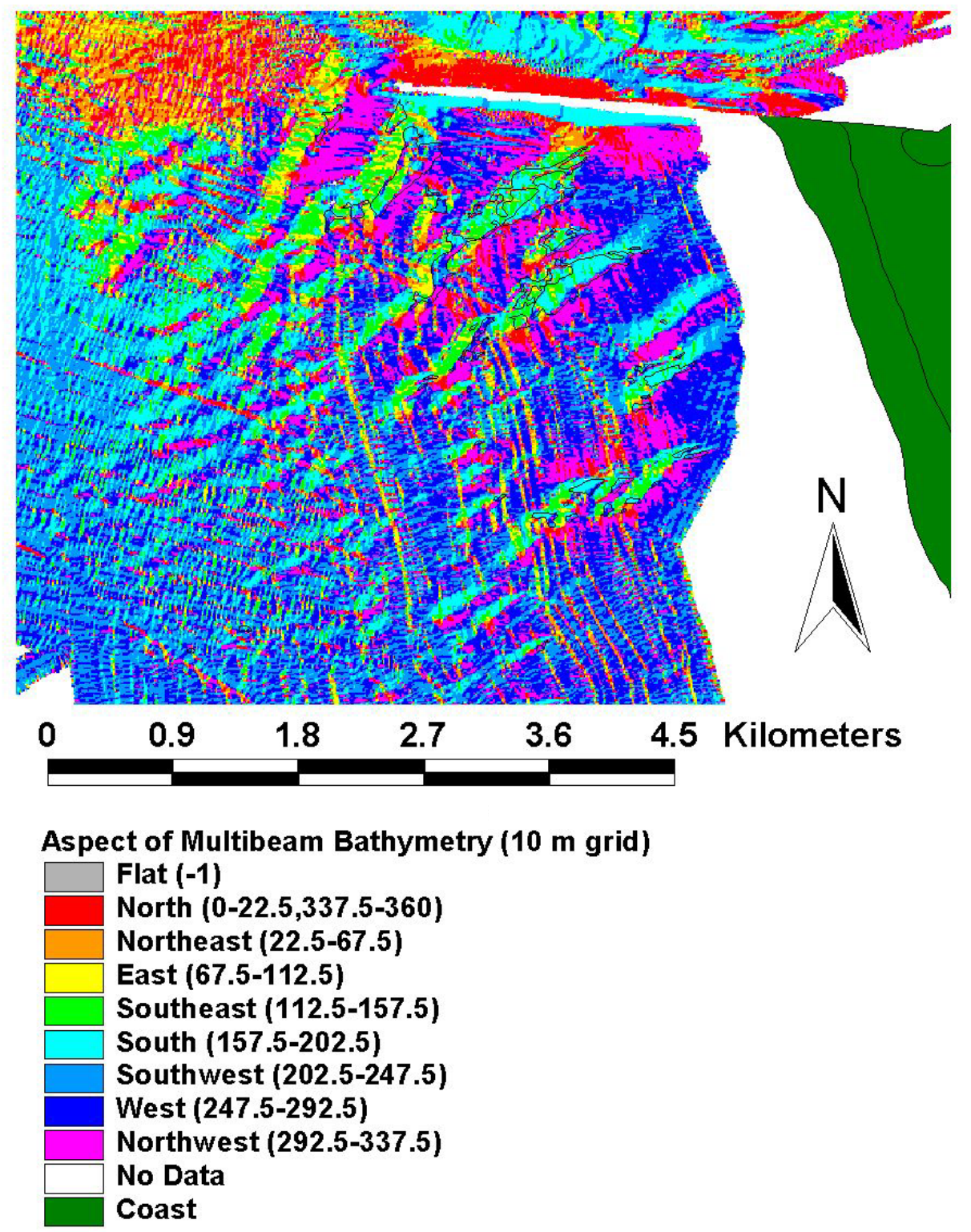

Figure 2. Aspect of seabed south of the jetty at Grays Harbor. Gravel-filled troughs are outlined in black and correspond to seabed which faces E-SE. These features are separated by NW-W facing seabed. 


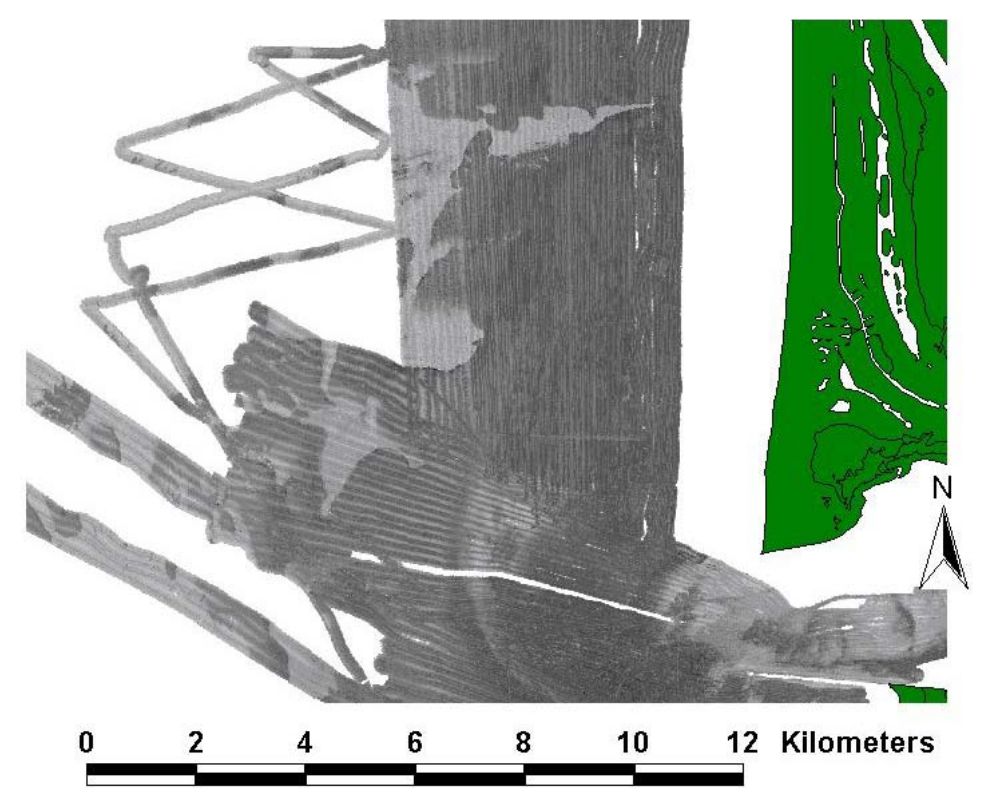

Figure 3. Large backscatter feature north of Grays Harbor which corresponds to a bathymetric depression that is 1-2 $\mathrm{m}$ deeper than the surrounding seabed. See Figure 4 for close-up of this feature.

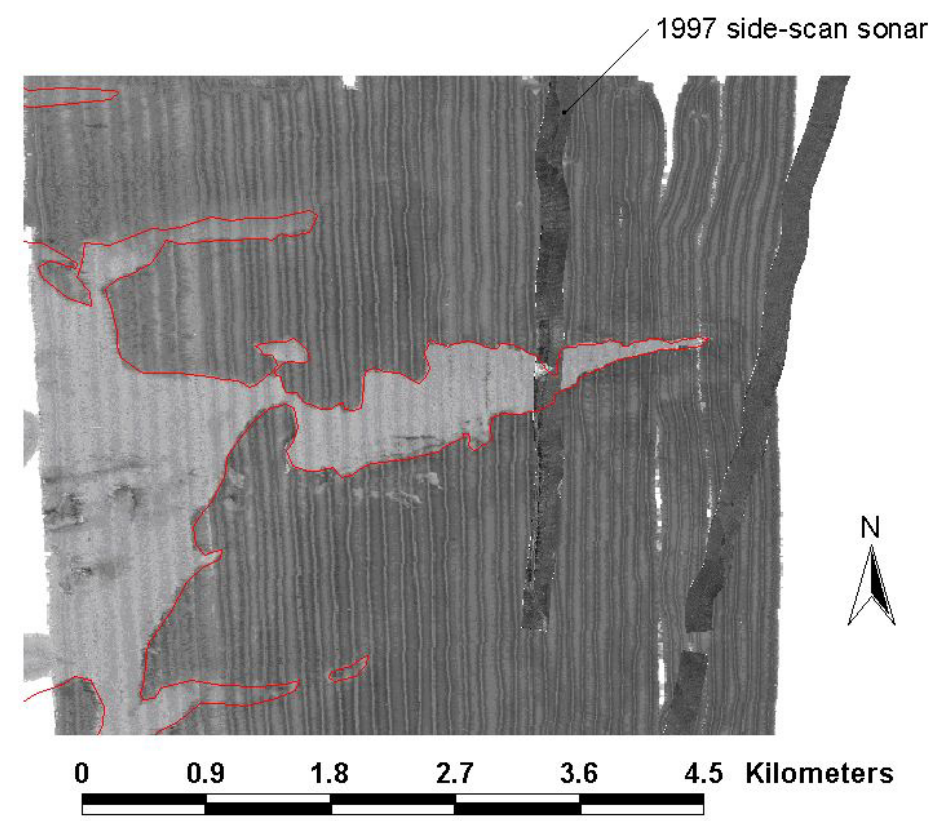

Figure 4. Close-up of nearshore extent of backscatter feature north of Grays Harbor. Sidescan sonar data collected in 1997 (Twichell et al., 2000) is overlain on the multibeam imagery and suggests that this feature has extended shoreward approximately $1 \mathbf{~ k m}$. 


\section{THE WAVE CLIMATE OF THE EASTERN NORTH PACIFIC: LONG-TERM TRENDS AND AN EL NIÑO/LA NIÑA DEPENDENCE}

Jonathan C. Allan, Oregon Department of Geology \& Mineral Industries

Paul D. Komar, College of Oceanic \& Atmospheric Sciences, Oregon State

University

\section{CONCLUSIONS}

- The wave climate of the eastern North Pacific has been documented through analyses of six buoys ranging from the Gulf of Alaska in the north to south-central California.

- The analyses show the expected latitude variations, with the largest waves occurring in the Gulf of Alaska and offshore from the Pacific Northwest (Washington and Oregon), where monthly averaged significant wave heights have ranged from 3.6 to $3.8 \mathrm{~m}$, and the largest measured significant wave heights are 14 to $15 \mathrm{~m}$.

- Long-term, progressive increases in wave heights and periods have occurred at mid-latitudes, reaching a maximum rate of increase of $0.042 \mathrm{~m} / \mathrm{yr}$ for the annual averages of the winter waves measured by the Washington buoy, representing a $1-\mathrm{m}$ increase during the 25 -year record of measurements.

- The largest annual significant wave heights measured through the years by the Washington buoy, generated by the strongest storms in terms of their wavegenerating properties, have increased from $8 \mathrm{~m}$ in 1975 to about $12 \mathrm{~m}$ in 1999 , a 50 percent increase.

- Compared with the Washington buoy, somewhat smaller increases are found for the Oregon buoy, still smaller increases offshore from northern California, while negligible change has been found for the south-central California buoys and in the Gulf of Alaska.

- Attempts have been made to relate the changing wave conditions to large-scale climate controls such as the East Pacific Teleconnection Index, a measure of the pressure difference between the Aleutian Low and Hawaiian High atmospheric centers, and to indices related to El Niño/La Niña cycles. While we have been unable to fully account for the long-term progressive increases in wave heights and periods, the variation in the wave conditions from year to year have been found to depend on these climate indices.

- The unusually strong storms that struck the Pacific Northwest coast during recent winters are in large part explained by the long-term increases in wave heights and periods, as are the resulting coastal-erosion impacts. 


\section{ANALYSES \& ACCOMPLISHMENTS}

The wave climate of the eastern North Pacific has been investigated through analyses of wave data collected during the past 30 years with buoys deployed by the National Data Buoy Center (NDBC) of NOAA. Presently there are some 30 buoys located along the West Coast of the U.S., six of which were selected for analysis extending from the Gulf of Alaska in the north to Pt. Arguello in south-central California (Figure 1). The six buoys were chosen because of their long records with few data gaps, and to provide a documentation of the latitude variation in the wave climate. The complete results of the study are contained in Allan and Komar (2000; 2002; in review).

The analyses of the wave climate show the expected latitude variations and seasonality of wave conditions, with the largest waves occurring during the winter in the Gulf of Alaska and offshore from the Pacific Northwest (Washington and Oregon), where monthly averaged significant wave heights have ranged 3.6 to $3.8 \mathrm{~m}$, and the largest measured significant wave heights are 14 to $15 \mathrm{~m}$. Of special interest is the discovery of progressive increases in wave heights at mid-latitudes, shown in Figure 2 as annual averages of significant wave heights $(H s)$ and annual average winter waves $(W H s)$, where "winter" is defined as October through the following March, the months when most storms along the U.S. West Coast occur. The greatest increase in wave heights is found for the Washington buoy, a rate of increase of $0.042 \mathrm{~m} / \mathrm{yr}$ for the annual averages of the winter waves (Figure 2 ); this represents a $1-\mathrm{m}$ increase during the 25 -year record of measurements. As is apparent in Figure 2, the rate of increase has been smaller off the coasts of Oregon and northern California compared with Washington, and is negligible in central and southern California, and in the Gulf of Alaska.

Most dramatic has been the increase in the largest annual significant wave heights measured through the years, generated by the strongest storms in terms of their wavegenerating properties (wind speeds, fetch length, and storm duration). Although the scatter of the measurements is greater than dealing with averages, the upward trend of the data is readily apparent and statistically significant, revealing an overall increase off the Washington coast from $8 \mathrm{~m}$ in 1975 to about $12 \mathrm{~m}$ in 1999, a 50 percent increase.

We have attempted to relate the changing wave conditions to large-scale climate controls such as the East Pacific (EP) Teleconnection Index, a measure of the pressure difference between the Aleutian Low and Hawaiian High atmospheric centers. While not providing an explanation for the long-term trends of increasing wave conditions, the EP is shown to be related to annual variations in wave heights above and below the long-term trends, and to latitude differences in the numbers of storms experienced each winter. Also found to be important to wave conditions during any particular year and at a certain latitude is the range of climate events between El Niños and La Niñas as measured by the Multivariate ENSO Index (MEI). A stepwise multiple linear regression analysis has established a systematic latitude dependence of wave heights on EP and MEI, with EP being most important to wave conditions in the Pacific Northwest and in northern California, while MEI and the occurrence of El Niños is more important in central to southern California. 
Unusually strong storms impacted the Pacific Northwest coast during recent winters, producing beach and property erosion at many sites. The severity of these storms is in large part explained by the long-term increases in wave heights and periods, together with the shift to positive EP-index values that produce stronger winds and larger waves in the North Pacific. We have undertaken detailed analyses of the strongest storms, made possible by the presence of several NDBC buoys immediately offshore from the coasts of Washington and Oregon, buoys that provide measurements of atmospheric pressures and wind speeds and directions, as well as of the generated waves (Allan and Komar, 2000; 2002; in review). Due to the northwestward tracks of the storms and their tendency to intensify as they approached the coast, higher wave conditions were experienced along the Washington coast than in Oregon, as were the generated storm surges as measured by tide gauges. Important to the erosional impacts were the total water levels produced by the run-up of the waves atop the measured tides, which were enhanced by storm surges that reached a maximum of $1.6 \mathrm{~m}$ as measured on the Toke Point tide gauge. Also important to the erosion during the winter of 1997-98 was the occurrence of a major El Niño, which increased monthly mean water levels by up to $0.60 \mathrm{~m}$, enhancing the hourly tidal elevations.

\section{QUESTIONS}

The results of this research concerning the wave conditions in the North Pacific raise questions that are important to both an understanding of the climate controls and how the results should be used in applications such as coastal-zone management. With wave records limited to 20 to 25 years, it has been difficult to fully establish the climatic controls on the wave conditions, and therefore to determine whether the long-term trend of increasing wave heights is a response to natural climate cycles or is due to global warming. Without a better understanding of the climate controls, we cannot confidently project whether the increases in wave heights measured during the past 25 years will continue in the next 25 to 100 years. This raises questions as to how one uses the results in coastal management, for example, in the establishment of set-back distances to ensure that coastal developments remain safe from the most extreme episodes of erosion that might occur during the next 25 to 100 years.

\section{REFERENCES}

Allan, J., and Komar, P.D. 2000. Are ocean wave heights increasing in the eastern North Pacific?, EOS, Transactions, American Geophysical Union, 81 (47), pp. 561, 566-567.

Allan, J., and Komar, P.D. in review. Spatial and temporal variations in the wave climate of the North Pacific, submitted to the Journal of Coastal Research.

Allan, J., and Komar, P.D. 2002. Extreme storms on the Pacific Northwest coast during the 1997-98 El Niño and 1998-99 La Niña, Journal of Coastal Research, 18(1), pp. 175-193. 


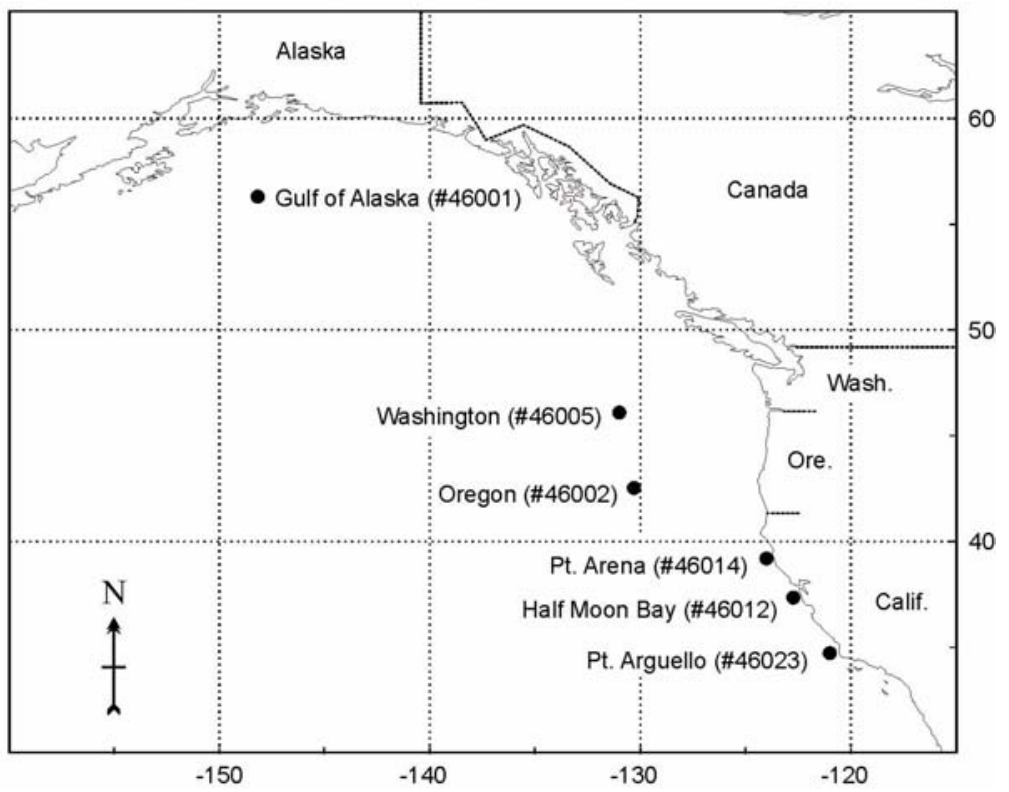

Figure 1. Locations of the wave buoys analyzed in this study.
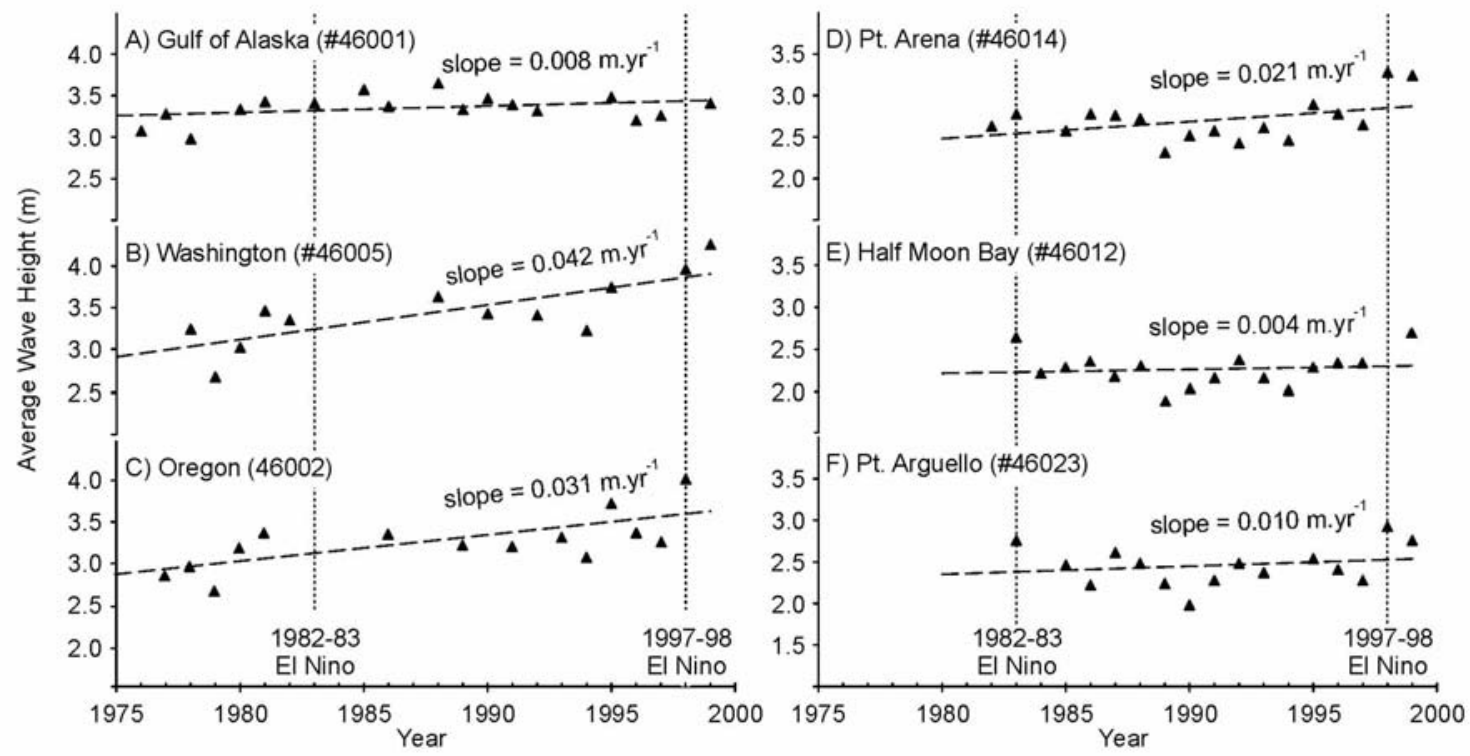

Figure 2. Long-term trends in the annual average significant wave heights $(H s)$, and annual average winter waves $(W H S)$. 


\title{
SWAN MODEL CALIBRATION AND VALIDATION ON THE SOUTHWEST WASHINGTON INNER CONTINENTAL SHELF
}

\author{
Meg Palmsten, University of South Florida
}

\section{CONCLUSIONS}

1) The SWAN model produces the best results on the Southwest Washington inner continental shelf when all formulations are set to model defaults except: wind input/ whitecapping formulation is the Janssen formulation, with $C D S 2=4.5, d=0.5$, and the bottom friction is calculated with the Madsen formulation, $K_{n}=0.05 \mathrm{~m}$.

2) The SWAN model reproduces field conditions well when the model is properly initialized.

3) The SWAN model was only properly initialized for this experiment when waves and wind originated offshore of the model boundary.

4) Peak direction at the NOAA buoy 46005 calculated from peak direction at the CDIP buoy using Snell's Law is not valid when offshore peak direction is influenced by winds from onshore.

\section{FIELD EXPERIMENT}

A wave refraction experiment was conducted from October through December of 1999 near the ebb-tidal delta at Grays Harbor, WA. The objective of the experiment was to collect data under many conditions for comparison with SWAN model output. An array of sensors was secured to each of five $2.4 \mathrm{~m}$ aluminum tripods deployed during the experiment (Figure 1). Data were collected at $2 \mathrm{~Hz}$ over half-hour bursts every one or two hours during the experiment.

\section{MODEL CALIBRATION}

Data from the field experiment were analyzed to estimate significant wave height, peak direction and peak period. The wave statistics were used to calibrate and validate the model.

\section{QUESTIONS}

1) What is a more robust method of estimating offshore wave direction?

2) How well does the SWAN model reproduce peak period? 


\section{ANALYSIS \\ Wave Statistics}

After checking the overall quality of the data using signal to noise ratio and correlation of signals, velocity data of poor quality were identified with a low pass filter. A spline interpolation was used to replace data points of poor quality. Significant wave height was calculated for each burst by integrating across the depth corrected pressure spectrum as described by Thornton and Guza (1982). Significant wave height was also calculated from deglitched horizontal velocity data using the spectral transfer function for horizontal velocity (Guza and Thornton, 1980) and integrating over the horizontal velocity spectrum (Thornton and Guza, 1982). Wave direction was determined at each frequency by calculating the inverse tangent of the cross spectra from pressure, $p$, and horizontal velocity in the cross-shore, $U$, and the cross spectra from pressure, $p$, and vertical velocity in the alongshore, $V$. Peak direction for each burst was reported at the peak frequency. Burst averaged wave statistics are plotted in Figure 2.

\section{Model Domain and Boundary Conditions}

Bathymetry for the model domain was developed from National Ocean Service historical sounding data and U.S. Army Corps of Engineers hydrographic surveys (Gibbs et al., 2000). Nested grids of $750 \mathrm{~m}$ and $500 \mathrm{~m}$ were used to reduce computational time. Wave height, wind velocity, and peak period observed at NOAA buoy 46005 (2779.8 m water depth) were used as boundary conditions for the model. Wave direction at the model boundary was calculated by reverse shoaling using Snell's Law and the peak wave direction observed at the Grays Harbor CDIP directional buoy (41.5 m water depth). Directional bins of $15^{\circ}$, and 15 frequencies between $0.05 \mathrm{~Hz}$ and $0.2 \mathrm{~Hz}$ were modeled. All other formulations within the SWAN model were set to the default parameters. Four time periods for model calibration were chosen when conditions were stable over the wave group travel time between the NDBC buoy 46005 and the study area calculated using linear wave theory over the $534 \mathrm{~km}$ distance. This constraint eliminated error due to changing conditions.

\section{Model Calibration and Validation}

The action balance equation drives the SWAN model

$$
\frac{\partial N}{\partial t}+\frac{\partial}{\partial x} c_{x} N+\frac{\partial}{\partial y} c_{y} N+\frac{\partial}{\partial \sigma} c_{\sigma} N+\frac{\partial}{\partial \theta} c_{\theta} N=\frac{S}{\sigma}
$$

$N(\sigma, \theta)$ represents the action density spectrum, equal to the energy density divided by wave frequency. The first term in the equation represents the local rate of change in $N$ with time, $t$. The second and third terms represent propagation in $x$ and $y$ space. The terms $c_{x}$ and $c_{y}$ are the propagation velocities in $x$ and $y$ space. The fourth term represents shifting of relative frequency due to variations in water depth and currents. The fifth term represents depth-induced refraction. The energy source terms on the right side of the equation account for generation, dissipation, and nonlinear interactions between waves.

Two formulations within the model were shown to produce changes in wave height greater than 3 percent, dissipation due to bottom friction and the formulation for wind input/ whitecapping. Changes in model formulation were iteratively carried out for a group of 
wave cases until the model reproduced field data well. Model results were improved when the dissipation coefficient, $C$, in the source term for bottom friction $\left(S_{d s, b f}\right)$ was calculated using the Madsen formulation for $C$ developed from the quadratic drag friction law and a roughness height, $K_{n}$, of $0.05 \mathrm{~m}$ was used. The general form for dissipation due to bottom friction is,

$$
S_{d s, b f}=-C \frac{k}{\sinh k h} E(f, \theta)
$$

where $k$ is wave number, $h$ is water depth, $E(f, \theta)$ is the energy density spectrum, $f$ is frequency and $\theta$ is direction. Model results were also improved when the Janssen formulation for wind input/whitecapping dissipation was used. This formulation for wave growth depends on wave age rather than a linear function and the dissipation source term is adjusted to determine a proper balance at high frequencies due to wavenumber rather than using a source term dependent on linear dissipation.

$$
S_{d s, w c}=-C_{d s}\langle\omega\rangle\left(\langle k\rangle^{2} m_{o}\right)^{2}\left[(1-\delta) \frac{k}{\langle k\rangle}+\delta\left(\frac{k}{\langle k\rangle}\right)^{2} N\right]
$$

Default values in the SWAN model for this equation are $C_{d s}=4.5$ and $\delta=0.5$. These constants were determined by tuning to produce results from the action balance equation in good agreement with data (Komen, 1994). In the equation, $m_{o}=4$ is the total wave variance per square meter, $k$ is the wavenumber, $\langle\omega\rangle$ is mean angular frequency, $\langle k\rangle$ is mean wavenumber, and $N$ is the action density spectrum.

Figure 3 shows the reduction in model error due to changes in model formulation. Error measurements are shown along the x-axis. The y-axis represents scale of the model error. The first bar in each error measurement is error for a tuned model run and the second bar represents error for a default model run. For all cases tested, model results improved for the tuned model run. Differences between modeled wave height and estimated wave height from field data were calculated using several statistics described by Ris (1997). The rms error $(R M S)$ is defined as,

$$
r m s=\sqrt{\frac{1}{N} \sum_{i=1}^{N}\left(X_{i}-Y_{i}\right)^{2}}
$$

where $N$ is the number of observations, $X_{i}$ is the observed value at location $i$, and $Y_{i}$ is the computed value at location $i$. Scatter index $(S I)$ is the RMS normalized by the mean of the observed wave parameters,

$$
S I=\frac{r m s}{\bar{X}}
$$

$\bar{X}$ represents the mean of the observed wave parameter,

$$
\bar{X}=\frac{1}{N} \sum_{i=1} X_{i}
$$


The MPI, model performance index, is a test of how well the model performs relative to a perfect model run minus the ratio of rms-error of the model to rms-value of the modeled changes in wave parameters from the up-wave boundary.

$$
M P I=1-\frac{r m s}{r m s\left(X_{\text {boundary }} ; Y_{i}\right)}
$$

MPI is most insightful when wave conditions vary greatly between offshore boundary conditions and nearshore output. MPI differs from $S I$ in that it normalizes rms by the difference in changes over the domain between observed and modeled conditions, while $S I$ compares differences in observed and model conditions. $O P I$, operational performance index, is rms-error normalized by the boundary conditions.

$$
O P I=\frac{r m s}{X_{\text {boundary }}}
$$

OPI provides insight into the scale of error compared with model output.

Significant wave heights calculated by the SWAN model using tuned coefficients were compared with estimated wave heights from field data. Modeled wave height compared well with wave statistics estimated from field data (Figure 4). Similar results were found for modeled peak direction (Figure 5).

\section{ACKNOWLEDGEMENTS}

This modeling study has truly benefited from the support and guidance of Peter Howd, Guy Gelfenbaum, and Chris Sherwood.

\section{REFERENCES}

Gibbs, A.E., Buijsman, M.C., and Sherwood, C.R. 2000. Non-navigational gridded bathymetry data Washington - Oregon coast: 1926-1998, Data release and description of methods, Version 1.0, U.S. Geological Survey Open-File Report 00448, 37 p. and CD-ROM.

Guza, R., and Thornton, E. 1980. Local and shoaled comparisons of sea surface elevations, pressures and velocities, Journal of Geophysical Research, 83 (C3), pp. 1524-1530.

Komen, G. 1994. Dynamics and Modeling of Ocean Waves, Cambridge, New York, 532 p.

Ris, R. 1997. Spectral modeling of wind waves in coastal areas: Report no. 97-4. Communications on Hydraulic and Geotechnical Engineering, Department of Civil Engineering, Deft University of Technology, 160 p.

Thornton, E., and Guza, R. 1982. Energy saturation and phase speeds measured on a natural beach, Journal of Geophysical Research, 87 (C12), pp. 9499-9508. 


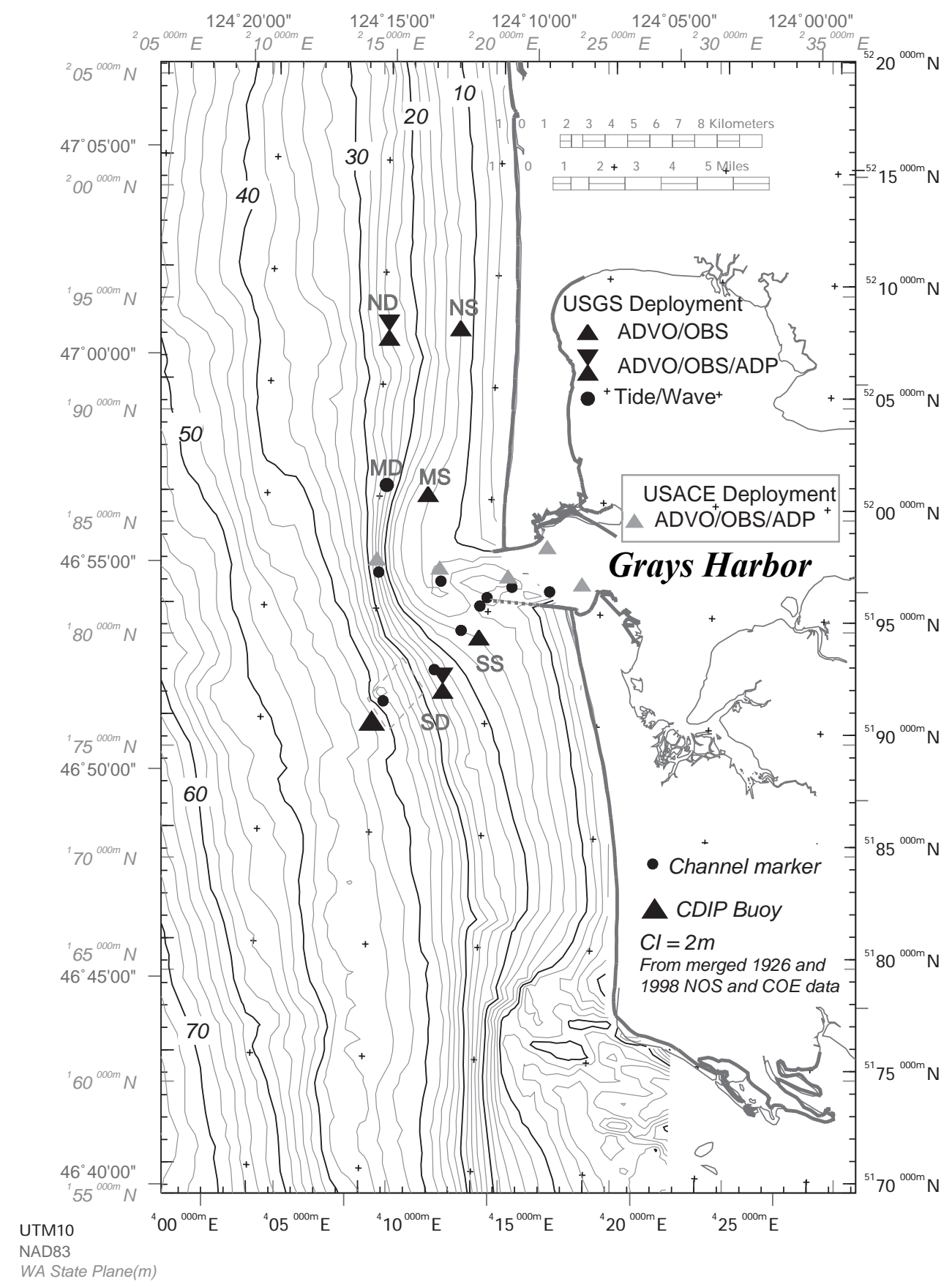

Figure 1. Instrument locations during the field experiment. 


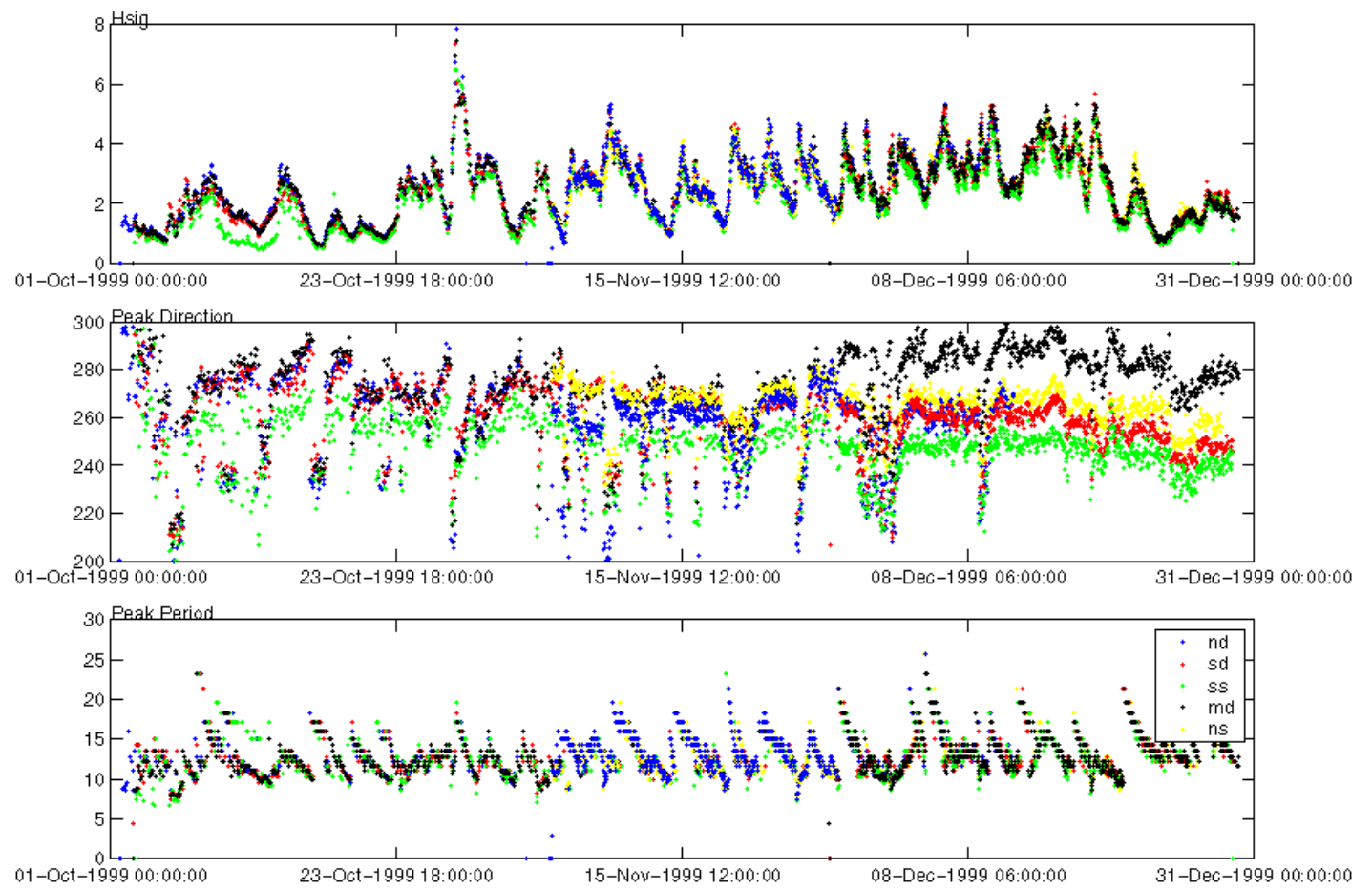

Figure 2. Burst averaged wave statistics collected during the field experiment.

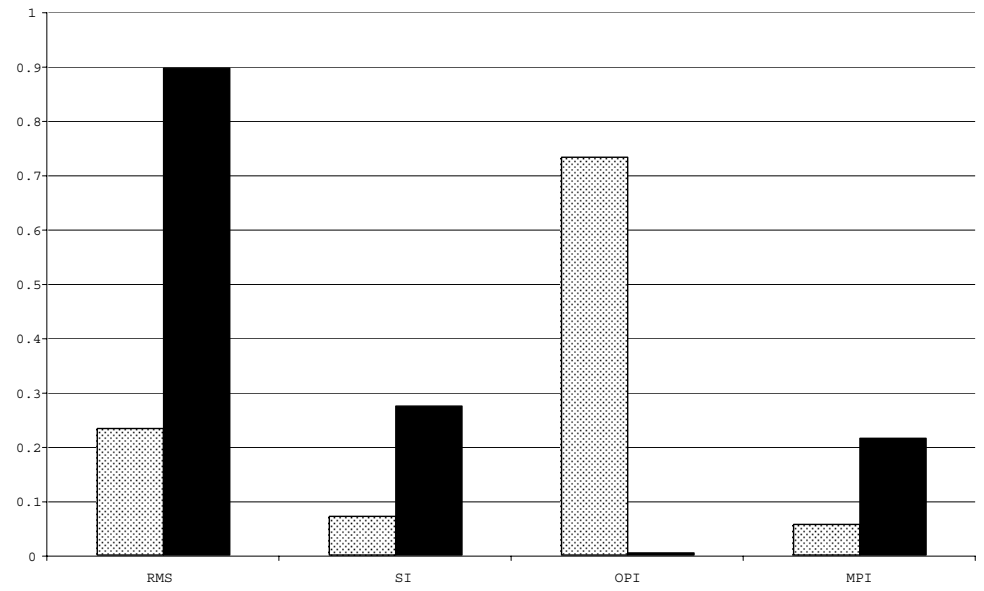

Figure 3. The first bar in each set represents error for a tuned model run. The second bar in each set represents error for a default model run. 
Modeled vs Estimated Significant Wave Height

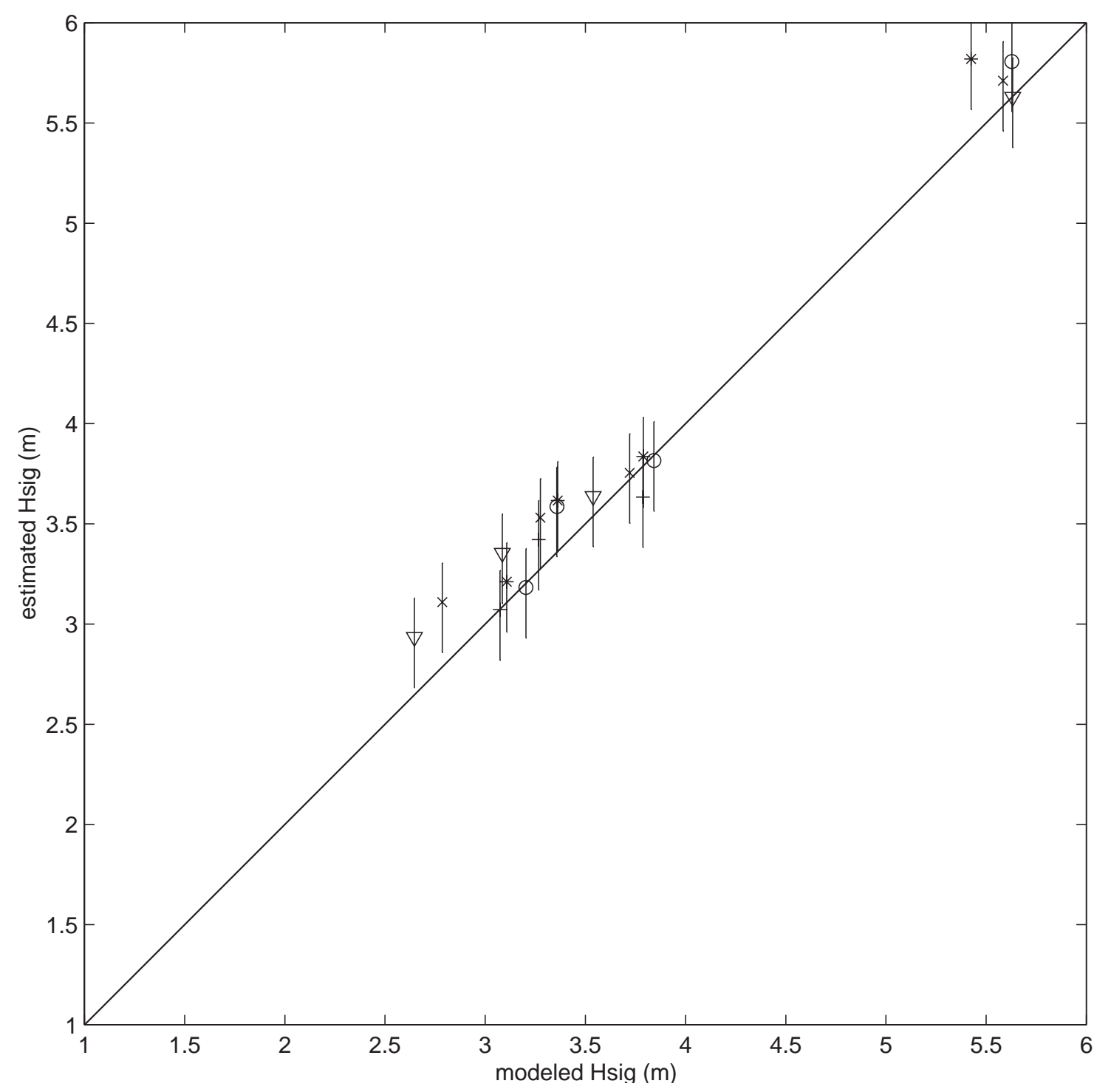

Figure 4. Modeled significant wave height compared with significant wave height estimated from field data: Site ND (o), Site NS (+), Site MD (*), Site SD (x), and Site SS ( $\nabla)$. 


\section{Modeled vs Estimated Peak Direction}

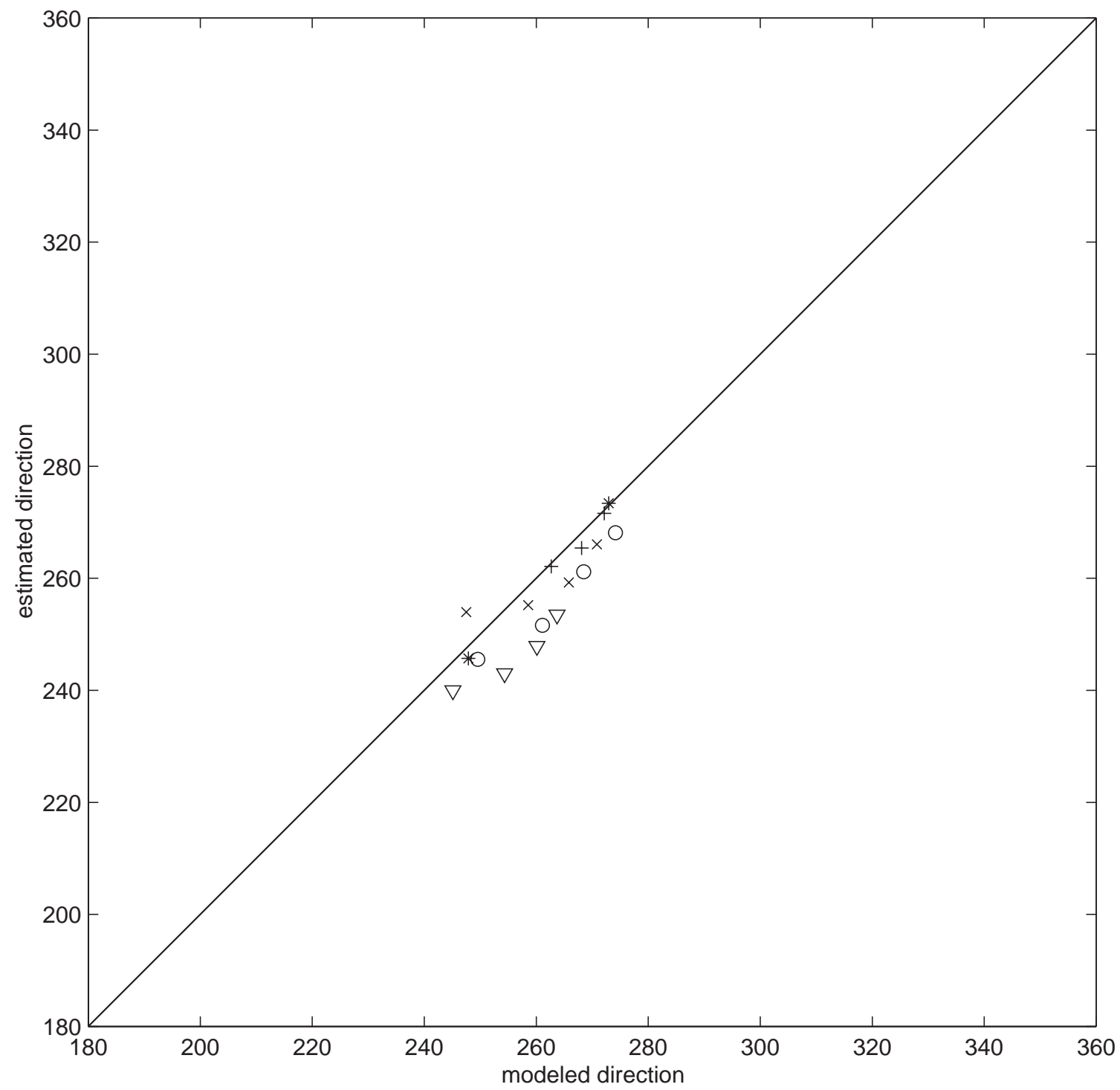

Figure 5. Modeled peak wave direction compared with peak direction estimated from field data: Site ND (o), Site NS (+), Site MD (*), Site SD (x), and Site SS ( $\nabla)$. 


\title{
SEDIMENT TRANSPORT DURING THE 1999 GRAYS HARBOR WAVE REFRACTION EXPERIMENT
}

\author{
Christopher R. Sherwood, U.S. Geological Survey
}

\begin{abstract}
Six tripods were deployed at shallow ( 14-m) and deep ( 24-m) sites on the northern, middle, and southern flanks of the Grays Harbor ebb-tidal delta from early October through December, 1999. Pressure records (for measuring waves and tides) were recorded at all locations except the northern, shallow site, where the instruments were physically damaged early in the deployment. Current velocity profiles from upward-looking acoustic-doppler profilers (ADPs) were recorded at two sites, and burst measurements (2 $\mathrm{Hz}$ for 17 minutes every 2 hours) of current velocities were obtained with acoustic doppler velocimeters (ADVs) nominally positioned $80 \mathrm{~cm}$ above the bottom at four sites. Concurrent, co-located measurements of optical backscatterance were made to provide estimates of suspended-sediment concentrations. Directional wave spectra show that the general direction of wave approach shifted from WNW to WSW as the North Pacific weather pattern shifted from summer to winter, and we were fortunate enough to capture a large storm (offshore significant wave heights of $8 \mathrm{~m}$ ) in late October and a sequence of about 8 smaller events with 4 to 5-m waves in November and December. As expected, wave directions indicate refraction around the ebb-tidal delta, and vary with incident wave period and direction. ADV measurements of distance from the bottom reveal both episodic and slowly varying changes. For example, at the deeper northern site, ADV elevations twice decreased by $20 \mathrm{~cm}$ during storms, indicating scour and settling of the tripod and/or significant accretion of the seabed. Between those episodic jumps, relative bottom elevation varied more slowly, suggesting migration of bedforms with amplitudes of $\sim 8-10 \mathrm{~cm}$. Direct estimates of sediment flux at the elevation of the ADV and optical backscatter sensors (OBS) were formed as the product of instantaneous current velocities and suspended-sediment concentrations. Sediment flux (bedload and suspended load) was also calculated from instantaneous velocities using an energetics-based equation, and a separate estimate of suspended-sediment transport was calculated from burst-mean currents and wave-orbital velocities using a wave-current model. Measurements and calculations indicate that cumulative sediment transport at all four locations was northward and offshore during our 3-month experiment, and there was little evidence for shoreward transport during fairweather conditions. Rates were highest at the southern sites, and higher in shallower water. Although peak rates occurred during the largest storm, cumulative transport was determined by the smaller events that followed. The contribution of tidal transport was small. These results indicate that sand on the ebb-tidal delta can be mobilized frequently under winter conditions, and can bypass the inlet at depths of at least $24 \mathrm{~m}$. The data also suggest that significant offshore transport occurs at these depths and highlights the importance of cross-shore transport well outside the surf zone.
\end{abstract}




\title{
MODELS, DATA, ASSUMPTIONS, AND WHAT WE KNOW FOR SURE
}

\author{
Peter Howd, College of Marine Science, University of South Florida
}

\section{CONCLUSIONS}

1) Waves - Waves reach extreme heights on the SW Washington coast - during Southwest Washington Coastal Erosion Study (SWCES) investigations significant heights in excess of $10 \mathrm{~m}$ have been measured. Use of the SWAN model has proven useful and can even be said to be highly successful. Some weaknesses have been found - namely that the results can be highly suspect when information for initialization of the model is incomplete. This causes some concern and provides some limits to the quantitative application of model results. Several examples of the comparison between observed wave characteristics and SWAN model results will be shown, with both cautionary and encouraging messages.

2) Currents - Extreme currents have been measured near the boundary between the inner shelf and the lower beach face, nominally between the 12 and $22 \mathrm{~m}$ isobaths. In the Study's early ADP measurements off Grayland (away from the Grays Harbor entrance) it was found that measurements of near bed mean currents can be statistically uncorrelated relative to those at the surface! This poses problems for simple, depthintegrated models. Some simple statistical calculations will be done to first show that we must worry about how mean flows vary with depth, followed by some suggestions based on the goals of the program (as seen by the author).

3) Sediment transport, beach profiles and budgets - This is where many aspects of our collective studies begin to merge. It's known that waves and currents are what move the sands, but how? What time scales and what spatial scales are appropriate? Unfortunately there isn't one answer to that question, there are many! This will be demonstrated using the concept of closure depth, which unfairly has come to represent the offshore edge of the beach system. The geologists see a "sedimentological" closure depth of $\sim 20 \mathrm{~m}$, empirical relationships from other coasts suggest a depth of less than $15 \mathrm{~m}$, and profile observations suggest something even shallower! Study scientists must be clear when dealing with the public and the press (and each other!) that artificial constructs, like closure, are correctly applied and understood in the context of the scientific questions being asked.

4) What is known for sure is that sand moves on the SW Washington coastline. Some transport patterns can be deduced, for instance, that over the past several thousand years, the sand from the Columbia River has moved fastest (or furthest) close to shore reaching Point Grenville long before covering the shelf. Obviously, a great deal more is known about the parts of the system, but a great challenge awaits as synthesis of the results from different studies with distinctly different goals and approaches begins to produce a picture of how this coastline may evolve over the next several decades. 


\section{FEASIBILITY OF A SUBMERGED SPUR TO CONTROL NAVIGATION CHANNEL SHOALING AT NORTH JETTY, GRAYS HARBOR: EVALUATION OF NORTH JETTY SEDIMENT TRANSPORT CONDITIONS}

Philip D. Osborne, Pacific International Engineering, PLLC

Vladimir Shepsis, Pacific International Engineering, PLLC

\section{CONCLUSIONS}

The U.S. Army Corps of Engineers (USACE), Seattle District, recently began a study on the feasibility of constructing a submerged spur dike off the western end of the Grays Harbor North Jetty, parallel to the Ocean Shores shoreline. This effort includes extensive physical and mathematical modeling and analysis of field measurements of sediment transport processes in and around the mouth of Grays Harbor.

Analysis of existing conditions suggests that sediment transport at the entrance of Grays Harbor estuary is controlled by several factors: short period and long-period waves, storminduced steady currents and tidal currents, configuration of the ebb delta, performance of the South and North Jetties, and sediment availability. In general, a conceptual model of storm-induced sediment transport at the entrance of Grays Harbor may be described as follows:

- During strong winter storms from the south, southwest, and west, sediment from the south bypasses the Grays Harbor entrance approximately following contours and offshore boundary of the ebb delta (at depths of up to 50-70 ft). Some of this sediment is deposited in the bar channel causing channel sedimentation and maintenance dredging. Sediment from south, southwest and west directions does not propagate significant amounts into Grays Harbor during winter storm events, due to the offshore component of storm driven flows and concentrated ebb flows, which dominate this environment. This sediment contributes insignificantly to sedimentation of the bar channel.

- The sediment that bypasses the South Jetty and ebb shoal during winter storms migrates to the north toward the Pacific beaches and or deposits offshore from the Ocean Shores beaches.

- During summer storms or swell when waves arrive from the north, northwest, and west, sediment migrates onshore and to the south where it accretes on Ocean Shores beach and a significant portion bypasses the North Jetty. The portion of sediment, which bypasses the North Jetty, enters the entrance to Grays Harbor along the north side of the entrance channel during the flooding tide. The net transport of southward by-passing sediment is directed into the inlet due to dominance of the flood tide on the north side of the inlet. Sediment from this movement is a major component of developing the inner bar between the jetties and entrance channel sedimentation. 
The conceptual model for sediment transport described above is based on only a limited understanding of nearshore processes in the vicinity of the North Jetty and Grays Harbor entrance. No measurements for characterizing hydrodynamic/sediment transport processes in close proximity to the North Jetty and along Ocean Shores are available. Previous field data collection efforts have focused on the inlet throat and the offshore margins of the ebb shoal. Therefore, improved understanding of current patterns and sediment loads in this area is required to evaluate, with greater certainty, the potential reduction in sand bypassing upon placement of a submerged spur dike near the submerged end of the jetty.

\section{ACCOMPLISHMENTS}

The first phase of work to study the feasibility of a submerged spur off the western end of the Grays Harbor North Jetty focussed on the following tasks:

1) feasibility of constructing a spur in the high energy wave environment at North Jetty.

2) documentation of existing conditions and evaluating hypotheses concerning mechanisms for sediment transport and circulation in the region of Grays Harbor entrance and ebb shoal; this involved consideration of the following:

- wave climatology,

- hydrodynamics and near bed velocity fields,

- suspended sediment transport, and

- short term and long term bathymetric and morphological change.

\section{QUESTIONS}

Research conducted as part of the first phase of work identified a need for greater understanding of the coastal processes controlling sediment transport and shoreline response in the nearshore areas directly north of the North Jetty. The research also raised questions concerning performance and functioning of the proposed submerged spur that require investigation prior to reaching a feasibility result.

There is little information on the functioning of a jetty spur and the resultant interaction with the water and sediment movement. This area has great need for research, and the first step is a measurement program to reveal the underlying physical processes. A major objective of the next phase of work is to investigate coastal processes associated with waves, currents, and sediment transport in the proposed project area. The approach will be to obtain detailed field measurements from the North Jetty area. The analysis of these measurements will provide information needed to test hypotheses concerning mechanisms for southward sediment bypassing of North Jetty and on the relative importance of crossshore and longshore sediment transport. The measurements will also provide information 
to verify wave, current and transport numerical models, thereby advancing their value as design tools to aid in the optimization of project performance.

The work proposed for the next phase of study will focus on evaluating functional performance of the proposed submerged spur, in terms of effectiveness in trapping and retaining sand, reducing the amount of sand that bypasses the North Jetty and enters the inlet, and in promoting a beneficial morphological response. Work is intended to address the following questions:

- What are the major hydrodynamic mechanisms and sediment transport rates in the vicinity of the North Jetty and how much southbound sand transport bypasses the North Jetty?

- How will the spur modify hydrodynamics and sediment transport processes locally? Will it be effective in terms of retaining sediment? Will it result in "positive" modifications to the nearshore bathymetry? Or will it result in scour and beach erosion?

- What are the potential changes to shoreline orientation and nearshore bathymetry due to the proposed structure? How will the changes in orientation affect the local sediment transport regime?

\section{ANALYSIS}

Understanding of wave characteristics and wave climatology in deep and shallow water at the study site is fundamental to evaluation of spur dike feasibility. Analysis was undertaken to identify the primary characteristics (wave height, period, direction, and spectrum) of the wave climate offshore of the Washington coast near Grays Harbor. Analysis included a review of previous studies on wave climate, an extremal analysis using data from January 1982 through June 2000 of the Grays Harbor CDIP buoy, and statistical analysis of wave heights, periods, direction, and spectral densities at 3 - hour intervals from January, 1994, through June, 2000. Plots of wave height, wave period distribution, and probability of non-exceedance, as well as values of minimum, maximum, significant, and average heights and periods were compiled for monthly ensembles, winter and summer ensembles, and cumulative ensembles. Directional analysis included directional distributions with percentage of occurrences as well as directional spectra for monthly, seasonal, and cumulative time periods. These data have been applied to assessing construction feasibility and for verification of 2D wave transformation models.

Characteristics of currents (speed, direction, occurrence) and circulation patterns were assessed from a review of previous physical and numerical modeling and related field studies and analysis of point measurements of near bottom current speed and direction obtained during instrument deployments in the Grays Harbor entrance and ebb shoal region (Cialone et al., 1999; Hericks and Simpson, 2000; Gelfenbaum et al., 1999). The analysis of point measurements included summarizing burst-averaged current statistics and distributions of near bottom peak flood, peak ebb velocity, and net currents. Time 
series of rms and significant wave orbital speeds associated with gravity wave motion $(T<20 \mathrm{~s})$ and infragravity wave motion $(T>20 \mathrm{~s})$ near the bed (Uo) for easterly and northerly components of current bursts were computed from the measured velocity data using spectral analysis. Vector summaries (compass plots) for the peaks of storm events and peak ebb and flood conditions in the inlet were used to summarize the information on near bottom flows.

Suspended sediment concentrations (or turbidity, depending on availability) were quality checked and analyzed in order to characterize time-averaged conditions and time-varying properties during two storm events. Suitable concentration time-series were then selected for computations of sediment flux components associated with steady currents and wave orbital motions. Burst-averaged concentration magnitudes were compared with Green and Black's (1999) predictive formulae for wave-induced reference concentration. Point estimates of the total burst-averaged suspended sediment flux were analyzed as a sum of three components, corresponding with mean (steady current), infragravity, and short-wave contributions. Wave components were analyzed using cross-spectral techniques.

Estimates of gross and net littoral drift were also made using the time series of wave parameters and application of the CERC formula using the methods outlined in Section III, page III-2-21 of the Shore Protection Manual (USACE, 1984). Results were compared with analysis of North Beach shoreline changes based on contour maps constructed from monthly detailed 3D topographic surveys (Ruggiero and Voigt, 2000). Sub-aerial beach survey data were used to derive integrated contour position time series and beach volume changes for comparison with estimates of sediment transport potential. Previous work examining long term changes in the shape and position of depth contours at the bar and entrance area since the navigational project was first constructed was also reviewed as part of the study.

\section{ACKNOWLEDGEMENTS}

The 1997-2000 shoreline data (beach profiles, 3D topographic maps, and nearshore bathymetry) were provided by the Coastal Monitoring \& Analysis Program (CMAP), Washington Department of Ecology, Olympia, Washington. Data collection and development costs were funded in part or in their entirety by the Department of Ecology, U.S. Geological Survey, or the National Oceanic and Atmospheric Administration in support of the Southwest Washington Coastal Erosion Study. CMAP reserves the right to revise or modify this data without notice.

Data from instrumented tripods were collected as part of the joint U.S. Geological Survey - Washington Department of Ecology Grays Harbor Wave Refraction Experiment (Gelfenbaum et al., 2000), conducted in October-December, 1999, also a part of the Southwest Washington Coastal Erosion Study.

Tripods measurements were also collected as part of the USACE Grays Harbor Estuary Physical Dynamics Study from 11-13 September to mid November 1999 (Cialone et al., 1999; Hericks and Simpson, 2000). 


\section{REFERENCES}

Cialone, M.A., Kraus, N.C., Nelson, E., Sumeri, A., Parry, R., Hericks, D.B., Grosskopf, W.G., and Kurrus, K. 1999. Data collection for establishing numerical models of Grays Harbor, Washington, Southwest Washington Coastal Erosion Workshop Report, 1998, U.S. Geological Survey Open-File Report 99-524, pp. 120-125.

Gelfenbaum, G., Sherwood, C.R., Kerr, L.A., and Kurrus, K. 2000. Grays Harbor wave refraction experiment 1999 data report, U.S. Geological Survey Open-File Report 00-404, 132 p. and 3 CD-ROMs.

Gelfenbaum, G., Sherwood, C.R., Peterson, C.D., Kaminsky, G.M., Buijsman, M., Twichell, D.C., Ruggiero, P., Gibbs, A.E., and Reed, C. 1999. The Columbia River littoral cell: A sediment budget overview, Proceedings of Coastal Sediments '99, ASCE, pp. 1660-1675.

Green, M.O., and Black, K.P. 1999. Suspended sediment reference concentration under waves: field observations and critical analysis of two predictive models, Coastal Engineering, 38, pp. 115-141.

Hericks, D.B., and Simpson, D.P. 2000. Grays Harbor Estuary Physical Dynamics Study, Final Data Report: Sep 11, 1999-Nov 17, 1999, Pacific International Engineering, Edmonds, WA.

Ruggiero, P., and Voigt, B. 2000. Beach monitoring in the Columbia River littoral cell, 1997-2000, Washington State Department of Ecology, Coastal Monitoring \& Analysis Program, Publication No. 00-06-26, 112 p.

U.S. Army Corps of Engineers 1984. Shore Protection Manual, Coastal Engineering Research Center. 


\section{Discussion Topics \& Reviews of Study Progress}




\section{AN INTEGRATED CONTEMPORARY SEDIMENT BUDGET FOR THE COLUMBIA RIVER LITTORAL CELL}

George M. Kaminsky, Washington Department of Ecology

Maarten C. Buijsman, Washington Department of Ecology

Peter Ruggiero, Washington Department of Ecology

Guy Gelfenbaum, U.S. Geological Survey

\section{CONCLUSIONS}

1) Both a conceptual and quantitative sediment budget, including the magnitudes and pathways of mass flux, has been developed to include all source and sink compartments of the Columbia River littoral cell.

2) It is evident that bypassing of sand across the Willapa Bay entrance by littoral transport and/or shelf transport is critical to the supply of sand to the northern sediment compartments. If the residual alongshore sediment transport north of Willapa Bay is less than approximately $0.8 \mathrm{Mm}^{3} / \mathrm{yr}$, then the supply from the lower shoreface would appear to be unreasonably high in order to balance the sediment budget.

3) One of the most uncertain yet critical quantities at present is the sedimentation rate of Willapa Bay. If Willapa Bay requires less infilling of sand, then the beaches to the north may receive a higher rate of supply from the south.

4) Important components to balancing the sediment budget are accurate estimates of Columbia River sediment supply and shoreface sediment supply. The historical data required to accurately quantify and constrain these sources is sparse.

5) Sediment budget estimates have a large influence on shoreline change predictions.

6) The results of shoreline modeling and morphodynamic analyses suggest that the net sediment transport along the upper shoreface and coast is directed away from the jettied estuary entrances. In contrast, the net regional sediment transport along the lower shoreface appears to be both northerly and onshore over decadal to century time scales throughout the entire littoral cell. Future shoreline position will likely be governed by a combination of sediment supply from the Columbia River, the ebb-tidal deltas, and the lower shoreface. Presently, the sediment supply from both the Columbia River and ebbtidal deltas appear to be declining if not already insufficient to maintain the existing regional configuration of the shoreline. These potential shoreline responses to changes in littoral supply underscore the importance of shoreface morphology and sediment transport to decadal scale coastal change.

7) A review of U.S. Army Corps of Engineers (1999) suggests that it is possible that none of the sand currently entering the Columbia River Estuary from the river is reaching the littoral environment. In recent decades (1984 to 1998), an average of $2.3 \mathrm{Mm}^{3} / \mathrm{yr}$ 
$\left(34.8 \mathrm{Mm}^{3}\right)$ of sand was dredged from the Mouth of the Columbia River and estuary and disposed of in deep-water ocean sites. This amount exceeds the estimated amount of sand supply from the upland drainage basin. Over the next two decades, the Corps proposes increasing the amount of sand removed from the Columbia River estuary and mouth to an average of $2.7 \mathrm{Mm}^{3} / \mathrm{yr}$, and over the same period remove approximately 2.3 $\mathrm{Mm}^{3} / \mathrm{yr}$ from the Columbia River. These proposed interventions enhance the potential for the Columbia River estuary to be a sink, rather than a source, of sand to the littoral cell.

\section{ACCOMPLISHMENTS}

1) The sediment budget has been schematized as a quantitative dynamic sediment flux model based on a conceptual understanding of transport pathways between the major sediment compartments.

2) The sediment budget is primarily based on historical shoreline position, topographic and bathymetric changes, wave-driven sediment transport modeling results, and a conceptual understanding of regional morphologic changes.

3) Bulk volumes and net sediment fluxes between compartments have been derived for the inner shelf, including the inlets and ebb-tidal deltas of the Columbia River and Grays Harbor, and the adjacent coastal barriers. A variety of data sets have been utilized, each of which lacks complete coverage or the spatial resolution and accuracy desired (e.g., Gibbs and Gelfenbaum, 1999). The data sets include 1954 and 1958 bathymetry collected by the U.S. Coast and Geodetic Survey (USC\&GS), and 1954 and 1998/1999 bathymetry of the U.S. Army Corps of Engineers (USACE). The 1998/1999 bathymetric data were merged with the 1999 nearshore data of the beach morphology monitoring program of the SWCES (Ruggiero et al., 1999), allowing for direct integration with the beach and topographic data. Topographic change was calculated using a Digital Elevation Model (DEM) developed by the SWCES from a laser mapping project conducted in 1998 by the National Oceanic and Atmospheric Administration (NOAA), the National Aeronautics and Space Administration (NASA), and the USGS (Sallenger et al., 1999). Shorelines derived from the 1950s National Ocean Service topographic sheets (NOS T-sheets) and 1995 NOAA aerial photography were processed by the SWCES and used to determine the area for topographic change analysis. The calculations of topographic change include bathymetry to an estimated annual depth of closure of approximately $11 \mathrm{~m}$ below mean sea level, or a modification thereof in areas with ebb-tidal shoals.

4) A paper on this on this topic has been submitted to the Proceedings of the 27th International Conference on Coastal Engineering (Kaminsky et al., 2000). Some of the contents of this abstract appear in this proceedings paper. 


\section{QUESTIONS}

1) What is the relationship between shoreline behaviour and shoreface morphodynamics? What combinations of geometric and physical process parameters regulate the potential of the lower shoreface (i.e., deeper than the annual closure depth) as a sediment source to the upper shoreface?

2) The wave climate in the Columbia River littoral cell combines with coastal currents to result in a net regional sediment transport to the north along the Washington shelf. However, shoreline changes and net sediment transport along the sub-cell beaches are driven locally by wave refraction and shoreline orientation, causing some reversals of net sediment transport within the sub-cells. How can both shelf and littoral sediment transport be best incorporated into the sediment budget given the present lack of data?

3) Can the uncertainties of sediment flux at the Columbia River mouth, the Clatsop Plains shelf, Willapa Bay, and the lower shoreface be better constrained with existing data and knowledge?

\section{ANALYSIS Introduction}

Since the construction of jetties in the early 1900s at the entrances to the Columbia River and Grays Harbor, shoreline change throughout the Columbia River littoral cell has been dominated by sediment supply from the flanks of the ebb-tidal deltas (Kaminsky et al., 1999). In general, shoreline advance has been greatest next to the jetties, decreasing alongshore over tens of kilometers, resulting in curvilinear sub-cells that function more independently than prior to jetty installation. Both historical bathymetric changes and the onset of coastal erosion adjacent to the jetties suggest a recent decline in sediment supply from the ebb-tidal deltas and, consequently, shoreline re-adjustment towards a new equilibrium configuration.

As this long term morphologic response to the jetties is occurring, a reduction in sediment supply from the Columbia River (Gelfenbaum et al., 1999) may also be reducing the continued feeding and bypassing of sediment across the ebb-tidal deltas to the adjacent coasts. Therefore, the littoral cell is likely co-evolving from a reduction in sediment supply from both internal (estuary entrances and ebb-tidal deltas) and external (Columbia River) source compartments of the littoral system. The influences of other factors such as climate change and relative sea level change may also be affecting the behaviour of the shoreline but these factors appear to be of second-order to the dominant trends of the past century attributed to the changes in sediment supply (Kaminsky et al., 1999).

Geological investigations in the Columbia River littoral cell have documented millennial scale coastal evolution and in particular, several centuries of shoreline behaviour prior to human influence (Peterson et al., 1999a). The use of ground penetrating radar (GPR) (Jol et al., 1998) and the vibracoring and sand-augering of the coastal barriers (Woxell, 1998) and estuaries (Peterson et al., 1999b) is providing critical data to constrain the sediment budgets. In addition, these efforts suggest long-term equilibrium conditions of the 
shoreline to which the present regionally-rotated shorelines may have a tendency to approach in the future as the sediment budget is reduced.

Historical reconstruction of shoreline change in the Columbia River littoral cell has been accomplished with late 1800s to mid 1900s maps and charts, and aerial photos since the 1950s (Kaminsky et al., 1999). Century to decadal scale regional shoreline change rates reveal the initial large perturbations resulting from jetty construction as well as the subsequent regional-scale trends toward equilibrium. The historical shoreline positions from the 1950s to 1995 are used for numerical model calibration. Bathymetric and topographic change analysis yield volume estimates of decadal-scale sediment flux among the sub-cells and compartments along the inner shelf. These estimates are combined with conceptual models to develop regional sediment budgets that are used in iteration with numerical modeling.

Contemporary morphological changes are documented through nested coastal monitoring along the Columbia River littoral cell. Beach surface mapping, cross-shore beach profiles and nearshore bathymetric profiles quantify short- to medium-term (event-seasonalinterannual) variability of the coastal planform and shoreline (Ruggiero et al., 1999). Bulk parameters of shoreline and profile change are being derived to compare short-term variability with decadal-scale regional trends. By documenting the range of spatial and temporal variability of the coastal system it becomes possible to assess the susceptibility of the coast to adverse impacts of morphologic change (Ruggiero et al., 2000; Voigt et al., 2000). In particular, separation of the variance from the mean trend in shoreline position is important in management scale predictions because the variance can be used to define the zone of possible shorelines that bracket the predicted shoreline position. Furthermore, the alongshore spatial variability of the variance may be linked to offshore features, beach slope, dune elevation, bar and trough geometry, or other morphological parameters, providing greater insight to the factors that influence shoreline behaviour.

\section{Columbia River Entrance and Adjacent Coasts}

Bathymetric change analysis at the Columbia River entrance (Figure 4) has shown that between 1958 and 1998 the outer ebb-tidal delta migrated offshore, accumulating 2.0 million cubic meters per year $\left(\mathrm{Mm}^{3} / \mathrm{yr}\right)\left(81 \mathrm{Mm}^{3}\right)$, while the inner delta (pre-jetty channel-mouth bar) and inlet eroded $2.8 \mathrm{Mm}^{3} / \mathrm{yr}\left(113 \mathrm{Mm}^{3}\right)$. The upper shoreface, shallower than $24 \mathrm{~m}$ along the southerly $14 \mathrm{~km}$ of Long Beach, accumulated $0.5 \mathrm{Mm}^{3} / \mathrm{yr}$ $\left(22 \mathrm{Mm}^{3}\right)$ over this period. On average the lower shoreface between the $24 \mathrm{~m}$ and $40 \mathrm{~m}$ depth contours along Long Beach eroded by approximately $30 \mathrm{~m}^{3} / \mathrm{yr} \mathrm{m}^{-1}$. It is assumed that the sand from the lower shoreface moved onshore during this period at a rate of $1.1 \mathrm{Mm}^{3} / \mathrm{yr}\left(44 \mathrm{Mm}^{3}\right)$ over a $35 \mathrm{~km}$ stretch of Long Beach. The topographic change analysis revealed that Long Beach accumulated $2.3 \mathrm{Mm}^{3} / \mathrm{yr}$ on the barrier and $0.3 \mathrm{Mm}^{3} / \mathrm{yr}$ on the spit at Leadbetter Point (total of $104 \mathrm{Mm}^{3}$ ) over its entire length during the same 40-year period.

The Clatsop Plains shelf eroded by as much as $3.4 \mathrm{Mm}^{3} / \mathrm{yr}\left(135 \mathrm{Mm}^{3}\right)$ between 1958 and 1998 as determined by bathymetric change analysis. This apparent erosion is displayed as a nearly uniform seafloor lowering of approximately $1.2 \mathrm{~m}$ extending from $15 \mathrm{~m}$ to $60 \mathrm{~m}$ 
water depth, suggesting a possible datum control problem. However, a consistent trend of seafloor lowering is also evident in other bathymetric data sets during the periods 1926 to 1958 and 1994 to 1998 , implying that the trend is real, leaving only the magnitude in question. The Clatsop Plains shoreline remained stable along the northern $8 \mathrm{~km}$ but advanced in the south, resulting in $0.7 \mathrm{Mm}^{3} / \mathrm{yr}\left(29 \mathrm{Mm}^{3}\right)$ of accumulation in the sub-cell between 1958 and 1998, which apparently was supplied by the eroding shelf.

Sediment supply rates from the Columbia River to the coast are not certain for any period. Gelfenbaum et al. (1999) estimated that the supply of sand to the estuary from the river was $1.4 \mathrm{Mm}^{3} / \mathrm{yr}$ over the period 1958 to 1997 . It has been suggested by previous investigators (e.g., Morse et al., 1968) that sand from the littoral environment also enters and potentially accumulates in the estuary. Through dredging, the USACE mechanically removes sand from the Columbia River entrance and littoral cell by disposing of sand on the mid-shelf in water depths greater than $40 \mathrm{~m}$ (USACE, 1999). Between 1956 and 1983, $0.9 \mathrm{Mm}^{3} / \mathrm{yr}\left(25 \mathrm{Mm}^{3}\right)$ of sand was disposed in deep water outside the littoral system. Between 1984 and 1998, $2.5 \mathrm{Mm}^{3} / \mathrm{yr}\left(34.6 \mathrm{Mm}^{3}\right)$ of sand was disposed in deep-water ocean sites. Therefore, it is possible that none of the sand currently entering the estuary from the river is reaching the littoral environment.

\section{GRAYS HARBOR ENTRANCE AND ADJACENT COASTS}

Similar to the Columbia River entrance, the Grays Harbor ebb-tidal delta migrated offshore between 1954 and 1998 (Figure 4), accumulating $1.4 \mathrm{Mm}^{3} / \mathrm{yr}\left(60 \mathrm{Mm}^{3}\right)$, while the inlet and inner delta eroded by $0.9 \mathrm{Mm}^{3} / \mathrm{yr}\left(40 \mathrm{Mm}^{3}\right)$. The southern flank of the delta offshore of the Grayland Plains eroded by $0.7 \mathrm{Mm}^{3} / \mathrm{yr}\left(29 \mathrm{Mm}^{3}\right)$, while the Grayland Plains accumulated $0.5 \mathrm{Mm}^{3} / \mathrm{yr}\left(20 \mathrm{Mm}^{3}\right)$ between $1950 / 51$ and 1995 . North Beach accumulated $1.3 \mathrm{Mm}^{3} / \mathrm{yr}\left(59 \mathrm{Mm}^{3}\right)$ during this period. Unfortunately, no bathymetric data are available for this period along much of the northern coast of North Beach and the southern coast of the Grayland Plains. Bathymetric change between 1927 (USC\&GS) and 1999 (collected by the SWCES) along the Grayland Plains shows an average trend of

shoreface lowering of $15 \mathrm{~m}^{3} / \mathrm{yr} \mathrm{m}^{-1}$ between the $7 \mathrm{~m}$ and $17 \mathrm{~m}$ depth contours over at least a $10 \mathrm{~km}$ alongshore section. From a mass balance perspective it is evident that sand is being supplied from the south by alongshore transport across the Willapa Bay ebb-tidal delta or further seaward. However, the erosion of the upper shoreface along the Grayland Plains indicates that this region does not accumulate sand, rather it is bypassed to the Grays Harbor ebb-tidal delta, and potentially northward to the North Beach shelf and coast.

\section{Integrated Sediment Budgets}

The historical morphologic change data presented in the previous sections have been integrated to develop sediment budget scenarios for the entire littoral cell that are used to calibrate the shoreline model and make preliminary predictions. The sediment budget has been schematized as a quantitative dynamic sediment flux model based on a conceptual understanding of transport pathways between the major sediment compartments. Through iteration, keeping the compartment values of highest accuracy fixed, the budget is balanced by allowing the remaining compartments to vary within a limited range 
constrained by data and modeling. One of many possibilities that could represent the historical (1950s to 1990s) transfers of sediment among compartments of the littoral system is shown in Figure 1a.

In Figure 1a, the suspect high rate of erosion of $3.4 \mathrm{Mm}^{3} / \mathrm{yr}$ on the Clatsop Plains shelf has been reduced to $1.8 \mathrm{Mm}^{3} / \mathrm{yr}$ to be closer to the erosion rate identified in the bathymetric data off Long Beach. This imposed condition requires a sediment supply of $1.4 \mathrm{Mm}^{3} / \mathrm{yr}$ from the Columbia River to balance the adjacent sediment compartments. It is evident that either the Columbia River supply to the coast has been similar to that estimated by Gelfenbaum et al., (1999) for the estuary, or the supply to the coast is less, requiring that the erosion of the Clatsop Plains shelf is closer to $3.4 \mathrm{Mm}^{3} / \mathrm{yr}$. The values for all the adjacent compartments that could otherwise balance this budget are not adjusted because they are thought to be more precisely known than either the Clatsop Plains shelf supply of sand or the Columbia River supply of sand due to additional or higher resolution data. The northward sediment bypass rate exiting Long Beach approximates the magnitude of sediment transport predicted by the calibrated model. The accumulation rate of

$0.6 \mathrm{Mm}^{3} / \mathrm{yr}$ in Willapa Bay accounts for both $0.3 \mathrm{Mm}^{3} / \mathrm{yr}$ for Leadbetter Point (an accreting curvilinear spit at the northern end of Long Beach not included in the model runs) and a roughly estimated $0.3 \mathrm{Mm}^{3} / \mathrm{yr}$ to account for sedimentation in Willapa Bay. It is assumed that the Willapa Bay entrance and ebb-tidal delta are in dynamic equilibrium. No sediment exchange between Grays Harbor and the coast is assumed based on the results of Peterson and Phipps (1992). The values for shoreface supply of sand to the coast for North Beach and the Grayland Plains are loosely constrained by the incomplete data from the Grayland bathymetry, and are allowed to respond to balance other inputs and outputs. The remaining variables in the system are based on available data.

Figure $1 \mathrm{~b}$ presents one possible future sediment budget applicable over the next two decades. The values of the outer and inner ebb-tidal deltas/inlets of the Columbia River and Grays Harbor have been reduced based on extrapolation of historical accumulation and erosion trends, respectively. The Columbia River sediment supply is assumed to be zero due to river flow regulation and removal of potentially available sand by dredging. The morphological response of reduced sediment flux from the inlets results in decreased accumulation of the coastal barriers and lower, but probably realistic, net sediment fluxes throughout the system.

\section{DISCUSSION}

A significant quantity of sediment may be lost to sinks such as the outer ebb-tidal deltas (as they approach equilibrium with the jetties), Willapa Bay (as it fills accommodation space), the coastal barriers (as they aggrade by aeolian transport), and the Columbia River inlet (as sand is removed by dredging and offshore disposal). If these sink quantities exceed the potential supply of sand from the shoreface and from the jetty-induced scour of the inlets and inner ebb-tidal deltas, the elimination of Columbia River sand supply would eventually result in an aggregate trend of shoreline retreat for the region. 
Sensitivity analysis of the sediment budget and shoreline modeling results reveal that if the Clatsop Plains shoreface is actually lowering by as much as the bathymetric change analyses suggest, then this sediment source diminishes the need for a high Columbia River supply to balance the budget. If the bathymetric change analyses for the Clatsop Plains shelf overestimates the actual amount of shoreface lowering, then the Columbia River and other sources in the system become more critical. In either case, it is recognized that these estimates of shoreface supply are higher than typical (Cowell et al., 2000), which may be explained by relatively higher energy effectively transporting finer sediment in the Columbia River littoral cell.

\section{REFERENCES}

Cowell, P.J., Stive, M.J.F., Roy, P.S., Kaminsky, G.M., Buijsman, M.C., Thom, B.G., and Wright, L.D. 2000. Shoreface sand supply to beaches, Proceedings of the 27th International Conference on Coastal Engineering, pp. 2495-2508.

Gelfenbaum, G., Sherwood, C.R., Peterson, C.D., Kaminsky, G.M., Buijsman, M., Twichell, D.C., Ruggiero, P., Gibbs, A.E., and Reed, C. 1999. The Columbia River littoral cell: A sediment budget overview, Proceedings of Coastal Sediments '99, ASCE, pp. 1660-1675.

Gibbs, A.E., and Gelfenbaum, G.R. 1999. Bathymetric change off the Washington Oregon Coast, Proceedings of Coastal Sediments '99, ASCE, pp. 1627-1642.

Jol, H.M., Peterson, C.D., Vanderburgh, S., and Phipps, J. 1998. GPR as a regional geomorphic mapping tool: shoreline accretion/erosion along the Columbia River littoral cell, GPR'98 International Meeting, Lawrence, KS, pp. 257-262.

Kaminsky, G.M., Buijsman, M., Gelfenbaum, G.R., Ruggiero, P., Jol, H.M., Gibbs, A., and Peterson, C.D. 1999. Synthesizing geological observations and process-response data for modeling coastal change at a management scale, Proceedings of Coastal Sediments '99, ASCE, pp. 1708-1723.

Kaminsky, G.M., Buijsman, M.C., and Ruggiero, P. 2000. Predicting shoreline change at decadal scale in the Pacific Northwest, USA, Proceedings of the 27th International Conference on Coastal Engineering, Sydney, Australia, pp. 2400-2413.

Morse, B.A., Gross, M.G., and Barnes, C.A. 1968. Movement of seabed drifters near the Columbia River, Journal of Waterways and Harbors, 94, WW1, pp. 91-103.

Peterson, C.D., Gelfenbaum, G.R., Jol, H.M., Phipps, J.B., Reckendorf, F., Twichell, D.C., Vanderburgh, S., and Woxell, L.K. 1999. Great earthquakes, abundant sand, and high wave energy in the Columbia Cell, USA, Proceedings of Coastal Sediments '99, ASCE, pp. 1676-1691. 
Peterson, C.D., Morton, R.A., Phipps, J.B., Qualman, D.R., Sorensen, O., and Vanderburgh, S. 1999. Great earthquake records in Holocene tidal-flat and accretionary-bank deposits from Willapa Bay and Grays Harbor tidal-basins of the central Cascadia Subduction Zone, USA, Abstract, EOS, Transactions, AGU Fall Meeting, Vol. 80, No. 46, Supplement, p. F733.

Peterson, C.D., and Phipps, J.B. 1992. Holocene sedimentary framework of Grays Harbor Basin, Washington, USA, Quaternary Coasts of the United States: Marine and Lacustrine Systems, SEPM Special Publication No.48, pp. 273-285.

Ruggiero, P., Côté, J., Kaminsky, G.M., and Gelfenbaum, G.R. 1999. Scales of variability along the Columbia River littoral cell, Proceedings of Coastal Sediments '99, ASCE, pp. 1692-1707.

Ruggiero, P., Voigt, B., and Kaminsky, G. 2000. Beach monitoring for enhanced decision making, Proceedings of the 17th International Conference of The Coastal Society, Portland, OR, pp. 516-524.

Sallenger, A.H., Krabill, W., Brock, J., Swift, R., Jansen, M., Manizade, S., Richmond, B., Hampton, M., Eslinger, D. 1999. Airborne laser study quantifies El Niño-induced coastal change. EOS, Trans. Am. Geophysical Union, 80 (8), pp. 89, 92-93.

U.S. Army Corps of Engineers 1999. Integrated Feasibility Report for Channel Improvements and Environmental Impact Statement, Columbia \& Lower Willamette River Federal Navigation Channel, Portland District, Portland OR, USA.

Voigt, B., Ruggiero, P., and Kaminsky, G. 2000. Towards the development of a decision support system for the Columbia River littoral cell, Proceedings of the 17th International Conference of The Coastal Society, Portland, OR, pp. 525-532.

Woxell, L.K., 1998. Prehistoric beach accretion rates and long-term response to sediment depletion in the Columbia River littoral system, USA, M.S. Thesis, Portland State University, Portland, OR, 206 p. 


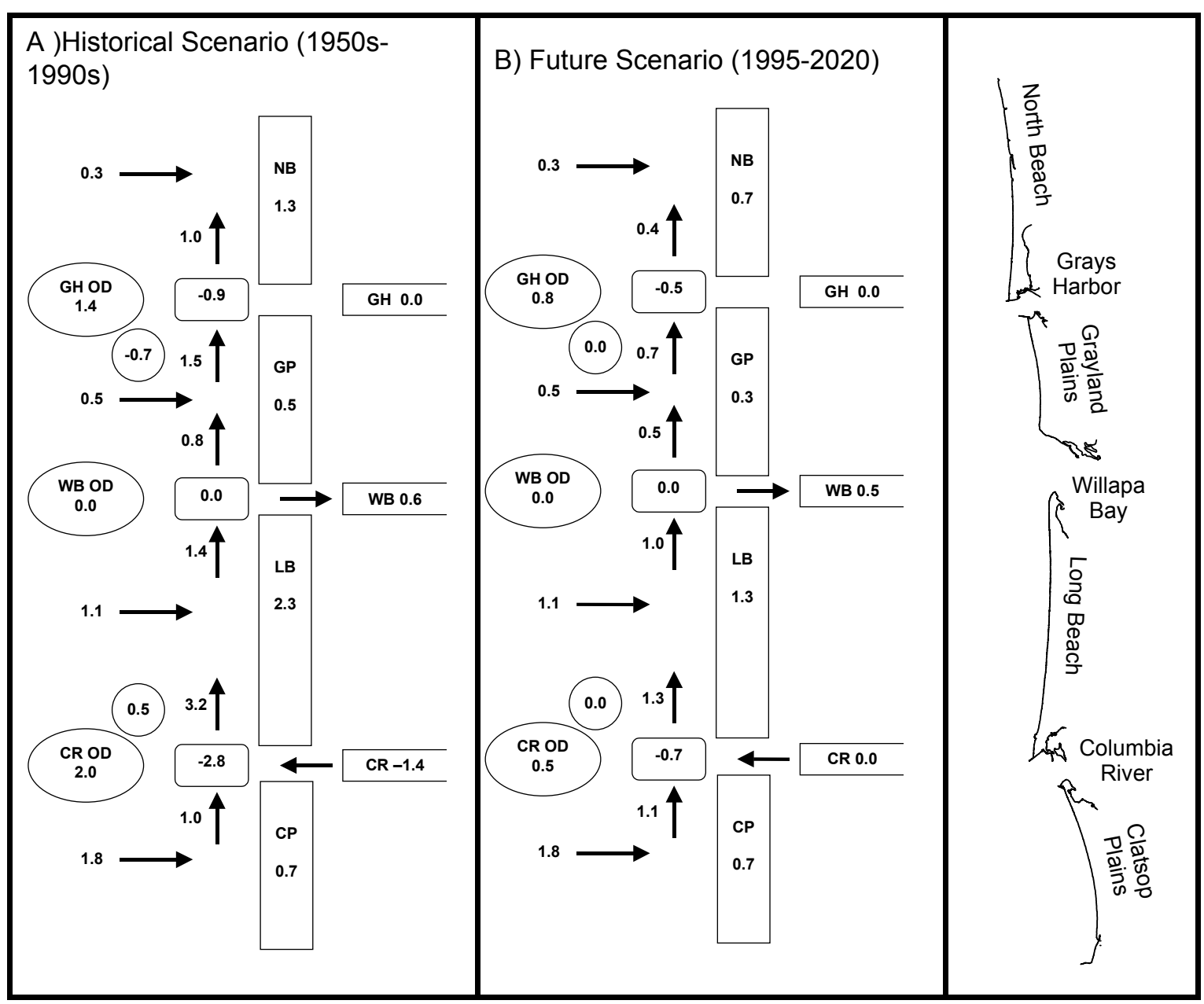

Figure 1. Quantitative sediment budget for the Columbia River littoral cell with a) a representative historical scenario and b) a possible future scenario. All values are expressed as $\mathrm{Mm}^{3} / \mathrm{yr}$ with negative values indicating sediment sources and positive values indicating sediment sinks. Fluxes in compartments portrayed by rectangles (estuaries and barriers), circles (other sand bodies), and ovals (outer deltas) have been determined through bathymetric or topographic change analyses. The rates of shoreface feeding are based on bathymetric change analyses but are typically allowed to adjust to balance the transports between the sediment compartments of the system. 


\title{
REGIONAL SEDIMENT MANAGEMENT IN COLUMBIA RIVER LITTORAL CELL: PROBLEMS AND OPPORTUNITIES
}

\author{
George M. Kaminsky, Washington Department of Ecology
}

\section{CONCLUSIONS}

1) The Southwest Washington Coastal Erosion Study (SWCES) was initially motivated by escalated erosion crises at Westport (1993), Willapa Bay (1994), Fort Canby (1995), and Ocean Shores (1995) along the Washington coast. Collaborative efforts among local governments, the Washington Department of Ecology, and the U.S. Army Corps of Engineers-Seattle District resulted in the first beach replenishment project along the southwest Washington coast, when in 1994, dredged sand was placed directly on the beach at Westport to fill the shoreline breach at the Grays Harbor South Jetty. Since that time, sand dredged from the Grays Harbor entrance channel has also been strategically used to reduce erosion in Half Moon Bay just inside the Grays Harbor entrance at Westport.

2) Over the past three years, efforts by local governments, the Department of Ecology, and the Seattle District Corps of Engineers to reduce the impacts of erosion at Ocean Shores, brought the realization that the use of dredged material was unlikely at Ocean Shores due to locally limited source volumes of dredged material. Ongoing work on evaluating modifications to the Grays Harbor North Jetty (Osborne and Shepsis, this volume) emphasize the importance of capturing even relatively small quantities of locally transported sand along the coast to reduce erosion potential.

3) Some of the SWCES research results over the past four years has suggested that sand supplies to sustain the existing coastline configuration are more limited than they have been in the past. The broad and shallow ebb shoals off Grays Harbor and the Columbia River that once promoted accretion of the beaches to the north have substantially eroded to the point that they now likely supply significantly less sand to the adjacent coasts. Along the beaches of Westport, offshore gravel deposits appear to be more prevalent, replacing the historical offshore sandbars. Cape Shoalwater, presently essentially extinct, has assimilated with the historical North Cove shoreline with rapid erosion continuing near the ocean entrance. The entire length of Benson Beach at Fort Canby has eroded at unprecedented rates in recent years. Of potentially even more concern is the rapid retreat of the southern Long Beach Peninsula over the past few years. Continuing sand losses offshore from dredging and the reduced sediment carrying capacity of the Columbia River both suggest limited supplies of sand may be available for replenishing the beaches in the future.

4) The strategic use of dredged material from the estuary entrances will be increasingly important to coastal communities in mitigating erosion trends. In fact, coastal communities and the U.S. Army Corps of Engineers, in cooperation with many state and federal agencies, are actively engaged in developing ways to enhance the beneficial use 
of dredged material at the mouth of the Columbia River. The Portland District Corps of Engineers moves an average of $3.4 \times 106 \mathrm{~m}^{3}$ per year of sand from the navigation channel in the lower estuary and mouth. Investigations by the SWCES suggest a relationship between the offshore steepening of the beach profile and shoreline change at Fort Canby, just north of the Columbia River entrance. These findings provide a baseline for optimizing the placement of dredged materials to reduce coastal erosion.

5) The utilization of dredged sand from navigation projects in the Columbia River, Willapa Bay, and Grays Harbor is one of the few viable options for reducing erosion in the Columbia River littoral cell. The utilization of dredged material to maintain sediment budgets and natural sediment dispersal pathways within the littoral cell is a key management application of the littoral cell concept. Although neither Washington State nor the local communities in southwest Washington have adopted a littoral cell management scheme, coordination of efforts to deal with coastal erosion issues among the Washington communities has been greatly enhanced since the inception of the SWCES.

6) The use of the sand resources that are dredged from the Columbia system has recently been elevated by Washington State through permit denials of future dredging and disposal plans proposed by the U.S. Army Corps of Engineers. On September 29, 2000 the Department of Ecology issued correspondence to the U.S. Army Corps of Engineers and the U.S. Environmental Protection Agency that it was unable to certify the proposed Columbia River Channel Improvements project, and in addition concluded that the Corps' proposed actions were not consistent with Washington's Coastal Zone Management Program (see http://www.ecy.wa.gov/news/2000news/crd_letters.html). Both of these decisions were in part based on the apparent unacceptable impacts to coastal resources resulting from the disposal of Columbia River sand at upland disposal sites and at deep-water ocean disposal sites. This situation underscores the central and pivotal role of the research conducted by the SWCES for helping to resolve contentious societal problems and to pursue new opportunities for science-based regional sediment management (RSM) in the Columbia River littoral cell.

7) SWCES investigators from the Washington Department of Ecology, the U.S. Geological Survey, many academic institutions, the U.S. Army Corps of Engineers, and local consulting firms (principally Evans-Hamilton and Pacific International Engineering) have amassed a large amount of data and information about our changing coast, and have gained much knowledge and experience over the past four years that must be cooperatively brought to bear to develop innovative solutions for the coastal challenges of the future. One of the largest challenges requiring additional research, monitoring, and engineering development is the management of dredged material in a way that is consistent with the coastal management objectives within the Columbia River littoral cell. 


\section{ACCOMPLISHMENTS}

1) The issue of RSM has been directly raised in recent correspondence from the Washington Department of Ecology to the Portland District Corps of Engineers and the U.S. Environmental Protection Agency.

2) A presentation to coastal communities on the potential benefits of pursing a RSM initiative with the Seattle and Portland Corps of Engineers Districts, and the SWCES was made in September 2000.

\section{ANALYSIS \\ Background}

RSM is a concept that the U.S. Army Corps of Engineers has been promoting to change the emphasis from managing coastal projects on an individual basis to a regional integrated basis. The Corps has initiated specific programs to assess the benefits of managing sediment resources as a regional scale resource rather than a localized project resource. The concept of RSM is a result of the 67th meeting of the Coastal Engineering Research Board (CERB).

The CERB (see http://bigfoot.wes.army.mil/cerb.html\#mark1) was established in 1963 to serve as an advisory board to the Chief of Engineers. The CERB is the successor to the Beach Erosion Board established in 1930. The CERB provides broad policy guidance and review of plans and fund requirements for the conduct of research and development of research projects in accord with the needs of the coastal engineering field and the objectives of the Chief of Engineers. The CERB meets semiannually at locations around the U.S. coastline and the Great Lakes on a rotating basis.

In May 1998, the 67th CERB meeting held in Fort Lauderdale, Florida focused on the theme of RSM. Following the 67th meeting, the CERB has stated that the goal of RSM is to retain all appropriate material in the littoral zone. The CERB defined that the purpose of RSM is to restore and maintain coasts as balanced natural systems. The rationale for implementing RSM is based on the recognition of dredged material as a finite resource.

The Water Resources Development Act of 1996 (WRDA '96) contains two sections that enable the Corps to improve regional sediment management. Section 204 allows the use of more costly disposal methods provided the added cost is reasonable relative to the environmental benefits that would be produced such as wetlands creation and erosion control. Section 227 allows the Federal government to work with coastal states to develop comprehensive plans for the conservation of coastal resources.

US Army Corps of Engineers initiatives in RSM are being implemented by Corps of Engineers Districts along the Northeast Florida coast (see http://nersm.saj.usace.army.mil) and the Northern Gulf coast (see http://www.sam.usace.army.mil/sediment/ sediment_homepage.htm). 
A good reference on RSM is an abstract presented at the 67th CERB meeting by Dr. Jim Houston, the Director of the Coastal and Hydraulics Laboratory at the U.S. Army Engineer Waterways Experiment Station in Vicksburg, MS. This abstract is available online at http://bigfoot.wes.army.mil/6714.html.

In the above abstract Dr. Houston states: "What is necessary to manage sediment on a regional basis with the recognition that sediment is a valuable resource? First, the resource needs to be quantified by determining its amount, relevant characteristics, and its distribution. Most U.S. coastal regions process bits and pieces of a definition of the resource usually in the form of discrete geophysical investigations, dredging and fill records, river-discharge records, and site-specific sand budgets. There are few, if any, comprehensive sand inventories that have been performed on a regional basis. Second, it is important to quantify the movement of the resource (for example, how much sediment is moving along different reaches of the coast in a region, bypassing inlets and navigation structures, being trapped in ebb and flood deltas, being impounded by structures, and being relocated by dredging and beach nourishment). Few studies have attempted to determine the movement of sediment on a regional scale. Finally, to manage sediment on a regional scale, one must have engineering tools that allow one to predict on a project and regional basis the effects that engineering activities will have on the system. Currently, it is difficult to reliably model coastal processes on a regional scale and predict how engineering activities will affect the system."

Fortunately, the SWCES has lead the development of sufficient regional data, tools, and a predictive capacity to actually demonstrate science-based RSM in the Columbia River littoral cell. All the building blocks are in place: a regional sediment budget has been derived (Gelfenbaum et al., 1999) and the sediment compartment volumes, net fluxes, and relative sensitivities of the integrated regional sediment budget are being refined (Kaminsky et al., 2000; Kaminsky et al., this volume (a)). Local project studies at Willapa Bay (e.g., Simpson, this volume; Morton et al., this volume) and Grays Harbor (e.g., Osborne and Shepsis, this volume; and Buijsman, this volume) are deriving more detailed local inventories of sand impounded or influenced by coastal structures. Finally, the engineering tools to model coastal processes on a regional scale and make predictions are well underway (e.g., Cialone et al., this volume, Cowell et al., this volume; Kaminsky et al., this volume (b)). It is clear that the combined and collaborative accomplishments in the last four years in the areas of coastal research, engineering, and management have set the stage for the fruition of a successful RSM initiative in the Columbia River littoral cell.

\section{Opportunities}

In light of the data, knowledge, and expertise developed by the SWCES, the U.S. Army Corps of Engineers, and local consultants, (as well as motivation by the need for improved use of dredged material), there appear to be new opportunities for developing a RSM initiative as a framework for harvesting research results for broad societal benefits. Such an initiative would be an appropriate means to continue addressing the impact of engineering projects, dredging disposal practices, and coastal management decisions on the sand resources. A RSM effort for the Columbia River littoral cell would represent the 
ultimate application of SWCES research results to both project engineering and coastal management and would take a "solution-oriented" approach.

For example, the utilization of dredged material to maintain sediment budgets and natural sediment dispersal pathways within the littoral cell would become a key management application of the RSM and littoral cell concept. Although neither Washington State nor the local communities in southwest Washington have adopted a littoral cell management scheme, coordination of efforts to deal with coastal erosion issues among the Washington communities has been greatly enhanced since the inception of the SWCES in 1996. A RSM effort partnered by the local, state, and federal agencies and initiated at the conclusion of the SWCES would enhance inter-governmental communication and provide a "common objective" framework for cooperation.

Coastal communities would benefit from regional shoreline change predictions to develop and justify mitigation measures and long-range financial plans. Local, state, and federal plans and projects could be modified and adapted based on updated monitoring data and model predictions related to regional sediment budgets.

The specific appropriate uses of clean dredged sediments would depend on site conditions, dredging volumes, sediment characteristics, economics, and environmental benefits. In general, appropriate uses of clean dredged sands for the southwest Washington coast may include examples such as the following:

- Beach enhancement - augmenting foreshores (beach face) and widening underwater slopes;

- Beach fill - reconstructing beaches or dunes;

- Beach nourishment- supplying existing beaches with sediment;

- Active offshore berm - providing cross-shore sediment supply to beaches;

- Passive offshore berm - attenuating wave energy and providing a barrier to offshore sediment movement;

- Feeder berm - providing cross-shore and longshore sediment supply to beaches;

- Headlands and spits - increasing longshore sediment transport to beaches;

- Channel restoration- restoring hydraulic and geomorphologic equilibrium at estuary entrances.

Similar to RSM projects in Florida and the Gulf coast, a RSM initiative in the Columbia River littoral cell could focus on such developments such as:

- a regional sediment management plan, 
- a regionally-coordinated littoral cell management plan,

- an interactive regional sediment budget analysis program,

- a calibrated regional coastal prediction system, and

- a regional database and data management framework.

More specific to information needs would be research focused on topics such as:

- a comprehensive sediment monitoring program to assess the delivery and transport of sediments from the Columbia River to the littoral cell,

- a beach and nearshore monitoring program to document the effectiveness of sand feeding to the littoral cell from dredged material disposal sites,

- an inventory of present sand resources within the Columbia River estuary,

- a bathymetric and topographic survey of the Columbia River estuary and adjacent shorelines,

- data collection and development of models that would assist in the study of sand transport through, and within, the Columbia River estuary and littoral cell,

- studies to evaluate the dispersive capacity of the nearshore zone,

- implementation of pilot projects to develop new methodologies and technologies for sand placement, and

- studies to assess the probable effects of projects on shoreline configurations.

\section{REFERENCES}

Buijsman, M. this volume. Historical bathymetric and topographic change analysis -an overview, Southwest Washington Coastal Erosion Workshop Report 2000, USGS Open-File Report.

Cialone, M.A., Kraus, N.C., Arden, H.T., Parry, R.M., and Herricks, D.B. this volume. Validation of numerical models: Grays Harbor, Washington, Southwest Washington Coastal Erosion Workshop Report 2000, USGS Open-File Report.

Cowell, P.J., Stive, M.J.F., Kaminsky, G.M., and Buijsman, M.C. this volume. Shoreface sand supply for barrier progradation, Southwest Washington Coastal Erosion Workshop Report 2000, USGS Open-File Report. 
Gelfenbaum, G., Sherwood, C.R., Peterson, C.D., Kaminsky, G.M., Buijsman, M., Twichell, D.C., Ruggiero, P., Gibbs, A.E., and Reed, C. 1999. The Columbia River littoral cell: A sediment budget overview, Proceedings of Coastal Sediments '99, ASCE, pp. 1660-1675.

Kaminsky, G.M., Buijsman, M.C., and Ruggiero, P. 2000. Predicting shoreline change at decadal scale in the Pacific Northwest, USA, Proceedings of the 27th International Conference on Coastal Engineering, Sydney, Australia, pp. 2400-2413.

Kaminsky, G.M., Buijsman, M.C., and Ruggiero, P. this volume (b). Predicting shoreline change at management scale, Southwest Washington Coastal Erosion Workshop Report 2000, USGS Open-File Report.

Kaminsky, G.M., Buijsman, M.C., Ruggiero, P. and Gelfenbaum, G. this volume (a). An integrated contemporary sediment budget for the Columbia River littoral cell, Southwest Washington Coastal Erosion Workshop Report 2000, USGS Open-File Report.

Morton, R.A., Purcell, N., Qualman, D., and Heeren, J. this volume. Evidence of largescale, long-term cycles of beach deposition and erosion, north Willapa Bay, Southwest Washington Coastal Erosion Workshop Report 2000, USGS Open-File Report.

Osborne, P.D., and Shepsis, V. this volume. Feasibility of a submerged spur to control navigation channel shoaling at North Jetty, Grays Harbor: Evaluation of North Jetty sediment transport conditions, Southwest Washington Coastal Erosion Workshop Report 2000, USGS Open-File Report.

Simpson, D. this volume. Bay Center channel and Willapa navigation studies, Southwest Washington Coastal Erosion Workshop Report 2000, USGS Open-File Report. 


\title{
BUT WHAT DOES IT ALL MEAN? DISTILLING THE SCIENCE FOR USE ON A LOCAL MANAGEMENT SCALE: OBSERVATIONS, RECOMMENDATIONS, AND EXAMPLES OF INFORMATION SHARING TOOLS
}

\author{
Christian J. Stewart, Christian J. Stewart Consulting
}

\section{INTRODUCTION}

The Southwest Washington Coastal Erosion Study (SWCES), initiated in 1996 and now in it's fifth and final year of activity, has generated an unprecedented amount of data and information on the coastal processes and geology affecting the portion of the Washington and Oregon shorelines extending from Point Grenville, Washington, in the north to Tillamook Head, Oregon, in the south.

Given that the Study is in it's final year of activity, there is now a pressing need on the part of the Washington Department of Ecology and the United States Geological Survey (cosponsors of the project) to generate from this extensive information, a series of final products that can be used at the local community level by coastal managers and the general public to assist in making coastal zone management decisions that are required to address a range of issues in the future.

To facilitate this activity, the author was invited to attend the fifth SWCES Workshop held November 15-17, 2000 in Olympia, Washington and to observe the type and level of scientific investigation being carried out and to provide comments, suggestions and ideas for translating or "distilling" this data into acceptable information tools or products.

\section{OBSERVATIONS FROM THE "OUTSIDE"}

What follows below are a series of observations made during the workshop that focus primarily on the level of science being carried out and on various issues relative to the sharing of the data being generated. They are considered "outside" observations, as the author has not been previously involved in the SWCES prior to this workshop, and thus brings what is hoped to be a "fresh" perspective to the Study. They are neither right nor wrong, but are simply meant to initiate thinking on how the data being developed in the Study can be used effectively.

\section{The Science is Amazing!...But...}

From a scientific perspective, the level of investigation and the quality of data and information that has been generated over the five years of the Study has been incredible and has focused on "state-of-the art" studies of coastal processes and geology. All investigators should be complimented on this, as the scientific base upon which to make coastal management decisions is now much greater than it was five years ago.

Yet, from a local community perspective, this type and level of research can be overwhelming and complex. It may, at times, be difficult for the local community to 
understand why some topics are being investigated in such a great level of detail and why others are not. It is important for us, as scientists, to provide clear and understandable linkages between our research topics, and what it is that a shore property owner, for example, observes in front of their house.

\section{The "Devil is in the Details"}

As more and more research is conducted, more and more questions are raised, which then leads to more research, which leads to more questions, and so on. This was evident from many of the presentations at the workshop, where, even though this is the last year of the Study, more questions on a number of detailed scientific topics were continuing to be raised. As scientists, we could spend our entire careers answering all of these more detailed questions for this section of coastline (not necessarily a bad thing), but at some point we need to ask ourselves when to draw the line and start providing some sound results and data that the local management community, or CZM policy makers can "hang" management decisions on.

\section{Have Confidence in the Data}

It is likely that we could continue to study this coastline for another 20 years and there still would never be enough data to make 100 percent accurate coastal management decisions. However, there certainly should be enough data generated and available now to help make confident coastal management decisions. If one looks at management of any type and at any level (e.g., corporations, department stores), it is common that management decisions are often, if not always, based on incomplete information. And so it should be here, although there seemed to be an underlying feeling at the workshop that we should not distribute incomplete interpretations generated in the SWCES until additional questions are answered.

As long as the data we are generating is scientifically defensible and has suitable caveats and limitations put upon it for data we feel is not yet complete, then we need to share that data with the local community and the policy makers. We also need to ensure that we work closely with them, so that they can accurately interpret the data and incorporate it into any policy decisions that need to be made. We should not be afraid to "draw a line on a map" and let the local communities know what potential impacts they may face in the future, no matter how severe they may seem to be.

\section{Data Changes...Policy Objectives Don't}

As highlighted above, we could focus on the science forever, but we risk doing this at the expense of providing results that are useful for making management decisions. It is important to remember that while the "numbers" (i.e., specific data) may change with continued research, the basic premise behind any management strategy will remain unchanged. For example, if we develop a policy based on existing data that states "we shall manage the sand supply to the system to maintain beaches in their natural state," then it is likely that new and more detailed data will not change that overall policy, but may change the way in which the policy is carried out. In those cases where additional research does result in new policies, or in the change of a policy, it is assumed that some type of formal 5 or 10 year policy review process would be in place to capture these 
situations. Again, don't be afraid to share data now, so that it can be used to formulate basic policies.

\section{Let Local Communities Decide Their Own "Degree of Risk"}

The "degree of risk" a community is willing to take relative to flood and erosion hazards is important. As such, we need to provide these communities with enough information so that they can adequately assess how much risk they face at present and how much potential risk they are willing to live with. Again, it comes down to a focus on the initial impetus for the Study, the local communities. If we conduct infinitely detailed research on topics and issues that they can not relate to or understand, then the Study, while greatly advancing the science of the coast, will ultimately be a failure at the local community level for whom it was intended.

\section{SO WHAT DO THE COMMUNTIES NEED TO KNOW?}

In the 15 years that this author has been dealing with property owners and local communities faced by flood and erosion hazards, the things that the average shore property owner wants to know comes down to a series of basic questions. These include: What is this? Why is it happening? Why is it here? Where did it come from? Why is it important? Why are you studying it? Perhaps most importantly, how does it impact me or my property (both from the financial and emotional perspective)? Finally, what can I do now or in the future?

As scientists, we need to be able to "distill" the detailed science and data we are producing and provide simple answers to these questions, so that people in the local communities can assess the impact on their property and make their own decisions on what they want to do (if anything) to mitigate these impacts.

\section{HOW CAN WE DISTILL OUR WORK?}

The following are some suggestions on how we can begin to provide the answers to these questions. Again, these are neither right nor wrong, they are simply meant to get everyone thinking about how we can provide the necessary information to the local communities in an effective and easily understood manner.

\section{Step Back and Extract}

We all need to step back from the detailed science we are conducting and extract the key items within our research that are applicable to coastal zone management. Ask yourselves why this research is important to coastal zone management and then answer this in the simplest manner possible, without jargon, and without raising additional questions. Perhaps a suggestion is that everyone add an additional paragraph or two to their extended abstracts for this workshop, under a title, "Implications for Coastal Zone Management." Another suggestion might be to take your present abstracts and write them as a newspaper article for a local newspaper, or as a 5 minute story on the television news. This may sound overly simple, but it forces us to step back and capture the basic, salient points of 
the work we are doing and thus answer the "so what?" that will ultimately get asked down the road.

\section{Establish Linkages}

Clear and easily understood linkages need to be established between what you are studying and what a property owner observes in front of their house. As an example, a person who sees their beach rapidly disappearing, may not understand why you are studying sediment trapping behind dams 50 miles upstream in the Columbia River, unless they are made aware that the sand entering the shore zone from the river is what helped form and maintain their beach in the fist place. The same applies to the level of detail or complexity in the science. For example, most property owners will not have any idea why, as an example, detailed 2D and 3D Ground Penetrating Radar examination of sediment structures under the beach and nearshore is important.

\section{Involve the Communities in the Science}

The local communities should be involved in the science. This goes beyond simply presenting your work at public open houses and workshops. While such open houses are sometimes helpful, they are often too late, because if community members don't like what you've done, or how you've done it, they will view things negatively. If, however, they have been involved in the project from the beginning and have had an active role in setting the research priorities or doing the field work for example, then they have a sense of "ownership" of the research and will be much more receptive to and understanding of the final outcomes. It also forces us as scientists, to slow down a bit and clearly explain to them what the work will accomplish and why it is important.

While the opportunity for this level of participation in the science aspect of the SWCES may be past, there is still an opportunity to involve the local communities in defining the final study outcomes and products. Get back to these communities and ask specifically what it is they would like to see come out of this work. Ask the town planners and policy makers if there are any specific tools they need to help them make informed decisions. Ask them the type of data and the format of data they need to help them make good and informed policy decisions.

\section{Develop a Communications Strategy}

Different target audiences will require different levels of information from the Study. For example, the type of information that a State policy maker requires to make policy decisions will differ dramatically from what a non-shoreline property owner with a passing interest in the Study requires. A good "communication strategy" is needed to start defining these "target" audiences, and then define the communication "vehicles" appropriate for each target. The level of detail that is appropriate for each target audience also has to be considered when developing the communication vehicles. For example, while a single, comprehensive web page may be the communication vehicle of choice, if it contains only detailed scientific data and information, it may only be suitable for a select few target groups. Given this, such a web site may have to be structured so that there are different "layers" of information that can be accessed by the various target audiences as needed. 


\section{INFORMATION PRODUCTS AND TOOLS}

There are a multitude of communication tools or vehicles that can be used for this study, some of which are already being employed. These include: CD-ROMs (for data, reports, maps, etc.), CD-ROMs (for multi-media, interactive learning tools), paper atlases, maps, and reports, fact sheets, news articles, web pages, visualization tools and animations, information management tools, document management tools, and GIS analysis tools. As mentioned, a good communications strategy should be developed to clearly define which of these tools will be appropriate for use in the SWCES.

\section{Examples}

Presented below are some examples of "high-tech", yet still user friendly, information management tools that have been used on other large-scale, environmentally based data collection activities. These examples are meant to illustrate some alternative ways of making large amounts of information available to the various interest groups who require it.

\section{Zambezi River Wetlands Information System (Z-WIMS)}

Z-WIMS is an Internet- and CD-ROM-based mapping and multi-media information system designed for IUCN (The World Conservation Union). The system allows users such as project managers, funding agencies, stakeholders and the public, to easily query the extensive database and view IUCN activities across the entire Zambezi River Basin in Southern Africa. Users can select to view interactive web maps, videos, photographs, reports, articles and newsletters, all relating to work in the Zambezi River Basin of Southern Africa. In both the Internet and CD-ROM versions, the query interface is located in a frame on the left of the screen, while the query results are displayed in a browser on the right hand of the screen (Figure 1). Details on the background and impetus behind Z-WIMS can be found in Law et al., 1999.

\section{Recession Rate Analysis System (RRA)}

In 1997 and 1998, the U.S. Army Corps of Engineers initiated an intensive coastal data collection and modeling activity of Great Lakes shorelines, beginning with Lakes Michigan, Erie and Ontario. A wealth of information is being collected including kilometer-by-kilometer data on recession rates, land use, land use trends, shore type (geology), type and quality of shore protection, offshore geology, and bluff characteristics. To manage and analyze this data, a Recession Rate Analysis System (RRA) was developed. The RRA is a flexible and customizable program that integrates a relational database management system (FoxPro) with a dedicated GIS package (Quikmap) that allows basic reporting, mapping, and visualization of all query results (Figure 2). Users can construct queries using all data types and combinations thereof. Details of the RRA can be found in Stewart (1999a and b), and on the web sites of the Lake Michigan Potential Damages Study (http://huron.lre.usace.army.mil/coastal/LMPDS) and Lower Great Lakes Erosion Study (http://www.cjscons.com/LGLES).

\section{The Flood and Erosion Prediction System (FEPS)}

As part of the Lake Michigan Potential Damages Study being carried out by the U.S. Army Corps of Engineers - Detroit District, a Flood and Erosion Prediction System 
(FEPS) is being developed by Baird \& Associates (Nairn et al., 1999) in order to predict potential flood and erosion damages associated with possible future hydrologic scenarios. FEPS includes: a coastal data base, graphical user interface, data processing and analysis tools, a 2D coastal process model, and custom ArcView GIS tools (Figure 3). It is a loosely coupled system developed with Visual C++ and Avenue (ArcView) and has links to various numerical models including those for cross-shore profile determination and wave run-up. The system allows users to create "projects" for studying any specified section of shoreline using the built-in data and coastal process modeling tools. More information on FEPS can be found on the web sites of the Lake Michigan Potential Damages Study (http://huron.lre.usace.army.mil/coastal/LMPDS) or the Lower Great Lakes Erosion Study (http://www.cjscons.com/LGLES).

\section{REFERENCES}

Law, M.N., Maher, R., Lash, T., and Hiscock, E. 1999. Zambezi Wetlands Information Management System, Proceedings of GIS99 - Thirteenth Annual Conference of Geographic Information Systems, pp. 90-93.

Nairn, R.B., Davis, J.E., and Thieme, S.J. 1999. A GIS-linked flood and erosion prediction system for Lake Michigan, Proceedings of the 4th International Symposium on Coastal Engineering and Science of Coastal Sediment Processes, pp. 1978-1993.

Stewart, C.J. 1999a. A GIS mapping tool for the presentation and analysis of coastal data along the shorelines of the North American Great Lakes, Proceedings of the 1999 Canadian Coastal Conference, pp. 487-498.

Stewart, C.J. 1999b. Development of a coastal zone database and GIS mapping tool for the analysis of coastal data along the shorelines of the North American Great Lakes, Proceedings of GIS99 - Thirteenth Annual Conference of Geographic Information Systems, pp. 130-134. 

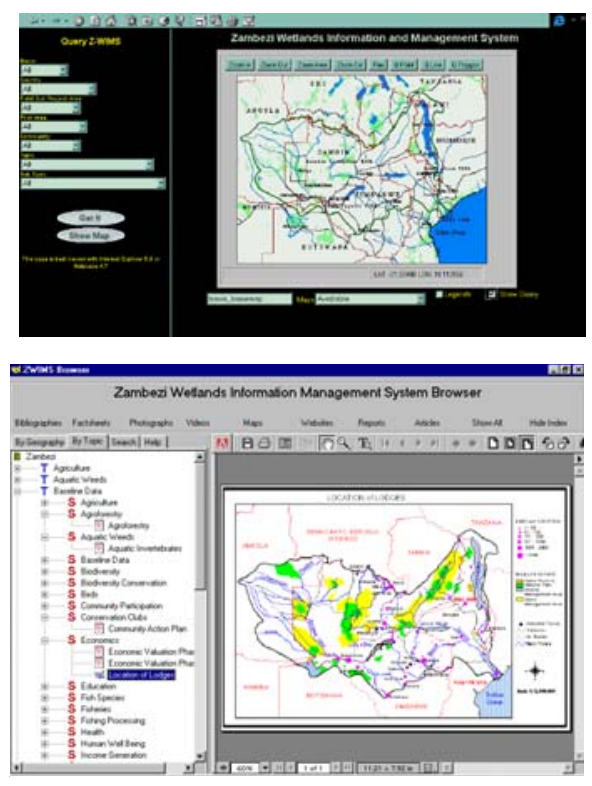

Figure 1. Z-WIMS Internet Browser (top) and CD-ROM Browser (bottom).

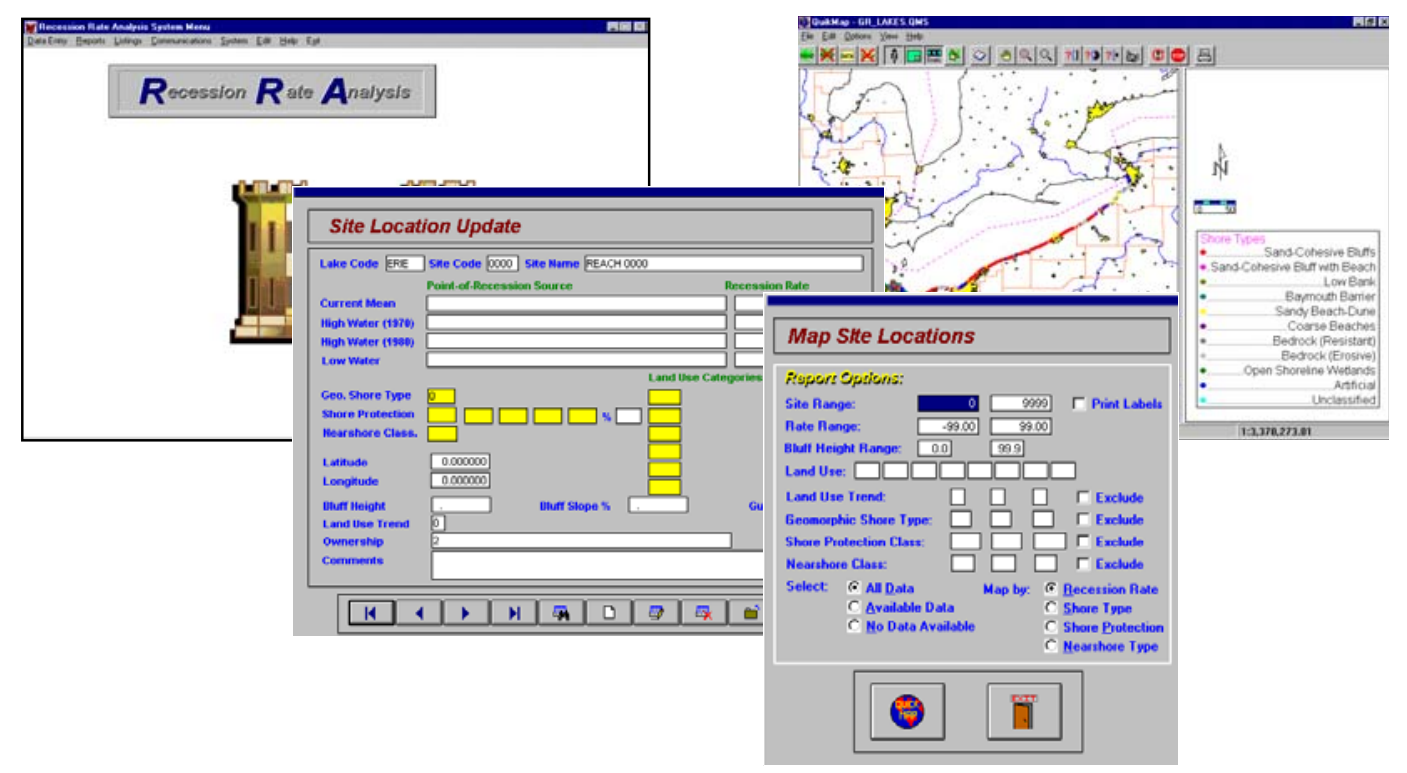

Figure 2. The Recession Rate Analysis System. 


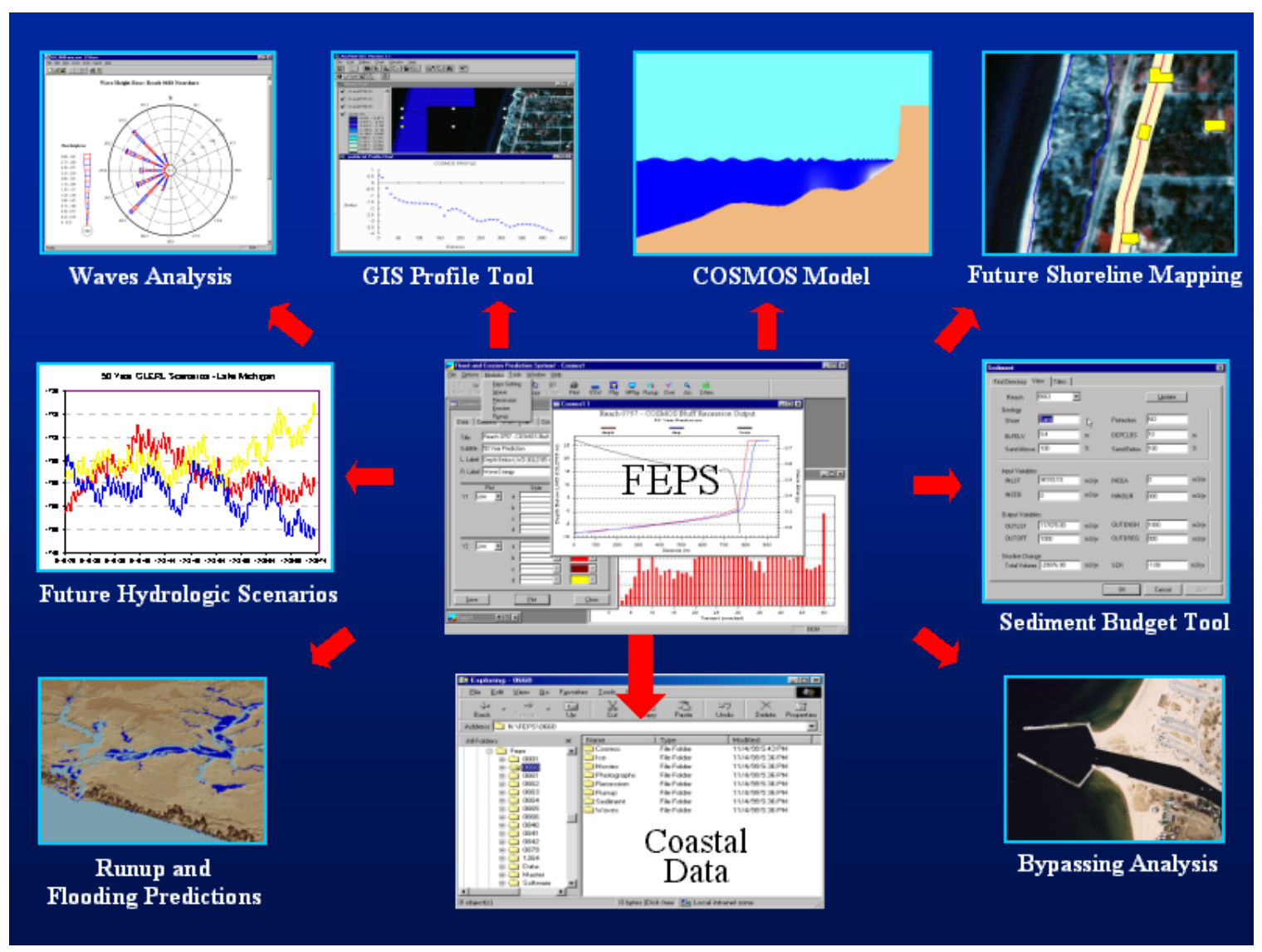

Figure 3. The Flood and Erosion Prediction System. 


\title{
COMING TO GRIPS WITH LARGE-SCALE COASTAL SYSTEMS - THOUGHTS ABOUT THE COLUMBIA RIVER LITTORAL CELL
}

\author{
Paul D. Komar, College of Oceanic \& Atmospheric Sciences, Oregon State \\ University
}

\begin{abstract}
ANALYSES \& ACCOMPLISHMENTS
It is a major undertaking to document and understand the changes that have occurred in large-scale coastal systems such as the Columbia River littoral cell (CRLC). The changes span decades to hundreds of years, with comparatively few "snap shots" of shoreline locations offered by aerial photographs, or in the distant past by old maps and charts of uncertain accuracy. Assuming one can adequately document the changes that have occurred, questions then arise as to the causes. Unfortunately, there typically is only a short-term documentation of the important processes of change - the wave climate, occurrences of major storms, and the dynamic responses of beaches. With such a limited record, questions related to the changes and causes include:
\end{abstract}

- Is the coverage of change documented by aerial photographs and maps adequate, and can one safely assume that changes between surveys were gradual?

- Can one reasonably assume that the processes operative today, and measured during the duration of the investigation, are representative of those that have occurred during the decades to hundreds of years of documented shoreline change?

- Have long-term shifts in Earth's climate affected the region?

- Have rare but catastrophic events impacted the area?

- To what degree have humans altered the environment, leading to changes not accountable solely by natural processes?

The study of the CRLC is now at a critical stage, a time for "coming to grips" with the data that have been collected during the five years of investigation, a time to synthesize the results and come to an understanding of the system as a whole.

The objective of this abstract is to provide an independent assessment of the goals of this investigation, and of the types of data that have been collected to meet those goals. With that objective, I have selected several topics for consideration. The selection is not meant to be comprehensive, covering all aspects of the Study, but instead includes only those where I might offer suggestions based on my experience in participating in studies of other large-scale coastal systems. My objective is also to provide encouragement in what may be the most difficult aspect of the Study, the synthesis of the results into a meaningful 
whole that represents the present understanding of the CRLC, and provides the basis for future investigations.

\section{THE GOALS OF THE STUDY}

This study of the CRLC, undertaken jointly by the Washington Department of Ecology and U.S. Geological Survey, was initiated in large part in response to recent occurrences of beach and property erosion. Erosion during the past decade represents a marked contrast to the long-term net shoreline accretion that had prevailed at most sites in the cell during historic times. A fundamental goal of the Study is to determine whether the recent erosion is a result of natural processes, or whether human impacts on the system in the form of dam construction on the Columbia River and jetties at the mouths of the Columbia River and at Grays Harbor have been the primary cause.

With that goal, fundamental decisions had to be made as to how comprehensive and far ranging the investigations would be. There is conflicting advice in making such a decision:

Don't be afraid to take a big step if one is indicated. You can't cross a chasm in two small jumps.

David Lloyd George

Chi troppo abbraccia nulla stringe.

(He who attempts too much achieves nothing.)

\section{Italian expression}

In that an understanding of the CRLC represented something of a "chasm", the decision was wisely in favor of a comprehensive study that involves a number of overlapping components. As summarized by Kaminsky et al. (1999), there was a recognition of the necessity for including a continuum of spatial and time scales, from meters to tens of kilometers, and from days to decades to centuries. Individual study topics included analyses of the history of shoreline change, sediment-budget determinations, investigations of human impacts in the Columbia River watershed, examinations of possible long-term climate changes and their effects on the littoral cell, to fairly detailed analyses of waves, nearshore currents, and how they affect the beach morphology. The initial expectation was that at the end of the Study, the synthesis of the results from the many individual investigations would lead to conclusions that meet the initial goal of the Study, an understanding of the roles of natural and human influences on the dynamics and evolution of the CRLC. Although the final synthesis is still underway, it is clear that the initial decision by the planners to undertake a comprehensive study was the correct approach, the only one with any hope of bridging the "chasm", leading to a satisfactory understanding of the CRLC. 


\section{PREHISTORIC FACTORS - THE TECTONIC SETTING OF THE CRLC AND CATASTROPHIC EVENTS}

The tectonic setting of the Pacific Northwest (PNW) is extremely important to understanding the long-term history and evolution of the CRLC. Being in a zone of convergence of the Juan de Fuca oceanic plate and the North American plate, the area is subject to major subduction earthquakes, with the most-recent occurrence having been in $\mathrm{AD} 1700$. Important to coastal processes and evolution is the generation of a severe tsunami by the earthquake, and abrupt subsidence of the land. It is now recognized that the PNW coast experiences slow aseismic uplift during periods between earthquakes, due to the accumulation of strain, with the seismic subsidence representing the release of that accumulated strain.

The investigation of the CRLC has recognized the importance of this tectonic setting, in particular the consequences of the rare but extreme subduction earthquake events. Certainly one of the most interesting discoveries has been that by Meyers et al. (1996), using a combination of ground-penetrating radar and cores, of stratigraphic records of the extent of shoreline retreat that occurred following subduction earthquakes, presumably a result of land subsidence and readjustment of the beach profile. The erosional scarp following the AD 1700 event has been clearly delineated by Peterson et al. (1999) along nearly the full length of the CRLC. Its position gives some indication of the expected extent of shoreline retreat as a consequence of future subduction earthquakes, of obvious interest to coastal-zone management, specifically to the establishment of set-back distances for the placement of critical infrastructure such as hospitals and schools, and also large structures such as hotels.

It appears that less consideration has been given to the longer-term, lingering effects of the AD 1700 event on the CRLC. As well as producing rapid shoreline erosion, the abrupt land subsidence would likely have changed water depths in the Columbia River estuary, in Willapa Bay and in Grays Harbor. Depths over offshore bars at the mouths of these estuaries would also have changed. It is likely that this would have altered paths and quantities of sediment movement within the CRLC, with the sediment yield from the Columbia River being reduced due to trapping by the deepened estuary, and with Willapa Bay and Grays Harbor becoming greater sinks of nearshore sediment. Such a consequence is suggested by our on-going study of Tillamook Bay on the Oregon coast (Komar and McManus, 1999). Cores of bay sediments reveal a much higher rate of beach-sand movement entering the Bay following the AD 1700 event, with a progressive decrease in the amount of beach sand relative to river-sand contributions during the subsequent 300 years. The pattern of changing beach versus river-sand contributions is fairly gradual up to the present, so it is possible that the $\mathrm{AD} 1700$ event is still having a lingering impact on sediment accumulation in Tillamook Bay. It is possible that this is also the case in the CRLC.

\section{SHORELINE CHANGE AND CAUSES}

One of the most important tasks in the study of the CRLC has been to compile all available surveys of past shorelines, provided by aerial photographs or in the more-distant 
past by maps and charts. This has been accomplished, with the results presented in various publications [e.g., Kaminsky et al. (1999)]. Most often the results are graphed as rates of erosion or accretion between documented shoreline positions, a presentation that can lead to misinterpretations since it assumes a gradual evolution between shoreline pairs, which may not necessarily be true.

As with most studies of large-scale coastal systems, there are comparatively few documented shoreline positions in the CRLC. One of special interest is the AD 1700 prehistoric shoreline inferred by Peterson et al. (1999) from the ground-penetrating radar record. The earliest historical shoreline position is derived from the 1868 U.S. Coast \& Geodetic Survey topographic chart (NOS T-Sheets), of interest since it pre-dates construction of jetties on the Columbia River and at the entrance to Grays Harbor. The next subsequent surveys are also NOS T-Sheets, for the periods 1926-1927 and 19501957. Further documentation is derived from aerial photographs taken in 1974 and 1995. Unfortunately, with such large time gaps between surveys, it becomes a challenge to interpret the causes of documented shoreline change. In particular, the extended period between 1883 and 1917, during which time the jetties where constructed and the largest shoreline changes occurred, are not well documented by surveys. The total change produced by the jetties is covered by the 1868 pre-jetty survey and 1926-1927 post-jetty survey, a span of 58 years. It is likely that by the time of the 1950-1957 survey, the major shoreline changes induced by jetty construction have been largely completed, so the subsequent change up to the 1995 shoreline position as analyzed by Kaminsky et al. (1999) represents an interval that can be taken to represent more of an equilibrium situation following the large-scale shoreline changes that occurred in response to jetty construction.

With only rare "snap shots" of shoreline positions spanning more than a century, it is problematic to infer sediment movements - directions and rates - that are responsible for the shoreline changes, or the patterns of accretion/erosion between documented shorelines. As accomplished by investigators involved in the study of the CRLC, this has had to be done through simultaneous considerations of the total sediment budget for the area. In particular, the large shoreline accretion rates following construction of the jetties are in large part a result of the massive onshore movement of sand derived from the bars offshore from the Columbia River and Grays Harbor. Again, unfortunately due to the paucity of surveys at that critical time, it is not possible to document in detail the resulting evolution of the shoreline in response to this massive onshore flux of sand.

With long intervals between shoreline surveys, particularly spanning the period prior to and after jetty construction, the interpretations may be overly simplistic. I am inclined to suggest that this may be the case since the present interpretation for the CRLC, based entirely on the onshore transport of sediment from the bars and its subsequent longshore movement, differs from my interpretation of shoreline changes that resulted from jetty construction on the Oregon coast (Komar et al., 1976). I concluded that most of the shoreline change resulted from longshore movements of beach sand, producing a pattern of shoreline accretion both to the north and south of the jetties, but with erosion at greater alongshore distances to supply that sand accumulation. Conditions within the "pocket 
beach" littoral cells of the Oregon coast are simpler than found in the CRLC, there not being a net longshore sediment transport within the cells since there are no major sources of sand like the Columbia River to support a net longshore transport. In hindsight, I likely erred in my analyses in not having satisfactorily accounted for possible contributions by the onshore movement of bay-entrance bars following jetty construction. However, the dominant shoreline response on the Oregon coast clearly involved the rotation of the shoreline about a nodal point, producing increasing amounts of accretion toward the jetty, and increasing erosion with distance away from the jetty beyond the nodal point.

Such a rotation is suggested by the analysis of Kaminsky et al. (1999, Figure 4) for the CRLC, specifically in the accretion/erosion rates for the 1920s-1950s period, suggestive of a nodal point of shoreline rotation approximately mid-way along the length of the Long Beach Peninsula. Also contributing to the shoreline change following jetty construction is the apparent longshore movement of a low-amplitude shoreline sand wave, initiated by the rapid onshore movement of sand from the bay-mouth bars, first generating a perturbation of the shore close to the jetties, with the sand-wave perturbation then advecting and diffusing alongshore as it migrates away from its point of origin. This pattern can be seen to some degree in the accretion/erosion graphs presented in Kaminsky et al. (1999), but more clearly in graphs prepared by Maarten Buijsman (pers. communication). The presence of a similar advecting/diffusing sand wave has been documented on the central California coast by Hicks and Inman (1987), in that case initiated in the form of a delta produced by a flood in an ephemeral river. The initial shoreline perturbations in the CRLC produced by the onshore movement of sand from the bay-mouth bars following jetty construction would have been similar to the delta investigated by Hicks and Inman (1987), except that the arrival of sand on the shore would have spanned a considerable period of time, likely representing progressively diminishing supplies from the bay-mouth bars over several decades following jetty construction, and possibly continuing at present.

\section{THE BUDGET OF SEDIMENTS}

A sediment budget is an application of the principle of conservation of mass to the quantities of coastal sediments, and involves identification of the sources of the sediments, their sinks (where they accumulate within the area of interest), and pathways of sediment transport linking the sources and sinks (Komar, 1998). Although based on a simple principle, the actual development of a sediment budget for an area of coast can be challenging, with many of its components having high degrees of uncertainty. In spite of such uncertainties, the attempt to development a sediment budget is a worthwhile endeavor, as it focuses one's attention on the critical components or sub-environments within the coastal zone, together with assessments of sediment movements and how human-induced changes such as dam construction on a river or the placement of jetties can alter conditions from their natural state. Ultimately, the formulated sediment budget summarizes what we know about that particular area of coast, and directs our attention toward what needs to be the objective of future research.

With the above view, I would argue that a comprehensive sediment budget for the CRLC will be the most important product of this study. However, the task set forth by the 
investigators is daunting: as outlined by Gelfenbaum et al. (1999, Figure 4), the prospective sediment budget for the littoral cell includes 22 environmental boxes, 32 if one includes the additional 10 that represent components of the Columbia River watershed and estuary. In total, there are 46 pathways of potential sediment movement between boxes. Furthermore, each component is to be evaluated at least twice, first for the prehistoric past prior to human impacts by dams and jetty construction, and again for the historic period with those impacts. This division into separate pre-historic and historic evaluations is fundamental to the overall goal of the Study, to assess the impacts humans have had on the system and whether those impacts are responsible for the recent shoreline erosion in the CRLC.

Can one really expect to evaluate that many components in a sediment budget during a five-year study? Probably not, but I am impressed by the degree of progress that has been made toward doing so, with the Study having wisely focused on the most important environmental boxes and sediment transport paths between those environments. Several of the individual studies within the program have been assigned the task of dealing with specific budget components [e.g., Gibbs and Gelfenbaum (1999), investigating the offshore bathymetry to determine sediment-volume changes on the continental shelf and in bay-mouth bars]. The results of these individual accountings of budget components contribute to the assessment of the total sediment budget for the CRLC, and a main objective of the final synthesis to be completed during the next few months will be a resolution of this budget. My experience with sediment budgets is that their development involves as much art (or intuition) as science, since there are so many unknowns and what is "known" has high levels of uncertainty. All one can do is make a reasonable effort toward developing a budget that balances the quantities of sand transported between the environmental boxes, and the changing volumes of sand within those boxes. We can expect no more than this from the developed CRLC sediment budget derived from this 5 -year study and synthesis of the results. There will be room for future investigations to improve on this best-estimate sediment budget.

Tis much better to do a little with certainty, and leave the rest for others that come after you, than to explain all things.

Issac Newton

\section{THE STUDY OF BEACH PROCESSES AND SHORELINE VARIABILITY}

Improvements in the understanding of long-term shoreline changes and sediment movements that bring about those changes require a knowledge of the causative coastal processes - the wave climate, the patterns of nearshore currents, how those processes affect sediment transport on beaches, the resulting changes in beach morphology in response to individual storms and on a seasonal basis, and how climate events such as El Niños and La Niñas can further affect those processes and beach responses. Of course, it is also through a study of these fundamental processes that we come to understand the factors that are important to episodes of beach and property erosion, occurrences that 
generally are associated with major storm events when high tides combine with the run-up of storm waves on beaches (Ruggiero et al., 2001).

Due to high wave energies and powerful nearshore currents, the beaches of the CRLC are extremely dynamic. For this reason, it was decided when this study (SWCES) was initiated to devote a major effort towards investigations of nearshore processes and beach variability. The level of effort has been very impressive, including analyses of waves, tides, and monthly to annual variations in mean water levels, and the documentation of beach morphology responses through a major program of repeated surveys at different temporal and spatial scales (Ruggiero et al., 1998, 1999). The beach morphology monitoring program has employed sophisticated and imaginative surveying techniques, including the use of an all-terrain vehicle (the CLAMMER) mounted with GPS, employed to survey the subaerial portion of the beach, while the offshore was surveyed using a Yamaha waverunner equipped with a GPS and echo sounder. This combination of surveys of the subaerial and subaqueous portions of the beaches is unprecedented in the Pacific Northwest due to the difficulty and danger in surveying in the face of its extreme environmental conditions. The Study is therefore making significant contributions to our understanding of how PNW beaches respond to the changing conditions of waves and tides, and how the responses can account for occurrences of beach and property erosion during extreme events.

The study has been particularly fortunate in its timing, having spanned the years that included the 1997-98 El Niño, one of the strongest on record, and followed by an abrupt shift to La Niña conditions during the winter of 1998-99, with the occurrence of an unprecedented series of major storms. With these serendipitous occurrences, the Study was able to document the unusual processes associated with these climate events, and the responses of the beaches within the CRLC, leading to particularly severe erosion at a number of "hot spot" sites (Kaminsky et al., 1998).

\section{APPLICATIONS TO COASTAL MANAGEMENT}

The study of the CRLC was initiated in large part as a response to recent occurrences of beach and property erosion, which departed from the long-term trend of net accretion. Thus, the underlying motivation of the Study was to understand the causes of erosion, with obvious ramifications to coastal-zone management. Yet, there appears to be some hesitation to face up to dealing with this application, drawing on the results of the investigation. I assume that this hesitation results from the fear of possibly upsetting political leaders and citizens of the coastal communities, who might view the results as a restriction on future shore-front development. This hesitation is unfortunate.

Essentially all of the investigations undertaken in the study of the CRLC have ramifications to coastal-zone management, especially in providing information as to the causes of shoreline change, erosion or accretion, and thereby in documenting potentially hazardous areas that are unsafe for development. Of course there are different levels of potential hazard, with the repeat of a subduction earthquake, tsunami and associated shoreline retreat having the greatest consequence. The studies by Meyers et al. (1996) and 
Peterson et al. (1999), documenting the impacts of past subduction earthquakes, particularly that in AD 1700, provide some guidance as to what might be expected in the advent of another great earthquake. The next level of hazard involves the long-term shoreline changes that continue those experienced during the past century, as documented by Kaminsky et al. (1999). In large part those changes are due to human impacts on the CRLC, the construction of dams in the Columbia River watershed, resulting in reduced sand supplies from that source, and the effects of jetty construction. Predictions of future shoreline changes and the resulting hazards in eroding areas depend on the development of the budget of sediments, which is the underlying cause of change, together with the use of computer shoreline models that project the trends into the future.

The final level of hazard is associated with the impacts of individual storms, which might occur during any winter, with the high tides and run-up of storm waves reaching elevations that are sufficient to eroded the dunes backing the beach (Ruggiero et al., 2001). At this level of frequency are occurrences of El Niño and La Niña climate events, which can alter the winter waves and tides, thereby affecting the resulting erosion of dunes backing the beach (Kaminsky et al., 1998).

Generally speaking, there is an inverse relationship between the frequency of occurrence of these events and the degree of beach and property erosion, with the commonly occurring winter storms producing the least amount of dune retreat, while a subduction earthquake, which occurs infrequently, has the greatest impact. Development along the shore front of the CRLC should reflect these different levels of hazards, with all structures avoiding the zone of frequent erosion by storms, while important structures such as schools, hospitals and fire stations be constructed well away from the shore so as to avoid even the most catastrophic events and shoreline changes - the occurrence of a subduction earthquake and the long-term shoreline changes produced by human impacts.

As a product of this study, information should be provided to the coastal communities concerning these levels of hazards, and also to educate the citizens as to what coastalmanagement measures might be followed in order to avoid the hazards. Ethically, this is necessary. One obvious approach is the development of set-back lines, with a series of lines at a site reflecting the different degrees of hazard. I suggest that example sites be selected to illustrate this approach toward coastal management, perhaps in park areas so as not to unduly give the impression that the Study team is attempting to impose set-back lines on the communities. It is hoped that the coastal citizens will come to recognize the wisdom of this approach, and that it is meant to protect them from the hazards inherent in living on the coast - to protect them from economic loss as well as from the potential loss of life.

\section{SYNTHESIS OF RESULTS}

The primary task remaining in this study of the CRLC is the synthesis of the results from the many individual investigations, yielding a whole that is greater than the sum of its parts. In undertaking the synthesis, one needs to be reminded of the initial goal of the Study - to develop an understanding of the roles of natural and human influences on the 
dynamics and evolution of the CRLC. One also needs to keep in mind the application that inspired this study, local problems with erosion, so another goal is a prediction of probable future trends of shoreline erosion or accretion, with recommendations as to possible coastal management tactics. Beyond meeting these over-riding goals of the Study, much of the effort toward synthesis will involve completing the details of the individual investigations and assuring that they are consistent with one another. As discussed above, this will primarily involve a resolution of the components within the budget of sediments.

How one goes about this synthesis in a practical sense is a personal matter, but the conditions need to be right for concentrated reflection. I personally do this best when alone, but in this study of the CRLC with such diverse information and data, there is the need for input from several individuals. I recommend that the group be kept as small as possible, three or four individuals, with the discussions undertaken in a small room.

There has never been a profound thought uttered in a large room.

\section{Lord Kenneth Clark}

Undertaking a synthesis for the CRLC is challenging in that the data have been collected over a 5-year period, and there have been tentative conclusions arrived at as the data have trickled in. There is a distinct hazard that some of these initial "conclusions", although still adhered to, may be incorrect according to more recent data. It is important in undertaking the synthesis that these early thoughts be re-examined.

Thinking is very far from knowing.

\section{Proverb}

Now, there is a law written in the darkest of the Books of Life, and it is this: If you look at a thing nine hundred and ninety-nine times, you are perfectly safe; if you look the thousandth time, you are in frightful danger of seeing it for the first time.

\section{G.K. Chesterton-The Napoleon of Notting Hill}

As initially set out by the planners, it was decided to undertake a comprehensive investigation, this being the only hope of bridging the "chasm", leading to a satisfactory understanding the CRLC. Metaphorically, the synthesis of the results represents the construction of that bridge over the chasm.

\section{REFERENCES}

Gelfenbaum, G., Sherwood, C.R., Peterson, C.D., Kaminsky, G.M., Buijsman, M., Twichell, D.C., Ruggiero, P., Gibbs, A.E., and Reed, C. 1999. The Columbia River littoral cell: A sediment budget overview, Proceedings of Coastal Sediments '99, ASCE, pp. 1660-1675. 
Gibbs, A.E., and Gelfenbaum, G.R. 1999. Bathymetric change off the Washington Oregon Coast, Proceedings of Coastal Sediments '99, ASCE, pp. 1627-1642.

Hicks, D.M., and Inman, D.L. 1987. Sand dispersion from an ephemeral river delta on the central California coast, Marine Geology, 77, pp. 305-318.

Kaminsky, G.M., Ruggiero, P., and Gelfenbaum, G.R. 1998. Monitoring coastal change in southwest Washington and northwest Oregon during the 1997/98 El Niño, Shore and Beach, Vol. 66, 3, pp. 42-51.

Kaminsky, G.M., Buijsman, M., Gelfenbaum, G.R., Ruggiero, P., Jol, H.M., Gibbs, A., and Peterson, C.D. 1999. Synthesizing geological observations and process-response data for modeling coastal change at a management scale, Proceedings of Coastal Sediments '99, ASCE, pp. 1708-1723.

Komar, P.D. 1998. Beach Processes and Sedimentation, 2nd edition, Prentice-Hall, 544 p.

Komar, P.D., Lizarraga, J.R., and Terich, T.A. 1976. Oregon coast shoreline changes due to jetties, Journal of Waterways, Harbors and Coastal Engineering, 102, pp. 1330 .

Komar, P.D., and McManus, J. 1999. Natural tracers of coastal sediments, Sand Rights '99: Bringing Back the Beaches, pp. 70-84.

Meyers, R.A., Smith, D.G., Jol, H.M., and Peterson, C.D. 1996. Evidence for eight great earthquake-subsidence events detected with ground-penetrating radar, Willapa barrier, Washington, Geology, 24, pp. 99-102.

Peterson, C.D., Gelfenbaum, G.R., Jol, H.M., Phipps, J.B., Reckendorf, F., Twichell, D.C., Vanderburg, S., and Woxell, L.K. 1999. Great earthquakes, abundant sand, and high wave energy in the Columbia Cell, USA, Proceedings of Coastal Sediments '99, ASCE, pp. 1676-1691.

Ruggiero, P., Kaminsky, G.M., Komar, P.D., and Plant, N. 1998. Coastal morphologic variability of high energy dissipative beaches, Proceedings of the 26th International Conference on Coastal Engineering, ASCE, pp. 3258-3251.

Ruggiero, P., Côté, J., Kaminsky, G.M., and Gelfenbaum, G.R. 1999. Scales of variability along the Columbia River littoral cell, Proceedings of Coastal Sediments '99, ASCE, pp. 1692-1707.

Ruggiero, P., Komar, P.D., McDougal, W.G., Marra, J.J., and Beach, R.A. 2001. Wave run-up, extreme water levels and the erosion of properties backing beaches, Journal of Coastal Research, 17(2), pp. 407-419. 


\title{
COLUMBIA-RIVER CELL COASTAL EROSION PROJECT: LIMITS TO KNOWLEDGE
}

\author{
Peter J. Cowell, Coastal Studies Unit, University of Sydney
}

\section{CONCLUSIONS}

Outcomes of the Southwest Washington Coastal Erosion Study (SWCES) are reviewed in terms of presently unresolved questions of significance to scientific and coastalmanagement objectives. These questions are addressed in relation to intrinsic and temporal limits to knowledge. Recognition of the distinction between such limits, methods for side-stepping these limits, related implications for the overall design of field investigations, and protocols for coastal management faced with comprehensive but uncertain information are, of themselves, important outcomes of the project.

The project is a state-of-the-art multi-scale investigation. Despite this, estimates for the regional sediment budget and an understanding of basic coastal behavior are not definitive. A key uncertainty arises from a deficit on the order of 1 million $\mathrm{m}^{3} \mathrm{a}^{1}$ between the best estimates of sand volume supplied from the Columbia River and sand deposited within the Columbia River littoral cell (CRLC) over the past few thousand years (currently reconciled by an hypothesized supplementary sand supply from the lower shoreface, Kaminsky et al., 1999). The discrepancy may be greater if leakage of sand from the CRLC is occurring (to the shelf and north around Point Grenville), issues that can be addressed adequately only be expanding the spatial scale of research to these potential sink zones.

Under present conditions (following extensive damming in the Columbia River drainage basin) the status of sediment supply from the river is even more uncertain, i.e., the Columbia may be a net sink rather than a weakened source, or it may be a neutral term in the sediment budget. What is clear, however, is that collapse of the ebb-tidal deltas due to jetty constructions has caused a significant perturbation in shoreline equilibria. Results of the Study demonstrate that this perturbation is the dominant source of coastalmanagement problems at present (erosion hot spots), but predictions depend to some degree upon mean-trend behavior of the cell, an issue involving uncertainty, as noted above. That is, boundary conditions in shoreline (UNIBEST) modeling require assumptions about sediment inputs to predict re-equilibration of the post-perturbation shoreline. Uncertainty therefore prevails regarding projected shoreline positions with respect to the property cadastre.

Further integration and synthesis of results is desirable to better exploit the wealth of data generated by the project, and thereby get around the effects of inherent uncertainties. Such syntheses constrain uncertainties in data by enforcing a structured test of consistency between the different, available data sets. Test structure is provided by competing hypotheses or through operational (logical) requirements of simulation models: e.g., data 
inversion for parameter fitting (for model calibration or in obtaining inverse solutions). Inverse simulation itself provides methods for tackling uncertainty head on.

Evaluation of competing hypotheses on supplementary sand supply are particularly significant in that regard. At least five hypotheses might be envisaged: a) former sand supply from the shelf through barrier roll-over during transgression, now incorporated within present coastal deposits as basal barrier, proto-barrier and backbarrier (flood-tidal delta) deposits, b) erosion of the northern flooding surface during the late stages of the transgression with southward littoral transport induced by the embayed paleo-topography, c) shoreface sand supply through erosion of the inner-shelf (lower shoreface), d) underestimation of Columbia-River supply rates, and e) a combination of a through $\mathrm{d}$.

Similarly, further synthesis of data on the fluctuating component of coastal change remains necessary to resolve impacts of extreme events. While changes on seasonal and annual times are being measured with state-of-the-art detail and accuracy, important opportunities remain for data synthesis and simulation on the decade-century time scales. Spatial analysis of dune ridges and changes in spit shorelines (historical and prehistorical) may give a better indication of extreme shoreline movements associated with a) climatic fluctuations (e.g., PDOs), b) coseismic-subsidence events, and c) autocyclic behavior (including the volumetric significance of mapped changes in spit shorelines which is yet to be resolved).

The now completed mapping of dune ridges and heavy-mineral layers (evident in ground penetrating radar (GPR) records, cores, and excavations) are an unusually rich set of indicators of fluctuating coastal change on the decade-century time scale. The challenge remains, however, to identify the relative contributions from the three drivers (climatic, coseismic, autocyclic) responsible for the inferred changes. The challenge is significant because the indicator features may be polygenetic and polycyclic. Nevertheless, the dated features provide valuable time markers to help refine variation in mean-trend coastal change throughout the past few thousand years. These markers allow calibration of computer-simulation experiments on the interaction between fluctuating and mean-trend modes of coastal change.

The remaining questions will be addressed best through formalized synthesis of result; therefore, this is the highest priority for the Study.

\section{ACCOMPLISHMENTS}

Project progress and outcomes were assessed based on a) developments reported at the 1998-2000 annual workshops, b) publications emanating from the project, c) systematic field reconnaissance (see Acknowledgments), d) discussions with project participants, and e) comparative assessment against results and principles derived from other coasts in the USA (Atlantic coast), Europe (North Sea and Mediterranean coasts), and Australia (southeast and southern coasts). 


\section{QUESTIONS}

The purpose of this paper is to review the limitations and opportunities stemming from the Southwest Washington Coastal Erosion Study (SWCES). The Study is scientifically significant because it is

- a state-of-the-art multi-scale investigation, and

- a stringent test for the limits of accuracy in measuring coastal change.

Few site-specific field studies of coastal processes involve such extensive and intensive investigation. We have an opportunity therefore to evaluate just how far we can push the limits of precision, explanation, and prediction when ranging an impressive array of methods and expertise against a set of practical and scientific problems at a given study site. That is, in addition to valuable site-specific knowledge issuing from the investigation, the project sheds light on limits to a) determining the nature and causes of the change, b) providing the basis for quantitative prediction of change, c) generating new scientific insights and laws, and d) informing coastal management and planning.

These limits to knowledge are of two types, intrinsic and temporal.

- The intrinsic limits relate to questions that are futile, regardless of their importance to project objectives. Answers to such questions cannot be resolved when a) manifest coastal behavior precludes detection of a coherent signal, or b) inherent nature of processes (non-linearity) prevents forthright quantitative prediction.

- Temporal limits to knowledge relate to the present boundaries of ever-advancing knowledge frontiers. We can expect that questions subject to temporal limits will yield eventually to further investigation or the development of new methods of measurement (e.g., resolution issues) or prediction.

The first part of this paper addresses some of these issues in general. The second part of the paper outlines some of the limits to knowledge reached by the project, and opportunities for future research arising from them.

\section{ANALYSIS}

\section{Intrinsic Limits to Knowledge}

Intrinsic limits to knowledge are not simply a manifestation of the knowledge-frontier at any given time. Some things cannot be inferred through reductive analysis of environmental measurements, nor predicted reliably from deterministic theory (Cowell and Thom, 1994; Phillips, 1999). Intrinsic limits in measurements result from the signal:noise problem, and in theory from nonlinear dynamics of systems driven by stochastic inputs (dynamic and stochastic complexity). 
Origins: The project explores (albeit unintentionally) the intrinsic limits to knowledge in coastal geosciences. This exploration concerns both practical application and scientific discovery. Thus, the broader scientific significance of the project goes beyond the immediate imperative of solving coastal erosion problems at Place $X$.

The existence of intrinsic limits means that, regardless of available scientific resources,

- answers to some questions are inaccessible;

- investigating these answers is a wasted effort.

Identification of intrinsic limits to knowledge could be one of the most significant outcomes of the project (both for local purposes and for research planning in general). More specifically, the project creates an opportunity to develop

1) research protocols for distinguishing between

a) feasible questions, and

b) futile questions;

2) methods for side-stepping the need for answers to key but futile questions;

3) guidelines for developing research plans that avoid intractable problems in projects of this type.

Probably the most important question facing the project concerns the present status of Columbia River sediment supply. Despite the considerable data available on the Columbia River (it must be one of the most managed rivers anywhere in the world) and analysis applied to these data before and during this project (Gelfenbaum et al., 1999), uncertainty remains as to whether the river is a net source or sink for coastal sediments at present (Kaminsky, this volume).

Quantification and prediction of sediment exchanges between the river and coast is subject to intrinsic limits to measurements. The problem arises, as is often the case in coastal processes, due to the oscillatory nature of the flows responsible for transporting sediments, and the problem of determining the relative contributions of different transport processes operating with different magnitudes and frequencies. Flood tides and ocean swell can be expected to drive sand into the lower estuary, whereas ebb tides and river flows are responsible for flushing sand out of the estuary. The net transfer over a tidal cycle is probably small compared to the gross fluxes during a single semi excursion; but the residual is the quantity important to the coastal sand budget.

If the catchment had not been extensively dammed, river flows and sediment delivery would probably overwhelm the tidal effects, and ensure that sediment accommodation space in the lower estuary remained unavailable; all sediments would be bypassed to the 
coast. Interception of river flow and sediments by the dams, and artificial deepening of the lower estuary due to dredging and possibly sea-level rise, all increase sedimentaccommodation capacity of the lower estuary. The question is whether the current sediment delivery by the river is enough (or more than enough) to fill the accommodation as it is created; if not, the lower estuary becomes a net sink for coastal sand.

Assessment of this question through investigation of sediments and morphology in the river faces the problem that transport patterns and evidence of them are spatially and temporally complex. Similar limitations affect direct measurement of sediment fluxes or flows. Evaluating sand transport rates from the flows is subject to additional uncertainty imposed by limitations in sediment transport theories (a limit that may be temporal, but more likely is intrinsic).

Figure 1 schematically summarizes the significance of intrinsic limits on the fundamental practical objective of the project, i.e., predicting future shoreline changes. The diagram plots time-series for the westward position of the shoreline averaged alongshore over the entire CRLC (based on generalization of the research results). The time series spans the past 4000 years (i.e., since barrier progradation commenced), with extrapolated scenarios for the next few decades. During the geological past, the shoreline prograded steadily due to sand supply from the Columbia River, although probably with a supplementary supply from another source, possibly the lower shoreface (1). In reality, variations would have occurred in supply due to climatic fluctuations and coseismic subsidence events (and subsequent rebound), causing irregularities in the overall mean-trend shoreline progradation. Subsidence and rebound events probably had direct and indirect effects; the direct effects involving shoreface adjustments (Bruun-type responses); the indirect effects involving (at least partial) interception of river sediment-supply due to deepening of the Columbia River with subsidence, with subsequent above-average supply to the coast during rebound when the sediments were trapped because the preceding subsidence tended to make the river too shallow.

The first effect of European settlement was vegetation clearance in the drainage basin. The probable result was temporary acceleration of Columbia sediment supply, until the regolith released was exhausted whereupon supply rates may have reverted to the geological mean trend (2a), or less if over-depletion of regolith occurred during the initial destabilization period. In any event, later effects of vegetation clearing on sand supply were effaced by the construction of dams throughout the Columbia drainage basin in the second half of the 20th century. Interception by the dams of the coarse-fraction sediment load probably eliminated much if not all sand supply from the river to the coast, and, hence, also the underlying mean-trend progradation of the coast (2b).

Construction of jetties at the entrances of the Columbia River and Grays Harbor, and the consequent collapse of the ebb-tide delta margins onto the coast, has overwhelmed the shoreline-change signal from the early 20th century onwards (3a). The shoreline effects have been greatest (and occurred earlier) in the immediate vicinity of the ebb-delta margins (3b). Here the initial rapid period of progradation due to onshore-directed sand transfers was followed by re-equilibration of the shoreline, which still persists $(3 b)$. 
Ongoing shoreline retrogradation (recession) is predicted in the ebb-delta margin segments of the shoreline ( $3 \mathrm{~b})$ whereas the overall alongshore-averaged shoreline position may stabilize (3a), i.e., unless the CRLC is leaky due to sand losses to the mid-shelf or alongshore beyond the bounding headlands (Tillamook Head and Point Grenville): the Sherwood and Phipps scenario (3c). Cell leakage will result in retrogradation of the spatially averaged shoreline unless and until effects of the increasing degree of shoreline embayment shuts down loss.

The uncertainty evident in the differences between projection $3 \mathrm{a}$ and $3 \mathrm{c}$ extrapolations in Figure 1 are resolvable because the uncertainty is due to temporal limits to knowledge. That is, the uncertainty could in principle be resolved by expanding the scope of investigation to include the mid-shelf and regions beyond the promontories bounding the CRLC to search for sand deposits for which sediment indicators are consistent with recent river sediments. (The prospect of such a resolution may be cold conform however, given the amount of money and effort already expended on the project.)

The envelope surrounding $3 \mathrm{a}$ in Figure 1 reflects the intrinsic limits associated with uncertainty about the present and future rates of sediment supply. A similar envelope can be expected in the mean-trend component of $3 \mathrm{~b}$ (for the delta-margin zones). For intrinsic limits, predictive uncertainty can never be resolved. The way forward therefore must be to adopt methods and protocols that accept uncertainty and deal with it as part of the solution. At a practical level, it may be desirable (often essential) for uncertainties attributable to temporal limits to be dealt with the same way, i.e., to yield more affordable and timely estimates of coastal change.

Methods of side-stepping key but futile questions: Well established methods are available for managing uncertainty in prediction and in decision making; but they appear seldom acknowledged (much less applied) in coastal science and management.

Analysis and prediction: The main problem facing a project of this type is that the key problems cannot be constrained sufficiently; formally, underdetermined problems for which solutions cannot be properly posed in a mathematical sense. Most geoscience field research involves problems of this type; the dilemma is not new. Formal methods are available however (albeit little used in coastal research), through inverse problem theory (Tarantola, 1987).

Inverse methods are used intuitively by geologists on a routine basis when reconstructing the evolution of deposits and other earth features, but many geologists have become concerned that their traditional approach a) does not pass the test of proof (falsifiability) demanded by scientific method, and b) involves insufficiently constrained questions in the sense that preferred explanations are tacitly selected from a range of alternative evolutionary possibilities (Schuum, 1991). Although inverse problem theory has its roots in mathematical geology, its application has become widespread in the fields of systems dynamics and information theory. Applicability to geosciences arises because usually we know the outcome (morphology and stratigraphy at present) whereas we seek the past and present inputs responsible for the manifest outcome (sediment supply and climatic 
forcings). Past inputs are not directly measurable, and determination of present inputs is generally not straightforward either because of the magnitude-frequency problem. Inversion techniques involve sampling and hypothesizing about the extent and structure of non-uniqueness supported by the available data and constraints. Trial and error methods are used, such as Monte Carlo Inversion.

Similarly, formal methods are available (but again, not often used) to make predictions under conditions of uncertainty. These methods include stochastic simulation (Banks and Carson, 1984) and fuzzy-set modeling (Zeng et al., 1997, 2001) or, at the very least, sensitivity analysis.

Inversion and prediction methods used to manage uncertainty both require a model (generally a computer model) to define the functional relationship between variables of interest for computational purposes. Thus, the research requires the conversion of concept models into a set of computational algorithms (which may be logic-based rather than mathematical). The conversion involves schematizing and then parameterizing the concepts; a process which itself tests and further generalize heuristic concepts.

A key example in the Study again relates to uncertainty in the overall sediment budget. The depositional volume is the best known component of this budget because it is available for direct measurement, even though it is an output of the system. Sediment sources and losses outside the Study area are not accessible for direct measurement and estimates are uncertain accordingly. Inversion would entail exploring the solution space for the supply and loss terms (i.e., the range of possibilities for each of these terms) that yield the measured depositional volume. Similarly, estimates for the predictive envelope of shoreline change ( $3 \mathrm{a}$ in Figure 1) can be obtained to quantify the most likely projections and the range of uncertainty (i.e., predictions expressed in probabilistic terms).

Management and decision making: Principles for application of uncertainty methods to decision making are also well established in the literature. They are seldom applied however in coastal management, probably because of the prevailing coastal-management culture. End users (coastal managers) are notorious in their dislike of probabilistic predictions. The reasons for the abstinence of this culture are not obvious however, given that probabilistic predictions are applied, informally in gambling and formally in the insurance industry, widely throughout society.

Although changing the culture of coastal managers may be beyond the scope of the Study, the demonstrated imperative to re-educate managers is one of the main outcomes of the project. That is, few stones have been left unturned in the investigation (compared to most coastal-hazard studies because usually resources are much more limited); so the remaining uncertainty in predictions is indicative of best practice at present (and probably indefinitely given the significance of intrinsic uncertainty).

What is required therefore are new protocols in coastal-management, although these protocols are not necessarily new in other areas of public and commercial administration. The protocols are likely to incorporate the following principles and conventions: 
1) Coastal management should

a) follow protocols that are recognized as international best practice (conventions for which may need to be established);

b) incorporate environmental quality assurance, through a Quality Management System such as ISO14001.

2) Decisions and planning should be consistent with the precautionary principle to

a) ensure intergenerational equity,

b) meet obligations under international agreements (e.g., Rio Convention), and

c) comply with the doctrine of the public trust (in the USA).

3) Coastal managers and decision makers should remain accountable in terms of due diligence requiring that

a) best-practice procedures are followed (understanding that failure to follow such procedures probably gives rise to personal and corporate liability for managers and experts alike);

b) best-practice procedures are formalized (legislatively sanctioned) as administrative instruments through

i) preparation of statutory management plans for specific coastal cells;

ii) availability of coastal-management guidelines for preparation of coastalcell management plans and evaluating developments against the plans.

Project design guidelines: Few coastal-research projects are as comprehensive, intensive, and exacting as the SWCES. The SWCES can demonstrate therefore where intrinsic limits to knowledge introduce futility into research plans. Experience gained in the project should be used to distil general guidelines for preparing practical research plans to assist formulation of future coastal-erosion and hazard-assessment studies elsewhere.

\section{Temporal Limits to Knowledge}

Expanding the knowledge frontier: Expansion of the knowledge frontier occurs by three means:

1) induction (more data, new measurement and analysis techniques, more detailed and extensive data integration and interpretation),

2) deduction (new theory and methods of prediction), and 
3) synthesis (assimilation of data and data products into a modeling framework, especially for purposes of explanation).

Induction. The first of these is usually the line of first resort when limits to knowledge are encountered in coastal geosciences, especially in field-based studies such as the SWCES. Moreover, the tendency usually is to collect more data rather than extend (or even undertake) data-integration. Eventually the problem becomes one of too much data, i.e., project resources go disproportionately into data collection rather than integration, interpretation, and synthesis (which in turn become exponentially more laborious as the data type and volume increases, while, ironically, the resources to undertake data processing and synthesis are progressively diverted to further data management and collection). The SWCES is at a stage where the balance has shifted from data collection to integration and synthesis, despite the temptation to collect more data to resolve remaining uncertainties.

Deduction. Expanding the knowledge frontier through deduction involves thinking outside the box, i.e., development of new ideas (which may fly in the face of conventional wisdom). For example, attributing part of the sand source for CRLC barriers to shoreface supply may be seen as a heresy of this type. There is no formula for such development work other than imagination and reasoning (which may be conceptual or mathematical). A mathematical breakthrough on the problem of nonlinear complexity in coastal morphodynamics (de Vriend, 1991) may be of immediate benefit to understanding coastal change in the CRLC. A more straight forward (and more plausible) development is the application of a new highly parameterized model, such as DELFT3D, proposed for investigation of meso-scale morphodynamics of the CRLC.

Generally, induction and deduction proceed in parallel and should inform each other. The application of theory to a field study involves models that require calibration using field data. Numerical experiments using computer models also require data assimilation. The result is a more formal version of data integration with the added advantage that the results not only portray coastal change. They also incorporate or infer explanation (of cause and effect) and prediction in accordance with laws on physical processes (rather than simple empirical extrapolation).

Synthesis need not depend upon availability or applicability of an appropriate model. Some problems are not amenable to available models of the day; development of a conceptual model is the only sensible approach to synthesis for such problems. Conceptual models are likely to be more appropriate with increasing complexity of processes and linkages between systems operating on different scales and in different parts of a study region. For this reason, conceptual models tend to be more common for problems on the geological scale.

The SWCES is a large, multi-scale, complex investigation. Existing temporal limits to knowledge can be expanded most effectively through further integration and synthesis of data. While powerful synthesis can be achieved through application of models like UNIBEST, STM, and DELFT3D, further advances in the project will necessarily involve 
conceptual synthesis. Such synthesis is well under way, but much remains at the level of intuition or hypothesis. Objectives of the project cannot be fulfilled until formalized synthesis is taken to a significantly higher level; this then is the highest priority for the project.

\section{Temporal Limits in the Columbia Littoral Cell:}

Multi-scale coastal change: Achievements and challenges. The SWCES objectives were directed at integrated multi-scale coastal research. This is one of a very few projects to attempt such an approach, which ipso facto demands multidisciplinary participation by geologists, geomorphologists, engineers, and oceanographers. While such a multidisciplinary presence is necessary, it may not be sufficient (although this remains an epistemological question). That is, the disciplinary divides also relate to separate time scales of interest: coastal oceanography, geomorphology, engineering, and geology respectively concern problems on increasing time scales. Coastal change on a geological time scale is necessarily the time-integrated outcome of sedimentary processes operating on the instantaneous time scale; but scaling up predictions on the short term to explain long-term change is not usually possible (Cowell and Thom, 1994). Moreover, according to hierarchy theory, nature can be partitioned into 'naturally occurring' levels that share similar time and space scales, and that interact with higher and lower levels in systematic ways (Haigh, 1987; Capobianco et al., 1998). The possibility exists therefore that investigation on each level may proceed somewhat independently of research severallevels removed in the hierarchy (which may be regarded simply as noise or boundary conditions on smaller and larger scales, respectively).

The list of papers in this report, and the corresponding authors, indicate teams of researchers mostly based in traditional fields of expertise, working separately on problems a) in different sub-environments of the CRLC, or b) on different scales. This may be a deficiency in the Study (but common to most multidisciplinary research), or it may reflect the natural partitioning in study of processes on different scales (as outlined above). Thus, another outcome of the project should be an evaluation of the extent to which the interdisciplinary divides are transcended, and the extent to which such transcendence is actually required (i.e., true multidisciplinary collaboration on specific research questions).

In any event, it is clear from the evolution of interest and participation in SWCES annual workshops that the Study has cultivated a significant improvement in the ability of researchers from different fields to speak the same language and understand how each research field informs the others (e.g., also a major outcome of the EU Fourth Framework Programme project, PACE). This is not a trivial outcome, although it may be difficult to sell it as a deliverable, so there needs to be tangible manifestation of the information crossover in joint publications. Nevertheless, recognition should be given to the capacity building that SWCES has delivered to the national coastal-research effort.

Spatial scale and scope of the Study: The spatial scale of the project, as defined by the Columbia River littoral cell, has pushed the limits of possibilities regarding detailed research over such a long and complicated stretch of coast (four markedly different sub- 
cells, three significant, contrasting estuaries, dramatic anthropogenic interventions). In terms of coastal management objectives, the scale of the project is significant because it extends beyond jurisdictional boundaries. Although this may seem an obvious requirement to gain a systematic understanding of the coastal change anywhere within the CRLC, studies of coastal change seldom go beyond state or county boarders, and most commonly are restricted to analysis of site-specific problems (e.g., individual erosion hot spots).

A worthwhile exercise therefore would be to evaluate the project in terms of what could have been, and what could not have been achieved regarding coastal-management recommendations through separate studies at the site-specific level. This question deserves a separate publication directed at coastal managers. The answer is not guaranteed; the whole-of-cell approach may seem essential for explanation and prediction of coastal change in terms of the sediment budget. Other methods are available, however, (and commonly used) at the site-specific and sub-cell levels, e.g., extrapolation of measured local rates of shoreline change, or sediment budget analysis through estimation of inputs and outputs across locally defined sub-cell boundaries.

In that regard, the CRLC itself may not be closed to sand exchanges beyond its boundaries: losses beyond Point Grenville have been hypothesized (Phipps and Sherwood). The only way to address this issue would be to expand the spatial scope of the Study beyond the CRLC in search of sediment sinks (or at least mineralogic tracers) to provide evidence and estimates of such losses. Similarly, there may be reason to expand the Study to south of Tillamook Head to evaluate shoreface supply from there to the CRLC, or at least as a worthwhile comparison to the CRLC. Such comparison might provide an 'experimental control' on coastal change under the same ocean environment but free from the forcing conditions of the Columbia River.

Expanding the spatial coverage of the project is probably unlikely to occur, but specific evaluation of the limitations caused by not doing so would be worthwhile. Similarly, it is worth evaluating to what extent methods applied to the CRLC could be applied fruitfully to separate sub-cells of the CRLC. Coastal managers should be particularly interested in the second question, because studies at that level are more likely to fit within their budgets and jurisdictional horizons.

Further data exploitation (some key questions): Further (and probably significant) expansion of the limits to knowledge on the CRLC will be achieved mostly through continued exploitation of existing data, i.e., through further integration and especially synthesis. Much of the data analysis, data-integration, and process modeling so far has delivered a phenomenological description of the CRLC. The potential is now ripe for synthesis of data through concept development (and hence hypothesis testing) and assimilation into formal modeling experiments.

Shoreline (UNIBEST) modeling is an example of how an extensive amount of data and other modeling results (wave climate) have been assimilated to produce quantitative explanation and practical prediction of morphological change (Kaminsky et al., 1999). 
The results of the shoreline modeling come close to meeting practical objectives of the Study, i.e., prediction of final, re-equilibrated time-average shoreline locations when the hysteresis effects of ebb-delta collapse has worked through the CRLC. The shoreline modeling however may not adequately address underlying mean trends or the superimposed fluctuating component of coastal change. The mean trend relates to the overall CRLC sediment budget, which remains uncertain (as discussed above). The uncertainty is not only attributable to difficulties in estimating the contemporary river supply (or sink capacity). The issue may also demand thinking outside the box, i.e., further synthesis regarding alternative models of overall coastal evolution (see below).

Fluctuating coastal change and perturbations: The superimposed fluctuating component of coastal change is being addressed through the beach and fore-dune surveys. A key objective here will be to determine the design erosion-volume associated with extreme storms, series of storms, and sea-level anomalies. Erosion responses are likely to vary along the coast due to effects associated with inlets and artificial structures. Beach monitoring is one element of the project for which continued data collection is necessary. The problem of course is, assuming PDO is the dominant driver of fluctuating change, several decades of monitoring is required before a single PDO cycle is detected (and even then $N=1, d f=0$ ). Nevertheless, monitoring is essential to provide timely and informed advice to coastal managers for adaptive decision making.

It may be possible to extract an alternative signal of design storm-erosion from data on the dune ridges that form distinctive event markers in the CRLC. Although a lifetime of effort has gone into the study of these features, further synthesis is required (together with GPR data and radiocarbon dating) to exploit their significance in estimating

- responses to extreme events,

- the propagation of disturbances through the CRLC, and

- the behavioral coupling of adjacent segments of the coast.

Although routinely associated with coseismic subsidence events, some of the ridges may be polycyclic and polygenetic (i.e., possibly originating also from major episodes of storms, or hiatuses in sediment-supply from the Columbia River due either to climatic fluctuations or episodic trapping of sediments following river deepening with a subsidence event, followed by a period of enhanced supply during rebound).

The ridges and shoreline histories of the barrier spits probably contain the most useful record of the fluctuating component of coastal behavior. Further evaluation of dune 'truncation' features on Tokeland and Kindred Spits are likely to provide a means of discriminating between climatic or Columbia-supply forcing; but radiocarbon dating is essential to provide adequate time control. Similarly, the episodic extension and retreat of Long Beach Spit, and the relationship of timing to event markers on Tokeland and Kindred Spits may yield insights into the relative contributions of the different forcings. Long Beach Spit fluctuations and Cape Shoalwater behavior may also be linked. So 
integration and synthesis on these data may shed further light on the autocyclic changes in the entrance to Willapa Bay.

CRLC sediment budget: Event indicators in new core data from Willapa Bay were collected to evaluate the sediment sink capacity of the bay. The cores contain indicators on a) the response of the tidal channel and flats in the bay to subsidence events, and b) the rates of salt-marsh and flood-plain progradation. Analysis of these data (especially in conjunction with radiocarbon dating) will provide clues on the equilibrium state of the estuary. From these clues it may be possible to estimate how far from equilibrium the Bay is at present, and hence its present sink capacity.

Further evaluation of the Willapa Bay sink capacity is important to help validate the overall CRLC sediment budget. The most important check required in this regard however relates to the more than 1 million $\mathrm{m}^{3} \mathrm{a}^{-1}$ sand supply currently attributed to the shoreface in the overall CRLC budget (Kaminsky et al., 2000). The proposition is not only scientifically controversial, it has implications for advancing broader scientific principles on a key issue, i.e., whether the shoreface is a sink or a source for beaches in general.

In the context of the CRLC, the shoreface sand-supply question evokes alternative hypotheses that appear not to have been raised previously. The implications of these hypotheses are of first-order importance to explanation and prediction of coastal change in the CRLC. Thus, a key recommendation of this review is that priority is given to further exploitation of available data to examine these alternative hypotheses. The alternative hypotheses are as follows:

a) Sand supply from the shelf through barrier roll-over occurred during transgression, and is now incorporated in present coastal deposits as basal barrier, proto-barrier, and backbarrier (flood-tide delta) sediments.

b) Erosion of the northern flooding surface occurred during the late stages of the transgression through southward littoral transport induced by the embayed paleotopography.

c) Shoreface sand supply occurs through erosion of the inner-shelf (lower shoreface),

d) Rates of sand supply from the Columbia River are under-estimated.

e) A combination of A through D.

Hypothesis A. The first of these alternative hypotheses relates to the usual mode of transgressive responses during the post-glacial sea-level rise on coasts with continentalshelf slopes similar to that of the Columbia shelf (Roy et al., 1994). That is, transgressive barriers are driven landward incorporating sand entrained from the shelf through barrier rollover. When transgression ceases, a legacy remains of a highstand deposit forming the 
barrier core for subsequent progradation. In SE Australia, for example, progradation occurred throughout the late-Holocene at rates of about $1 / 3 \mathrm{~m} \mathrm{a}^{-1}$, a rate not dissimilar to the Columbia coast over the last 4000 years.

Although sea level stabilized at the end of the transgression (6000 years BP), the transgressive sands are for the most-part buried by the later progradation, and they form a significant volume of the total barrier complex (Figure 2). Unlike in SE Australia, ongoing sea-level rise in the CRLC (Figure 3) means that, if transgressive barrier deposits exist, their depth of burial will be deeper. Further facies interpretation may be required to distinguish transgressive from prograded barrier sediments in the CRLC, with further radiocarbon dating needed to gauge timing of deposition in relation to sea level; available radiocarbon dates are mostly from the upper few meters. The overall implication here is that the transgressive component may be older than the prograded component by one or two thousand years, thus extending the period of accumulation and reducing the amount of sand that we must attribute to supply from the Columbia River.

Interpretation of the ravinement surface underlying the barrier (Twichell et al., this volume) is a key element for identification of a transgressive component. Preserved transgressive barriers cannot onlap a shoreface ravinement surface, but they may overlie a) a fluvial (lowstand) ravinement, or b) a ravinement cut within a transgressive barrier by migrating tidal inlets that are deeper than the thickness of the transgressive barrier. Further examination of the data on the ravinement (e.g., evidence of fluvial-channel scour) may provide a further test of Hypothesis A.

Hypothesis B. Offshore seismic and onshore coring data (Twichell et al., this volume; Peterson et al., 2002) show that the transgressive or low-stand ravinement surface is deeper toward the center of the CRLC (more specifically, deeper toward the river), rising especially toward the northern flanks of the cell. Before present accumulations of shoreface and innershelf deposits had established their current thickness toward the center of the CRLC, the bathymetry and shoreline must have formed a pronounced basin.

The shoreline would have stood further seaward on average by about $2900 \mathrm{~m}$ (assuming a $0.2^{\circ}$ shelf slope) 6000 years ago when sea level was roughly $10 \mathrm{~m}$ lower (Figure 3 ). The basin shorelines along the (especially northern) flanks of the CRLC were probably curved and trended more toward the northwest than at present. Such a shoreline configuration would have been strongly oblique to wave approach $\left(\alpha \rightarrow 45^{\circ}\right)$ inducing stronger, or perhaps near maximum $(v \propto \sin \alpha \cos \alpha)$ alongshore currents directed toward the center of the basin. Under these conditions, the shoreface and flooding surface toward the flanks of the cell would have been a source zone, and suffered both cliff retreat and planation as a consequence (so that the coast there would have resembled beach and scarp conditions prevailing toward Point Grenville at present).

According to Hypothesis B, prograded barrier development would have occurred in (large) part through Columbia River sand supply, supplemented by erosion from the flanks of the CRLC. Barrier development would have been controlled by the combined effects of lower shoreface aggradation toward the center of the cell, and the progressive advance 
of the shoreline (upper shoreface) at the center of the cell relative to the flanks. The shoreline controls according to this Hypothesis imply that Grayland Plains and North Beach barriers could not begin their progradation until the initial curvature of the shoreline (associated with the basin configuration) had reduced sufficiently to prevent most of the sediment from being swept further toward the center of the basin.

Interestingly, if the ravinement surface below the present barrier is proved to be cut by the transgressive shoreface (rather than by streams during the low stand or by inlet migration, as required if Hypotheses A is true), then Hypothesis B conditions are necessary to explain formation of the shoreface ravinement. That is, according to principles laid down by Roy et al. (1994), if Hypothesis A is false then Hypothesis B must be true. On the other hand, Hypotheses A and B can both be true.

Hypothesis C. Bathymetric-change analysis (Gibbs and Gelfenbaum, 1999) indicates shoreface lowering on historical time scales. Similar data plus geological and processbased evidence from elsewhere suggest that deepening of the lower shoreface may be common on coasts with inner-shelf gradients similar to or lower than that of the CRLC, and that such deepening has occurred throughout much of the mid to late-Holocene (Cowell, et al., 2001). The evidence indicates that sand liberated through shoreface lowering provides a source (in some cases the only source) for barrier progradation.

Hypothesis D. Further refinement of the Columbia River sediment supply throughout the past few millennia scarcely seems possible; this is a subject that has received much attention (Gelfenbaum et al., 1999). Nevertheless, Hypothesis D should be evaluated specifically in relation to uncertainty of estimates, and attendant considerations, contained within existing results and their documentation.

Hypotheses A - C would each benefit from synthesis of available data formally through computer simulation modeling (STM, UNIBEST, and possibly DELFT3D).

\section{ACKNOWLEDGMENTS}

This review draws in significant part through an extensive field reconnaissance undertaken in September 2000 under the highly informed guidance of Jim Phipps, Curt Peterson and Dave Percy (who nevertheless may not share all views expressed herein).

\section{REFERENCES}

Banks J., and Carson, J.S. 1984. Discrete-Event System Simulation, Prentice-Hall, New Jersey, 514 p.

Capobianco, M., Stive, M.J.F., Jimenez, J.A. and Sanchez-Arcilla, A. 1998. Towards the definition of budget models for the evolution of deltas, Journal of Coastal Conservation, 4, pp. 7-16. 
Cowell, P.J., and Thom, B.G. 1994. Morphodynamics of coastal evolution, In: Carter, R.W.G. and Woodroffe, C.D. (eds), Coastal Evolution: Late Quaternary Shoreline Morphodynamics, Cambridge, Cambridge University Press, pp. 33-86.

Cowell, P.J., Stive, M.J.F., Roy, P.S., Kaminsky, G.M., Buijsman, M. C., Thom, B.G., and Wright, L.D. 2001. Shoreface sand supply to beaches, Proc. 27th International Coastal Engineering Conference, pp. 2495-2508.

de Vriend, H.J. 1991. Modelling in marine morphodynamics, In Computer Modelling in Ocean Engineering '91, ed. A.S. Arcilla, M. Pastor, O.C. Zienkiewicz and B.A. Schrefler, Rotterdam, Balkema, pp. 247-260.

Gelfenbaum, G., Sherwood, C.R., Peterson, C.D., Kaminsky, G.M., Buijsman, M., Twichell, D.C., Ruggiero, P., Gibbs, A.E., and Reed, C. 1999. The Columbia River littoral cell: A sediment budget overview, Proceedings of Coastal Sediments '99, ASCE, pp. 1660-1675.

Gibbs, A.E., and Gelfenbaum, G.R. 1999. Bathymetric change off the Washington Oregon Coast, Proceedings of Coastal Sediments '99, ASCE, pp. 1627-1642.

Haigh, M.J. 1987. The holon: hierarchy theory and landscape research, In: Ahnert, F. (ed.), Geomorphological Models: Theoretical and Empirical Models, Catena Supplement 10, Catena Verlag, pp. 181-192.

Kaminsky, G.M. this volume. A review of Columbia River dredging: past practices and recent proposals, Southwest Washington Coastal Erosion Workshop Report 2000, pp. 29-36.

Kaminsky, G.M., Buijsman, M., Gelfenbaum, G.R., Ruggiero, P., Jol, H.M., Gibbs, A., and Peterson, C.D. 1999. Synthesizing geological observations and process-response data for modeling coastal change at a management scale, Proceedings of Coastal Sediments '99, ASCE, pp. 1708-1723.

Kaminsky, G.M., Buijsman, M.C., and Ruggiero, P. 2000. Predicting shoreline change at decadal scale in the Pacific Northwest, USA, Proceedings of the 27th International Conference on Coastal Engineering, Sydney, Australia, pp. 2400-2413.

Peterson, C.D., Jol, H.M., Woxell, L.K., Vanderburgh, S., Phipps, J., Percy, D., Reckendorf, F., and Gelfenbaum, G.R. 2002. Late-Holocene Shoreface Retreat Scarps from Ground Penetrating Radar Profiles: Columbia River Littoral Cell, Washington-Oregon, USA, U.S. Geological Survey Open-File Report (in prep).

Phillips, J. D. 1999. Earth Surface Systems: Complexity, Order and Scale, Malden, MA, Blackwell Publishers, 180 p. 
Roy, P.S., Cowell, P.J., Ferland, M.A,. and Thom, B.G. 1994. Wave dominated coasts, In Coastal Evolution, R.W.G. Carter and Woodroffe, C.D. (eds), Cambridge University Press, pp. 121-86.

Schumm, S.A. 1991. To Interpret the Earth: Ten Ways to be Wrong, Cambridge University Press, 133 p.

Tarantola, A. 1987. Inverse Problem Theory: Methods for Data Fitting and Model Parameter Estimation, Amsterdam, Elsevier, 613 p.

Twichell, D., Cross, V., Peterson, C.D., Percy, D.C., Vanderburgh, S., Phipps, J. and Herb, A. this volume. Latest Holocene evolution of the SW Washington shelf and coastal system, Southwest Washington Coastal Erosion Workshop Report 2000, pp. 124-125.

Zeng, T.Q., Cowell, P. and Zhou, Q. 1997. The Usher's approach (UshA) for the realization of fuzzy clustering theory for zonal analysis in raster-based GIS, Proc. of GeoComputation '97, pp. 15-22.

Zeng, T.Q., Zhou, Q., Cowell, P.J., and Huang, H. 2001. Coastal GIS: Functionalities and applications, Journal of Geospatial Engineering, 3 (2), pp. 109-126. 


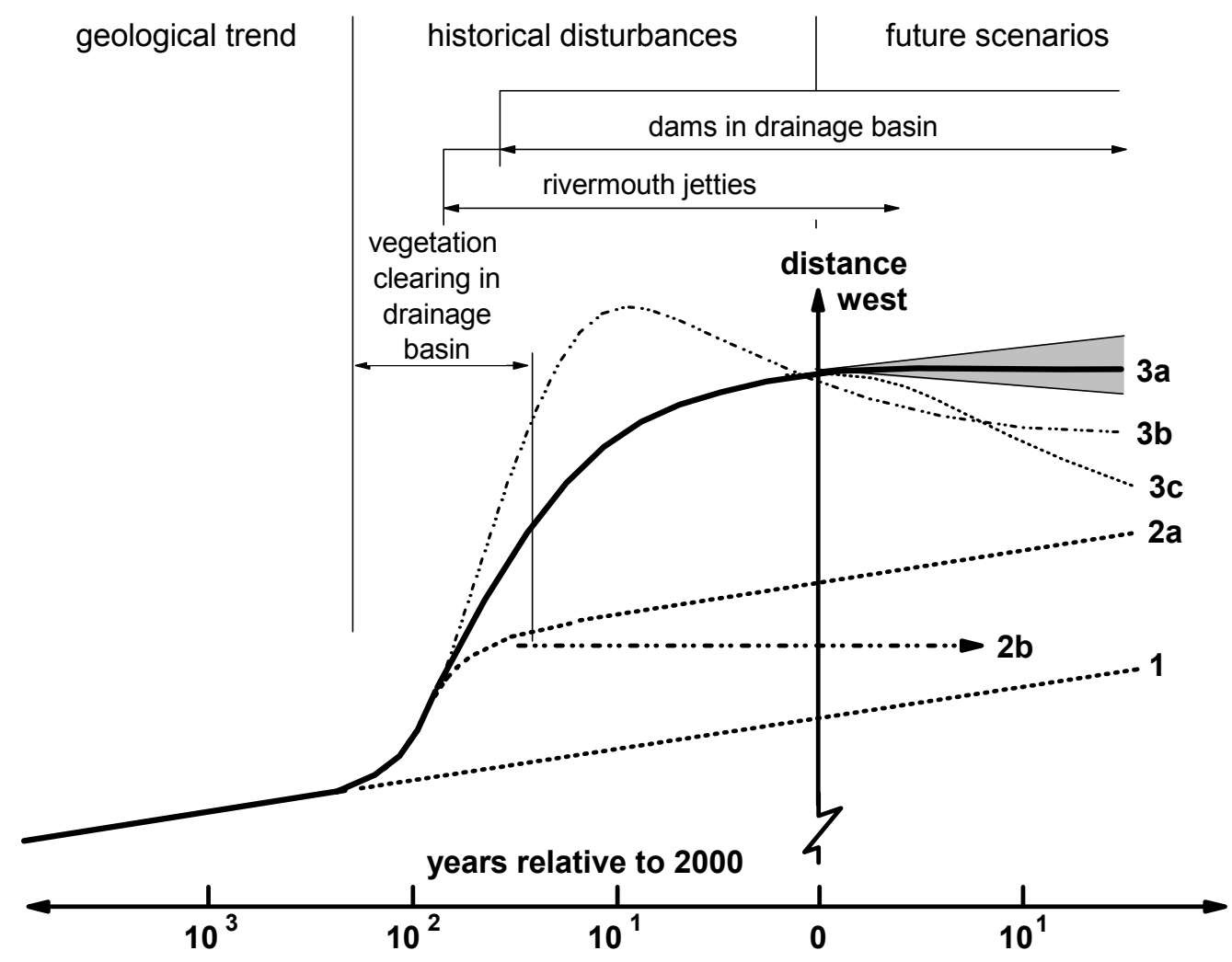

Figure 1. Schematic time series of cell-averaged shoreline distance west (barrier progradation), showing underlying mean trends (Plots $1 \& 2$ ) and scenarios projected several decades into the future (Plots $3 a-c)$ resulting from history of anthropogenic effects:

1 Geological mean-trend extrapolated without any anthropogenic effects.

2a Geological mean-trend extrapolated with effects of vegetation clearance in the drainage basin.

2b Geological mean-trend extrapolated with effects of vegetation clearance and subsequent sand interception due to construction of dams in the drainage basin.

3a All effects included for whole-of-cell average.

3b All effects included for delta-margin shorelines only (current erosion hot spots).

3c All effects included with added assumption that CRLC is leaky (sediment losses to mid-shelf and alongshore past Point Grenville). 


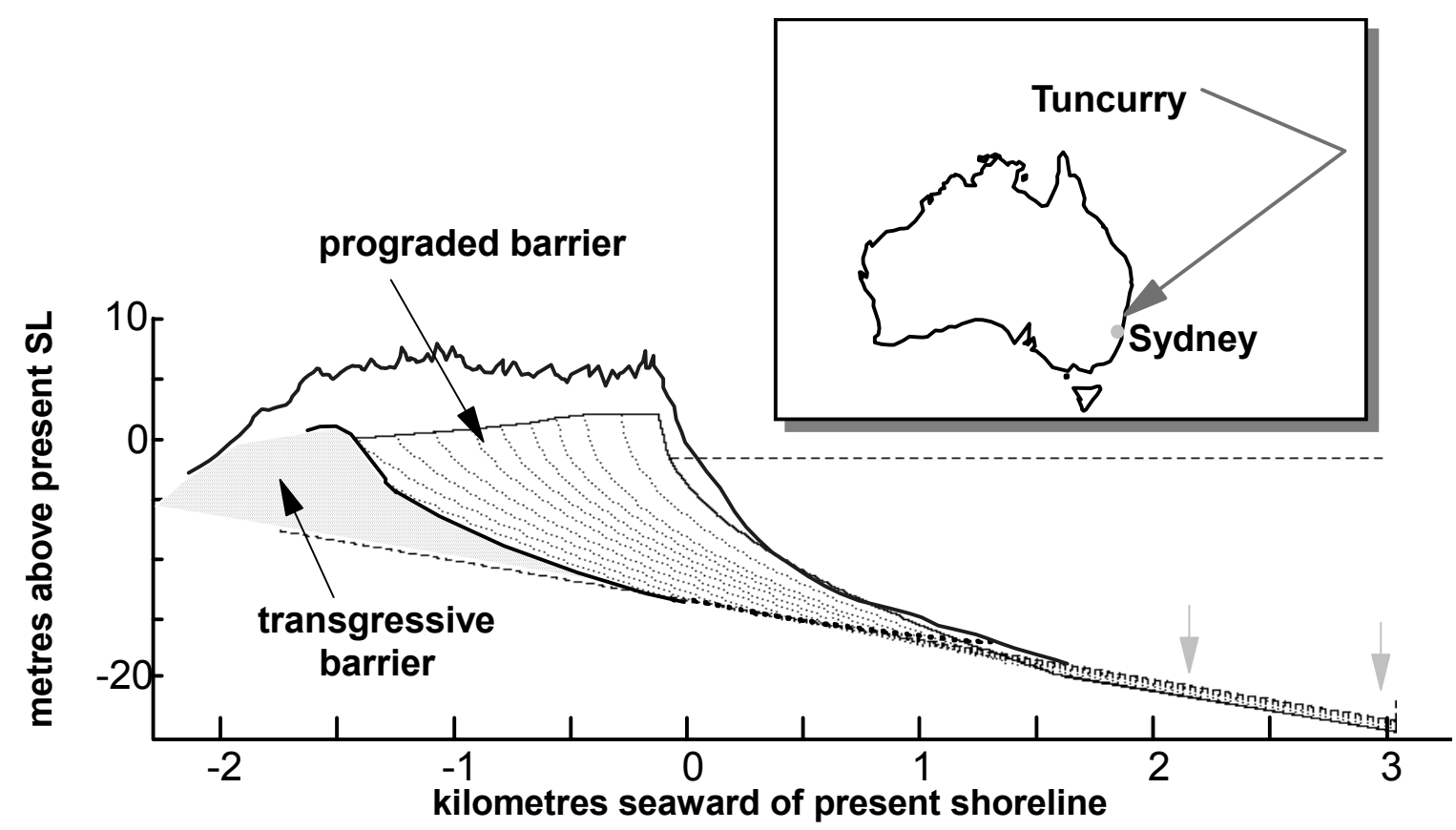

Figure 2. Transgressive and prograded barrier complex, Tuncurry SE Australia.

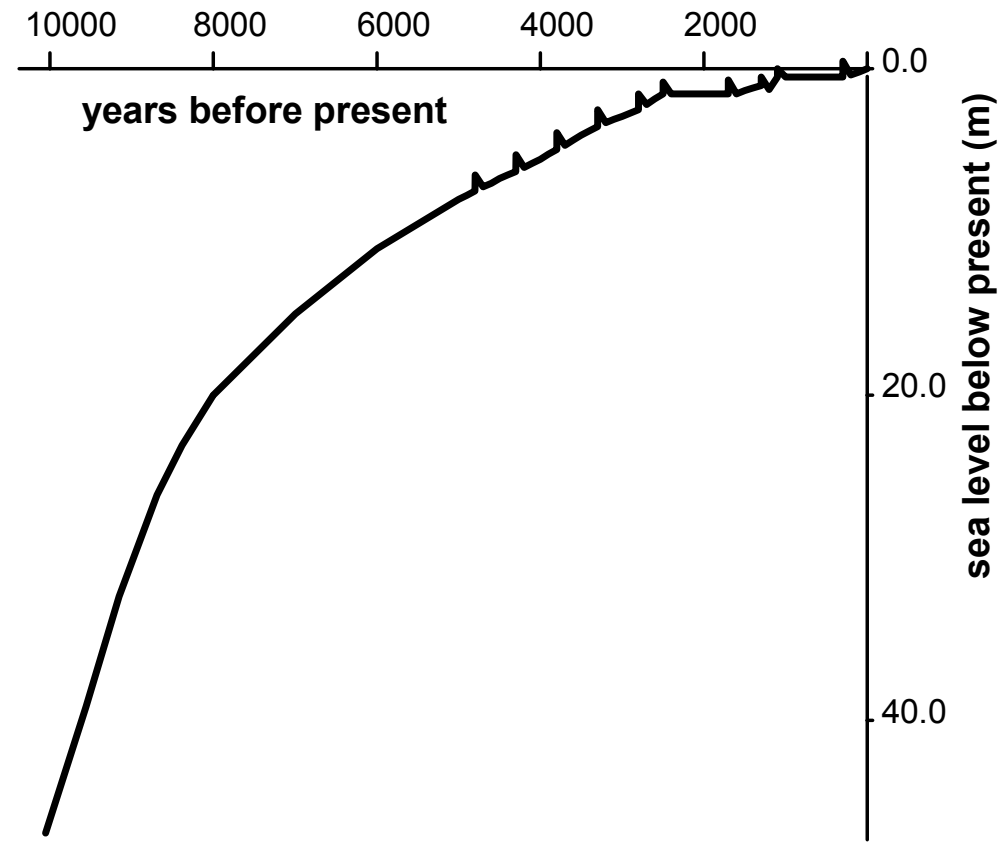

Figure 3. Sea level curve constructed by Curt Peterson based on marsh data (with known co-seismic subsidence events superimposed). 


\section{LIST OF ATTENDEES}

\section{DR. JONATHAN ALLAN}

College of Oceanic \& Atmospheric Sciences

Oregon State University

104 Ocean Administration Building

Corvalis, OR 97330

tel (541) 737-5010

fax (541) 737-2064

e-mail jonathan@oce.orst.edu

\section{MR. STEVEN BABCOCK}

U.S. Army Corps of Engineers

Seattle District Planning Branch

P.O. Box 3755

Seattle, WA 98124-3755

tel (206) 764-3651

fax (206) 764-4470

e-mail steven.d.babcock@usace.army.mil

\section{MS. DIANA BAKER}

Portland State University

P.O. Box 751

Portland, OR 97207-0751

tel (503) 725-3022

fax (503) 725-3025

e-mail psu13437@pdx.edu

\section{MR. PAUL BEAUCHEMAN}

U.S. Geological Survey

12201 Sunrise Valley Drive, MS 11

Reston, VA 20192

tel (703) 648-6654

e-mail pbeauche@usgs.gov 
MR. ERIC BRAUN

U.S. Army Corps of Engineers

Portland District

P.O. Box 2946

Portland, OR 97204-3495

tel (503) 808-4348

fax (503) 808-4344

e-mail Eric.P.Braun@nwp01.usace.army.mil

MR. MAARTEN BUIJSMAN

Washington Department of Ecology

Coastal Monitoring \& Analysis Program

Olympia, WA 98504-7600

tel (360) 407-7125

fax (360) 407-6902

e-mail mbui461@ecy.wa.gov

DR. MICHAEL CARR

U.S. Geological Survey

Marine and Coastal Geologic Surveys

345 Middlefield Road, MS 999

Menlo Park, CA 94025

tel (415) 354-3184

fax (415) 354-3020

e-mail mcarr@octopus.wr.usgs.gov

MS. MARY CIALONE

USAE Engineer Research \& Development Center

Waterways Experiment Station

3909 Halls Ferry Rd.

Vicksburg, MS 39180

tel (601) 634-2139

e-mail cialonm@wes.army.mil

\section{DR. PETER COWELL}

Coastal Studies Unit

Marine Studies Centre

University of Sydney, NSW 2006

tel 61-2-9351-2189

fax 61-2-9351-3644

e-mail P.Cowell@csu.usyd.edu.au 
MS. VEEANN CROSS

U.S. Geological Survey

384 Quissett Campus Woods Hole Rd.

Woods Hole, MA 02543-1598

tel (508) 457-2251

e-mail vatnipp@usgs.gov

MR. RICHARD DANIELS

Washington Department of Ecology

Coastal Monitoring \& Analysis Program

P.O. Box 47600

Olympia, WA 98504-7600

tel (360) 407-6427

fax (360) 407-6902

e-mail rdan461@ecy.wa.gov

MS. VICKI FERRINI

Marine Sciences Research Center

State University of New York

Stony Brook, NY 11794-5000

tel (631) 632-8685

e-mail ferrini@msrc.sunysb.edu

MR. CHUCK GALE

Pacific International Engineering, PLLC

144 Railroad Avenue, Suite 310

Edmonds, WA 98020

tel (425) 744-7700

fax (425) 744-1400

e-mail chuckg@piengr.com

\section{DR. GUY GELFENBAUM}

U.S. Geological Survey

Coastal and Marine Geology Program

345 Middlefield Road, MS 999

Menlo Park, CA 94025

tel (650) 329-5483

fax (650) 329-5190

e-mail gelf@octopus.wr.usgs.gov 
MS. ANN GIBBS

U.S. Geological Survey

Coastal and Marine Geology Program

345 Middlefield Road, MS 999

Menlo Park, CA 94025

tel (650) 329-5060

fax (650) 329-5197

e-mail agibbs@octopus.wr.usgs.gov

MR. EDWARD HANDS

U.S. Army Corps of Engineers

Waterways Experiment Station

3909 Halls Ferry Road

Vicksburg, MS 39180-6199

tel (601) 634-2088

e-mail Edward.B.Hands@wes02.usace.army.mil

\section{MR. DAVID HERRICK}

Pacific International Engineering, PLLC

144 Railroad Avenue, Suite 310

Edmonds, WA 98020-4121

tel (425) 744-7700

fax (425) 744-1400

e-mail davidh@piengr.com

\section{DR. PETER HOWD}

Department of Marine Science

University of South Florida

140 7th Avenue South

St. Petersburg, FL 33701-5016

tel (727) 553-1158

fax (727) 553-1189

e-mail phowd@marine.usf.edu

\section{MR. ROBERT HUXFORD}

Washington Department of Ecology

Coastal Monitoring \& Analysis Program

P.O. Box 47600

Olympia, WA 98504-7600

tel (360) 407-6780

fax (360) 407-6902

e-mail bhux461@ecy.wa.gov 


\section{DR. DAVID JAY}

Center for Coastal and Land-Margin Research

Oregon Graduate Institute

P.O. Box 91000

Portland, OR 97291-1000

tel (503) 690-1372

fax (503) 690-1273

e-maildjay@ese.ogi.edu

\section{DR. HARRY JOL}

University of Wisconsin, Eau Claire

Department of Geography

105 Garfield Ave.

Eau Claire, WI 54702-4004

tel (715) 836-3472

fax (715) 836-6027

e-mail jolhm@uwec.edu

\section{MR. GEORGE KAMINSKY}

Washington Department of Ecology

Coastal Monitoring \& Analysis Program

P.O. Box 47600

Olympia, WA 98504-7600

tel (360) 407-6797

fax (360) 407-6902

e-mail gkam461@ecy.wa.gov

\section{MS. LAURA KERR}

U.S. Geological Survey

Coastal and Marine Geology Program

345 Middlefield RD, MS999

Menlo Park, CA 94025

tel (650) 329-5243

fax (650) 329-5190

e-mail 1kerr@usgs.gov 
MR. ETIENNE KINGSLEY

Washington Department of Ecology

Coastal Monitoring \& Analysis Program

P.O. Box 47600

Olympia, WA 98504-7600

tel (360) 407-6436

fax (360) 407-6902

e-mail ekin461@ecy.wa.gov

\section{DR. PAUL KOMAR}

Oregon State University

College of Oceanic \& Atmospheric Sciences

Corvallis, OR 97331

tel (503) 737-5210

fax (503) 737-2064

e-mail pkomar@oce.orst.edu

\section{MS. DIANA MCCANDLESS}

Washington Department of Ecology

Coastal Monitoring \& Analysis Program

P.O. Box 47600

Olympia, WA 98504-7600

tel (360) 407-6104

fax (360) 407-6902

e-mail dimc461@ecy.wa.gov

\section{DR. LAURA MOORE}

USGS Center for Coastal Geology

6004 th Street South

St. Petersburg, FL 33704

tel (727) 803-8747 x3123

fax (727) 803-2032

e-mail 1moore@seas.marine.usf.edu

\section{MR. ROD MORITZ}

U.S. Army Corps of Engineers

Portland District

P.O. Box 2946

Portland, OR 97208-2946

tel (503) 808-4892

fax (503) 808-4875

e-mail hans.r.moritz@usace.army.mil 


\section{DR. PRADEEP NAIK}

Department of Environmental Science and Engineering

Oregon Graduate Institute

20000 NW Walker Road

Beaverton, OR 97006-8921

tel (503) 748-4056

fax (503) 690-1273

e-mail pnaik@ese.ogi.edu

\section{MR. ERIC NELSON}

U.S. Army Corps of Engineers

Seattle District Design Branch

P.O. Box 3755

Seattle, WA 98124-3755

tel (206) 764-3557

fax (206) 764-6795

e-mail eric.e.nelson@nps.usace.army.mil

\section{MR. PHILIP ORTON}

Department of Environmental Science and Engineering Oregon Graduate Institute

20000 NW Walker Rd.

Beaverton, OR 97006-8921

tel (503) 748-4092

fax (503) 690-1273

e-mail orton@ese.ogi.edu

\section{DR. PHIL OSBORNE}

Pacific International Engineering, PLLC

144 Railroad Avenue, Suite 310

Edmonds, WA 98020-4121

tel (425) 921-1720

fax (425) 744-1400

e-mail philo@piengr.com

\section{MS. MEG PALMSTEN}

USGS Center for Coastal Geology

6004 th St. S.

St. Petersburg, FL 33701

tel (727) 803-8747 x3019

fax (727) 803-2032

e-mail palmsten@cfcg.er.usgs.gov 
MR. DAVE PERCY

Portland State University

Department of Geology

P.O. Box 751

Portland, OR 97202-0751

tel (503) 725-3373

e-mail percyd@pdx.edu

DR. CURT PETERSON

Portland State University

Department of Geology

P.O. Box 751

Portland, OR 97202-0751

tel (503) 725-3375

fax (503) 725-3025

e-mail curt@ch1.ch.pdx.edu

DR. JIM PHIPPS

Grays Harbor College

PO Box 178

Cosmopolis, WA 98537

tel (360) 532-7173

e-mail toninjim@techline.com

MR. DAVE QUALMAN

Portland State University

P.O. Box 751

Portland, OR 97202-0751

tel (503) 725-3375

fax (503) 725-3025

e-mail toninjim@techline.com

DR. FRANK RECKENDORF

Reckendorf \& Associates

950 Market Street NE

Salem, OR 97301

tel (503) 364-6681

fax (503) 399-9421

e-mail frecken@open.org 


\section{DR. PETER RUGGIERO}

Washington Department of Ecology

Coastal Monitoring \& Analysis Program

P.O. Box 47600

Olympia, WA 98504-7600

tel (360) 407-6230

fax (360) 407-6902

e-mail prug461@ecy.wa.gov

\section{DR. VLADIMIR SHEPSIS}

Pacific International Engineering, PLLC

144 Railroad Avenue, Suite 310

Edmonds, WA 98020

tel (425) 921-1703

fax (425) 744-1400

e-mail vladimir@piengr.com

\section{DR. CHRISTOPHER SHERWOOD}

U.S. Geological Survey

Coastal \& Marine Geology Program

345 Middlefield Road

Menlo Park, CA 94025

tel (650) 329-5330

fax (650) 3295190

e-mail sherwood@octopus.wr.usgs.gov

\section{MR. DAVID SIMPSON}

Pacific International Engineering, PLLC

144 Railroad Avenue, Suite 310

Edmonds, WA 98020

tel (425) 921-1705

fax (425) 744-1400

e-mail dsimpson@piengr.com

\section{MR. CHRISTIAN STEWART}

Christian J. Stewart Consulting

1618 Candela Place

Victoria, British Columbia, Canada V8N 5P4

tel (250) 472-1699

fax (250) 744-7277

e-mail cstewart@cjscons.com 
DR. NELS SULTAN

Pacific International Engineering, PLLC

144 Railroad Avenue, Suite 310

Edmonds, WA 98020

tel (425) 744-7700

fax (425) 624-1388

e-mail nelss@piengr.com

MR. DAVE THOMPSON

210 NW 16th Street

Corvallis, OR 97330

tel (541) 753-7444

e-mail dt@coastal.udel.edu

MS. LAURA TORRESAN

U.S. Geological Survey

Coastal and Marine Geology Program

345 Middlefield Road, MS 999

Menlo Park, CA 94025

tel (650) 329-5268

e-mail ltorresan@usgs.gov

DR. DAVE TWICHELL

U.S. Geological Survey

384 Quissett Campus Woods Hole Rd.

Woods Hole, MA 02543-1598

tel (508) 457-2266

fax (508) 457-2310

e-mail dtwichell@usgs.gov

DR. SANDY VANDERBURGH

University College of the Fraser Valley

Department of Geography

33844 King Road, V2S 4N2

Abbotsford, British Columbia, Canada

tel (604) 853-7441

fax (604) 855-7558

e-mail vanderburghs@ucfv.bc.ca 


\section{MR. BRIAN VOIGT}

Washington Department of Ecology

Coastal Monitoring \& Analysis Program

P.O. Box 47600

Olympia, WA 98504-7600

tel (360) 407-6568

fax (360) 407-6902

e-mail bvoi461@ecy.wa.gov 


\section{GROUP PHOTOGRAPH}

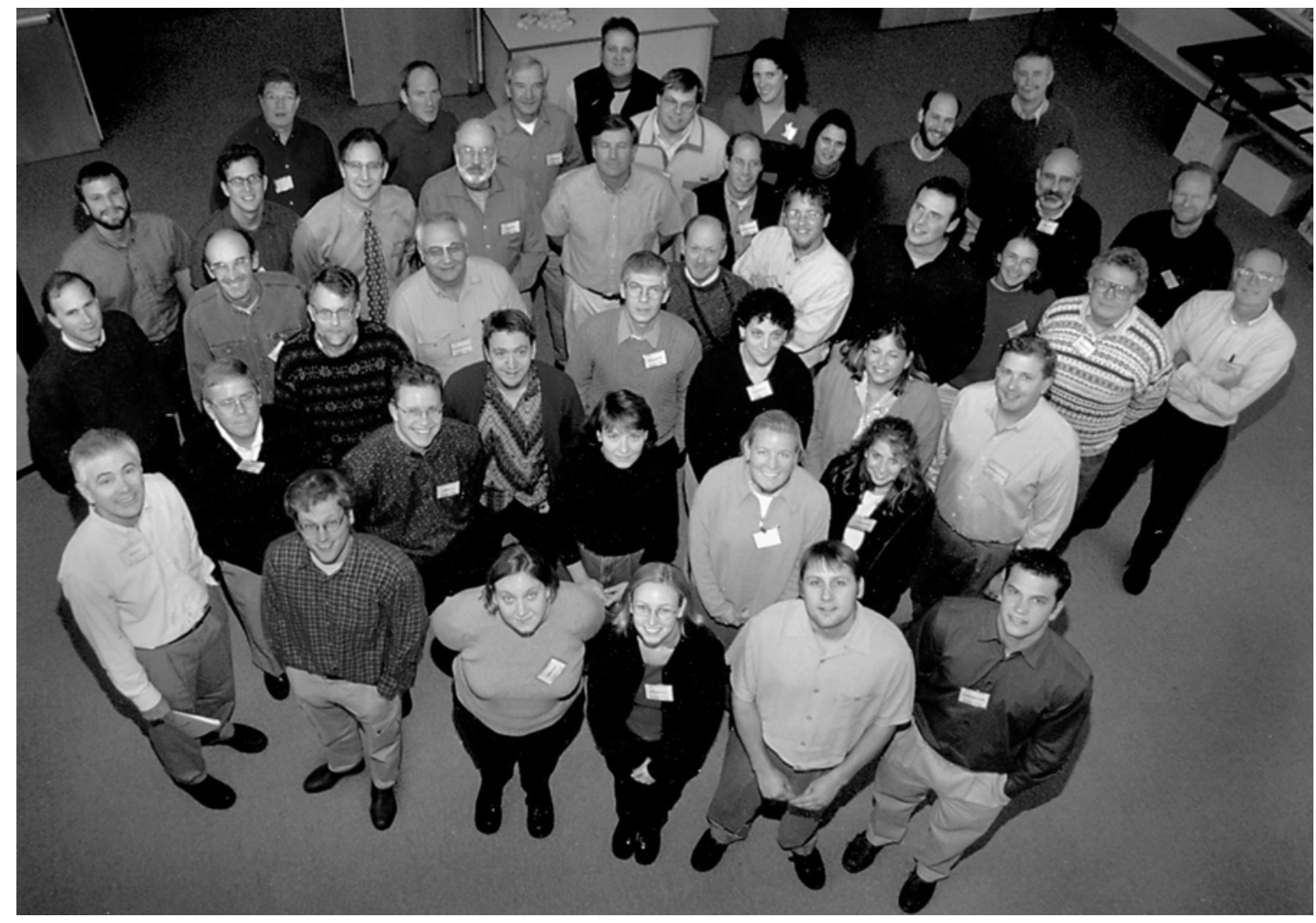

From left to right:

Front Row:

Second Row:

Third Row:

Fourth Row:

Back Row:

Not Pictured:
E. Hands, M. Buijsman, L. Kerr, M. Palmsten, P. Ruggiero, D. Thompson.

P. Beaucheman, D. Jay, H. Jol, D. Percy, D. Baker, L. Torresan, L. Moore.

P. Osborne, D. Twichell, F. Reckendorf, S. Babcock, D. Simpson, V. Ferrini,

A. Gibbs, C. Stewart.

E. Kingsley, P. Orton, E. Nelson, J. Phipps, C. Peterson, C. Sherwood, B. Voigt,

D. Qualman, V. Cross, P. Komar.

C. Gale, R. Moritz, D. Herrick, S. Vanderburgh, P. Howd, D. McCandless, M. Cialone, G. Kaminsky, P. Cowell, M. Carr, G. Gelfenbaum, E. Braun. J. Allan, R. Daniels, R. Huxford, V. Shepsis, N. Sultan 